Liberal Solidarity. Guaranteeing Access to Dutch Health Care Under the Banner of Private Initiative, 1848-2015

\title{
Roland Bertens
}




\title{
Liberal Solidarity. Guaranteeing Access to Dutch Health Care Under the Banner of Private Initiative, 1848-2015
}

Liberale solidariteit. Toegang tot gezondheidszorg in Nederland onder het vaandel van particulier initiatief, 1848-2015

(met een samenvatting in het Nederlands)

\section{Proefschrift}

\author{
ter verkrijging van de graad van doctor aan de \\ Universiteit Utrecht \\ op gezag van de \\ rector magnificus, prof.dr. H.R.B.M. Kummeling, \\ ingevolge het besluit van het college voor promoties \\ in het openbaar te verdedigen op
}

donderdag 7 januari 2021 des middags te 2.30 uur

door

\section{Roland Marnix Bertens}

geboren op 4 oktober 1989

te Zeist 


\section{Promotoren:}

Prof. dr. F.G. Huisman

Prof. dr. J.G. Sijmons

\section{Copromotor:}

Dr. R.A.A. Vonk 


\section{Table of Contents}

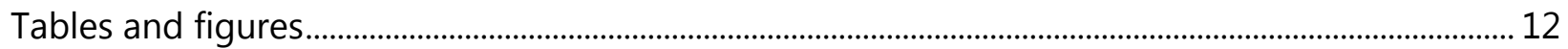

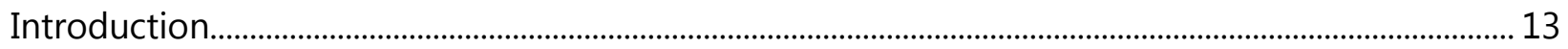

The Longue Durée of Dutch Health Care: Culture, Ideology and Legislation 1848-2015 ................. 13

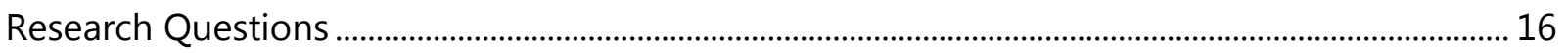

The Analytical Toolkit of Governmentality/Governance .......................................................................... 20

Bringing Back the Longue Durée: Periodizing Dutch Health Care.........................................................2

Historiography, Methodology, and 'Identity' of this Dissertation ...................................................... 28

Part I: Liberal Governmentality, 1848-1912 ……………………………………………………………....... 33

Introduction ................................................................................................................................................. 34

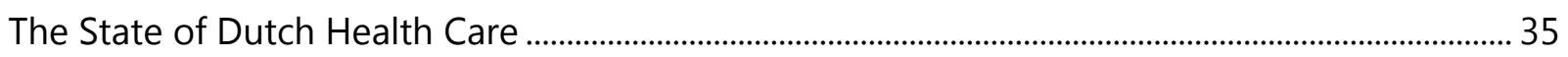

Medical Care and The Medical 'Profession' in the Early $19^{\text {th }}$ Century ................................................ 37

Bringing Doctors under One Banner............................................................................................................. 40

A Liberal Blueprint: the 1848 Constitution............................................................................................. 42

Health Care: A Concern for the State? ……………………………………………………………….... 44

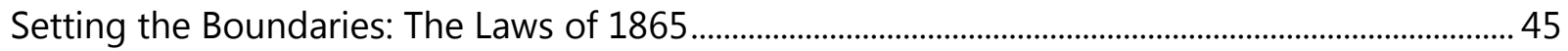

A New Governmentality for Health Care .............................................................................................. 48

Programmatic Laws, Stubborn Realities .............................................................................................. 49

Case Study: The State Inspectorate and the Fostering of Individual Care ………………..................... 51

A Marginal Role for Government: Poor Relief and Health Care ……………………………............. 54

Civil Society in Action .................................................................................................................................. 56

A Changing Political Landscape and a Society on the Move.............................................................. 58

The 'Social Question' and Limited State Intervention ...........................................................................6 60

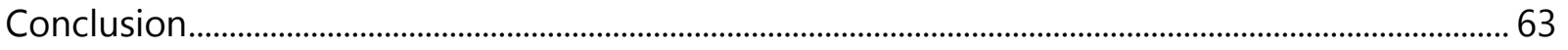

Part II: Hybrid Governmentality, 1912-1968 …………………………………………………………..... 65

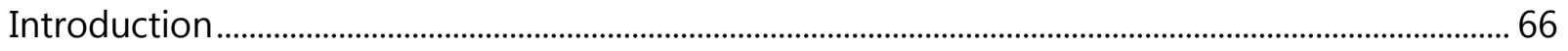

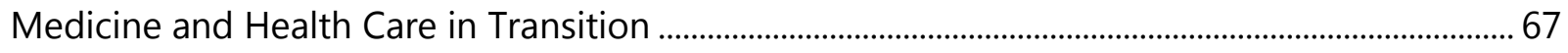




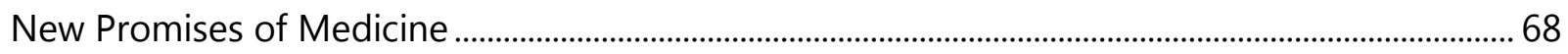

Great Expectations …………………………………………………………………………………......

Shifting Care: New Locations …………………………………………………………………………....

Social Ideals, Faltering Politics.............................................................................................................. 74

The Limits of the Legislature ..............................................................................................................

Limits of the Legislature, Act Two: Health Insurance ............................................................................ 79

The Trials of the State Inspectorate ........................................................................................................ 80

The Achilles' Heel of a 'Local' Governmentality .................................................................................. 82

From Arbitrariness to Accessibility ......................................................................................................... 85

Sickness Funds: The Bedrock of Dutch Health Insurance..................................................................... 86

Private Health Insurance: Lucrative or Lurid?......................................................................................... 89

State Intervention Through the Back Door............................................................................................. 92

Local Government Steps In .................................................................................................................... 94

Hospital Care: Convergence Between Private and Public Financing..................................................... 96

Health Care Financing: Rhetoric vs Reality ............................................................................................. 98

Private Initiative, Publicly Backed .......................................................................................................... 101

The Netherlands under German Control ..............................................................................................103

Cutting the Gordian Knot: The Introduction of Mandatory Health Insurance ...............................104

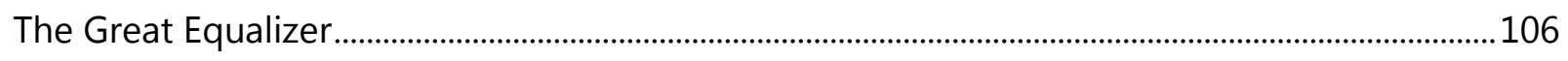

New Patients and a New Role for Sickness Funds .........................................................................108

Dreams in Exile: The Van Rhijn-Committee.........................................................................................110

Reinventing the Social Contract: The Beveridge Report......................................................................112

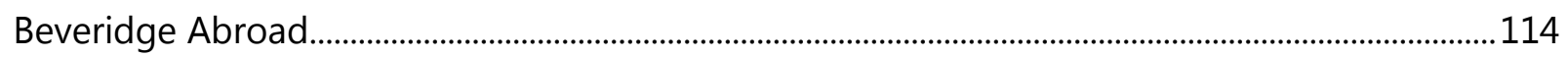

A Silent Death for Big Ambitions..................................................................................................... 116

A Return to Pre-War Thinking ........................................................................................................ 118

Catholics and Social-Democrats: A Recipe for Gradual Reform ......................................................... 121

New Times, New Health Care Politics? ...........................................................................................................123

Public Guarantees, Private Governance ..........................................................................................126

War, Reconstruction, Reorganization ................................................................................................ 128

Van Rhijn: A Rallying Cry for Private Initiative .................................................................................. 130 
A Political Matter Best Left to Parties in the Field

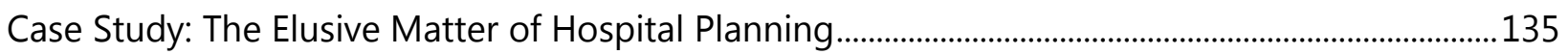

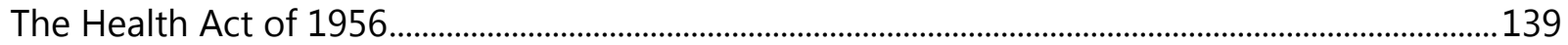

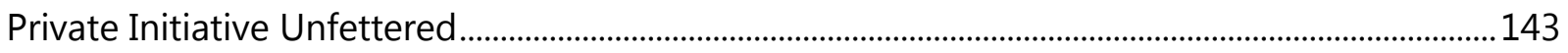

Converging on Care: Sickness Funds and Private Insurers .................................................................. 147

Under the Volcano: A Booming Economy and an Evolving Medicine ............................................149

Developments on the Curative Front............................................................................................... 151

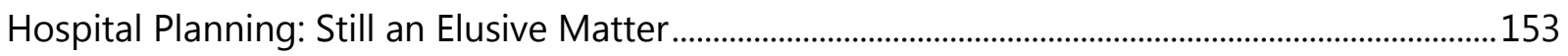

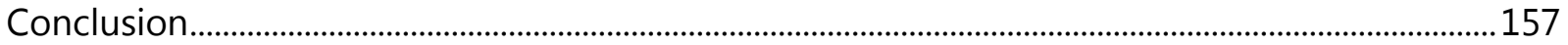

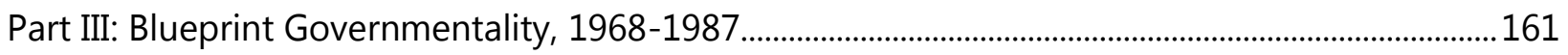

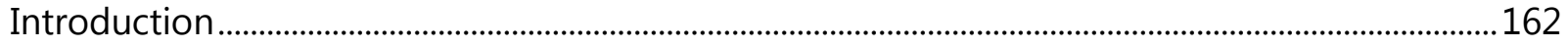

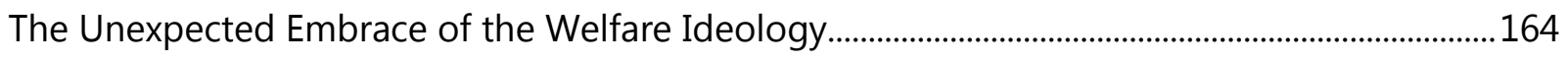

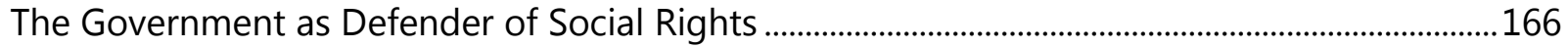

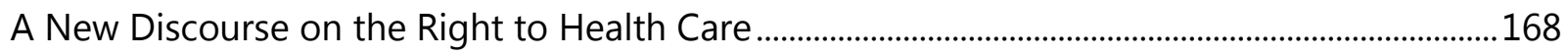

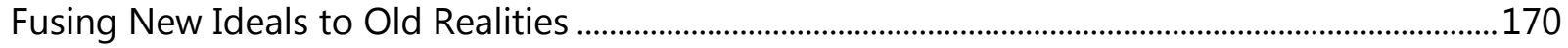

Cornerstones of the Welfare State, 1966-1968 ................................................................................. 173

The Exceptional Medical Expenses Act of 1968 ...................................................................................... 176

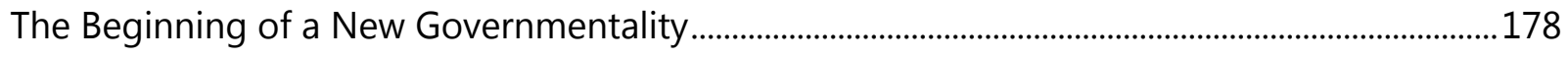

Small Steps Towards Organizing Health Care .......................................................................................... 181

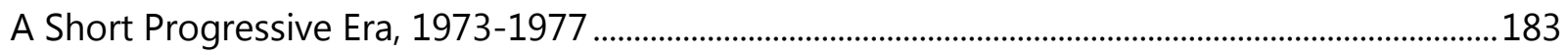

'Planning' as the New Governmentality ................................................................................................... 185

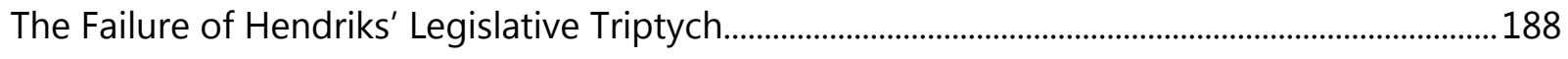

From Planning to Incremental Change ................................................................................................. 190

Cultural Resistance to the Welfare State .................................................................................................... 192

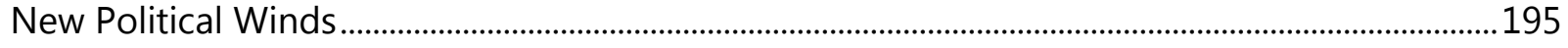

Reinventing Health and Welfare in a New Liberal Age .................................................................... 197

Curbing Costs, Assuring Access, 1977-1986 ………................................................................................ 199

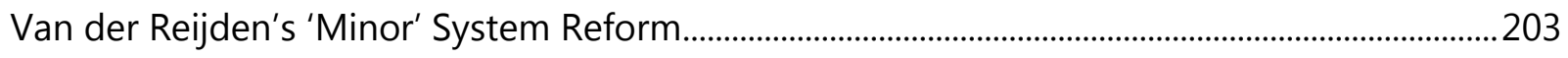

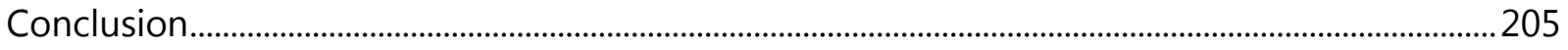

Part IV: Governmentality of the Regulated Market, 1987-2015 ….........................................................209 
Introduction

A New Blueprint for Regulating Health Care: The 1987 Dekker Report ..........................................212

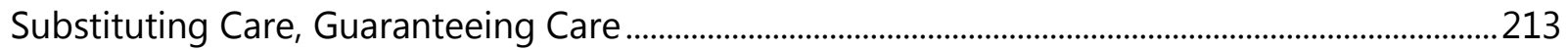

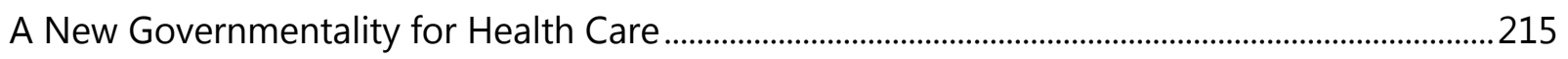

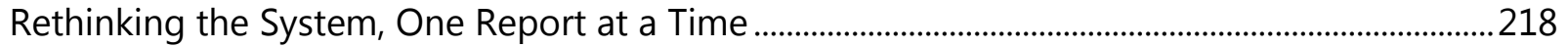

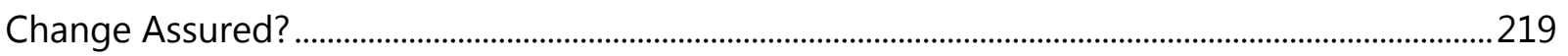

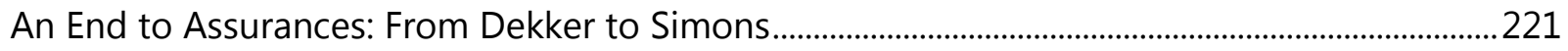

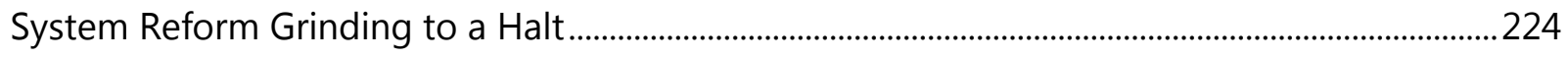

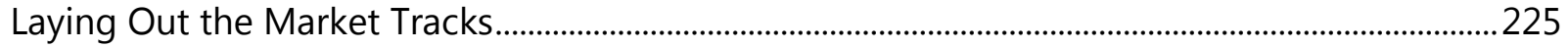

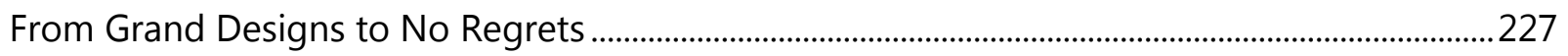

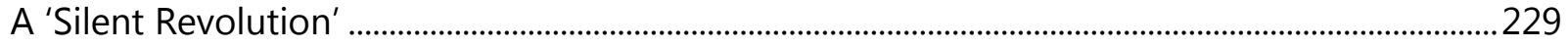

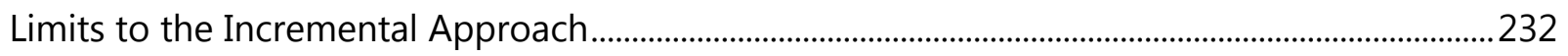

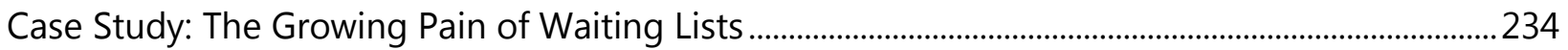

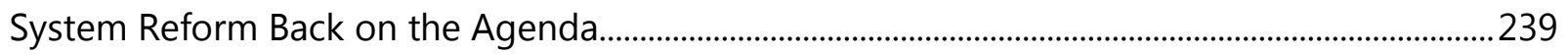

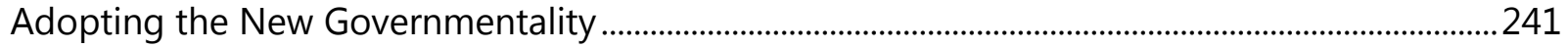

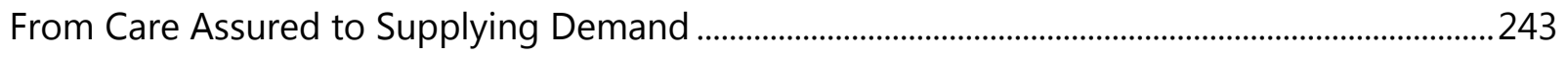

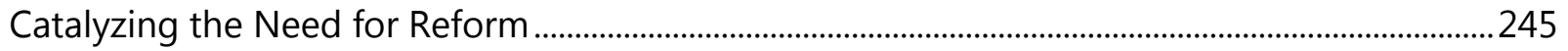

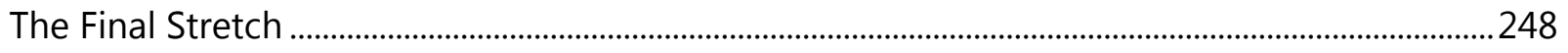

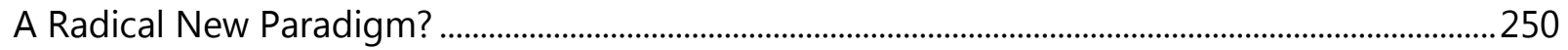

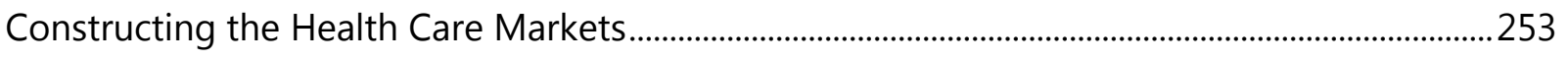

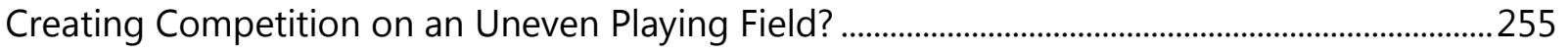

Competition Watchdogs: Fast Asleep or on a Tight Leash? .............................................................259

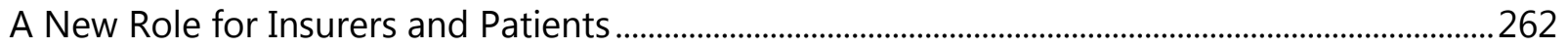

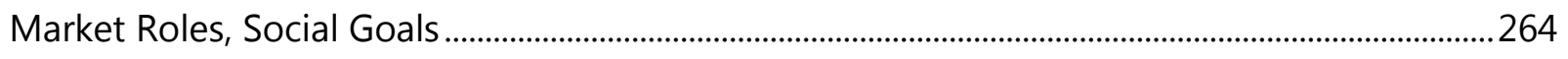

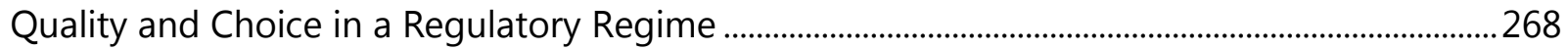

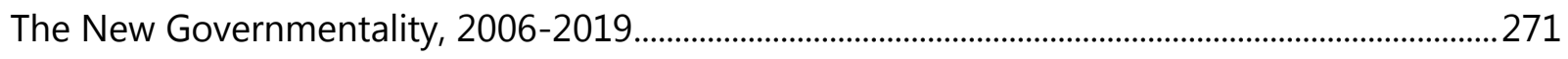

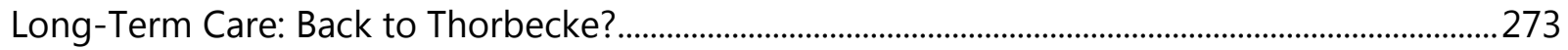

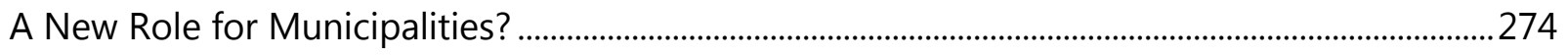

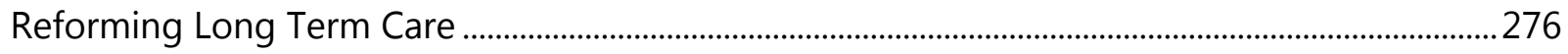

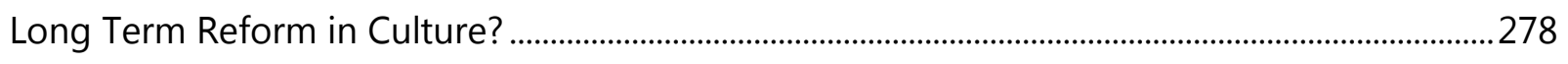


Conclusion .280

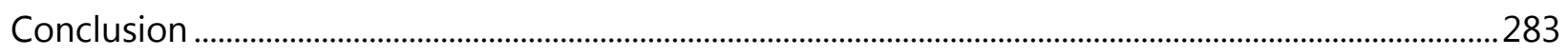

Dutch Health Care 1848-2015: Access to Health Care under a Banner of Private Initiative...........283

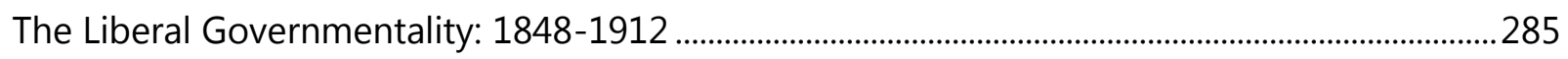

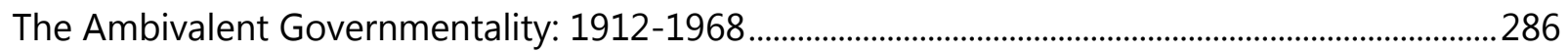

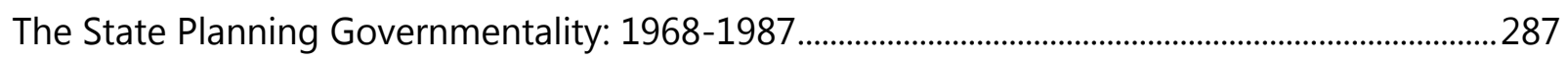

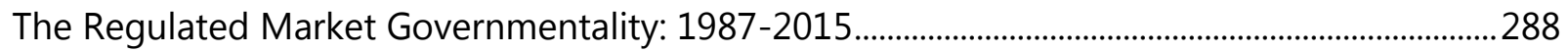

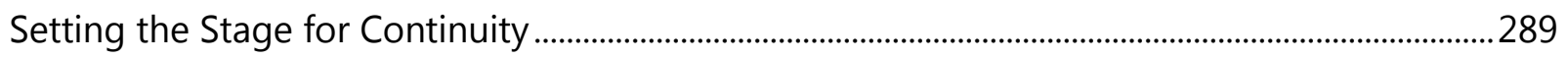

New Realities Filtered through the Old Rhetoric...............................................................................290

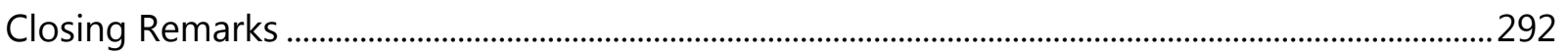

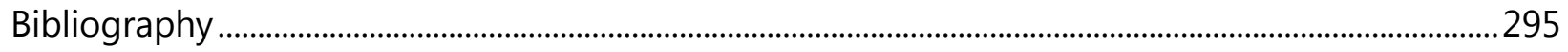

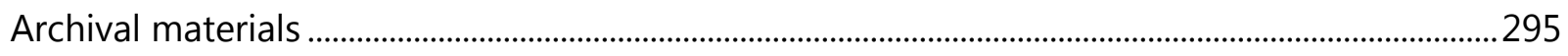

Parliamentary documents ............................................................................................................... 296

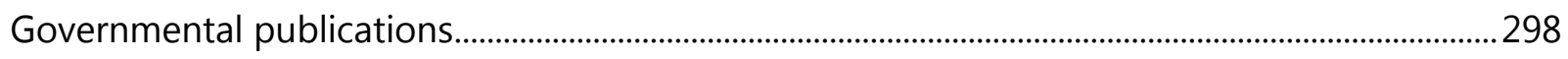

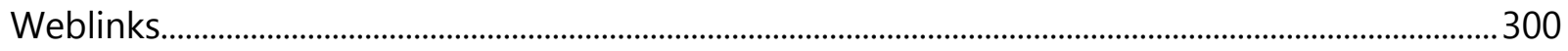

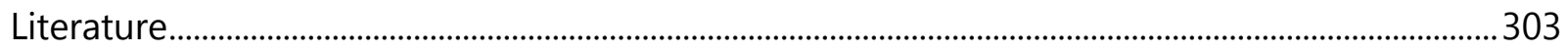

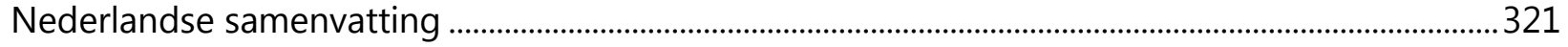

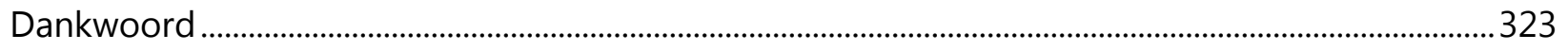

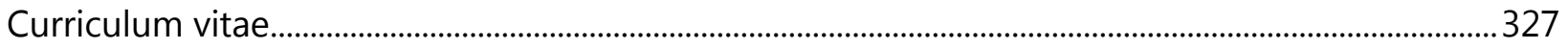




\section{Tables and figures}

Fig. I The four governmentalities of Dutch health care and the state

Table 2.1 Founding of new Cross Associations, 1890-1929

Table 2.2 Growth of sickness fund coverage, 1891-1941

Table 2.3 Boarding out of patients by municipal governments, 1914-1940

Table 2.4 Revenue streams of the Cross Associations in 1940

Table 2.5 Average expenditure per mandatory enrollee at sickness funds, in guilders ( $\left.f_{-}-\right), 1942-$ 1950

Table 2.6 Share of total health care costs in \%, 1953-1968

Table 2.7 Financing of the local Cross Associations in \%, 1957/1968

Table 2.8 Health care expenditures in guilders $(f,-), 1953-1968$

Table 2.9 Average expenditure in millions of guilders $(f,-)$ per mandatory enrollee at sickness funds, 1959-1967

Table 2.10 Doctors in The Netherlands, 1942-1960

Table 3.1 Health care expenditures in guilders x million (f.-), 1972-1980

Table 3.2 Health care expenditures in guilders x million (f.-), 1982-1988

Table 4.1 Number of sickness funds and private insurers, 1986-1996

Table 4.2 Estimated and actual volume growth in health care, 1990-2002

Fig. 4.3 The three markets comprising the 'regulated health care market'

Fig. 4.4 Market shares on the health insurance market, 2018

Fig. 4.5 Projected and Actual Health Care Expenditures under Mandatory Public Insurance (x billion, net costs), 2006-2018

Fig. 4.6 Distribution of Health Care Expenditures by Compartment in 2018 


\section{Introduction}

\section{The Longue Durée of Dutch Health Care: Culture, Ideology and Legislation 1848-2015}

"If we understand the nature of our legal argument better, we know better what kind of people we are."

Do systems have cultural and ideological histories? This abstract question lies at the heart of this dissertation, which takes a long term perspective in tracing the origins of Dutch health care provisions and the way in which access to them has developed in roughly the previous century and a half (1848-2015). This study was born out of earlier research which focused on the way in which health care came to be conceptualized in terms of a 'market' from the early 1980s onwards, after growing resistance to top-down control over the Dutch health care system. ${ }^{2}$ This research focused primarily on political and institutional developments in the field of health care: changes in the insurance system on the one hand, and the (fraught) way in which politicians tried to change the Dutch health care system from the late 1980s onwards. Within these developments, however, changing mentalities concerning how the system should best be governed also turned out to play a crucial role. More in particular, my attention was drawn to the fact that the practical changes taking place in this period were driven not just by a long institutional history, but also by cultural factors forming a foundation of ideological possibilities for change. This foundation consisted (and consists) of societal and cultural values and tendencies growing over a long time and expressing themselves in the broad arena of Dutch society, but also in the workings of the actors operating within health care - sickness funds, insurance companies, hospitals, care providers - as well as the general populace.

These values pertain to a vast and complex array of developments - the growth of, and desire to access, increasingly efficacious Western medicine in the past century and a half; social and economic changes calling for new types of security in the form of health insurance; the rise of complex and expensive institutions such as the hospital; but also evolving notions of personal and/or collective responsibility for health, the role of the state in providing a safety net for those struck by ill fortune, and the necessity to manage a health care system which from the 1970s

\footnotetext{
${ }^{1}$ Ronald Dworkin, Law's Empire (Oxford: Hart Publishing, reprint 1998) p. 11.

2 R. Bertens, Gezondheid tussen staat en markt. De opkomst van het marktdenken in het Nederlandse zorgstelsel, 1974-1987 (MA thesis: Universiteit van Amsterdam 2015); R.M. Bertens, Care, Cost and Questions of Control. Dutch Health Care Reform 1987-2006 (MA thesis: Utrecht University 2016).
} 
onwards became increasingly expensive. Tracing the way in which these values and developments evolved and influenced each other and the field of health care provisions called for going back to their 'roots' in the middle of the $19^{\text {th }}$ century (a choice I will expand on further on in this introduction). Doing so, moreover, seemed of the utmost historical interest. This is because their specificity within the Dutch context has led to striking developments in the past and present.

The most recent of these is what can be seen as an odd paradox in the way Dutch health care has been organized since 2006, of a health care market strongly embedded in governmental regulations. In that year, a health insurance system came into effect which created basic curative insurance for $100 \%$ of the Dutch population, covering nearly everything available in terms of efficacious modern (Western) medicine. This was absolutely unprecedented in The Netherlands. Before 2006, social health insurance for curative care was mandatory for some $70 \%$ of the population on the basis of the 1964 Sickness Fund Act (itself an updated version of the 1941 Sickness Funds Decree), with the remainder of the population having to insure themselves privately on a private health insurance market. ${ }^{3}$ Universal public insurance covering long-term 'care' for chronic illness and handicaps had already been in existence since 1968. The 2006 system overhauled this distribution radically: in creating a mandatory basic insurance scheme for every Dutch citizen, the distinction between private and public insurance was dissolved, while at the same time 'health care solidarity' within the system was enshrined to an unprecedented degree. $100 \%$ of the Dutch citizenry - defined as living within The Netherlands - was now mandatorily insured in a system with mechanisms built in to equalize expenses and guarantee access. The 2006 Health Insurance Act codified risk solidarity by instituting equal premium setting for young and old, healthy and sick, for the basic package, while income-related premiums and a scheme of government subsidies makes these premiums affordable for those under a certain level of income, creating income solidarity and allowing for affordable and equal access to quality health care for all. The coverage of the mandatory basic package is very extensive and is set by government - not insurers, all of whom must offer everything in the basic package and can only offer supplementary insurance for the small amount of health care provisions excluded from it. ${ }^{4}$ Care for those under 18 is reimbursed by the state, and health differences in insurers' respective populations are compensated through a Risk Equalization

\footnotetext{
${ }^{3}$ For a graph on social vs private insurance coverage in The Netherlands between 1935 and 2005, see R.A.A. Vonk and F.T. Schut, 'Can universal access be achieved in a voluntary private health insurance market? Dutch private insurers caught between competing logics', Health Economics, Policy and Law 14 (2019) 315-336, 317.

${ }^{4}$ Partly excluded (and therefore eligible for supplementary insurance) are certain types of dental care, physical therapy, alternative medicine, as well as copayments for lenses/eyeglasses and non-generic drugs.
} 
Scheme. ${ }^{5}$ By and large, a mandatory system of such wide scope and coverage can easily be designated 'social health insurance'.

And yet, if we look at the way the system is governed, the official term used is that of a 'regulated health care market'. Since 2006, private health insurers have been designated the 'directors' of health care, competing on premium prices for the basic insurance and (limited) supplementary insurance, while at the same time negotiating with care providers over the best services at the lowest prices. The philosophy underlying this system is to be found in its original 1987 blueprint, which noted: "The opinion has taken hold that a regulating, planning and paternalistic government should retreat in order to make place for a form of governance ['beheersmodel', RB] in which the state creates preconditions and the health care sector itself puts things in order." ${ }^{6}$ But the system codified in 2006 hardly pushed government out of the health care field in favor of private parties. Along with the Health Insurance Act, the Act on Market Regulation in Health Care came into force, creating the National Health Care Authority. ${ }^{7}$ This governmental body is tasked with stimulating competition on the markets for health insurance and health care provision, and has come to supplement the age-old State Inspectorate for Health Care traditionally tasked with regulating the quality of health care.

Overall, in 2006 the role of central government as a powerful guardian was therefore strengthened, guaranteeing broad accessibility, equal quality of care everywhere in the country, and keeping down the overall costs of the system through covenants, setting limits on prices for health services, and other measures. And indeed, entrepreneurial freedom in the private health insurance field has become far more restricted than before, with the most obvious 'social' aspect being that insurers have an obligation to insure anyone who applies for the basic package, ruling out risk selection - the denying of coverage to unhealthy or ill, and therefore expensive, clients. Most insurers also follow a non-profit policy, though they are not legally bound to do

\footnotetext{
${ }^{5}$ All of this applies to 'curative' care covered by the Health Insurance Act. The Act on Exceptional Medical Expenses of 1968 (mentioned above) remained in existence until 2015, when serious changes were set in with the introduction of the Wet langdurige zorg (Act on Long-Term Care). This scheme is financed through income premiums and has been mandatory for every Dutch citizen since its inception. Public insurance for long-term care has historically been very generous in The Netherlands, comparatively speaking, and for the previous decades has on average accounted for some $25-30 \%$ of all health care costs. For a quick overview of the system, see Ministerie van Volksgezondheid, Welzijn en Sport, Het Nederlandse Zorgstelsel (Den Haag: Ministerie van Volksgezondheid, Welzijn en Sport 2016) specifically p. 3-15. (https://www.rijksoverheid.nl/documenten/brochures/2016/02/09/het-nederlandse-zorgstelsel; https://international.commonwealthfund.org/countries/netherlands/, both accessed on 17-7-2019).

${ }^{6}$ Commissie Structuur en Financiering Gezondheidszorg (chair: W.P. Dekker), Bereidheid tot verandering ('s-Gravenhage: Distributiecentrum Overheidspublikaties 1987), 7-8.

${ }^{7}$ In Dutch: Zorgverzekeringswet; Wet marktordening gezondheidszorg; Nederlandse Zorgautoriteit; Inspectie voor de Gezondheidszorg en Jeugd (historically: Staatstoezicht voor de Volksgezondheid; Inspectie voor de Gezondheidszorg).
} 
so. ${ }^{8}$ Health care providers, for their part, are expected to provide high-quality services guaranteed by scrutinous visits from the State Inspectorate, Ministerial injunctions, fines, or even the closing down of their hospital department or medical practice. ${ }^{9}$ As a result, competition on the quality of care is also limited. Perhaps most significant, the general budget for health care is set at the Ministry of Health Care, with the responsibility of staying within the budget laid at the doorstep of insurers and care providers (on pain of being shorted financially in the following year). Given all this, the 2017 version of the standard handbook for health care law in The Netherlands states that:

The Act on Market Regulation [...] does not embody the freedom of market parties as much as the regulations and limits that government sets to make sure that the use of such freedoms serves the public interests of accessibility, affordability and quality of care. [...] We can also observe that both health care providers and health insurers are confronted with farreaching and costly obligations concerning administration, cost declaration, payment, supervision and the passing on of data to the Care Authority and other institutions. ${ }^{10}$

\section{Research Questions}

All this regulation leads to questions concerning the 'odd paradox' I mentioned above. Contrary to a clichéd image of capitalist markets running amok in driving up health care costs and prices, limiting access for already ill patients, and allowing private insurers and providers to turn large profits, the system instituted in 2006 seemed to embody both the desire for strong government oversight to guarantee equal access to a vast array of health services, as well as a governance structure not marked by central government being in control over the day-to-day practice of health care delivery and financing. However, it is clear that in a highly regulated system in which

\footnotetext{
${ }^{8}$ Moreover, at the time of writing (November 2019), a legislative proposal to create opportunities for making profits in hospital care has just been scrapped, while a proposal is being debated in Parliament which would prohibit the turning of a profit for insurers. For the former, see https://www.nrc.nl/nieuws/2019/10/28/kabinet-trekt-voorstel-voor-winstuitkering-in-ziekenhuiszorg-ina3978265 (28-10-2019). For the latter, see Kamerstukken II, 2015-2016 34522, no. 2.

${ }_{9}^{9}$ All of this on the basis of legislation which mostly finds it origins in the 1990s, when the move towards the health care market was already being prepared, and 'deregulation' was the ostensible watchword. See the Act on Quality, Complaints and Conflicts in Health Care (Wet kwaliteit, klachten en geschillen zorg, the 2016 successor of the 1997 Act on Quality in Health Care Institutions; Kwaliteitswet zorginstellingen 1997); the Act on Professions in Individual Health Care (Wet op de beroepen in de individuele gezondheidszorg) of 1994; Act on the Medical Care Agreement (Wet op de geneeskundige behandelingsovereenkomst of 1994, the seminal act enshrining patients' rights), and more.

10 J.C.J. Dute and J. Legemaate (eds.), Handboek gezondheidsrecht (Den Haag: Boom Juridisch; 7th edition 2017) 744.
} 
quality of care is maintained on an equal level nationwide, and in which foundational tenets of solidarity and equality severely limit differentiating between wealthier and poorer patients, the scope for true market competition through price or quality differentiation is limited. Moreover, in the build-up to the introduction of the 'market' in 2006, many of the structures in Dutch society that traditionally governed the health care field were abolished, shifting the responsibility for keeping the system in control primarily to bodies directly reporting to the Minister for Health (such as the Health Care Authority) and insurers - four of which by the end of 2018 accounted for $86,5 \%$ of the total health insurance market. ${ }^{11}$ Between an oligopoly of (mostly) non-profit insurers and a very strong regulatory presence for government, the 'market' part seems less relevant than the 'regulated' part in the 'regulated health care market' introduced in 2006. This is not to make a mockery out of the notion of the market in health care, but rather to illustrate elements which can seem paradoxical to anyone using the notions 'state' and 'market' in an everyday sense - that is, to quite an extent opposed. How can we explain such a seemingly convoluted mix of government-backed social insurance, administered by private insurers and provided by (mostly) private health care providers, and presented under a guise of 'market mechanisms' $?^{12}$ Add to these questions the fact that the system change of 2006 - the biggest one since 1941 - was enacted by Liberal Minister of Health Care Hans Hoogervorst. ${ }^{13}$ From the point of view of a political liberalism generally arguing for a small government and maximum freedom for individual citizens, a typical Liberal should have balked at the mere notion of government forcing mandatory health insurance onto every citizen, while effectively forcing wealthy citizens to subsidize poor ones. ${ }^{14}$

General remarks about health care systems elsewhere immediately point to the significance of nation-specific political and cultural notions about the role of the state versus the

\footnotetext{
${ }^{11}$ In 2018, there were a grand total of 23 health insurers falling under 10 concerns. See Nederlandse Zorgautoriteit, Monitor Zorgverzekeringen 2018 (Nederlandse Zorgautoriteit: Utrecht 2018) 5-7 (https://puc.overheid.nl/nza/doc/PUC 254666 22/1/, accessed on 17-7-2019).

12 This paradox or apparent incongruence of the strong or regulatory state in more market-oriented health care systems has been discussed by other authors. See: P. Hassenteufel et al, 'Programmatic Actors and the Transformation of European Health Care States', Journal of Health Politics, Policy and Law 354 (2010) 517-538; J.K. Helderman, G. Bevan, and G. France, 'The rise of the regulatory state in health care: a comparative analysis of The Netherlands, England and Italy', Health Economics, Policy and Law 7 (2012) 103-124.

13 'Liberal' in the sense of classical political liberalism, the philosophy espoused by Hoogervorst's People's Party for Freedom and Democracy (VVD).

${ }^{14}$ These premiums amounted to some $€ 1.000$ on a yearly basis already in 2006 . https://www.cbs.nl/nlnl/nieuws/2014/50/premie-basisverzekering-bleef-lange-tijd-gelijk-vermogens-van-zorgverzekeraarsstegen, accessed on 15-07-2019. Between 2011 and 2014, the average yearly premium for the basic insurance even rose to $€ 1.300$, and in 2008 , deductibles were introduced to raise cost-awareness on the side of patients (as of 2016 , at a minimum of $€ 385$, to be raised to a maximum of $€ 885$ at the insured's request).
} 
responsibilities of individual citizens in taking care of their own health and well-being. Vast differences between national health care systems alert us to the fact that though, by and large, Western industrialized nations (with the US as a notable exception) spend comparable percentages of GDP on health care provisions and witness similar life expectancies in their populaces, the way in which these provisions are offered and accessed differ vastly. ${ }^{15}$ If intercultural comparisons offer anything, the debate in recent years (and decades) in the United States on health care as a federal task can serve as a prime illustration of opposition to such schemes from political parties wary of government intervention in the private lives of citizens. ${ }^{16}$ The US and The Netherlands are wealthy nations practically capable of granting access to the same medical-scientific technologies and services to their populations. And yet, the way in which their respective health care systems are organized because of political and cultural considerations results in over $10 \%$ of the American population remaining uninsured for health care costs at the time of writing. ${ }^{17}$ To give another example: Canada, which is often seen by Americans as a country with 'socialized health care', offers its citizens many health provisions through federal legislation, but still some $30 \%$ of all costs are covered through private insurance. ${ }^{18}$ In the European context, health care systems can be vastly different from each other for a variety of reasons. Since its introduction in 1946, the UK has had a public, single-payer system in the form of the National Health Service. Health care providers are civil servants, and contrary to The Netherlands, Germany, and France (to name but a few) health care is paid for through general taxation, not via a mixture of employer, employee, and government contributions. Such a nationalized system seems an odd phenomenon for the historical birthplace of political liberalism. And yet, historical research can provide explanations for such

\footnotetext{
15 The OECD notes that for the top 15 biggest spenders in health care worldwide (with only Japan and the US lying outside continental Europe and the UK), in 2016 at least 10,4\% of GDP was spent on this sector, with the OECD35 average hovering around 9\%. In this inventory, the OECD arrived at 10,5\% of GDP in The Netherlands ( $8^{\text {th }}$ place), and $17,2 \%$ in the US (1 ${ }^{\text {st }}$ place). (https://read.oecd-ilibrary.org/social-issuesmigration-health/health-at-a-glance-2017/health-expenditure-as-a-share-of-gdp-2016-or-nearestyear health glance-2017-graph112-en\#page1, accessed on 6-8-2019). For life expectancy, see https://data.oecd.org/healthstat/life-expectancy-at-birth.htm.

${ }^{16}$ For a history of the American context, see B. Hoffman, Health Care For Some. Rights and Rationing in the United States since 1930 (Chicago: University of Chicago Press 2012).

${ }^{17}$ August 2019; for an overview of coverage (though figures differ somewhat) see e.g. E.R. Berchick, E. Hood and J.C. Barnett, Health Insurance Coverage in the United States: 2017. Current Population Reports (U.S. Government Printing Office: Washington, DC 2018); https://www.commonwealthfund.org/blog/2018/first-look-health-insurance-coverage-2018-finds-acagains-beginning-reverse; https://www.nytimes.com/2019/01/23/upshot/rate-of-americans-withouthealth-insurance-rising.html, both accessed on 6-8-2019.

${ }^{18}$ A. Maioni, Health Care in Canada (Oxford: Oxford University Press 2014) 37-38, 50, 80.
} 
seeming incongruences, placing national developments within broader international contexts and thereby illustrating both similarities and unique local situations. ${ }^{19}$

The reasons for such differences are manifold, but cannot be understood without looking into each system's long term historical background, in which developments in medicine, political constellations, economic welfare (or woes), and ideological notions of state and citizen responsibility intersected. As for The Netherlands, the system reform of 2006 is only one of the most recent outcomes of these developments recombining over time, much like the 1946 construction of the NHS in the United Kingdom, the 1984 introduction of the Canada Health Act in that country or the 2011 introduction of the Affordable Care Act in the USA. The Dutch case of a health care field 'directed' by health insurers and health care providers, but under the wings of a very influential government, is the result of a very long institutional and political-ideological gestation period. The ideas that led to both solidarity in access and price, as well as to market mechanisms for governing the system did not come out of thin air, and investigating them was the direct motivation for delving into the longer history of government, the health care 'field', and evolving ideological and cultural notions concerning the relationship between these two entities and the citizenry. If we go back to foundational notions of how government should operate with regard to those sectors of society providing 'social services' - which allow citizens to take a productive part in society - we see that the groundwork for this relationship with health care was laid in 1848, with the coming into force of a new constitution for The Netherlands. As a result, the scope of this dissertation stretches from that year to 2015 - which saw the most recent reordering of health care along what can be called both economic and ideological lines. And the questions guiding this dissertation can be summarized as follows:

"How have Dutch health care provisions developed under shifting political-ideological and legal constellations in the period 1848-2015? How did cultural and institutional developments impact the accessibility of health care? And how did consecutive philosophies for governing health care as a function of public government, civil society and private initiative influence the way in which health care institutions were organized in this period?"

\footnotetext{
${ }^{19}$ For an international discussion of health care as an element of 'citizenship' in the West, and the historical development of how this understanding has become embedded in health care systems see: $\mathrm{H}$. Oosterhuis and F. Huisman, 'The Politics of Health and Citizenship: Historical and Contemporary Perspective', in: F. Huisman and H. Oosterhuis (eds.), Health and Citizenship: Political Cultures of Health in Modern Europe (Abingdon: Routledge 2015) 1-40, specifically p. 1-4, 31-37.
} 


\section{The Analytical Toolkit of Governmentality/Governance}

As can already be inferred from the paragraphs above, this research stems in part from dissatisfaction with the terminology dominating current debates on state and market, public and private, when discussing something as layered as the configuration of health care in The Netherlands. More often than not, the monolithic and usually opposing notions of 'state' or 'market' serve to bring little clarity to our understanding of something as vastly complex as a health care system - both in The Netherlands and abroad. Moreover, the ways in which public services are carried out by market parties have in the past decades increasingly been cast in the framework of 'neoliberalism'. This is often taken as an apparently cogent and recognizable political ideology, in which a renewed liberal political-rhetorical dominance - liberals by and large supporting a small state - has seemingly been supplemented by the belief that markets in which goods and services are produced by private parties under competitive parameters are more efficient and cheaper than complex governmental bureaucracies. This in turn has called for governmental policies which focus on deregulation, privatization and an increase of power for market parties. These policies were mostly instituted in the 1980s and 1990s in many countries in the Western industrialized world - the United States and the UK foremost, under the respective reigns of Ronald Reagan and Margaret Thatcher. ${ }^{20}$ This notion of 'neoliberalism' seems limited at best as an analytical concept. Not only is liberal dominance a highly tendentious claim (even within the US and the UK, which saw Democratic and Labor parties in power in the 1990s and 2000s), but the notion of the 'market' as monolithically opposed to the 'state' glosses over the enormous complexities and ways in which public provisions and market parties are intertwined, as I have sketched out in the first paragraph above.

Nevertheless, the notion has proven useful in raising the question as to how, then, the complex interplay of state and market or public and private parties can be understood over time in the 'social' field of health care provision. Giving theoretical guidance to research is inevitable, if only to conceptualize vastly complex systems made up out of countless actors and accounting for enormous economic and social developments over time. An option for dealing with this is to set out a theoretical framework which allows for the testing of hypotheses. However, the complexity of studying the intermingling of political ideology and legislation with cultural values

\footnotetext{
20 For a nuanced discussion of the background and general characteristics of the neoliberal 'framework', see A. Gamble, 'Ideologies of governance', in: A. Payne and N. Phillips (eds.), Handbook of the International Political Economy of Governance (Cheltenham: Edward Elgar 2014) 13-31, 19-29. For critical discussions of the analytical limits and abuses of the concept, see: R. Venugopal, 'Neoliberalism as concept', Economy and Society 442 (2015) 165-187; T. Flew, 'Michel Foucault's The Birth of Biopolitics and contemporary neoliberalism debates', Thesis Eleven 1081 (2012) 44-65; M. Oudenampsen and B. Mellink, 'Voorbij de controverse: het Nederlandse neoliberalisme als onderwerp van onderzoek', Beleid en Maatschappij 462 (2019) 235-254.
} 
in the long evolution of a health care system offers serious challenges to attempts at such testing. Causal factors seem too complex and numerous, and definitions too constricting. Instead, my approach has been a more flexible and pragmatic one, making use of French philosopher Michel Foucault's notion of 'governmentality', as well as later iterations of that concept in the social sciences' use of the term 'governance' - a term which has gained currency in recent decades. ${ }^{21}$ Commenting on the growth of a new form of (liberal) political statecraft in the late 1970s, Foucault sought to uncover the way in which states and markets coincide in Western post-war nations, as well as the way in which these markets are often the result of conscious construction by the state. "There will not be the market game, which must be left free, and then the domain in which the state begins to intervene, since the market, or rather pure competition, which is the essence of the market, can only appear if it is produced, and if it is produced by an active governmentality." 22 This is a far cry from the classical view of economic marketplaces as free arenas, unfettered by state intervention. ${ }^{23}$ And as I have already sketched in the introductory discussion of the 'regulated market' introduced in 2006 in Dutch health care, the extent to which the system is constructed and regulated by government makes simplistic notions of 'state' versus 'market' implausible and not very useful as either analytical categories or terms with which the health care system can be understood in a quotidian, everyday sense. This criticism also holds in analyzing older relationships and structures in (Dutch) health care, as public and private, 'market' and 'state' already became deeply intertwined in the way in which insurers, providers and other health care institutions during the past century and a half came to face a government which increasingly saw the provision of health care as a social task and a responsibility of the collective.

Instead of a testable theory offering binary outcomes, what seems called for is therefore a sensitivity for re(de)fining what governmental and/or market/private power actually meant in the historical practice of Dutch health care. Here, Michel Foucault's notion of 'governmentality' can play an important role in fostering such a sensitivity. Foucault saw 'governmentality' as the 'art of government', much more than the specific definition of governmental power as exerted through set norms, legislation, punishment and other instruments. He incorporated this notion

\footnotetext{
${ }^{21}$ D. Levi-Faur, 'From "Big Government" To "Big Governance"?', in: D. Levi-Faur (ed.), The Oxford Handbook of Governance (Oxford: Oxford University Press 2012) 3-18, 5-6. See also N. Phillips and A. Payne, 'Introduction: the international political economy of governance', in: N. Phillips and A. Payne (eds.), Handbook of the International Political Economy of Governance (Cheltenham: Edward Elgar 2014) 1-9. P. 1: "It is almost too easy to introduce a book of this sort by invoking yet again the ubiquity that the term 'governance' has achieved across the social sciences since the 1990s [...]".

22 M. Foucault, The Birth of Biopolitics. Lectures at the Collège de France 1978-1979 (New York: Picador 2008; transl. G. Burchell), 121. See for elaboration - also where social policies such as the provision of health care are concerned - p. 131-147.

${ }^{23}$ Of course, often referred to in a hackneyed manner as the 'invisible hand' guiding the market, as set out by Adam Smith in his 1776's An Inquiry into the Nature and Causes of the Wealth of Nations.
} 
into his general body of works focusing on the exertion of power in human relations (often focusing on the Early Modern Period, that is until the late $18^{\text {th }}$ century). ${ }^{24}$ However, for the purposes of this dissertation, I will limit the scope of this term, using a conceptualization he employed to discuss post-war, burgeoning 'neoliberal' states in the Western world. In typical Foucauldian language - not generally known for its clarity - Foucault in 1978 typified the meaning of the 'state' and governmental power in this context as follows:

The state is not a universal nor in itself an autonomous source of power. The state is nothing else but the effect, the profile, the mobile shape of a perpetual statification (étatisation) or statifications, in the sense of incessant transactions which modify, or move, or drastically change, or insidiously shift sources of finance, modes of investment, decision-making centers, forms and types of control, relationships between local powers, the central authority, and so on [...] The state is nothing else but the mobile effect of a regime of multiple governmentalities. ${ }^{25}$

These claims, though somewhat obscure, provide a way for breaking open the idea that relationships between 'the' state and society should be seen as one-way, binary, or top-down affairs. To further clarify Foucault, we may supplement 'governmentality' with the more recent notion of 'governance'. In recent decades, 'governance' has gained currency in social and political science circles as a way to study policy-making and mechanisms of (political) action outside of the scope of government, traditionally defined. For instance, the 2012 Oxford Handbook of Governance in this regard speaks of governance as a 'science of shiftology': "Governance signifies a change in the meaning of government, referring to new processes of governing; or changed conditions of ordered rule; or new methods by which society is governed." 26

This makes 'governance' as a concept a prime instrument for historical analysis of change over time, and as we shall see, it is precisely such shifting processes, conditions and methods for governing and achieving public goals which clearly come to the surface at various points in the history of Dutch health care. At the same time, such shifting always leads to a complex new interplay of private and public interests and players, without any one specific actor or 'decisionmaking center' gaining the upper hand. This does, however, make 'governance' a somewhat

\footnotetext{
${ }^{24}$ For earlier discussions of the term: M. Foucault, Security, Territory, Population. Lectures at the Collège de France, 1977-1978 (Basingstoke: Palgrave Macmillan 2009; transl. G. Burchell); and specifically M. Foucault, 'Governmentality', in: G. Burchell, C. Gordon and P. Miller (eds.), The Foucault Effect. Studies in Governmentality (Chicago: The University of Chicago Press 1991) 87-104, in particular pp. 102-103.

${ }^{25}$ Foucault, Biopolitics, 77.

${ }^{26}$ R.A.W. Rhodes, 'Waves of Governance', in: Levi-Faur, Handbook of Governance, 33-48, 33.
} 
slippery concept: if it is everything, it runs the risk of being nothing. ${ }^{27}$ However, some examples illustrate what types of changes are at stake:

Some of the most dominant ways to think about shifts in governance include a shift from politics to markets, from community to markets, from politicians to experts [...] from Big Government to small government; from the national to the regional [...] from hard power to soft power, and from public authority to private authority. ${ }^{28}$

As we shall see, many of such types of shifts actually took place during the long evolution of health care and access to it in The Netherlands. However, it is only through historical analysis that abstract notions of 'governmentality' or 'governance' can become empirically grounded. In this dissertation, the types of shifts mentioned above will therefore be made explicit where necessary. Lastly, focusing on governmentality and governance allows a focus on factors outside of 'hard' political or economic developments which are seemingly paramount in influencing the way in which systems develop:

Governance can be seen at its simplest in relation to associations of various kinds. It provides a set of rules which defines the aims of the association, establishes the offices for carrying them out and lays down how the holders of these offices should be selected, what their duties are and how they are to be made accountable for what they do. Such rules prescribe behavior, set limits, create expectations and establish benchmarks [...] governance can be defined through formal constitutions, but will also depend on a much looser set of arrangements resting on traditions, conventions and precedents. ${ }^{29}$

Investigating the history of health care institutions and provisions provides the researcher with easy points of entry in the form of laws, which lay down the sets of rules, aims, offices, duties, accountabilities etc. aimed at achieving politically defined goals such as tasking certain institutions with providing health care or instituting mandatory insurance arrangements. Examples of these are the 1865 Act on State Medical Supervision, the 1941 Sickness Fund Decree or the 2006 Health Insurance Act. But significantly, broader notions of 'governance' look beyond the legalistic, focusing also on the traditions, conventions and precedents mentioned above. As we shall see, the strong forms of solidarity currently enshrined in the Dutch health care system have a long history, and more often than not influenced legislation rather than resulted from it. And these forms of solidarity can be traced to the way in which various actors in

\footnotetext{
27 See Perri 6, 'Governance: if governance is everything, maybe it's nothing', in: A. Massey and K. Johnston, The International Handbook of Public Administration and Governance (Cheltenham: Edward Elgar 2015) 5680.

${ }^{28}$ Levi-Faur, "Big Government" to "Big Governance", 7.

${ }^{29}$ Gamble, 'Ideologies of governance', in: Phillips and Payne, International Political Economy of Governance, 13-31, 15.
} 
health care - such as municipalities and private sickness funds - chose to act, not seldom stretching the interpretation of extant legislation to suit certain social goals deemed worthwhile.

Taken together, these definitions provide a way forward in gaining a nuanced understanding of the legal but also of the practical shifts in power, governance, and the financing of health care and its institutions over time. Moreover, given the way in which the state came to involve itself in the purposes of health care (fostering the population's health), as well as in the governing and financing of its institutes from about the middle of the $19^{\text {th }}$ century, we can extend these notions to analyze the relations between government and health care over a longer period of time than just the most recent 'neoliberal' era. In the Dutch context, nuancing monolithic notions of 'state' and 'market' is particularly fruitful, given how the literature often speaks of a strong, historically grown tradition of 'corporatism' in Dutch health care. ${ }^{30}$ This corporatism entailed the strange and not always harmonious marriage between central and local or regional governments on the one hand and (groups of) actors in health care on the other, actors such as sickness funds, private insurers, medical-professional associations and health care institutions. ${ }^{31}$ The ebb and flow of how these parties interacted calls for a much more fluid understanding of what constitutes decision-making centers and a realization that 'power' is highly relative in a field in which economic, social and political elements intersect to a large extent. At the same time, highlighting shifts in practical funding and governance arrangements may nuance one-sided notions of 'public' versus private' - or communal versus individual. We will see this in the way in which government increasingly came to subsidize and provide for health care from the early $20^{\text {th }}$ century onwards.

'Governance' and 'governmentality' should therefore be seen as analytical tools for modifying untenably monolithic notions of 'state', the 'market', the 'field' of health care, etc., both historically and in the present day. They may be used as searchlights which should not only focus our attention on shifts in power, decision-making, financing and more, but also on the limited use of 'state' and 'market' in complex systems. Where legislative changes or visible (re)distributions of power and responsibilities take place, I will in this dissertation often refer to these as shifts in 'governance' in this dissertation. The term 'governmentality' offers something

\footnotetext{
30 T.E.D. van der Grinten and J. Kasdorp, 25 jaar sturing in de gezondheidszorg: van verstatelijking naar ondernemerschap (Den Haag: Sociaal en Cultureel Planbureau 1999); M. van Bottenburg, G. de Vries and A. Mooij, Zorg tussen staat en markt. De maatschappelijke betekenis van de Ziekenfondsraad 1949-1999 (Zutphen: Walburg Pers 1999); R. Vonk, Recht of schade? Een geschiedenis van particuliere ziektekostenverzekeraars en hun positie in het Nederlandse zorgverzekeringbestel, 1900-2006 (Amsterdam: diss. University of Amsterdam 2013). For a short overview in English, see: C.H. Tuohy, Remaking Policy. Scale, Pace and Political Strategy in Health Care Reform (Toronto: Toronto University Press 2018), 106-109. ${ }^{31}$ For the pervasive thesis that this corporatism resulted from the history of religious division and political tolerance in The Netherlands, see e.g. K. van Kersbergen, Social Capitalism. A study of Christian democracy and the welfare state (Abingdon: Routledge 1995; reprint 2007) 43-46, 68-73.
} 
more, however. Not just 'governance', but also its underlying 'mentality' can be read in the term. This points to the more political-ideological or cultural underpinnings of the governing of complex systems. But shifts in complex systems are often slow-moving. This brings me to the second undercurrent of this dissertation.

\section{Bringing Back the Longue Durée: Periodizing Dutch Health Care}

This undercurrent is what underlies the choice for focusing on a period of more than 150 years, but it is also something of a promise. My goal has been the renewal of a focus on longue durée developments, as opposed to history which focuses on short term developments. First elaborated by French historian Fernand Braudel in his magnum opus La Méditerranée et le monde méditerranéen à l'époque de Philippe II, the longue durée approach proposes precisely that: only in taking a long term perspective do certain historical developments become clear to us. Braudel's interpretation of the longue durée was rather ambitious, as it spanned millennia. Few historical studies have taken their cue from Braudel in taking such a long time-frame. Nonetheless, in recent decades, even time-scales of centuries or decades - Braudel would have termed the latter histoire évenementielle - have gone out of fashion in (cultural-)historical research, influenced by developments such as micro history. Books written within this frame typically take as their focal point very short time spans, or very specific events or persons.

Recently, however, the focus on the longer time scale has been re-appraised by eminent historians Jo Guldi and David Armitage, who wished to once again make history relevant to policy-makers and the public at large by zooming out and allowing for insights gleaned from longer developments. "[...] historians once told arching stories of scale but, nearly forty years ago, many if not most of them stopped doing so." 32 This is a problem, as it has led to a widening of the gap between the academic writing of history and histories which can (and should) appeal to and inform a broader audience. Moreover, analytically speaking a focus on the short term pigeonholes the historian writing about very specific topics or timeframes. Though Guldi and Armitage also don't adhere to Braudel's original notion of the longue durée as timespans of millennia, their programmatic message is to warn against the dangers of historical myopia inevitably brought on by increasing specialization and a narrow focus in time or subject matter:

A lost sense of public purpose; a weakening grasp on the big picture; exploding scholarly productivity [...] a proliferation of 'histories' rather than 'history'; greater prestige for novelty and discovery rather than synthesis and theory: all these are familiar features of the human sciences in the late twentieth and early twenty-first centuries [...] The challenge now is to

32 J. Guldi and D. Armitage, The History Manifesto (Cambridge: Cambridge University Press 2014) 7. 
hold on to the palpable benefits of professionalism while also recovering connections with a broader public mission [...]. ${ }^{33}$

It seems a worthy cause to bring history back to a broader audience and to serve this 'public mission', and that is partly one of the goals of this dissertation. In the case of the broad topic at hand - the development over a century and a half of political-ideological thinking, social processes, scientific developments and mentality shifts - one might argue that current-day medicine and complex Western health systems are lightyears removed from the state of affairs in the middle of the $19^{\text {th }}$ century. This is how the longue durée should be understood in this dissertation. Though not without its limitations, taking a long perspective in analyzing something as complex as a health care system allows one to trace its foundational tenets, or even its specific 'identity'. These foundational aspects to the 'identity' of a system only show themselves to us when we take the long view.

Applying the conceptual lens of governmentality to the longue durée of Dutch health care and the state does indeed offer us fundamental new insights. This dissertation will shine a light on a great and recurring discrepancy between the political and public rhetoric concerning the role of the state, power relations, responsibilities, rights and more vis-á-vis health care, and the reality of how access to care and its governance and financing increasingly became a governmental affair in the period 1848-2015. The first term is not to be taken in a flippant or derogatory way, implying that, for instance, political parties employed hollow 'rhetoric' in pushing their political agenda. Rather, the term as used here also serves the longue durée perspective. In this dissertation, 'rhetoric' will be employed to refer to political and cultural ideas on the desired role of the state with regards to health care, which were broadly dominant in Dutch society in the period under study. For the longest time, political parties dominating the Dutch political scene clung to notions of state abstinence of the basis of their respective philosophies. The Liberals preferred the state be kept small in order to keep the private lives of citizens free from governmental interference. The religious parties fell into two groups. The Protestant/Reformed parties clung to 'sphere sovereignty' after the phrase coined by their foreman Abraham Kuyper in the 1870s and 1880s. Religious 'spheres' should be allowed to look after their own people, not just in terms of religious salvation but also where social security was concerned. The Catholics for their part clung to the ecclesiastical principle of 'subsidiarity': that which could be done by a lower body should not be taken up by a higher authority. All of these guiding philosophies prevented these parties from overtly imposing a 'strong' state influence on health care in the period until the Second World War. And with the socialists/Social-Democrats not partaking in real political power until 1939, competing political ideologies that sought more state intervention never thrived until the post-war period.

${ }^{33}$ Guldi and Armitage, The History Manifesto, 124. 
But even in the immediate post-war decades, the strong influence of 'pillarization' 'verzuiling', the strong segmentation of Dutch society along religious lines - prevented the rise of political dominance for more state-oriented parties, and also meant that anti-state rhetoric extolling the popular notion of 'private initiative' remained strong right up until the weakening of the 'pillars' by the late 1960s. This, then, finally created a window of opportunity for the Social-Democrats, who between 1974 and 1977 led the 'most progressive cabinet' ever in The Netherlands. However, both the incumbency and the successes of the Social Democrats were limited, leading to a renewed dominance of the confessionals and Liberals from the late 1970s through to the early 1990s. By this time, the old rhetoric of state abstinence on Liberal grounds, and the focus on private initiative/civil society that was espoused by the confessional parties, could elegantly be transmuted into a focus on the 'market' taking over tasks and responsibilities from what was by then an extensive welfare state.

What this seemingly coherent timeline of the political-ideological dominance of mostly Liberal and confessional political parties obscures, however, is a reality of growing access to health care, facilitated by both private and public (governmental) parties and traceable through analyzing legislation and the development of how access to health care came to be financed and facilitated over time. In this dissertation, the mismatch between the rhetoric of state abstinence and this actual reality of a growing role for the state will become clear through the analysis and discussion of growing municipal sponsoring and taking up of health care tasks in the period between 1912 and 1941; the growth of state influence in guaranteeing access to curative care with the 1941 Sickness Funds Decree; the influence of non-Social Democratic parties in erecting the extensive welfare state in the 1960s; and the unprecedented boom in regulation and legally enshrined solidarity in health care - under the rhetoric of the regulated health care market - enacted in the period between 1987 and 2006.

This summary turns on its head an overt focus on political and public rhetoric, allowing instead for a new periodization of the history of political interventions in health care, based in the subsequent 'governmentalities' over the course of a century influencing the access, organization and financing of health care. Moreover, it offers insights into what has historically worked in terms of health care policy in The Netherlands, what hasn't, and why. If we compare the dominant (political) rhetoric with the way in which, in reality, health care was increasingly provided for through public governance arrangements and financing, we get a specific succession of periods and 'governmentalities' as shown in figure I: 
Figure I The four governmentalities of Dutch health care and the state
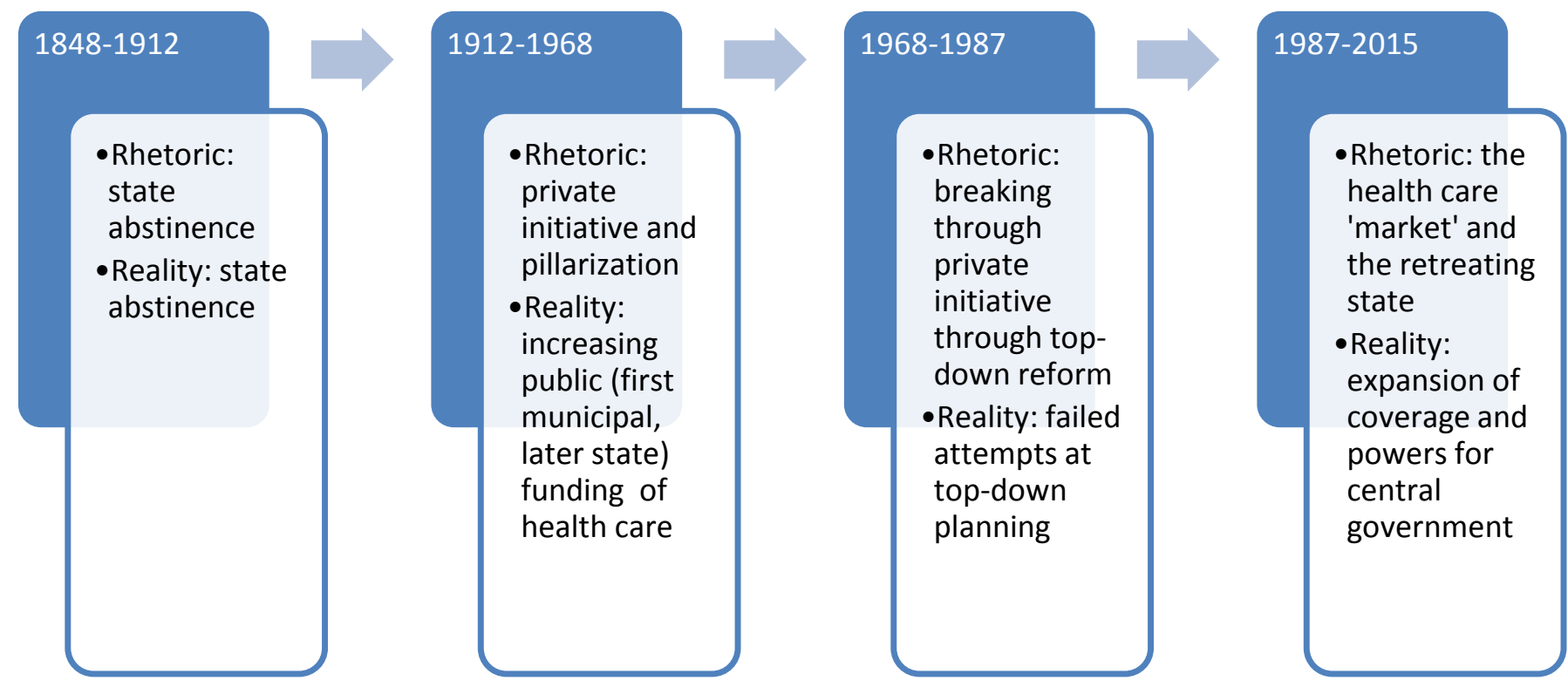

In this new periodization, the four periods immediately show the discrepancy between political rhetoric (sometimes turned into legislation), and what actually happened within the boundaries set by legislation, but also by economics and political and cultural sentiments. These periods create an impression of different 'Zeitgeiste' and governmentalities following on each other. These came be named as follows: the first, 'Liberal', governmentality of the $19^{\text {th }}$ century was succeeded by a 'hybrid' governmentality for a large part of the $20^{\text {th }}$. By the late 1960 s this was replaced by a 'blueprint' governmentality, which in turn gave way to the current governmentality of the 'regulated market'. These governmentalities constitute the four parts making up this dissertation.

\section{Historiography, Methodology, and 'Identity' of this Dissertation}

With regard to the position of this book in the historiography, it should be seen as expanding it along two axes. On the one hand, my aim is to expand our understanding of the evolving role of government with regard to health care along a temporal axis. Taking a longer time perspective has been done in earlier works. However, these books focus on the insurance market (and within that topic, mostly on the increasing access to health care through sickness funds). Moreover, taking as my starting point the constitutional reforms of 1848 and their foundational impact on the way in which both health care institutions and political-cultural sentiments evolved makes it 
possible to trace essential ideas through time, as well as institutions. This focus betrays my deep interests in cultural history and the history of ideas, but it also allows for a broader understanding of what is often called 'path dependency' in institutional theory circles. ${ }^{34}$ In this book, I hope to show how not just institutions, but also ideas set systems on a long track which influences developments seemingly propelled by other factors - in the case of health care, matters such as progress in the field of medical science, but also the prosperity levels of a given country.

For The Netherlands, these ideas can be summarized as the bottom-up growth of adherence to the social ideal of access to health care, combined with the idea that such access should not be achieved through heavy-handed government planning. Nevertheless, one cannot study systemic change without paying attention to the practical embedding of the ideas underlying such systems. Therefore, this dissertation might at times feel eclectic - but hopefully not eccentric - in focusing on broad political ideologies, but also on economic and social developments pushing the growing provision of health care in the Dutch context. Moreover, this book is also a legal history, in which the analysis serves to illustrate the two-way traffic through which law is both a product of given societal norms and values, but also an incubator for them an insight which can be easily overlooked by legal scholars maintaining a tight focus on the letter of the law, but also by historians of culture or ideas, who may overlook the practical (institutional and economic, but also normative) effects of the boundaries set by the law as a 'hard' institution. The quote by august legal scholar Ronald Dworkin with which I opened this introduction serves to illustrate this two-way traffic. By taking a longue durée analysis to the development of a complex system over time, 'what kind of people we are' indeed becomes clear through our legal and institutional history. At the same time, this history shapes how we organize our society in future, by laying new legislation in cultural and institutional tracks which have been formed over long periods over time.

The institutional focus of earlier literature brings me to my second axis: that of the horizontal 'field' of health care provisions and institutions. Where much system-oriented literature predominantly stuck to a political-institutional analysis of shifting power relations between government (usually seen somewhat monolithically as the Ministry of Health, a state institution) and primarily sickness funds and private insurers, I have broadened the scope in terms of institutions discussed. ${ }^{35}$ In this regard, the most direct additions are the discussions of

\footnotetext{
${ }^{34}$ See, e.g., J. Mahoney, 'Path Dependence in Historical Sociology', Theory and Society 294 (2000) 507548.

${ }^{35}$ See, e.g.: K.P. Companje, Over artsen en verzekeraars. Een historische studie naar de factoren, die de relatie ziekenfondsen-artsen vanaf 1827 op landelijk en regionaal niveau hebben beïnvloed (Twello: Van Tricht 1997); Van der Grinten and Kasdorp, 25 jaar sturing in de gezondheidszorg; Van Bottenburg, De Vries and Mooij, Zorg tussen staat en markt; I. de Haan and J.W. Duyvendak, In het hart van de
} 
the municipalities in the first half of the $20^{\text {th }}$ century, the growing and crucial role of hospitals (the 'temples' of modern medicine), and the private Cross Associations - ubiquitous local health care associations at their height between the 1920s and 1970s, which were perceived by Liberal and confessional contemporaries as the prime example of successful health care institutions in The Netherlands organized 'bottom-up'. The municipalities and Cross Associations fulfill a very important, yet understudied role from the perspective of social solidarity and subsidiarity increasingly going hand in hand within an emerging Dutch health care system. ${ }^{36}$ This is because the way they increasingly strengthened access to health care for ordinary Dutchmen and women must have played an important role in establishing growing access to health care as a desirable social goal among the general populace. ${ }^{37}$

Moreover, in expanding these two analytical 'axes', this book adds to an understanding of an evolving health care system as partly an ideological and cultural phenomenon, an approach touched upon in the three (in my opinion) best books on the subject: Robert Vonk's Recht of schade (2013); Henk van der Velden's Financiële toegankelijkheid tot gezondheidszorg in Nederland, 1850-1941 (1993); and Paul Juffermans' Staat en gezondheidszorg in Nederland (1984). This dissertation extensively uses the insights of those books (among many others), while it also expands their respective focal points. But special credit also needs to be given to my first supervisor Frank Huisman, for pointing me in the direction of statesman Thorbecke as both the

verzorgingsstaat. Het ministerie van Maatschappelijk Werk en zijn opvolgers (CRM, WVC, VWS), 1952-2002 (Zutphen: Walburg Pers 2002); K.P. Companje, Convergerende belangen. Belangenbehartiging van de zorgverzekeraars in historisch perspectief 1900-2001 (Zeist: Zorgverzekeraars Nederland 2002); J.G. Sijmons, Aanbodregulering en de Wet toelating zorginstellingen (Groningen: diss. Groningen University 2006); K.P. Companje (ed.), Tussen volksverzekering en vrije markt. Verzekering van zorg op het snijvlak van sociale verzekering en gezondheidszorg 1880-2006 (Amsterdam: Aksant 2008), as well as its international pendant: K.-P. Companje, R.H.M. Hendriks and K.F.E. Veraghtert, Two Centuries of Solidarity: German, Belgian and Dutch social health insurance 1770-2008 (Amsterdam: Aksant 2009); R. Vonk, Recht of schade. Internationally speaking, the most recent work has been C.H. Tuohy, Remaking Policy. Scale, Pace and Political Strategy in Health Care Reform (Toronto: Toronto University Press 2018), chapter 8, and see also J.K. Helderman et al, 'Market-Oriented Health Care Reforms and Policy Learning in The Netherlands', Journal of Health Politics, Policy and Law, 30 1-2 (2005) 189-209; Helderman, Bevan, and France, 'The rise of the regulatory state in health care'. Only recently has the first attempt been made to supplement the mostly institutional focus of these works with a more cultural-historical perspective on the core elements defining health care within the Dutch welfare state (but then only since 1945); K.-J. van Klaveren, Het onafhankelijkheidssyndroom. Een cultuurgeschiedenis van het naoorlogse Nederlandse zorgstelsel (Amsterdam: Wereldbibliotheek 2016).

${ }^{36}$ The best study of municipal endeavors in this regard is the short, but very rich book by A.H.M. Kerkhoff, Honderd jaar gemeentelijke geneeskundige en gezondheidsdiensten (Bussum: Dick Coutinho 1994). Also: $\mathrm{H}$. van der Velden, 'The Dutch Health Services before Compulsory Health Insurance 1900-1941', Social History of Medicine 1996, 49-68.

${ }^{37}$ Although a truly cultural-historical dissertation, focusing on the experience of getting health care and fleshing out practical instances of 'solidarity' in (mostly) the pre-war period, would be most welcome. 
architect and the representative of the first coherent policies and legislation developed for the relationship between health care and the Dutch state, after this was reconceptualized in the new constitution of 1848. Frank highlighted the importance of Thorbecke in this regard in conversations we had during the coming about of this dissertation as well as in an as-yet unpublished article, which pushed me towards studying the ideological and cultural embedding of medicine and health care as more than governed merely by scientific and economic factors. ${ }^{38}$

From the outset, my ambition has been to create an overarching synthesis, allowing a comprehensive understanding of how Dutch health care and the state's role in relation to it has evolved on cultural, institutional, economic and political grounds for the past century and a half. Such a broad approach has here and there inevitably limited the depth of my study in terms of research and level of detail. Methodologically speaking, much of the dissertation rests on extensive use of secondary literature, as well as primary sources and - especially in later chapters - political and Parliamentary documents, which grew in quantity as the role and stake of the state in health care became larger. Outside of literature directly concerned with the history of Dutch health care and its institutions, more general books and articles on Dutch political, cultural and economic history were used, as well as legal literature dealing with changes in legislation - a literature which, again, grew as time progressed and health care laws grew in number and impact. In terms of archival research, I was guided towards blind spots or interesting subject matter from the perspective of governmentality found in the literature or primary sources. Given how the dissertation deals primarily with the role of government and national legislation, archival material was accessed at the National Archive in The Hague.

I gladly welcome discussion on the broad scope taken in this dissertation, but in three of the four parts I have also tried to compensate for the potential drawbacks of such an approach by inserting vignettes intended to put detailed empirical flesh on the more conceptual bones of my general thesis. These minor case studies concern the practical regulation of health care by the State Inspectorate in the 1850-1900 period (part 1); debates on regulating hospital infrastructure in the middle of the $20^{\text {th }}$ century (part 2); and waiting lists in health care as a catalyst for speeding up the market transition in the closing years of the $20^{\text {th }}$ century (part 4 ). In terms of subject matter, the caveat is that most of the subjects in the field of health care studied in this thesis pertain to curative care, and less to long-term care (access to which was codified in 1968) and, especially, mental health care (which was a matter of state interference already in the early $19^{\text {th }}$ century). ${ }^{39}$ I of course take all responsibility for the inevitable limitations of such a

\footnotetext{
${ }^{38}$ F.G. Huisman, 'Ziek en gezond in het huis van Thorbecke', (forthcoming article).

${ }^{39}$ For the latter, see the volumes of: H. Oosterhuis and M. Gijswijt-Hofstra, Verward van geest en ander ongerief. Psychiatrie en geestelijke gezondheidszorg in Nederland (1870-2005) (Houten: Bohn Stafleu van Loghum 2008), and also C.T. Bakker, Geld voor GGZ: de financiering van de geestelijke gezondheidszorg en de invloed van geld op de zorgpraktijk (1884-1984) (Amsterdam: Amsterdam University Press 2009).
} 
broad focus and the general conceptual thrust of the book. However, discussions with many of the academic authors concerning themselves with this topic during the past years have strengthened my belief in my conclusions, as well as the notion that in historical research depth and scope are not, and should not be, mutually exclusive categories. ${ }^{40}$ On a final note: unless otherwise noted, all translations from Dutch into English in this dissertation are my own.

${ }^{40}$ Of course my supervisors Frank Huisman, Jaap Sijmons and Robert Vonk, but also Karin Bakker, Nele Beyens, Timo Bolt, Jan Huurman, Noortje Jacobs, Henriëtte Roscam Abbing, Erik Schut, Henk van der Velden, Joost Vijselaar, Bastiaan Wallage, and others. 


\section{Part I: Liberal Governmentality, 1848-1912}

In which a Liberal governmentality for state and society is devised, and the rhetoric and reality of state absence in health care run parallel 


\section{Introduction}

"And the sign of a liberal State and a liberal Government is, that they foster the development of autonomous power; autonomous power in province, municipality, association and individual. To foster means to create the general conditions under which such development is possible. Should this mean, that the State has to care for everything, has to cure all ailments and wants of society? Do we wish to return to the situation in which all work needs to obtain life, consecration and seal from the State government? To the contrary. One of the first laws is abstinence: abstinence from anything which exceeds its calling as a legal association." ${ }^{11}$

Where should a history of health care and its governance in The Netherlands begin? From our current-day perspective and our understanding of state-backed 'right' to health care, or even the notion that access to health care can or should be a collective affair, one can summarily say that such ideas did not hold sway before the mid-19 ${ }^{\text {th }}$ century - and, because of that, neither did the state's inclination to interfere in (individual) health care or to provide for it. Various reasons can be given for this: a general lack of efficacious (science based) medicine, limited financial means on the side of the state to provide for health care, as well as little or no (national) coordination, organization or interest on the part of doctors and health care providers. However, perhaps the most important reason from a perspective of governance was the at that time dominant political ideology with regard to the ordering of Dutch society. By the late $19^{\text {th }}$ century, this situation began to change. But to make clear the starting position of those farreaching changes and the growing but complex entanglement of government in health care in the $20^{\text {th }}$ century, I will in this chapter first set out the cultural, political and institutional developments that took place in roughly the second half of the $19^{\text {th }}$ century. Two dates are of particular importance from this perspective: 1848 and 1865. The new constitution of the former year, as well as legislation pertaining to health care passed in the latter, opened the door for a fundamentally new relationship between the state on the one hand and care for both collective and individual health on the other. During the $19^{\text {th }}$ century, this relationship did not fully develop. However, the changes set in motion in 1848 and 1865 influenced the relations between patients, doctors, budding health institutions and the state in ways which would lead to layered and continuously changing dynamics of power, financing and formal responsibility in the $20^{\text {th }}$ century. In fact, in this period a specific Liberal 'governmentality' developed, which set the tone for legislation and governmental interventions in health care for much of the $19^{\text {th }}$ and early $20^{\text {th }}$ centuries. This governmentality was a product of cultural and ideological sentiments prevalent in

\footnotetext{
1 J.R. Thorbecke, 'Narede', in: J.R. Thorbecke, Parlementaire redevoeringen, vol. 6, 1865-1866 (Deventer: A. ter Gunne 1870) v-xx, viii.
} 
the mid- $19^{\text {th }}$ century, and it acted as a catalyst in the way in which the role of the state vis-á-vis health care would evolve. Before turning to these developments and their significance, we must first look at the role of the state and the organization of medicine before this period. Was there much to govern in the first place at this time?

\section{The State of Dutch Health Care}

Broadly speaking, the care for one's personal health in the $19^{\text {th }}$ century and before was an individual affair. On the one hand, religiously-inspired caritas, expressed in arrangements centering around parish or community, afforded the sick and destitute some relief. ${ }^{2}$ On the other, collective financial arrangements between gainfully employed guild members were ubiquitous. But the notion of the state bearing responsibility for the health and wellbeing of citizens was absent - the focus lay on local networks based on mutual help for providing some sort of financial assistance in case of illness or other misfortune. ${ }^{3}$ As a result, the state as legislator or governing agent played no role in the relation between doctor and patient, let alone as guarantor of access to care or enforcer of state-mandated health insurance.

On the level of collective health, however, the picture was rather different. Within Dutch cities and municipalities, for a long time initiatives had been undertaken to limit the spread of (primarily) infectious diseases. Prior to the late- $19^{\text {th }}$ century understanding of bacteria and viruses as pathogens, these diseases were often attributed to environmental factors, with malaria as perhaps the most evocative example - 'mal aria' meaning 'bad air' in Medieval Italian. But regardless of any understanding of what caused such diseases, in the Middle Ages and the Early Modern Period measures to combat them were to be found everywhere, and ranged from local regulations concerning burials to those regulating where (animal) refuse was to be disposed of - preferably not on the city streets. ${ }^{4}$ However, such regulation was born from fear, far more than from altruistic or ideological notions of collective interventions by the state for the benefit of individual citizens. Epidemic diseases were a scourge much feared by all social classes and had to (and could only) be stopped through collective effort. Contrary to many current-day public health interventions, the attempts to prevent such outbreaks therefore hardly stemmed

\footnotetext{
${ }^{2}$ A. de Swaan, Zorg en de staat. Welzijn, onderwijs en gezondheidszorg in Europa en de Verenigde Staten in de nieuwe tijd (Amsterdam: Bert Bakker 2004) 35-39.

${ }^{3}$ See: L.A. van der Valk, 'Gilden, gildenbussen en vrijwillige contracten: de ontwikkeling van de verzekeringsmarkt 1780-1850', Tijdschrift voor sociale geschiedenis 272 (2001) 175-200.

${ }^{4}$ For Early Modern examples of such regulations in the city of Groningen, for instance, see: F.G. Huisman, Stadsbelang en standsbesef. Gezondheidszorg en medisch beroep in Groningen 1500-1730 (Rotterdam: Erasmus Publishing 1992) 17-21.
} 
from a humanitarian or health rights-based perspective, but far more often from a fear of contagion and outbreak causing wanton illness and death. ${ }^{5}$ It would therefore be anachronistic to label such activities as 'public health' measures in the modern sense. ${ }^{6}$

This situation of health care regulations at (primarily) the local level persisted far into the $19^{\text {th }}$ century, and was not limited to The Netherlands. However, the unique ordering of the Dutch political landscape would have a strong effect on the way health care regulation in general would be able to develop. This had to do with the long tradition of power being decentralized and exercised at regional and local levels. ${ }^{7}$ To this tradition came an apparent end with the institution of, first, the Batavian Republic in 1795, and, after a short reign by Napoleon's brother Louis, the creation of the United Kingdom of the Netherlands in 1813. Following the Napoleonic model, in short order many elements of state unification and centralization, such as a national penal and civil code, as well as new tax and education laws, were introduced. ${ }^{8}$ With these changes, proposals to reform (the regulation of) health care were also put forward. Looking to fashion a system of governmental control and supervision after the French model, as well as a 'medical police' after the ideas of the German physician Johann Peter Frank, the 'Batavian reformers' envisioned far-reaching governmental oversight of health care. This new vision with regard to health care included health care administrators and supervisors at the level of the national government, new regulations concerning care for the poor and mentally ill, as well as a significant reorganization of the ranks of health care practitioners and of their education. ${ }^{9}$

Ultimately, these far-reaching plans came to very little. What was enacted under the reign of King Willem I - who ruled from 1813 to 1840 - was ultimately but a shadow of what the reformers had envisioned. Alongside a national Quarantine Act of 1805 and measures concerning cow pox inoculation in 1814 , the most significant step in the early $19^{\text {th }}$ century was the 1818 Act on the Practice of Medicine. What this act put in place was a hierarchy of supervisory measures at the local and provincial levels. New provincial and local Committees of

\footnotetext{
${ }^{5}$ De Swaan, Zorg en de staat, 19-20, 131-145.

${ }^{6}$ Prior to the $19^{\text {th }}$ century, 'medical policing' or 'social medicine' (in the way intended by mid-19 ${ }^{\text {th }}$ century social reformers) were more apt designations for measures aimed at preventing or combating disease on a collective level. See: E.S. Houwaart, De hygiënisten. Artsen, staat en volksgezondheid in Nederland 18401890 (diss. Rijksuniversiteit Maastricht: Maastricht 1991) 2.

7 See, e.g.: M. Prak and J.L. van Zanden, Nederland en het poldermodel. Sociaal-economische geschiedenis van Nederland, 1000-2000 (Amsterdam: Bert Bakker 2013) 7-16.

${ }^{8}$ R. Aerts, 'Een staat in verbouwing. Van Republiek naar constitutioneel koninkrijk, 1780-1848', in: R. Aerts et al, Land van kleine gebaren. Een politieke geschiedenis van Nederland 1780-2012 (8th revised edition: Amsterdam: Boom 2016) 13-108, 61-63.

9 Houwaart, Hygiënisten, 12-13; R.B.M. Rigter, Met raad en daad. De geschiedenis van de Gezondheidsraad 1902-1985 (diss. Rotterdam University 1992) 17-18.
} 
Medical Research and Precaution were created, committees which consisted of 'men capable and experienced in every area of Medicine', and which were tasked with the very broad duty of supervising the practice of medicine. In practice, this meant setting exams for medical practitioners and guarding the quality of medical care in a broad sense, as well as monitoring possible signs of epidemic outbreaks. Significantly lacking in the $1818 \mathrm{Act}$, however, was a mandate for these committees to actively encourage or initiate public health measures - in fact, they were forbidden from doing so. These committees had to meet four times a year, and along with two commissioners for Health Affairs, they reported to the Minister of Internal Affairs. To give an indication of the limited effectiveness of this centralized State Medical Board: after 1825 there was but one commissioner left with the task of providing advice to the Minister concerning health policy for the whole of the Dutch kingdom. ${ }^{10}$

\section{Medical Care and The Medical 'Profession' in the Early 19th Century}

The patchy supervisory structure brought into existence in 1818 matched the patchwork of health care provisions that at the time existed in the Dutch kingdom. In general, one may posit that for much of the $19^{\text {th }}$ century there was not a single medical 'profession' to speak of - and neither was there one 'medicine'. According to sociologist of professions Eliot Freidson, what sets a profession apart from any other 'regular' skilled work is a demarcated body of specialized knowledge put in practice by a group that has control over its own training programs.

Moreover, such a group has a uniting ideology underpinning the reason for and usefulness of its work over and above financial gain. ${ }^{11}$ None of these elements were clearly present until at least the middle of the $19^{\text {th }}$ century. Instead, health care in The Netherlands at this time consisted of a motley collection of healers, herb sellers, traveling surgical specialists, as well as a legally recognized hierarchy of medical practitioners. The separate categories of city doctors, surgeons, and rural doctors had a distinct relationship to each other and distinct places in a hierarchical order. What they had in common was their recognized right to treat external afflictions of the body. This in opposition to the diagnosis and treatment of 'internal' afflictions and diseases. These were the province of the academically schooled doctores medicinae, who had a formal monopoly on internal medicine. Until the official dissolution of the separate categories of internal medicine, (external) medicine and obstetrics in 1838, the professional spheres resulting

\footnotetext{
${ }^{10}$ Ibid., 16-17.

${ }^{11}$ E. Freidson, Professionalism. The Third Logic (Cambridge: Polity Press 2001) 1-2, 127.
} 
from this division were kept intact in order to protect the competencies of these groups of doctors and the respective markets for the services provided by them. ${ }^{12}$

This division of labor said little about the effectiveness of the services and remedies offered, however. For one thing, most of the knowledge put in practice by academically schooled doctors was theoretical, building on the ancient physiological and humoral theories of the Greek and Roman physicians Hippocrates and Galen - sometimes supplemented by newer insights of, for instance, the Leiden physician and polymath Herman Boerhaave. ${ }^{13}$ Writing about the period before 1850, the historiographer of the Dutch Medical Association Henri Festen stated that internal medicine was practiced solely with the help of the 'unarmed senses', with the doctor's eyes, ears, and touch serving to inspect the patient's heart rate, temperature, and occasionally, urine. ${ }^{14}$ Alongside the information obtained through such physical markers, the personal story and background of the patient were important - building on the Hippocratic tradition, doctors inquired into a patient's work and life routines, habits, exercise, drinking, and more. Such methods of analysis usually led to therapeutic courses of action including bloodletting or purging (to restore the balance of the body's 'humors') as well as changes in lifestyle, diet, sex life etc. (the patient's 'regimen'). ${ }^{15}$ Other forms of medical intervention were limited. Perhaps somewhat hyperbolically, Festen wrote that of all potential 'remedies' known and used around the middle of the century, quinine and opium were the only truly efficacious ones. This state of affairs did not go unnoticed among the general population: "It is no wonder that the public hardly appreciated the doctors, who, despite their uttering of Latin verses at the sickbed, were capable of little more than and differed little from quacks." ${ }^{16}$ It is therefore quite probable that those groups of healers which were on a lower rung in the official hierarchy (such as traveling eye doctors, dentists, and doctors removing bladder stones) were far more effective in treating the cures they were hired to address and trusted than their academically schooled counterparts.

\footnotetext{
12 Houwaart, Hygiënisten, 17-19.

${ }^{13}$ See N. Beyens, Immer bereid en nooit verlegen. Hector Treub. Vrouwenarts in een mannenmaatschappij (Amsterdam: Boom 2013) 38, for an account of the conservative and stagnant state of the Leiden medical curriculum in the early 19th century (Boerhaave had already died in 1738); and A. Klijn, Verlangen naar verbetering. 375 jaar academische geneeskunde in Utrecht (Amsterdam: Boom 2010) 58-60, 66-76, for a similar situation at the Utrecht medical faculty.

${ }^{14} \mathrm{H}$. Festen, Geschiedenis van de Koninklijke Nederlandsche Maatschappij tot bevordering der Geneeskunst. 125 jaar geneeskunst en maatschappij (Utrecht: KNMG 1974) 40.

${ }^{15}$ In general, classical medicine put great store in the healing properties of 'Nature' left to its own devices, with therapeutic interventions such as purging or bloodletting aimed more at nudging the body to restore its natural balances than anything else. See, e.g. R. Porter, Blood and Guts. A Short History of Medicine (London: Allen Lane 2002) 99-100.

${ }^{16}$ Festen, 125 jaar, 41, quotation on 43.
} 
Adding to the confusing array of medical hierarchies there was a lack of balance in the provision of health care between cities and the countryside. Given the possibilities for building a lucrative private practice in the city, doctores medicinae hardly ventured into the countryside, leaving the care for a significant part of the population in the hands of rural doctors and other healers. But even within the cities, 'academic' medical care was limited and lackluster. During the heydays of medical developments in Paris - where the hospital and clinic were developed in the early $19^{\text {th }}$ century, and the internationally renowned physician René Laënnec tried out his newly invented stethoscope on scores of hospital patients - in The Netherlands, tradition was clung to. In 1817, the Utrecht hospital numbered forty patients in total, whereas the combined hospitals in Paris housed some $41,000 .{ }^{17}$ The Leiden medical faculty did little more than 'tread worn-out paths' ${ }^{18}$ Bedside medicine at medical faculties was limited to observation and abstract theorizing, and not until the 1840s would the focus slowly begin to shift towards more empirical-scientific observation and medicine. ${ }^{19}$

Given such a lack of uniformity in medical education, the provision of health care and the distribution of medical knowledge and techniques, it is hardly surprising that for most of the $19^{\text {th }}$ century one other element constitutive of a profession was lacking: legal recognition and protection of doctors as a professional group. ${ }^{20}$ This was not merely the result of a policy of non-interventionism by the state, however. To the contrary, the variety of medical practitioners was in part the result of active state intervention. Under the French occupation, free market thinking had led the state to dissolve the guilds and the municipal collegia medica which had come into existence in the Dutch Republic. This type of professional collective had protected the interests of the professional groups of surgeons and doctores medicinae, respectively, in the cities where they were centered. By setting the conditions for the education and medical practice of their respective membership, they had served to maintain the divide between professional groups and to regulate competition. As a result, the dissolution of the collegia and guilds in 1798 did not lead to unification of medical practice, but rather to incoherence and to a fragmentation of what medical care was on offer, as well as to a fierce competition amongst groups which up till then had kept themselves in check through self-organization. ${ }^{21}$ It was

\footnotetext{
${ }^{17}$ The largest Amsterdam hospital housed some 500 patients on average in this period. Klijn, Verlangen, 60.

${ }^{18}$ W. Otterspeer, De werken van de wetenschap. De Leidse Universiteit, 1776-1876 (Amsterdam 2005), 248254, 415-417 (cited in Beyens, Immer bereid, 38).

${ }^{19}$ We see this for instance in Utrecht (Klijn, Verlangen, 69-76). For the general rise of 'scientific medicine' (and its effect on a professional medical identity), see e.g. W.F. Bynum, Science and the Practice of Medicine in the Nineteenth Century (Cambridge: Cambridge University Press 1994), 218-221.

${ }^{20}$ Freidson, Professionalism, 128.

${ }^{21}$ See: M.J. van Lieburg, 'De tweede geneeskundige stand (1818-1865). Een bijdrage tot de geschiedenis van het medisch beroep in Nederland', in: Tijdschrift voor geschiedenis 96 (1983) 433-453.
} 
precisely this relative 'free for all' of the first half of the $19^{\text {th }}$ century which effectively pushed doctors to start arguing for more government intervention in the organization of health care.

\section{Bringing Doctors under One Banner}

By the middle of the $19^{\text {th }}$ century, the combined causes of a wide variety in medical care, limited state supervision, and a lack of clear institutional organization led to calls for new and effective legislation. The centralized structure of the State Medical Board had led to little real quality control, and the disappearance of collective regulation in 1798 in order to make place for market competition had the effect of uniting doctors of various ranks and statures in clamoring for some form of professional recognition by the state, or even for monopoly status. The Committees of Medical Research and Precaution had shown to be arbitrary in the fulfillment of their duties: quackery or unauthorized medical practice was not punished adequately, control over educational standards and the practice of medicine was hit-and-miss, and the principal task of furthering 'public health' was dependent on local governments who were often disinclined to spend money or time on such matters. ${ }^{22}$ As a result, critical doctors had been arguing for some years that the supervisory mechanisms in place since 1818 had fallen far short of expectations, and in the 1820s and 30s various medical societies had sprung up out of a concern with both medical developments and the protection of doctors' interests. ${ }^{23}$

In 1842, these calls for new legislation were met by a report produced by a state committee. This committee shared many of the concerns which had been brought to the attention of the government in recent decades, but its report hardly managed to address them. A half-hearted legislative proposal based on it was rejected by a large majority in Parliament. Nevertheless, the report touched on three elements which would in the next decades fuel debates on the identity of the medical profession and its relationship to the state. These were the unity of medical education and practice, the quality of medical education, and the duties and responsibilities involved in state medical supervision. ${ }^{24}$ By the end of the $1840 \mathrm{~s}$, these issues came to a head at a national level. Factors that led to calls for uniform demands on medical practitioners, Festen tells us, were "[...] the meagre standing of the medical class, the bad relationships between doctors, and [...] the delay in revising medical legislation. This last fact in particular was seen as the vitium originis of all evil, giving the impulse to the foundation of the Association." 25 This was the Dutch Medical Association, which was created in 1849. Growing

\footnotetext{
22 Houwaart, Hygiënisten, 24-25, 53-55.

${ }^{23}$ Ibid., 60-61.

${ }^{24}$ Ibid., 56-59.

${ }^{25}$ Festen, 125 jaar, 61.
} 
tensions over increased internal competition and the dire financial position of many doctors had taken on such a force by the middle of the 1840s that previously unorganized doctors academic or otherwise - decided, for the first time, to form an interest group. ${ }^{26}$

By the time of its inception, the new Association - which had a federative structure united under its banner twenty-three local departments, and some six hundred members of all medical stripes, not just academically schooled doctors. The initial scope of the Association was very broad: instead of merely defending the (financial) interests of a nascent medical profession, research into furthering public health was an important element, and to this end various subcommittees were installed. These dealt with various scientific-medical fields such as anatomy, pharmacology, internal medicine and medical policing. However, the primary goal was clear to all involved: to revise medical legislation in order to put an end to fragmentation and to the lack of clarity in the medical field. ${ }^{27}$ Eight years later, this quest for unity and uniformity within the field of medical practitioners was transferred to the arena of budding medical science, with the founding of the Dutch Medical Journal. This Journal was the first of its kind in seeking to gather together the disparate, although abundant 'medical journalism' in The Netherlands, and in its link to the Medical Association, with its primary goal already visible in its first year, witness the liberal attention it paid to new legislation concerning health care. ${ }^{28}$

It would take quite some time for the unity proclaimed by the new Medical Association to have any real influence on policy-making. Still, its founding was highly relevant, if only as an indication of a broader development. Much like the dissolution of the guilds and the collegia medica in 1798 had been based on political developments, so the notion of political organization was spurred on by more general developments in the ordering of the Dutch state and by the ideas of its principal statesman of the middle of the $19^{\text {th }}$ century: Johan Rudolf Thorbecke. It is with Thorbecke's name that the first steps towards coherent legislation and state interference in Dutch health care are usually associated, and with them a significant year: 1865. In that year, Thorbecke pushed through four seminal laws concerning health care and medicine which he had been working on for some two decades, and which formed part of his larger project of reshaping the Dutch political landscape. What was this larger project? And what new vision for health care and its relation to the state did it imply? To answer these questions, we must first look at the achievement Thorbecke is best known for: his 1848 constitution, which had a significant impact on both the organization of the Dutch state and on the future development of governance structures in health care.

\footnotetext{
${ }^{26} \mathrm{Ibid} ., 48$, for the growth in medical practitioners in the first half of the $19^{\text {th }}$ century.

${ }^{27}$ Ibid., 87-89.

${ }^{28}$ Editorial, Nederlands Tijdschrift voor Geneeskunde, 11 (1857) 1-2. For articles discussing proposals for new legislation, see ibid., p. 529-570; 603-611; 694-696; 699-710.
} 


\section{A Liberal Blueprint: the 1848 Constitution}

In 1848, Thorbecke invigorated the sleepy Dutch political scene by establishing himself as a Liberal thinker and politician of stature. ${ }^{29}$ Keeping pace with political upheaval across Europe, that year saw the introduction of a new constitution in The Netherlands, with Thorbecke as its principal architect. Pushed by fears inspired by (violent) revolution elsewhere in Europe, King Willem II hastily signed it. The thrust of the new constitution lay in reducing the power of the monarch, introducing ministerial responsibility and a parliamentary democracy. As such, Thorbecke's reforms very much resembled new constitutions being written throughout Europe. ${ }^{30}$ However, underlying his vision for political reform was a very specific conception of the state's role in society. Inspired by the Fichtean and Hegelian philosophy he had picked up while studying in Germany in the 1820s, as well as by the French Revolution, Thorbecke's frame of reference was the importance of historical forces acting on individuals and society. ${ }^{31}$ For him the Revolution had epitomized a radical and inevitable break with older modes of government and philosophies of statehood. On the one hand, it had broken the absolute power of the monarch as personified by Louis XIV. On the other, Thorbecke saw in it a development which had been going on for some time but had recently been put in higher gear: the continuing expansion of state intervention in the lives of citizens. Instead of limiting itself to the imposition of taxes and to military recruitment, government more than ever before now took an interest in "the private lives of citizens, their safety, welfare, moral culture" and more. ${ }^{32}$ This development had also elicited a new degree of interest on the part of citizens in the 'common good', and brought with it the gradual dissolution of smaller communities and spheres into the larger community of the State. ${ }^{33}$ It was in this sense that Thorbecke characterized the $19^{\text {th }}$ century as the 'century of citizenship'. ${ }^{34}$

But how to translate that 'citizenship' into a new blueprint for the Dutch state? If private interests and the common good were becoming more intertwined, what type of state ordering

\footnotetext{
29 Despite widespread poverty and the near-bankruptcy of the state, by the early 1840 s "Thinking about state organization was a matter for individuals, elites and small-scale public opinion." (Aerts, 'Staat in verbouwing', 104).

${ }^{30}$ For the constitution in general, see $\mathrm{H}$. te Velde, 'Van grondwet tot grondwet. Oefenen met parlement, partij en schaalvergroting 1848-1917', in: Aerts et al, Land van kleine gebaren, 109-194, 112-117; P. de Rooy, Republiek van rivaliteiten (5 ${ }^{\text {th }}$ revised edition: Amsterdam: Wereldbibliotheek 2014) 59-60, 63-65. ${ }^{31}$ For an interpretation of Thorbecke as (German) philosopher first and (Dutch) statesman second, see J. Drentje, Thorbecke. Een filosoof in de politiek (Amsterdam: Boom 2004), e.g. p. 12-19.

32 J.R. Thorbecke, 'Over het hedendaagsche staatsburgerschap', in: J.R. Thorbecke, Historische schetsen (Den Haag: Martinus Nijhoff; 2nd edition 1872) 84-96, 85-87. This essay 'on modern citizenship' was written in 1844 , predating his constitution by four years.

${ }^{33}$ Thorbecke, 'Staatsburgerschap', 87.

${ }^{34}$ Ibid., 84.
} 
would allow citizens to further both optimally? And how should government be organized to achieve these goals? These questions stood at the center of Thorbecke's project of constitutional reform. In an 1844 essay he laid down his vision:

The first and most important article of [the State's] as yet unwritten constitution envisions one large national community, collectively ordered by its members. The State wants to become in an absolute sense what the local and provincial communities, according to our constitution, should be in only a limited way. That is, communal self-government, based on the shared competence of members, with privileges excluded. ${ }^{35}$

When translated into a new constitution and lower legislation a few years later, these general ideas laid down the two tracks along which the Dutch nation-state would develop after 1848. On the one hand, Thorbecke's focus on 'self-government' emphasized the need for limited state intervention, even if the state more than before was guided by the people's will (though expressed by only a very marginal portion of the people, as we shall see). On the other hand, the Liberal project of enabling citizens to realize their potential and to adequately voice their interests in the political arena meant that certain preconditions for the personal development of these citizens had to be met. These two elements - a small government nevertheless providing a certain level of safeguards for the development of its citizens - would also be central to the health care legislation of 1865 .

While Thorbecke's ideology provided a vision for the self-realization of citizens, it also implied a formal-legalistic perspective on the framework through which citizens could best come to govern their own as well as shared interests. After determining the boundaries for the exercise of power on the centralized level - limiting the (arbitrary) power of the king through ministerial responsibility and exhorting Parliament to move beyond its preoccupation with the interests of a small group of social elites - Thorbecke in his first cabinet (1849-1853) set out a new governance structure for The Netherlands in the spirit of his constitution. The year 1851 saw the enactment of the Act on Provinces and the Municipality Act, which created the three-tiered government structure of political entities that to this day exists in The Netherlands: state, province, and municipality. The intended relation between these layers of government was one of inverted hierarchy and importance, however. For Thorbecke, central government should not be the principal locus of power. Instead, what could be achieved on a lower level to allow the fledgling Dutch nation-state to prosper should first be done on that level. Only those matters which transcended local boundaries or were too big to deal with within the confines of a local community should be moved up to the level of the province or the state. ${ }^{36}$ Tellingly, the word used by Thorbecke for the lowest level in this legal structure - 'gemeente' - means municipality

\footnotetext{
35 Ibid., 88.

${ }^{36}$ E.g. De Rooy, Republiek, 64-65.
} 
in a legal sense, but can also mean 'community' as in a group of people or even a specific religious congregation. Thorbecke himself saw the acts instituting this three-tiered 'House', with an emphasis on the lowest administrative level, as among his most important historical achievements. ${ }^{37}$ Only in this way could his ultimate goal be achieved: " [...] the formation of a powerful whole [...] powerful not solely or primarily through government authority, but through the organic connection, each within their own circle, of its independent members; and through the honest will of the citizenry to serve that whole and contribute to the general welfare." ${ }^{38}$

\section{Health Care: A Concern for the State?}

By the early 1850s, then, the blueprint for a Dutch state grounded on principles of limited, primarily local governmental intervention had been drawn - a blueprint imbued with the notion that the state should provide citizens with the opportunity to develop themselves. What of the relevance of Thorbecke's new vision for the state and of its relation to society for the health care legislation that was enacted some fifteen years later? Let us turn, first, to the liberal program and promise of 'self-realization'. In 1844 Thorbecke very much acknowledged the problem of citizens' competence in governing themselves and their communities. In language reminiscent of his contemporary, French statesman-philosopher Alexis de Tocqueville, Thorbecke had asked the question whether "the majority would ever be able to govern? Shall competence and wisdom not always be limited to the few?"39 When the constitution's ideal of increased political participation of citizens was enshrined in the 1850 Electoral Law, only some $2.5 \%$ of the total Dutch population was allowed to vote. ${ }^{40}$ But if 'competence and wisdom' were necessary criteria for effective self-government, should strengthening these elements in the population not be an absolute duty for the state? For Thorbecke, the answer to this question was a qualified 'yes'. Though the state should take care to interfere as little as possible in individual lives, it was clear

\footnotetext{
${ }^{37}$ And not without reason; the Municipality Act would not be seriously revised until 1992, almost a century and a half after its institution. For discussion of these acts and Thorbecke's ideas about them, see: R. Aerts, Thorbecke wil het. Biografie van een staatsman (Amsterdam: Prometheus 2018) 446, 454-456.

${ }^{38}$ Thorbecke, 'Narede', xvii.

39 Thorbecke, 'Staatsburgerschap', 88-89.

${ }^{40}$ Thorbecke's Electoral Law of 1850 had the strange effect of actually lowering the number of eligible voters based on census criteria - from 90.000 before 1848 to some 80.000 after 1850 . This on a total population of 3 million. (Te Velde, 'Van grondwet tot grondwet', 115.) As far as political participation was concerned, for Thorbecke the representatives of the people were to be more important in the political debate than the actual people themselves: direct or absolute democracy was not at all what Thorbecke had in mind. "In the constitution of 1848 not the people, but the representation was sovereign. As such, the constitution was a bit old-fashioned." (De Rooy, Republiek, 60.)
} 
that the excitation of 'national force' in the population would not come about by itself: at the national level certain conditions had to be met.

Education in particular was "above all the means to awaken autonomous life", but it was clear also that limiting poverty, for instance, would take away obstacles on the road to realizing the full potential of citizens. ${ }^{41}$ Though not directly Thorbecke's handiwork, in the decades following the new constitution, various social laws were enacted which followed this logic. The Poor Law of 1854, the Act on Public Schools of 1878, and the Labor Law of 1889 all served to combine socially progressive agendas with the removal of obstacles to self-fulfillment. ${ }^{42}$ And sure enough, although Thorbecke had not yet explicitly mentioned health care as one of the elements with which the State should be concerned in his 1844 programmatic essay, in 1862 he presented a coherent set of legislation to replace the 1818 laws governing the quality of health care in the Dutch nation-state. By then, legislation pertaining to health care had come to be seen as important to the notion of 'self-realization', as infectious disease and unhealthy living conditions clearly created obstacles for citizens to realize their true potential in actively partaking in communal life. And though it would take three years for these legislative proposals to arrive at the floor of Parliament, when they were voted into action after some three weeks of Parliamentary debate, it was clear that many of Thorbecke's beliefs with respect to the way the state should be organized had also found their way into the 'governmentality' regarding health care.

\section{Setting the Boundaries: The Laws of 1865}

Thorbecke's vision with regard to health care produced four laws, which together espoused three principles: quality, equality and governmental supervision of health care at the local level. ${ }^{43}$ The first law pertained to the preconditions necessary for certain medical professionals to get licensed (doctors, midwives, apothecaries, and their trainees) ${ }^{44}$ The thrust of this law was the creation of a single medical 'class', replacing the confusing and hard to control array of medical practitioners sketched above. By forcing doctores medicinae, surgeons, rural doctors and others into one medical framework Thorbecke intended to create equality - not just within medical

\footnotetext{
${ }^{41}$ For the quote on education, see: Thorbecke, 'Narede', ix.

${ }^{42}$ See, for this social legislation: De Rooy, Republiek, 91, 112-113.

${ }^{43}$ For this analysis I lean heavily on F. Huisman, 'Ziek en gezond in het huis van Thorbecke', (forthcoming article). See also: Aerts, Thorbecke wil het, 598-601; D.J. Wolffram, Vrij van wat neerdrukt en beklemt. Staat, gemeenschap, sociale politiek, 1870-1918 (Amsterdam: Wereldbibliotheek 2003) 38-39, 45-49.

${ }^{44}$ Wet regelende de voorwaarden tot verkrijging der bevoegdheid van geneeskundige, apotheker, hulpapotheker, leerling-apotheker en vroedvrouw 1 June 1865 (Staatsblad no. 59).
} 
ranks, but also for the population. Controlling who was allowed to practice medicine through standardized medical education would ensure that doctors, midwives, and apothecaries no longer would have to compete on unequal terms with a variety of healers. But it also guaranteed that a peasant in the rural provinces would (in due time) be treated by someone with roughly the same education as a doctor treating a well-to-do merchant in a big city. Thorbecke here took a gamble on the future, as reforming the medical curriculum would not happen until 1878, leaving him vulnerable to criticisms of jumping the gun. However, despite serious debate in Parliament as to the effectiveness of imposing uniformity on a group of professionals of such dissimilar backgrounds and education, Thorbecke's laws passed, officially creating the medical 'class' and profession which had been foreshadowed by the founding of the Dutch Medical Association. ${ }^{45}$

The second and third laws concerned what happened after education: the practice of medicine and pharmacology. ${ }^{46}$ Being essentially of a penal nature, the revised Act on the Practice of Medicine and its companion act on pharmacy of 1865 gave legally recognized medical professionals protection through an important instrument. From now on, anyone caught practicing medicine or pharmacy without being properly schooled would be subject to punishment in the form of fines or even imprisonment, giving government powers to ensure that quality of care was up to one standard. During the Parliamentary debates, the full import of these laws was lost on no one: what they in effect created was a monopoly on the practice of (academic) medicine and pharmacology. Significant here is that during the debates, specific provisions which would have given the state the power to revoke a doctor's title or apothecary's license in case of severe misconduct were voted down. Though the ultimate version of these laws did contain some obligations for doctors and apothecaries - such as filing causes of death for the purpose of collecting medical statistics or always having enough pharmaceuticals in store - the benefits now bestowed upon these classes were unmistakable. In granting these groups an exclusive title respectively license, necessary elements for the creation of distinct and protected 'professions' were introduced by the state. ${ }^{47}$

What, finally, of the officials and committees of control and supervision which had been performing their duties so haphazardly since 1818? Thorbecke's political philosophy came to the fore most prominently in the final law, which was the most important from the analytical perspective of the new 'governmentality' created in $1865 .{ }^{48}$ No longer would quality control and

\footnotetext{
45 Huisman, 'Ziek en gezond', 12, 24-27.

${ }^{46}$ Wet uitoefening geneeskunst 1 June 1865 (Staatsblad no. 60) and Wet regelende de uitoefening der artsenijbereidkunst 1 June 1865 (Staatsblad no. 61).

${ }^{47}$ Huisman, 'Ziek en gezond', 30-32, 34-42. In 1876, a separate Act on the Preconditions for Practicing Dentistry came into force as well.

${ }^{48}$ Wet regelende het Geneeskundig Staatstoezicht 1 June 1865 (Staatsblad no. 58).
} 
public health be furthered by a State Medical Board, but by a new, central, authority: that of the State Medical Supervision. The highly localized Committees of Research and Precaution - which offered little more than an honorary title to 'men capable and experienced' in Medicine -were to be replaced by independently operating state officials, forbidden from practicing medicine or pharmacology to prevent conflicts of interests. These officials were tasked with investigating and promoting public health, as well as making sure that health care laws were complied with. To this end they could enter public buildings and write reports, as well as inspect apothecaries' inventories without prior notice. The new health care inspectors fell under the direct control of the Minister of Internal Affairs, and were appointed by the King. This being the case, this proposal elicited great concern on the part of parliamentarians who feared centralization and a strongly bureaucratized health care - in Parliament, fears of 'British', 'French' or 'Prussian' situations were voiced. ${ }^{49}$ And would a lack of democratic control by qualified medical professionals of who supervised medicine not lead to incompetent or arbitrary state interference in what was seen as the private sphere of individual health care?

Thorbecke would have none of this. Doctors misunderstood both the goal of this law, as well as the way in which it would be implemented. First, the primary task of the new inspectorate was to safeguard and improve public, not individual health. This might seem rather limited from the perspective of ameliorating the general good health, but it was in line with Thorbecke's emphasis on the state establishing no more than the preconditions for self- and communal development. Within this framework, matters such as trade, art, and (scientific) medicine would have to come to fruition from the bottom up..$^{50}$ Monitoring the conduct of individual doctors or the welfare of individual patients would go beyond the primary task of creating stable conditions at a state or population level. And even here, Thorbecke's 'House' and especially his Municipality Act of 1851 played an important role. Though the new inspectors for health care were to report to the Minister on an annual basis, the primary responsibility for furthering and implementing public health measures was laid with municipal governments. Though the prosecution of unlicensed medical practitioners was a state matter (through the Public Prosecutor's office), when it came to the primary task of giving advice and taking measures to improve public health, inspectors had to turn to the province or the municipality. Only in this way could the desired 'national force' be stimulated, also where health was concerned. But this arrangement also tied the fate of public health to the willingness of local government to act,

\footnotetext{
49 Huisman, 'Ziek en gezond', 22; Houwaart, Hygiënisten, 184.

${ }^{50}$ Thorbecke, 'Narede', viii: "In essence, goals or means there are vital forces other than that of the State, which the church, education, science, or art have to form and govern in society; forces in whose sphere state sanction or coercion does not apply." See also Houwaart, Hygiënisten, 178-179: Thorbecke wanted to stimulate research into public health - one of the principal tasks of the new Inspectorate - but not medical science or the organization of (medical) scientists.
} 
which would lead to a situation in which nothing much happened on this front until the early $20^{\text {th }}$ century.

\section{A New Governmentality for Health Care}

With Thorbecke's four laws, the legal framework within which health care as practice, science, and matter of public interest would be able to develop within the new state ordering was clearly outlined. On a deeper level, Thorbecke's seminal laws also outlined a specific 'governmentality' for the relationship between national and local governments on the one hand, and private practitioners and actors concerned with providing health care on the other. In terms of formal 'governance' arrangements, several medical professions had received official recognition and protection by the state through the monopoly created by the Acts on the Practice of Medicine and Pharmacy. In return, they had to begin meeting standards of uniform education and practice, and would have to furnish State Inspectors with mortality statistics in order to arrive at a better understanding of developments in public health, which for the first time created a link between the national government and private medical professionals. The role of the newly founded State Inspectorate itself was also a clear step up from the diverse ways in which the quality of medicine and health had been supervised previously. In theory, strong and uniform supervision at the national level had now been created, replacing the local committees of oversight (and their disadvantages).

And yet, in every respect, ' 1865 ' breathed the spirit of Thorbecke's Liberal constitution and his ideological-philosophical emphasis on the local level as the starting point for all productive initiatives in (Dutch) society. Here the 'mentality' part of the concept of 'governmentality' speaks to the imagination. For Thorbecke-biographer Remieg Aerts, the legislation on health care in essence mirrored all of Thorbecke's legislative projects, which by and large sought to keep national government's intervention in social and individual life to a minimum. But as was noted earlier, this was not out of disinterest for the well-being and possibilities for development of the citizenry:

The intention was to create an open playing field to all social parties. Legislation setting conditions ['kaderwetgeving'] and general rules had to create room for initiatives coming from self-organizing society, the notion which would later come to be known as civil society. That was the core of the programme of $1848 .^{51}$

${ }^{51}$ Aerts, Thorbecke wil het, 601. 
This governmentality, as well as the general emphasis on minimal state intervention would stay dominant for a long time, because notions of subsidiarity, self-governance and 'sphere sovereignty' would become the cornerstones of new political parties arising in the decades after Thorbecke. Its impact on the development of health care would be long-lasting. We will return to this later on in this chapter, after first turning to the practical effects of the 1865 laws in the decades immediately following their coming into force.

\section{Programmatic Laws, Stubborn Realities}

"While Thorbecke's health care legislation was of great value to the professionalization of medicine, regulating public health was still a matter for local government." ${ }^{52}$ So what of the practical workings of Thorbecke's beloved 'local level'? How did the new 'law on the books' translate into 'law in action', and how did it influence the practice and organization of medicine and public health? Here, Thorbecke's high hopes for society and municipalities picking up what central government should and would not do led to anticlimactic results: in the historiography, the consensus is that the State Inspectorate for Health Care founded in 1865 was mostly ineffective in the first half century of its existence. ${ }^{53}$ This was not because of inactivity: where furthering public health was concerned, the Inspectorate could hardly be accused of being lax in propagating the new and ambitious legislation of 1865. Surveying end-of-year reports up until the early $20^{\text {th }}$ century provides a wealth of examples of Inspectors from all over the country commenting on bad water supplies, the sale of meat of dubious freshness and quality, open sewers, rat infestations, unsanitary conditions in schools, and more. ${ }^{54}$ Usually, drawing attention to such deplorable situations led to the advice or even to exhortations to municipal governments to act. But Thorbecke's much-extolled 'local level' proved to be the Achilles' heel for the new governance structure. Good intentions notwithstanding, Inspectors too often found their efforts at stimulating public health stymied by unwillingness on the part of local governments.

\footnotetext{
52 Wolffram, Vrij van wat neerdrukt, 47.

53 Houwaart, Hygiënisten, 228-230; A. Querido, Een eeuw Staatstoezicht op de Volksgezondheid, (Den Haag: Staatsuitgeverij 1965), 23-26, 119-121, 127-132; Rigter, Met raad en daad, 19-20; Festen, 125 jaar, 52. Its biggest impact would be its use of statistics to point to developments in disease and death on the level of the population (though the way in which this was done still left much to be desired; Houwaart, Hygienisten, 194-196, 232).

${ }^{54}$ For the period before 1901 - when legislation was revised with the Health Act - the annual reports of the State Inspectorate for the years 1866, 1876, 1886 and 1896 were surveyed.
} 
In essence, Thorbecke's delegation of the care for public health to municipalities led to the question of 'problem ownership'. Concerning initiatives in health care and public sanitation, the Inspectorate had been brought into life primarily as an advisory body: "The power, exercised by the State Medical Supervision, can be no more than that of persuasion. But that power will be strong enough", Thorbecke had claimed optimistically during Parliamentary debates. ${ }^{55}$ However, although the new constitutional framework and Thorbecke's 'House' had stressed the importance of initiatives on the local level, it was far from clear how the governance of collective issues such as public health should take form. In general, the 1851 Municipality Act had raised the question " [...] what Thorbecke really meant with his creation, the municipality." ${ }^{56}$ More importantly, the new hierarchy of political communities had failed to provide a clear notion of where financing for public health measures should come from, effectively making this dependent on the checkbook and whim of individual municipalities. This had the effect that all too often, Inspectors presented proposals for furthering public health, only to note in their annual reports that 'proposals were not carried out. ${ }^{57}$ Nor did a nascent 'civil society' immediately seem keen on rallying around Thorbecke's call for private initiative, as private insurance arrangements and organizations aimed at furthering public health did not become a real force in society until the late $19^{\text {th }}$ century (these will be discussed below and in the next chapter).

All in all, this combination of factors led to both limited interest and limited effectiveness as far as furthering public health as a state matter was concerned. Not until the $20^{\text {th }}$ century would local governments become increasingly concerned with matters of public health, and not until three decades into that century would the (financial) organization of municipalities be rearranged to allow for a stronger role of the central state in providing financial support. In the meantime, however, the range of subject matter that the State Inspectors was tasked with supervising was subtly expanded. Between 1865 and 1900, various laws were enacted which broadened the scope of the Inspectorate: among them the Funeral Act of 1869, the Cattle Act of 1870, and, most significantly, the Act on Infectious Diseases of $1872 .{ }^{58}$ All of this pointed to the unmistakable change initiated by Thorbecke's 1865 legislation: the fundamental notion that the State should set the preconditions for stimulating public health. This notion, coupled with ongoing progress in the medical understanding of (infectious) disease, opened the door for ever

\footnotetext{
55 Thorbecke, cited in Rigter, Met raad en daad, 19.

${ }^{56} \mathrm{~S}$. Couperus, De machinerie van de stad. Stadsbestuur als idee en praktijk, Nederland en Amsterdam 1900-1940 (Amsterdam: Amsterdam University Press 2009) 11.

57 See also Querido, Een eeuw staatstoezicht, 23.

58 See Querido, Een eeuw staatstoezicht, 43-52, for an overview. The Act on Infectious Diseases gave mayors new and far-reaching instruments in case of epidemic outbreaks, such as the right to quarantine patients. However, in practice the effects here were also often limited, with municipalities failing to put provisions in place and centralized government unwilling to enforce them. (Rigter, Met raad en daad, 20).
} 
more state intervention and interest in the health of its citizens. But it would take a while for such intervention to begin in earnest.

\section{Case Study: The State Inspectorate and the Fostering of Individual Care}

What of 'individual' health care - as opposed to the Inspectorate's main interest in health at the collective level? Thorbecke himself had seen the furthering of public health as the most important duty for the state where health care was concerned - leaving individual practice in the hands of medical professionals who after 1865 were protected by state-sanctioned monopolies on education and titles. But the next century would bring a sea-change in precisely that area: the care for the health of the individual patient by his or her doctor, and the concomitant gradual move away from the combating of infectious diseases which endangered the collective. This would also have a large effect on the desire for access to individual care, and on increasing initiatives on the part of government to providing it. Was there any sign of this in the decades after 1865 ?

Alongside stimulating municipalities to take public health measures, the Inspectorate was concerned with the individual practice of medicine: its second official task was to monitor "the compliance with legal regulations pertaining to health care". ${ }^{59}$ From the perspective of individual health care, this mostly meant acting against unlicensed practitioners on the basis of the Act on the Practice of Medicine. For much of its first few decades, the Inspectorate served primarily the interests of those medical professionals falling under the new monopolies - as noted, not just doctors, but also midwives and apothecaries. Inspectors had the right to act against unlicensed practitioners, in the worst case submitting an official report for prosecution by the Public Prosecutor. And this task was taken up in all seriousness: in 1866, Inspectors acted some 30 to 40 times nationwide to limit the practice of medicine by those unqualified under the new laws. ${ }^{60}$ However, when it came to addressing reprehensible actions by licensed health practitioners, Inspectors acted only twice. ${ }^{61}$ Although the total number of transgressions of the laws of 1865 is impossible to establish, we can get an idea on the basis of the yearly summaries of actions undertaken. In its first annual report, the Inspectorate dryly summarized its

\footnotetext{
${ }^{59}$ Article 1 of the Act on State Medical Supervision.

60 Depending on how one counts the various warnings, the giving of 'signals' to practitioners or Public Prosecutors, as well as the submission of official reports. State Inspectorate for Health Care, Verslag aan den Koning van de bevindingen en handelingen van het Geneeskundig Staatstoezigt in het jaar 1866 (Den Haag: Van Weelden en Mingelen 1866), 181-189.

${ }^{61}$ Ibid., 198. The two cases concerned the treatment of chickenpox without informing the municipal government and an apparent case of malpractice leading to the death of a woman in childbirth.
} 
effectiveness: "It does not seem too bold to deduct [...] that what some medical officials have noted concerning [...] bad compliance with regulations is not an exaggeration. " ${ }^{2}$ Given the Inspectorate's infancy and the outbreak of a serious cholera epidemic in the year 1866-67, this limited effectiveness was understandable. ${ }^{63}$ But in the following decades, the number of actions undertaken to limit the unqualified practice of medicine hardly increased: by 1896, the section concerning the general compliance with laws and regulations had disappeared entirely from the reports, and the Inspectorate's interest in dealing with unqualified persons amounted to no more than 32 cases being pursued in that year. ${ }^{64}$

Surveying Dutch jurisprudence (legal rulings) in roughly the same period provides a similar picture of legal or judicial interventions in the practice of individual health care. ${ }^{65}$ The majority of cases brought before a judge concerned the unlicensed practice of medicine - such as a dispute over the questions whether the removal of a wart should be seen as a 'curative operation' and whether such removal would therefore require a license. ${ }^{66}$ But 'majority' is a relative term: striking is the absolute paucity of legal proceedings concerning medicine or pharmacy. A survey with five-year intervals over the period 1857-1900 reveals, in most years, only a handful of cases or less. The simple explanation for this is the lack of legislation that might have settled disputes over medical (mal)practice in court. Only three laws provided possibilities for limiting patients' freedom of movement and thereby potentially wrongfully imprisoning them. The Act on Infectious Diseases and the Quarantine Act both provided possibilities for quarantine, whereas the Lunacy Act of 1884 concerned the institutionalization of mental patients. Given the limited use of the first two acts, as well as the weak position of the insane - who could be institutionalized on the instigation of their families or the Public Prosecutor and the ruling of a judge $e^{67}$ - it makes sense that the records show no cases

\footnotetext{
62 Ibid., 198.

${ }^{63}$ The Inspectorate itself noted this outbreak as a hurdle to the effective fulfillment of its task in its first year. Ibid., 4-5.

${ }^{64}$ State Inspectorate for Health Care, Verslag aan den Koning van de bevindingen en handelingen van het Geneeskundig Staatstoezigt in het jaar 1896 (Den Haag: Geneeskundig Staatstoezigt 1896) 67-68.

65 For this survey, the registers of the jurisprudential weekly Weekblad van het recht were examined for the years 1857, 1861, 1865, 1870, 1875, 1880, 1885, 1890, 1895, and 1900. Terms used were 'apotheker', 'artsenijbereidkunst', 'geneeskunst', 'geneeskunde', 'geneesheren' en 'zorg' - with the last term, 'care', being notably absent in the entire period.

${ }^{66}$ The Court of Appeals in Haarlem answered both questions affirmatively and sentenced the offender in question to a fine of 5 guilders. Weekblad van het recht 576672 (1895), p. 3 (Arrondissements-Rechtbank Haarlem, 13-6-1895).

${ }^{67}$ For a discussion, see A.M. Mooy, De krankzinnigenwet van 1884 (diss. Utrecht University: Utrecht 1964) e.g. p. 37-39. Despite legal safeguards against wanton incarceration of mental patients, the role of the patient in the process was minimal. See also: H. Oosterhuis and M. Gijswijt-Hofstra, Verward van geest en ander ongerief. Psychiatrie en geestelijke gezondheidszorg in Nederland (1870-2005) (Houten: Bohn Stafleu van Loghum 2008) 74-76, 79.
} 
pertaining to these laws. However, where curative care was concerned, more legal actions might have been expected in cases of, for instance, surgery gone wrong. Doctors fell under the remit of the Penal Code's provisions on (most relevantly) abortion, assisted suicide, wrongful death or injury, as well as breaking their vow of silence and leaving in a helpless state those in their care. ${ }^{68}$ But the jurisprudential record provides hardly any trace of the policing of licensed medical conduct through penal or civil action. ${ }^{69}$ (Indeed, an 1881 overview of medical legislation did not even feature a section on penal or civil provisions relevant to medical practice). ${ }^{70}$

On the one hand, this points to a legal culture not accustomed to seeing the licensed practice of medicine as something falling within the scope of (punitive) law. The same goes for the 'medical culture', with the Dutch Medical Journal reporting very few court cases concerning medical practice in the first decades of its existence. ${ }^{71}$ Most of them concerned (again) the transgression of the boundaries of medical practice by unlicensed individuals, although an 1865 case involving the death of a patient caused by administering too much morphine by a licensed doctor was duly noted. ${ }^{72}$ On the other hand, such limited evidence for legal intervention in the practice of medicine in the (late) $19^{\text {th }}$ century illustrates the way in which Thorbecke's legislation as yet offered only the most formalistic legal safeguards for patients and for a national standard of quality of medicine. This had come to the fore already in the Parliamentary debates on the Act on the Practice of Medicine, when a proposed article that would allow the State to revoke a

${ }^{68}$ G.W. Bruinsma, Nieuw Geneeskundig Wetboek. Overzicht en aanwijzing van wetten, besluiten, reglementen enz. Die van belang zijn voor Geneeskundigen, Apothekers enz. (Haarlem: De Erven F. Bohn 1898) 221-225.

${ }^{69}$ For this, Weekblad van het recht was surveyed for the years 1865, 1875, 1885 and 1894, to find cases concerning 'mishandeling', 'verminking', 'dood door schuld', and 'doodslag/manslag' - with the second term, 'disfiguration', being of particular interest (this was also codified in art. 1407 of the Civil Code as a specific ground for financial reparations, if it came about as the result of intentional or careless conduct). None of these criminal acts were mentioned in connection to medical care in the years taken into consideration. (It should be noted, however, that Weekblad van het recht only published appeals cases, providing little insight into court rulings which had been accepted by parties in the first instance.)

${ }^{70}$ S. Gratama, Geneeskundige Wetten. Met Aantekeningen, Bevattende de Jurisprudentie tot den Laatsten Tijd, benevens Koninklijke Besluiten, Ministerieele Beschikkingen, Beslissingen van Geneeskundige Raden en Aanschrijvingen van Inspecteurs en Adjunct-Inspecteurs voor het Geneeskundig Staatstoezicht (Schoonhoven: S. \& W.N. van Nooten 1881).

${ }^{71}$ Here, the years 1857, 1865, 1877 and 1885 were surveyed. In these years, most attention was paid to the new legislation of 1865, and hardly any to legal cases concerning an individual practitioner's conduct. (See footnote 29, for instance, for 'legal coverage' over the year 1857).

72 Editorial, 'Berichten Binnenland', Nederlands Tijdschrift voor Geneeskunde 8 Tweede Reeks, Eerste Afdeling (1865) 383. However, the practitioner in question (a country doctor) was convicted for the 'unlicensed practice of Medicine within the city of 's-Hertogenbosch', not on the basis of a provision from the penal code (such as manslaughter). The legal point of contention here still revolved around the hierarchy between rural doctors and doctores medicinae. Moreover, the author's mentioning of the publicity surrounding the case points to its exceptional character. 
medical license in case of gross misconduct had been voted down. ${ }^{73}$ Patients had little recourse to legal action, and well-intentioned but unlicensed healers had more chances of appearing before a judge than reckless doctors with a medical license. Furthering individual health care had ultimately not been Thorbecke's ultimate goal; creating recognized classes of medical professionals which would further medicine and science on their own terms, was. The marketplace and social control within the medical profession were probably seen as the best safeguards for patients against doctors who did not deliver or even made matters worse. For now, individual health care was definitely not seen as a matter for the state to concern itself with too much, let alone police actively.

\section{A Marginal Role for Government: Poor Relief and Health Care}

This was also not the case where government's role in providing access to individual health care was concerned. In the middle of the $19^{\text {th }}$ century, care for individual health could be found with a wide variety of healers. As noted, patients (especially in rural areas) often had to content themselves with whatever limited care was on offer, but it is very much the question whether academically schooled doctors were more efficacious than those other healers they so reviled. More pressing, however, was the question of money: how to pay for medical care? Not just illness itself, but especially the resulting loss of income during a forced absence from work would have been a frightening prospect for the many (often unschooled) laborers making up the Dutch workforce. Around this time, Dutch society was made up of a large segment of laborers and farmers, with only a relatively small bourgeoisie or lettered class. ${ }^{74}$ Industrialization would not begin in earnest until sometime later, as we will see below. Still, this did not preclude the rise of new arrangements for the financing of health care around the middle of the century. Alongside private practice for the wealthy, in the second half of the $19^{\text {th }}$ century two new forms of providing or dealing with the costs associated with illness came into existence: sickness funds on the one hand, and municipal poor relief on the other.

To begin with the latter: in 1854 the Poor Law was enacted, extending the reach of government with regard to the welfare of the Dutch citizenry by providing forms of poor relief to the destitute - and creating access to some health care provisions was seen as part of this. This reflected Thorbecke's concern with fighting poverty as duty of the state in order to enable citizens to develop themselves. However, the 1854 law was enacted by the Van Hall-cabinet

\footnotetext{
${ }^{73}$ Huisman, 'Ziek en gezond', 36.

${ }^{74}$ Te Velde, 'Van grondwet tot grondwet', 124.
} 
which succeeded Thorbecke's first cabinet. ${ }^{75}$ In an important sense, this cabinet followed Thorbecke's precept that the state should refrain from interfering in private lives, but was of a more conservative nature. As a result - and much to Thorbecke's dismay - the Poor Law enacted in 1854 created a very limited role for municipal governments in offering relief to the destitute. What the law stressed was the importance of the already existing network of religious and charitative institutions for poor relief - and much of Thorbecke's disdain for the ultimate Act was caused by its religious character, which was antithetical to his desire to separate state and church. ${ }^{76}$ As it stood, the law consolidated an important principle: the primacy of private initiative in caring for the poor and sick. Availing itself of Thorbecke's three-tiered state ordering, the law still charged the recently created municipality with a duty. It should provide forms of relief (which could include health care), but only in case of absolute necessity - after citizens had been turned away by religious or other charities, and could also not rely on help from friends or relatives. ${ }^{77}$

With this arrangement, (minimal) state intervention in health care for the absolutely destitute had been introduced, but with two crucial caveats. On the one hand, the primacy of non-state philanthropic initiatives was codified. On the other, it was recognized that, should government intervene to provide some form of poor relief, it must do so at the lowest possible administrative level. It would take a couple of decades for municipalities to start fulfilling this role, not before an economic downturn in the 1870 s and 1880 s forced many religious charities to cut what medical care they offered or funded for the poor. ${ }^{78}$ But even then, it was not until the revision of the Poor Law in 1912 that municipal governments carved out a more distinct role for themselves in this respect - we will return to this development at length in Chapter 2. It was only then that shifts in the governmentality as envisioned by Thorbecke and now enshrined (too extensively for Thorbecke himself) in the Poor Law of 1854 would gradually take place.

It should be noted that one exception was made to this emphasis on private parties and the local level. Where the care for the mentally ill was concerned, initially provinces and later municipalities were given the task of financing and/or providing care. A legal basis for these responsibilities was laid with the Lunacy Act ('Krankzinnigenwet') of 1841. This act (and its

\footnotetext{
75 Thorbecke led cabinets between 1849-1853, 1862-1866, and 1871-1872. https://www.parlement.com/id/vh8Inhrp1wzu/periode 18481872 het tijdperk van.

${ }^{76}$ Older, but still useful here, is: P.B.A. Melief, De strijd om de armenzorg in Nederland 1795-1854 (diss. Nijmegen University: Groningen: J.B. Wolters 1955) 188-212. Also: D.J. Wolffram, Vrij van wat neerdrukt, 30-35.

77 H.F. van der Velden, Financiële toegankelijkheid tot gezondheidszorg in Nederland, 1850-1941 (diss. Rotterdam: Erasmus University Rotterdam 1993) 32-33.

${ }^{78}$ Van der Velden, Toegankelijkheid, 33-34; K.-P. Companje, Over artsen en verzekeraars. Een historische studie naar de factoren, die de relatie ziekenfondsen - artsen vanaf 1827 op landelijk en regionaal niveau hebben beïnvloed (diss. Utrecht: Utrecht University 1997) 33-34.
} 
revision in 1884) laid the responsibility for providing mental institutions and sufficient beds with the provinces. After 1854 everyday care for the mentally ill was to be paid for by municipalities, on the basis of Article 29 of the Poor Law. Nevertheless, both responsibilities left plenty of room for a mix of public and private initiatives. For instance, only the province of North Holland created its own asylums. ${ }^{79}$ Instead, many provinces subsidized or financed (through loans) the construction of private mental institutions. ${ }^{80}$ Nevertheless, this was the one area where public bodies had a fairly well-defined task. On the eve of the First World War, provincial spending on the total cost of care for the mentally ill lay at some $15 \%$, while municipalities accounted for some $50 \%$ of these costs. Central government played a marginal financial role, which became smaller with time. ${ }^{81}$ On the whole, the role of central government in the care for mentally sick patients remained rather limited, both in terms of direct financing as well as governance. But as noted, until the early $20^{\text {th }}$ century, this role was still far greater than that played by municipalities in facilitating access to curative health care through the Poor Law. Serious changes in that regard - and therefore a shift in the governmentality of health care - would only take place after 1912 and will be discussed in the next chapter.

\section{Civil Society in Action}

The second source for making health care affordable and accessible to the general population was provided by the sickness funds - indeed an expression of the 'social initiative' that Thorbecke had hoped would blossom on the basis of his constitutional program. The funds came to be founded in increasing numbers from the middle of the $19^{\text {th }}$ century onwards. ${ }^{82}$ The principle was simple: to hedge against possible future illness, debility, or death, members of a fund would contribute money on a periodical basis, creating a pool from which individuals could

\footnotetext{
${ }^{79}$ Meerenberg in 1849, followed by Duin en Bosch only in 1909. See H. Oosterhuis and M. Gijswijt-Hofstra, Verward van geest en ander ongerief. Psychiatrie en geestelijke gezondheidszorg in Nederland (1870-2005) Vol I (Houten: Bohn Stafleu van Loghum 2008) 87, 96.

${ }^{80}$ For this, see: C.T. Bakker, Geld voor GGZ. De financiering van de geestelijke gezondheidszorg en de invloed van geld op de zorgpraktijk (1884-1984) (diss. Universiteit van Amsterdam: Amsterdam University Press 2009) 27-36, 46.

81 By 1909, the total amount spent on such care was a little over 3 million guilders. Private parties contributed nearly $22 \%$, whereas the state government paid some $15 \%$ (this included paying for the State Inspectorate, as well as for care for 'state patients' such as mentally ill soldiers or prisoners). By 1929, however, the state did not even pay $6 \%$. This was in part because in 1924 a state subsidy arrangement was rescinded. See Bakker, Geld voor GGZ, 49-50.

82 The sickness funds had been around for longer, but became more prevalent in the second half of the $19^{\text {th }}$ century. For the earlier period, see L. van der Valk, 'De ziekenfondskwestie rond 1840: een Amsterdams of een nationaal probleem?', Gewina 26 (2003) 22-39, 27-30.
} 
draw should personal disaster strike. For most of the $19^{\text {th }}$ century, these funds were small, often numbering only a few hundred members. ${ }^{83}$ More significant was the rapid expansion of the number and types of funds. For instance, in 1846, to create a steady income and to attract patients which were not well-off enough to pay for private practice, the very first doctor-run sickness fund was founded in Amsterdam. By 1890, there were 27 of these funds nationwide, with the Amsterdam fund insuring some $16 \%$ of the population of that city. ${ }^{84}$ Alongside these 'doctor's funds' there existed or emerged mutual funds - run by members and harking back to similar collectives in the guild era - factory or corporate funds, and commercial funds. It should be noted, however, that many types of funds were based on (Christian) philanthropy or solidarity. It is estimated that by the beginning of the $20^{\text {th }}$ century, a little over 600 funds insured between 15 and $17 \%$ of the Dutch population. ${ }^{85}$ Between private practice, philanthropy-based poor relief and the unknown proportion of the population that simply did not 'consume' health care, this was a significant amount. By the turn of the century, such institutions began to constitute a serious actor in the general landscape of Dutch health care. Though joined in the first decades of the $20^{\text {th }}$ century by commercial private insurers, sickness funds would prove to be the first port of call for health insurance for the Dutch population for more than a century. And they would not give up territory easily to reformers wishing to bring health care under the aegis of the state.

The latter half of the $19^{\text {th }}$ century thus shows a picture of chequered health care provisions. These were still highly fragmented, and an individual had three possibilities to access care by a medical practitioner: private practice for the wealthy; sickness funds for those sufficiently solvent to contribute small amounts on a regular basis; poor relief for those absolutely insolvent. ${ }^{86}$ Only the latter category had, after 1854 , partly become the responsibility of municipal poor relief institutes - and thereby of local government. But for a long time, little was happening on that front. All in all, Thorbecke's notion that government would stimulate (public) health as an essential component in the promotion of self-fulfillment was, for now, wishful thinking. But within the governmentality set out by him in his broad constitutional project of 1848 and incorporated in health care in 1865, there had also not been much to wish for. It was clear that within the Liberal context, expectations were high for societal initiatives to take flight - with government for now staying far away from serious interventions in health care.

\footnotetext{
${ }^{83}$ For a discussion of the various types of funds and their memberships, see: K.-P. Companje, R.H.M. Hendriks and K.F.E. Veraghtert, Two Centuries of Solidarity: German, Belgian and Dutch social health insurance 1770-2008 (Amsterdam: Aksant 2009), 98-104.

${ }^{84}$ Ibid., 104.

85 Ibid., 114-115.

${ }^{86}$ Though, as a qualification, the role of philanthropy in private practice should also be noted, with many doctors using their income from wealthy patients to be able to provide some forms of care to poor patients. See, e.g.: Companje, Over artsen en verzekeraars, 43.
} 
The first signs of change in this respect started to show only by the last decade of the century. By then, both private initiative and a new call for greater social legislation were on the rise. For this to happen, two important developments had to take place. The first was the rise of the modern political party in The Netherlands; the second the 'catching up' of the country with the rest of the world as a result of industrialization and rapid changes in the structure of society.

\section{A Changing Political Landscape and a Society on the Move}

Thorbecke's 1848 constitution had, by limiting the power of the king, on two fronts opened the door to a new type of politics. On the one hand, the principal powers of decision-making were taken out of the hands of the monarch and moved to a large extent to Ministers and Parliament. This changed the importance of Parliament and had the effect of gradually opening up national politics, changing it from a social club for wealthy males to a place where the public interest could be served by those representing a broader part of the population. On the other hand, it now became possible for precisely those representatives to present coherent political visions. Under a powerful monarch, there had been little room for political groups expounding specific ideas about society. And the 'Liberalism' for which Thorbecke would be remembered was more a philosophy of legal proceduralism than a political program - the state should guarantee equal rights and, in part, equal opportunities for citizens, but that would be the extent of government intervention. ${ }^{87}$ However, in the decades following the introduction of the new constitution, several groups organized themselves to achieve specific goals in the new political arena.

The first topic which caused battle lines to be drawn concerned education, one of the elements most essential to Thorbecke's vision of self-realization. In 1878, a liberal government instituted a new Education Act which not only funneled more funds to public education, but tried to remove its religious elements as well. Already in 1868 Catholics had protested the increasing gap in public education between scientific schooling and religious thought. ${ }^{88}$ However, the 1878 Act was a catalyst for a whole new type of politics, and for the birth of the political party in The Netherlands. The push for this came from the 'anti-revolutionary' Protestant Abraham Kuyper, who saw the liberal and modernizing age not as a sign of progress, but rather as a threat to the Dutch Christian-historical tradition. ${ }^{89}$ For Kuyper, the Liberal assault on non-secular education was only the latest step in this development. It strengthened his

\footnotetext{
${ }^{87}$ P. de Rooy, A Tiny Spot on the Earth. The Political Culture of the Netherlands in the Nineteenth and Twentieth Century (Amsterdam: Amsterdam University Press 2015) 93.

88 De Rooy, Republiek van rivaliteiten, 82.

${ }^{89}$ The 'anti-revolutionary' referred to the ideals of the French revolution, which Kuyper thought deeply inimical to this tradition - not (or at least not initially) to fears of a socialist uprising.
} 
conviction that religion and religious communities should be represented by a coherent voice at the level of national politics. In 1872 Kuyper had already launched an anti-revolutionary newspaper, and in 1879 he presented the first Dutch political program, aimed at rallying Protestants of various stripes around the cause of defending the (Protestant) Christian identity in affairs of state and society. As the political party was a new phenomenon, this was no easy feat. Kuyper had to muster all his rhetorical prowess to provide a convincing historical account of Protestantism (with its many internal divisions) as a coherent religious denomination. Though Catholics were an obvious target against which to construct an identity for his new constituency, Kuyper realized that at the level of politics and religion, Liberals (and socialists, in the future) presented the biggest danger to religious 'districts of souls'. Clearly, secular voices in the new political arena should be seen as the primary adversary. ${ }^{90}$

Kuyper's new way of doing politics had far-reaching effects, and was instrumental in turning politics into an ideology-driven game. For Kuyper, political parties should operate from fundamental principles (such as those laid down in his program) which would then be brought to bear upon any social issues under discussion in the political debate. This was a far cry from the sedate political discussions dominant until that time, and his vision had an immediate effect on Dutch politics as a whole. ${ }^{91}$ For an understanding of the development of both future debates on access to health care and the role the state should play in this, two particularly significant consequences of the 'new politics' are worth highlighting. First, Kuyper's emphasis on bringing religion back into discussions about state and society also pushed the Catholics - a repressed group in Dutch society until 1848 - towards taking a more active political stance. Although the power of the Church always played a role in the question to what extent Catholics could and would formulate their own goals in national politics, Kuyper's attack on secular public schooling created space for a new Catholic political consciousness at the national level. ${ }^{92}$ From 1896 onwards, when the first program for Catholics was presented, this meant that Dutch politics was marked by a new power bloc formed by the religious parties, a bloc which would be enormously influential for much of the $20^{\text {th }}$ century. Essential to this development from the perspective of governmentality was the belief shared by both the Protestants and Catholics - and of course also the Liberals - in autonomy for (religious) groups within society, with the centralized state at a safe remove. A founding principle for this separation of state and church - but now on religious, not secular grounds - was Kuyper's mantra of 'sphere sovereignty'. Freedom of religious conscience could only be guaranteed if the state kept its distance from (religious) communities. ${ }^{93}$ On the part of the Catholics, the principle of 'subsidiarity' was crucial. In the

\footnotetext{
${ }^{90}$ For an extensive discussion, see: De Rooy, A Tiny Spot, 111-115.

${ }^{91}$ See Te Velde, 'Van grondwet tot grondwet', 135-137.

92 Ibid., 138-139.

93 For this, see De Rooy, A Tiny Spot, 121-124; H. Post, 'Soevereiniteit in eigen kring plooit pluriforme samenleving', Tijdschrift voor Religie, Recht en Beleid 23 (2011) 52-71, 52-53.
} 
ecclesiastical hierarchy, that which could be done at a lower level, should not be taken up at a higher one. ${ }^{94}$ Together, these mantras would provide the underpinning of so-called 'pillarization', the division of Dutch civil society along political and religious lines for much of the $20^{\text {th }}$ century. They would also have strong effects on the modalities in which government (at least as a visible actor) would become involved in 'social goals' such as health care.

The second important consequence of national politics being shaped by a religious group was that a strong socialist presence in national politics was pre-empted. ${ }^{95}$ Kuyper and his new party very much recognized the international impact of burgeoning socialism, which also led him to establish a link between (Protestant) Christianity and the plight of the working class. In a foundational lecture given in 1891, Kuyper cautiously but effectively jumped on the socialist bandwagon:

The worker also was created by God as a vulnerable creature, one whose power can be broken through illness and injury, and which will fade with age [...] though God's Word does not give him a right to grumble, much less revolt, it nevertheless gives [him] the right to complain, to issue a charge against an organization of society which so painfully deprives him of what was ordained by God in his divine mercy. ${ }^{96}$

Such thinking would by the early $20^{\text {th }}$ century steer Kuyper's as well as other parties' politics in a more social direction, also where health care provision and insurance were concerned. But any role envisioned for the state in this regard would now have to be squared with the Protestant notion of 'sphere sovereignty', the Liberal tenet of 'state abstinence', and the Catholic principle of 'subsidiarity'. What developments were the new political parties faced with?

\section{The 'Social Question' and Limited State Intervention}

By the 1870 s, Dutch society was on the move. In industrialization, The Netherlands came late to the party compared to surrounding countries. The rapid growth of urban centers such as Amsterdam and Rotterdam (facilitated by a new railway network) only took place in the last

\footnotetext{
${ }^{94}$ This principle of subsidiarity was first formulated in the papal encyclical Rerum Novarum of 1891 - just as the Catholics were beginning to be truly politically active in The Netherlands - and later reiterated in the encyclical Quadragesimo Anno of 1931. Accessible via: http://www.vatican.va/content/leoxiii/en/encyclicals/documents/hf I-xiii enc 15051891 rerum-novarum.html and http://www.vatican.va/content/pius-xi/en/encyclicals/documents/hf p-xi enc 19310515 quadragesimoanno.html. ${ }_{95}^{9}$ De Rooy, Republiek, 93.

${ }^{96}$ A. Kuyper, Het sociale vraagstuk en de christelijke religie. Rede bij de opening van het sociaal congres op 9 november 1891 (Amsterdam: J.A. Wormser 1891), 39.
} 
quarter of the $19^{\text {th }}$ century. But once that happened, things moved fast. The population of Amsterdam and Rotterdam, for instance, grew from 240.000 in 1860 to 510.000 in 1910, respectively 120.000 in 1869 to 460.000 in $1913 .{ }^{97}$ By the 1890 s, cottage industries came to be complemented by the first large companies, which brought with them new relations between workers and industrialists - relations which some forty years earlier had led Karl Marx, living in London, to think through the political ramifications of the poor living conditions for the growing working class. But in The Netherlands, specific political conditions and the form that industrialization took led to a kind of velvet revolution in the sphere of social politics and legislation. Fears of socialist uprisings were fed by alarming reports from abroad, and from the 1870 s onwards, the 'social question' ('sociale quaestie') began to play a role in all political circles. ${ }^{98}$ But on the whole, the picture is one of gradually increased political influence for ordinary citizens ${ }^{99}$, improved living conditions and wages ${ }^{100}$, and consensus as to the necessity for legislation implementing basic measures of social security such as insurance against illness and injury. In the last quarter of the $19^{\text {th }}$ century, politicians of all stripes agreed that they could no longer stand idly by as a growing working class became exposed to the new and growing dangers of large-scale industrial production. This widespread empathy for the plight of the working class was instrumental in preventing socialism from taking serious root in The Netherlands. Though the Social Democratic Union and its successor, the Social Democratic Workers' Party were founded in 1881, respectively 1894, the ultimate impact of radical voices on this side of the political spectrum were rather limited. ${ }^{101}$ More relevant for the way in which the administration and practical implementation of social legislation would be organized was the

\footnotetext{
${ }_{97}$ These places were also breeding grounds for social upheaval, such as the 'Eel revolt' (Palingoproer) in Amsterdam of 1886, in which a working class game led to a violent clash between the police and the inhabitants of the Jordaan neighborhood (Te Velde, 'Van grondwet tot grondwet', 148). For demographics, see J.C. Kennedy, Een beknopte geschiedenis van Nederland. (Amsterdam: Prometheus 2017) 280 . The general population in The Netherlands grew from 5,1 million in 1900 , to about 8,8 million in 1940. (CBS Statline, accessed on 3-4-2018: http://statline.cbs.nl/Statweb/publication/?DM=SLNL\&PA=37556\&D1=a\&D2=1,21,41\&VW=T.)

${ }_{98}$ See e.g., De Rooy, Republiek, 95-98; Kennedy, Een beknopte geschiedenis, 287-289; Wolffram, Vrij van wat neerdrukt, 61-67.

${ }^{99}$ In terms of suffrage in The Netherlands, an almost linear trajectory can be seen in its extension for adult males: from $11.3 \%$ in 1870 , to $26.8 \%$ in 1890 , and $59.1 \%$ in 1910 (with no large jumps in intervening years). J.L. van Zanden and A. Van Riel, Nederland 1780-1914. Staat, instituties en economische ontwikkeling (Amsterdam: Balans 2000) 315. In 1919 female suffrage was instituted in The Netherlands.

100 De Rooy, Republiek, 116-118.

101 The most striking example of this was 'Troelstra's mistake', the 12 November 1918 attempt by Socialist Pieter Jelles Troelstra to declare the socialist revolution in The Netherlands. Already a day later, Troelstra had to concede his mistake by denying he ever declared a revolution, with the socialists getting just $22 \%$ of the vote in the previous election. (https://www.parlement.com/id/vhzpckjlgvz9/de vergissing van troelstra 1918, consulted on 28-112017).
} 
newly voiced emphasis on 'sphere sovereignty', as well as Thorbecke's 1848 blueprint for the state.

We can see these elements in the very first legislation concerning mandatory insurance and medical care, the Accident Act (Ongevallenwet) of 1901, which is widely seen as the first step in the development of the Dutch welfare state. ${ }^{102}$ As an illustration of the extent to which social thinking had influenced politicians who half a century before had emphasized a limited role for government, this law was enacted by a social-liberal cabinet termed the 'cabinet of social justice'. ${ }^{103}$ By the time the Accident Act was conceived, debate had been raging for two decades on the question of responsibility for injuries suffered in the course of employment in the (mostly) new industrial sector. But by 1897, consensus was such that a mandatory insurance scheme providing financial safety in case of such injuries was presented by the cabinet. ${ }^{104}$ The Accident Act set the tone for debates and ideas about the administration of mandatory insurance. By the time the Act was presented to Parliament, many employers were in fact already working towards instituting insurance schemes for their workers. However, the first draft of the Act gave government a central role in this process, with the institution of a State Insurance Bank in which employers would deposit premiums. This public ordering of a system for social security quickly elicited such objections on the side of employers that it led to the creation of their first interest group in 1899. ${ }^{105}$ But also on the political front, objections to a centralized system were quickly voiced. Tellingly, it was Abraham Kuyper who wrote an amendment to the proposed Act, in which the administration of a mandatory insurance system would be left to employers, emphasizing the primacy of 'private initiative'. Though this amendment was not accepted outright, in spirit it was represented in the law which would go into effect in 1903. The Accident Act made insurance for workers mandatory and created a State Insurance Bank, but employers were given the option of depositing premiums there or in an institution of their choosing. To this latter end, in 1902 the Central Employers' Risk Bank was created. The compromise thus

\footnotetext{
102 See, e.g.: De Rooy, Republiek, 129-130; K. Horstman, 'Om het beheer van de arbeidsongeschiktheid. Het politieke debat over de Ongevallenwet en het wel en wee van een medische markt', Tijdschrift voor Sociale Geschiedenis 254 (1999) 383-406, 385; F. Noordam, 'De personele werkingssfeer van de Nederlandse sociale verzekering (1901-2001)', in: J. Berghman et al (eds.), Honderd Jaar Sociale Zekerheid in Nederland (Delft: Eburon 2003) 19-35, 19.

${ }^{103}$ For a discussion of social liberals and social legislation, see: F. de Beaufort and P. van Schie, Sociaalliberalisme (Amsterdam: Boom 2014) 112-127; Wolffram, Vrij van wat neerdrukt, 96-97, 103-106. Other key legislation of this cabinet pertained to housing, education and child labor.

104 For the growth of this consensus, see: W. van der Zwaard, Van rechtsgrond tot grondrecht. Sociale wetgeving en het dilemma van particulariteit (1840-1960) (Den Haag/Utrecht: MA thesis Raad voor Maatschappelijke Ontwikkeling 2013) 30-35.

105 The Dutch Employers' Association.
} 
reached guaranteed state backing of an important element of social security for workers, while leaving the practical implementation mostly in the hands of parties 'in the field'. ${ }^{106}$

The Accident Act for the first time tied medical professionals to mandatory social arrangements instituted by the state. The relevance of the Act to medical practice was not just the rise of a new subclass of doctors (insurance doctors), or the debates that work-related illness brought about with regard to the relationship between curative and preventive medicine. ${ }^{107}$ This legislation also strengthened the link between a group holding a medical monopoly, and the state as well as employers. An important effect was the way in which doctors became involved in the relationship between worker and employer, with medical diagnoses and 'sick notes' coming to exert great influence over the allocation of sick-pay. ${ }^{108}$ At the time, medical professionals were not yet prepared to influence policy and legislation. In a contemporary commentary, the doctor J.W. Deknatel noted with some disbelief that doctors had not been involved in the preparation of the Accident Act. ${ }^{109}$ This awareness had yet to be developed, as would a stronger connection between national legislation and the mandatory provision of health care.

\section{Conclusion}

All in all, the final decades of the $19^{\text {th }}$ century seem to present a break with Thorbeckian handsoff governance, as The Netherlands began to show a different face in economic and social affairs, a change which called for more safeguards by the state. However, it was clear that solutions to the new and growing social problems very much bore the mark of ' 1848 '. In that year, a new Liberal 'governmentality' had been introduced for the way the Dutch nation-state would ideally be allowed to develop and flourish, according to the main architect of the new Dutch constitution, the Liberal statesman Johan Thorbecke. The political-ideological 'rhetoric' employed by the dominant political parties by the late $19^{\text {th }}$ century matched the vision put forth in 1848 of either limited legislation in social affairs, or legislation which created preconditions in the Thorbeckian mold, while leaving the practical implementation and administration of the new safeguards to parties in the field. The 1903 Accident Act, for instance, in effect met Thorbecke's

\footnotetext{
${ }^{106}$ See Van der Zwaard, Rechtsgrond, 37-39; and for a more detailed account, D. Rigter, 'Het effect van de invoering van de Ongevallenwet 1901 op de gezondheidszorg', in: K.P. Companje (ed.) Tussen volksverzekering en vrije markt. Verzekering van zorg op het snijvlak van sociale verzekering en gezondheidszorg 1880-2006 (Amsterdam: Aksant 2008) 97-172, 109-111.

107 For this, see: Horstman, 'Om het beheer', 390-394, 398-399.

108 Companje, Over artsen en verzekeraars, 119; Horstman, 'Om het beheer', 400.

109 J.W. Deknatel, Inleiding tot de studie van den werkkring der geneeskundigen bij de verplichte verzekering tegen ongevallen, overgedrukt uit het Nederlandsch Tijdschrift voor Geneeskunde 1900, Deel I (Amsterdam: 1900) 4 , quote on p. 7.
} 
ideal of letting 'civil society' or 'private initiative' take care of social matters within a framework of social protection set by the state. Where health care was concerned, access for ordinary citizens was still very much an individual affair, unless one was a member of a sickness fund or could fall back on what meagre municipal support there was to be had under the Poor Law of 1854. All in all, Thorbecke's focus on private initiative and 'social force' still underpinned much legislation on this front, although in practice such initiative often did not yet live up to the great expectations the statesman had of it in the mid- $19^{\text {th }}$ century. A contemporary observer comparing the state of medicine, the medical profession, and the provision of health care in 1890 to those of a century before might not have been all that impressed by the changes. This is because in practice, these were mostly marginal.

Still, underlying these matters by this time was a firmly entrenched Liberal 'governmentality' for the relationship between health care and the state. From 1865 onwards, there was a legal framework which recognized that health care was a distinct sphere of society, worthy of legal protection and stimulation. And, though still in embryonic form, ingrained in this legislation was the notion of the population's health as something to be safeguarded and promoted by the state. The first half of the $20^{\text {th }}$ century would see many of these elements defined more sharply, and on a bigger scale. But equally crucial was the organizational principle underlying this multi-facetted vision of health care for The Netherlands, the various elements of which can be traced back not just to Thorbecke's 1865 laws, but also to the new constitution of 1848 and the Municipality Act of 1851 . This principle proclaimed that whatever could be done at lower levels - close to the people and to the communities making up the nation - should not be taken up by central government. But although Thorbecke's new framework was rooted firmly in the political philosophy of Liberalism, the vision and boundaries it set with regard to the development of medicine and health care would provide future generations plenty of space to expand the role of government, central or local, and often in subtle rather than overt ways. This is precisely what happened around 1912, when a revision of the Poor Law opened the door for more municipal interventions in health care, and the dominant Liberal and confessional rhetoric began to give way to new realities in power, financing, and access to health care. It was then that cracks in Thorbecke's Liberal governmentality for the state and health care began to appear, and a governmentality of 'private initiative, publicly backed' began to supersede it which allowed for increased governmental support in creating access to health care for ordinary citizens. We turn to that period and that 'governmentality' now, which would be dominant for most of the $20^{\text {th }}$ century. 


\section{Part II: Hybrid Governmentality, 1912-1968}

In which the Liberal rhetoric of state abstinence is reinforced by Protestant and Catholic political philosophies, but in reality government becomes involved in the provision of health care 


\section{Introduction}

"In various areas, the sphere of action of the government has slowly expanded [...] Through the progress of science in many areas, through the increased traffic between citizens of the same state and between various peoples, through the recognition that too much freedom of the individual vis-á-vis the community can only lead to detachment, the desire has risen for the state to create and foster general rules for the various circumstances which can occur in societal traffic and social life. Also where health is concerned, the conviction has slowly grown that the interference of government must and can be extended further." ${ }^{11}$

In 1896, doctor and future politician Cornelis van der Mijle published an overview of legislation pertaining to health care in The Netherlands since 1818. In large part, it covered the laws instituted by Thorbecke in 1865. New, however, was the attention paid to social legislation. This was not yet treated extensively by Van der Mijle - in fact, it was at the time so limited that it was only discussed in an appendix. In terms of a mentality shift, however, the passage quoted was telling. The fact that the state was now discussed as an important actor in fostering and regulating the growth of 'social life' was highly significant. In Thorbecke's time (he died in 1872) Liberals by contemporary definition had kept away from rallying around specific interests or formulating a broad vision for the centralized organization of society. And as we have seen in the previous chapter, the new political factions coming to the fore from the 1870s onwards rallied around philosophies which showed great similarities in terms of an aversion to a strong (central) government. But by the turn of the century, the 'social question' and changes in the structure of Dutch society meant that the idea of government taking over tasks from private initiative and codifying responsibilities was slowly becoming more acceptable to many.

Changes in legislation as the state's response to industrialization were already taking place in the late $19^{\text {th }}$ century, as we have seen in the previous chapter. But in the first decades of the $20^{\text {th }}$ century, progress in medical science, the rise of new medical institutions, as well as rising prosperity levels led to growing demand from the general public for access to health care services, and to (failed) attempts to strengthen the role of government in facilitating it. However, on the national level, politics and policies concerning health care in the period from the turn of the century to the late 1930 s seemingly continued the Liberal governmentality enshrined by Thorbecke in 1848 and 1865. Attempts to establish more centralized control over health care

\footnotetext{
${ }^{1}$ C.H.A. van der Mijle, Onze Geneeskundige Wetgeving. Historisch overzicht der inzonderheid sinds 1813 uitgevaardigde Voorschriften op Geneeskundig gebied, met bijzondere beschouwing der thans van kracht zijnde Bepalingen. Handboek voor geneeskundigen, apothekers, ambtenaren en gemeentebesturen (Ooltgensplaat: M. Breur 1896) vii.
} 
provisions would fail almost as a matter of course in the period before the Second World War. The confessional parties which came into their own in this period - keeping real socialist influence at bay - stressed private initiative and sovereignty for separate (religious) groups in society. Rapidly growing institutions such as the sickness funds, as well as an increasingly powerful Dutch Medical Association, saw state intervention as unnecessary interference in a 'private' area of society. As a result, the (limited) desire for strong legislation and better regulation of health care led to anything but a coordinated mix of provisions or even a safety net for basic health needs. Instead, it led to a grass-roots flurry of activity with regard to both individual and public health.

However, from 1912 onwards, a subtle but important revision of the Poor Law caused these private initiatives to be supplemented in earnest by new initiatives while financing arrangements coming from local governments jumped into the gap left by a lethargic central state. Therefore, despite the fact that the arena of national politics was still dominated by confessional and Liberal factions who espoused a philosophy of state abstinence, important shifts in the financing and organization of health care were taking place 'on the ground'. The steady growth of public arrangements had effects on what citizens came to expect from (local) government in terms of increasing access to health care. Moreover, seen from the perspective of 'governmentality', these shifts began to create a serious gap between the political rhetoric of state abstinence on the national level, and a reality of an increasing assumption of social tasks by municipalities, which in this period began to function as 'social laboratories'. This gap was only accentuated by the fact that by the 1930s the state increasingly came to finance municipalities, leading to indirect state subsidy of something which was not officially a state responsibility. After the Second World War - during which the 1941 Sickness Funds Decree for the first time involved the national state in the provision of mandatory sickness fund insurance - both this governmentality and this misfit between rhetoric and reality remained in place up until the early 1970s. Let us first turn to the rapid and radical developments in health care and its organization, as well as the failures of legislation on the national level, before addressing the important local changes in 'governmentality' that took place in the first half of the $20^{\text {th }}$ century.

\section{Medicine and Health Care in Transition}

When Thorbecke granted a monopoly to (academically trained) medical practitioners in 1865 , there was not yet much reason to believe that in the near future the diagnostic and curative possibilities of medical science would significantly expand. However, in the decades following this legislation, scientific and curative medicine underwent a stormy development. Though it is doubtful whether such changes immediately led to better prospects for patients, in at least two 
respects they had important consequences. On the one hand, the rate at which medical knowledge grew led to the rise of medical specialties and specialists from the 1900s onwards, at the expense of the age-old general practitioner. Arguably, this tied into an increase in the use of medical services, with the number of doctors in proportion to the population rising rapidly in the first decades of the $20^{\text {th }}$ century. It was also directly connected to the second important development: the rise of new places where medicine was practiced. The first decades of the $20^{\text {th }}$ century, but especially the period after 1920, saw the shift from the doctor's office or the patient's home, to the hospital and the clinic. This was part of a broader shift in how health care (either public or individual) was provided. Where mental health and home care were concerned, too, the first half of the $20^{\text {th }}$ century set in motion developments which arguably solidified the institutional setting of health care in society, moving care for patients from the private setting of the home to complex organizations. This was a great change from how medicine, midwifery, care for mental patients and other forms of health care had been practiced in the previous decades and centuries. Moreover, this new institutional setting posed new questions about accessibility, as the new possibilities and the 'temples' of medicine came with an increasingly hefty price-tag. Medical developments in the period after 1900 gradually forced both 'private initiative' as well as public bodies to think about the delivery and financing of such care. Thorbecke's legislation of 1865 had gone no further than to establish a medical monopoly, and to have a State Inspectorate play a role in the improvement of public health. Now, increasingly influential social ideals of providing access to health care had to be brought to bear upon the growing supply of health care provisions.

\section{New Promises of Medicine}

The developments that pushed forward the rise of new locations for practicing medicine, as well as the rise of specialisms within health care, came from various directions. The most 'internal', in a sense, was the rapid international advance of medical science and technology, resulting in new medical specialties, as well as new diagnostic, curative and (in time) preventive methods. Where diagnostics were concerned, one can point to inventions such as the ophthalmoscope in 1851, the gastroscope in 1881 and the bronchoscope in $1898 .{ }^{2}$ For the second and third elements, developments in bacteriology, pathology and surgery broke ground rapidly. ${ }^{3}$ Of particular note here were the discoveries of Louis Pasteur and Robert Koch of the bacilli responsible for,

\footnotetext{
2 W.F. Bynum, 'The rise of science in medicine, 1850-1913', in: W.F. Bynum et al, The Western Medical Tradition. 1800 To 2000 (Cambridge: Cambridge University Press 2006) 111-245, 167; A. Juch, De medisch specialisten in de Nederlandse gezondheidszorg. Hun manifestatie en consolidatie, 1890-1941 (diss. Erasmus University Rotterdam: Rotterdam 1997) 53.

${ }^{3}$ For a general international overview, see: Bynum, 'The rise of science', 111-245.
} 
respectively, anthrax and rabies, and tuberculosis, in the $1880 \mathrm{~s}^{4}{ }^{4}$ Though effective preventive action such as mandatory vaccination would be a long way off in many countries, the effect on the public's perception and expectation of what medical science could bring would be enormous. ${ }^{5}$ Soon, research institutes and laboratories began to be established in large numbers, funded by public money or philanthropic endowments. ${ }^{6}$ In the field of pathology, Rudolf Virchow's emphasis on cells as the crucial unit governing disease processes and the human body proved instrumental for new discoveries (with Virchow himself having identified leukemia already in 1847). ${ }^{7}$ On a level that was less incomprehensible to outsiders, advances in surgery had become possible with the introduction of anesthetics in 1846 and antisepsis in 1867. From the 1870 s onwards, these methods for taking pain out of the equation in surgery and for limiting deaths from infection pushed surgeons across the Western world to cut ever deeper into the human body - a sea change from the doctor of just a few decades earlier, who had been confined to observing patients because of the dangers of open wounds getting infected. Within years, surgeons were exploring regions thus far unexplored, such as the abdominal and thoracic cavities, the larynx, and even the brain. ${ }^{8}$ With this came public attention for the spectacular operations now regularly performed, as well as a 'cult of the surgeon'. ${ }^{9}$ By the early 1900 s, further developments like the X-ray (1895) and the electrocardiogram (1903) offered very specific technologies which in theory would vastly increase diagnostic potential - the human body could now be examined without opening it up.

These were broad international developments, which would take time to land in specific national contexts. Still, the effects they had on the contemporary imagination must have been enormous. At an 1899 meeting commemorating the Dutch Medical Association's 50th anniversary, the seminal medical developments of the past half century were still evaluated somewhat cautiously in a speech: "It is true, that on balance the expansion of internal therapies is

\footnotetext{
${ }^{4}$ Bynum, 'The rise of science', 123-131; Porter, Blood and Guts, 84-90.

${ }^{5}$ For vaccination programs against diphtheria and tuberculosis in the 1920s internationally, see $C$. Lawrence, 'Continuity in crisis: medicine, 1914-1945', in: Bynum et al, The Western Medical Tradition, 247403, 338-339. In The Netherlands, smallpox vaccination for children, teachers, as well as prisoners and soldiers was already mandatory between 1872 and 1928 (in that year, it was suspended because of meningitis outbreaks resulting from vaccination). G.H. Spruyt, 'Politicians and Epidemics in the Bible Belt', Utrecht Law Review 12 (2016) 114-126, 114-115.

${ }^{6}$ In general, see: Bynum, Science and the Practice of Medicine, 152-158. For The Netherlands, see: I. Vledder et al, 'Particuliere laboratoria in Nederland. Deel 1: opkomst en bloei, 1865-1914', in: NEHA-Jaarboek voor economische, bedrijfs- en techniekgeschiedenis 62 (1999) 249-290.

7 Bynum, 'The Rise of Science', 120-123.

8 Porter, Blood and Guts, 123-127, 132-134.

9 Bynum, 'The rise of science', 155-156, 159-160. For accounts of the broad use of the (awfully) ineffective 'radical surgery' for tumours, see also: S. Mukherjee, The Emperor of All Maladies. A Biography of Cancer (New York: Scribner 2010) 64-71.
} 
negative." ${ }^{10}$ But looking over the impressive array of technologies and theories produced in the preceding period, the speaker nevertheless noted that the 'therapeutic nihilism' of the past would be superseded in the near future by a convergence between doctors' 'knowing' and their 'doing', and the harnessing of nature's powers to increase medicine's capacities. ${ }^{11}$ In the decades after this speech, these promises would lead to important changes in not just the practice, but also the organizational framework of medicine.

\section{Great Expectations}

From about 1890 the impact of these new discoveries and technologies came to be felt in The Netherlands. Where Thorbecke's focus on public health measures had been justified by hygienists' and sanitarians' emphasis on such measures as the most effective way to bring down mortality rates, the discoveries of the second half of the 19th century increasingly fed the belief in individual medicine as crucial and as more effective in combating illness and death. This would soon lead to a growing demand for the services of physicians - general or specialist - and the rapidly expanding number of hospitals in which they plied their trade. Whether the belief in either public or individual medicine was actually justified in the first decades of the $20^{\text {th }}$ century can be seriously doubted. For The Netherlands, there is limited cultural-historical research on the acceptance of the new scientific medicine. But a case study of the southern province of Limburg captures a change in sentiment. During the second half of the $19^{\text {th }}$ century, "People were not unprepared with regard to their fate [....] primitive healing [...] was embedded in folk culture and was within closer reach of the working classes than the rational medicine of doctors [...] especially concerning the questions surrounding birth, illness and death, people traditionally wove a braid of practices, sayings, religious and superstitious practices. ${ }^{12}$ Apart from such beliefs and ways of doing things in the transitional period after 1865 - it would take some generations for academically schooled doctors to 'replace' the broad variety of healers of old - there were considerations of cost: often, calling for the doctor was prohibitively expensive. ${ }^{13}$

However, by the early $20^{\text {th }}$ century, the academic doctor was slowly becoming a less intimidating figure for many in Limburg and elsewhere. In part, this was the result of a new type of ritual being introduced: "These young doctors were closer to the people, were less patriarchal

\footnotetext{
${ }^{10}$ S. Rosenstein, 'De vooruitgang der geneeskunde in de laatste vijftig jaren', Nederlandsch Tijdschrift voor Geneeskunde 353 (1899) vol. II, 114-122, 120.

${ }^{11}$ Rosenstein, 'Vooruitgang', 116, 122.

12 J.F.R. Philips, Gezondheidszorg in Limburg. Groei en acceptatie van de gezondheidsvoorzieningen 18501940 (Assen: Van Gorcum 1980) 247-249, quote on p. 247.

${ }^{13}$ Philips, Limburg, 251-252.
} 
and used different methods. Next to their houses they installed consultation rooms, mysterious spaces which smelled of carbol, in which patients were examined, where the doctor, wearing a stethoscope around his neck, performed percussion and auscultation". ${ }^{14}$ It is hard to pinpoint the exact change in sentiment and the shift towards a more positive appreciation of the new class of doctors, but it must be attributed to a complex interplay of factors: the new aura given to academic medicine by the 1865 legislation, the gradual acceptance and introduction of new technologies, the push (from both government and business) towards institutionalized health examinations and insurance arrangements, as well as the broad focus on preventive medicine promoted by the State Inspectorate and local initiatives (to be discussed below). Whatever the weight of these specific causes, the figures with regard to the growth of health care provisions in the late $19^{\text {th }}$ and early $20^{\text {th }}$ centuries speak for themselves. In the outlying province of Limburg, general physicians unmistakably came to replace the mix of doctores medicinae and 'heelmeesters' in the period between 1851 and 1905. This led to a decline in the overall numbers: from 38 doctors medicinae and 26 'heelmeesters' versus 0 doctors in 1851, to 2 doctors medicinae, 2 'heelmeesters' and 40 doctors in 1905. By 1920, this number had already grown to 95 academically trained doctors. Furthermore, between 1910 and 1938, the number of doctors per 10.000 inhabitants went from 2,8 to 4 in Limburg. These developments mirrored important changes on the national level: in the same period this ratio went from 5 to 7 in The Netherlands in general. ${ }^{15}$

At the same time, another important development took place: the differentiation of what it meant to be a doctor. Already in the late $19^{\text {th }}$ century, groups of doctors interested in medical conditions affecting specific parts of the body or the population, such as psychiatrists (1871) and gynecologists (1887) had begun organizing in professional associations. But from 1890 onwards, this development really took off. Despite a large variety of definitions concerning what the term 'specialist' precisely meant, the Dutch Medical Association went from counting 32 specialists in six cities in 1883, to 136 in 1900, to 361 (in 26 cities) in $1910 .{ }^{16}$ By 1930, over a 1.000 doctors selfidentified as specialists, about a quarter of the total number of doctors. ${ }^{17}$ These specialists increasingly came to use new and expensive therapies and instruments - I have already mentioned the introduction of the X-ray machine, which must have spoken greatly to the imagination for its ability to show the human body beyond the mere skin-deep. Moreover, the

\footnotetext{
${ }^{14}$ Ibid., 256.

${ }^{15}$ Ibid., 36, 41-42.

16 Juch, De medisch specialisten, 23, 84-88. For an internationally comparative account of the rise of medical specialties, see: G. Weisz, Divide and Conquer. A Comparative History of Medical Specialization (Oxford: Oxford University Press 2006).

${ }^{17} \mathrm{H}$. van der Velden, 'Groot of klein: de opbouw van het Nederlandse ziekenhuiswezen, 1890-1950', Tijdschrift voor Sociale Geschiedenis 25 (1999) 407-424, 413. Van der Velden puts the number of specialists in 1910 at 462.
} 
use of such instruments also necessitated a gradual change in the location where medical action took place. The quickly growing groups of medical specialists increasingly worked in outpatient clinics, alongside the (patient's) home. But increasingly, they also began to work from (psychiatric) hospitals, which grew rapidly in the early $20^{\text {th }}$ century. ${ }^{18}$

\section{Shifting Care: New Locations}

One of the most crucial changes in medicine and, more broadly, health care in the first half of the $20^{\text {th }}$ century, was the changing nature of the institutions in which such care was provided. The most obvious - and costly - of these institutions was the hospital. But in the area of mental health, too, the first decades of the $20^{\text {th }}$ century saw a rapid increase in institutions and institutionalized patients. A parallel but less eye-catching development in The Netherlands is presented by the so-called 'Cross Associations.' After the turn of the century, these small, local associations mushroomed in rural areas across the country. Initially founded for fulfilling tasks in the area of public, collective health, nursing increasingly became for them a vital task. Curative interventions in the (psychiatric) hospital or specialist clinic were thus increasingly complemented by a type of care outsourced to small, local institutions financed through collective arrangements - something quite different from what would mostly have been care in the home by friends or family members before that time.

Some numbers on the growth of these three types of institutions gives an indication of the scaling-up of 'health care' in this period - an unprecedented historical caesura, both nationally as well as internationally. From the early 1900s, the hospital landscape underwent significant changes. ${ }^{19}$ New technologies, expanded possibilities for surgery, and the aforementioned rise of specialists who increasingly worked in hospitals, meant that both the demand for hospital care as well as the number of hospitals grew exponentially in this period. In 1850, The Netherlands counted about 45 hospitals. ${ }^{20}$ By 1890, this number had risen to about 80. But by 1920, the number of hospitals in The Netherlands had reached a peak of some 250, offering at least 21.000 beds. ${ }^{21}$ The scale of the average hospital changed considerably in the

\footnotetext{
18 Juch, Medisch specialisten, 121-125.

${ }^{19}$ In general, see Porter, Blood and Guts, 145-151. For The Netherlands, see: E. Houwaart, 'De ontwikkeling van het ziekenhuis in de moderne tijd', in: M.S.C. Bakker et al, Techniek als cultuurverschijnsel. Casusboek (Heerlen, Open Universiteit 1996) 238-355.

${ }^{20}$ Vonk, Recht of schade, 42.

${ }^{21}$ A 1920 tally by a government committee counted 244 hospitals, accounting for some 20.500 beds - but The Hague and Rotterdam did not send in data, and hospitals under construction were not taken into account. National Archives, inventory 2.04.55, no. 326; Verslag van de Commissie voor de
} 
following years, however, as evidenced by a total bed count of 30.000 in 1934 . About a third of these beds were under governmental control - among them those in the large academic hospitals. The remainder was divided amongst confessional and non-religious private philanthropic organizations. ${ }^{22}$ It was noted at the time that the care offered by many of the (often smaller) hospitals was 'primitive'. ${ }^{23}$ Moreover, given the absence of centralized statistics on hospital costs, it is hard to arrive at an estimation of the growth of costs in this period - it was not until the mid-1930s that the question of costs became a serious issue. The rapid growth of hospitals on the whole provides a striking picture of the change in institutional setting in which care increasingly was provided.

A similar development took place with regards to the Cross Associations. The first of these had been founded by Jacobus Penn, a State Inspector for Health Care who by 1875 had become so disillusioned by the lack of municipal activity in the field of public health that he decided to organize a private service in Hilversum for furthering this cause. ${ }^{24}$ In a period in which the State Inspectorate, despite its best intentions, often failed to move municipal governments in furthering public health, this formula proved to be a great success. Table 2.1 illustrates this (the numbers represent local Associations founded in each of these periods, not the grand total):

Table 2.1 Founding of new Cross Associations, 1890-1929²5

\begin{tabular}{|l|l|l|l|l|l|l|l|l|}
\hline Type/Period & $\begin{array}{l}\text { Before } \\
1890\end{array}$ & $\begin{array}{l}1890- \\
1899\end{array}$ & $\begin{array}{l}1900- \\
1904\end{array}$ & $\begin{array}{l}1905- \\
1909\end{array}$ & $\begin{array}{l}1910- \\
1914\end{array}$ & $\begin{array}{l}1915- \\
1919\end{array}$ & $\begin{array}{l}1920- \\
1924\end{array}$ & $\begin{array}{l}1925 \\
1929\end{array}$ \\
\hline $\begin{array}{l}\text { Green and } \\
\text { White Cross } \\
\text { (secular) }\end{array}$ & 20 & 46 & 177 & 222 & 128 & 77 & 38 & 38 \\
\hline $\begin{array}{l}\text { White- } \\
\text { Yellow Cross } \\
\text { (catholic) }\end{array}$ & - & - & - & 5 & 42 & 59 & 117 & 144 \\
\hline
\end{tabular}

Source: Centraal Bureau voor de Statistiek, Overzicht van de Kruisvereenigingen in Nederland (Den Haag: Rijksuitgeverij 1942)

Ziekenverzorging, p. 11. Houwaart counts 265 hospitals in 1920. Houwaart, 'De ontwikkeling van het ziekenhuis', 241.

${ }^{22}$ Van der Velden, 'Dutch Health Services', 62-63; Van der Velden, 'Opbouw Nederlandse ziekenhuiswezen', 413.

23 'Verslag van de Commissie voor de Ziekenverzorging', appendix on hospitals, p. 11.

${ }^{24}$ Rigter, Met raad en daad, 20; Centraal Bureau voor de Statistiek, Overzicht van de Kruisvereenigingen in Nederland (Den Haag: Rijksuitgeverij 1942) 7-8. On the Cross Associations in general, see: M. van der KolkKousemaker, Het beleid van Het Witte Kruis, Het Groene Kruis en Het Wit-Gele Kruis over de periode 18751945 (diss. Universiteit Utrecht: 2005).

${ }^{25}$ The largest Protestant cross association - the Orange-Green Cross - was not founded until 1939. 
As time progressed and cities increasingly founded their own municipal health services (see par. 2.4), the biggest wave of growth for these Associations in rural areas passed. Still, by 1941 there was a grand total of 1335 local Cross Associations, up from a handful in the period before $1890 .{ }^{26}$ Alongside the technologically sophisticated types of care patients could receive in hospitals, district nursing, local public health measures, vaccination and more were thus increasingly organized through local cells operating under larger umbrella organizations which either had a confessional or secular signature. These associations increasingly came to be seen as the core of the sacrosanct 'private initiative'. And yet, their budgetary needs would gradually also bring government into the equation.

Finally, a short note on changes in care for the mentally ill. As noted in Chapter 1 , such care was the only type officially made a task for provincial and municipal public authorities on the basis of the Lunacy Act of 1841/1884 and the Poor Law. Statistics gathered through the State Inspectorate for Asylums document well the rise in asylum populations as well as the institutions that took care of them. In 1842, there were 31 such institutions, which gradually grew in size but decreased in number, to 14 in 1884. In the period between 1856 and 1881 the number of people cared for in these institutions rose from 1.828 to over $4.300 .{ }^{27}$ After this, serious growth again set in, both in terms of patient numbers and institutions. By 1920, some 16.000 mental patients were treated in a grand total of 32 institutions, 19 of which were under public administration. ${ }^{28}$ Much like the care offered by hospitals and district nursing, care for the mentally ill thus went from something of a cottage industry to a large-scale endeavor, necessitating new and bigger buildings as well as ever-expanding budgets.

\section{Social Ideals, Faltering Politics}

The rapid developments in medicine's 'internal' as well as institutional side began to change ideas about health care as a mere a private affair by the early $20^{\text {th }}$ century. As discussed in the previous chapter, at the turn of the century access through sickness funds was provided to a little less than a fifth of the Dutch population. For another part of the population poor relief provided essential medical assistance. But in the wake of debates leading up to the Accident Act and of

\footnotetext{
${ }^{26}$ CBS, Overzicht van de Kruisvereenigingen, 8, 12.

27 Bakker, Geld voor GGZ, 31.

${ }^{28}$ G. Blok, 'Soelaas voor geest en samenleving: de GGZ als werkveld', in: H. Hillen, E. Houwaart and F. Huisman, Leerboek medische geschiedenis (Houten: Bohn Stafleu van Loghum 2018) 207-219, $210-211$.
} 
developments abroad, political debate gradually came to see access to health care as partly a collective responsibility.

Broader changes than just developments in medicine played a role here. The working class and the 'social question' had been an issue from the last quarter of the $19^{\text {th }}$ century, but in the early $20^{\text {th }}$ century, a burgeoning and more prosperous middle class began to arise. In the absence of national legislation facilitating access to care for this (relatively affluent) group which could not apply for municipal poor relief, these citizens increasingly had a hard time paying for (ever more costly) health care. At the same time, in this period various cultural developments paint a picture of growing support for a notion of accessible health care. Political rhetoric emphasized charity and philanthropy as crucial elements in the creation of social coherence and for achieving social goals. ${ }^{29}$ Many (though definitely not all) sickness funds had a philanthropic and non-profit signature. Finally, although the rapid, unregulated growth of new medical provisions and institutions was in line with the Liberal and Confessional notions of the 'organic growth' of private initiatives, it was clear that such growth was leading to an uncoordinated 'patchwork'. Such a patchwork did not always lead to the stimulation of the 'national force' that Thorbecke had hoped for so furiously half a century before. All of these elements came together in early attempts at legislating health care.

However, as far as increasing access to individual as well as to public health provisions were concerned, until 1941 central government did not manage to insert itself into the broad field of private initiatives or (officially) strengthen its power over local governments. In large part, this had to do with the political constellation of the first half of the $20^{\text {th }}$ century. The death of Thorbecke in 1872 in a sense also signaled the end of Liberal dominance in Dutch politics, and as we have seen, that decade also saw the rise of Kuyper's (Protestant) Anti-Revolutionary party. Still, between 1888 - which saw the first coalition cabinet of Protestants and Catholics - and 1918, the Liberals and (mostly) Protestants dominated the political scene. This continued the dominance of the principles of Liberalism and 'sphere sovereignty' in political discourse. After 1918, the power of the Liberals severely declined in favor of the Catholic party. In the interwar years, this party therefore dominated politics with the Protestants. And, as we have seen, the Catholics stressed 'subsidiarity' as a philosophy of limited state intervention. It was not until 1939

\footnotetext{
${ }^{29}$ The term 'solidarity' was reserved primarily for the socialists, but as Kuyper's 1891 lecture illustrated, Christian Samaritanism also amounted to solidarity with the working classes and the necessity to create equal access (principally through private initiatives) to health care. For Catholics, charity was of course engrained in the notion of Caritas, but the papal encyclical Rerum novarum of 1891 specifically addressed the plight of the working classes and called for social bulwarks against the negative effects of unbridled capitalism in a new industrial order. (http://w2.vatican.va/content/leo-xiii/en/encyclicals/documents/hf Ixiii enc 15051891 rerum-novarum.html, accessed on 12-12-2017.)
} 
that the first Social-Democrat officially entered government. ${ }^{30}$ Still, the aforementioned cultural sentiments had an impact on how not just private, but also public bodies began to comport themselves in increasingly facilitating access to care. The Liberal-confessional 'governmentality' with regard to health care would evolve, but not solely as a result of private initiative. Especially from 1912 onwards, new public subsidies and financing arrangements led to serious shifts in influence over how health care was provided. We must first understand the limits of politics on the national level, before we examine these far less visible, but no less significant shifts on the local level.

\section{The Limits of the Legislature}

Where mandatory health insurance is concerned, The Netherlands take up an exceptional position in European history. In 1883/84, Chancellor of the German Empire Otto von Bismarck had set the tone by instituting, first, mandatory sickness insurance and, one year later, accident insurance (with old-age insurance trailing shortly behind in 1889). Though the extent of social insurance would vary from country to country, and the motives for enacting it in Germany and elsewhere always lay somewhere on a continuum between solidarity with and fear of the working classes (the 'social question' often implied a socialist threat), this legislation set an example which was followed rapidly by countries across the globe. ${ }^{31}$ Comparatively speaking, The Netherlands was therefore an outlier. However, that legislation concerning mandatory sickness insurance did not get off the ground in The Netherlands in this period was not for lack of trying.

The first attempt at codifying mandatory health insurance for workers took place in 1904 . Here, political (and spiritual) leader of the Protestants Abraham Kuyper played an important role. After an electoral victory putting Protestants and Catholics in charge in 1901, Kuyper as leader of the new cabinet drafted a bill granting comprehensive medical care, sick pay and funeral compensation to workers. Much of the logic governing the Accident Act could be recognized in this bill. Although criticism of the existing sickness funds was a reason for Kuyper to focus on the creation and/or national recognition of new, privately governed administrative bodies (modelled after the Bismarckian Krankenkassen), the strong emphasis on private initiative and limited government in Kuyper's worldview were essential elements of this new plan for state-backed

\footnotetext{
${ }^{30}$ For a quick overview of these cabinets, see: https://www.parlement.com/id/vh8Inhrp1wzr/periode 18881918 antithese and https://www.parlement.com/id/vh8Inhrp1wzs/periode 19181939 interbellum, both accessed on 06-112019.

31 A. Hu and P. Manning, 'The global social insurance movement since the 1880s', Journal of Global History 5 (2010) 125-148, in particular p. 133-135.
} 
health insurance. ${ }^{32}$ Private parties would see to the execution and administration of a public provision. The effects of this first bill, as well as that of Kuyper's successor Veegens, however, never materialized. Neither Kuyper (in 1904) nor Veegens (in 1907) got the chance to send their draft bills to Parliament before their respective cabinets fell. ${ }^{33}$ Still, these first forays into mandatory health insurance set off a debate on illness insurance which led to a succession of politicians concerning themselves with the issue: the Anti-Revolutionary Talma in 1913, the Catholic Aalberse in 1919, the Christian-Historical Unionist Slotemaker de Bruïne in 1926 and the progressive liberal Slingenberg in $1936 .{ }^{34}$ In this debate, the socialists conspicuously lacked real political power - they consistently represented some $20 \%$ of the electorate after 1917 , but didn't enter government until 1939. ${ }^{35}$ But again, the fact that politicians from nearly every corner of the political spectrum concerned themselves with the issue attests to the widespread feeling that something needed to happen to provide at least minimal support to workers falling sick. But while other countries in Europe and beyond were working to institute some forms of health care provisions for citizens, The Netherlands trailed behind. What were the reasons for this?

The first politician to continue on the path of drafting legislation concerning access to health care after Veegens was Syb Talma, of Kuyper's Anti-Revolutionary Party. In 1913, Talma presented a legislative bill for support in case of illness. However, with this bill Talma effectively removed medical care from the insurance scheme. Talma made an essential distinction by separating sick pay from the reimbursement for medical care - something which Kuyper had not done, and which was fairly unique in the broader European context. This separation was telling for the way it preferred private initiative in health insurance to strong government intervention in this sphere. Instead of giving government a role in the operations of sickness funds, Talma proposed legislation which would create something of a detour: he wanted to institute semipublic 'Labor Councils', which would administer insurance schemes for which workers could apply to be eligible for sick pay. ${ }^{36}$ As far as medical care apart from sick pay was concerned,

\footnotetext{
${ }^{32}$ For a detailed discussion, see K.P. Companje, 'Ziekteverzekering volgens Bismarckrecept?', in: Companje, Tussen volksverzekering en vrije markt, 47-95, 67-74. The most significant provisions of the proposed bill concerned the reimbursement of medical care, as well as $70 \%$ of a worker's income, up to a maximum of 180 days. Included in this medical care would also be dental and hospital care, significant provisions because of their high cost. The costs incurred because of illness would be reimbursed by the sickness funds or 'kassen', which would principally be private organisations (regardless of their backgrounds as mutual funds, private insurers, or confessional organisations).

${ }^{33}$ Veegens' bill differed so little from Kuyper's that it is not discussed separately here. See Companje, 'Bismarckrecept', 75-76.

${ }^{34}$ The Christian-Historical Union was a party with a Protestant-Reformed signature.

${ }^{35}$ https://www.parlement.com/id/vh8Inhrpfxu8/sociaal democratische arbeiderspartij, referenced on 5-32018.

${ }^{36}$ Companje, Two Centuries, 111-113; K.P. Companje, 'Ziekenzorg en ziekengeld gescheiden verzekeringen, 1908-1940', in: Companje, Tussen volksverzekering en vrije markt, 225-350, 270-271. Talma's reasoning
} 
Talma argued that given the free status of medical professionals, government could not impose state-sanctioned health care. Such a recognition of the freedom of the medical profession has been interpreted as a sign of the increasing power of the Dutch Medical Association. ${ }^{37}$ But it also fit in well with the framework set out in 1865 by Thorbecke, with regard to both the autonomy and the monopoly power of certain medical professions and to the desirability of a limited role of government in guaranteeing access to health care in general.

It immediately became clear that such thinking was broadly shared among both the political classes as well as the players in 'the field'. The new type of public organs proposed by Talma was immediately seen by many within as well as outside politics as undesirable and unnecessary. As noted in the discussion of the Accident Act, many employers had in the previous decade begun instituting sickness benefit and insurance schemes for their workers, something which both they and many politicians preferred over the (perceived) bureaucracy inherent to government bodies. On the other side stood the Medical Association and the sickness funds discussed in detail below - which were becoming increasingly powerful groups in this constellation of actors. As a result, even though Talma had been driven (more than Kuyper) by notions of private initiative and limited governmental intervention, he was forced to water down the role of the Labor Councils, leaving the administration of insurance to already existing administrative organs. In 1913, his Sickness Benefits Act was passed in Parliament, but with much of its original intent removed. ${ }^{38}$

The failure of Talma's ideas cast a dark shadow over the next thirty years of attempts to legislate sick pay. The outbreak of the First World War, as well as far more ambitious plans for health insurance by Talma's successor Treub, led to the 1913 Act immediately being shelved. Moreover, Treub resigned in 1916, leaving the issue pending. ${ }^{39}$ The next politician making serious work of health insurance was Piet Aalberse. In 1919, this Catholic Minister of Labor - who had been an important figure in the Catholic social movement ${ }^{40}$ - presented a draft bill on sickness benefits which very much resembled Talma's 1913 Act. Much like that legislation, the core of Aalberse's proposal revolved around the question of public or private administration of sick pay. However, the governmental council advising him on the bill - the High Labor Council instituted by Aalberse himself - presented him with an unpleasant surprise when it argued in favor of benefit arrangements offered by private companies. By 1919, such arrangements were

here was that the legal foundation for sick pay was its link to work: if workers fell sick, they should be compensated because of their status as gainfully employed citizens.

${ }^{37}$ Ibid., 111. See p. 268-269 for Talma's arguments for medical autonomy in this respect.

${ }^{38}$ Companje, Two Centuries of Solidarity, 113.

${ }^{39}$ Ibid., 156-157.

${ }^{40}$ K.P. Companje and D. Rigter, "Ontwerp der wet regelende de ziekenverzorging', of de spanning tussen overheidsfinanciën en volksgezondheid, 1918-1941', in: Companje, Tussen volksverzekering en vrije markt, 399-476, 402. 
legion, and when it turned out that Aalberse's plans would require mandatory contributions of workers for financing sick pay - where in the current situation, employers often paid in full for this - opposition to the Minister's plans was picked up by an unlikely combination of workers' and employers' associations. By 1921, reservations revolving around the question of public/private administration were aggravated by developments not unique to the Dutch political situation: an economic downturn put a stop to costly social legislation. ${ }^{41}$ Nevertheless, it was clear that widespread resistance to governmental interference in the employer/employee relationship in case of illness formed an important backdrop to this failure. It was not until 1930 that a Sickness Benefits Act following the line set out by Talma came into effect. However, by that time the offering of sick pay by companies was firmly entrenched, with some $90 \%$ of employers having chosen to organize social arrangements for their employees, thus keeping government interventions at bay. ${ }^{42}$

\section{Limits of the Legislature, Act Two: Health Insurance}

If in this period it proved hard to get central government to play a role in the private sphere where the provision of sick pay in case of illness was concerned, attempts at instituting a mandatory health insurance scheme fared even worse. Since Talma had been forced to reduce the role of the semi-public Labor Councils as insurance brokers in 1913, Aalberse in 1920 set out to work from the premise of the primacy of the sickness funds and private initiative. In a draft bill submitted that year, voluntary insurance was regulated in terms of the demands set for sickness funds. These pertained to the income limit for fund members, the make-up of their boards, and the health care provisions (which were extensive) that were covered in a compulsory insurance package under this new Health Insurance Act. As a stimulus to the development of health care, Aalberse gave national government a significant role in the realization of these goals. The proposal was to subsidize health care to the tune of ten million guilders per year - these state subsidies were to be used for improving hospitals, as well as for the cost of administration and the expensive hospital and nursing care that were covered by the mandatory package. With such funding, sickness funds would be able to cover their costs - making a profit would be legally prohibited, as care concerned a social provision. Despite applying for a sickness fund policy itself being voluntary, a link was made with the Sickness Benefits Act. That act stipulated that in order to be eligible for sick pay, workers had to be insured for medical costs through a sickness fund recognized by government. In this way a compromise was found: a statutory obligation for

\footnotetext{
41 This fear of exploding costs was also crucial in the debate in other countries, see Hu en Manning, 137. ${ }^{42}$ Companje, Two Centuries of Solidarity, 158-162. See also A.C. van Bruggen, 'Arts en samenleving. De Ziektewet-Talma', Ned. Tijdschr. v. Geneesk. 64 (1920) 2582-2593.
} 
workers to insure themselves was deemed undesirable; but linking fund membership to eligibility for sick pay was acceptable. However, already in 1922 Aalberse was forced to retract his bill because of the expected explosion of costs. ${ }^{43}$

In the following two decades, several legislative proposals on health insurance were put forward - in 1927, 1930, 1936 and 1939. All of these, however, presented merely a shadow of what Aalberse had envisioned in 1920. In a crucial sense, Aalberse's bill had been an anomaly. Of all the proposals from Talma onwards, only this bill had presupposed a serious financial stake of central government in the provision of health care. What remained of it in the successive proposals was the procedural task for government to formally recognize sickness funds - also from the perspective of the Sickness Benefits Act. However, none of these bills made it past Parliament (most of them not even being submitted). ${ }^{44}$ Overall, fears of financial overrun proved too much of a hurdle for successive ministers interested in instituting a form of mandatory health insurance for (mostly) the working class. But ultimately, it was the political and social emphasis on bottom-up initiative (in the form of sickness funds, employer-based insurance schemes, or municipal poor relief) which was instrumental in blocking or at least diluting attempts to give government a role in the field of health insurance and provision. It would take a different type of political policy to break this stalemate, one which would only be introduced in 1941 by the German occupier. For now, the governmentality of small government and private initiative in health insurance was firmly entrenched in health care.

\section{The Trials of the State Inspectorate}

In terms of legislation aimed at the financing and facilitating of individual health care, the early decades of the $20^{\text {th }}$ century were thus rather disappointing. But also where public health was concerned - envisioned by Thorbecke as the primary province of government intervention objections and circumstances similar to those obstructing the proposals on sickness pay and insurance played an important role in halting the increasing participation of central government. The history of attempts to legislate public health perfectly illustrates the stalemate between, on the one hand, a growing support for to the notion that this was something to be stimulated or guaranteed by government, and on the other, an unwillingness and general lack of effectiveness across the political board to put either power or money into the hands of governmental bodies. These (relative) failures to legislate public health care center around two trajectories: the several

\footnotetext{
${ }^{43}$ Companje en Rigter, 'Ontwerp der wet', 420-424; Companje, Two Centuries of Solidarity, 163-164. 44 Ibid., 164-166.
} 
changes made to the 1865 Act on the State Inspectorate, and the 1919 proposal to institute District Health Services. ${ }^{45}$

Where the State Inspectorate was concerned, the limited effectiveness of this public body in the latter half of the nineteenth century had not gone unnoticed (for this ineffectiveness, see Chapter 1). As a result, already in 1886 and 1895 legislative proposals to strengthen its operations were conceived, but never submitted to Parliament. In September 1899, however, a proposal was submitted which aimed to clarify and strengthen the power structures governing the State Inspectorate. The accompanying Memorandum to this new Health Act ('Gezondheidswet') stated it thus: what was needed was "[...] powerful, knowledgeable central leadership [...] as well as powerful local support for the interests of the public health" in order "to make the State Inspectorate a vital force [...]." ${ }^{\prime 46}$ To this end, a Central Health Council would be created, which would stand at the top of a new hierarchy of State Inspectors and municipal Health Committees. This new Health Act was passed without serious opposition, giving the state supervisory structure a fresh start: the Health Council would consist of seven members, four of whom were Head Inspectors. These in turn would instruct local Inspectors (sixteen in total) on public health policy. The local Inspectors, for their part, had to supervise the municipal Health Committees, which were public administrative bodies tasked with investigating and acting on public health concerns at the local level. In general, the State Inspectorate could rejoice that its mandate was broadened to include anything concerning 'public health' - without a clear definition of what this entailed, giving it carte blanche to concern itself with a broad variety of matters. ${ }^{47}$

Despite the new organizational structure and theoretically strong position for the Health Council, it straightaway became clear that the Inspectorate was dogged by two interconnected problems: an unclear mandate, and limited effectiveness in stimulating change at the local level, caused by lack of interest and respect on the part of municipal authorities for the Inspectors and Health Committees. First, despite talk of leadership for the Health Council, this new body was legally and effectively under control of the Minister of the Interior. This limited its authority to giving advice to the Minister. This would not have been so bad, were it not for the fact that the internal organization of the Council also stood in the way of it becoming an effective body for advising on health policy. Within the Council, the uneven mix of experienced administrators and hygienists made for unclear coordination and "stopped in its tracks team spirit within the

\footnotetext{
45 'Districtsgezondheidsdiensten'.

${ }^{46}$ Memorie van Toelichting accompanying the proposal, cited in a historical account by J. Th. Terburgh (the Head Inspector) in National Archives, inventory 2.15.38, no. 18. Verhandeling van de hoofdinspecteur dr J.Th. Terburgh inzake de geschiedenis van het Staatstoezicht op de Volksgezondheid (1928), p. 27-28.

${ }^{47}$ See D. Cannegieter, Honderdvijftig jaar Gezondheidswet (Assen: Van Gorcum 1954) 121-128.
} 
Council." ${ }^{48}$ Already in 1910, a proposal to change the ineffective structure was submitted, but retracted. In 1919, Minister Aalberse submitted a new proposal, which effectively moved control from the Council to the Minister and a Director-General overseeing both the Health Council and the State Inspectors. This proposal passed without a vote, attesting to the limited belief in the system as it had existed up until that moment. ${ }^{49}$ However, this raised the question whether such a change did not simply mean a reversal to the situation of 1865 - limited effectiveness on the part of the Inspectorate, because of a lack of authority - precisely the reason for the legislative changes of 1901 in the first place. ${ }^{50}$

Moreover, immediately after the First World War, budget cuts were high on the agenda as far as public health was concerned. In 1920, the scope of the Inspectorate was expanded to bring it in line with new legislative tasks (such as supervising child hygiene, tuberculosis, and alcohol abuse). Yet, between 1924 and 1936, the number of medically trained Inspectors was cut back from ten to seven. So, despite various attempts, the State Inspectorate still did not meet the high hopes Thorbecke had had for it in 1865. Between 1939 and 1946, at least seven plans for revising the general structure of governmental intervention in public health were presented. ${ }^{51}$ We recall Thorbecke's optimistic assessment of 1865 that the Inspectorate's powers to 'persuade' local governments to act on public health issues would be enough to make the new public body a success. This had turned out to be wishful thinking, as within the so-called 'House' set out by Thorbecke himself, municipalities were not at all keen on central government looking over their shoulder. This problem came to the fore even more prominently where it concerned the organization of public health care.

\section{The Achilles' Heel of a 'Local' Governmentality}

Another victim of budget cuts would be the legislative proposal on District Health Services, submitted in November 1920. However, here too questions of the distributions of power and responsibilities between public and private entities were arguably as important as direct financial concerns. Much as had been the case after the creation of the State Inspectorate, the primary target of public health interventions and advice - the municipal governments - were still not charmed by the perspective of having a governmental body and civil servants advising them on local policy. But there was also the crucial question of who should bear the financial burden of

\footnotetext{
${ }^{48}$ Cannegieter, Gezondheidswet, p. 121-122, 131-133. Quote on p. 132.

${ }^{49}$ Ibid., 143-144, 146.

${ }^{50}$ National Archives, inventory 2.15.38, no. 18. Verhandeling van de hoofdinspecteur dr J.Th. Terburgh inzake de geschiedenis van het Staatstoezicht op de Volksgezondheid (1928), 40-41.

${ }^{51}$ Cannegieter, Gezondheidswet, 182-183.
} 
public health operations. In 1928, Head Inspector Terburgh, in a short history of the Inspectorate, commented on Thorbecke's too optimistic vision in this regard. According to Thorbecke, Terburgh stated, "the municipalities had the duty to take measures and bear the cost on the basis of the Municipality Act. But this has turned out to be an issue not easily solved by posterity!"52 And yet, the rise of municipal health services discussed later on in this chapter shows that, from the 1910s onwards, many municipalities were in fact willing to invest (limited) funds in health services. More important was the resentment felt toward government interlopers telling municipalities what to do.

The local Health Committees, already in existence since 1865, were often at the receiving end of such disdain. As noted, these Committees were to have a serious role in the structure updated in 1901. They operated under supervision of the local Inspectors, but were seen as seminal because of their proximity to municipal health policy. Nevertheless, much like the Inspectors themselves, these institutions were outsiders in the local hierarchy, as they were formally instituted by central government. Moreover, they often had enormous areas of operation: by 1903 there were 130 Health Committees, on a total of some 1100 municipalities. ${ }^{53}$ Given these combined problems, in 1920 Minister Aalberse submitted a legislative proposal to give these Committees a stronger mandate, through the institution of overarching regional District Health Services. Half of the cost for instituting these Services would be borne by the state, the other half by municipalities. Public health matters these services would be tasked with covered certain classic duties for the Inspectorate, such as advising on infectious diseases and collecting statistics. At the same time, more practical and local matters such as combating venereal disease and alcoholism were brought within their mandate. ${ }^{54}$ In total, the cost was estimated at some four to five million guilders (although exact estimations differed). ${ }^{55}$ Nevertheless, a real discussion of costs never got off the ground. The initial proposal was met with criticism, as the tasks of the new District Services were seen as too vaguely circumscribed. By 1921-1922 a revision of the proposal was submitted but not discussed in Parliament, and it was only in 1928 that a very broad estimate of the cost was presented. The reactions to this proposal were very telling, as the criticisms leveled at the Ministers responsible for proposing

\footnotetext{
52 National Archives, inventory 2.15.38, no. 18. Verhandeling van de hoofdinspecteur dr J.Th. Terburgh inzake de geschiedenis van het Staatstoezicht op de Volksgezondheid (1928), 18.

${ }^{53}$ Cannegieter, Gezondheidswet, 126, 151. P. 152 for Cannegieter counting 1113 municipalities by 1921.

${ }^{54}$ National Archives, inventory 2.15.38, no. 219, betreffende de Instelling van Gezondheidsdiensten. Directeur van de Gemeentelijke Geneeskundige Dienst Leiden, Dec 1926, 'Schets van een districtsgezondheidsdienst Leiden-Gouda met raming der jaarlijkse bedrijfskosten', p. 2.

${ }^{55}$ Ibid., Nota omtrent de kosten van gezondheidsdiensten, p. 7, puts the total cost at some four to five million guilders, on top of what the national government was already paying at that time. C.J. Brenkman, 'Districts-Gezondheidsdiensten. Een nieuw stadium', Tijdschrift voor Sociale Geneeskunde 12 (1928) 145148 puts the total cost at f. 4.650.000, while noting that the financial overview was 'unclear'.
} 
and then delaying the legislation laid bare conflicts at the heart of issues of public or private governance and initiative.

This is because much like the discussions on government inserting itself into health insurance, political debate involved the notion that private initiative and local governments providing for public health services would better suit the Dutch political-cultural system. ${ }^{56}$ This assumption that informed the dominant political rhetoric was, however, challenged by voices from the more progressive side of the political spectrum. Medical doctor and socialist MP A. De Vries-Bruins, as well as the director of the Amsterdam municipal health service L. Heijermans, offered some sharp critique. De Vries-Bruins had been responsible for getting the Minister to provide an estimate of what the District Services would cost. In arguing that precisely such openness and transparency on the national level was needed, she stated about the emphasis on private initiative: "How can Parliament influence and check this work, so important to the general public's health?"57 And speaking from the perspective of the largest municipal health service in operation at the time, Heijermans asked: "Are private parties and companies then without error? Does one not also find persons there who shirk their duties? Does everything there go according to the rules of efficiency?" More to the point, Heijermans noted about the uncoordinated and incidental character of health services dependent on private initiative: "As soon as in a private organization a highly dedicated person dies or steps down, we all too often see that either the organization as a whole comes crashing down like a house of cards, or that Government has to step in to take over this task." 58 Such criticisms of the weak spots of 'private initiative' and of the governmentality of the local level - with its often arbitrary character - laid bare a crucial problem with this philosophy: neither equality of access nor successful supervision of the general quality of provisions could be guaranteed if there was no central body or government taking responsibility for them.

As we have seen in Chapter 1, such notions of quality and equality had been central to Thorbecke's 1865 legislative project. But the local level was (still) the Achilles' heel of the system of limited interventions by central government, as health care provisions were scattered and uneven, and dependent on the means and will of individual actors (be they private parties or municipalities). However, critique was of no avail. In 1933, the proposal for instituting District Health Services was retracted. The focus on private initiative had simply been too strong, and, apart from that, much was by now happening on that front, in terms of health care provisions being created. Moreover, by this time many municipalities had also begun instituting health

\footnotetext{
${ }^{56}$ For this debate, see: Kerkhoff, Honderd jaar gezondheidsdiensten, 39-43; Cannegieter, Gezondheidswet, 153-164, 169.

${ }^{57}$ Cited in Cannegieter, Gezondheidswet, 163-164.

${ }^{58}$ L. Heijermans, 'Open brief Aan Zijne Excellentie den Minister van Arbeid, Handel en Nijverheid', Tijdschrift voor Sociale Geneeskunde 6, vol. 12 (1928) 179-185, 180.
} 
services of their own. ${ }^{59}$ It is now time to move away from the failures of the national legislature, and to examine these developments 'on the ground' - the promotion of access to health care provisions for a larger proportion of the population, facilitated by both private and public parties. It is here that real changes in the governmentality, developments that had its origin in the mid-nineteenth century, began to take place in earnest.

\section{From Arbitrariness to Accessibility}

Despite the absence of central government in health insurance in the period before the Second World War, provisions for citizens to insure themselves against health care risks, as well as new services, grew steadily. In this respect, we can speak of three 'compartments' which gradually developed (mostly) outside of the remit of national legislation. The starting point here is the sickness funds, which by the 1890 s rapidly began to grow in numbers. These funds take up a central role in the past two decades of the historiography of Dutch health care, with authors looking at the various types of funds and their role in the system. ${ }^{60}$ This is understandable, given the key role these funds played in the provision of health care in the $20^{\text {th }}$ century. More recently, Robert Vonk has added an important new perspective to the understanding of access to health care in the second 'compartment', by systematically studying the market for private health insurance - insurers catering to those people exceeding the income limit for sickness funds, but unable to pay out-of-pocket for private practice. ${ }^{61}$ Not fitting well into either of these compartments were the smaller collective arrangements called 'hospital insurance associations', which in this period came to provide insurance for increasingly expensive hospital care, thereby crossing the boundaries between the compartments of sickness fund and private income limits. (We will discuss these further on.)

However, compared to both the hospital insurance associations and the private insurers, the public, third 'compartment' came to take up a disproportionately large share of the financial pie as time progressed. This compartment we have already encountered in the previous chapter. It offered the option for those unable to pay for even sickness fund insurance to appeal to the Civil Poor Board ('Burgerlijk Armbestuur') of their municipal government on the basis of the Poor

\footnotetext{
${ }^{59}$ Kerkhoff, Honderd jaar gezondheidsdiensten, 36-43; Cannegieter, Gezondheidswet, 153-164, 169.

60 See: Companje, Over artsen en verzekeraars; Companje, Convergerende belangen; H.C. and E.W. van der Hoeven, Om welzijn of winst. 100 jaar ziekenfondsen en sociale zekerheid (Deventer: Kluwer 1993); B.E.M. Widdershoven, Het dilemma van solidariteit. De Nederlandse onderlinge ziekenfondsen, 1890-1941 (Diss. Tilburg University: Amsterdam: Aksant 2005). For the $19^{\text {th }}$-century rise of the different types of funds, see J. van Genabeek, Met vereende kracht risico's verzacht. De plaats van onderlinge hulp binnen de negentiendeeeuwse particuliere regelingen van sociale zekerheid (diss. Vrije Universiteit Amsterdam; Amsterdam 1999). ${ }^{61}$ Vonk, Recht of schade.
} 
Law. Strikingly, in the first half of the twentieth century - as attempts to create national legislation on mandatory health insurance and access failed - it was precisely this public, local type of poor relief which would increasingly come to offer financial assistance to not just the poor, but to the growing middle class as well in matters of health care. This became increasingly urgent because of growing hospital costs, and municipalities more and more came to subsidize both hospitals and their patients. In the historiography, only Henk van der Velden has paid significant attention to the interplay between poor relief, the sickness funds and the private segment. ${ }^{62}$ A new synthesis of (financial) data, however, allows us to understand just how large the share of public interventions had come to be in the provision of health care by the beginning of the Second World War. At the same time, an analysis of the three compartments sketched above shows how a broadly shared notion of providing accessible health care to citizens (regardless of their income) came to grow among the spectrum of public and private entities despite the absence of any real centralized regulation of such access.

\section{Sickness Funds: The Bedrock of Dutch Health Insurance}

As far as the sickness funds are concerned, I will point here primarily to the 'unifying' element of all these provisions: their sheer variety and lack of uniformity. As noted in the previous chapter, the latter half of the $19^{\text {th }}$ century saw the growth of an impressive array of collective insurance arrangements. The abolition of guilds in 1812 created a vacuum caused by the disappearance of insurance previously offered in the context of organized professions. This led to the rise of various new types of funds and insurance companies: philanthropic funds, doctors' funds, commercial funds, and, from the late nineteenth century, factory and workers' funds. ${ }^{63}$ As we have seen, by 1900 the total coverage of such funds amounted to 15 to $17 \%$ of the Dutch population, with the percentage rising drastically in the previous decade, up from $10 \%$ in $1891 .^{64}$ But this development went into even higher gear in the first decades of the twentieth century, as can be seen in table 2.2:

\footnotetext{
${ }^{62} \mathrm{H}$. van der Velden, 'The Dutch Health Services before Compulsory Health Insurance 1900-1941', Social History of Medicine 1996, 49-68.

63 Van Genabeek, Met vereende kracht, 13, 303-305.

${ }^{64}$ Companje, Two Centuries of Solidarity, 106, 115.
} 
Table 2.2 - Growth of sickness fund coverage, 1891-1941

\begin{tabular}{|l|l|l|l|l|l|}
\hline Year & $\mathbf{1 8 9 1}$ & $\mathbf{1 9 0 0}$ & $\mathbf{1 9 2 6}$ & $\mathbf{1 9 3 6}$ & $\mathbf{1 9 4 1}$ \\
\hline $\begin{array}{l}\text { Sickness } \\
\text { fund } \\
\text { coverage }\end{array}$ & $10 \%$ & $16 \%$ & $28 \%$ & $39 \%$ & $46 \%$ \\
\hline
\end{tabular}

Source: Companje, Two Centuries of Solidarity, 106, 115

Such a rapid increase of enrollment in these funds was the result of growing prosperity, but also of a growing belief in medicine as efficacious, while we also see the effects of an expanding middle-class on the one hand and increased urban industrialization on the other. ${ }^{65}$ Industrial workers moving from rural areas and their kinship or community-based forms of 'warm' solidarity, had to look for new ways to insure themselves against risks, and found these in sickness funds - even if these were often founded and run by factory bosses, doctors, or entrepreneurs. The largest expansion here took place in the urban industrial centers in the western and eastern parts of the country. ${ }^{66}$

All of this led to a proliferation of funds, with the important addition that not one single type of fund ever managed to gain a dominant position in the field. By 1936, mutual funds (with mutual support as their main motive) provided care to some $27 \%$ of sickness fund enrollees; commercial funds to some $16.5 \%$; and factory funds, which had diminished in importance in the preceding decades, to only $10 \%$. The single largest bloc by this time were the funds associated with the Dutch Medical Association (discussed in more detail below): in 1937 these accounted for about a third of all people insured through sickness funds. However, presenting any of these groups as a coherent collective suggests a unity which was absent more often than not. Among commercial funds as well as mutual ones, there was much diversity, and even doctors' funds backed by the Medical Association did not always agree amongst each other or with the Assocation's board. ${ }^{67}$ In 1913, a small group of mutual funds organized the first interest group, in a bid to offer counterweight to the organizing doctors. In 1932, Catholic funds created a Union through which discussion and negotiation with the government or with doctors could be coordinated. ${ }^{68}$ But these organizations were small, and all things considered, the diversity of the funds stood in the way of uniform thought and action. Most significant, perhaps, was a lack of political clout on the side of the sickness funds. The reason for this is probably that political

\footnotetext{
${ }^{65}$ Vonk, Recht of schade, 40-44.

${ }^{66}$ Companje, Two Centuries of Solidarity, 170-171.

${ }^{67}$ Ibid., 173-176.

${ }^{68}$ Companje, Convergerende belangen, 38, 70.
} 
ideology hardly played a significant role in the backgrounds of the funds. Whereas socialism and Catholicism were powerful agents for change in health care in surrounding countries, in The Netherlands such backgrounds only played a marginal role, and in this period the funds never managed to voice a coherent position concerning the future of health care or their role in it, mirroring the lack of such a sentiment or vision in politics in general. ${ }^{69}$ Instead, political, ideological, and philanthropic motives often intersected in the practical attempts of funds to provide a modicum of health care to their insureds at reasonable prices, be they Catholic factory workers, Protestant teachers, or Liberal journalists.

We may note some similarities among the various types of funds from the perspective of the type of security that was offered to insureds and of the funds' operations in what was essentially a free market. First of all, the target group of the funds: this consisted of a (not always sharply defined) range of citizens able to set aside a periodical sum for the insurance of medical costs. Private practice was often defended tooth and nail by doctors, while those below the lower income limit of the funds had to apply for medical care under the Poor Law. Still, as noted above, on the eve of the Second World War nearly half of the Dutch population had attained a measure of medical security through a fund. Secondly, the packages offered by these funds varied, but often covered standard physician care and basic medicines. ${ }^{70}$ As the century progressed, the coverage of hospital or expensive specialist care became an increasing problem. The advent of hospital care and a growing faith of the citizenry in hospitals as curative institutions was something sickness funds could easily respond to without raising insurance premiums to unacceptable levels. This opened the door for new arrangements, which will be discussed below, to come to fruition. Finally, the fundamental dynamic governing the sickness funds' outlook and operations was not government intervention, but contracting with doctors. The dominant contract was based on a subscription model, whereby doctors were paid on a capitation basis not for individual services rendered, but per enrolled patient. This was an important element in the financial solvability of the funds but also in the increasingly strained relationship with doctors. Though funds often had a motive of mutual help, risk selection was necessary to keep the pool of insureds relatively 'affordable' for the fund in question. However, the fund model of capitation meant that the burden posed by seriously ill patients would be borne by doctors (as the funds paid per patient, not per individual medical treatment). ${ }^{71}$

Selective contracting was something of an inevitability, as sickness funds could not be assured of financial solvability. This resulted in the need for funds to exclude bad risks (so-called 'burning houses'): the old or chronically ill, from their insurance pool. In spite of this, funds did

\footnotetext{
${ }^{69}$ By contrast: in Belgium, socialist and Catholic workers' funds together covered nearly $80 \%$ of the total number of fund members around 1930. (Companje, Two Centuries of Solidarity, 166).

70 Companje, 'Bismarckrecept', 56.

${ }^{71}$ Vonk, Recht of schade, 84.
} 
come to emanate and emphasize a culture of accessibility to health care, and their way of operating was often marked by significant leniency. ${ }^{72}$ That this was part of a broader cultural development not brought on by government intervention or legislation, is illustrated by the second 'compartment' that increasingly provided access to health care: private health insurance for those not eligible for sickness fund policies.

\section{Private Health Insurance: Lucrative or Lurid?}

The growing interest in sickness funds as significant players in the field of health care by the late nineteenth century was marked by the appearance of three reports in short order. These reports presented an overview of the number and types of funds in existence, and commented on the need for streamlining access to them in an industrializing society. However, they also signified a shift in mentalities concerning the (non-)profit character of health insurance. Two of these reports were commissioned by the Dutch Medical Association and one by the philanthropic Association for the General Benefit. ${ }^{73}$ The first report, presented in 1890, made an inventory of some 215 sickness funds and commented on such a changing mentality when noting that:

It seems incomprehensible, that, often, a large number of persons subscribe to a fund whose directors retain the right to one-sidedly change the terms and agreements [...] Though this situation is lamentable and very much calls for a warning, our Association would not have to act on it directly, were it not for the fact that [...] such funds threaten treatment of the sick on the one hand, and the interests and dignity of the medical profession on the other. ${ }^{74}$

If we leave aside the opportunistic second part of this quote, it is interesting because of its rejection of funds primarily aimed at the financial gain of their boards or directors. The funds referred to here were known as 'exploitation funds', and from the late nineteenth century onward, they would increasingly be frowned upon. The 1895 report noted that the financial motive was 'old-fashioned' in comparison to those newer funds which primarily served the interests of the insured: "The newer funds have aspired to combat the focus on individual financial gain and arbitrary opportunism of which there are far too many examples among the

\footnotetext{
72 R.A.A. Vonk, 'In It For the Money? Insurers, Sickness Funds and the Dominance of Not-For-Profit Health Insurance in The Netherlands', in: B. Harris (ed.), Welfare and Old Age in Europe and North America: The Development of Social Insurance (London: Pickering \& Chatto 2012) 167-187, 168.

${ }^{73}$ Maatschappij tot Nut van 't Algemeen.

${ }^{74}$ M. Juda, J.C. van Dooremaal en J. Menno Huizinga, 'Rapport over den toestand der ziekenfondsen in Nederland', NTVG 26 II (1890) 134-147, 140. Though a report commissioned for the Dutch Medical Association, co-author Menno Huizinga was both a practicing physician and a State Inspector for Health Care.
} 
older funds. ${ }^{175}$ This weakening of the profit motive for the sickness funds is interesting in itself, but it is mirrored by developments in the market for private, for-profit insurance companies in the first third of the twentieth century. ${ }^{76}$

The demographic and economic developments in the early $20^{\text {th }}$ century created a niche for health insurance entrepreneurs: "Around 1915, the paradoxical situation arose whereby people who wanted access to medical care were better off poor, if they were not rich." ${ }^{77}$ As sickness funds were accessible only to that segment of the population within certain income brackets, growing costs for health care adversely affected the part of the population which had traditionally payed for care out-of-pocket. Increasingly, only private insurance made it possible for this middle-class group to protect themselves financially against costly medical afflictions or operations. It was this demand which for-profit health insurers sought to meet. Starting from the first decade of the twentieth century, many new insurers started offering health insurance as their sole product (mono-line insurance). In doing so, they had more freedom than the funds, as their dominant insurance policy was based on post facto reimbursement of health care costs, not on a pre-contracted set of services. This meant that private insurers did not have to negotiate with health care providers, and often the coverage under private health insurance policies was more extensive. ${ }^{78}$ On the other hand, it did mean that the financial risks were borne by the insurer, in contrast to the way in which risks in the relationship between sickness funds and doctors lay with the latter group, because of the capitation model of payment discussed above. This is one of the reasons why the private insurance market never really took off. In an age in which actuarial science was far from developed, insurers (or funds, for that matter) had very little substantive criteria on which to base assessments of a potential client's future health. ${ }^{79}$ And this was reflected in the number of bankruptcies: between 1900 and 1920, the liquidation rate for newly founded private companies was 50\%, on a total of twenty new companies. Between 1921 and 1940, some 100 new companies entered the market, with about a third of these not surviving this period or having to liquidate their health insurance portfolio. ${ }^{80}$

\footnotetext{
${ }^{75}$ W. Stoeder et al, De Ziekenfondsen in Nederland. Rapport Uitgebracht door eene Commissie van Onderzoek (Amsterdam: S.L. van Looy \& H. Gerlings 1895), p. 63.

${ }^{76}$ The term 'private' here refers primarily to the market that was served, not to the legal shape these organizations took, i.e. government-organized (funds were also 'private' operations in this latter sense). The terms public-private would become relevant in health care only after 1941.

77 Vonk, Recht of schade, 48. I base this paragraph on Vonk, Recht of schade, chapter 1 and two related synoptic articles in English: Vonk, 'In It for the Money?; R.A.A. Vonk and F.T. Schut, 'Can universal access be achieved in a voluntary private health insurance market? Dutch private insurers caught between competing logics', Health Economics, Policy and Law (2018) 1-22.

${ }^{78}$ Vonk, 'In It for the Money', 169.

${ }^{79}$ Vonk, Recht of schade, 53-55.

${ }^{80}$ Ibid., 37.
} 
But the lack of sound actuarial insights also had an effect on the perception of private health insurers. Because of the entrepreneurial hazard created by insuring people whose medical risks could only be estimated very loosely, for-profit insurers often employed stringent selection criteria. In order to keep their portfolios healthy, insurers refused chronically ill or older clients, or unilaterally terminated contracts in case someone became gravely ill and, therefore, vastly expensive. Although such problems could also be found with sickness funds, this increasingly created a feeling that private (for-profit) health insurance was a market for charlatans and 'freebooters' not concerned with providing patients with adequate health care for fair prices something which sickness funds were increasingly striving for. Such sentiments lived not just among the broader public, but also among companies offering other insurance products. ${ }^{81}$ Partly as a result, this led to a change in modus operandi for many private health insurers. As time progressed, private health insurance increasingly came to be of interest to multiple-line companies - which offered other types of insurance as well - but not because of any potential profits to be made through health insurance. Quite the contrary: by the 1930s, such companies started to move into health insurance and hospital insurance plans because of their marketing value. Contrary to for instance fire insurance, health insurance was called upon relatively often, making for a tight bond with patient-clients and thus for the opportunity to sell other insurance products.

Given the importance attached to a good reputation by multiple-line insurers and this specific marketing potential, the profit motive moved to the background, allowing for more lenient policies, less strict selection of patients, and even the acceptance of financial losses with an eye to the compensation that could accrue through selling customers for health insurance other types of insurance. ${ }^{82}$ It also meant that 'private' health insurance increasingly got a social character, aimed at offering good health insurance policies at decent prices. Overall, compared to the sickness funds the private health insurance industry also remained relatively small: by 1940, only some $9 \%$ of the population had a hospital insurance plan through a private insurer, and only a tenth of that had comprehensive health insurance through such a company. ${ }^{83}$ Needless to say that a wholly different part of the population was dependent on public access to health care: those too poor to be eligible for either private insurance or sickness fund coverage. Here, although not much happened on the national front in terms of facilitating access, government in fact came to play an increasingly large role through activities deployed by municipalities.

\footnotetext{
${ }^{81}$ Ibid., 59-61.

82 Ibid., 170; Vonk, Recht of schade, 57-58, 72-75.

${ }^{83}$ Vonk, 'In It For the Money', 170.
} 


\section{State Intervention Through the Back Door}

The failure of top-down government intervention can easily create the impression that civil society and private initiative were the sole compartments responsible for creating access to health care in the first half of the twentieth century. However, although the sickness funds have taken up a large share of the attention in the literature, from the perspective of public interest in (access to) health care and of governmentality, a more subtle but very significant development took place. In 1912, the Poor Law of 1854 was revised to officially give municipal governments (Thorbecke's focal point for 'autonomous power') a task which they had gradually been taking over in the past two decades: the care for the poor and destitute. The official recognition and expansion of this task calls for a nuance to the dichotomy of 'state' and 'private' parties. Although contemporary debates marked a reluctance with regard to 'government' interference in the life of citizens as organized through private or religious communities, the increasing role of the municipality as a force for social change was oddly often not recognized as a direct increase in state power. It was at any rate seen as more acceptable in the confessional-liberal climate of the period. This is illustrated well in a short book on the 1912 Poor Law revision by J.R. Snoeck Henkemans, a socially progressive Protestant wine merchant and politician:

There must be a spiritual link between the poor person and his benefactor. That is why the State is not the organ for true care for the poor [...] It is therefore right that the new Poor Law does not institute state care. The mercy of the free charity of church and private persons ['particulieren', RB] is put first and foremost and protected and strengthened in various places. And where, at last, government should intervene, it should not be the State, but the Municipality [capitalized in original, RB]. ${ }^{84}$

This quote still very much captures the essence of the 1854 Poor Law. As we will recall, this law had officially given municipal governments only a very marginal role in poor relief. The relevance for health care was that such relief included medical care for those unable to pay for this themselves. But as noted in chapter 1, article 21 stipulated that civil (municipal) government could only provide relief to the poor after assuring itself that all options for religious or philanthropical relief were exhausted, and even then it could only be provided in case of 'absolute inevitability'. However, such a strict legal provision did not curb the discretionary space that individual municipalities had to offer more relief to the destitute than was strictly necessary. Indeed, before 1912, the Civil Poor Boards of, amongst others, Amsterdam, Delft, Groningen and Zaandam already offered financial support alongside that of private and church institutions, a

\footnotetext{
84 J.R. Snoeck Henkemans, Christendom en Maatschappij. De Sociale Beteekenis der Nieuwe Armenwet (Utrecht: G.J.A. Ruys 1912) 8.
} 
practice known as 'dubbele bedeling' or double support. ${ }^{85}$ But subsidiarity was " [...] the letter and spirit of the foremost article." ${ }^{86}$ This was also in keeping with the notion that poor relief was, in first instance, a measure to keep people from turning to illegal ways of providing for themselves, thereby threatening public order. ${ }^{87}$

For decades, however, the 1854 Poor Law had faced the criticism of providing too little for the destitute classes. As religious financial funds dwindled, more and more relief and care had been transferred to local governments, but these only had a very light mandate because of this principle of 'absolute inevitability'. In 1912, however, the Poor Law was revised, in light of the 'social question' discussed earlier, and as a result of serious debate on the specific topic of poor relief starting from about $1890 .{ }^{88}$ In the revision, the criterion of 'absolute necessity' was abandoned. This had an important effect on the way in which municipalities could expand their responsibilities in taking care for the destitute. ${ }^{89}$ Moreover, a change in wording testified to a subtle but important shift in the intent of the law: 'support' of the poor was now changed into 'care' for the poor. ${ }^{90}$

The results of this blurring of boundaries between private and public poor relief were significant - in spirit, as well as in practice. In 1879, 44\% of all poor relief had been supplied by government (mostly through municipalities), with the remainder being offered through religious and private organizations. By 1913, the balance was $57 \%-43 \%$. But by 1938 , public financing accounted for $81 \%$ of poor relief - four-fifths of the grand total of about 135 million guilders spent nationwide on discharging the tasks stipulated by the Poor Law. Moreover, in this period the amount spent per capita on poor relief had increased five-fold. ${ }^{91}$ As one historian of Dutch poor relief summarized it: "Although central government officially distanced itself from

\footnotetext{
85 J.W. Jurrema, 'De Armenwet 1912-1922. Werking der Wet op de Burgerlijke Armenzorg. Wenschen en wegen ter verbetering', in: Geschriften van de Nederlandsche Vereeniging voor Armenzorg en Weldadigheid te Amsterdam XXXII (1922) 5-48, 8.

$86 \mathrm{~J}$. Smissaert, Overzicht van het Nederlandsch Armwezen (Haarlem: H.D. Tjeenk Willink \& Zoon; 2nd edition 1910) 13-16, 20-21, quote on p. 20.

${ }^{87} \mathrm{H}$. Goeman Borgesius, De nieuwe Armenwet. Met beknopt overzicht van stelsel en inhoud der wet, den tekst en aanteekeningen bij de artikelen (Sneek: J.F. van Druten 1912) 1: "Bedeeling van overheidswege kan niet geheel worden gemist, zoo werd beweerd, want een goede politiezorg brengt mee dat men den arme voor den hongerdood bewaart, opdat hij niet tot vertwijfeling gerake en daardoor gevaarlijk worde voor de openbare orde en voor de veiligheid."

${ }^{88}$ Smissaert, Nederlandsch Armwezen, 269-271; Goeman Borgesius, Armenwet, 6-9.

${ }^{89}$ Goeman Borgesius, Armenwet, 13-15.

${ }^{90}$ From 'ondersteuning' to 'verzorging'. This wording was changed in Chapter III of the 1912 Poor Law. (Goeman Borgesius, Armenwet, 37.) See also Jurrema, 'Armenwet', 6.

${ }^{91}$ From $f$ 3,- to $f 15,5$, on a population that increased from a little over 4 million people to nearly 8,7 million people. (Centraal Bureau voor de Statistiek, Armenzorgstatistiek over het jaar 1938 ('s Gravenhage: N.V. Drukkerij Albani: 1940) 47-48). This was excluding state and local government support of the unemployed. In 1938, such support amounted to another 135,2 million guilders.
} 
supporting the [...] unemployed, private initiative and the persons involved apparently came to see this as a government task, for which public poor relief bore responsibility in the absence of other organizations." ${ }^{\prime 92}$ This bearing of responsibility for health care expressed itself especially in two areas: the rapid growth of municipal health services from the 1910s onwards, and the way in which local government started to radically subsidize access to hospital care in this period.

\section{Local Government Steps In}

Where health care was concerned, the role municipalities carved out for themselves grew rapidly from the early twentieth century onwards - over and above the relief now officially entrusted them on the basis of the new Poor Law provisions. Faced with a lack of central steering and ineffective legislation, municipalities by this time also began to concern themselves with the infrastructure and provision of services, besides offering financial support. ${ }^{93}$ This is an interesting historical development in and of itself: prior to the twentieth century, it was the lack of municipal initiative which had driven Health Inspectors to despair - but also to action, witness Jacobus Penn and his founding of the first Cross Association in 1875. This increased interest on the part of local government is therefore striking. However, it should be understood in the context of the historical urgency brought about by the social question and the changes to Dutch society at the end of the nineteenth century. It is no surprise that the first municipal health services consisting of curative health services, preventive services, or a combination of both - first arose in the cities. After all, it was here that growing industrialization and rapid urbanization led to new dangers to both individual (industrial accidents) and public health (epidemic outbreaks) ${ }^{94}$ Such factors were sometimes directly responsible for the founding of a municipal health service, as in Rotterdam (accidents in the rapidly expanding harbor) or Groningen (an outbreak of scarlet fever). ${ }^{95}$ Moreover, the acceptance of such services marches in step with the growth of new private initiatives concerned with (public) health.

In this development, the capital led the charge in stepping in where central government or its instruments (the State Inspectorate, the municipal health councils) failed. Already in 1889, Amsterdam employed two doctors concerned with examining the health of municipal workers. In

\footnotetext{
92 L. van der Valk, Van pauperzorg tot bestaanszekerheid. Een onderzoek naar de ontwikkeling van de armenzorg in Nederland tegen de achtergrond van de overgang naar de Algemene Bijstandswet, 1912-1965 (Delft: Eburon 1986) 70.

${ }^{93}$ The short, but most comprehensive and insightful account is Kerkhoff, Honderd jaar gezondheidsdiensten.

${ }^{94}$ Kerkhoff also bases himself on De Swaan, Zorg en de staat. See Kerkhoff, Gezondheidsdiensten, 29-31.

${ }^{95}$ Kerkhoff, Gezondheidsdiensten, 46-49.
} 
1893, a health service came into existence, which by 1903 employed eighteen general physicians, nine surgeons, and five midwives. This service was expanded rapidly, with a health service for newborns created in 1903, alongside a service employing school doctors in 1907, and an emergency service in 1908. In 1923, all of these services were merged to form a combined medical and health service. ${ }^{96}$ Other large cities quickly followed suit. The Hague and Utrecht founded services offering medical examinations, care for the poor, vaccinations and ambulances in 1914. By 1920, Groningen, Rotterdam and Maastricht were similarly equipped. Smaller towns also picked up on this trend, however. Hilversum (where the first Cross Association was founded) had a service by 1920, as did Zaandam. ${ }^{97}$ A 1920 survey by Head Health Inspector Terburgh testified to initiatives in Frisian Leeuwarden, as well as Zwolle and Deventer (Overijssel). ${ }^{98}$ This is not to say that all these public entities were extensive or even long-lasting - the service in Arnhem was terminated in 1926, while those in Breda and Eindhoven counted only one civil servant tasked with overseeing the entire operation. Still, the rapid growth and extent of the tasks municipalities took upon themselves is impressive. ${ }^{99}$ A 1929 vademecum for municipal boards, written by the director of the Amsterdam health service Heijermans (whom we have already encountered above), featured chapters on subjects as diverse as housing, insects and rodents, garbage disposal, drinking water, milk and foodstuffs, sports and swimming pools, as well as the combatting of epidemic diseases. ${ }^{100}$ Municipalities increasingly also hired doctors to provide social health care. The extent of such services could vary from town to town, and it is hard (which it even was for contemporaries) to come to general conclusions about the increased vigor with which municipal governments took their tasks to heart. ${ }^{101}$ However, the growing interest of local governments in providing health care services was undeniable. Much like other collective provisions that were taken up by municipalities in this period - water supplies, transportation - the expansion of municipal health services could take place through a combination of growing social concerns and a notable absence of coordination by the state.

\footnotetext{
${ }^{96}$ Ibid., 24-26.

${ }^{97}$ Ibid., 26-29, 45.

${ }^{98}$ National Archives, inventory 2.15.38, no. 219, Stukken betreffende de organisatie van de gezondheidsdiensten in Nederland (onder andere kosten, gebiedsvaststelling, vestiging in kleinere plaatsen, regelingen), reply by the Regional Inspector for the North-Eastern provinces, d.d. 15-11-1920.

${ }^{99}$ No extensive research has been done on the total number of services in existence. Kerkhoff gives a careful estimate of at least twenty-two services by 1935 - a doubling of the number of 1920 . However, he also notes that the actual number by this time more likely neared forty. Kerkhoff, Gezondheidsdiensten, 4445. Cannegieter cites a 1921 article which arrived at a total of twenty-seven (rudimentary) services, but only for municipalities numbering at least 25,000 inhabitants. Cannegieter is somewhat sceptical about the effectiveness of municipal interventions, given the 1,113 municipalities in existence in 1921. But given the fact that the services seemed to have existed especially in larger cities, this meant that a fairly large percentage of the population would have fallen within their remit. Cannegieter, Gezondheidswet, 152. $100 \mathrm{~J}$. Heijermans, Gemeentelijke gezondheidszorg in Nederland (Amsterdam: Ontwikkeling 1929). 101 A.H.M. Kerkhoff, Raadsbesluiten als remedie. Openbare gezondheidszorg in Zwolle en de regio IJsselVecht 1900-1995 (Rotterdam: Erasmus Publishing 2001) 16-17.
} 
Whatever Thorbecke had envisioned when in 1851 he created his 'Municipality' was not entirely clear. But they often came to function as 'laboratories for social legislation', also in the area of health care. ${ }^{102}$

\section{Hospital Care: Convergence Between Private and Public Financing}

It is hard, though, to come to unequivocal conclusions with regard to the financial role municipal governments came to play in health care services, despite the revised Poor Law's emphasis on better documentation concerning poor relief. In 1923, correspondence concerning the revision of statistical tables published by the Statistics Netherlands (Centraal Bureau voor Statistiek) noted that "It is not possible, even by approximation, to say what value should be attached to the data thus received [provided by institutions for poor relief, RB]." ${ }^{103}$ In 1935 the CBS still noted that in large cities such as The Hague, Rotterdam and Utrecht, "doctors cannot be bothered to accurately keep note of the names of patients" in the context of care for the poor. ${ }^{104}$ Nevertheless, it is possible to gain an impression of the increase of municipal interest in that most costly affair, hospital care. For an understanding of the social role municipalities increasingly came to play, it is helpful to look at subsidizing arrangements for hospitals and hospital patients. With the advent of new medical technologies, paying for operations or a stay in hospital became an ever greater problem for average citizens in the first decades of the twentieth century. In response, private insurers had begun to develop a market for wealthier citizens. However, even here the costs of the new diagnostics and techniques increasingly became prohibitive. From the 1920s onwards, dealing with rising hospital costs was therefore also partly done through the (mostly rural) 'hospital insurance associations'. These associations were private organizations based on solidarity, which by 1940 provided hospital insurance to some $25 \%$ of the Dutch population. ${ }^{105}$ Given the complementary character of what these associations offered next to the limited forms of care offered by sickness funds - usually not including hospital care - they were looked upon favorably by doctors as well as the government,

\footnotetext{
102 N. Randeraad, 'Gemeenten tussen wet en werkelijkheid', in: N.C.F. van Sas and H. te Velde (eds.), De eeuw van de Grondwet. Grondwet en politiek in Nederland, 1798-1917 (Deventer: Kluwer 1998) 246-265, 263.

103 National Archives, inventory 2.04.55, no. 611, Centrale Commissie voor de Statistiek, 'Bericht op schrijven van 8 juli 1919, No. 5506, Afd. A. betreffende Statistiek van het Armwezen', s-Gravenhage 5 mei 1923, p. 4.

104 National Archives, 2.04.55, 611, Centrale Commissie voor de Statistiek, 'Nota van mr. Coffrie betreffende het verzamelen en verstrekken van gegevens inzake het verleenen van kostelooze genees-, heel- en verloskundige hulp buiten ziekenhuizen', 1935 p. 3.

105 Centraal Bureau voor de Statistiek, De verzekering tegen de kosten van Ziekenhuisverpleging in Nederland op 1 Januari 1940 (Den Haag: Albani 1940) 7.
} 
making available as they did ever more expensive hospital care to patients who would otherwise be unable to afford it. ${ }^{106}$ However, these care associations could in turn be seen as complementary to the tasks municipalities had by this time begun to take upon themselves. Table 2.3 provides an overview of the number of patients admitted to confessional or private hospitals, but paid for by municipal governments across The Netherlands:

Table 2.3 - Boarding out of patients by municipal governments, 1914-1940

\begin{tabular}{|l|l|l|l|l|l|l|}
\hline Year & $\mathbf{1 9 1 4}$ & $\mathbf{1 9 1 9}$ & $\mathbf{1 9 2 5}$ & $\mathbf{1 9 3 0}$ & $\mathbf{1 9 3 5}$ & $\mathbf{1 9 3 9}^{\mathbf{1 0 7}}$ \\
\hline $\begin{array}{l}\text { Persons } \\
\text { admitted for } \\
\text { care to } \\
\text { hospitals }\end{array}$ & 38.543 & 48.247 & $\begin{array}{l}50.683 \\
\text { (including } \\
\text { institutions } \\
\text { for the } \\
\text { elderly etc.) }\end{array}$ & 61.265 & 73.372 & 89.771 \\
\hline $\begin{array}{l}\text { Municipal/Civil } \\
\text { Poor Board } \\
\text { subsidies }\end{array}$ & $\mathrm{f} .432 .170$ & $\mathbf{f} 9.815 .870$ & $\begin{array}{l}\text { f6.993.292 } \\
\text { (after } \\
\text { returns) }\end{array}$ & $\begin{array}{l}\text { f 7.198.312 } \\
\text { (after } \\
\text { returns) }\end{array}$ & $\begin{array}{l}\text { f } 8.209 .519 \\
\text { (after } \\
\text { returns) }\end{array}$ & $\begin{array}{l}\text { f } 8.870 .650 \\
\text { (after } \\
\text { returns) }\end{array}$ \\
\hline
\end{tabular}

Sources: Jurrema, 'De Armenwet', 39; Centraal Bureau voor de Statistiek, Armenzorgstatistiek for the years 1925, 1930, 1935, 1939

There could be great differences between municipalities. For instance, a socially progressive city such as Amsterdam by 1934 subsidized hospital care to such an extent that it was available to practically every inhabitant. ${ }^{108}$ Haarlem went from $f 85,000$ in hospital care subsidies in 1913 , to $f 777,000$ in 1938 - even though the population grew from just 70,000 to 136,000 in this period. ${ }^{109}$ All in all, the nearly nine million guilders spent on subsidizing care by the end of the decade was but a fraction of the more than 130 million guilders spent on poor relief in general. Nevertheless, relatively speaking the numbers are significant. Although by the end of the 1930s a quarter of the population had some access to hospital services through the hospital associations - the amount of days covered was often limited - the total amount of money the associations

\footnotetext{
106 Vonk, Recht of schade, 71.

1071940 is left out, because of the outpour of financial support as a result of the war. CBS, Armenzorgstatistiek over 1940 ('s Gravenhage: Drukkerij Albani C.V. 1942) 7.

${ }^{108}$ Vonk, Recht of schade, 70.

109 W.B. Smit, Het vraagstuk der ziekenhuisverpleging voor de gemeenten (diss. Rijksuniversiteit Utrecht: H.D. Tjeenk Willink \& Zoon: Haarlem 1939) 13-14.
} 
provided was some 2,5 to 3 million guilders, just $5 \%$ of the total spent on hospital care in 1939. ${ }^{110}$

\section{Health Care Financing: Rhetoric vs Reality}

A focus on 'private initiative' therefore obscures the relatively large role public institutions actually came to play in opening up access to (hospital) care, prior to legislation regulating such care. In 1935, an unofficial committee was instituted by the Ministry of the Interior. ${ }^{111}$ This committee-Frederiks was tasked with cutting the budget for hospital provisions - in doing so, it followed in the steps of an earlier committee which had saved some 1,3 million guilders in the budget for psychiatric asylums. This was no simple or obvious task. The government had no legal say over hospitals, as there was no legislation granting it any control, financial or administrative (unlike the field of asylums, in which central government had powers under the Lunacy Act of 1884). Still, the committee members set to work diligently, in 1937 producing a legislative proposal which would (temporarily) make the building or expansion of new hospital facilities dependent on approval by the Crown. In the Memorandum to the proposal, it was estimated that in 1932 alone government had indirectly spent over 20 million guilders in subsidizing or delivering hospital care, "most of which is financed by municipal governments". ${ }^{112}$ These numbers are hard to corroborate by the Poor Law statistics. But a careful estimate provides a striking insight. If, by 1939 , the private hospital insurance associations accounted for just $5 \%$ of all hospital costs by providing between 2,5 and 3 million guilders, and municipal governments had by 1932 already covered 'most of' 20 million guilders, it does not seem an unreasonable estimate that in 1939 municipalities financed between five and six times the cost of hospital care provided by the private associations. This would mean that municipalities took care of $25 \%$ to $35 \%$ of all hospital costs on the eve of World War II. This was a substantial amount, if we take into account that on the national level there was no provision on the part of the government that guaranteed access to health care, while at the local level the mandate of the Poor Law for providing health care was still only very loosely formulated.

\footnotetext{
110 K.P. Companje and R.A.A. Vonk, 'Ziektekostenverzekeringen en wettelijk geregelde arbeidsverhoudingen tot 1941', in: Companje, Tussen volksverzekering en vrije markt, 173-224, 194-195. ${ }^{111}$ National Archives, inventory 2.04.47.02, no. 2, Betreffende de instelling van een (niet-officiële) Commissie bezuiniging kosten ziekenhuiswezen. See also: H.R. Wolf, 'Een wissel op de toekomst. Mislukte ziekenhuiswetgeving, 1935-1951', in: W.P. Blockmans and L.A. van der Valk (eds.), Van particuliere naar openbare zorg, en terug? Sociale politiek in Nederland sinds 1880 (Amsterdam: NEHA 1992) 195-208. 112 National Archives, inventory 2.04.47.02, no. 2, Betreffende de instelling van een (niet-officiële) Commissie bezuiniging kosten ziekenhuiswezen.
} 
Lacking definitive numbers, we have also a more direct indication for the large role municipalities had by this time come to play: the single attempt at legislation in this period through which central government would have inserted itself financially into health care. As we have seen above, in 1920 Minister Aalberse proposed central government subsidize sickness funds and hospitals with 10 million guilders annually. However, as table 2.3 shows, in 1919 municipal governments across the nation already subsidized hospital care with nearly 10 million guilders. Despite this fact, the Aalberse-bill did not even reach the floor of Parliament, as the Finance Minister argued it would be too much of a strain on the government budget. In short, this meant that where political support for ten million guilders in subsidies by central government could not be found, local governments were in fact already furnishing similar amounts of money to increase access to health care for their citizens. A gap was clearly growing between the (political) rhetoric of state abstinence and private initiative, and the reality of a rapidly growing role for local government in providing access to both public and individual health services.

This growth was theoretically not in opposition to the Liberal governmentality instituted in 1848 and extended in 1865 to health care - in the previous chapter, we have seen how local government was to play an important role in promoting (public) health after that latter year. However, what began to seriously undermine the rhetoric of local initiatives in the 1920 s and 1930s was the increasing control that central government in the preceding decades had obtained over municipalities' revenues and expenditures. Already in 1865, when municipalities were no longer allowed to levy excises, the first forays into diverting revenue streams from local to central government had been made. Instead, municipalities would from now on be eligible for state subsidies. In 1897, this scheme was expanded to allow more generous subsidies, as municipalities had increasingly come to be saddled with increasing social responsibilities (among which providing support under the Poor Law, with the decline of religious funding). State subsidies became more generous, while the fiction of municipal primacy remained mostly intact. This was further undermined in 1929, when a law came into effect which now also prohibited municipalities from levying income tax. ${ }^{113}$ The fiction that municipalities had much say over their revenues was now even harder to uphold, but the system of state subsidies (as opposed to direct centralized funding of these social tasks) stayed in place. Not that local government did not benefit from this arrangement. Municipal support increasingly became a burden in the years following the 1929 financial crisis, mostly because of financial support of the unemployed (health care, as noted, was but a marginal part of this). The 1929 Act on Financial Proportions created a Municipal Fund, which gave central government the option to supply additional funding for poor relief. Furthermore, an Act on Indigent Municipalities created a state official with the authority to

\footnotetext{
${ }^{113}$ For a discussion of these legislative steps, see: C. van den Berg and H.J.D. Revers, De financieele verhouding tusschen het rijk en de gemeenten (Alphen aan den Rijn: N. Samsom N.V. 1936) 8-11, 19-30.
} 
monitor municipal poor relief, which could lead to 'emergency' subsidies. Even though the Poor Law itself was therefore not revised to allow for more centralized subsidizing of, e.g., health care, this new indirect way of financing undermined the autonomy of municipalities, even if the intention only was to keep them financially afloat. ${ }^{114}$ In doing so, central government became involved in subsidizing hospital patients.

But public bodies by this time had also come to play a significant role outside of the financing of just hospital stays. A 1942 overview of the Cross Associations that operated across the country inventoried financial streams, and for the year 1940 the distribution was as shown in Table 2.4:

Table 2.4 Revenue streams of the Cross Associations in $\mathbf{1 9 4 0}$

\begin{tabular}{|l|l|l|l|l|}
\hline $\begin{array}{l}\text { Total } \\
\text { revenues }\end{array}$ & $\begin{array}{l}\text { Contributions by } \\
\text { members } \\
\text { (families) }\end{array}$ & $\begin{array}{l}\text { State subsidies } \\
\text { (mostly for } \\
\text { tuberculosis) }\end{array}$ & $\begin{array}{l}\text { Provincial } \\
\text { subsidies }\end{array}$ & $\begin{array}{l}\text { Municipal } \\
\text { subsidies }\end{array}$ \\
\hline f. 3.621 .796 & f. 1.859 .396 & f. 325.940 & f. 80.193 & f. 632.404 \\
\hline
\end{tabular}

In this inventory, municipal governments accounted for some $17 \%$ of the total income of the Cross Associations, with public revenue streams in general totaling nearly a third of the funding of these associations by 1940. One third of funding might not seem much, were it not for the facts that the Cross Associations were the most visible example of 'private initiative' in health care provisions, and that there was still no legislation directly regulating public subsidies to these parties. And as we have seen in table 2.1, especially Catholic 'Crosses' had been founded in large numbers since the early 1920s. Put mildly, this points to a discrepancy between the rhetorically dominant principle of subsidiarity (and 'sphere sovereignty' for Protestants) and the way in which public funding was increasingly keeping private initiative provisions financially afloat. For instance, without providing numbers on the specific evolution of financing, the Statistics Netherlands noted that in the case of the rising cost of district nursing, "Government subsidy in

\footnotetext{
114 Van der Valk, Pauperzorg, 174-180. In general, governmental attempts to gain control over finances in the crisis years of the 1930s seemed to have had the unexpected effect of enlarging central government. Prime minister Colijn (1933-1939) sought to stabilize finances through major cuts and increased governmental control of spending and subsidies. Paradoxically, this led to an ever-increasing government bureaucracy, with e.g. the Ministry of Economic Affairs growing from 80 civil servants in 1934, to over 300 in 1939. M. Hoogenboom, Standenstrijd en zekerheid. Een geschiedenis van oude orde en sociale zorg in Nederland (Amsterdam: Boom 2004) 249-254.

115 Centraal Bureau voor de Statistiek, Overzicht van de Kruisvereenigingen in Nederland (Den Haag: Rijksuitgeverij 1942) 15. Some caution is called for, as Cross Associations sometimes exploited hospitals, and it is not clear (though unlikely) whether the subsidizing of boarded-out patients fell under these subsidies.
} 
many cases broke the vicious cycle [of prohibitive financial constraints; RB]". ${ }^{116}$ As was the case with hospital care and municipal health services, the national government increasingly came to play a crucial role in guaranteeing access to (far) more than just basic health care needs - despite the dominant rhetoric which since Thorbecke had revolved around the minimal state.

The reach of municipal governments in providing health care to the poor has been estimated to extend to no more than $10 \%$ of the population eligible for poor relief by $1920 .{ }^{117}$ However, if we take into account the subsidizing of private initiatives and institutions, as well as the support of patients cared for in private hospitals - patients who increasingly were not eligible for support on the basis of the Poor Law - we find that these numbers obscure the actual financial support given through municipalities, which in effect greatly expanded the limited duties these local governments had on the basis of the 1912 Poor Law. Moreover, from a cultural-ideological point of view, it does not seem implausible to assume that the role that municipalities took upon them in providing a social safety net for those too poor for the sickness funds, or for the increasingly expensive hospitals, had an effect on what average citizens came to expect of their local government. In this respect, bottom-up governmental support, instead of much-reviled top-down government intervention, undoubtedly created a notion of social security in an era in which legislation on the level of national politics faltered time and again.

\title{
Private Initiative, Publicly Backed
}

\begin{abstract}
The state is not a universal nor in itself an autonomous source of power. The state is nothing else but the effect, the profile, the mobile shape of a perpetual statification [...] in the sense of incessant transactions which modify [...] sources of finance, modes of investment, decisionmaking centers, forms and types of control, relationships between local powers, the central authority, and so on [...].
\end{abstract}

This quote by Michel Foucault, which was already put forth in the introduction, allows us to step back and take something of a bird's-eye view in the discussion of the 'governmentality' of Dutch health care which had come to replace the Liberal governmentality of the nineteenth century from about 1912 onwards. In the first four decades of the $20^{\text {th }}$ century, the dominant political rhetoric on the national level prevented real legislative successes granting the state more say over access to health care. In this legislative vacuum, important changes nevertheless took place 'on the ground,' providing

\footnotetext{
${ }^{116}$ Ibid., 16.

117 Van der Velden, 'Dutch Health Services', 57.
} 
increasing access to a burgeoning (scientific) medicine and health care for average citizens. Both public and individual health care were increasingly provided by private actors such as sickness funds, for-profit insurers and Cross Associations, parties which rapidly grew in size and number in this period. However, in the absence of national regulations guaranteeing access to health care, municipalities also increasingly took it upon themselves to provide such access to their citizens. They did so by creating municipal health services, but also by subsidizing access to increasingly expensive hospital care. Going back to the quote above, we can say that important changes were taking place as a result of this in sources of finance of health care (subsidies), modes of investment (public alongside private), as well as the relationship between local powers (municipalities) and the central state, which showcased an increasing interest and stake of public actors in facilitating what was still very much seen as a private responsibility and sector in the dominant political-cultural rhetoric of the time.

But as time progressed, the central state also became involved in facilitating access to health care through revisions of the scheme that regulated financial traffic between central and local governments. Despite surface-level 'rhetoric', it was clear that by the 1930s, the Liberal governmentality of minimal state intervention in health care had been subtly transformed to a new governmentality, one we might name the governmentality of private initiative, publicly backed. Despite the fact that political debate was dominated by notions of liberalism, 'sphere sovereignty' and subsidiarity, it was clear that in actual reality, serious 'statification' had been taking place in the two decades after 1912. A growing divergence between the dominant 'rhetoric' of limited state power, and the 'reality' of its actual influence, was beginning to show.

This growing mismatch between rhetoric and reality and the fluid relationship between public and private were not lost on the historical actors debating the role of the state in health care at this time. In 1935, a short report was presented on a possible reorganization of the State Inspectorate for Health Care - the last in a long line of proposed or actually realized changes made in the previous decades, none of which were particularly successful, as we have seen earlier. Despite the fact that the Inspectorate had, since its inception in 1865, argued for ever greater powers in improving public health and controlling the bodies responsible for this task, the closing remark of the report showed anything but coherence as to a future division of labor and responsibilities. In proposing a new mix of financing and governance arrangements, the author stated:

All government financing of health care will be brought together and controlled and allocated under the supervision and responsibility of representatives of Government and private initiative, which will lead to cooperation between all interested organs [...] Through 
this new organization will come about a certain measure of centralization, and yet also district-wise decentralization, while private initiative will retain its full freedom to act. ${ }^{118}$

This ambivalent embrace of both centralized and decentralized government, and of both public and private institutions in providing health care, was in a sense exemplary for the way in which the broad field of health care provisions and arrangements grew organically between 1912 and 1941. However, not too long after this report appeared, the role of the state would be codified in the Sickness Funds Decree imposed in 1941 by the Nazi authorities in The Netherlands, a Decree which rather forcibly involved the central state in the provision of health care through a mandatory insurance arrangement. As such, the Decree seemed to indicate a clear break with the non-interventionist governmentality of the previous decades. However, after the war, the precise way governmental responsibility for health care was allowed to develop continued quite naturally the practices and governmentality of the state vis-á-vis health care which had grown in the period 1912-1941. We turn first to the way in which the Sickness Funds Decree represented a historical break, before discussing the continuities in health care governance of the post-war decades.

\section{The Netherlands under German Control}

The German overthrow of Dutch political sovereignty was a rapid affair. On 10 May 1940 Germany invaded The Netherlands. Just five days later, after the bombardment of Rotterdam, a capitulation treaty was signed. By then, the Dutch government had already transferred to London, and a Nazi civil administration was installed three days later, headed by the Austrian Arthur Seyss-Inquart. Given the absence of a democratically elected government, all legislative changes introduced during the occupation were Decrees lacking Parliamentary preparation which left a lot of leeway for the Dutch state administrators remaining in office to continue policy lines set out before the war. Given the perceived 'racial kinship' between Germany and The Low Countries, the philosophy Hitler set out for governing The Netherlands was based on

\footnotetext{
118 In the original: "Alle overheidsgelden voor gezondheids- en ziekenzorg worden tezamen gebracht en onder toezicht en verantwoordelijkheid der regeering beheerd en besteed door vertegenwoordigers van Overheid en particulier initiatief, waardoor zal worden verkregen samenwerking tusschen alle belanghebbende organen [...] Door de nieuwe organisatie zal komen een zekere mate van centralisatie, doch ook districtsgewijze decentralisatie, terwijl het particulier initiatief de volle vrijheid van handelen houdt." National Archives, Inventory 2.04.47.02, no. 12, Commissie Bezuiniging Kosten Ziekenhuiswezen. The status of the report is not entirely clear, but it seems to have come from the Inspectorate itself, and was forwarded as such by the Minister of Social Affairs to the Minister of the Interior.
} 
economic integration and a (relatively peaceful) indoctrination with National-Socialist ideology. ${ }^{119}$

One of the targets here was the institution of a health insurance scheme regulated by the state. On the one hand, the Nazis wanted to bring the Dutch economy in line with the German one, as in future these economies would be inextricably connected. ${ }^{120}$ On the other, the German occupier saw the creation of a system through which a large part of the population would (finally) gain real access to health care as an expression of its social interest in the well-being of the Dutch population. The exceptional lack of a mandatory insurance scheme in The Netherlands would ideally make its introduction an easy win for the German occupiers. Political reality, however, would turn out to be less manageable. The Sickness Funds Decree came about through a back-and-forth between Dutch administrators and the German officials tasked with instituting such a scheme. Let us first turn to the history behind this seminal piece of legislation before discussing its effects on the 'governance' of health insurance, a history which has been described before by Karel-Peter Companje and Robert Vonk. ${ }^{121}$

\section{Cutting the Gordian Knot: The Introduction of Mandatory Health Insurance}

The most important actors in the construction of the first national health insurance scheme were Cornelis van den Berg, the Dutch director-general of the Health department (part of the Ministry of Social Affairs), and Reinhard Jakob, the German official tasked with overseeing social security legislation in the occupied Dutch territory. On entering office, Jakob asserted that the limited development of social security stood in the way of economic integration between Germany and The Netherlands. Especially in the area of health care, no effective system was in place, calling for legislation which would put the Dutch population on the same footing as the Germans.

Before the war, Van den Berg had been rather content with the hodgepodge of private arrangements between doctors, sickness funds, and hospital insurance associations. In fact, he had been partly responsible for the last of the six proposals towards health insurance put forth in the period between 1904 and 1939 (under Social-Democratic minister Jan van den Tempel). This proposal, concerning the institution of a council which would oversee the sickness funds, was what Van den Berg now put forward to take the initiative in regulating the provision of health

\footnotetext{
119 De Rooy, Republiek, 173-175.

${ }^{120}$ R. Vonk, 'Een taak voor de staat? De Duitse bezetting en de invoering van de verplichte ziekenfondsverzekering in Nederland, 1939-1949', BMGN - Low Countries Historical Review 1273 (2012) 328, 10-11.

${ }^{121}$ Companje, 'Het Ziekenfondsenbesluit', 478-490; R. Vonk, 'Een taak voor de staat?'.
} 
insurance through sickness funds. It aimed at a very light form of government intervention, and nothing in it would have remotely created a mandatory insurance scheme, overseen by government. It was therefore no surprise that Jakob cast aside this proposal, opting instead to write one himself. His ideas for reforming what was on offer through the sickness funds focused on a mandatory insurance scheme for a large segment of the population, with contributions by both workers and employers - as was the case in the system devised by Bismarck - and overseen by government. ${ }^{122}$ These ideas would have resulted in a truly revolutionary intervention in the access to Dutch health care. Jakob's proposal aimed at creating one state-governed sickness fund, through which some $90 \%$ of the population would have been insured. Insurance premiums would be collected and forwarded to the state fund by Labor Councils. ${ }^{123}$ Unsurprisingly, the proposal caused great upheaval in the ministry's Health department. In an internal memo, Van Den Berg noted that it "could practically be assumed, that the coming into force of such a decree would mean the death of all existing sickness funds. For this, there is no ground whatsoever. [...] The shutting down of all funds would lead to great consternation among insureds, as well as doctors, pharmacists and dentists, and understandably so." ${ }^{\text {"124 }}$ Were the proposal to become publicly known, let alone implemented, doctors and private insurers would immediately balk at having their private customers reduced to a marginal percentage of the population, while the large variety of sickness funds would cease to exist with the stroke of a pen. ${ }^{125}$

But aside from considerations concerning the field parties' response to such an attempt at state centralizing, as we have seen in the previous chapter the notion of centralizing sickness fund insurance through a state-led institution was diametrically opposed to the confessional and Liberal politics dominant before the war. However, Dutch officials had little power to stop Jakob. But, to Jakob's surprise (and dismay), his proposal was also struck down on the German side. First, Seyss-Inquart rejected the proposal on the grounds of the upheaval that such a radical reordering of the Dutch system would cause. In response to this, Jakob wrote a second proposal in which the percentage of the population covered was reduced. But even this amended version never left the department. This time around, Jakob was called to Berlin to justify his proposal for radical change. There, Robert Ley - head of the German Labor Front - chastised him for devising an insurance scheme which would effectively be more generous than that providing health care

\footnotetext{
122 Vonk, 'Een taak voor de staat', 12.

${ }^{123}$ Mandatory insurance would be instituted for all payroll workers with a maximum income limit of $f$ 6.000 ,-. Independents with an income of up to $f 3.600$,- would also be brought under the Sickness Act. By way of contrast: in the Aalberse-proposal of 1920 for regulating voluntary health insurance through sickness funds, the income limit had been set at $\mathrm{f} 2.500,-$. See: H.C. van der Hoeven, Ziekenfondsen en de Duitse bezetting (Den Haag: Koninklijke Vermande B.V. 1989) 30; Companje en Rigter, 'Ontwerp der wet', 420.

${ }^{124}$ National Archives, inventory 2.15.37 (Afdeling Volksgezondheid), no. 872, Letter from Van den Berg to the Secretary-General of the Ministry of Social Affairs, d.d. 01-04-1941.

125 See also: Van der Hoeven, Ziekenfondsen, 31-32.
} 
to the German population. ${ }^{126}$ A less ambitious plan was called for, and this is what Jakob produced in the summer of 1941. The Sickness Funds Decree was a much watered-down version of what Jakob had originally envisioned. Still, its impact on health insurance and the sickness fund field was significant. Under the new legislation, workers insured on the basis of the 1930 Sickness Benefits Act would be mandatorily insured for a wide and centrally set variety of medical services, with their employers paying half of their premiums. To facilitate this, these insureds would have to enroll in sickness funds, which had to be officially recognized by government as administrators of the mandatory scheme. ${ }^{127}$ Alongside mandatorily insured workers, citizens earning below the income limit could enroll voluntarily for sickness fund coverage, continuing the sickness funds' prewar practice of facilitating access to health care.

\section{The Great Equalizer}

The immediate effects of the Sickness Funds Decree, which came into force on 1 November 1941, were far-reaching. First, the range of health care provisions covered in the state-set package for people now mandatorily insured through the Decree increased drastically. Under Article 14 of the second Executive Decree (Uitvoeringsbesluit), care falling under any sickness fund policy would include the services of a GP, a midwife, and medical-specialist help; stay in a sanatorium for treating tuberculosis, as well as medicines and bandages. Covered up to a certain limit were various medical aids such as glasses, glass eyes, orthopedic shoes and more, as well as $\mathrm{X}$-ray examinations. Curative dental care was covered as well, with conservative and prosthetic dental care requiring supplementary payment. Very significant from the perspective of the prewar problems concerning the financing of hospital stays was the inclusion in the centralized package of hospital care of up to 42 days. ${ }^{128}$ From now on, paying for such care would no longer be dependent on personal finances or local (municipal) circumstances, as it was covered under the standardized health care package each sickness fund had to offer. Moreover, tying the Sickness Funds Decree to mandatory insurance on the basis of the Sickness Benefits Act (which forced employers' pay-outs to cover lost wages in times of sickness) meant that there was now a financial pool for sickness fund expenditures. This, coupled with an ever-advancing medical science - antibiotics, for instance, became in the mid-1940s the first mass-produced drug rapidly drove up costs, as shown for a few (expensive) provisions in table 2.5:

\footnotetext{
${ }^{126}$ Vonk, 'Een taak voor de staat', 13.

${ }^{127}$ H.C. and E.W. van der Hoeven, Om welzijn of winst, 137.

128 Tweede Uitvoeringsbesluit Ziekenfondsenbesluit, d.d. 23-10-1941, art. 14. See also: K.P. Companje, 'Het Ziekenfondsenbesluit en de verstrekking van zorg', in: Companje, Tussen volksverzekering en vrije markt, 629-708, p. 629-636, 654-678.
} 
Table 2.5 Average expenditure per mandatory enrollee at sickness funds, in guilders $(f,-)$, 1942-1950

\begin{tabular}{|c|c|c|c|c|c|}
\hline & 1942 & 1944 & 1946 & 1948 & 1950 \\
\hline GP care & 3,19 & 3,21 & 4,71 & 4,70 & 5,17 \\
\hline Specialist care & 1,36 & 1,39 & 2,58 & 3,20 & 4,86 \\
\hline Dental care & 0,96 & 0,92 & 0,99 & 1,76 & 2,21 \\
\hline Hospital care & 3,21 & 3,08 & 3,73 & 5,09 & 7,74 \\
\hline $\begin{array}{l}\text { Medicines and } \\
\text { bandaging }\end{array}$ & 2,60 & 2,86 & 3,64 & 4,53 & 5,49 \\
\hline
\end{tabular}

Source: Economisch-Sociologisch Instituut, 'Enige notities over de financiële positie van het Centraal Ziekenfonds', in: C.W.A. van Uden, Gezondheidszorg in eigen hand. Vijfentwintig jaar geschiedenis van het Centraal Ziekenfonds in het bisdom Den Bosch (Tilburg: Centraal Ziekenfonds voor het Bisdom 's-Hertogenbosch 1955) 155-179, 176. ${ }^{129}$

Overall, the average cost per enrollee increased rapidly, going from $f 24,59$ in 1947 to about $f 33$ already in the year $1950 .{ }^{130}$ Highly significant from the point of view of access as now legally established, was the measure of equality in care provision now created through government setting the mandatory package. Looking back, a 1960 historical overview of the direct effects of the Sickness Funds Decree noted several distinct benefits brought about by the measure. The first was that sickness fund provision of care was no longer a matter of philanthropy - strongly mitigating the arbitrary nature of, for instance, municipal support in matters of health care financing. The second was the uniformity brought about in the provisions provided for, which had also greatly increased the overall quality of care. Finally, relevant from the perspective of access and affordability was the fact that the upper income limits for eligibility for sickness funds were raised, and that the system for financing them also created a form of income solidarity. Not only did employers from now on pay half of sickness fund premiums, but premiums for employees were nationally set at a fixed percentage of income. Before 1941, nominal premiums had been the norm, meaning that every adult insured at a sickness fund paid the same periodical amount, regardless of income. ${ }^{131}$ It would still take a long time after the introduction of the Decree before the notion of a broad right to health care as something to be guaranteed by

\footnotetext{
129 These statistics pertain to the national costs for sickness fund insureds, not merely the Central Sickness Fund of the diocese Den Bosch.

130 'Memorie van Toelichting', in: Ontwerp Ziekenfondswet, waaromtrent door de Minister van Sociale Zaken en Volksgezondheid advies is gevraagd aan de Sociaal-Economische Raad ('s-Gravenhage: Staatsdrukkerijen Uitgeverijbedrijf 1951) 45-78, 48. These numbers do not account for inflation, but the rise was explicitly made note of as rapid in this report.

${ }^{131}$ Ziekenfondsraad, Kort overzicht van de ontwikkeling van de Nederlandse ziekenfondsverzekering (Amsterdam: Ziekenfondsraad 1960) 10, 42-43.
} 
government would be developed - the Sickness Funds Decree had the marks of both the prewar and the Nazi emphasis on maintaining a healthy workforce. But the practical effects of sickness funds now having to offer a similar package undoubtedly impacted the public's thinking about health care as something backed by government.

\section{New Patients and a New Role for Sickness Funds}

Alongside the uniformization of what sickness funds would from now on offer to their mandatory enrollees, the immediate effect on sickness fund enrolment as a result of the Decree was significant. On January 1 1941, some 47,9\% of the population was insured through sickness funds. On the last day of that year, enrolment had risen to nearly $60 \%{ }^{132}$ Within a year, access to basic health care provisions through sickness funds thus went up by more than a fifth. Among this new client base were not just mandatory but also voluntary enrollees, who by 1946 accounted for more than a third of sickness fund insureds. ${ }^{133}$ Here a different form of solidarity than income solidarity was soon instituted by the sickness funds: from 1947 onwards, the voluntary insurance package offered access to the exact same (extensive) health care provisions as was covered in the mandatory package. ${ }^{134}$ Nevertheless, the revolutionary character of government-imposed health insurance was mitigated by the growth of pre-war insurance arrangements, which we have already seen in the previous chapter. Over and above some $45 \%$ of the population insured through sickness funds in 1940, nearly $25 \%$ of Dutch people already had some form of hospital coverage through the hospital insurance associations, and some 8 to $10 \%$ had an insurance policy through a private insurer. Already by 1940 , some $70 \%$ of the population was therefore insured for a (significant) measure of health care costs. ${ }^{135}$ Internationally speaking, this was high. Germany, which of course in 1884 had already originated mandatory health insurance, by that year had $60 \%$ of the population insured through funds, with some $10 \%$ being covered through private insurers. Belgian (state-subsidized) mutual funds reached no more than 40 to $50 \%$ of the populace, with hardly any private insurance. ${ }^{136}$ In The Netherlands, prevalence of health insurance arrangements on the basis of 'private initiative' without government backing was therefore exceptionally high even before the war. Still, besides relieving municipalities from

\footnotetext{
132 Van der Hoeven, Ziekenfondsen en de Duitse bezetting, 54.

133 By that year, $66,3 \%$ of the Dutch populace had health insurance through a sickness fund. $25,8 \%$ of the populace were voluntary enrollees. Vonk, Recht of schade, 128.

${ }^{134}$ K.P. Companje, Convergerende belangen, 185.

135 Vonk and Schut, 'Universal access', 7.

${ }^{136}$ Vonk, Recht of schade, 90-91.
} 
their increasing share in hospital costs in the preceding period, the Sickness Funds Decree had an important effect on health insurance coverage.

But the most important aspect of the Decree arguably lay in the way it broke through the political stalemate which had existed since the first decade of the $20^{\text {th }}$ century. The German 'intervention' had a big impact on the way sickness funds were run, as well as their relationship to the state. Despite his pre-war reluctance to facilitate a larger regulatory role for the state in the field of health insurance, by 1941 Van den Berg stated that "Sickness funds are in the first place institutions working for the population's health, and so are, in a far more limited sense, insurance companies." 137 Such a statement encapsulated the essence of what the Decree would bring about. With its introduction, sickness funds went from their pre-war status as private operators selling insurance policies, to what were, in effect, administrators (though private) of a government-mandated insurance scheme. ${ }^{138}$ The effect was two-fold. On the one hand, sickness funds rapidly decreased in number. The Decree ordained that any fund which wanted to offer the state-set package under the terms of mandatory insurance had to get official recognition. For this, proofs of financial solvability, contracts with doctors and specialists and hospitals (new phenomena for the funds) and more complex administrative procedures had to be developed. In response to this, many (especially smaller) funds decided to opt out of the whole business altogether. When the dust blown up by the Decree had settled, only 204 out of the 637 pre-war funds had sought and received official recognition from the Ministry. On the other hand: many funds had also opted out because of what they saw as their effective relegation to the status of private administrators of a state-mandated social provision. "The funds from now on occupied a place as organizations within civil society, the grey area between government and the private market." ${ }^{139}$

However, seen from the longue durée perspective of health care governmentality in The Netherlands, the breakthrough character of the Sickness Funds Decree must be mitigated to quite some extent. In effect, the Decree signified a real change in 'governance', with the formerly independent sickness funds now coming within the remit and responsibility of the state. Contrary to the pre-war period - in which legislation had given local public government only a very circumspect responsibility in creating access to some health care provisions - the Decree was instrumental for the way it now gave central government a strong role as a guardian tasked

\footnotetext{
${ }^{137}$ National Archives, Afdeling Volksgezondheid, inventory 2.15.37, no. 872, Letter from Van den Berg to the Secretary-General of the Ministry of Social Affairs, d.d. 01-04-1941, p. 3. In Dutch: "Ziekenfondsen zijn immers in de eerste plaats instellingen op het gebied van de volksgezondheid en slechts in zeer beperkten zin verzekeringsinstellingen."

${ }^{138}$ Although they did retain autonomy over the voluntary and supplementary insurance packages they offered.

139 K.P. Companje, Convergerende belangen, 171-172. Quote on p. 172. See also Vonk, 'Een taak voor de staat', 17.
} 
with safeguarding and regulating access to extensive health care provisions for a significant segment of the population. However, despite this change in governance structures, the pre-war mentality of a focus on private initiative and government at a distance in fact remained dominant. The fact that a third of the pre-war sickness funds chose to accommodate to their new role, in the process expanding their operations significantly, had to do with broader cultural and political developments which radically (yet at the same time subtly) impacted thinking about health care and the responsibility of the state towards its citizens in guaranteeing it. These notions of responsibility and access to a health care as a social right expanded, and yet the dominant political rhetoric for nearly three decades after the war would be cast in the framework of 'pillarization', which continued to stress private initiative and the Catholic principle of subsidiarity, and which will be discussed in more detail below. It would be some time before the state came to be seen as a welcome guest in health care, and even then with many reservations. Let us first turn to the ideological developments which strengthened the notions of health care as a collective responsibility in the post-war decades, before discussing in depth the way in which the pre-war governmentality in fact very much remained in place during this time.

\section{Dreams in Exile: The Van Rhijn-Committee}

While on the continent, the German overlords cut the Gordian knot of pre-war political prevarication on health insurance, across the Channel preparations were being made for the future of The Netherlands in terms of social policy after the war had ended. By 1943, the Dutch government-in-exile in London was already looking forward to an end to the Nazi tyranny. However, such hopes for victory were accompanied by the understanding that an unqualified return to the prewar era would not be possible, or - more importantly - desirable:

It is our strong belief in victory and the restoration of our fatherland, that already allows us to look past our dark present to the possibilities for the future. The Dutch people will, after liberation, through great effort have to rebuild a new house. [...] among the new relations and under pressure of new ideas, with great force shall rise to the fore the question of the creation of social security for all members of society. ${ }^{140}$

\footnotetext{
140 Van Rhijn-Committee, Sociale Zekerheid. Rapport van de Commissie, ingesteld bij Beschikking van den Minister van Sociale Zaken van 26 maart 1943, met de opdracht algemeene richtlijnen vast te stellen voor de toekomstige ontwikkeling der sociale verzekering in Nederland. Deel I. Overzicht van de bestaande stelsels in Nederland en een aantal andere landen, benevens van de in sommige dezer landen uitgewerkte plannen tot herziening en uitbreiding der bestaande voorzieningen ('s-Gravenhage: Algemeene Landsdrukkerij 19451946) 1-2. In Dutch: "Het is juist dat vaste vertrouwen in de overwinning en in het herstel van ons vaderland, dat ons reeds thans over het donkere heden heen doet uitzien naar de mogelijkheden voor de
} 
These words were spoken by Social-Democrat Jan van den Tempel, Minister of Social Affairs in the exiled cabinet, at the installation of a committee tasked with creating an overview of existing social insurance and social provisions in The Netherlands - among which health care. But the underlying purpose of the committee, headed by former government official and Minister of Agriculture, Arie van Rhijn, was more ambitious: creating an overview was only the first step towards radically reimagining social provisions in The Netherlands, which were generally seen to constitute an incoherent, limited and ineffective patchwork. Van den Tempel tasked the committee with considering four specific issues. The first was the broadening of the goal of social insurance: "The desideratum is: the creation of "freedom from want", guaranteeing a reasonable livelihood to all members of the community [...]". ${ }^{141}$ Next was putting an end to the incoherence of social insurance in The Netherlands through unifying social provisions. Here, "The community will now come more to the fore than the individual company, because this revolves around national provisions." ${ }^{142}$ The third point also tied in with a stronger focus on the community as the new linchpin for social provisions. Moving away from work and gainful employment at a company (through which insurance was mostly obtained before), the question was how social welfare for all members of society could be made possible through individual contributions to the financial pool. Finally, an estimation of the financial consequences of such a radically new network would have to be drawn up, including the consideration of a new financial distribution between insureds, employers, and the state. ${ }^{143}$

With these goals, the Van Rhijn-Committee set to work. In accepting his task, Van Rhijn himself went even further than Van den Tempel, stating that:

We strive for the ideal of social justice, which forms the background to the quest for security and safeguards from want in life. Such social justice can only be attained when man does not have to live in constant fear for his naked existence and that of his family, but can rather pursue the higher destination to which he was called into this world. ${ }^{144}$

toekomst. Het Nederlandsche volk zal zich, na de bevrijding, met geweldige inspanning van al zijn krachten, een nieuw huis moeten bouwen. [...] daarbij zal [...] onder de nieuwe verhoudingen en onder den druk van de nieuwe opvattingen, bovenal met groote kracht het vraagstuk van het scheppen van bestaanszekerheid voor alle leden der bevolking naar voren komen."

${ }^{141}$ Van Rhijn, Sociale Zekerheid Deel I, 3.

142 Ibid., 4.

${ }^{143}$ Ibid., 5.

144 Van Rhijn-committee, Sociale zekerheid Deel I, 7. Tellingly, Van Rhijn himself was until 1946 a member of the Protestant Christian-Historical Union, after which he joined the newly formed Labor Party. https://www.parlement.com/id/vg09II5ssays/a a aat van rhijn, accessed on 15-11-2018. 
The committee's ideas on how these ambitious and visionary goals could be achieved were laid out in a substantive, three-part report, which would be published in 1945-46. ${ }^{145}$ The first part provided a general overview of the (scattered) social provisions in The Netherlands, alongside discussion of various national systems. ${ }^{146}$ In the second part, a new groundwork for general social insurance was laid. The third part was concerned with the organization of medical care in The Netherlands. Where health care was concerned, Van Rhijn's plans primarily focused on the organization of provisions, which was generally seen to be a patchwork ineffective in providing timely and sufficient health care to those who needed it. With the Sickness Funds Decree in place, which was treated in the first part of the report as a major step in the development of social insurance, the issue at stake was primarily "[...] a medical-organizational problem. It is neither a problem of insurance, nor of philanthropy, so long as we prioritize the achievement of "freedom from want", also where treating sickness is concerned [...]." ${ }^{147}$ To this end, much of the third part of the Van Rhijn-report went back to a line of policy that had been unsuccessful for even longer than the failed attempts at instituting mandatory insurance: the organization of medicine through district health services. This will be discussed after looking at the broader international impact of the new political philosophy of creating 'freedom from want'.

\section{Reinventing the Social Contract: The Beveridge Report}

The report's lofty words and Van Rhijn's ambitious ideas of social justice and security would have sounded highly welcome to an audience just coming out of a devastating war. And devastating the war had been: The Netherlands was one of the worst hit of the countries overrun and plundered by the Nazis. Despite its rule by a civil, not a military administration, the economic damages sustained during the war were vast. ${ }^{148}$ Restoring the nation, as Van den Tempel had envisioned in 1943, would indeed be a gargantuan effort. But the new goals of 'social security'

\footnotetext{
145 The most extensive discussion of the Van Rhijn-report is to be found in T. Kappelhof, 'Omdat het historisch gegroeid is'. De Londense Commissie-Van Rhijn en de ontwikkeling van de sociale verzekeringen in Nederland (1937-1952)', Tijdschrift voor Sociale en Economische Geschiedenis 12 (2004) 71-91.

${ }^{146}$ Outside of the UK - discussed in the next paragraph - the first part of the report discussed social security systems in the US, Canada, New Zealand, Australia, South Africa, and the Soviet Union. Also included in the report was a Recommendation towards providing income security, resulting from the $26^{\text {th }}$ meeting of the International Workers' Conference in 1944, which Van Rhijn and Minister Van den Tempel attended.

${ }^{147}$ Van Rhijn-committee, Sociale zekerheid. Deel III. De Organisatie van Geneeskundige Voorzieningen en de Rehabilitatie van Gebrekkigen (Den Haag: Algemeene Landsdrukkerij 1946), 199.

148 De Rooy, Republiek, 185; J.L. van Zanden, The Economic History of the Netherlands, 1914-1995: A Small Open Economy in the 'Long' Twentieth Century (London: Routledge 1998) 123-124.
} 
came to fruition in a far broader context than just the Dutch one. This was so because in the war years this notion had become an integral part of the Allied idiom. In January 1941, Franklin Roosevelt, in his presidential State of the Union address, had outlined 'four freedoms': freedom of speech, freedom of worship, freedom from fear and freedom from want. Not only the first three freedoms were directly opposed to the totalitarian regimes of Nazism and Stalinism - atheistic, anti-democratic regimes propped up by censorship and brute force. Also the fourth element freedom from want - was seen as a direct challenge to these regimes, which ostensibly offered their populations much in terms of economic progress, but at great cost to their other freedoms. And it was recognized that the pre-war experience of abject poverty and economic instability following the 1929 Depression had created a breeding ground for dangerous new political systems. "[...] the rise of a despicable movement such as National Socialism is to be blamed partly on the discontentment of unemployed workers, uprooted small businessmen, oppressed farmers, and an insufficiently remunerated white collar proletariat." ${ }^{149}$ It was this backdrop also against which, in August 1941, Roosevelt was joined by Winston Churchill in producing the Atlantic Charter, a document outlining eight liberal goals for the post-war world, among which were full economic collaboration between nations and the establishment of 'social security'. ${ }^{150}$

One document, written in the vein of this new social philosophy, was even more instrumental in influencing 'Van Rhijn': the 1942 Beveridge-report. In 1941 the economist William Beveridge was commissioned by the British government to produce a survey of 'social insurance and allied services', and to make recommendations towards their post-war improvement. Initially commissioned as a way to pacify the political troublemaker Beveridge, the end result was something far removed from Prime Minister Churchill's socially conservative agenda. ${ }^{151}$ In surveying what also in Britain was seen as a 'patchwork' of social insurance and provisions, Beveridge argued that only a radically comprehensive reordering would suffice in providing the British public with the security of subsistence he thought they were entitled to after two world wars. "A revolutionary moment in the world's history is a time for revolutions, not for patching." ${ }^{\prime 152}$ But truly revolutionary was the way in which Beveridge envisioned a new role between citizens and the state. Where before the war - much as in The Netherlands - social arrangements for combating poverty or providing health care had taken shape in a force field of countless private parties and a broadly liberal stance towards government intervention in these

\footnotetext{
149 Van Rhijn-committee, Sociale zekerheid Deel I, 14.

150 http://avalon.law.yale.edu/wwii/atlantic.asp, accessed on 15-11-2018. See also Vonk, 'Een taak voor de staat', 17-18; Van Rhijn-committee, Sociale zekerheid Deel I, 13, and Van Klaveren, Het onafhankelijkheidssyndroom, 40-43.

151 There are extensive writings on Beveridge and the birth of the welfare state in the UK. I base myself on one of the most recent: C. Renwick, Bread for All. The Origins of the Welfare State (London: Allen Lane 2017), in particular p. 214-239, 249-257.

152 W.H. Beveridge (chairman), Social Insurance and Allied Services (London: 1942) 6. Accessed via https://archive.org/details/in.ernet.dli.2015.275849/page/n4 on 20-11-2018.
} 
areas, Beveridge now argued that the state should simply provide for a minimal level of subsistence, provided citizens contributed financially to schemes for social security. ${ }^{153}$

The thrust of Beveridge's plans was not born out of mere social considerations, however. Beveridge made his plea in a way which would also appeal to a more liberal audience: social security was not just a gift to the British population after two devastating wars, it was also quite simply an economic necessity. A pension would provide for those no longer employed, while actively combating poverty in the working-age population was absolutely necessary to get people back in the workforce. Accessible health care also played a role here in achieving this latter goal, because of the way it would limit sick days. ${ }^{154}$ In having everyone contribute to hedge collectively against financial or medical misfortune, Beveridge also dismissed the old argument that government welfare would make people lazy. Still, as a policy document of great force and influence, the general impact of Beveridge's report was to add to a new understanding of the responsibilities government had in relation to its citizens' welfare and well-being. In the words of sociologist T.H. Marshall, commenting in 1949 on the growth of 'social citizenship' in the $20^{\text {th }}$ century, what had been set was the "[...] image of an ideal citizenship against which achievement can be measured and towards which aspiration can be directed." 155

\section{Beveridge Abroad}

The Beveridge report's combination of economic thinking and social vision immediately struck home with the British public and the media, if not the government. Winston Churchill, as leader of the Conservative party, was not amused by Beveridge's political grandstanding and called for a more gradual (if any) expansion of social provisions after the war. ${ }^{156}$ But times had changed. On its appearance in the fall of 1942, Beveridge's report quickly made headlines and sold 600.000 copies with its call for the state to focus on vanquishing the five 'evil giants' of Want, Disease, Ignorance, Squalor, and Idleness. ${ }^{157}$ Especially striking was how fast knowledge of the report's contents - which were, after all, dry writings on insurance arrangements - spread among the

\footnotetext{
153 Beveridge, Social Insurance, 121-124. Beveridge outlined six groups of people who would have varying social needs, and proposed having the gainfully employed pay the same ('flat-rate') premium to account for these needs, should they arise. Differentiation in income would lead to income solidarity through general taxation (through which the rich would contribute more to general state funds used for the social security scheme).

${ }^{154}$ Renwick, Bread for All, 228-229.

155 T.H. Marshall, 'Citizenship and Social Class', in: T.H. Marshall, Citizenship and Social Class and other essays (Cambridge: Cambridge University Press 1950) 1-85, 29.

${ }^{156}$ Renwick, Bread for All, 234-235.

157 Juffermans, P., Staat en gezondheidszorg in Nederland (Nijmegen: SUN 1984), 142.
} 
general British public. A survey held just two weeks after its publication showed that some $95 \%$ of the population knew about Beveridge's plans, with social classes across the board supporting them. The most radical proposed change - providing health care to all through nationalizing health services - could count on support from $88 \%$ of the surveyed constituents. ${ }^{158}$ This broad level of support originated from both wartime solidarity, as well as discontent with the pre-war patchwork of health provisions - both of which resulted in a political about-turn. In 1945, Churchill and his Conservatives were ousted from power by a landslide victory for the Labor Party. This heralded the rapid construction of the welfare state in Britain, starting with the introduction, in 1946, of the National Health Service, the pièce de resistance of Beveridge's proposals. ${ }^{159}$

But the UK was not the only country where social reform followed rapidly after the end of the Second World War. In Scandinavia, 'Beveridge' as a model for social security was quickly copied. ${ }^{160}$ France and Belgium saw the introduction of far-reaching social security reforms at the end of the war. It is interesting to note here the broad democratic consensus in many countries concerning the implementation of Beveridge's new philosophy of 'social citizenship'. In Britain, the Beveridge-report had been an absolute bestseller among the general public. In Canada, democratic support for such plans had even received official form a few years before: in British Columbia (a province with a strong left-leaning and labor constituency) already in 1937 a referendum had been held on comprehensive health insurance, with $59 \%$ of the population supporting it. ${ }^{161}$ As far as France was concerned, the post-war introduction of comprehensive social security had, in the words of its originator Pierre Laroque, a 'democratizing' intent. ${ }^{162}$ Sweden, though it also implemented extensive welfare programs only after the war, had been governed from 1932 onwards by a social-democratic party much appreciative of social policies. ${ }^{163}$ And in the US - even though health care had been scrapped from the 1935 Social

\footnotetext{
158 Beveridge, Social Insurance, 6, for the 'five giants'. Renwick, Bread for All, 230-231.

159 The seminal history of the NHS is C. Webster, The National Health Service. A Political History (Oxford: Oxford University Press 1998).

$160 \mathrm{Hu}$ and Manning, 'Global Social Insurance', 141-142.

161 Maioni, Health Care in Canada, 20-21.

162 D. Luyten, 'Social Security and the End of the Second World War in France, the Netherlands and Belgium. Social Peace, Organizational Power and the State', in: S.-L. Hoffman et al, Seeking Peace in the Wake of War. Europe, 1943-1947 (Amsterdam: Amsterdam University Press 2015) 247-275, 257.

${ }^{163}$ B. Larsson, M. Letell and H. Thörn, 'Transformations of the Swedish Welfare State: Social Engineering, Governance and Governmentality. An Introduction', in: B. Larsson, M. Letell and H. Thörn, Transformations of the Swedish Welfare State. From Social Engineering to Governance? (Houndmills: Palgrave MacMillan 2012) 3-22, 6.
} 
Security Act - a vibrant public debate on entitlements to social benefits including health care took place after the war, though to little avail. ${ }^{164}$

Regardless of the specific governance arrangements made to provide expanded social security in different countries, two elements were key to many such reforms. On the one hand, the state became inextricably implicated in the provision of social help through the compulsory character of new social legislation. Second was the goal of unification of social arrangements. ${ }^{165}$ In Britain, Beveridge's report had raised fears among liberals and conservatives because of Beveridge's contention that its proposals for social reform should be both comprehensive and implemented as one program: there could be no cherry-picking. ${ }^{166}$ Also in other countries - and in the Van Rhijn-report - this focus on creating order in what before had often been a chaotic hodgepodge of social policies and practices was seen as essential for achieving the 'freedom from want' that was so sought after.

\section{A Silent Death for Big Ambitions}

The vision of a unified social policy goes a long way towards explaining the response - or rather, non-response - that the Van Rhijn-report met upon its publication in The Netherlands, shortly after the war. As noted, 'Beveridge' had been the primary inspiration for Van den Tempel to commission Van Rhijn's his survey of Dutch social insurance arrangements. But contrary to Beveridge's enormous impact, 'Van Rhijn' was met with a far less enthusiastic response in the post-war years. The report did not go unnoticed on publication. ${ }^{167}$ On the appearance of its second part in October 1945, the weekly of the Organization of Dutch Municipalities asked: "What is named Social Security is that which thus far has been called 'social insurance' or 'workers' insurance [in The Netherlands; RB] Will current measures be completely reimagined [...] Or will change be limited to piecemeal improvement of the existing arrangements, which have not grown as one coherent whole [...]?"168 Initially, the government seemed to be striving for the former, with the post-war emergency cabinet-Schermerhorn mentioning the 'London committee' whose recommendations would serve to revise the system of social security, " [...] expanding it

\footnotetext{
${ }^{164}$ Although Medicare and Medicaid were of course introduced in the mid-1960s. See Hoffman, Health Care for Some, 24-30, 53-62, 120-137.

165 For this, and a comparison between France, Belgium and The Netherlands, see: Luyten, 'Social Security'.

166 Renwick, Bread for All, 228.

167 A.L. Scholtens, 'Sociale Zekerheid', in: Weekblad voor Gemeentebelangen 24: 19 (1945) 193-197; A.L. Scholtens, 'Sociale Zekerheid II', in: Weekblad voor Gemeentebelangen 24: 27 (1945) 309-313; A.B. Michielsen, 'Sociale Zekerheid. Het Rapport-van Rhijn', in: Katholiek Cultureel Tijdschrift 1 vol. 2 (1945-46) 382-387; L. van Egeraat, 'Nederland krijge sociale zekerheid', in: De Nieuwe Eeuw 28: 1410 (1947) 124. 168 Scholtens, 'Sociale Zekerheid', 193.
} 
from a worker's insurance to a general people's insurance." ${ }^{169}$ But political optimism about the issue quickly waned, in large part because of resistance on the part of established parties. This resistance very much echoed pre-war sentiments concerning the role of government in social affairs. A legal scholar who in late 1947 defended his dissertation on the unification of social insurance, summarized the state of (familiar) political and social positions in an era of state-led reconstruction:

[...] state interference is a current, but unpopular issue [...] The liberal position [is] that government intervention is only permitted where autonomous societal forces fail. The Catholics recognize the principle of subsidiarity. State intervention only there, where societal organs are ineffective administrators. Calvinists adhere to sphere sovereignty [...] Government intervention only if and when [social] circles lack force or action in fulfilling communal goals, affecting the people as an autonomous whole. ${ }^{170}$

It was clear that the Dutch political parties that gained power after the German oppressor had gone were rapidly reverting to the pre-war rhetoric of state non-intervention, a philosophy which, as we have seen in previous chapters, united the Liberal and Confessional parties dominant from Thorbecke's time until 1939 and which had been foundational to the governmentality of Dutch health care in that period. However, the war and the resulting new 'social ideology' in Western political thinking did not leave the Dutch political scene untouched: from now on, the Social-Democrats would have a serious role to play in Dutch politics. These socialists had reorganized themselves during the war, uniting under the banner of the Labor Party (Partij van de Arbeid) from February 1946 onwards. In this way, they finally made electoral headway in the July 1946 elections, though hardly with a landslide victory such as the one which had propelled Labor to power in the United Kingdom. Their 29 seats in the Second Chamber (Tweede Kamer) of Parliament gave them near-equivalence to the Catholics, who won 32 seats (all of this on a grand total of 100 seats). This gave both parties not only a combined $61 \%$ of the vote, but also set in motion a governmental collaboration which would last until 1958 as the 'Roman-Red coalition' - discussed below. ${ }^{171}$

However, as far as the socialists were concerned, the main difference, according to the author cited above, was that they did not see the state as an 'ultimum remedium' ${ }^{172}$ Radical new

\footnotetext{
169 Kabinet Schermerhorn/Drees, 'Troonrede 20-11-1945', heading 8, 'Sociale Zaken en Volksgezondheid' (https://www.parlement.com/id/vjw7eih0q7q3/troonrede 1945 volledige tekst).

170 M.G.L. van Schouwenburg, 'Hervorming der sociale verzekering', Sociaal Maandblad 2: 12 (1947) 270282, 276. For the dissertation, see: M.G.L. van Schouwenburg, Unificatie der sociale verzekering (diss.: Universiteit Leiden 1946).

171 https://www.parlement.com/id/vh8Inhronvwk/kabinet beel i 1946 1948, accessed on 6-12-2018; until 1956, the Second Chamber of Parliament counted 100 seats, after which it was changed to 150. https://www.parlement.com/id/vh8Inhronvwq/tweede kamerverkiezingen 1956, accessed on 14-1-2019. 172 Schouwenburg, 'Hervorming', 276.
} 
ideas about the relationship between the state and civil society and individual citizens were, however, not to be expected. This became immediately clear when the plans presented in the Van Rhijn-report were rapidly dismissed by what should have been the Social-Democratic rankand-file. Immediately after the war, the Labor Foundation (Stichting van de Arbeid) was founded as a platform for employers' and employees' organizations to facilitate collaboration during post-war reconstruction. ${ }^{173}$ Far from creating an antagonistic relation between workers and employers, this organization served to prevent what could have otherwise been strikes or a revival of class-struggle rhetoric - limited though this had historically been in The Netherlands.

As we have seen in the previous chapter, in the interwar period employers had already managed to forestall strong government interventions in social insurance by creating their own social arrangements, for instance in terms of sick pay. This logic now extended to the response to the Van Rhijn-report. In a June 1946 congress on social insurance, the employer-employee led Labor Councils spoke out against a comprehensive and state-directed system of insurance. Much like the major political parties, it contended that the existing administration of insurance through companies functioned adequately; 'private initiative' was not so unsuccessful that government intervention was necessary. With such across-the-board resistance, Van Rhijn and his SocialDemocratic peers in government were left in the cold: only the small Communist Party wholeheartedly endorsed a state-run social insurance scheme. By 1947, Van Rhijn again chaired a second, 'mixed' committee on social insurance - 'mixed', as had not been the case with the first report, this committee's preparations included consultation with 'social partners' such as the employers' and employees' organizations. The resulting report no longer spoke of Beveridge; in general, it was reluctant to speak of comprehensive social insurance. ${ }^{174}$ The optimistic reformmindedness of the war years seemed to have dissipated. The second Van Rhijn-report was shelved indefinitely, and though Van Rhijn himself would fulfil the role of state secretary for Social Affairs in the period 1951-1958, it was not until the closing of that period that the welfare state in The Netherlands was again put seriously on the agenda.

\section{A Return to Pre-War Thinking}

The rapid disappearance of enthusiasm for broad reform in welfare provisions could be seen as a failure from the perspective of an international comparison; and The Netherlands as a 'welfare

\footnotetext{
${ }^{173}$ https://www.socialezekerheidsstelsel.nl/id/vhnnmt7jpb01/stichting van de arbeid, accessed on 6-122018.

${ }^{174}$ Vonk, 'Een taak voor de staat', 21-22; Kappelhof, 'Historisch gegroeid', 88-89. For Van Rhijn's limited political successes, see: https://www.parlement.com/id/vg09ll5ssays/a a aat van rhijn.
} 
laggard'. ${ }^{175}$ However, given the pervasive pre-war rhetoric of government non-intervention in social life, it is more accurate to see Van Rhijn's vision of radically reorganizing Dutch society as an anomaly, an (overly) ambitious attempt by social progressives to link up with historic developments elsewhere. The Netherlands hardly became a Social-Democratic powerhouse immediately after the war, and the inaction in social affairs instead represented well the sentiment of a significant part (if not the majority) of the Dutch population. Most illustrative of this development was the failure of the so-called 'Breakthrough' (Doorbraak) in the immediate post-war period. During the war years, political support had been growing for a radical break with the pre-war division of society along religious and ideological lines. Not only did the government-in-exile in London feature (in earnest for the first time) Social-Democrats such as Jan van den Tempel. ${ }^{176}$ Queen Wilhelmina, the symbolic as much as political leader of the exiled government, in a 1942 radio broadcast already stated that "Whoever says liberation, must also say renewal." Moreover, in The Netherlands, a group of political and cultural leaders taken prisoner and interned in the Sint-Michielsgestel prison camp envisioned the creation, after the war, of a broad people's movement, which would transcend petty factional lines so prevalent before the war. ${ }^{177}$

This call for change did indeed to some extent manage to cut through party and religious lines. The founding of the so-called Dutch People's Movement shortly after liberation was a joint effort of Social-Democrats, Catholics, Protestants and independents, hoping to spread the message of broad democratic renewal and calling for the founding of a progressive party with cross-factional support from the electorate. But the first post-war election, in 1946, served to show the tenacity of confessional and ideological thinking among the populace. Although the Labor Party did profit from the 'Breakthrough'-notion, entering government with nearly a third of the votes, the historiographical consensus is that the Breakthrough was, at least politically, a failure. ${ }^{178}$ In part, post-war increased support for the Social-Democrats mirrored developments elsewhere: after initial support for democratic renewal and the social-democratic agenda,

\footnotetext{
${ }^{175}$ K. van Kersbergen, 'Religion and the Welfare State in the Netherlands', in: K. van Kersbergen and P. Manow (eds.), Religion, Class Coalitions, and Welfare States (Cambridge: Cambridge University Press 2009) 119-145, 119.

176 The 1939 De Geer II-cabinet was technically the first cabinet featuring (two) Social-Democrats. However, this was a pre-war 'emergency' cabinet formed under the shadow of the looming Nazi threat, and as such featured members from all parties to ensure broad support in the face of war. https://www.parlement.com/id/vh8Inhrp8ws1/kabinet de geer ii 1939 1940, accessed on 20-1-2019. 177 De Rooy, Republiek, 180-182. Quote by Wilhelmina on p. 180. See also J. Kennedy, Nieuw Babylon in aanbouw. Nederland in de jaren zestig (3rd revised edition; Amsterdam: Boom 2017) 35-38.

178 De Rooy, Republiek, 182-183; Kennedy, Nieuw Babylon, 39-40. For a nuanced discussion, see: B. Mellink, 'Tweedracht maakt macht. De PvdA, de doorbraak en de ontluikende polarisatiestrategie (1946-1966)', Low Countries Historical Review 1262 (2011) 30-53, in particular p. 31-41.
} 
electoral successes were limited immediately after the war. ${ }^{179}$ In The Netherlands, the initial support was partly a response to the liberalism of the socio-economic policies of the 1930s center-right Colijn-cabinets, which had not succeeded in alleviating the unemployment and misery following from the Great Depression - which reached its high point in 1935, with some $20 \%$ of the population unemployed. ${ }^{180}$ Such circumstances had led to a discontent which made the post-war vision of guaranteed subsistence and security for all attractive to the electorate. But although the Social-Democrats entered government for the first time, it soon turned out that after five years of dictatorial occupation, the people's wish was for a 'return to normalcy'. This meant falling back on pre-war ways of thinking - and organizing society.

In terms of organizations and morals anchored in ideology or religion, for much of the late 1940s and 1950s The Netherlands would revert to its pre-war ways of doing things - this was the high point of so-called 'pillarization' in The Netherlands, the division of political and social life along the lines of Protestantism, Catholicism, socialism, and those who did not wish to fall under one of those headings (among which the Liberals). ${ }^{181}$ And as James Kennedy, who studied the transition from the deeply religious and conservative Netherlands of the 1950s to its internationally exceptional progressive makeover in the 1960s, summarized the early 1960s: "Tourists were still impressed by the conservatism, the calm and the religiousness of the country. ${ }^{182}$ This rapid cultural 'return to normalcy' after the war was important, as it reflected pre-war ways of thinking about the state, the community and citizen responsibility. This also affected thinking about health care, as we shall see. And yet, in a few important respects, the political and mental change brought about by the necessity of post-war reconstruction, the new social vision expounded by Van Rhijn and his peers abroad, and the call for democratic and cultural renewal of the Breakthrough ideology, set The Netherlands on a new politicalideological track. Despite the restoration of the 'pillars', a shift in ideas with regard to the necessity of government intervention took place, which would eventually allow the post-war social vision to win broad support, albeit more gradually than in many other countries.

\footnotetext{
179 For this, see: D. Orlow, Common Destiny. A Comparative History of the Dutch, French, and German Social Democratic Parties, 1945-1969 (New York: Berghahn Books 2000), in particular p. 44-53, 63-64.

180 See P. de Rooy, 'Een zoekende tijd. De ongemakkelijke democratie 1913-1949', in: R. Aerts et al, Land van kleine gebaren, 195-282, 229-235. The Protestant Anti-Revolutionary Party and Christian-Historical Union won only 13 respectively 8 seats in the 1946 election. The unexpected newcomer immediately after the war was the Communist Party, which won 10 seats in Parliament. But both the Labor Party and the Catholics were vehemently opposed to communism, a unifying factor in the Roman-Red coalitions.

181 The classic study of 'pillarization' is A. Lijphart, Verzuiling, pacificatie en kentering in de Nederlandse politiek (Amsterdam: De Bussy 1968), although there has since been much historiographical discussion of the sturdiness and coherence of the 'pillars'. Translated as The politics of accommodation: pluralism and democracy in the Netherlands (Berkeley 1968).

182 Kennedy, Nieuw Babylon, 56.
} 


\section{Catholics and Social-Democrats: A Recipe for Gradual Reform}

Where for much of the $19^{\text {th }}$ and early $20^{\text {th }}$ centuries a natural bond had existed between Liberal and Christian parties - Protestant and Catholic - because of their shared resistance to state intervention, after the war Catholics and Social-Democrats became (unlikely) bedfellows. This partnership resulted from convergence on a few levels. On the one hand there was a shared working-class constituency. The Liberals had always represented the wealthier middle and upper classes. Protestant (Reformed or otherwise) politics was more based on religion than on class but what was consistently emphasized was the mantra of 'sphere sovereignty', even at the expense of potential socio-economic benefits for their voters through increased governmental action. Such thinking barely changed after the war. "Foremost is a governmental policy which forcefully maintains the separation between State and Society (Government and business), in order to escape state omnipotence and state socialism, the greatest threat of our time", thus read the 1948 election program of the Protestant Anti-Revolutionary Party. ${ }^{183}$ From 1948 onwards, however, the Anti-Revolutionaries would consistently suffer electoral decline. ${ }^{184}$ The Liberals, too, had drifted far from their dominant position before 1918. In the three elections between 1948 and 1956, the newly formed People's Party for Freedom and Democracy (Dutch: VVD) never received more than $8.8 \%$ of the vote. ${ }^{185}$

The Catholics, on the other hand, as an historically marginalized group (large in number though it had always been) now saw the socio-economic emancipation of their voters within reach. In the interwar decades, the Catholics could consistently count on a third of the votes. ${ }^{186}$ But they had to share governmental power with Liberal and Protestant parties. After 1946, this balance of power shifted because of the new support for Social-Democratic ideals, which were compatible with social policy beneficial to Catholic (working-class) constituents. Moreover and most crucially, the Labor Party had renounced much of its volatile background in previous years in order to become more palatable to potential political partners. Already by the late 1930s, the

\footnotetext{
183 Anti-Revolutionaire Partij, Program van Actie 1948, http://pubnpp.eldoc.ub.rug.nl/FILES/root/verkiezingsprogramma/TK/arp1948/arp1948.pdf, accessed on 11-1-2019, p. 8

184 De Rooy, 'Een zoekende tijd', 281.

185 Documentatiecentrum Nederlandse Politieke Partijen Rijksuniversiteit Groningen, 'Verkiezingen en regering 1948-1963 VVD', https://vvd-digitaal.dnpp.nl/perioden/1948-1963/verkiezingen-en-regering, accessed on 12-1-2019. The VVD's predecessor, the Liberal State Party (founded in 1921 as a coalition of various smaller liberal fractions) had never been a large party, with four seats in 1937 as an absolute low point. https://www.parlement.com/id/vh8Inhrp8wtg/liberale staatspartij de vrijheidsbond, accessed on 14-1-2019.

${ }^{186}$ Van Kersbergen, 'Religion and the Welfare State', 124.
} 
Social-Democratic Worker's Party had dropped the 'class struggle' from its party program, and after the war, and with its reinvention as the broader Labor Party, any links with Marxism or communism were definitively cut. ${ }^{187}$ This was necessary, given the heavy resistance to the socialist or communist ideology from the confessional side in previous decades. ${ }^{188}$ But more striking was the way in which the Social-Democrats broadened their ideological outlook. In opening up to (inevitable) cooperation with Christian partners, the Labor Party professed itself as an adherent of 'personalist socialism'. At the foundational conference of the Labor Party, in 1946, former Liberal-Protestant preacher Willem Banning formulated this new vision for the SocialDemocrats thus:

The social, political and spiritual situation of our Western civilization has resulted in groups, other than merely the proletariat, speaking out in no uncertain terms on the structuring of the production process with regard to community property [...] This [personalist socialism] consciously does not presuppose an all-encompassing view of life and the world, but rather certain foundational notions with regard to man and society, which Roman-Catholics, orthodox and Liberal Protestants, and non-Christian humanists seem to share, and which are sufficient for communal action to radically reform the structure of society. ${ }^{189}$

These 'foundational notions' could be summarized as personal development - both spiritual and material - not unduly hindered by capitalism's focus on 'property and power as governing values in life', and facilitated by society and state. It was clear that the way in which the Labor Party now opened up made possible the creation of a new 'Christian (socialist) Humanism' ${ }^{190}$ The Catholics saw potential in cooperating with a social-democratic party in such accommodating form which catered to the same part of the electorate and was amenable to pursuing social policy goals while dropping the communist emphasis on heavy-handed social interventions on the part of the government. ${ }^{191}$ This left room for the setting of boundaries by the government, with actual administration left to the parties in the 'field' - much as it had been the case with (the limited)

\footnotetext{
187 De Rooy, Republiek, 183. Still, some of the trappings of the party were retained: 'The International' remained a staple sing-along at party rallies, for instance.

188 The Catholics had played an important role in effectively quarantining any socialist influence. Only in case of 'absolute necessity' could political cooperation with the Social-Democrats be considered, it was decided in 1921. De Rooy, 'Een zoekende tijd', 224-225.

189 W. Banning, 'Een nieuwe bladzijde', Socialisme en Democratie 3 (1946), 18-21, 19. For the discussion of 'personalist socialism', see also Van Kersbergen, 'Religion and the Welfare State', 130-131.

190 See https://www.parlement.com/id/vgok2t90lozj/w willem banning, accessed on 12-1-2019.

191 Van Kersbergen, 'Religion and the Welfare State', 132-133. The most significant element setting the Catholics apart from Liberals and Protestants was a more Keynesian approach to economics (shared, of course, by the Social-Democrats).
} 
social policy before the war. ${ }^{192}$ That the Catholics for their part also opened up politically was evidenced by the changing of the party's name to the Catholic People's Party.

In the post-war context of restoration, and with the new winds of Beveridge and others blowing, this new political mix would prove to become the bedrock of the Dutch welfare state, which would expand rapidly from the late 1950s onwards. However, in the period between 1946 and 1958, governments composed of Catholics and Social-Democrats first focused on (economic) restoration of the country and of societal institutions. Despite the new social ideals resulting from the Second World War, this restoration where possible took place within the ideological mold of limited state intervention and strong reliance on private initiative or on the self-organization of field parties. Also in health care, it would turn out that this pre-war 'governmentality' was tenacious. As we will recall from the previous chapter, by the late 1930s Dutch health care provisions formed an incoherent patchwork without any apparent central point of coordination. In the first decades after the war, attempts to create such coordination through more centralized control failed in the face of a political rhetoric not much different from that dominant before the war. However, as we have also seen, before the war the influence of government (especially on the local level) had in fact become substantial in health care, through back-door subsidizing and the supporting of access. This gap between rhetoric and reality would grow wider in the 1950s, when attempts to organize the structure or governance of health care from above failed, but the government's role in guaranteeing access through financing arrangements continued to grow ever larger. After having discussed the broader ideological developments which led to new ideas on the role of the state, we must now return to how these ideas found their way into debates on health care, its organization and its financing.

\section{New Times, New Health Care Politics?}

Where health care was concerned, the newly elected post-war government of socialists and Catholics found itself in markedly changed territory. Nevertheless, the pervasiveness of the prewar Dutch governmentality on the state's limited role in health care was evidenced by the fact that the two biggest changes in this regard had been international 'imports'. We have seen how the Van Rhijn-report was very much inspired by the British Beveridge-report, while the most important caesura in health insurance had been the Sickness Funds Decree, introduced by the Nazis and without deliberations in the Dutch Parliament. And the Van Rhijn-report had fallen flat

\footnotetext{
192 Van Orlow, Common Destiny, 45-46, 53-54, also shows that such a widening of the term 'socialism' was not limited to the Dutch Labor Party - although, according to him, this transformation led in The Netherlands to the most fruitful electoral results.
} 
rapidly, in the face of broad resistance to big government in health care (and social security provisions in general). But what of the Sickness Funds Decree? Did this represent a radical break with pre-war notions of subsidiarity and sphere sovereignty?

As noted, in Britain the most significant change resulting from the Beveridge-report had been the founding of the National Health Service - a single-payer, top-down organization providing health care for every British citizen. As far as The Netherlands were concerned, the Van Rhijn-report led to little immediate result, but the 1941 Sickness Funds Decree was immediately seen as an important step in furthering social arrangements. ${ }^{193}$ Two important elements in the state's role in the way health insurance was now provided through the sickness funds must be discussed. The first concerns the staying in place of the Sickness Funds Decree. The second was the renewed interest in the (top-down) organization of health care, to which we will turn in later paragraphs. First, an evaluation of the Sickness Funds Decree's post-war survival is in order. This is because this survival beyond the Nazi administration in The Netherlands gives pause. As discussed earlier in this chapter, the Decree greatly improved access and equality of coverage for a sizable new part of the populace. At the same time, the sickness funds that had been so instrumental in providing access to health care in the pre-war period had effectively become state administrators under the German occupier. As a decidedly top-down measure and, moreover, the most visible one in the area of social policy, the Decree therefore broke with the prior decades of state non-interventionism. The question therefore rises why it was not immediately rescinded - like so many other Decrees instituted by the Germans. ${ }^{194}$

As we have seen earlier, concerns over the affordability of health care (especially access to hospital care) had gradually grown in the prewar decades. This period had seen a rapid growth in sickness fund membership, but with increasing medical possibilities and expectations and the uncoordinated growth of hospitals and various forms of local-level care (in the form of the Cross Associations and municipal organizations), the unevenness generated by the lack of systemic organization was increasingly seen as a problem. The absence of a regulatory framework or codified 'right' to health insurance and the ensuing fragmentation had begun to pose serious problems for municipalities who picked up the financial slack on the basis of the broadly worded Poor Law. It is therefore not unimaginable that mounting concerns would have eventually led to successful legislative action on either hospital costs (construction or tariffs), mandatory insurance, or a more uniform and regulated form of financing for access to care. Here, it is hard not to recall the trajectory which had been set in motion already in 1904 by Abraham Kuyper. When plans were made in 1951 for revising the Sickness Funds Decree, the accompanying memorandum stated that: "Before [its] introduction [...] already for decades there

\footnotetext{
193 Van Rhijn-committee, Sociale zekerheid Deel I, 28-30.

194 See H. Jonkers, Het Koninklijk Besluit Bezettingsmaatregelen van den 17 Sept. 1944 (Goes: Fa. Gebrs. Stepman 1945).
} 
had been the need for legislation pertaining to the insurance for medical care." Therefore, despite the "abnormal circumstances, under which [it] was born, as well as the haste with which it was introduced [...] it cannot be called unfavorable for our country, given the relations at the time." 195

Such hindsight can be distorting. Nevertheless, the combination of growing governmental backing of health care, rapidly growing enrollment in sickness funds and hospital insurance associations in the first half of the $20^{\text {th }}$ century, as well as the non-profit motive of the sickness funds meant that the Decree was a somewhat unwelcome but nevertheless very effective way of mitigating the problems mentioned above. In 2012, Robert Vonk discussed the question of the acceptance of the Sickness Funds Decree at length, concluding that the Decree was "[...] a compromise agreement which did right by both German as well as Dutch interests and desires". Moreover, highly relevant was that " [...] with just small adjustments, it would fit into the social politics of the Roman-Red coalition." ${ }^{196}$

Where the parties in the field were concerned, it was significant that the main potential obstacle to introduction and successful implementation of the Sickness Funds Decree had been severely weakened in the war. The most vocal opposition to the Decree had come from doctors, one of whom commented on the Van Rhijn-report as follows: "The severing of ties to the fatherland should be seen as a mitigating circumstance for the fact, that this London doctor committee has lost [...] a correct view on the position and achievements of private practitioners in The Netherlands. [...] what is seen as a cure [in England, RB] would be utterly ineffective for us. Dutchmen, stay true to yourselves!"197 Patriotic sentiment aside, criticism of doctors fulminating against the Decree after the war centered on two elements: the cutting back of private practice through the growing number of those eligible for sickness fund insurance, but also the growth of doctors' practices and resulting (perceived) overcrowding. ${ }^{198}$ Indignant cries such as the one above would be in vain, however. Any real chance for an organized doctors' revolt had disappeared because of the weakening of the Dutch Medical Association in the war. And with the sickness funds reluctantly accepting the beneficial effects of the Decree after the war, serious resistance never emerged. ${ }^{199}$ Moreover, the Decree had been made palatable through maintaining the sickness funds' private status, and through involving funds, doctors, and hospitals in writing the accompanying Implementing Decrees - an intervention by Director-

\footnotetext{
195 'Memorie van Toelichting', in: Ontwerp Ziekenfondswet, first quote on p. 45, second on p. 46. 196 Vonk, 'Een taak voor de staat', 5.

197 C. Blanksma, 'Critiek op "sociale zekerheid" (Rapport van Rhijn, Deel III)', Medisch Contact 21 (3-011947) 4-9, 8-9.

198 Juffermans, Staat en gezondheidszorg, 184-185.

199 Vonk, 'Een taak voor de staat', 15, 22-25.
} 
General Van den Berg of the Ministry of Social Affairs, who shortly after the war more in general insisted on the 'Dutch' character of the Decree. ${ }^{200}$

\section{Public Guarantees, Private Governance}

All of this argues for a pragmatic understanding of the Decree and its staying in place after the war. Significant from an ideological perspective, however, was the way in which the Decree had codified something many parties - private and public - had been striving for in the decades before the war. Despite the fact that many sickness funds opted to leave the business rather than stay on as administrators of a government scheme, the changes brought about by the Sickness Funds Decree codified the fundamental goal of strengthening access to a broad set of health care provisions for a large part of the population - which, as we have seen, was the underlying goal of many (non-profit) sickness funds before the war. That strengthening was moreover not achieved through nationalizing health care - which had of course happened in the UK in 1946 which made it more acceptable. Oddly, however, where other countries implementing Beveridge-type reforms supported democratic participation in implementing or debating social security policies, for The Netherlands this hardly seems to have been the case. By 1950, a committee studying health care reform for the think tank of the Catholic Party noted that: "Had this report covered the subjects of business organization or radio broadcasting, it would have been alive in public opinion [...] As it stands, we see a development located at some distance from the public field [...] which, outside of the circle of those directly involved, has hardly been the subject of study and the conscious forming of opinion." ${ }^{201}$ Still, within the post-war context of a call for stronger social policies and the restoration of the war-battered nation, the codifying of better and affordable access to health care for a substantive part of the population must have been a welcome solution to a social question which had become increasingly pressing before the war.

Both the pragmatic and ideological acceptance of the 1941 legislation came together in the half-hearted political response to the Sickness Funds Decree after the war. As a matter of politics, the most noxious part of the Decree seemed to have been the fact that it was a tainted Nazi product which had provided the solution to the question of mandatory workers' insurance. The immediate post-war government tepidly noted that "The Sickness Funds Decree enacted during the occupation cannot be rescinded, but must rather be revised, in first instance to strip it

\footnotetext{
200 Vonk, 'Een taak voor de staat', 25.

${ }^{201}$ Centrum voor Staatkundige Vorming, Grondslagen voor een Wettelijke Regeling van de Gezondheidszorg ('s-Gravenhage 1950), 5.
} 
of its German elements. A general revision will be taken up shortly." ${ }^{202}$ However, such talk of a broad revision would turn out to be wishful thinking. In an interesting reversal of the pre-war failure of efforts to legislate for mandatory health insurance, the decade and a half after the war saw several attempts at tailoring the Sickness Funds Decree to a more 'Dutch' way of doing things, all of which stranded. When the Sickness Funds Decree was finally transformed into the Sickness Fund Act in 1964, it was mostly a conversion in name, as we will see in the next chapter. ${ }^{203}$

In large part, failures to adapt the Sickness Funds Decree after the war resulted from limited urgency to do so. This, in turn, was because a crucial component of the desired 'Dutch' way was introduced shortly after the war. The Sickness Funds Decree in 1941 had concentrated leadership of the sickness funds in one position, in accordance with the Nazi Führerprinzip. However, precisely such top-down leadership was a source of irritation with respect to centralized state control - civil servant Van den Berg from the Ministry had fulfilled this role in the war years. But by mid-1946, Social-Democratic Minister of Social Affairs Willem Drees presented the idea to institute a Sickness Fund Council (incidentally, a proposal first put forward by Van den Berg in 1939). This Council would break the power of the chairman, distributing it amongst representatives of all interest groups from the field of health care, in order to arrive at consensual decisions on policy, tariffs, and care provisions delivered through the funds. By October a legislative proposal was presented, and in April 1947 it passed. From 1949 onwards, the operations of the sickness fund system were therefore governed by a corporatist council containing representatives from the government, sickness funds, medical associations, and employers' and employees' organizations. ${ }^{204}$ Although this construction did not silence all criticism of the post-war situation of more state control over health care, it nevertheless provided enough of a recognition of the autonomy of the field parties and of 'private initiative' to placate these parties. ${ }^{205}$

In terms of governmentality and of Foucault's notion of 'statification' taking place through changes in decision-making centers, this was a development of great significance. Under the aegis and responsibility of a government which now guaranteed access to the broad mandatory insurance package, all parties involved could nevertheless uphold the idea that the locus of decision-making still lay for an important part with civil society and 'private initiative'. Rhetoric and reality with regard to state-backed health care deliberated upon by a corporatist

\footnotetext{
202 Bijlagen II, 1945/46, 123, no. 2, p. 18.

203 See K.P. Companje, 'Verzekering van zorg 1943-2007: gezondheidszorg of sociale zekerheid?', in: Companje et al, Tussen volksverzekering en vrije markt, 559-628, 565-566; 569-572.

${ }^{204}$ M. van Bottenburg, G. de Vries and A. Mooij, Zorg tussen staat en markt. De maatschappelijke betekenis van de Ziekenfondsraad, 1949-1999 (Zutphen: Walburg Pers 1999) 67-69, 74-76.

205 Vonk, 'Een taak voor de staat', 25-26.
} 
council in which both public and private interests were represented, were now wedded to each other in the Sickness Fund Council. Therefore, with the 1949 introduction of the Council, old political practice as well as the dominant governmentality so prevalent before the war could be perpetuated to quite an extent. And this Council would remain an essential actor in the Dutch health care system for half a century, attesting to the tenacity of this primacy of private initiative governance within a publicly regulated system. But what of the second important post-war change: the growing necessity of an effective organization of the health care provisions that the government now had a stake in? Here, a greater role for the state would still be a long way off, as we will now see.

\section{War, Reconstruction, Reorganization}

On the one hand, collective membership for all the Crosses [Cross Associations, RB], to be paid by the sickness funds, seems attractive [...] However, my feelings warn me against this quite strongly. He who has the money holds the golden reins, and will be able to influence the work of the Cross Associations to an unprecedented extent [...] Moreover, such a method would kill the private initiative so rightly lauded in The Netherlands - which, between ourselves, is not always ideal, but still better than the method of "giving everything for nothing", thereby playing into the people saying that "we have a right to that". 206

In 1943, when these words were written by Chief Inspector for Health Care Cornelis Banning to Piet Muntendam, who would become State Secretary for Health Care in 1951, it was not yet clear whether the Sickness Funds Decree would be a lasting measure - and as such, whether thinking about systematic links between the sickness funds (providing curative care) and the Cross Associations (providing mostly public health/preventive care) was really necessary. But with the Decree staying in place after the war, and within the post-war spirit of renewal and restoration, discussions on how to coordinate health care to best serve the public's health again came to the fore. In the previous chapter, we saw that earlier efforts by the government to foster cooperation between health services and to create more coherence had stranded on arguments of private initiative, financial constraints, or a combination of the two. But after the war, ideas about structuring health care regained urgency because the state had become a partner in the provision of health care for a significant part of the population. In 1943, Banning might have been wary of giving people a "right" to health care, but when the Sickness Funds Decree stayed in place, such a right became a reality policy-makers had to deal with and to provide for. For the

\footnotetext{
206 National Archives, inventory 2.15.38, no. 255, Letter from Chief Inspector Cornelis Banning to Regional Health Inspector for Groningen Piet Muntendam d.d. 2-11-1943, p. 1.
} 
(Social-Democratic) politicians and civil servants getting the Ministry of Social Affairs up and running again after the war, this could only be achieved through rational, top-down structuring.

Important factors contributing to a renewed interest in structuring health care were initially the impact the war had had on the organization of care, as well as the heightened incidence of various diseases which highlighted the shortcomings and limited reach of the health care 'patchwork'. ${ }^{207}$ Before the war many commentators had assessed positively the comparative quality of health care in The Netherlands. The effectiveness of the pre-war arrangements of municipal services, sickness fund insurance, and private initiatives such as the Cross Associations, had been high in keeping mortality and illness in The Netherlands low, internationally speaking. ${ }^{208}$ This in contrast to the UK, where Beveridge's NHS was perceived as a necessary relief in a Britain where " [...] throughout the inter-war period there was a palpable sense of crisis, even panic, about the lethargic pace of improvement [of health services]". Despite having a National Insurance Act since 1911 - which met some health care costs - "[...] the greater part of the population continued to live in conditions of Dickensian squalor." ${ }^{209}$ By contrast, in The Netherlands the situation seemed far less urgent.

But after the war, the post-war sense of renewal also rejuvenated debates on improving the overall structure and coherence of Dutch health care provisions with an eye to quality and access. The occasion for putting the organization of health care on the agenda again was the third part of the Van Rhijn-report, published in 1946. Attaining 'freedom from want' would have to be achieved through solving problems of a 'medical-organizational' nature, as Ben Sajet, the author of this part of the report put it. ${ }^{210}$ After giving a comprehensive overview of all existing provisions and legislation concerning health care, Sajet noted that the development of medicine and care was continuously showing a tendency toward expansion: in terms of disciplines, comprehensiveness and number of people seeking and being able to get help. Moreover, that expansion showed an ongoing systematization and cooperation in medical matters, in order to attain "the highest degree of physical and social healing." All of this was increasingly done in the name of "modern political and social notions", which implied that paying for such expansion was

\footnotetext{
207 See M. van Lieburg, 'The Civil Medical Services in The Netherlands during World War II', in: J.F.Ph. Hers and J.L. Terpstra (eds.), Stress. Medical and Legal Analysis of Late Effects of World War II Suffering in The Netherlands (Leiden 1988) 15-29, specifically p. 16-20.

208 L.C. Kersbergen, 'Openingsrede', in: Handelingen van het Nederlandsch Congres voor Openbare Gezondheidsregeling 1943-1946 (16 April 1946) 12-16, 15-16; Van Lieburg, 'Civil Medical Services', 21-22. ${ }^{209}$ Webster, National Health Service, 4.

${ }^{210}$ Van Rhijn-committee, Sociale Zekerheid Deel III, 199. Chair of the medical subcommittee and author of part III concerning medical matters was Ben Sajet, GP and city council member for the Socialist Workers' Party in Amsterdam for nearly 40 years. J.Z. Baruch, 'Dr. B.H. Sajet, sociaal-geneeskundige van formaat', NTVG 130 (1986) 2273-5.
} 
more and more the province of governmental financing, and less that of philanthropic parties. ${ }^{211}$ The author then came to conclusions which went back to Minister Aalberse's 1920 legislative plans: overarching district health councils would have to be installed, ensuring uniformity and simplicity in the organization of health care. These councils were to be headed by 'medicalhygienists' and there would in total be some 16 to 18, distributed over the country. Crucial was the choice left by Sajet: the councils could be seen as either private services or governmental bodies. The latter, however, had the author's preference, given "The great interests at stake in the organization of Public Health [...]." ${ }^{\prime 212}$

\section{Van Rhijn: A Rallying Cry for Private Initiative}

As we have seen, the socially progressive Van Rhijn-report quickly became synonymous with state intervention. This was also the case where health care was concerned. Much as it had happened in the area of broader social insurance, the central focus on the state of the Van Rhijnreport served as a rallying cry for interest groups to take a (mostly critical) stance. In the absence of direct government intervention and concrete legislative proposals, by the time the third part of Van Rhijn's report began to circulate, the momentum for serious change was mostly gone. This gave the parties in the field the opportunity to acquire a dominant position in the discussion concerning governmental or private control over these councils, and what the relationship between the two should be. This led to a string of reports all over the spectrum of statismprivate initiative, the most important combined result of which was to create a general state of confusion over what form the organization of health care should take, if any. ${ }^{213}$ One of these reports is worth looking at in some detail. In 1950, the Catholic Party's think-tank (Centrum voor Staatkundige Vorming) published a report on possible health care reform. This report carried real weight, coming from an organ that advised the largest party in government. But it also served to show that the discussion about the organization of health care had hardly progressed from the moment the Catholics and Social-Democrats had embraced each other in 1945, and that, moreover, the discussion was deadlocked by conceptual confusion.

We have already seen that the authors of the report noted a lack of interest on the part of the general public concerning the organization of health care. For those in the know, however, the rapid developments in medicine (discussed below) were impossible to deny, as were the effects they had had on the growing necessity of the collective to step in to ensure that average

\footnotetext{
${ }^{211}$ Van Rhijn-committee, Sociale Zekerheid Deel III, 195-196 (quotes on 196).

212 Ibid., 199-200.

213 Juffermans, Staat en gezondheidszorg, 143-145; Van Klaveren, Onafhankelijkheidssyndroom, 48.
} 
citizens got access to health care. These developments were seen as positive by the Catholic authors, as was the increased interest of the state in public health and welfare. "[...] we do not wish to return to the liberal philosophy, which saw the task of the state as solely negative". ${ }^{214}$ But any further expansion of such interest would for them have to take into account the unique nature of care for the sick, which was so inseparably connected to care for the soul and to confessional identity. Moreover, the Catholic principle of subsidiarity again should play a crucial role, a role which was described elegantly by reference to the encyclical Quadragesimo Anno:

[it is] a disturbance of the just order, to cede to larger bodies of a higher order that which can be done by smaller ones of lesser rank; because all social work must, by virtue of its being and nature, support the limbs of the social body, but may never dissolve them in the larger whole, destroying their individuality. ${ }^{215}$

So how to bring this philosophy in line with a positive role for the state in matters of health care? The answer was by now a familiar refrain: private initiative would have to retain primacy in the provision of health care, but there was room for representative councils fostering discussion and cooperation between these private institutions. These would include civil servants, but mostly representatives from private organizations - of which the Cross Associations were prime examples. ${ }^{216}$ On the face of it, therefore, the Catholics reverted to their pre-war stance on the subject, even though private initiative was a term "[...] used so often, that its meaning is in danger of blurring. ${ }^{217}$ Moreover, anyone could see that such councils would be perfectly toothless. Were they instituted, they could at best gently nudge private organizations to change their ways. But whether real change could thus be effected in terms of their modus operandi (let alone finances) was highly doubtful.

However, the report showed an interesting shift in the way the Catholics now openly began to endorse governmental subsidies for these nominally 'private' institutions, in effect embracing the shift from the rhetoric that emphasized the identity of these care providers as private institutions, to the reality of how they were increasingly funded - that is, by the government. As we saw in the previous chapter, this covert funding by the state had already increasingly been the case in the first half of the twentieth century, but without open recognition of the fact. Now, the report first praised private initiative for fostering self-sufficiency and autonomy in creating those provisions "which are within personal reach or can be achieved through free association", before going on to criticize a state "[...] granting a "right to health care" to be realized in its manner, that is to say inevitably collective, more or less uniform and, to

\footnotetext{
${ }^{214}$ Centrum voor Staatkundige Vorming, Wettelijke Regeling Gezondheidszorg, 8-10, quote on p. 10.

215 Ibid., p. 13-14, quote on p. 13.

${ }^{216}$ Ibid., 31-32, 35-39.

${ }^{217}$ Ibid., p. 12.
} 
make it acceptable to all, technically, materialistically oriented." ${ }^{218}$ However, when it came to discussing the way in which private initiatives could continue doing their beneficial work, precisely such uniform and collective action by the state was proposed. "[...] a powerful contribution by the government towards creating certainty in the financing of private work is not only necessary [...] it is also utterly incorrect to assume that such participation is a matter of benevolence [...] such participation [should] rather be seen as an obligation for government [...]."219

Despite holding firmly on to a philosophy as old as Catholic political participation in The Netherlands, the benefits brought about by a government that concerned itself with the health and welfare of its citizens were by now clearly recognized. But in maintaining that private initiative should be left free to organize its own operations, while simultaneously relying on public subsidies, the Catholics argued for the benefits of public involvement without its negative consequences - financial support, but without control. It seems that in health care, as in other areas of 'pillarized' Dutch society, this highly ambivalent stance typified how confessional private initiative approached the link between public and private social provisions. Dutch sociologist J.A.A. van Doorn in 1978 summarized it thus: what the separate (religious) pillars wanted was to "rule in their own house, but have the house be paid for by the collective." 220 And this was a position they would be able to maintain for quite some time, given the general failure of alternative plans to strengthen governmental control over health care. The authors of the Catholic report knew this, as two of them also took part in the most important governmental body that discussed health care reform in the decade and a half after the war: the Central Committee for Health. We will turn to that now, to further understand the tenacity of the old governmentality and ways of thinking about state and private initiative in Dutch health care.

\section{A Political Matter Best Left to Parties in the Field}

The Van Rhijn-report galvanized actors outside of the governmental bureaucracy to an unprecedented extent: "It was not state committees as in the nineteenth century, but private groups and persons who came up with plans", noted Jan de Vreeze in 1968. ${ }^{221}$ De Vreeze had

\footnotetext{
${ }^{218}$ Ibid., first quote on p. 17-18, second quote on p. 19.

${ }^{219}$ Ibid., p. 25.

220 J.A.A. van Doorn, 'De verzorgingsmaatschappij in de praktijk', in: J.A.A. van Doorn and C.J.M. Schuyt (eds.), De stagnerende verzorgingsstaat (Amsterdam: Boom Meppel 1978) 17-46, 29. In Dutch: "Baas in eigen huis, en het huis ten laste van de gemeenschap".

221 J.Th.M. de Vreeze, Voor en na de Gezondheidswet 1956. Eadem sed aliter (Nijmegen: inaugural lecture Catholic University Nijmegen 1968) 4.
} 
been a former secretary of the Catholic White-Yellow Cross and a central figure in Catholic 'private initiative' in health care in the mid- $20^{\text {th }}$ century. It is true that the rapid appearance of several reports on health care organization pointed to the dominant position of private initiative in the field of health care provision since the 1920s - of which the Cross Associations, which had so rapidly expanded since that decade, were the best example. But under the influence of new Social-Democratic ideals, as well as the greater role for the state after the introduction of the Sickness Funds Decree, the institution of the Central Committee for Public Health (Centrale Commissie voor de Volksgezondheid) signified a subtle shift towards more government interest and influence in health care - apart from the 'hard' intervention of the Sickness Funds Decree, and despite the rapid failure of Van Rhijn's far-reaching plans.

This Central Committee was founded on January 22, 1945 by Social-Democrat Jan van den Tempel in the exiled London-government, with the aim of serving two purposes. The most important direct goal was the reconstruction of a health care hit hard by the occupation. ${ }^{222}$ However, the second goal was more in line with Van Rhijn's long-term vision: the committee was to concern itself with the future organization of health care in The Netherlands. As such, the government had a need of "contact with those who deal with health care on a daily basis." Yet the way to achieve such contact was not to simply request or wait for the 'field parties' to respond to top-down governmental proposals concerning health care. Instead, the Committee from the beginning was composed of a variety of governmental and non-governmental parties: the Chief Inspector for Health Care, the Director of the Central Institute for Public Health (Rijksinstituut voor de Volksgezondheid), and several doctors, alongside representatives of the Cross Associations, the Association of Dutch Municipalities and the sickness funds and hospitals. It was chaired by the Director-General of Public Health (then still a subdivision of the Ministry of Social Affairs). ${ }^{223}$

The form the Committee took was rather interesting: having no formal basis in the law, an MP somewhat jokingly termed it an 'illegal' body. Prime Minister Willem Drees himself called it 'curious' at the inaugural meeting. Be that as it may, the Committee was given a broad mandate, as it was commissioned to provide either solicited or unsolicited advice to government. ${ }^{224}$ This form distinguished it from the existing bodies that until then informed the government: the State Inspectorate for Health Care - whose remit of repressive supervision was limited by the duties assigned to it by the Health Act - on the one hand and the Health Council (Gezondheidsraad) on the other. The province of the latter body was to inform government on

\footnotetext{
${ }^{222}$ National Archives, inventory 2.27.15 (Centrale Commissie voor de Volksgezondheid), no. 8.

223 Ibid.

${ }^{224}$ National Archives, inventory 2.27.15, no. 1, p. 1-2. The designation 'illegal Health Council' was used by Member of Parliament De Vries-Bruins; Handelingen II, 20-12-1945, p. 121.
} 
health matters from a purely medical-scientific point of view. ${ }^{225}$ The Central Committee, however, was allowed much leeway to discuss anything pertaining to the organization of health care, and it took this broad mandate to heart. For more than ten years, its members deliberated on matters ranging from the combating of tuberculosis and venereal disease to the position of district nurses. ${ }^{226}$ On multiple occasions, it was also asked directly by the Ministry to come up with or comment on (legislative) proposals to change or improve the provision, financing or coordination of health care. The Central Committee thus represented a break with the past, both in terms of membership and in the broad scope that the committee got to think about the organization of health care. However, though the government by now clearly saw the general organization of health care as a state task, it wished to improve that organization through consultation with parties in the field. This was a shift from pre-war attempts at instituting public bodies, when legislative proposals were prepared at the Ministry and presented to Parliament. Now, even though the state had become stronger in the provision of individual health care through the Sickness Funds Decree, the role private initiative played in the deliberative process concerned with the organization of health care had actually grown larger with the Central Committee.

This had clear effects on the effectiveness of the committee in strengthening the state's power in matters of health care. It soon became clear that for its novel character, the interest of the Central Committee in doing so were severely limited by what its members saw as the 'historical growth' of the health care field in The Netherlands. Despite the mixed composition of the Committee, it soon turned out that the representatives of private initiative health provisions had the upper hand. The sickness funds might have become subjected to real government oversight in 1941, but the 'free field' of Cross Associations (preventive care), as well as the municipalities (curative and preventive municipal services) and the hospitals (curative care) would turn out to be much harder to regulate top-down. By 1954, speakers at the $53^{\text {rd }}$ Dutch Congress for Public Health Organization tried to understand why the forward-looking spirit of 1945 had led to little concrete legislative results. After observing that out of ten post-war legislative proposals concerning health care, only three had made it through Parliament, C. Goudsmit - a civil servant at the Ministry of Social Affairs - noted the following: "The question as to why little has happened after the war in the field of health care legislation, is not easy to answer. The legislative path is, after all, slow [...] How hard is it to create general satisfaction; government

\footnotetext{
225 There was, however, confusion over the question whether the Health Council would not be secondary to the new Committee, with the latter's objectives as broadly formulated as they were. See Rigter, Met raad en daad, 125.

${ }^{226}$ National Archives, inventory 2.27.15, no. 1, for the minutes of the Committee's plenary meetings between February 1946 and December 1956.
} 
must account for what is alive in the minds of the people." ${ }^{227}$ Goudsmit was undoubtedly right: the legislative path can be long and arduous, and not only in health care. But it is instructive to examine closer some of the discussions so deeply steeped in the principles of subsidiarity and sphere sovereignty that both political parties and actors in the field referred to time and again. We will look at an issue which would grow into one of the most pressing concerns in health care after the war: the growth and expansion of financially costly hospitals, which by now had partly become a problem for the state, as hospital care was covered under the mandatory sickness fund arrangement.

\section{Case Study: The Elusive Matter of Hospital Planning}

A good illustration of the way in which 'pillarized' negotiation and parleying about the organization of health care stifled any effective policy interventions is provided by the failed attempts at legislating the construction and organization of hospitals in the years shortly after the war. ${ }^{228}$ In the context of limited financial means and post-war restoration, hospitals in this period were subject to financial constraints set by the Ministry of Restoration and Housing concerning salaries, prices and the construction of new buildings. ${ }^{229}$ But when the Ministry of Social Affairs (with Van Rhijn by now its Secretary-General) attempted to institutionalize a form of governmental oversight with regard to the construction of new hospitals, the ambitions of the Social-Democrats rapidly got bogged down in discussions on private initiative and resistance to 'statification'. This serves as a good case study for understanding the return to age-old positions on the relationship between the state and the parties organizing social provisions, such as health care, on the local level.

By late 1946, the first post-war legislative proposal concerning hospital construction began circulating in the Ministry of Social Affairs. This proposal continued the debate set in motion in 1935 concerning rising concerns over hospital costs, and the fact that the government had no say whatsoever in these growing expenditures - despite the increasing role of municipalities, as we have seen in the previous chapter. In response to the 1935 governmental committee, in 1938 three hospital organizations produced a report, proposing the creation of a Hospital Council. Such a council would have the final say in giving a hospital permission for new

\footnotetext{
${ }^{227}$ National Archives, inventory 2.27.20, no. 3, 'Reply by Mr Goudsmit', p. 1. The legislation that had been successful was the Act instituting the Sickness Fund Council, the Act on Tuberculosis Screening and a revision of the act protecting students and teachers from infectious disease.

${ }^{228}$ Little has been written on this. For a more contextual (but somewhat speculative) discussion, see: Wolf, 'Een wissel'. Also: Juffermans, Staat en gezondheidszorg, 172-176.

229 Juffermans, Staat en gezondheidszorg, 172-173.
} 
construction or expansion and would - unsurprisingly - be made up out of a delegation of hospital directors. In reaction, the Ministry of Social Affairs responded with a proposal of its own, in which officials from the Ministry would have seats on this Hospital Council. This plan led to nothing before the war, and neither did a Decree proposed in 1943 which never came into force. $^{230}$

After the war, the draft Hospital Act (Ziekenhuiswet) presented by Minister for Social Affairs Joekes picked up where this legislative project had left off, but now within the context of the state's new responsibilities and the Central Committee's task to conceptualize a more thought-out and sturdy organization of health care. The Memorandum to the Act (which was put forward in 1948) noted that evolving medical possibilities, as well as increased demand for hospital care meant that hospitals had begun to lag behind, necessitating renewal and reconstruction. However, contrary to psychiatric hospitals, regular hospitals were bound by no legal regulations whatsoever. This state of affairs created the "[...] not imaginary danger, that an unbridled urge towards expansion and construction of new hospitals would have undesirable effects from the perspective of the public's health". After all, "Now more than ever, governmental money is involved in the building and exploitation of hospitals [...]." ${ }^{231}$ Although a Hospital Council such as the one first proposed in 1938 - which would have the power to grant permits for building and exploiting hospitals and care institutions - was a good idea, it would therefore have to include representatives of hospital organizations, but also public servants safeguarding the interests of the state.

In his desire to gain broad support from parties in the field, Joekes sent his draft to the Central Committee for Health for consultation. The Committee was, after all, seen as a representation of local and 'private initiative', featuring as it did not just Health Inspectors, but also doctor-politicians, chairs of Cross Associations, the organized municipalities, and more. ${ }^{232}$ Unsurprisingly, the responses were varied. That subjecting hospitals to governmental control was

\footnotetext{
230 Wolf, 'Een wissel', 198-200.

${ }^{231}$ National Archives, inventory 2.27.15, no. 55, Ontwerp-Memorie van Toelichting Regeling van het Ziekenhuiswezen (Ziekenhuiswet 1948), p. 1-2.

232 From the public field came Cornelis Banning (Chief Inspector); E.J.A.A. Quaedvlieg (Veterinary Chief Inspector); W. Aeg Timmerman (director of the State Institute for Public Health (Rijksinstituut voor de Volksgezondheid). Representing Catholic private initiative was MP Chris Mol, who was a member of Parliament for the Catholic Party between 1946 and 1956, and also fulfilled roles as chair of the WhiteYellow Cross and a mutual hospital insurance association. Chairman Brutel de la Rivière had been chairman of the Dutch Medical Association from 1945 until 1947, after which he headed the Health and Food Councils. Muntendam was by now Director-General of Public Health at the Ministry of Social Affairs. More 'neutral' members of the Committee were J.J. Backer Dirks, a Rotterdam dentist; H.W. Julius, a doctor and professor at the Utrecht Academic Hospital; G.H.Ch. Cath, Secretary-General of the confessionally neutral Green Cross Association. N. Arkema chaired the Association for Municipalities. R.L. van Voorthuysen vicechaired the Association for Municipal Hospitals.
} 
a matter far more complex than mere economic arithmetic was shown by the reply of H.W. Julius, professor of general medicine at the Academic Hospital Utrecht. "[...] I do not feel confident to provide a well-founded judgment on a matter concerning questions of social, sociomedical, (financial-)political, religious, ecclesiastical, and many other natures, not even counting personal sentiment and preference." ${ }^{233}$ Where Julius held back in judging the proposal, Minister Joekes met with stiff resistance from other members of this authoritative Committee. First and foremost was the question whether private initiative had failed, or could be pushed aside by central government in this way. Was government intervention in the development of the hospital landscape really necessary? Had private initiative failed to such an extent that legislation should bring order from above? Minor details aside, many of the parties involved answered these questions in the negative. The Catholics reiterated the notion of subsidiarity. A short report on the draft legislation, presented to the board of the Association of Catholic Hospitals, chose a gentle approach, arguing that exploiting hospitals (and care institutions) was foremost a duty of the Church, Catholic or otherwise. Hospitals run by the church had heretofore not raised any real concerns, as the " [...] Dutch hospital landscape, grown out of particular initiative, in general meets very high standards." But going beyond arguments of religious responsibility and subsidiarity, the authors also argued that municipalities would be hindered in their autonomy, even though these parties had historically shown " [...] enough responsibility to maintain hospitals of high quality." The proposed Hospital Act was therefore judged to be "of little use". At most, the appointing of a type of hospital liaisons - expressly not government inspectors could be considered in order to facilitate contact between the boards of hospitals, thereby improving coordination within the health care landscape. ${ }^{234}$

N. Arkema, the spokesman for the Association of Dutch Municipalities in the Central Committee, was less subtle than the authors of the Catholic report had been earlier. Arkema commented that the municipalities had two principal objections to the proposed Hospital Act. The first pertained to the way in which the Act would give the Hospital Council powers over institutions for long-term care, something which municipalities saw as their province par excellence. Arkema acknowledged that there was room for improvement in these institutions, but doubted whether state oversight would be the best way to achieve it. "This concerns a matter best judged at the local level." ${ }^{235}$ The second, more general argument, questioned the efficacy of instituting governmental bodies in order to have hospitals meet medical-technical demands. "In this way, the freedom of private and confessional parties and municipalities to found hospitals is

\footnotetext{
${ }^{233}$ National Archives, inventory 2.27.15, no. 55, Letter from H.W. Julius to the Central Committee for Health, d.d. 8-9-1949.

${ }^{234}$ National Archives, inventory 2.15.38, no. 252. W.J.A.J. Duynstee and W.R. Casparie, Rapport over een Voor-ontwerp Ziekenhuiswet, d.d. 20-5-1949. Quotes on p. 3, resp. 2.

${ }^{235}$ National Archives, inventory 2.15.38, no. 252, N. Arkema, letter to the Chair of the Central Committee for Health, d.d. 17-08-1949, p. 1.
} 
completely curtailed." ${ }^{236}$ As an alternative, Arkema proposed the writing of a small booklet collecting municipal 'best practices' in the area of quality control and oversight. Such a book and increased cooperation between municipalities would pre-empt the need for any form of centralized control. ${ }^{237}$

Arkema's stance was a bit too radical for Committee chair Jan Jacques Brutel de la Rivière, who sent the remarks by the spokesman for the municipalities to the Minister separately, as a sort of 'dissenting opinion'. But Arkema's judgement was not far off from what the general Committee concluded with regard to the 1948 proposal. A year and five meetings after the Committee had received the request from the Minister, the resulting advice pulled the rug from under any attempts at real governmental control over the hospital landscape. Although instituting a Hospital Council was deemed palatable - if it was constituted mostly by hospital representatives - the powers this Council would get under the Act proposed by Joekes were such that the autonomy of private parties would be limited to an unacceptable degree. Despite the national scarcity of building resources, the Committee judged that the rationing of these resources was in the capable hands of the Ministry of Restoration and need not be brought under the Ministry of Social Affairs. Moreover, when such rationing would no longer be necessary, neither would state control over hospital building. All in all, the majority of the Committee agreed on " [...] religious and humanistic grounds that the freedom to build a hospital, where private initiative or municipalities judge this necessary, cannot be limited unless this is absolutely necessary." ${ }^{238}$

In such reasoning, the principles of liberal-humanism, sphere sovereignty and Catholic subsidiarity came together. Recognizing the resistance from the field, Joekes withdrew the concept and replaced it with a revised draft in August 1951. This draft conceded many of the points raised by the Committee. The Hospital Council would feature only three civil servants, alongside (at least) nine hospital representatives, as well as one representative each from the sickness funds, long-term care institutions, and the Dutch Medical Association. This Council would still have the power to grant permission for the building of hospitals. However, Arkema's points had hit home: municipal colleges would have the final say in the construction or exploitation of care homes. ${ }^{239}$ Again, the Central Committee was asked to give its say on the revised proposal. By now, and with the severe watering down of the initial proposal, it was easy for opponents of state control to give the final push. After another year of discussions, Brutel de

\footnotetext{
236 Ibid.

237 Ibid., 2.

${ }^{238}$ National Archives, inventory 2.27.15, no. 55, J.J. Brutel de la Rivière (chair of the Central Committee for Health), Advice Concerning the Draft Hospital Act, d.d. 1-11-1949, p. 2. Arguments on p. 1-2.

239 National Archives, inventory 2.27.15, no. 55, Ontwerp van wet tot regeling van het Ziekenhuiswezen, August 1951, articles 3 and 5.
} 
la Rivière wrote to the State Secretary for Health that resistance to centralized control was such, that the only viable option would be to give the general Health Inspectorate powers of 'repressive oversight'. This implied that Inspectors had the possibility to propose sanctions against hospitals or care institutions which did not meet certain quality criteria. However, any prior authorization for the building or the exploitation of hospitals was scrapped from the proposal, as was its original core provision, the Hospital Council. ${ }^{240}$ (The only permits given would be to mental hospitals, but this infrastructure was already a matter of governmental concern and had been for nearly a century). At the most, it was proposed that hospitals should in the future 'apply' to government - i.e. inform the Ministry of their existence. Hollowing out the 1948 proposal to such an extent sounded the death knell for hospital legislation. Ideas about top-down structuring of the hospital landscape were shelved for nearly 20 years. For furthering debate and coordination concerning the functioning of health care more generally, Brutel instead deferred to the Health Act, which was also being discussed by the Central Committee and to which we will now turn. ${ }^{241}$ In the meantime, "One should not overestimate the importance of a law [...] private initiative [...] has already been fruitfully at work to continuously improve the quality of the hospital system." 242

\section{The Health Act of 1956}

By 1952, the Central Committee for Public Health had therefore either failed or succeeded where hospital care was concerned, depending on the perspective one takes. From the perspective of the Social-Democrats and Van Rhijn's quest for providing government-regulated health provisions and security, the result of the Central Committee's deliberations and the withdrawal of Joekes' legislative proposal was a clear failure. From the older but still-dominant governmentality and rhetoric of local and/or private initiative bringing health care to the people, it was instead a great success. These two perspectives also come to the fore in evaluating what would be the Committee's most tangible result: a proposal to revise the 1919 Health Act. This act, as we have seen in the previous chapter, had gone through an arduous process of revision upon revision over the half century since the 1865 founding of the State Health Inspectorate - generally without great success in terms of strengthening the effectiveness of the Health Inspectorate. Now, in the post-war context, the government thought to act upon the impulse to coordinate health care, while simultaneously meeting the demand for revising this ineffective legislation,

\footnotetext{
240 National Archives, inventory 2.27.15, no. 56, Betreffende: Ontwerp van wet tot regeling van het ziekenhuiswezen, d.d. 19-12-1952, p. 1-3.

${ }^{241}$ Ibid., p. 13.

242 National Archives, inventory 2.15.38, no. 252, Vereniging van Katholieke Ziekenhuizen, 'VoorontwerpZiekenhuiswet', d.d. 21-12-1951, p. 3.
} 
which had been heard for quite some time. Let us first gain an understanding of the issues as perceived by contemporaries. Old legislative proposals as well as the new proposals put forward by the Van Rhijn-report through better coordination sought to make an end to the highly arbitrary and fragmented nature of health care provisions. The state of affairs was summarized clearly in mid-1955 by what would have been an observer looking at the matter from the perspective of local government. Discussing the 'historical growth' of health care provisions in The Netherlands at the Congress for Public Health Organization, mayor Antonie Klein of Meppel, a rural Dutch town, observed:

[...] it can be concluded that our Dutch (public) health care has grown from the bottom up, instead of being imposed or even organized top-down. Sprung from thousands of smaller groups, carried by countless local communities [...] in this way has grown the human machinery of our (public) health care, in a thousand ways, spontaneous and carried by countless nameless people. These origins have contributed greatly to the inner strength of this machinery, but they have also led to unfettered growth, which necessitated government interventions, with the trimming knife as well as with the fertilizer of state subsidies. $^{243}$

As attested by the words of the mayor, not much had happened in the way of coordinating the development of health care provisions. What governmental incursions had been made into the field of (public) health care had been done out of strict necessity. It was this situation which the Central Committee for Public Health now tried to remedy through legislation. However, from the first proposal presented to Parliament in 1952, it was clear that no revolutionary change in terms of who could influence, let alone control health care was to be expected. The Health Act put forward was mostly a procedural affair. It contained no articles regulating specific provisions such as the care for the mentally ill, the combating of alcohol or opium abuse or infectious

\footnotetext{
${ }^{243}$ A. Kleijn, 'Organisatie van de gezondheidszorg in de locale sfeer', in: Nederlands Congres voor Openbare Gezondheidsregeling. Klein congres 1955. Gehouden op 7 juni te Utrecht (Den Haag: Lankhout-Immig N.V. 1955) 6-15, 12. In original: "Zo kan concluderend van onze Nederlandse volksgezondheidszorg worden getuigd, dat ze van onderop is gegroeid en niet van bovenaf opgelegd of zelfs maar georganiseerd. Voortgekomen uit duizenden kleine groepen, gedragen door talloze plaatselijke gemeenschappen [...] uit al die kleine groepen en plaatselijke gemeenschappen dan is, duizendvormig, spontaan en gedragen door ontelbare namelozen, het menselijk apparaat van onze volksgezondheidszorg gegroeid en tot ontwikkeling gekomen. Deze wijze van ontstaan is aan de innerlijke kracht van dit apparaat in hoge mate ten goede gekomen, maar het heeft mede geleid tot die wilde groei, die in menig opzicht en gedurig het ingrijpen van de overheid van node had, zowel met het snoeimes als met de kunstmest der subsidie."
} 
diseases. These provisions were laid down in specific legislation, such as the Lunacy Act. ${ }^{244}$ Instead, what the Health Act proposed was to expand the institutional framework for coordinating health provisions. This was done by creating new councils - exactly what had been proposed by Van Rhijn, Banning, the Catholic think tank, and others. Social-Democratic Minister Suurhoff wished to complement the existing Health Council and the State Inspectorate with two new (types of) bodies. The Central Council for Public Health (Centrale Raad voor de Volksgezondheid) would be an official continuation of the (unofficial) Central Committee created in 1945. However, instead of advising government on a broad variety of public health matters, its main task was now the furthering of cooperation and deliberation between the various parties in the field of health care. ${ }^{245}$ In effect, though the Committee retained the possibility to advise the government on the organization of health care, its potential effect on national legislation was thereby lessened. This fact was stressed further by the way in which the act tasked the nation's provinces with creating provincial health councils, perhaps euphemistically named 'peripheral organs' in the memorandum to the act. Again, these councils would not have executive powers, but rather the task to coordinate between various parties: "The Provincial Council has, in the first and maybe most important place, the task to stimulate and promote health care provided by others". 246

It did not take much for critics to point out that the proposed act looked very much like the emperor's new clothes. With the Minister's contention that the new organization would "Leave room for every desired development", any real ambition on the part of the government to structure health care seemed to have faded. ${ }^{247}$ Instead, what the act codified was a capitulation to private initiative. "With the implementation of this act, our country will have accepted a new, even unique principle in the sanitary-organizational field. A very important part of Public Health will be exempt from governmental control and transferred to private associations and municipal boards", a critical doctor opined. ${ }^{248}$ During the parliamentary debates on the topic, critics who supported the state's role lauded the increased interest the government showed in furthering the public's health, while criticizing the half-hearted way in which it attempted to do so: several MPs considered that " [...] this proposal was submitted because between 1919 and now, change to the Health Act had been argued for many times." But it remained to be seen whether creating new councils would actually bring about the change that had been called for so often. ${ }^{249}$

\footnotetext{
244 Bijlagen Handelingen II, 1952/53, 2981, no. 3, p. 3.

245 Ibid., 4.

246 Ibid., p. 8.

${ }^{247}$ Ibid., p. 3.

248 J.J. van Loghem, 'De nieuwe Gezondheidswet', Ned. T. Geneesk. 10014 (28-01-1956) 238-239, 238.

249 Bijlagen Handelingen II 1953/54, 2981, no. 4, p. 2.
} 
An important part of the proposal focused on the allocation of seats for the new councils: in the initial proposal, it seemed that public officials would have majority representation. To make sure this would not be the case, Catholic MP Chris Mol submitted an amendment which argued for parity in representation between private initiative and public officials on both the Central Council for Public Health and the Provincial Councils. Predictably, the Labor Party and the Communist Party voted against this amendment, but it passed with 47 against 26 votes in favor. ${ }^{250}$ As a result, where deliberations on the organization of health care was concerned, private initiative was officially recognized as an equal partner to government. Getting equal representation, however, was not enough. By now, as we have seen in the report by the Catholic Party's think tank, parties in the field of health care appreciated government's increasing interest and sense of ownership in health care. However, they wanted this increased interest to be reflected also in the financing of private initiatives. In response to what was seen as the " [...] precarious financial situation [of] the free societal organs and institutions", critics pointed out that without the Health Act creating an official scheme for subsidies, private initiative would remain wholly dependent on the (arbitrary) goodwill of the government. ${ }^{251}$ But here, Minister Suurhoff used the argument of autonomy against private parties. Precisely because of the manifold nature of health care provisions which had grown 'organically', it was unclear how an overarching scheme for financing could really support effective initiatives while limiting ineffective ones. More in general, the Health Act was concerned with the organization of health care, not its financing. ${ }^{252}$ It would still take more than a decade before the link between the structure of health care and its finances was recognized in the face of the growing need for cost control.

After years of debate among the members of the Central Committee for Public Health, this Act, which gave neither great powers to the government nor financial security to private health initiatives, was all that seemed achievable. In the final stage before the new Health Act was voted in, members of the Senate discussed it and disagreed with Minister Joekes' contention that the new law would leave room for 'every desired development.' Rather, "[the proposal] serves to freeze certain historically grown relations" ${ }^{253}$ A crucial result of the Sickness Funds Decree had been the legal codification of equal access to a standard package of (curative) health care provisions. Where the remainder of health care in The Netherlands was concerned, Senators observed that without a real role for the government in its organization, fragmentation would remain the norm, and that, contrary to governmental involvement, the vast array of organizations providing health care could not be called to account in public. This would leave the public's broader health interest subject to the whims and financial position of countless

\footnotetext{
${ }^{250}$ Van Klaveren, Onafhankelijkheidssyndroom, 61-62.

251 Bijlagen Handelingen II 1953/54, 2981, no. 4, p. 1.

252 Bijlagen Handelingen II 1954/55, 2981, no. 5 (Memorie van Antwoord), p. 2.

253 Kamerstukken I, 1955/56, 2981, no. 49, p. 1.
} 
Cross Associations and municipal services. ${ }^{254}$ However, such 'whims' accorded well with the historically grown character of health care in The Netherlands. Commenting after the law was passed, Goudsmit (already cited above) made the following observation: "It is the irony of history that it was the liberal Thorbecke, who, at a time when state abstinence was widely preached, passed an act creating the bureaucratic organization of a State Inspectorate for Health Care, and [now] the socialist Suurhoff gives to private initiative the role it deserves in that organization. [italics in original; RB]"255

\section{Private Initiative Unfettered}

In the historiography, the evaluation of the 1956 Health Act has been mixed. Henri Festen, chair of the Central Council for Public Health between 1970 and 1978, in 1985 wrote with some annoyance that the act "[...] which in 1956 came in existence after exceptionally long preparation, could not really be seen as legislation fit for the health care and societal development of that time [...]". ${ }^{256}$ Historian Paul Juffermans stated that it was "[...] a meagre conclusion to the - by now long gone - desire for post-war reform [...] It was neither fish nor fowl." ${ }^{257}$ More recently, historian Kees-Jan van Klaveren has given a more positive assessment in arguing that, for all its shortcomings, the Health Act for the first time managed to get the government involved in the organization of Dutch health care. ${ }^{258}$ These evaluations argue from the perspective of intent, however: either the intent of Social-Democrats to expand governmental power over the workings of health care, or the intent of 'field parties' and municipalities to keep their operations in their own hands. To further understand the ongoing governmentality of private initiative, publicly backed, it is important to look at the practical effects the Health Act had on the development of health care facilities. Who controlled how health care provisions developed in the years after the Act was passed? How did this tie in with organizational and financing arrangements? In the previous chapter the rapid growth of both Cross Associations and municipal health services from the late $19^{\text {th }}$ century to the onset of World War II was discussed. The continuation of this development in the post-war decades, without serious government control or coordination, took place for everything in health care outside of what was government-mandated through the Sickness Funds Decree (even though 'control' was relative

\footnotetext{
254 Ibid., p. 2.

255 C.J. Goudsmit, 'De nieuwe Gezondheidswet', in: C.J. Goudsmit, Volksgezondheid en Recht (Ymuiden: Vermande Zonen N.V. 1966) 28-32, 31-32. (Reprint from Tijdschrift voor Sociale Geneeskunde 09-03-1956).

${ }^{256} \mathrm{H}$. Festen, Spanningen in de gezondheidszorg. 25 jaar Centrale Raad voor de Volksgezondheid (Zoetermeer: Nationale Raad voor de Volksgezondheid 1985) 11.

257 Juffermans, Staat en gezondheid, 148.

258 Van Klaveren, Onafhankelijkheidssyndroom, 62-63.
} 
even in that area, given the funds' private character and the far-reaching power of the Sickness Fund Council). Let us take a look at what 'private initiative' meant on the ground. How did the health services offered by the municipalities and the Cross Associations, defended so fiercely against government incursions, fare in this period?

To begin with the municipalities, the Sickness Funds Decree had meant a radical break with the way in which local government had become involved in health care over the previous decades. The most immediate consequence was the way in which municipalities were relieved from what before the war had become an increasing financial strain: the subsidizing of hospital patients via the back door provided by the Poor Law. With the sickness fund package now including a broad array of curative care for the middle classes, as well as up to 42 days in hospital, municipalities no longer had to strain the scope of the Poor Law to create access to such expensive care. This became even less of a problem in 1965, when the General Act on Financial Assistance (Algemene Bijstandswet) came into force. This act, which would be an important milestone in the construction of the broader Dutch welfare state, replaced the older provisions of the Poor Law, moving financial responsibilities from the municipal level to a staterun scheme. As a result of these developments, it seemed that many of the tasks municipalities had taken upon themselves since the 1920s - mostly through appointing municipal doctors would disappear because of this new centralizing legislation. But instead, local governments started to diversify their health care activities in the 1950 s and '60s. The loss of curative tasks was to some extent compensated for by the taking up of medico-administrative tasks on the one hand, and preventive ones on the other. By 1962, staple tasks for municipal services and doctors included emergency medicine, but also forensic services, medical check-ups and vaccinations. ${ }^{259}$ The expansion of the welfare state from the 1960s onwards only added to this diverse array of tasks. With the 1965 Act on Financial Assistance, the need arose for increased socio-medical evaluations of the health of unemployed persons seeking assistance. Next to that, the call for improved living conditions for the elderly called for new governmental oversight of care homes. Where preventive tasks were concerned, municipalities expanded their pre-war practices of improving sanitary conditions to limit infectious disease, but also began to offer screenings and regular check-ups. ${ }^{260}$

Overall, the expansion of these health services proceeded at a fairly gradual and linear pace: by 1965 there were 49 municipal health services on a grand total of 966 municipalities in The Netherlands. Despite their limited number, these services existed for the benefit of more than half of the Dutch population, with each of the 14 largest cities (100.000 inhabitants or more)

\footnotetext{
${ }^{259}$ A. Brouwer, 'Het gemeenteartsen-probleem en de gemeentelijke gezondheidsdiensten (I), Tïdschrift voor Sociale Geneeskunde 4019 (1962) 537-546, 540-541.

260 Kerkhoff, Honderd jaar gezondheidsdiensten, 65-74.
} 
having instituted such a service. ${ }^{261}$ Contrary to the period preceding the war, the post-war collation of general statistics on the cost of health care moreover makes it possible to move from estimates where municipal spending on health care is concerned, to actual costs and the relative share of municipalities. Table 2.6 shows this development and the levelling off in the late 1960s (a result of the 1968 General Act on Extraordinary Medical Expenses discussed in the next part): ${ }^{262}$

Table 2.6 Share of total health care costs in \% (preventive and curative, undivided), 1953$1968^{263}$

\begin{tabular}{|l|l|l|l|l|}
\hline Year & $\mathbf{1 9 5 3}$ & $\mathbf{1 9 5 8}$ & $\mathbf{1 9 6 3}$ & $\mathbf{1 9 6 8}^{\mathbf{2 6 4}}$ \\
\hline Municipalities & $\sim 10,2$ & 8 & 9 & 3.7 \\
\hline $\begin{array}{l}\text { Central } \\
\text { government }\end{array}$ & $\sim 11$ & 13 & 13 & 15.4 \\
$\begin{array}{l}\text { Families (private } \\
\text { financing) }\end{array}$ & $\sim 74$ & 76 & 75 & 78.6 \\
\hline
\end{tabular}

Source: Centraal Bureau voor de Statistiek, Kosten en financiering van de gezondheidszorg in Nederland (Series 1953, 1958, 1963, 1968)

As we can see, the comparison with spending by the state shows that for much of the post-war decades, municipalities still had a serious role to play in financing various forms of health care although the role of the central government was clearly growing, and it cannot be deduced from the numbers how much of municipal financing ultimately came from the state's Municipality Fund. Much in line with a focus on the individual in health care (though now often made mandatory through the Sickness Funds Decree) contributions by families and individuals remained crucial.

While the municipalities accounted for various health services in the cities, the private Cross Associations continued their pre-war activities of offering health care in (mostly) rural areas. As we have seen, the initial focus had lain on the combating of infectious diseases, in the absence of municipal action on that front. But by the middle of the 1950s, the tasks of the 'Crosses' were expanded to include home nursing, child care (pre- and postnatal, and all the way through primary school), the fighting of tuberculosis, venereal disease, cancer, and providing

\footnotetext{
${ }^{261}$ Geneeskundige Inspectie van de Volksgezondheid, De gemeentelijke gezondheidszorg en zijn organisatie (zp: 1965), 10, 35.

262 Centraal Bureau voor de Statistiek, Kosten en financiering van de gezondheidszorg in Nederland 1968 ('sGravenhage: Staatsuitgeverij 1972) 31.

${ }^{263}$ For the broader rise of health care costs in this period, see part 3. The year 1953 is a close estimate, as the statistical bureau retrospectively adjusted health care costs for that year without recalculating the relative shares (costs were recalculated from 818 to 770 million guilders, making for a small difference). ${ }^{264}$ Excluding costs created by the new AWBZ, discussed in the next chapter. These amounted to another 374 million guilders.
} 
mental health care. Much like the municipal services, they were therefore protean by nature: "Whichever needs there were in the domain of public health, the Cross Associations have provided." 265 This flexibility contributed to their great success, a development which continued after the war: subscription to the Associations doubled from $30 \%$ to $60 \%$ of the population between 1940 and 1957. ${ }^{266}$ By 1957, there were 1579 local associations, up from 1335 in $1941 . .^{267}$ If the important role the Crosses played in the totality of health care was clear to proponents of private initiative, the increased stake placed in them by government was at the same time hard to miss. In the discussion of the Health Act, we have seen that neither proponents of more state intervention nor private associations arguing for the standardizing of state subsidies saw their desires fulfilled in the enacted legislation. But despite the fact that subsidies for the Cross Associations in the 1950s and '60s retained a (mostly) unregulated character, the importance of public financing already begun in the pre-war era only grew. ${ }^{268}$ The increasing share of public money in the financing of what remained privately operated health services attested to a continuation of the rhetorical focus on 'sovereignty' versus the reality of government financing, as seen in Table 2.7:

\section{Table 2.7 Financing of the local Cross Associations in \%, 1957/1968}

\begin{tabular}{|l|l|l|l|}
\hline Source of revenue & State subsidies & Municipal subsidies & $\begin{array}{l}\text { Contributions } \\
\text { (families) }\end{array}$ \\
\hline White-Yellow 1957 & $23 \%$ & $20 \%$ & $39 \%$ \\
\hline Green 1957 & $24 \%$ & $17 \%$ & $39 \%$ \\
\hline White-Yellow 1968 & $30 \%$ & $27 \%$ & $29 \%$ \\
\hline Green 1968 & $30 \%$ & $24 \%$ & $39 \%$ \\
\hline
\end{tabular}

Source: H. Gijselhart e.a., Beleid in de maatschappelijke gezondheidszorg. Een beleidssociologische studie van de kruisverenigingen (Rotterdam 1975), 334, cited in Juffermans, Staat en gezondheidszorg, 195-196.

By the late 1960s, secularization and deconfessionalization set in, a development which would take its toll on the autonomy of Cross Associations organized along religious lines and underpinned by confessional ideologies of state non-intervention. On the political front, moreover, convergence between the historically charity and solidarity-based Crosses and the expansion of the welfare state gradually put 'private initiative' under pressure, as provisions were increasingly incorporated in the mandatory sickness fund package or placed under the Act on

\footnotetext{
265 Centraal Bureau voor de Statistiek, Statistiek van de plaatselijke kruisverenigingen 1957 (Zeist: Uitgeversmaatschappij W. de Haan N.V. 1960) 7, 10 (quote on p. 7).

266 Juffermans, Staat en gezondheidszorg, 194.

267 CBS, Statistiek plaatselijke kruisverenigingen 1957, 10; CBS, Overzicht van de Kruisvereenigingen, 8, 12.

268 In 1961, a scheme for subsidies to national and provincial Cross Associations that aimed at partially subsidizing personnel costs was implemented by Minister Veldkamp. Juffermans, Staat en gezondheidszorg, 244.
} 
Extraordinary Medical Expenses. ${ }^{269}$ This convergence of 'social' and 'private' motives also took place in a business sector concerned with the financing of health care: the market for private health insurance.

\section{Converging on Care: Sickness Funds and Private Insurers}

In the previous chapter, the evolving relationship between the sickness funds and private (forprofit) health insurers in the period between 1900 and 1940 was discussed. The most important conclusion was that the for-profit health insurance industry faltered in that period because of a lack of insight into health determinants, as well as resistance to their sometimes harsh policies including risk selection and unilateral termination of contracts - in a country in which more socially oriented sickness funds had become increasingly dominant after the late $19^{\text {th }}$ century. The introduction of the Sickness Funds Decree in 1941 had radical effects on this relationship, but it nevertheless led to a continuation of the trend set in in the first decades of the $20^{\text {th }}$ century. Two noteworthy things took place. On the one hand, the division of market shares between sickness funds and for-profit insurance companies further developed in favor of the former. In 1940, some $70 \%$ of the population had some form of health insurance. Of the insured, $45 \%$ were covered by sickness funds, with the remainder divided between commercial and notfor-profit insurers, as well as hospital insurance associations. As we have seen, the 1941 Decree had an immediate impact on this division. Already at the end of $1941,60 \%$ of the entire population was insured through sickness funds, with this number rising to some $70 \%$ by 1950 , and fluctuating between $65 \%$ and $75 \%$ in the decades that followed. ${ }^{270}$ This created what Robert Vonk and Erik Schut have recently called a "mixed public-private system of social and private insurances", with the rest of the population constituting a steady customer base for private insurance companies - that part earning too much to be eligible for insurance through a sickness fund. ${ }^{271}$

However, instead of leaving this significant portion of the Dutch population to for-profit insurance companies, sickness funds collectively opted to influence the post-war system by founding their own private health insurance companies. These companies, called 'superstructures' (built on the 'base' of the sickness funds) had an explicitly non-profit motive, and were in theory and practice aimed at providing social health insurance outside of the sickness fund sector. Being legally separate from their sickness fund counterparts, but factually

\footnotetext{
269 Ibid., 245-248.

270 Vonk and Schut, 'Universal access in voluntary private health insurance', 3.

${ }^{271}$ Ibid., 8.
} 
tied to them through the use of the same administrative structures, these superstructures could offer very affordable, comprehensive health insurance to people whose income exceeded the funds' upper limit and who were at risk of being denied coverage by commercial insurers (because of potentially expensive pre-existing conditions, for instance). ${ }^{272}$ In effect, this undercut what had been intended by the Sickness Funds Decree as a strict divide between 'social' (sickness fund) and 'private' (free market) health insurance policies. But, tellingly, in line with the post-war 'Van Rhijn'-spirit, government officials did not decide to act on such gaming of the system by outlawing these superstructures. Instead, a blind eye was turned to their rapid rise. ${ }^{273}$ And this rise was rapid indeed: the superstructures quickly turned out to be enormously popular with Dutch citizens in the 'private' segment: between 1950 and 1959, their share of the private health insurance market went up from $8 \%$ to $40 \%$. This clearly happened at the expense of commercial insurers, whose share dropped from 57 to $35 \%$ in this period. ${ }^{274}$ With this, a uniquely Dutch convergence of 'social' and 'private' insurance took place, with the sickness funds expanding their influence and policy of offering comprehensive care at affordable prices. ${ }^{275}$

The second development was in a sense a mirror development, compared with the first. In the face of the enormous success of the superstructures, as well as increasing criticism of such harsh insurance practices as selective contracting and one-sided termination of contracts, commercial health insurers gradually started to adopt the social signature of the sickness funds. This happened in two ways. On the one hand, commercial insurers increasingly acted on the (historical) criticism of their harsh insurance practices. From the early 1950s onwards, the practice of insurers to terminate contracts one-sidedly was gradually abandoned, while reimbursement for longer hospital stays became increasingly common. Potential health risks such as newborns were no longer easily denied coverage. ${ }^{276}$ The commercial identity of many insurers was therefore retained, but its 'asocial' aspects were toned down. Collectively, the commercial insurers also in an important way changed their tune. As a result of the negative perception of the commercial branch of health insurance, but also because of the adverse financial effects of ever more lenient insurance policies, these companies from the mid-1950s started to coordinate their actions, forming a cartel in 1957. However, this cartel was not aimed at keeping out new competitors or at pushing up prices for consumers. Instead, its purpose was to create a General Health Insurance Policy, which could be offered by all its members at an equal premium to insureds. This Policy contained all of the abovementioned novel insurance aspects, showing the

\footnotetext{
${ }^{272}$ F.T. Schut, Competition in the Dutch Health Care Sector (diss. Erasmus Universiteit Rotterdam 1995) 137140.

${ }^{273}$ Vonk, Recht of schade, 150-154.

274 Vonk and Schut, 'Universal access', 9.

275 Vonk, Recht of schade, 150.

276 Ibid., 155.
} 
willingness (born of necessity) to move towards a more social provision of health care - though, of course, still at higher rates than those paid by sickness fund patients.

This new balance between public and private health insurance was a delicate one: even though the government appreciated the social signature of the sickness funds, it was recognized that private insurance for those above the sickness fund income limit formed a type of subsidy necessary for keeping the system of the sickness funds affordable. By 1960, 'private' patients could pay up to nine times as much for health services as their sickness fund peers, allowing doctors and hospitals to charge sickness fund patients affordable rates. ${ }^{277}$ For the time being, and with the commercial insurers moving more and more towards providing 'social' insurance, there were no interventions needed in this convergence between the different types of insurance. But by the late 1960s, the more 'social' character the private insurers now embraced led them into financial trouble. But these problems were not limited to the commercial health insurance sector. On the horizon, the rapid expansion of medical possibilities and exploding costs loomed.

\section{Under the Volcano: A Booming Economy and an Evolving Medicine}

While lawmakers, insurers, and the many actors in Dutch health care were attempting to give new shape to the patchy organization of health care, two developments were taking place which would structurally change its provision and the financial burden it would come to present. On the one hand there was the beginning of a 'golden age' in medicine shortly after the war, and on the other the enormous economic growth witnessed by The Netherlands in the post-war decades. It was these developments which would, from the mid-1960s onwards, give a new sense of urgency to (political) control over the cost of health care. These developments were hardly limited to The Netherlands: dealing with rising health care costs would become a perennial policy aim in many Western industrialized nations which had expanded social provisions after the war. But differing national histories and political and institutional cultures led to different outcomes. When the economy took a downturn and the urgency to control costs became one of the principal themes in health care politics in the 1970s, the long history of 'organic growth' and government non-intervention in Dutch health care would deeply influence the new blueprints for its organization and financing. Let us first see how The Netherlands came to live 'under the volcano' because of economic growth.

277 Vonk en Schut, 'Universal access', 10-11. 
Before the war, general economic policy had reflected the philosophies of the parties in power: the liberal and confessional parties by and large held that government should keep its distance from the free workings of the market. This changed somewhat in response to the impact of the Great Depression in the 1930s: under the Protestant (Anti-Revolutionary) Prime Minister Colijn, some measures aimed at protecting the economy were instituted in what was " [...] a radical break with the long tradition of non-intervention [...]." ${ }^{278}$ In 1935 the socialist party presented a Labor Plan based on new Keynesian insights: the government should both actively stimulate employment through the creation of public works and adopt active planning strategies for guiding the economy. And by this time the Catholics had also become more inclined towards Keynesian interventions - with their interest in what was increasingly the same working-class constituency as that of the Social-Democrats. ${ }^{279}$ But the Labor Plan was dismissed by AntiRevolutionary Prime Minister Colijn as being too interventionist. However, the 1939 emergency Act on Price Inflation and Hoarding (Prijsopdrijvings- en Hamsterwet) for the first time introduced government control over prices, also in health care. This somewhat oddly named act was aimed at ensuring that the public would not feel inclined to hoard certain supplies in the face of the chaos of war, as this would artificially push up purchase prices. ${ }^{280}$ Although it targeted the prices of general consumer goods, the 'Hoarding Act' for the first time also allowed government to set tariffs for hospital treatment. Changes to these prices would be subject to governmental consent, but this arrangement became irrelevant when in 1940 all tariffs were frozen under the German occupation. However, when the Sickness Funds Decree was introduced a year later, this freezing of tariffs dampened the blow of what could otherwise have been rapidly rising costs for (especially) expensive hospital care. ${ }^{281}$

After the war, control over tariffs remained in place - the mantra for the next decade and a half was austerity, with the immediate post-war period described as "the years of discipline and ascesis". ${ }^{282}$ In large part, this had to do with post-war financial conservatism, aimed at reconstructing a country which had been battered and looted in the war years. In order to stimulate growth and regain an internationally competitive position, the Roman-Red coalitions of the 1940s and '50s took a far more directive approach in nursing the Dutch economy back to health. Alongside the Ministry of Restoration's power to grant permits for building or expansion - as we have seen in the discussion of hospital planning - the most significant measure in this regard for the general economy was 'guided wage politics', through which the government artificially kept wages low until the end of the 1950s, in consensus with the employer and

\footnotetext{
278 Van Zanden, The Economic History of the Netherlands, 114.

${ }^{279}$ Ibid., 117. See Van Kersbergen, Social Capitalism, 90.

280 Bijlagen II, 1938/39, 271, no. 2-3, p. 3.

${ }^{281}$ K.P. Companje et al, Vijftig jaar kostenbeheersing in de zorg. Deel I: 1966-1995 (Den Haag: Sdu 2018) 18.

282 J.C.H. Blom, 'Jaren van tucht en ascese. Enige beschouwingen over de stemming in herrijzend Nederland (1945-1950)', BMGN - Low Countries Historical Review 962 (1981) 300-333.
} 
employee-based Labor Foundation. ${ }^{283}$ Added to this was the financial support from the Marshall Plan, which greatly spurred on the initial reconstructive boost and fostered the integration of international (European) trade. ${ }^{284}$ And soon enough, the austerity imposed by the Roman-Red coalition began to bear fruit: between 1949 and 1973, the growth rate of the economy rose to an average of $5 \%$ per year, whereas unemployment dropped below $2 \%$ and Dutch exports and industrialization boomed. ${ }^{285}$ However, this had a paradoxical effect: the economy took off so rapidly that after restoration, sensitivity to expanding costs and the need to control them virtually disappeared from sight. ${ }^{286}$ In 1959 the Roman-Red coalition was ousted in favor of a center-right cabinet of Confessionals and Liberals, parties which would (in varying combinations) reign until the Social-Democrats again entered government in $1973 .{ }^{287}$ Strikingly, much of the rapid expansion of the Dutch welfare state can be attributed to these parties, who before that time had always preached state non-intervention. In rapid order, legislation aimed at expanding social provisions was instituted under the Liberal-Confessional axis of the 1960s. The General Act on Old Age of 1957 (state pensions) was a Social-Democratic product, but the 1960s saw the birth of expensive provisions such as the 1963 Act on Child Support, the 1967 Act on Work Disability, and the aforementioned General Act on Financial Assistance of 1965. As a result, government expenditures as percentage of GDP went from 29\% in 1950, to 35\% in 1960, and $45 \%$ in 1970 . Expenditures in social provisions doubled from $10 \%$ to $20 \%$ of GDP between 1950 and $1970 .{ }^{288}$ Under the clear blue sky of unprecedented growth, the 'trees grew to the heavens', as a contemporary phrase had it.

\section{Developments on the Curative Front}

Where medicine was concerned, the trees also grew to the heavens in the post-war period. "[...] for some three decades after 1945, if measured by the hopes expressed by the public, the media, governments, and the commercial and industrial sectors, Western medicine enjoyed a wide and unprecedented faith in its power to deliver health to the developed nations and perhaps the world as a whole. ${ }^{\prime 289}$ Contrary to the half century before - in which belief in medical progress was hardly ever matched by practical results - there were now good reasons for such faith. The

\footnotetext{
283 Prak and Van Zanden, Nederland en het poldermodel, 248-249.

284 Van Zanden, The Economic History of the Netherlands, 128-130.

285 Ibid., 134-135.

286 Prak and Van Zanden, Poldermodel, 250-253.

287 Only the short-lived Cals-cabinet of 1965-66 featured the Labor Party in this period.

${ }^{288} \mathrm{H}$. De Liagre Böhl, 'Consensus en polarisatie. De kwaliteit van de democratie 1945-2000', in: R. Aerts et al, Land van kleine gebaren, 283-349, 302, 311; De Rooy, Republiek, 205.

289 Lawrence, 'Continuity in crisis', 389-390.
} 
two post-war decades alone saw the discovery and development of radical new techniques and pharmaceuticals such as penicillin, corticosteroids (anti-inflammatory), streptomycin (effective against tuberculosis), assisted respiration in intensive care, open heart surgery, and kidney and hip replacement. ${ }^{290}$ Most of the new discoveries were to be found in the curative sphere, with penicillin setting the scene as an absolute miracle drug. And, much as in the pre-war period, these curative developments rapidly found their way to the hospital. In 1951, Chief Inspector Banning proposed a list of the facilities a 'modern' hospital should have as a bare minimum. Among these should be an operating room, a laboratory, an X-ray facility, a gynecological room with maternity ward, a room for nursing children, an outpatient facility and a morgue. Biomedical personnel should include a chief physician, a surgeon and an internist, as well as a visiting pediatrician, radiographer, gynecologist, ENT doctor, ophthalmologist, dermatologist, pathologist, and a laboratory technician. ${ }^{291}$ It was clear that medicine had progressed vastly from the 'family doctor' of the late $19^{\text {th }}$ century, when the Dutch Medical Association had for the first time started counting medical specialists.

Laudable as these developments were, they soon began to attract attention for the costs they brought with them. In 1953, for the first time a committee was assigned the task to produce a general overview of the cost of health care in The Netherlands, including the relative share paid by each level of government and by private citizens. This overview took as a primary criterion those forms of care "in which a doctor decides on action", while it also included few hygienic expenses, as well as the costs of medical training, administration, and those incurred in case of employee absenteeism through illness. Under these criteria, the total expenditure on health care in 1953 amounted to $f,-820$ million (later adjusted to 797 million): a total of 3,3\% of gross domestic income and 3,8\% of total government expenditure. ${ }^{292}$ Under less turbulent medical auspices or without the important role government had come to play in health care after the war, such expenses might have been deemed acceptable. However, the periodical monitoring of costs by Statistics Netherlands from this year onwards showed the unmistakable development of table 2.8:

\section{Table 2.8 Health care expenditures in guilders (f,-), 1953-1968}

\footnotetext{
290 See J. Le Fanu, The Rise and Fall of Modern Medicine (New York: Basic Books: revised edition 2012), for the 'twelve definitive moments' of medicine between 1941 and 1984; also A. Hardy and E.M. Tansey, 'Medical enterprise and global response, 1945-2000', in: Bynum et al, Western Medical Tradition, 405-533, 405-406, 470-476, 487-494.

291 National Archives, inventory 2.27.15, no. 55, (Stukken betreffende het adviseren aan de minister inzake een ontwerp van wet tot regeling van het ziekenhuiswezen), 'Brief van C. Banning aan Brutel de la Rivière, d.d. 27-11-1951'.

${ }^{292}$ Centraal Bureau voor de Statistiek, Kosten en financiering van de gezondheidszorg in Nederland in 1953 (Zeist: Uitgeversmaatschappij W. de Haan N.V. 1957) 7, 17.
} 


\begin{tabular}{|c|c|c|c|c|}
\hline Year & 1953 & 1958 & 1963 & $1968^{293}$ \\
\hline $\begin{array}{l}\text { Guilders x } \\
\text { million }\end{array}$ & 797 & 1.358 & 2.226 & 4.937 \\
\hline As \% of GDI & 3,3 & 3,9 & 4,5 & 5,4 \\
\hline $\begin{array}{l}\text { As \% of total } \\
\text { government } \\
\text { spending }\end{array}$ & 3,8 & 4,2 & 4,9 & - \\
\hline
\end{tabular}

Source: Centraal Bureau voor de Statistiek, Kosten en financiering van de gezondheidszorg in Nederland (Series 1953, 1958, 1963, 1968)

This growth was attributed to three factors: the growth of the population, the rise of wages and prices - the most important aspect - and the expansion of the volume of health care goods and services. For instance, the population grew by $11 \%$ between 1953 and 1968. However, the total costs for health care increased more than six-fold. ${ }^{294}$ And though prosperity levels were rising rapidly, this rise did not run parallel to the increase of health care cost as percentage of gross domestic income. But in the context of the booming economy, such growth was not yet perceived as a cause for alarm. Despite some attention paid to rising health care costs, the way the economy developed in the ' 50 s and ' 60 s did not yet lead to health care policy aimed at curbing expenditures which were increasingly becoming a financial time-bomb.

\section{Hospital Planning: Still an Elusive Matter}

This can in particular be seen in the domain of hospitals. For most of the 1950s, the government managed to prevent a rapid increase in health care cost by curbing hospital expenditures through the aforementioned freezing of prices (which also affected salaries, especially for nursing). The argument for keeping hospital costs low was that with the Sickness Funds Decree in place, social provisions should be kept in check and not grow faster than the general cost of living. Moreover, hospital expansion or the building of new locations was still tied to Ministerial permission on the basis of the Reconstruction Act - that is, to the Minister of Economic, not of Social Affairs, as we have seen in the discussion of hospital planning. This distinction is important, as it meant that the government exercised quite some influence in the hospital field in the period 1945-1960, that is, within the broader context of necessary reconstruction. However, resistance to general governmental planning remained strong as ever and even

\footnotetext{
293 Excluding costs created by the Act on Exceptional Medical Expenses introduced in that year. These amounted to another 374 million guilders.

294 CBS, Kosten gezondheidszorg 1968, 30-31.
} 
increased, as tight control over tariffs and expansion meant that privately-run hospitals increasingly had to use their own capital to keep going - an increase in tariffs would have obviously softened this problem, but was expressly forbidden. As a result, capital reserves dwindled rapidly, leading to limited new investment and causing the Dutch hospital landscape to become seriously antiquated by the early 1960 s. $^{295}$

However, by that time the financial reins were loosened to a significant extent. With the return to power of the Liberal and Confessional parties and with the economy in full swing, the 1960s saw a liberalisation of the hospital field. ${ }^{296}$ From the early 1960 s onwards, permission for building new hospitals was granted much more easily, and in 1965 the Restoration Act was mostly rescinded. This led to rapid expansion, illustrated by an upsurge in hospital beds. Between 1945 and 1960, the number of beds had grown from about 36,000 to 58,000. However, rather than installing beds in newly built rooms, much of this expansion was achieved through more intensive use of existing space and temporary barracks, with at most 5,000 beds being put in new buildings. However, with the loosening of governmental regulation, between 1960 and 1970, some 20.000 new beds were added in newly constructed hospitals. ${ }^{297}$ Here, the failure of the attempts at hospital legislation manifested itself. Under reconstruction, both price controls and building limitations had nipped potential cost explosions in the bud. Now, liberalization went hand in hand with a complete lack of planning or even distribution. As a result, hospitals were built haphazardly, and after the lean post-war years, many were happy to see a thriving hospital and health care scene. However, instead of rate of 4,75 hospital beds per 1,000 inhabitants that was broadly considered tenable, by 1970 this had amounted to 5,4 per 1,000. ${ }^{298}$ And although the government tried to control tariffs for a somewhat longer period, liberalization here also took place from the late 1950s onwards. In 1961, the Act on Price Inflation and Hoarding was scrapped, and in 1962 an organ consisting mostly of representatives from the field of health care was instituted to discuss the prices of nursing (Centraal Orgaan

Ziekenhuistarieven). ${ }^{299}$ Three years later, the government would again gain some more say in this

\footnotetext{
295 Juffermans, Staat en gezondheidszorg, 176-183.

${ }^{296}$ During the De Quay-cabinet of 1959-63, the economy reached a record growth of $9 \%$. Moreover, in 1959 a large supply of natural gas was found in Groningen (Slochteren). Under this cabinet, general guided-wage politics were abandoned, while the General Act on Financial Assistance was passed in parliament. https://www.parlement.com/id/vh8Inhronvwe/kabinet de quay 1959 1963, accessed on 26-22019.

297 Juffermans, Staat en gezondheidszorg, 170-172, 221-223.

${ }^{298}$ Ibid., 223.

299 For a history of this, see: $\mathrm{H}$. Festen, 'De geschiedenis van het ontstaan van het Centraal Orgaan Ziekenhuistarieven', in: L.J. de Wolff (ed.), De Prijs voor Gezondheid. Het Centraal Orgaan

Ziekenhuistarieven (Baarn: Ambo 1984) 13-45, specifically p. 30-45.
} 
matter with the Act on Hospital Tariffs, discussed in the next chapter. ${ }^{300}$ However, as these figures on the various costs of sickness fund enrolment show, this was to little avail:

${ }^{300}$ Ibid., 223-227; K.-P. Companje et al, Vijftig jaar kostenbeheersing, 19-20. 
Table 2.9 Average expenditure in millions of guilders $(f,-)$ per mandatory enrollee at sickness funds, 1959-1967 301

\begin{tabular}{|l|l|l|l|l|l|l|}
\hline Year & $\mathbf{1 9 5 9}$ & $\mathbf{1 9 6 1}$ & $\mathbf{1 9 6 3}$ & $\mathbf{1 9 6 5}$ & $\mathbf{1 9 6 7}$ & $\begin{array}{l}\text { Growth } \\
\mathbf{1 9 5 9} \\
\mathbf{1 9 6 7}\end{array}$ \\
\hline GP care & 10,31 & 12,30 & 14,22 & 17,48 & 24,11 & $233 \%$ \\
\hline Specialist care & $\mathbf{1 2 , 4 8}$ & $\mathbf{1 4 , 4 8}$ & $\mathbf{1 8 , 1 6}$ & $\mathbf{2 3 , 4 0}$ & $\mathbf{3 0 , 2 7}$ & $\mathbf{2 4 3 \%}$ \\
\hline Dental care & 4,94 & 5,79 & 6,60 & 8,88 & 11,65 & $235 \%$ \\
\hline Hospital care & $\mathbf{2 6 , 1 5}$ & $\mathbf{3 0 , 3 2}$ & $\mathbf{4 0 , 6 2}$ & $\mathbf{6 3 , 0 1}$ & $\mathbf{9 2 , 4 7}$ & $\mathbf{3 5 4 \%}$ \\
\hline $\begin{array}{l}\text { Medicines and } \\
\text { bandaging }\end{array}$ & 11,13 & 13,71 & 17,79 & 24,81 & 33,12 & $298 \%$ \\
\hline Total & $\mathbf{7 7 , 7 4}$ & $\mathbf{9 0 , 4 6}$ & $\mathbf{1 1 4 , 4 1}$ & $\mathbf{1 6 0 , 1 5}$ & $\mathbf{2 2 4 , 3 3}$ & $\mathbf{2 8 9} \%$ \\
\hline
\end{tabular}

Table 2.9 shows how the new wonders of medicine manifested themselves mostly in the hospital as the 'temple' of medicine - expenditures here grew far more rapid than in other areas of medicine. But the development set in motion in the pre-war period continued, as the number of medical specialists grew and performed their complex procedures in a wide new range of disciplines. That these expensive medical specialists were increasingly present as providers of health care (covered in part under the Sickness Funds Decree) is shown by their rapid increase in numbers, especially compared to general practitioners. This is shown in table 2.10:

\footnotetext{
${ }^{301}$ National Archives, inventory 2.21.218, no. 171, Ziekenfondsraad, Cijfers Secretariaat Ziekenfondsraad. See also: Ziekenfondsraad, Studiecommissie Ziekenfondsverzekering, Werkgroep Onderzoek Kostenstijging, Resultaten van een onderzoek naar de oorzaken van de kostenstijging bij de verplichte ziekenfondsverzekering in de periode 1948-1960 (Amsterdam 1964); Stichting Nationaal Ziekenhuisinstituut, Ontwikkeling van de ziekenhuiskosten 1953-1968 ('s-Gravenhage 1969).
} 
Table 2.10 Doctors in The Netherlands, 1942-1960

\begin{tabular}{|l|l|l|l|l|l|}
\hline Year & $\mathbf{1 9 4 2}$ & $\mathbf{1 9 4 8}$ & $\mathbf{1 9 5 3}$ & $\mathbf{1 9 5 8}$ & $\mathbf{1 9 6 0}$ \\
\hline $\begin{array}{l}\text { General } \\
\text { practitioners }\end{array}$ & Ca. 3200 & Ca. 3300 & 3630 & 4320 & 4405 \\
Specialists & 689 & 1720 & 2710 & 3590 & 3910 \\
\hline
\end{tabular}

Source: Kamerstukken II, 1961-1962, 6808 no. 3, p. 18

These numbers become even more impressive when we consider their growth in proportion to the population. In 1900, there was one medical doctor for every 2,540 inhabitants. By 1920, this had risen to one doctor per 1,950, to one per 1,240 in 1940 and to one per 901 inhabitants in $1960 .{ }^{302}$ All of this meant that, by the 1960s, the growth of sickness fund expenditures and the general medical field, as well as the rise of general health care costs were beginning to take on serious proportions. By 1966, the first cautious call for tying the organization and the financing of health care together was presented with the Health Report. When in 1968 the government took financial responsibility for chronic illness and disability with the Act on Extraordinary Medical Expenses, the state's involvement in health care expenditures grew even larger. At long last, this necessitated serious interventions by the state in order to gain more control over health care. In this way, serious attempts were finally made to replace the old governmentality, steeped in Liberal and confessional (political) philosophies of state abstinence, with one in which the state took a far more active role in coordinating and influencing the provision of health care to its citizens. However, this new governmentality would not be long-lasting, and would in effect only be dominant in health care politics and policy-making between the late 1960s and 1987. We turn to that period in the next part.

\section{Conclusion}

In a sense, the 1941 Sickness Funds Decree seemed to have created a real break with the governmentality of private initiative with growing public backing increasingly becoming a reality after 1912. The Decree, introduced by the German occupier after 40 years of political lethargy, finally created a mandatory insurance scheme for a significant part of the population. Moreover, with this Decree, sickness funds were brought into the fold of governmental oversight, as they effectively became private administrators of a public social provision - seemingly a revolutionary

302 Kamerstukken II, 1961-1962, 6808 no. 3, p. 18. 
development. But by the time liberation came around, this increased access to health care accorded well with how such access had been growing as a result of private and public initiative in the first decades of the $20^{\text {th }}$ century, when sickness funds, Cross Associations, and municipal governments took it upon themselves to offer various health care services under increasingly social goals. Too narrow a focus on the way in which the Sickness Funds Decree impacted the governance of health care in The Netherlands obscures the fact that where the mentality concerning the role of the state in health care was concerned, the two decades after the war show a remarkable degree of continuity with the preceding period. In a sense, where growth in sickness fund enrollment was concerned, the biggest strides were made in the uniformization of the package now offered - and determined by the government.

However, we saw that before the war a remarkably high percentage of the population had already obtained a form of health insurance without any government backing. These numbers undoubtedly went up, and the introduction of government in the provision of social health insurance was an absolute novelty. But where the dominant governmentality was concerned, much remained the same. In part this was intentional, as with the retention of the private status of sickness funds and the creation of the Sickness Fund Council in 1949. But for a larger part it had to do with the entrenched positions and ideologies concerning the desired amount of centralized control in The Netherlands. By the middle of the 1950s, as the quote opening this chapter showed, the private and public local parties which had already made headway in expanding health care provisions in the first four decades of the $20^{\text {th }}$ century had contrived to create a vast but uncoordinated patchwork of health care provisions. In this sense, Thorbecke's century-old vision had turned into a reality in health care (though of course Thorbecke himself could not have foreseen the flight medicine would take in the twentieth century). Outside of sickness fund provisions, health care mostly remained a 'free for all', and in the post-war decades any attempts at gaining control over the organization or to implement strict 'governance' arrangements for the field proved futile. Nevertheless, the development set in in the first half of the twentieth century continued unabated: despite surface level rhetoric on state non-interventionism in these areas, public subsidizing and stimulation of nominally private health services only grew after the war. But both politicians and representatives of 'private initiative' deemed this a desirable situation, as long as private control and administration of these services remained firmly in place.

That such a situation was still deemed broadly desirable is illustrated by what could have been a legislative triumph: the 1956 Health Act. But in the fragmented Dutch political and ideological landscape - to which The Netherlands returned immediately after the war - the Health Act was typical of the notion that a compromise is something in which no one really gets what they want. As a result, private initiatives - including costly hospitals - could continue to grow relatively unfettered, but government would not back such services through an official 
financing arrangement. And yet the legislation now in place to guarantee access to a wide set of uncoordinated health care provisions mostly suited the new political constellation of SocialDemocrats and Catholics who ran the country for nearly fifteen years after the war had ended. New thinking about increased involvement of the state with the social well-being of its citizens had taken root across the Atlantic, in anti-totalitarian political philosophies most adequately expressed in the British report on social security by William Beveridge - the core ideology of which was taken home to The Netherlands in the Van Rhijn-report published shortly after the war. But although the plans proposed by the Van Rhijn-report were never fully implemented, the way in which things such as the Sickness Funds Decree and increasing governmental subsidies to health care extended access to health care ever further fit this ideology well. However, all these developments continued to take place under the pervasive rhetoric of 'private initiative'. In the two post-war decades, the resultant health care 'patchwork' did not yet give cause for real alarm. Instead, it allowed many parties to uphold the rhetoric of (pillarized) autonomy against the increasing reality of government intervention. For now, such intervention still took the form of financial support - uncoordinated as it was, for lack of legislation. It would take the boom of the economy of the late 1950s and '60s to push the new social philosophy of the welfare state to its limits in The Netherlands, as well as to force the government - when the economic downturn came - to finally take the reins in coordinating health care. We will now turn to the era of 'planning' in health care, a period in which attempts were made to break away from the old philosophy concerning the governance of health care. 



\section{Part III: Blueprint Governmentality, 1968-1987}

In which the social ideology of access to health care is taken up by the state, but a new governmentality of state 'planning' in health care fails 


\section{Introduction}

"The organization of health care, given the limits of the means currently at our disposal in The Netherlands, has not developed proportionate to the flourishing of either social development or scientific progress. This means that the efficacy of health care for both the ill and healthy is such, that it becomes practically impossible for the average Dutch citizen to meet his responsibilities towards safeguarding the health of himself and those in his care." ${ }^{1}$

When the words above were uttered, in 1967, Dutch health care was on the verge of a major development: the introduction of mandatory health insurance for 'high' health risks, or the types of chronic conditions (disabilities, handicaps, and later also care in a home for the elderly) private individuals would never be able to insure themselves against on a private health insurance market because of the inevitable costs they would bring with them. The major change compared to the way sickness funds had by now been providing curative care for over 25 years, was that government directly backed this new type of insurance. Every Dutch citizen would from now on, through a universal income premium, be included in this scheme for 'Exceptional Medical Expenses'. In that way, some of the critique uttered by the speaker above was about to be met: the government would now take an important responsibility for the health of every citizen, creating, for the first time, a national insurance for (long-term) care. Moreover, this time around such an insurance was not an imposition by an occupier: instead, it came from a staunch representative of the Dutch political landscape in the 1960s: Catholic Minister of Social Affairs Gerard Veldkamp.

The ethos of the speaker cited above was very telling. These words were spoken by Piet Muntendam, whom we have already encountered in the previous chapter as one of the architects of the 1956 Health Act. Though Muntendam, as a Social-Democratic State Secretary, had wanted the Health Act to be more state-centered, we have seen that the version that ultimately made it through Parliament was virtually toothless, with neither proponents of bigger

\footnotetext{
1 P. Muntendam, 'Samenvatting en slotwoord', in: Nederlands Congres voor Openbare Gezondheidsregeling, Doelmatigheid van de organisatie van de zorg voor de volksgezondheid. Congres 1967 (Amsterdam: reprint of Tijdschrift voor Sociale Geneeskunde 45; 2 (1968), p. 30. In original: "De organisatie van de gezondheidszorg binnen de grenzen van de middelen, die ons in Nederland momenteel ter beschikking staan, heeft zich niet zodanig ontwikkeld, dat zij aangepast is aan de maatschappelijke ontplooiing en wetenschappelijke ontwikkeling. Dit betekent dat de doelmatigheid van de gezondheidszorg voor zieken en gezonden zodanig is, dat de Nederlander in zijn verantwoordelijkheid voor de gezondheid van zichzelf en de zijnen wel tekort moet schieten."
} 
government nor those extolling the autonomy of private initiative in health care getting what they wanted. The Act left various parties unsatisfied, but at the same time unwilling to more fundamentally shake up the way health care was organized. Little had changed in the 'patchwork' of Dutch health care provisions and the government's control over it. As a result, though Muntendam in 1967 still mentioned the 'personal responsibility' of individuals for their own health care and that of their family and loved ones, he also tied their failure to do so to the haphazard organization of health care services which had grown 'organically' over the better part of the preceding century. This had clearly been in line with the governmentality set out by Thorbecke in the $19^{\text {th }}$ century, but by now, the lack of coordination was seen as a fundamental obstacle to citizens' responsibility for taking care of their own health.

Significantly, however, by 1967 Social-Democrats such as Muntendam were no longer alone in critiquing the limitations of a system that had grown organically. Contrary to the postwar decades, by the time the former State Secretary spoke, the welfare ideology set out by Beveridge and Van Rhijn had become more politically mainstream. It was especially the Catholics who would expand the welfare state in the 1960s, embracing a larger role for the state in matters such as health care. And the effects of these changes would be profound. In the period between 1968 and 1986, the seemingly biggest and most visible expansion of 'government' in health care took place. First, access to health care was legally codified further. In 1965, the Sickness Funds Decree was turned into the Sickness Fund Act, signaling the Dutch government's willingness to consolidate a system which offered a large part of the population access to curative care. And in 1968, the government took responsibility for the abovementioned 'exceptional medical expenses'. But in 1974, when the realization came that the prevailing methods for organizing and financing health care made controlling costs virtually impossible, the government also set out on a course of top-down 'planning' in an attempt to get a grip on a system spinning out of control fast. In this way, the 1970s through the mid-1980s must be understood as a period in which a new governmentality for health care was pursued, creating for the first time a true caesura in both governance and the mentality concerning power and control in health care since Thorbecke laid the foundation for the 'organic' development of society.

However, this was very much a governmentality of power born of necessity: after a century of uncoordinated growth of health care arrangements and an increasing financial involvement of the collective in facilitating access to these arrangements, the state now had to take action to keep the system viable in the long run. But it was precisely the failure of this policy and governmentality of 'planning' which by the middle of the 1980 s already brought to the fore the resilience of the long-standing culture of autonomy in both Dutch health care institutions and among the general public. Legislative attempts undertaken in this period to give central government control over health care petered out or stayed on the books for decades 
without being put into practice; field parties which had been used to their autonomy for decades protested against increasing governmental bureaucracy; and in an era of growing critique on the undemocratic character of institutions (such as those in health care), citizenpatients increasingly clamored for a smaller role for government in the welfare state, while at the same time desiring a bigger role as autonomous 'health care consumers'.

This illustrates Foucault's point that 'governmentality' is a far more useful concept than 'government' to understand the exercise of power in a context as complex as that of health care: despite new national legislation giving the state a bigger interest, and more influence, in health care in the post-war decades, various forces were tugging at the newly founded welfare state and health care provisions from the 1970s onwards. If anything, policymakers at Ministries had to act humbly in order to get things done in terms of cost and quality control, strongly downplaying the idea that 'government' means 'strong' or 'effective' government. At the same time, it seemed that historically grown forms of solidarity were by this time supported by the public at large, allowing the central government to codify this solidarity through national legislation. The question was no longer whether the government was an invited guest at the health care party, but how it should behave. By the middle of the 1980s, when the loud vocabulary of 'planning' was traded in for the subtle etiquette of 'incremental changes', the rhetoric of small government in health care returned. The reality of extensive government backing and regulating of ever-growing access to health care, however, only grew. These seeming opposites would return in the 'market blueprint' of 1987, the subject of the next chapter. But let us first see how the government got such a big role to play in health care in the 1960s.

\section{The Unexpected Embrace of the Welfare Ideology}

To understand how government got to be involved in health care to such a large extent in the 1970s and '80s, we must take a step back in time and discuss the general backdrop for the growing involvement of the state in social matters in the decades before that. In the previous part, it was shown how access to health care grew in the two post-war decades without an overt government presence. However, with the acceptance of the ideology of the welfare state and the notion that the state bore responsibility for citizens' social security in the 1960s, (central) government would increasingly play a larger role in financing and organizing welfare provisions. This would ultimately lead to government taking more control over such provisions - and among those also health care provisions. The first real step in embracing the notion that the state had to step in to provide social security to vulnerable members of society had been the 1947 Emergency Act on Old-Age Relief (Noodwet Ouderdomsvoorziening), a temporary 
measure to create a state pension, given permanence in 1957. In health care, this was matched by the creation of a scheme for sickness fund insurance for the elderly. ${ }^{2}$ This legislation elevated its face, Social-Democratic Prime Minister Willem Drees, to star status ('Father Drees'.) But it would also for fifteen years be the swan song of Social-Democratic participation in government. After the post-war marriage with the Catholic party came to an end in 1958, the Social-

Democrats would not return to power until 1973 (excepting a role in the short-lived Cals cabinet of 1965/66). This was hardly for lack of ideas or ideological fervor. Instead, after thirteen years of Roman-Red consensus politics, what bothered the Social-Democrats was precisely a lack of political action. Restoring the nation had been a necessary and laudable goal in the post-war decade, but with the economy gaining real momentum again, the Labor Party increasingly criticized the fact that the new wealth did not trickle down to the less well-off through expanded social provisions. By the time of the 1956 elections, they argued that "[...] in previous years, the desire to restore pre-war relations has continuously grown stronger. The initial desire for reform has not proven resistant to the lure of economic growth. Despite an abundance of progressive, social desires, a turn has been made towards restoring old property and income relations." 3

But also the return of pre-war cultural relations irritated the Social-Democrats. What was needed was a middle-ground politics striving for " [...] a new society, a true community, which trumps 'pillarization' in the realization of shared responsibility." 4 This was partly a response to the Catholics, who in 1954 had increased the differences of opinion with their coalition partner through a publication by the Dutch bishops. This publication had emphasized precisely the necessity of Catholic unity and the strengthening of the Catholic pillar: although voting Labor could hardly be forbidden, the bishops decreed that it was 'irresponsible'. Besides this, it forbade true Catholics to read socialist newspapers or to take part in Social-Democratic organizations. ${ }^{5}$ With this Catholic attack on their then coalition partner, religious-ideological identity was again made into a core element of Dutch politics and societal life - much as it had been in the pre-war decades. The Catholics had good reason to believe that strict pillarization would work in their favor: between 1920 and 1960, the percentage of the population which was actively Catholic had risen to nearly $40 \%{ }^{6}$ The importance of religion would not be long-lasting, however: by the middle of the 1960s secularization began to set in, and by the late 1960 s, the pillarized order was irreversibly on the way out. ${ }^{7}$

\footnotetext{
2 K.P. Companje, 'Het Ziekenfondsenbesluit en de gevolgen voor de verzekering van zorg, 1940-1986', in: Companje, Tussen volksverzekering en vrije markt, 477-558, 511.

${ }^{3}$ Partij van de Arbeid, 'Verkiezingsprogram 1956', 2, http://dnpprepo.ub.rug.nl/244/1/Verkiezingsprogram\%20PvdA\%201956.pdf, accessed on 18-3-2019.

${ }^{4}$ Ibid.

5 'Bisschoppelijk Mandement van 1954'.

${ }^{6}$ De Rooy, Republiek, 194-196.

7 Ibid., 216-217, 242; Kennedy, Nieuw Babylon, 106-109.
} 
But when the Social-Democrats left government in 1958, the Catholics were at their zenith in terms of political and societal power, a position they would retain until 1967 . This, as well as the fact that the Social-Democrats were replaced by the Liberals and the Protestant parties as formation partners in the cabinets of the 1960s, makes all the more remarkable the fact that in this period the welfare state came to be expanded so radically. ${ }^{8}$ The pervasive notion of the pre-war era (and after, as we have seen) that a government should let society and cititzens develop primarily on their own terms was now traded in for a far broader understanding of the role of government in furthering the route to 'freedom from want' - and that by precisely those parties which had argued for state non-intervention in the preceding century. This ideological turnabout was facilitated greatly by the very positive economic situation of the 1950s and 60s. But thirteen years of governing together with the Labor Party had also led to a convergence in social goals and rhetoric. Moreover, although the Labor Party was no longer part of the government, it was still a powerful opposition party, winning nearly a third of the votes in the 1959 election. Roman-Red was now traded in for 'Roman versus Red'. But this did not mean that the Catholics reverted to the mostly pre-war stance of staunch subsidiarity. The Catholics, now politically dominant, wanted to show that "[...] progressive policy was possible even without socialists." 9 This position in the coming decade would also be clearly expressed in legislation concerning access to health care.

\section{The Government as Defender of Social Rights}

In the 1960s the Catholics became the flag-bearers for expanding the role of government in protecting the weak and less fortunate in society. Here, they walked the line between the new progressiveness and older Christian notions of self-sufficiency. "The KVP [Catholic People's Party, RB] stands for a Christian-social politics for the benefit of the entire population. It supports man's Christian duty to guard the interests of others, but also [his] own responsibility and autonomy [...]." ${ }^{10}$ This echoed the personalist socialism the Social-Democrats had embraced after the war to seek common ground with the Catholics as a coalition partner. It also found expression in the ideas of the Catholic policy-makers most directly responsible for expanding

\footnotetext{
${ }^{8}$ The 1959 elections saw the Catholics enter government with 49 seats in the Second Chamber, the Liberals with 19, and the Anti-Revolutionary Party and the Christian-Historical Union with a combined 26. Little changed with the 1963 elections, and the Marijnen-cabinet of 1963-1965 was a continuation of the previous cabinet. https://www.parlement.com/id/vh8Inhronvwe/kabinet de quay 1959 1963; https://www.parlement.com/id/vh8Inhronvwd/kabinet marijnen_1963_1965, both accessed on 19-3-2019. ${ }^{9}$ De Rooy, Republiek, 205.

10 KVP, Manifest 1959 (election programme KVP 1959), accessed via http://dnpprepo.ub.rug.nl/239/ on 0702-2020.
} 
the welfare state: Marga Klompé (the first ever female Dutch minister, heading the Ministry of Social Work) and Gerard Veldkamp, Minister of Social Affairs and Health for most of the 1960s. As noted in the previous chapter, in 1963 the General Act on Financial Assistance (Algemene Bijstandswet) was accepted in Parliament as a joint effort by these Ministers. After the creation of pensions for the elderly, now support for the destitute was for the first time taken up by the central government. This act serves as a good illustration of the meaning of the acceptance of the welfare ideology envisioned by Beveridge and Van Rhijn twenty years before - but it also attested to an explicit shift in governmentality where providing relief for the poor was concerned.

This task for the longest time had been the province of local government in the form of municipalities, as we have seen in the previous parts. But changes now set in signified an important shift in both the governance structures and the mentality with regard to the administration of social provisions. Up until 1965, the Poor Law of 1912 (originally: 1854) was still in operation. We have seen in part 2 that the philosophy underlying this act had been that of subsidiarity: local public bodies (municipalities) could only provide support after private (ecclesiastical) options had been exhausted. From this perspective, the Act on Financial Assistance stood for a rather radical shift. On the face of it, the practical arrangements for providing financial care to the poor remained largely the same: local government was tasked with providing assistance after assessing the financial needs of individual citizens. But this was now done with the central government taking financial responsibility for these citizens: municipalities had to offer assistance, but they could henceforth forward the bill to the Ministry of Social Affairs. The subsidiarity principle in matters of financing was therefore given up in the Act. Moreover, age-old notions of poverty and unemployment as reflections of the moral quality of the persons involved were now traded in for a rules-based, formalistic system in which the government had a responsibility for persons who, for whatever reason, could not support themselves. In this way, the logic which had reigned since the first legislation on poor relief of 1854 - assistance as a matter of ecclesiastical grace or municipal goodwill - was traded in for the logic of assistance as a right. ${ }^{11}$ In a crucial sense, old ideas about the administration of poor relief were now fulfilled. As was noted in the first part, Johan Thorbecke had already decried the arbitrary nature of ecclesiastical poor relief. Whether because of moral prejudice towards the poor or because of limited funds, financial assistance would remain haphazard if there was no clearly defined and legally protected equal distribution. And though it would be anachronistic to state that Thorbecke's wish was directly fulfilled, more than a century after the original Poor Law

\footnotetext{
$11 \mathrm{~J}$. Vos, 'De Algemene Bijstandswet: van armenzorg naar een recht op werk en inkomen', in: Berghman et al, Honderd jaar Sociale Zekerheid, 249-264, 250-253; Centraal Bureau voor de Statistiek, Statistiek van de algemene bijstand 1965 en 1966 ('s-Gravenhage: Staatsuitgeverij 1969) 8; Kamerstukken II, 1962/63, 6796, no. 5, p. 1.
} 
was enacted, the problems with the arbitrary distribution of funds were addressed by the way the General Act on Financial Assistance introduced equal and non-arbitrary distribution. The broader significance of this was that it supplied an essential ingredient to the rights-based thinking of the welfare state.

Where health care was concerned, such thinking had by this time been around for two decades, but only to a limited degree. The introduction of the Sickness Funds Decree by a foreign oppressor had put an end to the pre-war discussions about the question whether (a portion of) Dutch citizens had a right to health care, but it had done so by forcing through a mandatory insurance scheme. Significantly, elements so important to the Act on Financial Assistance of 1965 were already present in the 1941 Decree: the mandatory health care package, the sickness fund premiums, and the income limits were set by the government, thus imposing upon the sickness funds a policy of equal distribution. But the post-war acceptance of the Decree was hardly a matter of ideological fervor, as we have seen in the previous part. Van Rhijn's ambitious vision of a government guaranteeing 'freedom from want' had been laid aside within just a few years after being presented, and the reason The Netherlands has been seen as a 'welfare state laggard' was because the 1950s had mostly seen a reversal to the pre-war emphasis on private initiative and citizens taking care of themselves. The Sickness Funds Decree had brought government into the provision of health care to an unprecedented extent, but its staying in place after the war was a result of practical, rather than ideological justifications of the growing role of the government.

\section{A New Discourse on the Right to Health Care}

As time progressed, however, this pragmatic stance began to change. What took place was an important shift in discourse, or the way health care and access to it was conceptualized. In the previous chapter, we already came across the civil servant Goudsmit. Goudsmit was a legal advisor at the Ministry of Social Affairs and Health and member of the Sickness Fund Council. His legal background and positions in the field of health care led him to reflect on the growth of health care legislation in previous decades, and in 1954 he argued at the Congress for Public Health Organization for the creation of a special subdiscipline of health care law. This subdiscipline should be concerned with the study of everything ranging from the sickness fund field to the rules with regard to doctor-patient confidentiality. ${ }^{12}$ Goudsmit did not yet connect strictly procedural matters in governing health care to the more material matter of the right to

\footnotetext{
${ }^{12}$ C.J. Goudsmit, 'Volksgezondheid en Recht', in: C.J. Goudsmit, Volksgezondheid en recht (Ymuiden: Vermande Zonen N.V. 1966; reprint from Tijdschrift voor Sociale Geneeskunde 1954) 7-26.
} 
health care itself. Instead, what 'health care law' should provide was the " [...] creation of preconditions for an effective curative and preventive health care." ${ }^{13}$ Professor of general medicine Henri Julius, Goudsmit's co-speaker at the conference, did in fact reflect on the 'right to health care', but came to a rather negative conclusion: "What we currently experience, is that people no longer feel responsible for their own well-being, because there is the possibility for claiming access to health care provisions (sickness funds, social insurance, accident legislation, etc.). ${ }^{14}$ In order to prevent the general populace from becoming spoiled, legislation pertaining to the furthering of health "[...] must be influenced by a very serious striving towards intrinsic participation on the part of the beneficiaries of a right-to-health." ${ }^{15}$

Such thinking very much fit in with the notions of subsidiarity and autonomy so prevalent in both the political and confessional discourse of the time. But Goudsmit in his lecture made a remark which rather preluded future thinking about a 'right to health care'. "It may well be, that [...] in a certain period or a certain country there is no incentive for creating legal rules, but the development of social relations slowly creates the desirability of new legal rules [...] and the legislator would be remiss if he did not catch up with the times." ${ }^{16}$ When Goudsmit uttered these words, he was referring to a growing new legal consciousness concerning a 'right' to health care. In the first decade and a half after the war, jurists working both within and outside of the broad field of health care increasingly became attuned to the notion that health care was something citizens (in the West) had a fundamental right to. All of this happened in the broader context of the developing notion of certain 'social rights' that governments should facilitate, an important catalyst for which had of course been the Second World War - as we have seen in the previous chapter. In short order, the right to health care was developed and codified in various international treaties and organizations, the most important of which were the World Health Organization (installed in 1948), the Universal Declaration of Human Rights (1948), the Rome Treaty (1950) and, somewhat later, the European Social Charter (1961). ${ }^{17}$

The rapid growth of a human and social rights discourse on the international level did not immediately lead to legislative changes - indeed, the 1948 Declaration of Human Rights was termed "curious" by a professor of Dutch labor law, as its status as a legal document was limited. ${ }^{18}$ And the burgeoning field of 'health care law' Goudsmit had argued for in 1954 was not

${ }^{13}$ Goudsmit, 'Volksgezondheid, 25.

${ }^{14}$ H.W. Julius, 'Het Recht op gezondheid', Tijdschrift voor Sociale Geneeskunde 32; 17 (1954) 340-350, 348.

${ }^{15}$ Julius, 'Recht op gezondheid', 349.

${ }^{16}$ Goudsmit, 'Volksgezondheid', 8.

${ }^{17}$ For this summary, see H.J.J. Leenen, Sociale grondrechten en gezondheidszorg (diss.: Rijksuniversiteit Utrecht 1966) 67-80.

${ }^{18}$ F.J.H.M. van der Ven, 'Sociale grondrechten', Maandschrift Economie 18; 3 (1953) 89-104, 93-94. 
immediately infused with the more ideological notion that access to health care was a human right. This did not mean, however, that a document like the Declaration of Human Rights did not cast a wide shadow: "Legally its import merely seems to "provide an indication of which rights can be said to belong to the "rights of man and the fundamental freedoms" [...] Meanwhile, its political significance appears to have far surpassed its legal significance."19 By the late 1960s, debate was still raging over the exact definition and scope of the subdiscipline of health law ${ }^{20}$ However, a fundamental right to health care was conceptualized systematically for the first time in The Netherlands in the 1966 dissertation of the 'founding father' of health care law in The Netherlands, Henk Leenen. Leenen was secretary-general of the Catholic White-Yellow Cross Association and secretary of the Catholic Doctors' Association, and joined the ensemble of Catholic thinkers with a more progressive stance towards governmental responsibility in providing access to health care. In 1966 he came up with a comprehensive understanding of the 'social right to health care', which nevertheless left room for responsible behavior on the part of both citizen and government:

The right to health care entails entitlement to skilled care which takes into account all relevant aspects of health and which, in scope, is dependent on the possibilities society has; moreover, it includes entitlement to a globally equal provision of care in a given society, care which should be within reach for everyone and the financing of which is guaranteed; it moreover includes the right to a sound structure in which health care can function properly and which fosters the cohesion between the various sectors of health care and their relation to society as a whole, and in which the responsibility of persons, social groups, institutions and organs and the government is expressed $[\ldots] .{ }^{21}$

Still, Leenen noted that whereas the right to health care had been made explicit in international documents, within the Dutch legal order it had grown only implicitly. ${ }^{22}$ And indeed, in writing about this 'implicit growth', Leenen was referring to a recent event which had illustrated that access to health care was by now seen as a fundamental and desirable element of the Dutch legal order by politicians of varying ideological stripes.

\section{Fusing New Ideals to Old Realities}

\footnotetext{
${ }^{19}$ Ibid.

${ }^{20}$ See H.J.J. Leenen, 'Gezondheidsrecht. Een poging tot plaatsbepaling', Tijdschrift voor Sociale Geneeskunde 46 (1968) 778-785, 780-782.

${ }^{21}$ Leenen, Sociale grondrechten en gezondheidszorg, 84.

22 Ibid., 83.
} 
In 1962, a new proposal was put forward to replace the Sickness Funds Decree - the last in a long line of proposals put forth after the war, none of which were successful. In part 2, we saw that Prime Minister Drees put off the revision of the 'German' decree to a later moment, only to stall this development with the creation of the Sickness Fund Council in 1949. In 1951, Minister of Social Affairs Joekes wanted to replace the Sickness Funds Decree with a 'Dutch' law, but his proposal stranded before it could arrive on the parliamentary floor because of a lack of support from the advisory Social and Economic Council. But in 1959, various problems facing the funds led to two reports by the Sickness Fund Council and a report by the Social and Economic Council in 1961, with all of these reports focusing on fragmentation and the rising costs resulting from the mandatory sickness fund scheme. ${ }^{23}$ This revitalized the legislative process, and the task of replacing the Sickness Funds Decree fell to the Catholic Gerard Veldkamp, who would serve as Minister of Social Affairs and Health from 1961 to 1967.

Veldkamp takes up an important place in the context of Dutch health care legislation. Not only has he been described as a 'legislative Hercules', but his prolific output both as a politician and a publicist makes it possible to reconstruct his role as a Catholic politician who espoused a more inclusive understanding of the responsibilities for the government in social affairs. ${ }^{24}$ Such thinking undoubtedly already began with his 1949 dissertation, in which he proved himself critical of an over-reliance on the principle of subsidiarity and "do-it-yourself" in the administration of the social workers' insurance. ${ }^{25}$ But Veldkamp's dissertation was merely the beginning of his partaking in the Catholics' revaluation of old notions of the relation between state, individual, and society. In the mid-1950s, he co-authored what would turn out to be a sixvolume Catholic philosophical-sociological exploration of 'human society', which broadly argued for the indissoluble link between the individual aspiring after physical, mental, and spiritual selfdevelopment within the community in which he found himself. Compared to the ideas that were dominant before the war, greater emphasis was now laid on the shared responsibility of individual and society. In the 1956 volume, attention was paid to health care. It is worth noting that already then - in the same year that changes to the Health Act proposed by Catholic MP

\footnotetext{
${ }^{23}$ Kamerstukken II, 1961/62, 6808, no. 3, p. 11-12.

${ }^{24}$ For 'legislative Hercules', see: A.H.M. Kerkhoff and W.P.M. Dols, 'De Algemene Wet Bijzondere Ziektekosten. Debatten en ontwikkelingen tot 1987', in: Companje, Tussen volksverzekering en vrije markt, 709-794, 723.

${ }^{25}$ Veldkamp called this the principle of 'het zelf doen'. G.M.J. Veldkamp, Individualistische karaktertrekken in de Nederlandse sociale arbeidsverzekering: een critisch onderzoek naar de grondslagen der sociale arbeidsverzekering (diss. Universiteit Tilburg 1949), 299-300. Noteworthy is the fact that Veldkamp's dissertation supervisor was Franciscus van der Ven, who we encountered above, commenting on social human rights. Van der Ven also supervised Veldkamp's State Secretary Louis Bartels, which undoubtedly shaped their combined thinking when preparing the Health Care Report 1966 and the Exceptional Medical Expenses Act, discussed below.
} 
Chris Mol effectively made government toothless in health care - Veldkamp and his co-author noted that such new ideas also had serious implications for the role of the state:

Meanwhile, man does not only have the duty to look after his own health. Even though that is his first responsibility, at the same time he carries a responsibility for the health of others. [...] After all, everyone has a duty of solidarity to contribute to the furthering of the health of others. A system of mandatory insurance can be based in part on this duty. ${ }^{26}$

Moreover, the authors paid attention to the budding 'right to health care'. This right should not be seen as one giving citizens specific, enforceable claims to health care. Instead, the government should create the conditions under which the health of individuals would best be served. But these 'conditions' were interpreted fairly broadly in the following paragraph: they should include the governmental ordering of health care; sickness fund insurance; subsidizing private initiative; the building of hospitals; social-medical research and the furthering of preventive medicine. ${ }^{27}$

Such a broad understanding of the role of government in health care, as well as a new interpretation of the responsibility of state and citizens were formative for Veldkamp. In 1963 he shared these ideas with young Catholic students with these ideas at a conference, now in his capacity as Minister of Social Affairs and Health:

I readily agree that the need for social insurance must not mean an evasion of all risk. Such a process would diminish the willingness to carry any risk. And yet, I am also of the opinion that it is an exaggeration to say that the striving for social security would undermine every form of responsibility. [...] Personal responsibility means social responsibility, and so the responsibility for the risks that can befall others! ${ }^{28}$

This thinking carried over into his work in legislating health insurance. The first step here was the 1962 proposal to replace the Sickness Funds Decree. Veldkamp had been playing with the idea of proposing near-universal health insurance, but had had to put that idea aside in the face of expected criticism and the overhaul of the system it would entail. ${ }^{29}$ What was needed twenty years after '1941' was simply the "replacement of occupational law still in force". ${ }^{30}$ At the same time, however, Veldkamp almost in passing noted a very important development in the perception of the citizenry concerning health care: "[Mandatory sickness fund] insurance has

\footnotetext{
${ }^{26}$ J. Ponsioen and G.M.J. Veldkamp, De menselijke samenleving. Volume II. Vraagstukken der hedendaagse samenleving (Bussum: Paul Brand N.V. 1956) 357-358.

${ }^{27}$ Ibid., 358-359.

${ }^{28}$ G.M.J. Veldkamp, 'Openingsrede', De welvaartsstaat. Verslag van het congres gehouden op 22 en 23 april 1963 ter gelegenheid van het XIIle Lustrum van de Katholieke Studentenvereniging Sanctus Virgilius (n.p. 1963) 12.

${ }^{29}$ Kerkhoff and Dols, 'Algemene Wet tot 1987', 725-727; Kamerstukken II, 1961/62, 6808, no. 3, 2.

30 Kamerstukken II, 1961/62, 6808, no. 3, 1.
} 
proven to be an excellent means to provide medical care for large parts of the population; the public's health is served by it to an important extent, and it is alive in the legal consciousness ['rechtsbewustzijn'; italics are mine; RB]." ${ }^{\prime 31}$

That Veldkamp intended to honor this consciousness was attested by the fact that the Sickness Fund Act concretized almost verbatim what the 1941 Sickness Funds Decree had enshrined in terms of access to health care for individual citizens, without proposing any real change in the execution and administration of the provision of health care through the sickness funds. Interpreted critically, the Sickness Fund Act was little more than a piece of legislation that streamlined policy concerning the sickness funds, while it replaced the 'toxic' German legislation of 1941 with an 'authentically Dutch' law. Practically speaking, it pulled together various laws regarding the sickness funds. Where coverage was concerned, it officially codified the option for citizens who earned less than the wage limit for sickness funds to nevertheless take out a voluntary insurance policy with a sickness fund - a long-standing practice now laid down in law. It also recognized the right of insureds to contest decisions concerning their reimbursements by codifying an appeals procedure. ${ }^{32}$ All of this amounted to a fairly weak version of what Veldkamp had initially hoped would be a more comprehensive and unified mandatory health insurance. And yet, the Sickness Fund Act should be seen as the first clear expression on the part of the Dutch state of its desire to codify its role in guaranteeing equal, affordable and qualitatively sound health care to a significant part of the populace, an intent which had hardly been professed openly in the post-war decades. True enough, the governance structures put in place by the Nazi oppressor were retained. But the governmentality shifted in an important way: Dutch politicians who before the war would have openly resisted the idea that the state had a real role to play in health care now saw and supported the benefits of centrally-regulated access and equality. The Sickness Fund Act was passed in Parliament without any struggle, taking effect in October 1964, and setting the stage for the more ambitious health care reforms that were in the making.

\section{Cornerstones of the Welfare State, 1966-1968}

These reforms started with what can rightly be seen as the first broad policy document covering health care in all its facets in The Netherlands. In February 1966, Veldkamp and his (fellow

\footnotetext{
${ }^{31}$ Ibid., 1.

32 Ministerie van Sociale Zaken en Volksgezondheid, 'Persbericht No. 1811. Ontwerp Ziekenfondswet ingediend' ('s Gravenhage 21-08-1962) 1-2; Leenen, Sociale grondrechten, 56. From 1972, appeals decisions began to be published in a monthly: Rechtspraak Ziekenfondswet en Algemene Wet Bijzondere Ziektekosten (Amsterdam: Ziekenfondsraad 1972-1983).
} 
Catholic) State Secretary Louis Bartels presented to Parliament the 1966 Public Health Report (Volksgezondheidsnota 1966), a sprawling document numbering over 200 pages - excluding over 100 pages of appendices mapping the nature of health care provisions in The Netherlands. ${ }^{33}$ As one commentator noted, "Even though the name suggests that such a report appears every year, this is in fact the first time that a Dutch government in this way presents, elucidates, and accounts for its policies [in the field of health, RB]." ${ }^{34}$ The report was indeed ambitious: it started off with an ideology-laden introduction to "starting points for policy", followed by a lengthy history of health care provisions in The Netherlands, and a discussion of the quality of health care and its structure. The final chapter proposed policy plans for the future. Its sprawling nature was one of the root causes of the critique the report received when it was discussed in Parliament. Instead of focusing on specific problems and coming up with appropriate solutions, the report's ambitions and goals were diffuse. For many political parties, its ambition was not matched by precision and sufficient distinctness in setting out a clear line of policy for the future: the Labor Party lamented its lack of a plan for universal health insurance; confessional Members of Parliament (Catholic and Protestant) argued that increasing governmental influence would pose a serious threat to private initiative in health care; progressive doctor Arie Querido, professor of Social Medicine at the University of Amsterdam and a highly visible figure in public health policy in the preceding decades, argued instead that the report did not propose enough to strengthen the role of government. ${ }^{35}$ And indeed, in the report Veldkamp and Bartels seemed hesitant to provide a clear (political) vision for the future of health care. Taken together, its main arguments revolved around furthering 'health protection and improvement' as a consequence of the government assuming responsibility for the total structure of health care. To this end, better support, harmonization and coordination between health services was deemed necessary, as was providing information to the public on how to stay healthy. Of note (and in line with the times) was also the attention paid to environmental issues that posed a threat to public health, and to (relatively minor) changes in legislation needed to curb such threats. ${ }^{36}$

All in all, contemporary readers had reason to be disappointed at the end of the report. For two reasons, it nonetheless holds historical significance. The first is that Veldkamp and Bartels for the first time brought together the structure of health care and governmentcoordinated policy with regard to its costs. Given the way in which health care had developed in

\footnotetext{
${ }^{33}$ Kamerstukken II, 1965/66, 8462, no. 1. See for a discussion: Van Klaveren, Onafhankelijkheidssyndroom, 117-120.

34 J.F. Rang, Zorgen over de Volksgezondheidsnota 1966 (reprint from: Anti-Revolutionaire Staatkunde, 36 4, april 1966) 1.

35 H.G. Abma, 'De Volksgezondheidsnota 1966', De Banier. Partijblad van de Staatkundig Gereformeerde Partij (6-10-1966) 2-3; Van Klaveren, Onafhankelijkheidssyndroom, 119.

${ }^{36}$ Kamerstukken II, 1965/66, 8462, no. 1, p. 166-169, 211-213, 233.
} 
The Netherlands, as well as the way in which government had increasingly taken responsibilities upon itself in guaranteeing access to it, making policy choices would become inevitable at some time in the future. "It is increasingly becoming clear, that the total rise of expenditures of health care provisions makes a setting of priorities necessary [...] The less urgent will have to give way to the necessary." ${ }^{137}$ Though they hardly mentioned specific budgetary measures, the authors made clear that the growing stake of the government in health care would soon call for "efficient, integrated policy". ${ }^{38}$ For now, however, Veldkamp was not concerned about health care costs becoming unmanageable. In fact, the Public Health Report expressed his ideological interest in governmental aspirations to further improve the health of citizens, noting that " [...] the (public) health system should not fall behind compared to the growth in spending power ['welvaartsontwikkeling', RB], and this increased spending power should be used to develop underdeveloped parts of the health sector [...]." ${ }^{39}$ It would still be nearly a decade before the cost of health care did become a serious concern for policymakers. Still, the fact that Veldkamp argued for more control on the part of the government over the organization of the (public) health care sector was an interesting turnabout compared to the 'subsidiarity' preached by the Catholic part of the political spectrum in preceding decades. From the perspective of governmentality, even more interesting was a remark which would foreshadow the failure of attempts at top-down 'planning' of health care in the next decade. Overseeing the historical growth of Dutch health care led Veldkamp and Bartels to observe the following:

Great pluriformity, both in the relations between governmental and non-governmental parties and in social life, is not just very typical of the structure of Dutch health care, but it constitutes an element which is essential to health care policy. A policy which does not do justice to the essential characteristics of this structure will be doomed to failure, given Dutch relations. ${ }^{40}$

Secondly, the Public Health Report should be seen as an ideological mission statement, rather than as a concrete policy document. It is striking to what extent its first chapter goes back to ideas we already encountered in earlier publications by Veldkamp, cited above. Though Veldkamp and Bartels argued for 'self-care' as a primary responsibility for citizens, the way in which government was held responsible for creating the conditions under which such care could come to fruition, was extensive. ${ }^{41}$ Moreover, such governmental responsibility only seemed to be growing. This is because the authors of the report already alluded to their next legislative project: a broad national insurance for 'uninsurable risks': that is, chronic illness, handicaps, or recurring mental illness. ${ }^{42}$ All in all, the Public Health Report formed the bridge between an era in

\footnotetext{
${ }^{37}$ Ibid., 136. See also p. 233.

${ }^{38}$ Ibid., 14.

${ }^{39}$ Ibid., 12.

${ }^{40}$ Ibid., 42.

${ }^{41}$ Ibid., 10.

42 Ibid., 14.
} 
which the national state had subtly but increasingly facilitated access to health care through subsidies and a reliance on the 'local level', and an era in which it would come to see itself as an indispensable linchpin in the provision of equal, affordable, and accessible health care. Seen in this light, the report was an overture to the 'cornerstone of the welfare state': the 1968 Exceptional Medical Expenses Act. ${ }^{43}$

\section{The Exceptional Medical Expenses Act of 1968}

This act (Algemene Wet Bijzondere Ziektekosten, from here on: AWBZ) had been some time in the making. ${ }^{44}$ Immediately upon entering office in 1961, Veldkamp set to work on a broad, mandatory insurance for what he initially termed 'high' health risks; that is, ailments the treatment of which was so expensive no citizen could pay for it, and no insurer would cover it. As noted above, this plan was in line with Veldkamp's initial plan for a more extensive mandatory health insurance package than the one offered at the time by the Sickness Funds Decree. The original idea had been to create a legislative 'triptych' of insurance: basic universal insurance for uninsurable risks, broad (curative) insurance for the majority of the population (a bigger group than at the time was covered under the Sickness Funds Decree) and a remaining compartment for private insurance. ${ }^{45}$ Despite the relative failure of the second piece of the triptych - as we have seen, the Sickness Fund Act hardly extended coverage of the mandatory sickness fund package - mandatory insurance for 'high' health risks proved to be a fruitful undertaking. This attested to broad acceptance of the notion that society, through the government, should show solidarity with those unfortunate enough to have been born with a chronic infirmity or debilitating illness. ${ }^{46}$

This is not to say that Veldkamp took his task lightly, as was illustrated by the thoroughness with which he set to work in gaining advice from advisory bodies as well as Parliament, over the course of six years. Moreover, there were limits to solidarity. In his first proposals to legislate long-term care, Veldkamp tried to include specialist and hospital care in the AWBZ - slyly importing curative arrangements into what was primarily an act aimed at longterm care - but this soon met with a storm of criticism. Doctors opposed the idea that the AWBZ 'package' should be so broad, as incorporating such care in a mandatory insurance scheme would have a negative impact on lucrative private practice - an argument heard since the first

\footnotetext{
${ }^{43}$ See, for 'cornerstone': Van Klaveren, Onafhankelijkheidssyndroom, 120.

${ }^{44}$ For an in-depth discussion of the political trajectory to the AWBZ, see Kerkhoff and Dols, 'Algemene Wet tot $1987^{\prime}, 729-745$.

45 Ibid., 709-710.

${ }^{46}$ Ibid., 740.
} 
attempts at legislating the sickness funds. ${ }^{47}$ Private insurers saw a direct attack on their business model, as expensive hospital care still necessitated insurance for those above the sickness fund income limit. ${ }^{48}$ Finally, the Social and Economic Council, representing employers and employees, expressed concerns over the rising premiums employers would have to pay into the insurance scheme. ${ }^{49}$ When Veldkamp left politics in 1967, his successor Roolvink (from the AntiRevolutionary Party) bowed to such critique, removing the first year of hospital and medicalspecialist care from the AWBZ coverage. But with those concessions, the Act passed Parliament without a vote on 24 October $1967 .{ }^{50}$

This meant that, from now on, the state guaranteed access to a broad package of care arrangements for chronic or lifelong ailments, through a national insurance that was financed by wage premiums (initially set at a nominal $0.4 \%$ of income), employer premiums, as well as a direct state subsidy and (small) personal contributions. ${ }^{51}$ From January 1, 1968, every inhabitant of The Netherlands ['ingezetene'; $\mathrm{RB}^{52}$ ] would be mandatorily insured for treatment and/or nursing care in institutions for the mentally handicapped and for dependent children suffering from sensory and/or motor handicaps (such as blindness respectively polio). From April 1, 1968, this package was expanded with the coverage of treatment in hospitals, sanatoriums, and psychiatric institutions - that is, after one year of uninterrupted treatment, which took into account the critique discussed above - as well as nursing homes. ${ }^{53}$ People were automatically insured through their sickness fund or private health insurer, and the distribution of revenue streams now was done through the central government and delegated to the Sickness Fund Council.

This was a truly revolutionary development for Dutch health care, even if the rightsbased character of the AWBZ mirrored earlier welfare state legislation. The social signature of the act, which substantially brought the government into health care, was enhanced by the fact that it was very open-ended in terms of the types of health care provisions it included and the percentage of the population that in the future could call on it, as well as in the way it was financed. In providing the legal justification for legislation which would insure 'high' risks, Veldkamp in 1962 already noted the prospective growth of AWBZ-beneficiaries:

\footnotetext{
${ }^{47}$ Ibid., 736.

48 Vonk and Schut, 'Universal access', 11-12.

${ }^{49}$ Kerkhoff and Dols, 'Algemene Wet tot 1987', 735.

50 Ibid., 736-737.

51 Ibid., 742; G.P. Sijses, Algemene Wet Bijzondere Ziektekosten (Deventer: Kluwer 1968), 65.

52 The right to AWBZ-coverage was not tied to having the Dutch nationality. See Sijses, Algemene Wet, 26.

53 Sijses, Algemene Wet, 22, 65. This phased introduction was arranged in order to limit costs. In 1964, the maximum amount of hospital days covered under the Sickness Fund Act had been raised to 365, up from the 70 it had been raised to in 1955. Kamerstukken II, 1967/1968, 9717, no. 3, p. 5.
} 
[...] the abovementioned heavy health risk is continuously growing. There are multiple causes for this [...] In the first place, the post-war years have shown how, through the application of modern medical therapy, many who would in earlier times have died because of intercurrent illness, now stay alive. Second, as a result of the ageing of the population, which is in part a result of progress in medicine, the number of sufferers from a chronic disease has grown rapidly. ${ }^{54}$

The growing group of citizens which would have to make a claim on AWBZ provisions in the future, as well as the fact that the law gave them a right to "[...] medical treatment, pharmaceuticals, (nursing) care in institutions, which include, at least, hospitals and nursing homes [...]" made it clear that the AWBZ was of no small importance in the central government's guarantee of access to health care. ${ }^{55}$ Moreover, it makes it tempting to assume that Veldkamp, through his AWBZ, tried to create a back-door through which some elements of his universal insurance would still be achieved. ${ }^{56}$ Living (well) past the retirement age was gradually becoming the demographic norm, making every Dutch citizen potentially eligible for expensive government-mandated health care in nursing homes and other types of long-term treatment. The open-ended nature of the act also opened the door for rapidly growing expenses, as room was created for expanding those institutions which could offer AWBZ-care. As a commentator on the act noted somewhat dryly: "Attention shall have to be paid to the 'pulling [aanzuigende]' effects of the new act." ${ }^{157}$

\section{The Beginning of a New Governmentality}

With the AWBZ, and the legislative work of Veldkamp more generally, the gradual growth of a legal discourse on the right to health care and the actual governmental practice of expanding access to it since the 1912 Poor Law came together both ideologically and practically. The reality of the government taking a social interest - with both central and local government increasingly subsidizing or organizing health care arrangements - was, at long last, complemented by a new discourse or rhetoric of health care as a human right and a responsibility of the collective - now interpreted more and more as the government, and less in terms of (religious) social collectives. In the two decades after the Sickness Funds Decree had been instituted, the right of citizens to appeal to their government for support in medical matters was still subject to debate, though

\footnotetext{
54 Ibid., 15. Sijses was citing from the letter Veldkamp sent to the Social and Economic Council on August 24 1962, requesting advice on potential legislation for long-term care.

${ }^{55}$ Art. 6, paragraph 2 AWBZ.

${ }^{56}$ This was also the critique in Parliament of the Liberal Rietkerk on the final form of the AWBZ. The Liberals nevertheless were in favor of the act, because of its solidarity with handicapped children. See Kerkhoff and Dols, 'Algemene Wet tot 1987', 739.

${ }^{57}$ Sijses, Algemene Wet, 25.
} 
the practice of health care provision increasingly pointed in that direction. By the late 1960s, however, there could no longer be any doubt about this. And by this time, it seemed that the ways in which such care had historically been provided also came more and more under governmental control. This is because the AWBZ also marked the transition to a fundamentally new type of governance in Dutch health care. It would still be a few years before a new 'governmentality' in the form of 'planning' was put forward with the 1974 Structure Report (which will be discussed further on). The AWBZ nevertheless should be seen as an important practical milestone in codifying both the social ideology and new forms of governance concerning financing and the role of central government, as opposed to local government or private initiative (which had historically provided much long-term care). Three specific developments are of note here.

Firstly, the AWBZ changed the financing of the system of long-term care in important ways. Before the act, governmental subsidies towards financing such types of care were delivered through (initially) the Poor Law, and then the General Act on Financial Assistance of 1965. The administration of both acts had been a matter for municipal governments. Only with the latter law had the central government become directly implicated, as it now had to retrospectively reimburse municipalities. (Under the Poor Law, financial streams had been far less clear - see chapter 2). But with the AWBZ, the municipal middleman was cut out. The various types of funds financing the AWBZ went directly to a newly created General Fund for Exceptional Medical Expenses, which fell under the Minister of Social Affairs. And ostensibly, in the scheme of the AWBZ the health care 'field' still had a serious role to play, as the General Fund was managed by the Sickness Fund Council. ${ }^{58}$ But from the word go, the increased role of the government in how the money was managed was crystal clear. In its first year, funding for the AWBZ amounted to 591 million guilders. Of this, no less a sum than 405 million was a direct government subsidy. ${ }^{59}$ And though the AWBZ-scheme - much like the sickness funds - was funded in part by an income-related premium, the fact that these funds were now channeled to the government meant that many revenue streams historically coming from 'private initiative' were now made a governmental affair. ${ }^{60}$

Secondly, the AWBZ gave off an unequivocal signal: from now on, access to certain expensive types of health care would be guaranteed by the government. Although exact numbers are hard to come by, this shift from arbitrary financing to guaranteed financing had a significant effect on the growth of health care provisions covered under the new act. ${ }^{61}$ Where

\footnotetext{
${ }^{58}$ Sijses, Algemene Wet, 71-72.

59 Ibid., 65.

60 Kerkhoff and Dols, 'Algemene Wet tot 1987', 745.

${ }^{61}$ See Vonk, Recht of schade, 195; O. van Heffen and T. Kerkhoff, 'Gezondheidszorg: van blauwdrukdenken naar incrementeel sleutelen', in: W. Trommel and R. van der Veen (eds.), De herverdeelde samenleving. De
} 
before the AWBZ, hospitals had been the absolute frontrunners in terms of cost, they were now joined by institutions in the fields of mental health, nursing, and care for the handicapped. In June 1968, costs for building and/or expanding such institutions were already estimated to be 161 million guilders, while the building permits granted in that year ran to nearly 400 million guilders. ${ }^{62}$ But it also soon became clear that the AWBZ had an effect beyond 'intramural' care care offered 'within the walls' of such institutions. The AWBZ's 'pulling effect' mentioned earlier was illustrated, for instance, by the fact that various curative and extramural provisions came to be added to the package in the years just after the passing of the act. These were political decisions, but they attested to the fact that the 'right to health care' could be interpreted very broadly under positive ideological and economic circumstances. In 1971, for instance, certain hospitals were given permission to perform kidney transplantations covered by AWBZ funds, and in 1974 the vaccination package already paid for by the government since 1957 was included, illustrating that provisions which theretofore had been subsidized on a case-by-case basis now were moved into the universal insurance scheme. And after a long period of financial uncertainty, the Cross associations - which merged into a national organization in 1973, see below - in 1980 became officially recognized as providers which were reimbursed under the new scheme. ${ }^{63}$ It soon became clear that 'long-term care' for 'uninsurable risks' was a flexible category, allowing many new additions to the government-backed package.

The third and final element concerned perhaps the most visible exercise of governmental power under the new act. Much like the Sickness Funds Decree had first given the government power over the sickness funds through its setting, by decree, of admission requirements (in order for sickness funds to act as carriers for the new insurance), the AWBZ introduced requirements for providers of health care on the one hand and for insurers on the other. Through these admission requirements, something was achieved which had already featured in the discussions concerning hospital legislation that were discussed in the previous part. From now on, any health care institution which wanted to apply for offering AWBZ-care had to get approval through the Sickness Fund Council. Hospitals would be checked on the quality of medical care, whereas an institution for blind children, for instance, would have to meet certain pedagogical standards. This gave government the first real instrument for quality control of health care institutions. ${ }^{64}$

ontwikkeling en herziening van de Nederlandse verzorgingsstaat (Amsterdam: Amsterdam University Press 1999) 185-215, 188-189; Kerkhoff and Dols, 'Algemene Wet tot 1987', 746-749.

${ }^{62}$ Companje et al, Vijftig jaar kostenbeheersing, 27.

${ }^{63}$ Kerkhoff and Dols, 'Algemene Wet tot 1987', 747, 752, 755-757; Van Klaveren, Onafhankelijkheidssyndroom, 125.

64 Sijses, Algemene Wet, 54-56; Van Heffen and Kerkhoff, 'Blauwdrukdenken', 189. 
But also in a second, more subtle way did the government increase its say over the provision of care. This is because, with the AWBZ, private insurers were brought ever further into the fold of social insurance provision. In the previous chapter, we have already seen how the 'superstructures' founded by the sickness funds in the late 1940s and 1950s began to make inroads on the market for private health insurance for citizens whose income exceeded the sickness fund limit. The way in which the policies offered by these superstructures demonstrated a social motive, with little risk selection and lenient rates, had forced the private insurers to also limit the more 'anti-social' elements in their policies, such as risk selection and rejection of the chronically ill. Through the AWBZ, the government now pushed these insurers even further towards a social position. When Veldkamp had introduced his plan to include hospital and medical-specialist care in the AWBZ, this was partly done to create access to such types of care for the chronically ill. But as noted above, hospital and specialist care were crucial parts of the policies offered by the private insurers. In a bid to remove the necessity for such drastic provisions in the AWBZ, the organized private insurers now began to offer a uniform insurance product for these chronic health care 'risks'. ${ }^{65}$ To make this expensive policy financially possible they created a risk pool in which both the united commercial insurers and the superstructures participated. With this concession, it was possible for Veldkamp's successor Roolvink to remove hospital and specialist care from the AWBZ, as the chronically ill whose income exceeded the income limits of sickness funds could now reasonably buy insurance for their ailments on the private market. As a 'reward' for this social stance, private insurers were officially recognized as carriers of the AWBZ-insurance and were also given seats on the Sickness Fund Council. This brought them ever further into the 'social insurance family', a development which would clear the ground for a wave of acquisitions and mergers with sickness funds in the 1990s. ${ }^{66}$

\section{Small Steps Towards Organizing Health Care}

The years 1966 and 1968 mark the first true moments in which the central government came to be seen as a desired and necessary actor in the provision of a health care which had for so long been dominated by notions of sphere sovereignty, subsidiarity, and private initiative. But the milestones in Dutch health care policy of the 1960s also made inevitable a new 'governmentality': in keeping a broadly accessible health care affordable, after more than a century of (nominally) hands-off policy the central government had to step in. The 'spirit' of Thorbecke which had so emphasized the 'local level' in society and health care could be shelved

\footnotetext{
65 Or health care 'realities', as a representative of a private insurer in 1966 termed a diabetic needing insulin on a regular basis. See Vonk, Recht of schade, 183-184.

${ }^{66}$ Ibid., 182-188, 200; Vonk and Schut, 'Universal access', 11-12.
} 
- but only for a relatively short time. The late 1960s marked the beginning of an era of unprecedented government 'planning', which would nonetheless already end in 1987. But in the intervening years, developments nevertheless took place which fundamentally changed the relationship between the government and the health care field, and for the first time created the notion of and the need for a coherent health care 'system'.

The starting point for these developments was a direct reaction to the introduction of the AWBZ. In 1967 State Secretary Roelof Kruisinga dusted off an old idea: state regulation of hospital building and expansion. As we have seen in the previous part, the early 1950s had sounded the death knell for such legislation, when it got bogged down in discussions concerning the primacy of private initiative. In the decade and a half that followed, various reports had appeared which argued for regulation, but no legislative attempts had been made. ${ }^{67}$ But now, with the state more involved through the Sickness Fund Act and the AWBZ, its interest in fostering coherence and financial sustainability of the health care system was becoming more urgent. In September 1968, Kruisinga therefore presented a Hospital Building Act (Wet Ziekenhuisbouw) to Parliament. This act gave the government powers which previously would have met with stiff resistance from the parties in the field: the power to grant permission for building or expanding hospitals, with the final goal of instituting a national hospital plan. A Council for Hospital Building would be instituted, which would include representatives from the health care field. ${ }^{68}$ The idea was to create a "[...] well-proportioned system of complementary health care provisions." ${ }^{\prime 69}$ By 1968 , perceptions of the necessity of such governmental powers had clearly changed compared with the situation of not even twenty years before. In fact, the act was perceived by many as too vague and not powerful enough for bringing health care institutions under control. The organized sickness funds judged the act too specific: not just the hospitals would have to be brought fall under its control in order to achieve serious health care 'planning'. After all, the AWBZ had brought a broad new array of health care institutions under the insurance umbrella, which the proposed act did not aim to regulate. ${ }^{70}$ In Parliament, the act was criticized for not being centralistic enough, as it leaned heavily on the judgement of provincial administrations with regard to the building of new regional hospitals ${ }^{71}$ In the revised Act on Hospital Provisions (Wet Ziekenhuisvoorzieningen), Kruisinga met these criticisms to a certain extent: now, hospital equipment and departments (for different medical specialties) would also fall under the act. In this (slightly) expanded form, it was passed on July $1,1971 .^{72}$

\footnotetext{
${ }^{67}$ Kamerstukken II, 1967/1968, 9717, no. 3, p. 7.

${ }^{68}$ Sijmons, Aanbodregulering, 118-124.

${ }^{69}$ Kamerstukken II, 1967/1968, 9717, no. 3, p. 9 (cited in Sijmons, Aanbodregulering, 129).

${ }^{70}$ Companje et al, Vijftig jaar kostenbeheersing, 28.

${ }^{71}$ Sijmons, Aanbodregulering, 132.

72 Ibid., 132-134; Companje et al, Vijftig jaar kostenbeheersing, 28.
} 
The Act on Hospital Provisions, alongside the Act on Hospital Tariffs instituted by Minister Veldkamp in 1965, for the first time gave the government instruments to control both the financing and the organization of health care, with an eye to keeping down rapidly rising expenditures. ${ }^{73}$ But for the time being, Kruisinga's act would be a shot across the bow: many of the act's most important provisions did not go into effect until 1979, because coming up with an implementable hospital plan proved harder than expected. ${ }^{74}$ The Central Organ on Hospital Tariffs which had been instituted in 1965 did not begin to exercise cautious control over tariffs until the mid-1970s. ${ }^{75}$ Moreover, the liberal-confessional governments that until 1973 were in power made little use of the new possibilities for control granted them by this legislative dyad concerning hospital planning and tariffs, and left health care to develop as it had done in earlier decades: fairly unhindered. ${ }^{76}$ This, however, made it inevitable that the act was incorporated in the broader vision of health care 'planning' that became a centerpiece of political rhetoric in the middle of the 1970s, when cost control became a focal point on the health care agenda. We must turn to that era now.

\section{A Short Progressive Era, 1973-1977}

While 1968 marked a revolutionary year in Dutch health care, it is of course also known internationally as a year of revolutionary uprisings, with action aimed at furthering democratization, expanding civil rights, and generally combating authoritarian and traditionalist structures and ways of life. In The Netherlands, the year '1968' passed without any real uprisings or political terrorism from the left or right. Still, the progressiveness of the era did not go unnoticed, with protests at universities for more democratization, as well as playful ('ludieke') actions by the rather visible collective known as the Provo's (from 'provocation'), getting plenty of attention and attesting to a shift in the political wind already in 1966-1967. ${ }^{77}$ By the time Veldkamp put his stamp on Dutch health care legislation with his Christian-based vision of solidarity, the pre-eminence of religion in both politics and society at large was already waning. After creaking under its own weight, 'pillarization' finally came to a standstill. In 1966, this had already been visible in national politics, when growing political divides led Catholic MPs to bring down a government led by one of their own, at the same time that the upstart party Democrats

\footnotetext{
${ }^{73}$ Companje et al, Vijftig jaar kostenbeheersing, 28, 30.

74 Sijmons, Aanbodregulering, 134-135, 141. The first hospital plan would not see the light before 1984, see: H.L. Booij, Wet Voorzieningen Gezondheidszorg (doctoral thesis Rijksuniversiteit Utrecht 1988) 23.

${ }^{75} \mathrm{H}$. ter Heide, 'Ervaringen met het COZ als ordeningsmodel', in: L.J. de Wolff (ed.), De Prijs voor Gezondheid. Het Centraal Orgaan Ziekenhuistarieven (Baarn: Ambo 1984) 47-64, 57-59.

${ }^{76}$ Van Heffen and Kerkhoff, 'Blauwdrukdenken', 189.

77 D. Hellema, Nederland en de jaren zeventig (Amsterdam: Boom 2012) 27; De Rooy, Republiek, 209-214.
} 
'66 argued for a broad renewal of what they perceived as an ossified political structure. Moreover, The Netherlands were becoming increasingly secularized, and though the Catholics managed to hold onto power during the three cabinets that reigned from 1967 to 1972, their fortunes were fading rapidly. ${ }^{78}$

Politically speaking, it is remarkable how well an 'old-guard' coalition of Catholics, Protestants and Liberals rode out the first (and most visible) wave of progressivism, as the 19671971 De Jong-Cabinet sat out a full term. ${ }^{79}$ The general progressive impulse of the 1960s did not immediately swing voters who had always squarely supported the party representing their (religious) identity. But by the time of the 1971 elections, the parties which had reigned since 1958 for the first time in a long time received less than half of the votes. ${ }^{80}$ And by 1973 , a party which had had to content itself with looking on from the sidelines as the welfare state was being established was now again at the forefront of change. In that year, the Labor Party came back from exile with nearly $30 \%$ of the votes. Moreover, they were joined by progressive iconoclasts on the left: the aforementioned Democrats '66 and the Political Party Radicals (PPR). The confessionals were not fully down and out, though, and the Catholics (18\% of the votes) and Protestant Anti-Revolutionaries (9\%) completed out what would be termed 'the most progressive cabinet' The Netherlands has ever seen. $^{81}$

Despite the confessional elements in the cabinet, under the leadership of firebrand Social-Democrat Joop den Uyl the new government set its ambitions for social renewal and progressive policy high. Den Uyl had been around for a while, and had in the 1950s and the 1960s published essays that had called for income redistribution and a broad sharing of the wealth created in times of economic prosperity. ${ }^{82}$ In leading this new cabinet, he finally got the chance to put his ideas into practice and to build on them. ${ }^{83}$ Moreover, the creation of social provisions in the previous decades now tied in with the broader movements towards democratization, political renewal and social justice felt worldwide in the 1960s. Connecting these developments could be seen as the essential project of the 1973-1977 cabinet: what was called for was to make use of the 'malleability of society' ['maakbaarheid van de samenleving'; $\mathrm{RB}$ ]. From the outset, this cabinet set the bar high: its principal goal would be to bring about "

\footnotetext{
78 Hellema, Jaren zeventig, 144; De Liagre Böhl, 'Consensus en polarisatie', 319-322.

${ }^{79}$ For context, see: Kennedy, Nieuw Babylon, 191-196.

${ }^{80}$ https://www.parlement.com/id/vh8Inhronvwa/kabinet biesheuvel i en ii 1971 1973, accessed on 1704-2019. The Catholics, Protestants (ARP and CHU) and the Liberals together received $49,3 \%$ of the vote. ${ }^{81} \mathrm{http}: / /$ www.parlement.com/id/vh8Inhronvw9/kabinet den uyl 1973 1977, accessed on 25-11-2016.

${ }^{2}$ De Weg naar vrijheid in 1951; Om de kwaliteit van het bestaan in 1963 (which would also form the basis for the 1963 election program of the Labour Party. See De Liagre Böhl, 'Consensus en polarisatie', 311, and https://www.wbs.nl/publicaties/honderd-jaar-joop-den-uyl-1919-1987, accessed on 17-04-2019.) ${ }^{83}$ Den Uyl had earlier been Minister of Economic Affairs, but in the 1965-1966 Cals-cabinet, which only lasted for one year.
} 
a [...] fundamental change to our society, aimed at an even spread of income, wealth, power, knowledge and influence. ${ }^{\prime 84}$ That change would also pertain to health care, because of the role this played in allowing people to development themselves.

On the face of it, after a decade in which the Catholics had increasingly incorporated a social signature within their politics, such rhetoric was hardly radical. But the Social-Democrats reiterated an element less prominent in the political rhetoric of the confessional (let alone liberal) parties: the notion of democratization. Health care would play the role of creating a level playing field for all people and all groups. And the cabinet-Den Uyl went even further: "[the cabinet] wishes to prioritize the improvement of the quality of existence [...] over a slavish following of technical developments. It wishes to couple prosperity with well-being." ${ }^{\prime 85}$ The progressives embraced a comprehensive concern for the overall 'well-being' of Dutch citizens. Major social legislation was already in place now it was time for a comprehensive 'remaking' of society on egalitarian grounds. Such a grand vision presupposed further government intervention in the lives of citizens; 'well-being' would not come about through private initiative alone. The role of the government needed to be expanded to make sure everyone reaped the benefits of post-war prosperity.

\section{'Planning' as the New Governmentality}

There was, however, a problem: whereas an even distribution of wealth did not necessitate extra funding, expanding the welfare state did. And in this respect, the progressives ran into bad luck: the exceptionally pleasant economic circumstances which had allowed the Catholics to greatly expand welfare provisions in the previous decade took a turn as the progressives entered office. Den Uyl in the cabinet's inaugural statement already termed the economic situation "far from sanguine", but this was even before The Netherlands were truly hit by the effects of the global economic oil crisis of $1973 .{ }^{86}$ The Netherlands had taken the side of Israel in the Yom Kippur war and were therefore targeted by an OPEC embargo. This led to a rapid rise in oil prices, which hit the burgeoning post-war industrial sector especially hard. But the 1973 crisis would only be the first in a series. Moreover, it was worsened by the abandonment, in the 1960s, of the 'guided wage politics' which had been broadly thought desirable during post-war restoration, as well as the by now high government investment in the welfare state and the diminishing returns on investment in business. The second oil crisis which started in 1979 prolonged and even

\footnotetext{
${ }^{84}$ Handelingen II, 1972/1973, 41, p. 1565.

85 Ibid., 1565.

${ }^{86}$ Ibid., 1567.
} 
worsened the economic slump. Between 1977 and 1981, the national budget deficit grew from $3,8 \%$ to $8,2 \%{ }^{87}$ Despite the ambitious goals of the progressive cabinet, the economic downturn therefore quickly made clear that the post-war belief in near-unlimited growth had been unwarranted. ${ }^{88}$ Moreover, it called for immediate political action, since it prompted the question how the social achievements of the new welfare state could be retained while its cost could be kept in check?

Shortly after the new cabinet entered office, an ambitious answer to this question was formulated for the health care sector. The Structure Report Health Care, presented to the cabinet in August 1974 by the Catholic State Secretary Jo Hendriks, opened with the ominous assertion that "Great concern exists in our country over the functioning of health care." ${ }^{89}$ Although the report started off by praising Dutch medical care as being among the best in the world, the main thrust quickly became clear: the most urgent concern about health care was its rapidly rising cost. And the numbers were disconcerting indeed. In 1953, the total cost of health care expenditures had been about 750 million guilders; by 1972 they had grown to some ten billion. This would have been less of a problem had economic growth kept pace. But whereas in 1953 health care accounted for 3,1\% of gross domestic income, by 1972 this had grown to $6,7 \%{ }^{90}$ Internationally speaking, this development was no exception, and the report proposed looking to the United Kingdom and the Scandinavian countries by way of comparison. ${ }^{91}$ But the more general problems brought on by the welfare state, as well as advancing medical technology and the concomitant medicalization of society - a process in which personal problems come to be seen as problems to be solved through medical-technical interventions - nevertheless called for solutions tailored to national and local contexts. Concerning the Dutch context, the report's conclusions were unequivocal: the 'patchwork' of health care provisions and financing schemes that had been criticized after the war was still very much in place. Across the board, there was a lack of mechanisms for keeping expenditures in check, an incoherent and uneven spread of provisions, a lack of cooperation between institutions and too little policy where the training of new medical professionals was concerned. ${ }^{92}$ The message was clear: post-war financial growth had blinded policy-makers to the near-absolute lack of coordination within the system, allowing it to grow organically. And now that the proverbial trees no longer grew to the heavens, coordination from above would be precisely what was needed to avert financial catastrophe. "To

\footnotetext{
${ }^{87}$ De Liagre Böhl, 'Consensus en polarisatie', 329; Prak and van Zanden, Nederland en het poldermodel, 263-264.

88 Ibid.

89 J.P.M. Hendriks, 'Letter accompanying the Structuurnota Gezondheidszorg 1974' (Kamerstukken II, 1973/1974, 13012, no. 1) 1.

90 J.P.M. Hendriks, Structuurnota Gezondheidszorg (Kamerstukken II, 1973/1974, 13012, no. 2) 5, 38.

${ }^{91}$ Ibid., 5.

92 Ibid., 6-7.
} 
increase efficiency, curb unchecked growth, remedy existing lacunae in the provision of health care $[. .$.$] what is needed is the planned structuring of health care.."93$

In a general sense, the Structure Report was agenda-setting: now that health care had become a basic right through the extensive legislation of the 1960s, the government would have to have a say in its organization and financing. What was primarily contested were not the social benefits of access to health care, but its cost-efficiency. And in line with the times and with the signature of the progressive cabinet, keeping costs low and efficiency high would have to be achieved through far more top-down ordering of health care than had been the case. Still, for a report which ostensibly heralded the era of government 'planning' in health care, it is remarkable to what extent it still clung to the historically grown character of Dutch health care provisions. The two main axes along which State Secretary Hendriks wished to reorganize health care were the introduction of 'echelons' of care, and a structured ordering of health care provisions on a regional basis. The former element referred to the creation of functional 'echelons' within health care: the first echelon would be primary care, such as access to GPs and physical therapists. If treatment needed to be more extensive, patients could then be sent on to 'second line-care' such as the hospital or medical specialist. Strengthening the 'first line' would, it was reasonably presumed, bring down the cost of the expensive hospital and medicalspecialist system, through the substitution of as many intramural provisions as possible by extramural ones. Years before, Kruisinga had already argued for such a substitution, after which little had happened. ${ }^{94}$ The second element of Hendriks' plan, 'regionalization', in a sense echoed earlier ideas about implementing district health services, which would serve as regional bases from which health care provisions could be coordinated. The idea that decentralized organization offered the best option for streamlining the Dutch health care field was also very much a central point in Hendriks' view. Though the central government could set norms and see to it that they were met, "[...] it has proven impossible [...] to plan and govern the factual workings of health care from such a central point." ${ }^{\prime 95}$ 'Planning' was therefore not synonymous with the central governing, let alone nationalization of health care. Still, the fact that the government now openly took up the challenge of coordinating the broad range of health care provisions was a historical break and an attempt at instituting a new governmentality. How did this attempt fare?

\footnotetext{
${ }^{93}$ Ibid., 8.

${ }^{94}$ Companje et al, Vijftig jaar kostenbeheersing, 42.

95 Kamerstukken II, 1973/1974, 13012, no. 2, p. 10.
} 


\section{The Failure of Hendriks' Legislative Triptych}

Given those 'great concerns', it was clear that action was called for, and in first instance, the Structure Report was met favorably by the parties in the field, though its vague nature was immediately a target of critique. ${ }^{96}$ Significantly, the Structure Report built on a report by a committee chaired by Henri Festen, whom we have briefly encountered in the previous chapter as chair of the Council for Public Health. To realize 'planning' Hendriks proposed a set of changes which would give the government still more control over various areas of health care. These changes can be summarized as a 'triptych' of legislation, aimed at regulating health care provisions, tariffs, and creating a financial backbone to the system in the form of a compulsory insurance scheme. To begin with this last element: after discussing the negative effects of the fragmented financing arrangements for health care - government subsidies, AWBZ and sickness fund premiums (voluntary and mandatory), as well as contributions by private citizens and other sources - Hendriks noted that the first and second echelon would have to be financed through a "uniform insurance scheme.."97 Perhaps because of the historical, and to be expected, resistance to a compulsory insurance which would offer the entire population access to the combined coverages offered by the Sickness Fund Act and the AWBZ, Hendriks almost as a side note proposed it in the Structure Report. That plan never came to fruition. Already in mid-1975 finance Minister Wim Duisenberg decided to anticipate the perceived future effects of the economic crisis, and curbed government expenditures on social provisions. As a result, an early proposal by Hendriks for government-backed compulsory health insurance was inevitably dead on arrival and was not even presented for discussion to Parliament. ${ }^{98}$ This was a problem for the entire planning project, because it failed to give the government a strong instrument for influencing health care providers through centralized financing. Instead, care providers in the curative sectors remained financed through sickness fund and/or private insurance cash flows, with only the AWBZ granting government some power through its holding of the purse strings. ${ }^{99}$

Hendriks' second plan fared only slightly better. In 1976, the Act on Health Care Provisions (Wet Voorzieningen Gezondheidszorg, from here on: WVG) was presented to Parliament. The main purpose of this law was to expand on the Act on Hospital Provisions of 1971. As we have seen, not only was that act virtually dormant until 1978 , it was also limited to bringing structure only to the hospital landscape. With the WVG, Hendriks instead proposed to structure all health care provisions. In order to do so, coherence would have to be achieved in

\footnotetext{
96 Van Klaveren, Onafhankelijkheidssyndroom, 151, 153.

${ }^{97}$ Kamerstukken II, 1973/1974, 13012, no. 2, p. 43, 45.

${ }^{98}$ Hellema, Jaren zeventig, 156; Kerkhoff and Dols, 'Algemene Wet tot 1987', 751.

${ }^{99}$ Booij, Wet Voorzieningen Gezondheidszorg, 113.
} 
the totality of provisions through a system of permits, quality controls, networks of public health services, and more. All of this to serve the ends of cost and quality control, as well as an even and coherent spreading of health care services. ${ }^{100}$ This proposal immediately set off a storm of critique: groups such as the organized doctors, but also the confessional and liberal parties balked at concrete steps for curbing private initiative and medical entrepreneurship. ${ }^{101}$ The need for organizing health care might have been broadly understood and shared, but it was clearly not matched by new a enthusiasm about the prospect of the for government taking up this organization in such a radical way. As a result, Hendriks was sent back to the drawing board, and it was only six years and three revised proposals later that the act was accepted by Parliament, under the stewardship of Hendriks' successor Els-Veder Smit. ${ }^{102}$

The WVG laid bare the limits of the planning ideology as a new governmentality within the context of Dutch health care. It is true that Hendriks was less of a political street-fighter than Veldkamp had been. ${ }^{103}$ However, both the historical growth of a highly uncoordinated patchwork of provisions and a lack of consensus about the question who should be put in charge of coordination now that the financial need was rising were arguably more important factors in answering the question why the ideology of 'planning' was hard to turn into reality. In any case, the WVG lacked clarity concerning the roles and responsibilities of the various parties who would have to be involved in structuring health care - the central government, but also provinces and municipalities - which led to an unwieldy and needlessly complex legislative instrument. ${ }^{104}$ The WVG was a typical 'framework law', which relied to a large extent on the promise and necessity of future lower grade regulatory measures to give real shape and meaning to how planning in health care would be achieved. ${ }^{105}$ And when it was voted into law in 1982, the WVG was enacted without many of its most important provisions: the sections on quality, planning, and permits, for instance, stayed in abeyance until a later implementation date. ${ }^{106}$ Years later, when the WVG had failed to achieve any of its original goals, a commentator noted in 1988: "Herein lies, in part, an explanation for the curious phenomenon that an act which passed through Parliament successfully later has hardly been implemented five years later; all serious points of contention have been pleasantly avoided in the act itself, and would

\footnotetext{
100 Sijmons, Aanbodregulering, 145; Booij, Wet Voorzieningen Gezondheidszorg, 8-11.

${ }^{101}$ Van Klaveren, Onafhankelijkheidssyndroom, 153-154.

${ }_{102}$ C. Generaal and N. Mensink, De Ziekenfondsen, de Wet Voorzieningen Gezondheidszorg en de Wet Tarieven Gezondheidszorg (doctoral thesis Rijksuniversiteit Utrecht: 1983) 15.

103 See e.g. Kerkhoff and Dols, 'Algemene Wet tot 1987', 724.

${ }^{104}$ See also Kamerstukken II, 1985/86, 19387, no. 3, p. 3.

105 Booij, Wet Voorzieningen Gezondheidszorg, 8.

${ }^{106}$ Sijmons, Aanbodregulering, 149.
} 
still have to be fought over in reality." ${ }^{107}$ Without ever leading to real results in curbing costs or structuring health care, the act was definitively rescinded in $1996 .{ }^{108}$

The Den Uyl-cabinet in this sense had clearly overestimated the malleability of this sector of society. And indeed, what would become the most successful part of Hendriks' intended triptych - the Act on Health Care Tariffs - built on an earlier era of health care 'structuring' in its expansion of the tariff legislation enacted under Veldkamp in 1962. The Act on Health Care Tariffs (Wet Tarieven Gezondheidszorg, from here on: WTG) was presented on the same date as the WVG, and it met the same critical response. However, both its goal and how to achieve this were far clearer from the start: a Central Organ for Health Care Tariffs would be tasked with setting upper limits and guidelines for the rates and fees used in care institutions and by health care professionals. This organ (COTG) would be a public body, independent of the health care 'field', and the guidelines for setting tariffs would now be created by the joint Ministers of Health, Finance, and Social Affairs. Any health care provider charging higher rates than the set tariffs would be liable to punishment. ${ }^{109}$ After criticism of the centralistic nature of this act, an amended proposal granted the parties in the field representation in the COTG - thus diminishing the power of the state in the setting of tariffs - and with that amendment, the act passed in November $1980 .{ }^{110}$ This act, which also came into force under Hendriks' successor, would prove to offer some of the best options for keeping growing health expenditures in check, as from 1983 onwards the legal infrastructure for regulating tariffs would be used as the first real budgeting instrument in health care. Nevertheless, in once again conceding power to 'field parties', the last panel of the intended triptych, too, did not create as powerful a role for the state as had been originally envisioned.

\section{From Planning to Incremental Change}

On balance, it is safe to say that for the most part Hendriks' ambitious plans failed. Despite a favorable reception of the 1974 Structure Report and its grand plans to bring down the rapidly rising health care costs, the historically grown web of health care proved resilient to state control. A recent overview details a number of practical effects following from Hendriks' report,

\footnotetext{
${ }^{107}$ Booij, Wet Voorzieningen Gezondheidszorg, 8-9. See pp. 113-115 for a discussion of why the act faltered.

${ }^{108}$ Van Klaveren, Onafhankelijkheidssyndroom, 154.

${ }^{109}$ See E. Plomp, Winst in de zorg. Juridische aspecten van winstuitkering door zorginstellingen (diss. Universiteit van Amsterdam 2011) 105-107 and G.R.J. de Groot, Tarieven in de gezondheidszorg (diss. Universiteit Utrecht 1998) 19-24.

110 De Groot, Tarieven, 22-23.
} 
effects which attest to anything but successful and structured top-down 'planning'. Between 1975 and 1979, a combination of departmental measures led to a building cap for care institutions; a marginal slowing down of the wages for nursing (and then only until 1976); reduction in beds in non-academic hospitals (but 'controlled growth' in academic ones); as well as some tweaking of tariffs for certain medical applications. ${ }^{111}$ These measures had unmistakable effects here and there, and they attested to the fact that Hendriks had been a realist in terms of what could be achieved - even if he had overestimated how it could be achieved. What was aimed for with the Structure Report was not a reversal of the upward spiral of health care costs from the $1960 \mathrm{~s}$, but the capping of costs to a maximum of $8 \%$ of the national income. ${ }^{112}$ But though the splash the 1974 report had made was big, its vague recommendations for policy, lack of link to financing (a new health insurance scheme), and the rapid running out of steam of its primary legislative instrument quickly saw to it that the rhetoric of planning foundered on the only attainable reality of keeping down costs in health care through incremental change. This meant that for the time being, the government could only influence costs and institutional arrangements in health care on the basis of Veldkamp's Act on Hospital Tariffs and Kruisinga's Act on Hospital Provisions. It is not clear to what extent Hendriks' plans would have led to more cost reduction, had they been enacted in the way originally envisioned. As it stood, the smaller measures taken instead did little to assuage fears of cost growth or ease the continued need for a coherent health care policy. Table 3.1 shows the way in which costs grew in the era of 'planning':

Table 3.1 Health care expenditures in guilders $x$ million (f.-), 1972-1980

\begin{tabular}{|l|l|l|l|l|l|}
\hline & $\mathbf{1 9 7 2}$ & $\mathbf{1 9 7 4}$ & $\mathbf{1 9 7 6}$ & $\mathbf{1 9 7 8}$ & $\mathbf{1 9 8 0}$ \\
\hline $\begin{array}{l}\text { Intramural } \\
\text { care }\end{array}$ & 5.521 & 7.922 & 10.962 & 13.396 & 15.857 \\
\hline $\begin{array}{l}\text { Extramural } \\
\text { care }\end{array}$ & 4.335 & 5.597 & 7.083 & 8.485 & 9.943 \\
\hline $\begin{array}{l}\text { Financing } \\
\text { through } \\
\text { AWBZ }\end{array}$ & 2.064 & 3.061 & 4.317 & 5.302 & 6.750 \\
\hline $\begin{array}{l}\text { Total costs as } \\
\text { \% of GDP }\end{array}$ & 6,7 & 7,0 & 7,5 & 7,7 & 8,1 \\
\hline
\end{tabular}

Source: Centraal Bureau voor de Statistiek, Kosten en financiering van de gezondheidszorg 1972-1992. Costs and financing of health care 1972-1992 ('s-Gravenhage: Sdu 1994) 6-7.

${ }^{111}$ Companje et al, Vijftig jaar kostenbeheersing, 47-48.

112 Ibid., 35-36. 
All in all, health care costs remained well within the range of 8-9\% of GDP until the early 1990s (see table 3.2) - an important achievement in its own right resulting from the policy measures introduced by Hendriks and his successors. Where the 1966 Health Report had still been circumspect in noting that a systematic policy concerning costs would become necessary in the near future, by the time Hendriks presented the 1974 Structure Report, cost control had come to be seen as an indispensable element of the relationship between the state and a health care to which it now guaranteed access through the Sickness Fund Act and the AWBZ. And though 'planning' as a paradigm for more top-down, centralized control over health care had rapidly failed, the fears of exploding health care costs and the perceived need to curb them through some form of policy measures would never again leave the agendas of policy-makers. More than anything, this would be the lasting legacy of 'planning'. As a new form of 'governmentality', however, attempts to give the state a real say in the structuring and financing of health care was a clear failure. But given the long history of 'organic growth' in health care, as well as the ideology that had driven that growth for much of the previous century, it is questionable whether any politician could have radically changed this governing philosophy (even if they even would have wanted to do so).

One final element of Hendriks' report has not yet been discussed, an element which paradoxically played into the growing resistance to more governmental control of health care, apart from critique voiced by the established parties of health care providers, insurers, and sickness funds. In line with the times and with the progressive signature of his cabinet, Hendriks had argued that a greater role for the patient in an ever-expanding health care system would be necessary:

Ultimately, all health care revolves around the patient. In a time of rapidly changing medicaltechnological developments and an increasing scale and bureaucracy in the provision of health care, vigilance is called for in order to protect the inalienable individuality of the patient and the degree of openness and democracy of the health care system. ${ }^{113}$

It would be precisely these notions of 'alienation' and democracy which, from the middle of the 1970s, would increasingly be used to critique the paternalistic nature of an ever-expanding welfare state, especially as conceived by the progressive Den Uyl-cabinet.

\section{Cultural Resistance to the Welfare State}

113 Kamerstukken II, 1973/1974, 13012, no. 2, p. 21. 
Historians argue over the extent to which the progressive cabinet of 1973-77 was successful in achieving its far-reaching social goals. ${ }^{114}$ Unfortunate, in any case, was the outbreak of an economic downturn during its tenure. Moreover, the question will forever remain whether a comprehensive engineering of society would have happened if the next cabinet would have featured the Social-Democrats. Initially, the Labor Party achieved an enormous success in the 1977 election, winning more than a third of the vote. However, by this time the Catholics and Protestants had regrouped, for the first time jointly presenting themselves as the ChristianDemocratic Appeal (Christen-Democratisch Appèl, CDA). But the Liberals were also making a comeback. And when the endless discussions about the forming of a new cabinet foundered on another important medical matter - abortion - the Social-Democrats were once again left on the side-lines. ${ }^{115}$ Instead, once more a confessional-liberal cabinet came into power, which despite the favorable results of the Labor Party in the election - seemed attuned to a desire on the part of the general populace to revert to older ways of thinking about how society should be organized.

Regardless of all the concrete plans for the social engineering of a 'malleable society', the financial downturn had quickly put a brake on far-reaching reform. But it seems doubtful whether the social agenda of the Den Uyl-cabinet would have been carried out even if finances had allowed it to do so. The reason is that by the end of the 1970s fundamental critique of the expanded welfare state came to be expressed ever more loudly. By the late 1970s, sociologists started noting a 'crisis of the welfare state'. ${ }^{116}$ With this, they pointed to the apparently negative effects the welfare state had on the autonomy and self-sufficiency of citizens. ${ }^{117}$ Far from enabling citizens to achieve self-fulfillment - which, as noted, had been one of the main aims of the progressive cabinet - it seemed as though social benefits sapped citizens of their private initiative and independence. One of the most influential critiques of this period was a 1979 book by social philosopher Hans Achterhuis, ironically titled The Market of Well-Being and Happiness. In this book, Achterhuis relied heavily on the social critiques of the Austrian philosopher Ivan Illich. According to Illich, Western society had become increasingly medicalized in the past decades, allowing doctors to impose their 'medical regime' ever further on society, with sometimes devastating consequences in the form of iatrogenic (i.e. 'doctor-induced') medical ailments. ${ }^{118}$ This development, along with the explosive expansion of the welfare state in the

\footnotetext{
${ }^{114}$ E.g. De Liagre Böhl, 'Consensus en polarisatie', 324-325; Hellema, Jaren zeventig, 178-179.

115 https://www.parlement.com/id/vh8Inhronvwv/tweede kamerverkiezingen 1977, accessed on 18-042019; Hellema, Jaren zeventig,

116 J.A.A. van Doorn and C.J.M. Schuyt (eds.), De stagnerende verzorgingsstaat (Amsterdam: Boom Meppel 1978); P. Thoenes, De crisis als uitdaging: opstellen over heden en toekomst van de verzorgingsstaat (Amsterdam: Kobra 1984).

${ }^{117}$ Van Klaveren, Onafhankelijkheidssyndroom, 166-167.

118 He did so in his 1974 Medical Nemesis.
} 
past decade, led Achterhuis to assert that "Every human being is treated as a patient from the cradle to the grave. This leads to a crippling dependency on professional care, which destroys self-care and autonomy." ${ }^{119}$ Where thirty years before Beveridge and Van Rhijn had argued for a 'cradle to the grave' role for government, in the context of an increasingly vocal and critical citizenry, such a vision for society now seemed undesirable. Very telling is that Achterhuis wrote his critique from the position of an insider - he taught social philosophy to social workers - an illustration of the way in which traditional conservative criticism of state intervention in the lives of individuals was now joined by critical voices from the left side of the political spectrum.

Moreover, such criticism was not limited to mere observers. In 1978, a collection of lectures was published by Wim Meijer, who had been State Secretary of Culture, Recreation and Social Work in the now-defunct progressive cabinet. Reflecting on the expansion of the welfare state in his introduction, the conclusions were far from optimistic. For one thing, Meijer signaled that under the new system solidarity had become a government affair, where it used to be 'spontaneous'. For another, in previous years criticism from within the welfare sector itself had grown, centering on the increased bureaucracy and the overall grip of government on the field. As such, Meijer concluded that "The crisis in the welfare state [...] is [...] not solely about financing [...] can the experience of solidarity [...] still go together with expanding professionalization and institutionalization?"120 All in all, from both the fields of health and welfare and the general culture, support for the interventionist welfare state seemed to be waning by the late 1970s. As a broader cultural development, historian Kees-Jan van Klaveren has recently summarized it thus:

From two sides, resistance to the welfare state grew. Leftist movements and thinkers critical of society, who had initially called upon government to reform matters, were now battling all institutes and institutions that exerted power and thus obstructed the individual in his or her selfdevelopment - and the government was the symbol of power and authority. On the other side of the political spectrum a conservative backlash was growing which offered increasingly forceful resistance to those espousing progressive reform. ${ }^{121}$

\footnotetext{
119 H. Achterhuis, De markt van welzijn en geluk. Een kritiek van de andragogie (Baarn: Basisboeken Ambo 1979/80) 40. Ten years later, the book had already been reprinted ten times. A similar critique is to be found in H. Vuijsje, Nieuwe Vrijgestelden. De opkomst van het spijkerpakkenproletariaat (Baarn: Anthos 1977).

${ }^{120}$ W. Meijer, Welzijnsbeleid. Een keuze voor verandering van de maatschappij (Alphen aan den Rijn: Samsom 1978) 20.

${ }^{121}$ Van Klaveren, Onafhankelijkheidssyndroom, 133.
} 


\section{New Political Winds}

All of this did not mean that the ideological foundations of the Den Uyl-cabinet crumbled or were razed immediately upon the installation of the 1977 confessional-liberal Van Agt cabinet. Prime Minister Dries Van Agt - who had been Vice Prime Minister in the previous cabinet instead started his tenure by steering a careful course between the progressiveness of the previous cabinet, and a more conservative stance: "The cabinet is aware that the government is not equipped to relieve all social wants and meet all needs [...] This does not mean that the government cannot take up new tasks [...]". ${ }^{122}$ Fighting injustice, meeting social needs, and helping people who were in a bind they could not get out of themselves would still remain fundamental tasks for the state. But a gradual letting go of the notion that the government could and should shape society could already be discerned as a core policy goal, one informed by the recent critiques of the paternalistic welfare state as a burden more than a relief. "Giving people responsibility does not mean saddling them with problems they cannot solve. What it does mean is to take people seriously, respecting them for their own sake, not mollycoddling them by solving every issue for them, and giving them the chance to develop themselves, also in the service of others." ${ }^{123}$ Moreover, by the time the confessionals and liberals once again took up governmental power, the financial crisis was in full swing. This would necessitate drastic costcutting measures, measures which had not come about through 'planning'.

The Van Agt-cabinets (1977-82) therefore formed a bridge between the political progressiveness of the (short) Den Uyl-era, and the new political winds of the $1980 \mathrm{~s}$, which would swiftly put an end to heavy-handed 'planning' in health care and to a large role for government in general. ${ }^{124}$ But if we take into account the long history of subsidiarity, sphere sovereignty and liberal individualism in Dutch politics and society, the conclusion seems warranted that what happened in the 1973-1977 progressive years was an exception to the emphasis that had been placed on private initiative in The Netherlands since the middle of the $19^{\text {th }}$ century. However, relatively novel was the wish to have and to keep rights and provisions that had been granted through national social legislation real and accessible, while at the same time costs were controlled. Combining the two motives of retaining the social progress made with the welfare state, without, however, giving the central government too much power, would from now on be a core goal in health care policy-making. In the following decade, a new strategy was proposed in the hopes of reconciling these seemingly opposed goals. This

\footnotetext{
122 Handelingen II, Regeringsverklaring 16-01-1978, p. 332 (via

https://www.parlement.com/id/vh8Inhronvw8/kabinet_van_agt_i 1977 1981).

${ }^{123}$ Ibid., p. 332.

${ }^{124}$ Van Agt would lead two other cabinets, which taken together ruled for only one year.

https://www.parlement.com/id/vh8Inhronvw7/kabinet van_agt ii 1981_1982, accessed on 11-05-2019.
} 
happened against the backdrop of a new political and ideological order, which first took root in an Anglo-American environment, but quickly found its way into Dutch politics as well.

The (Dutch) 1980s are often seen as the period in which 'neoliberalism' became the general political ideology with regard to how society should be ordered: provisions which had been provided by the state would therefore now have to be delegated to the market, on the assumption that the 'invisible hand' would force market parties to operate at their most efficient in a competitive environment. ${ }^{125}$ In The Netherlands, this development is often seen as running parallel with the political reign of the three cabinets led by Christian-Democrat Ruud Lubbers (1982-1994). It is indeed true that, in what was a far cry from the 1973-1977 cabinet, the political coalitions of Liberals (VVD) and Christian Democrats (CDA) quickly distanced themselves from the progressives' comprehensive view of government. ${ }^{126}$ In the inaugural statement of the 1982 cabinet, Lubbers was unequivocal in stating that, in times of scarcity, citizens could be expected to be thrown back on their " [...] own responsibility and initiative". ${ }^{127}$ Moreover, this renewed emphasis on private initiative was complemented by a focus on business and market parties. "[...] various types of privatization, among which delegating to citizens what the government has heretofore done, as well as applying the profit motive, must be supported [...] from now on government policy must be systematically checked for its effects on business." ${ }^{128}$ In this respect, the political winds set in motion from 1982 onwards reflect the international developments of the time, in particular the political reigns of Ronald Reagan in the U.S. (1981-1989) and Margaret Thatcher in the UK (1979-1990). ${ }^{129}$ The political desire for a balanced budget that had already been expressed by the Den Uyl-cabinet was now complemented with an emphasis on the limited role of government.

Echoing Margaret Thatcher, Ruud Lubbers and his administration quickly came to speak of the Netherlands in terms of a company, in need of 'managing' through 'no-nonsense policy'. ${ }^{130}$ Underlying the desire to give free rein to business in order to stimulate job growth was the assumption that an increased role for business and civil society would have to come at the cost of the size and influence of the government. It would take quite a few years before this new philosophy of making government 'lean and mean' was really implemented. For instance, only at the end of the 1980s did the number of government civil servants come to be drastically

\footnotetext{
125 See, e.g., Hellema, Jaren zeventig, 259-261, 272.

${ }^{126}$ However, in the third Lubbers cabinet of 1989-1994, the Social Democrats replaced the Liberals. https://www.parlement.com/id/vh8Inhronvw3/kabinet lubbers iii 1989 1994, accessed on 18-04-2019. ${ }_{127}$ Handelingen II, 1982-1983, 21 (inaugural statement of cabinet Lubbers-I, 22-11-1982) p. 641-642. ${ }^{128}$ Ibid., 636.

129 Gamble, 'Ideologies of governance', in: Payne and Phillips, International Political Economy of Governance, 19-29.

${ }^{130}$ S. Keulen, Monumenten van beleid. De wisselwerking tussen Nederlands rijksoverheidsbeleid, sociale wetenschappen en politieke cultuur, 1945-2002 (Hilversum: Verloren 2014) 182-183.
} 
reduced. ${ }^{131}$ But the new political drive towards shifting responsibilities and the primacy in enacting change in society back to citizens, civil society and the marketplace was unmistakable. In just a few years, the 1973-1977 focus on 'planning' and 'remaking society' would once again be replaced by a strong emphasis on private initiative and the maxim of small government. However, the by now accepted notion of solidarity and broad support for access to affordable and equal health care limited the possibilities for what the 'market' could achieve in health care. By the time a new 'blueprint' for structuring health care was produced in 1987, it was clear that old ideas about private initiative and subsidiarity could be presented alongside a significant role for the government as guarantor of solidarity and access to health care.

\section{Reinventing Health and Welfare in a New Liberal Age}

Where health care and welfare services were concerned, it is striking how quickly the new political order of the 1980s revitalized old traditions of private initiative. This began already in 1983, when the so-called General Act on Specific Welfare (Kaderwet Specifiek Welzijn) was discarded by the new Minister for Health, Elco Brinkman (of the confessional CDA-party). This act - first presented to Parliament in 1977 - had been intended to bring together the broad range of welfare services, among them health care, social work, and other services. However, both the 'framework' character of this law and its by now increasingly critiqued intent on bringing about 'cradle-to-the-grave' welfare provisions, in the early 1980s led to rapidly dwindling support. Moving away from legislation which would keep citizens protected 'from the cradle to the grave', Brinkman instead wanted to stimulate the development of a 'caring' society, in which citizens first and foremost took care of themselves, their friends and their relatives, before turning to the government for aid. ${ }^{132}$ This abandoning of the far-reaching ideas of the 1970s was a blow to progressives, but the emphasis on citizen responsibility was not at all surprising or, as we have seen, new. In fact, the 'neoliberal' political winds of the 1980s harked back to age-old political positions with respect to Liberalism and autonomy - both for and within Protestant and Catholic communities.

Moreover, though the (financially-driven) emphasis on business as a motor for social change was a rather new element in this discourse, recasting citizens in terms of 'critical consumers' and society as a marketplace allowed the development of new notions of autonomy

\footnotetext{
${ }^{131}$ For the changes in the administrative body, see Keulen, Monumenten, p. 189-190.

132 Van Klaveren, Onafhankelijkheidssyndroom, 195-197; De Haan and Duyvendak, In het hart van de verzorgingsstaat, 126-129, 179-183.
} 
and independence which tied in quite naturally with older ones. This can be seen in the development of the new notion of 'critical patients', who henceforth should be legally empowered in order to achieve the form of self-realization considered unattainable in a paternalistic welfare state. On the level of legal discourse concerning the right to health care, this development had already been set in motion in 1973, when the second professor in health care law in The Netherlands, Jacob Rang, held an inaugural lecture arguing for 'patient rights'. "It is obvious that in both medical ethics and medical morals the patient is the key figure; but when it comes to translating this fact to legislation, the patient seems to have disappeared." ${ }^{133}$ Shortly thereafter, governmental committees set out to work on preparing legislation which would codify such 'patient rights'. ${ }^{134}$ Moreover, these calls found broader institutional resonance when patient advocacy groups came to be founded, such as the General Association for the Furthering of Patient Interests (Algemene Vereniging tot Behartiging van de Patiëntenbelangen) of 1975, which for the first time came to represent the general interests of patients, not just the interest of certain patient groups. ${ }^{135}$

All of this attested to changing winds in how patients were perceived in an era in which not an overbearing state, but the protection offered by individualized rights seemed to fit in better with the new notion of autonomous citizens. In 1981, State Secretary of Health Care Els Veder-Smit published the Report on Policy Concerning Patients (Nota Patiëntenbeleid 1981). In this report, she asserted that 'consumers' had too little influence on health care provisions, which was a problem given the latter's uncoordinated growth in previous years. Veder-Smit argued that the recent rise of patient federations was an attempt by patients to (re)gain control of their autonomy in an increasingly bureaucratic health care system. As it was, patients " [...] could easily become dependent on a powerful centralistically-organised system capable of influencing [their] life in significant ways [...] This heightens the sense of alienation in all concerned." ${ }^{136}$ And just a year later, the influential Scientific Advisory Council for Government Policy (Wetenschappelijke Raad voor het Regeringsbeleid) published its Re-evaluating Welfare Policy, which stated that "The criticism leveled at the well-being sector [...] is, in its comprehensiveness, a cultural critique." ${ }^{137}$ Although the merits of the expanded welfare state were seen by all, "Citizens seem to be alienated by existing institutions which are meant to

\footnotetext{
133 J.F. Rang, 'Patiëntenrecht', in: Vereniging voor Gezondheidsrecht, Oratiebundel gezondheidsrecht. Verzamelde redes 1971-2011 (Den Haag: Sdu Uitgevers 2012) 43-72, 49.

${ }^{134}$ For this new discourse on patients' rights, see: N. Jacobs, Ethics by committee. Governing human experimentation in the Netherlands, 1945-2000 (diss. Universiteit Maastricht 2018) 114-127.

135 See, e.g.: P. Muntendam, 'De betekenis van patiëntenverenigingen voor de gezondheidszorg in Nederland', Ned. T. Geneesk. 12322 (1979) 933-936.

${ }^{136}$ E. Veder-Smit, Nota Patiëntenbeleid 1981 (Den Haag: Staatsuitgeverij 1981) 11-13 (quote on p. 13).

137 Wetenschappelijke Raad voor het Regeringsbeleid, Herwaardering van Welzijnsbeleid (Den Haag: Staatsuitgeverij 1982) 297.
} 
embody and safeguard solidarity." ${ }^{138}$ In order to combat this sense of alienation and confusion among patients, as well as among health care professionals who operated in a system growing increasingly complex, what was called for was more citizen participation and responsibility, and more social equality and decentralization, at all levels, of health care and welfare policy.

Significantly, the introduction of market elements into (specifically) health care was suggested, in order to create 'incentives' for all parties to move beyond bureaucratization and towards more efficiency and clarity in the way services were provided. ${ }^{139}$ Such ideas resonated in medical circles, in which the almost continuous legislative changes and the sword of Damocles of cost control of the post-Hendriks decade were leading to increasing insecurity and irritation.

Economists and legal scholars followed up on the perceived need to deregulate and 'marketize' health care, continuing the line of reasoning set out by the WRR. ${ }^{140}$

In this light, the new governmentality of the 'regulated health care market' proposed in the late 1980s was a radical break with the most recent governmentality of planning, but not with older notions of independence, autonomy and the primacy of citizens in social affairs, now tied to the need to contain costs. But the health care system would not have taken the turn it ultimately did - combining market elements with a mandatory health insurance scheme for all Dutch citizens - had it not also been for the strong growth of social access to health care made possible in the post-war era. That there was a strong line of continuity in this tradition even under the 1980s confessional-liberal cabinets can be seen by looking at two lines of policy aimed at keeping health care financially sustainable: the continuation of the structuring plans set out by Hendriks in 1974, and the introduction of a 'minor system reform', which would have major consequences for the social character of the health care system.

\section{Curbing Costs, Assuring Access, 1977-1986}

The initial push towards 'privatization' and reducing the role of the state in social affairs was hardly ideology-driven. By the end of the 1970s, the worldwide economic crisis hit the Netherlands hard. As noted, the 1977-1981 cabinet-Van Agt, comprised of Christian Democrats and Liberals, had initially looked for a middle ground in reconciling social needs and financial prudence: the cabinet's program set out as the primary task of the cabinet "[...] the curbing of

\footnotetext{
138 Ibid., 8.

139 Ibid., 289-293.

140 See, e.g.: J.P. Kasdorp and G. Schrijvers, 'Deregulering, een recept voor de gezondheidszorg?', Conference Deregulering in de gezondheidszorg (Utrecht: Rijksuniversiteit Utrecht 1984) 7-36; H. Roscam Abbing and F.F.H. Rutten, Verleden en toekomst van het ziektekostenverzekeringsstelsel in Nederland (Deventer: Kluwer 1985) 119-133.
} 
unemployment and inflation". ${ }^{141}$ In the following years, however, a nuanced position would prove unsuited for the times. Between 1977 and 1981, the state deficit grew from 3,8\% to 8,2\%, in part because the cabinet was confronted with strong opposition to proposed cutbacks. ${ }^{142}$ Meanwhile, as shown in table 3.1, the need to curb rising costs in health care remained unabated. By 1980, costs for health care had grown to 8,1\% of GDP, up from 6,7\% just eight years earlier. Action was still called for, and the challenge was taken up by the Liberal Els VederSmit, who became State Secretary for Health Care. We have already seen how both the acts on health care provisions (WVG) and tariffs (WTG) were instituted under her tenure, although the tariff act would only become really effective as a policy instrument after 1983, under VederSmit's successor. The ill fate of the WVG as a comprehensive 'planning' act has been discussed above. Instead, curbing costs now was to be achieved through small or 'incremental' steps. However, though focusing on the substitution of expensive types of care with less expensive ones (intramural for extramural, for instance) and despite the 1977 cabinet's proposal to demand supplementary payment for certain types of medical care, small measures were as of yet not very effective. ${ }^{143}$ Most significant from the perspective of governmentality shifts with regard to private and public provision of health care was the way in which in 1980 the extramural care provided through the Cross Associations came to be financed through the AWBZ. These associations, which twenty years before had still been the exemplars of 'private initiative' in health care - though they had become increasingly dependent on government subsidies, as we have seen - under increasing financial pressure saw the benefit of officially being brought into the governmentally mandated insurance scheme. Veder-Smit managed to have a motion to that effect passed in 1979, and on January 1,1980 , the 'Crosses' came within the fold of Veldkamp's broad national insurance. In terms of governmentality, this was a significant shift, as what had been the pinnacle of 'private initiative' in (public) health care arrangements for decades now became part of the national scheme of distributing funds for long-term care. ${ }^{144}$

Moreover, by the time the first cabinet-Lubbers entered office, the financial situation had become so fraught that no one questioned the need for financial austerity any longer. In fact, the emphasis on tightening the belt of government finance became even stronger. Where Veder-Smit had been tasked with saving some 2 billion guilders in health care, her successor Joop van der Reijden in 1982 was immediately tasked with cutting back a further 3 billion guilders. Moreover, growth in health care expenditures would have to be stopped entirely by

\footnotetext{
${ }^{141}$ A.A.M. van Agt e.a., Bestek '81. Hoofdlijnen van het financiële en sociaal-economische beleid voor de middellange termijn (Den Haag: Staatsuitgeverij 1978), p. 5.

142 De Liagre Böhl, 'Consensus en polarisatie', 329.

${ }^{143}$ Companje et al, Vijftig jaar kostenbeheersing, 50-60, 66.

144 Kerkhoff and Dols, 'Algemene Wet tot 1987', 756-757.
} 
1986. ${ }^{145}$ To achieve such ambitious goals, Van der Reijden set out two lines of policy that focused on the 'supply-side' of health care. On the one hand, there was the curbing of costs in health care provisions through measures focused on keeping in check 'buildings, beds, and budgets'. ${ }^{146}$ On the other, Van der Reijden went out on a limb in tackling services: he wished to lower tariffs and fees of medical specialists and GPs. Moreover, Van der Reijden again took up the challenge of reforming the system of financing, in essence going back to what Veldkamp in the 1960s had hoped would become a coherent triptych of health insurance forms. ${ }^{147}$ We will return to this third element in the next paragraph.

On balance, the effect of the various policy measures Van der Reijden took to meet his budget targets was a mixed-bag. With his hard-headed way of negotiating and operating, Van der Reijden resembled Veldkamp more than Hendriks. And much like Veldkamp, his tactics proved effective in quite a few areas. Despite tough negotiations with doctors, in 1985 Van der Reijden managed to come to a General Agreement on salaries for specialists and a Covenant with GPs. Salaries for other health care workers were frozen, in a continuation of the policy set in by Hendriks. ${ }^{148}$ And in 1983 the aforementioned Act on Tariffs was changed so that it could now be used to effectively sanction hospitals and other intramural institutions for exceeding allocated budgets (by shorting them the following year). ${ }^{149}$ Nevertheless, some actions had entirely unintended consequences, such as the introduction of mandatory supplementary payments for prescription medicines into the sickness fund package. As a result of this, the number of prescriptions was indeed cut back. However, to compensate, doctors began to prescribe more medicines per prescription, effectively making the measure useless. ${ }^{150}$ Substitution of clinical by polyclinical care was hardly a success, and the State Secretary's target for reducing the number of beds was achieved almost nowhere. On the whole, budgeting proved to be the most effective measure for keeping down costs. ${ }^{151}$ And ultimately, Van der Reijden was surprisingly successful in keeping the way in which health care expenditures rose in check, as is illustrated by table 3.2:

\section{Table 3.2 Health care expenditures in guilders $x$ million (f.-), 1982-1988}

\begin{tabular}{|l|l|l|l|l|}
\hline & 1982 & 1984 & 1986 & 1988 \\
\hline $\begin{array}{l}\text { Intramural } \\
\text { care }\end{array}$ & 18.201 & 18.679 & 19.675 & 20.420 \\
\hline
\end{tabular}

\footnotetext{
145 De Haan and Duyvendak, In het hart van de verzorgingsstaat, 218.

${ }^{146}$ Kamerstukken II, 1983/1984, 18 279, no. 2.

147 De Haan and Duyvendak, In het hart van de verzorgingsstaat, 217-219.

148 Ibid., 219.

149 Plomp, Winst in de zorg, 107-108.

150 Kerkhoff and Dols, 'Algemene Wet tot 1987', 760-761.

${ }^{151}$ For this, and for the overall effectiveness of cost interventions in the Van der Reijden period, see Companje et al, Vijftig jaar kostenbeheersing, 126-128.
} 


\begin{tabular}{|l|l|l|l|l|}
\hline $\begin{array}{l}\text { Extramural } \\
\text { care }\end{array}$ & 11.252 & 12.012 & 13.225 & 14.426 \\
\hline $\begin{array}{l}\text { AWBZ- } \\
\text { financed } \\
\text { care }\end{array}$ & 7.889 & 8.385 & 8.767 & 9.516 \\
\hline As \% of GDP & 8,4 & 8,1 & 8,2 & 8,1 \\
\hline
\end{tabular}

Source: Centraal Bureau voor de Statistiek, Kosten en financiering van de gezondheidszorg 1972-1992. Costs and financing of health care 1972-1992 ('s-Gravenhage: Sdu 1994) 6-7.

Overall, the patchwork of measures taken in the 1980 s to curb rising costs was a far cry from what Hendriks had hoped would be the elegant legislative triptych of WVG, WTG, and national health insurance which would have granted government a coherent set of instruments to steer the direction health care would take. Instead, Van der Reijden's relative success in cutting costs and steering the course of health care through varied governmental measures led to what might be termed emergent government control in health care - despite Van der Reijden's own party's emphasis on once again slimming down the central state in health care, the mix of smaller measures instituted (especially budgeting) would give the state types of influence that would only grow in strength as time progressed, while limiting the perception that it was creating too much of an overt role for itself. The move towards more incremental measures was born of necessity rather than desire. Nevertheless, it would prove far more effective than top-down policymaking. However, in one very important respect a shift in governmentality had occurred: the 1983 change to the Act on Tariffs for the first time gave the government a serious say over the budgets of hospitals and other intramural institutions - even if general financing had not yet been streamlined through national legislation. Still, budgeting was but one element of a broader package of planning measures which never came to fruition.

At the same time, despite the surface rhetoric of a 'return' to citizen and patient initiative and autonomy in health care, it is clear that the policymakers who worked within the ideological paradigm of the 1980s clung to the notion that the government should guarantee broad access to health care. This is illustrated by the way in which they followed the lines set out by Hendriks for curbing costs. In essence, these policy lines only rarely came down to limiting access to health care - in effect, cutting back provisions for patients - but rather to streamlining the organization and financing of the provisions of health care; in other words, they affected the supply, rather than the demand side. However, with the failure of the planning paradigm, structuring came about through various bottom-up instruments which showed coherence primarily in the politicians wielding them. 


\section{Van der Reijden's 'Minor' System Reform}

For Van der Reijden, this coherence was to be found in his final policy success, one which had been toyed with by various predecessors but which, in practice, had proven too politically toxic many times over: the expansion of mandatory health insurance to a broader part of the population. Van der Reijden had proven to be quite the 'fixer' in terms of cutting health care costs - much like his Prime Minister, 'political trouble-shooter' Lubbers ${ }^{152}$ - but now a Christianbased form of solidarity, similar to the one which had inspired Veldkamp a decade and a half before, came into the picture. ${ }^{153}$ Van der Reijden's final, but very major intervention in the health care system, was in a sense the last (and maybe most serious) measure in the vein of 'planning'. This operation would be termed the Minor System Reform, but its implications in guaranteeing access to health care, while it at the same time opened the way for the convergence between sickness funds and (for-profit) private insurers a decade later, were profound. In passing, attention already has been paid in this and previous chapters to the way in which after the war the sickness funds offered voluntary access to their packages to groups of citizens not qualifying for compulsory insurance (e.g. small businessmen). Moreover, in 1957, sickness fund insurance had been opened up to the elderly, which was a subtle but very important development. Before the creation of compulsory insurance, sickness funds often had to resort to risk selection to keep themselves afloat financially, and this had sometimes meant keeping out costly patients such as the chronically ill and/or elderly. However, with the creation of a new government-backed sickness fund scheme for the (costly) elderly, the costs for keeping this scheme afloat had continuously grown. This was reflected not just in the rise of sickness fund premiums; the government also supplemented funding to ensure access for the elderly, which in effect meant subsidizing a portfolio of increasingly expensive sickness fund patients. By the 1980s, these amounted to nearly $8 \%$ of the population. ${ }^{154}$

For their part, commercial insurers were caught in a bind. These had, in previous decades, increasingly moved towards the social provision of health insurance and were in 1968 by way of a sort of reward also included in the AWBZ scheme, as we have seen. However, they were now faced with the same cost increase as the sickness funds because of an ageing population and new medical technologies. These insurers, however, could and did not wish to revert to harsher insurance policies (such as risk selection), as this would surely give the government an argument for pushing through universal health insurance. The only option left to the private insurance

\footnotetext{
152 Van Klaveren, Onafhankelijkheidssyndroom, 174.

${ }^{153}$ And, like Veldkamp, Van der Reijden set out his notions in his 1987 memoirs, Onze kostelijke gezondheid, in which he took a stance against the increasing presence of 'market rhetoric' in health care. J.P. van der Reijden, Onze kostelijke gezondheid (Amsterdam: Balans 1987).

${ }^{154}$ R. Bertens and R. Vonk, E Pluribus unum. Forging a public-private health insurance system in the Netherlands (forthcoming).
} 
industry was to offer attractive (cheap) policies to low-risk sickness fund insureds in a bid to get them to switch to private insurance. By and large, this strategy was successful, with the predictable result that the sickness funds were left with the expensive health risks, a development which by the early 1980s practically bankrupted the voluntary sickness fund schemes. ${ }^{155}$ Because of this, Van der Reijden now saw possibilities for pushing through what has been called a 'limited universal insurance'. ${ }^{156}$ In order to keep the sickness fund scheme sustainable and affordable, a portion of the health 'risks' under the sickness fund would have to be transferred to the private insurance segment. In doing so, Van der Reijden did not operate in a vacuum: many parties already anticipated political action to keep sickness fund prices affordable, with for instance private insurance in 1983 beginning to subsidize the sickness funds to the tune of 180 million guilders. This was seen by many as a manoeuver to divert attention from the private insurers' predatory practice of 'hijacking' young and healthy sickness fund insureds. $^{157}$

As a result, Van der Reijden saw an opening and proposed a system reform that concerned only the insurance schemes offered on a voluntary basis and those for the elderly, as these were practically bankrupt. These voluntarily insured and the elderly, moreover, represented a significant portion of the population - some 2,5 million people. Van der Reijden showed great political talent by cajoling and convincing parties on the left (who wanted a broad basic insurance) and on the right, who argued for cutting the sickness fund package to reduce costs or were in favor of a different proposal altogether. Despite such criticism, in March 1986 Van der Reijden managed to get the Act on Access to Health Insurance (Wet Toegang Ziektekostenverzekering) accepted by Parliament. Through this act, voluntary sickness fund insurance (including the separate insurance scheme for the elderly) was dissolved. The insureds it concerned were instead divided amongst sickness funds (1,7 million) and private insurers (800.000), on the basis of their income. In line with Van der Reijden's social motives, private insurers were now obliged to offer a standardized health insurance package with maximized premiums to those over 65 , which effectively closed the option of risk selection or an endless raising of premiums for those formerly insured through a sickness fund. To further strengthen solidarity, two satellite acts were passed which forced those who were privately insured to contribute financially to the sickness funds' portfolio (Act MOOZ), and to even out the differences between private insurers with a healthy portfolio and those with an unhealthy one (Act ILPZ). ${ }^{158}$ To outsiders, all of this may have seemed the incomprehensible workings of an

\footnotetext{
155 Vonk and Schut, 'Universal access', 12-14.

${ }^{156}$ Kerkhoff \& Dols, 'Algemene Wet tot 1987', 766.

${ }^{157}$ Ibid., 763.

${ }^{158}$ See, for all of this: Kerkhoff \& Dols, 'Algemene Wet tot 1987', 761-768; Vonk and Schut, 'Universal access', 14-15; Vonk, Recht of schade, 251-255. The abbreviations stood for 'Wet Medefinanciering
} 
arcane insurance system, but Van der Reijden's 'minor' reform "Was the most radical government intervention in the world of health care security since the Sickness Funds Decree of 1941." 159

One of the reasons Van der Reijden managed to get his acts passed in Parliament, was that he continuously argued that the 'minor' system reform was a mere prelude to something bigger: a plan for universal health insurance resembling what Veldkamp had initially hoped for in the 1960s. Though political support for such a broad overhaul - which neither Veldkamp nor Hendriks had managed to achieve, as we have seen - might have been very hard to garner had Van der Reijden actually proposed a plan to that effect, a 'minor' system reform was clearly more acceptable. But the subtle effects of the Minor System Reform would be enormous: not only had a financial crisis in the insurance scheme for the elderly and those voluntarily insured at a sickness fund been averted, but a sizeable part of the historically most vulnerable, expensive, and hard to insure segment of the population was now pushed forcefully into the lap of private insurers, who could no longer differentiate premiums or refuse to accept this particular group of insureds into their portfolio. The direct effects of such a change would have been far less visible to the general public than a broad 'system overhaul' would have been. However, Van der Reijden's reforms further strengthened the social elements of both the sickness fund and private insurance schemes, opening the way for a convergence between the two branches in the 1990s.

However, van der Reijden never got a chance to launch his triptych of AWBZ, sickness fund, and complementary insurance. That electoral support for the practical policies, as well as the general ideological position of the first Lubbers-cabinet was broad, is illustrated by the fact that the confessionals and liberals retained their position in the 1986 elections without any problem. Most ministers even returned to their posts, a rarity in Dutch political history. But that van der Reijden did not return in the second Lubbers-cabinet, despite his enormous successes as a 'fixer' of expenditures in health care, attests to the fact that in health care, too, a new governmentality in line with the times was called for. This governmentality was that of regulated competition. We turn to that 'new' governmentality - which in crucial senses echoed older ones - in the next part.

\section{Conclusion}

Oververtegenwoordiging Oudere Ziekenfondsverzekerden' and 'Wet Interne Lastenverevening Particulier Ziektekostenbedrijf'.

159 Vonk, Recht of schade, 254. 
By the middle of the 1980s, when the era of 'planning' in health care came to an end, a provisional endpoint was reached in developments which in the late 1950s would hardly have seemed possible. Although broad access to many curative provisions had been achieved with the Sickness Funds Decree of 1941, the two post-war decades had mostly seen a return to the rhetoric of government abstinence apart from necessary restoration, and of the preservation of relations in health care as they were, without the further expansion of the 'welfare state' that shortly after the war was believed to be so necessary by Beveridge and Van Rhijn. That health care provisions nevertheless could develop without obstruction, as we have seen in the previous chapter, came about despite regulation that guaranteed access to health care rather than because of it. But by the middle of the 1960s, economic expansion was increasingly accompanied by new notions of the 'right to health care' and by the spreading of the welfare ideology beyond the social-democratic circles where it had originated. This led policy-makers from outside the socialist fold to conceptualize and implement much further-reaching welfare provisions than the Social-Democrats had ever achieved. While the Catholic Marga Klompé had been responsible for creating national social security for the indigent - replacing local responsibility by financial backing for national responsibility - her colleague Veldkamp firmly engrained the health care field with notions of solidarity and government-backed access. In 1965, the Sickness Fund Act codified those ideas with respect to curative care. But in 1968 Veldkamp went even further by creating comprehensive access to provisions for long-term care. The result of this far-reaching legislation was that from now on, patients who would previously have had a very hard time getting insurance or financial support for their chronic conditions now got guaranteed access to care through the state. That such seminal legislation was enacted by Catholics (and won broad political support) attests to the fact that by now the welfare ideology was widespread.

At the same time, such a rapid expansion of the welfare state and of access to health care provisions accelerated the need for centralized structuring of health care, especially when the economy started taking a turn for the worse from the middle of the 1970s. The fact that the maxim used for such structuring was 'planning' was very much a sign of the times: in 1974 State Secretary Hendriks proposed to introduce a triptych of legislation which would give the government unprecedented control over health care (albeit 'decentralized') and he did so in the most left-wing, progressive cabinet the Netherlands has ever seen. Now, however, echoes of the notions of liberalism, sphere sovereignty and subsidiarity - though often no longer religiously inspired - came to be heard again, and not just in the health care field. Hendriks' legislative 'triptych' of regulating health services, tariffs, and instituting universal health insurance stumbled over objections from both political parties and the parties in the field, but it also ran up against broad cultural resistance to an all-encompassing 'cradle to the grave' welfare state. By the late 1970s, such a state was increasingly critiqued by both the left and the right for fears that it would sap individual citizens of their autonomy. When different political winds started blowing 
in the late 1970s and early 1980s, broad support for the 'nanny state' was dwindling in the Netherlands, and the relatively short era of radical progressivism in Dutch politics was again followed by more than a decade of confessional-liberal dominance. Under that dominance and the leadership of Christian-Democrat Ruud Lubbers, mantras of privatization, deregulation, and letting market parties take care of social provisions which had been taken on by the government in the previous two decades, came to be heard ever more loudly.

Now, both the intended governance - the structuring of the totality of health care provisions - and the underlying mentality - the notion that the state should play an overt role in structuring health care - were traded in for a new governmentality of the 'regulated health care market'. However, the new rhetoric of the 'market' in health care and other social provisions can easily obscure the level of continuity in how government continued to safeguard and even expand access to health care. Policymakers from the late 1980s onwards to the present day would fairly consistently maintain a rhetoric of minimal government interference, while respecting the reality of a system that now included a comprehensive right to health care. In fact, the introduction, in 2006, of the regulated health care market would extend this reality to an unprecedented degree. But the age-old notions of subsidiarity and autonomy would interlock surprisingly well with the emphasis on solidarity and the broad role for government in health care that had been developed in the post-war decades. In the period to which we now turn, the state and the health care field would be whistling echoes of Thorbecke's tune again but the times had changed radically, and there would be no going back to the Liberalism of old. 



\section{Part IV: Governmentality of the Regulated Market, 1987-2015}

In which the introduction of the 'health care market' goes back to an old governmentality, but the state's role in providing access to health care grows larger than ever 


\section{Introduction}

"The cabinet is of the opinion that there must be a revision of the role of the various parties in health care. The starting point is that public interests in health care must remain uncompromised. In part because of its constitutional task, the government holds itself responsible for guaranteeing necessary, accessible care of good quality for all Dutch citizens, regardless of age, health prospects or income. The government will set the boundaries within which parties will have the opportunity to be more active than is currently the case. Through a suitable system of "checks and balances", these parties must stimulate each other to offer good, efficient care, optimally suited to the desires of citizens. Through such a strategy, the government aims to strengthen the ability of the health care sector to operate in an innovative and self-regulatory fashion." ${ }^{1}$

When the quote above was published in a seminal 2001 report, the call for the government to reform the health care system in order to gain more control over costs, quality, and access was at its peak. As we have seen in the previous chapter, attempts at instituting more state control over health care through 'planning' in the period between the early 1970s and the mid-1980s failed rapidly. But the necessity for control remained, as costs in health care kept rising, and the government by now was deeply implicated in the provision of health care through the Sickness Fund Act and the AWBZ. In 1987, a new governmentality for health care was therefore presented, which both acknowledged the state's task in providing for care while at the same time it went back to old forms of governance and governmentality in health care. The proposal put forward in the important 'Dekker-report' of 1987 was one of instituting a 'regulated health care market': instead of the 'paternalistic', big government of the preceding decades, the parties in the field would once again have to take the reins in keeping costs in health care at an acceptable level. This would have to be achieved through the introduction of elements of competition into the relations between insurers and health care providers, with both parties

\footnotetext{
${ }^{1}$ In the original: "Het kabinet meent dat er sprake moet zijn van een herziening van de rol van partijen in de gezondheidszorg. Uitgangspunt is dat de publieke belangen in de gezondheidszorg geborgd blijven. Mede gezien haar grondwettelijke plicht acht de overheid zich er verantwoordelijk voor dat noodzakelijke zorg van goede kwaliteit, voor alle Nederlandse burgers toegankelijk is, ongeacht hun leeftijd, gezondheidsvooruitzichten of inkomenspositie. De overheid zal de kaders stellen waarbinnen partijen meer dan nu de mogelijkheid zullen hebben om actief te kunnen zijn. Door een passend systeem van "checks and balances» moeten deze partijen elkaar er toe aanzetten om goede en doelmatige zorg tot stand te brengen die maximaal aansluit bij de wensen van burgers. Het kabinet beoogt langs deze weg het innovatief en zelfregulerend vermogen van de gezondheidszorgsector te vergroten." Parts of this chapter appeared earlier in R. Bertens, Care, Cost and Questions of Control. Dutch Health Care Reform 1987-2006 (RMA thesis; Utrecht University 2016).
} 
trying to win the favor of insureds/patients and in the process bringing down costs while also reducing bureaucratic overhead. However, the right to health care now guaranteed by the government meant that the state would still have a large role to play in regulating health care (among which its cost), and the Dekker-report, crucially, also solidified the significant access to health care by now provided by the system, as it proposed introducing a basic national insurance for the entire Dutch population. The old governmentality of 'private initiative' therefore was fused together with the extensive responsibilities that the central state had taken on in the post-war decades to provide the Dutch citizenry with access to health care. This development had unmistakable paradoxical qualities: a blueprint had to be provided by the state in order to bring about a health care 'market'.

System reform was a long time coming. Already in 1986, when State Secretary Van der Reijden finalized his Minor System Reform, Prime Minister Lubbers was abandoning the notion that governing health care in a way which would both guarantee broad access to health care and optimize cost-effectiveness could best be achieved through top-down measures. Behind the scenes, both the new governmentality and the rhetoric with respect to recasting the health care system in a market mould - which had begun to arise in the early 1980s - were now increasingly seen as the way to go in an age of slimming down government and 'giving back control' to patients who were increasingly seen as critical health care consumers. However, after the Dekker-report, it would still take some twenty years before its proposals were introduced in a substantial way. The opening quote above comes from the 2001 report Supplying Demand (Vraag aan Bod), which again revived ideas of the 'Dekker' report after some 15 years of political negotiation had failed to bring about the changes that had been proposed by 'Dekker'. In this part, we will look at the way in which the new governmentality put forward in 1987 led to a flurry of political activity with initially few legislative results. However, despite bombastic political rhetoric of 'grand system reform' leading to little result during the late 1980s and 1990s, such parties in the field as insurers and hospitals did in fact very much begin to prepare for a transition towards the 'health care market'. At the same time, notions of solidarity and the state's responsibility for providing for health care were strengthened through the growing problem of waiting lists in health care. By 2006, when the health care market was introduced, state and market, government and private initiative had become entwined in unprecedented ways, raising the question to what extent the rhetoric of this latest (and current) governmentality of Dutch health care matches up to its reality. But let us first turn to its blueprint: the 1987 Dekker-report. 


\section{A New Blueprint for Regulating Health Care: The 1987 Dekker Report}

In 1981, a report on the future of Dutch industry, written by a committee chaired by Dutch captain of industry Gerrit Wagner of Royal Dutch Shell, had been presented to the government. ${ }^{2}$ While such an approach might have made intuitive sense for the business sector, in 1986 it was transferred to health care policy-making - by now very much a concern for public policy, given the importance of the Sickness Fund Act and the AWBZ. Why Prime Minister Lubbers came up with the idea to charge Wisse Dekker with chairing a committee which would have to write a new 'blueprint' for health care is not entirely clear. But that this position was given to Dekker is a telling sign of the times. Wisse Dekker had until recently been CEO of the electronics giant Philips, one of the biggest capitalist enterprises the Netherlands had ever seen. To expect from Dekker a report which would emphasize socialist-style, top-down government interventions would have been wishful thinking, to say the least.

But this was not at all the intention of the political coalition now in power. With Joop van der Reijden having left the political scene in 1986, his Liberal successor Dick Dees made it abundantly clear that the coalition of confessionals and liberals wanted to get rid of all last remnants of Hendriks-style 'planning'. In his speech at the installation of the Dekker-committee, Dees left little to the imagination of the committee members in charging them with the task to produce a new proposal for reorganizing health care: "I do not wish to impose an absolute choice for one specific strategy. I would, however, emphatically propose that you pay attention to a more market-oriented one." ${ }^{3}$ The committee in part reflected such thinking. Dekker's group consisted of professors in econometrics and public financing, as well as cardiologist Arend Jan Dunning - all from outside the governmental bureaucracy (even if Dekker himself was the only real 'representative' of the business sector). But the committee also reflected the long tradition of corporatism and (religious) private initiative in The Netherlands. One member of the sevenheaded group was also a member of the Senate for the Christian-Democratic Appeal, as well as a director of the Reformed Association for 'Social Affairs'. ${ }^{4}$ Rounding out the committee was Henk Leenen, whom we have encountered in the previous chapter as one of the 'founding fathers' of health care law and by now professor of the Social backgrounds of health and health

\footnotetext{
${ }^{2}$ Adviescommissie inzake het industriebeleid, Een nieuw industrieel elan (Den Haag: Staatsuitgeverij 1981).

${ }^{3}$ Cited in Vonk, Recht of schade, 281.

${ }^{4}$ J.J.M.S. Leyten-de Wijkerslooth de Weerdesteyn, who had been very active in the participation of the Catholic People's Party in the Christian-Democratic Appeal.

(https://www.parlement.com/id/vg09Ilmk0bzj/j_j m s madeleen leyten de wijkerslooth). G.J. Hazenkamp was director of the Stichting Landelijke Gereformeerde Raad voor Samenlevings-Aangelegenheden. See Dekker-report, p. 1.
} 
care at the University of Amsterdam. Support from the Ministry came in the form of two advisors, the Directors-General of Health and Welfare Services.

When the report appeared in March 1987, anyone who might have feared that rethinking the health care system along market lines would lead to harsh for-profit insurance practices, a return to risk selection of chronically ill and therefore expensive patients, and a primary focus on personal responsibility was put at ease. In fact, most of the direct criticism of the report would shortly come from the united for-profit insurers, who saw in it their future demise. This is because Dekker's report combined the old rhetoric of private initiative with the broad accessibility and predominantly social character that had come to characterize the Dutch health care system over the past century. In the opening words of the report, Dekker's committee stated that:

The proposals made in this report all serve one goal: to create an efficient system that is sufficiently flexible to allow the supply-side of health care to meet demand without obstacles. Proposals [...] therefore all aim for the same goal: to take away obstacles to efficiency and flexibility, while guaranteeing essential values such as quality, accessibility and justice. ${ }^{5}$

But although the Dekker-report built on historical foundations, it immediately became clear that its views of how all these aims should be achieved heralded a new era. A blueprint for health care reform under the new governmentality of the 'regulated market' was born.

\section{Substituting Care, Guaranteeing Care}

What was needed to implement such a new governmentality was already reflected in the title of the report: Willingness to Change (Bereidheid tot verandering). ${ }^{6}$ Whether this title should be seen as wishful thinking or rather as an observation of the facts is not entirely clear. But that such a radical change would necessitate a new way of thinking on the part of the various parties both within and outside of the health care field was hard to miss. It was broadly conceded that the government should gain control over a health care system which was now no longer only marked by growing costs, but also by a broad discontent with the more centralized approach taken since the 1970 s. "The committee sees as essential the safeguarding of solidarity and justice, elements which are rightfully key characteristics of the current system [italics in original,

\footnotetext{
${ }^{5}$ Commissie Structuur en Financiering Gezondheidszorg (chair: W.P. Dekker), Bereidheid tot verandering ('s-Gravenhage: Distributiecentrum Overheidspublikaties 1987), 39.

${ }^{6}$ See for general discussions of the Dekker-report: Vonk, Recht of schade, 285-288; Sijmons, Aanbodregulering, 151-152; Schut, Competition in Dutch Health Care, 73-76; Companje, Convergerende belangen, 260-261; Helderman, 'Market-Oriented Health Care Reforms, 197-198.
} 
RB]." ${ }^{7}$ However, provision and organization of health care at the time was thought inadequate to safeguard these goals while keeping health care affordable. Serious reform was needed, and to this end, Dekker's report put forward three fundamental proposals.

In a general sense, Dekker first proposed that the health care system should be geared towards more efficiency, both with respect to the delivery of care and to the way the system as a whole was organized. Regarding the latter element, "The committee holds as its philosophy that legislation should mostly set conditions. Only in the last instance should the government regulate in a direct manner." ${ }^{8}$ Deregulation was seen as positively opposed to the way in which legislation and regulation had become increasingly centralized and tightly ordered in the previous decade. Such regulation had led to increasing complexity, ever greater levels of detail, and limited room for negotiation between the various parties in health care. All of these elements stood in the way of achieving maximum cost-effectiveness and overall efficiency in the system. Removing these obstacles would be achieved through the merging and slimming down of relevant legislation and the scrapping of acts which had not achieved their goals (such as the Act on Health Care Provisions, perceived as Hendriks' crown jewel not even ten years earlier). ${ }^{9}$ But according to Dekker such slimming down was not only called for in the area of legislation. A key notion put forward in the report was that of substitution, through which "[...] supply can be tailored to both wishes and necessities [...] moving it from an undesired to a desired place, while maintaining quality." In using such a broad definition, the committee wished to stretch the notion of 'substitution' to include more than just a narrow focus on replacing expensive types of health care with equally efficacious but cheaper types. "Substitution does not merely mean moving care from specialist to GP, but it also means opting for a varied supply of health care which is goal-oriented and tailored." ${ }^{10}$ Broadly speaking, this was the vaguest recommendation of the entire report and would ultimately lead to little.

The second - and, according to the committee, most important ${ }^{11}$ - proposal for reform was a dangerous bet to anyone familiar with the history of health insurance reform in The Netherlands. In order to keep the health care system affordable and accessible in the long run, the committee stated that it would be unavoidable to revise the system of health insurance. Replacing the broad variety of health insurance arrangements in existence - the sickness fund insurance, the insurance arrangements for civil servants, the private scheme - there would be a mandatory basic insurance policy for every inhabitant of The Netherlands. Creating this broad

\footnotetext{
${ }^{7}$ Dekker-committee, Bereidheid, 9.

${ }^{8}$ Ibid., 87.

${ }^{9}$ Ibid., 95.

${ }^{10}$ Ibid., both quotes on p. 9.

${ }^{11}$ Ibid., p. 11: "The committee sees a radical reform of the current system of health insurance schemes as inevitable and as such considers this reform to be the core proposal of the advice."
} 
insurance scheme would be achieved through a merging of the health care provisions covered under the AWBZ, as well as (parts of) the sickness fund insurance package and certain welfare services. Generous as the plan to create a broad basic insurance seemed, in merging the two public schemes (AWBZ and sickness fund), elements of consumer choice, personal responsibility and limited coverage were also deemed necessary. With this plan, the Dekker-committee proposed that the new scheme to be created would cover around $85 \%$ of all health care provisions, with the remaining $15 \%$ to be insured on the private health insurance market. Provisions falling under the mandatory scheme would include long-term care (which was up until then covered by the AWBZ), as well as medical-specialist and hospital care, obstetric care, preventive medicine, revalidation, and dental care for those under 18 years. Left out of the package and seen as candidates for the 'supplementary' insurance package were matters such as extramural medicines, medical aids, and dental care for those over 18 years. But even where the $15 \%$ 'free market' provisions were concerned, it was clear that the principles and extent of social access which had grown into Dutch health care over time was now firmly propagated by the members of the Dekker-committee. "[...] supplementary provisions will not be luxury products, and many will want to get supplementary insurance. The committee therefore finds it important that such insurance will in principle be available and attainable." The government would have to enforce mandatory acceptance of clients by insurers and maybe even set a maximum premium for such insurance policies. ${ }^{12}$

With this proposal for serious reform of the system, Dekker reopened a trajectory for policy which had been closed off after Hendriks' notion of creating national insurance had failed some thirteen years earlier. By the late 1980s, however, circumstances had changed. Not only were costs still rising, but Joop van der Reijden's 'Minor System Reform' had brought commercial and social insurance closer together in terms of providing social access to health care provisions. This made the proposal to merge the various forms of insurance that co-existed less radical than it had been in the 1970s. Still, given the long history of failed health insurance legislation and reform, Dekker's proposal was in this respect quite a gamble, and indeed one that would not pay off in the decade-and-a-half after his report was presented. This did, however, not apply to the third proposal for reform: putting Dutch health care on a market footing.

\section{A New Governmentality for Health Care}

\footnotetext{
12 For discussion of the insurance scheme, see ibid., p. 49-54, quote on p. 54.
} 
Already with the first two proposals, it was clear that 'Dekker' proposed a radical break with the incremental approach taken after Hendriks' 1974 Structure Report had failed to achieve the restructuring of health care through a top-down legislative triptych. Indeed, it was precisely these small regulatory steps which had led to the jungle of rules criticized by the committee. Instead, more comprehensive governmental action towards structuring the system as a coherent whole was called for. This desire became most apparent in the third proposal for reform, which can be termed its most radical in terms of the governmentality of the system. Much as had been the case with Hendriks' 1974 report, this new governmentality proposed a blueprint for how health care should be organized in terms of financing and structure. Where Hendriks' governmentality had been labeled one of 'planning', Dekker's soon came to stand for introducing the 'market' into health care. But much like Hendriks' idea of 'planning' still focused on decentralization and more, but definitively not absolute, governmental power, Dekker's notions of what a health care 'market' should look like had deeply paradoxical qualities. After discussing the necessity of merging the disparate types of insurance, the Dekker-committee argued that in order to create more 'incentives' for efficient policy, procedure and prudent use of health care services, the liberty of parties - insurers and health care providers - to negotiate with one another and to pursue more freedom of choice had to be stimulated through the construction of a health care 'market'. At the same time, Dekker and his peers did not take this to mean that either the accessibility or the affordability of care for citizens should be put at risk. This called for a balancing act of policy measures.

On the one hand, both insurers and health care providers would have to be liberated from what Dekker et al saw as regulation constricting the freedom of negotiation and contracting. Budgeting and the role of the central government in regulating the sickness funds' social insurance scheme allowed only limited innovation. Moreover, the Sickness Funds Decree of 1941 had created the obligation for sickness funds to contract every care provider in their region of operation, which for the sickness fund scheme had ruled out serious negotiations over prices, as the sickness funds could ultimately not exclude care providers from a contract. ${ }^{13}$ This had stood in the way of differentiation between the (cost-)efficiency of different providers. Moreover, outside the large cities - in which multiple funds were active - patients could not actively choose their sickness fund, a situation that did not encourage market behavior by the sickness funds in order to actively attract clients (and to reduce their prices). All of these practices were possible in the private insurance sector, which according to Dekker meant that the convergence of the semi-public sickness funds with the private insurers would create ways

\footnotetext{
${ }^{13}$ For this, see: R.M. Bertens and F.G. Huisman, 'Vrije artsenkeuze: recht of macht?', Ned Tijdschr Geneeskd 2016 160, via https://www.ntvg.nl/artikelen/vrije-artsenkeuze-recht-macht/volledig.
} 
to solve all of these problems in one go. ${ }^{14}$ "To promote a much-needed equilibrium between supply and demand, the committee places great stock in competition between insurers. The position of patients will be strengthened through letting insurers actively compete for insureds, while also letting them contract freely with care providers. ${ }^{15}$ This would allow private insurers to contract selectively with the best and cheapest care providers.

At the same time that Dekker's report presented new market mechanisms and incentives for competition between the parties in the field, as well as the rhetoric of the 'critical health consumer', it was clear that this should not clash with the notions of 'quality, accessibility and justice' set out in the introductory remarks of the report. Compared to some 25 years before, Dutch health care had become enmeshed in a complex interplay of governmental bodies, semipublic and private parties, all of which operated under legislation that safeguarded the access of Dutch citizens to health care. Some of this access was related to income (the sickness fund package) whereas the AWBZ automatically covered every inhabitant of the Netherlands. And where the Dekker-committee was concerned, the market could not take the place of such access. It was merely seen as a more efficient way to preserve and foster the quality and future accessibility of affordable care. All in all, the proposal for a national insurance covering some $85 \%$ of health care provisions for every Dutch citizen was far removed from a free-for-all market game. And as we have seen, Dekker proposed that the remaining 'free' $15 \%$ would stay within reach of every citizen, in part through governmental interventions. In this way, the most radical break presented in the 1987 report for reorganizing health care was the conscious construction of a market environment for health insurance and health care provision, to a large degree safeguarded and regulated by the government. In the most clear-cut expression yet of such thinking, the governmentality of gaining control over an increasingly expensive health care system was formulated as follows:

The opinion has taken hold that a regulating, planning and paternalistic government should retreat in order to make place for a form of governance ['beheersmodel', RB] in which the state creates boundary conditions and the health care sector itself puts things in order. ${ }^{16}$

This 'opinion' did not merely reflect an analytical and empirically founded perspective on what model would work best in pushing down costs in health care while retaining quality and solidarity. It tied in with the cultural shift away from the 'nanny state' discussed in the previous part: "Attention is also given to the personal responsibility of citizens for their health and to

\footnotetext{
${ }^{14}$ The sickness funds were 'semi-public' in the sense of being private foundations or corporations administering the mandatory public sickness fund insurance.

${ }^{15}$ Dekker, Bereidheid, 13.

${ }^{16}$ Dekker, Bereidheid, 7.
} 
forms of aid which should be provided by society, close to home [...] This critique does not stand alone, but reflects a changing climate of thinking about the welfare state." ${ }^{\text {"17 }}$

The whole package of elements proposed by Dekker's committee seemingly presented a fundamentally different way of thinking - a mentality change - with regard to the question how health care should be governed, one which tied in with the discontent that had grown after the period of 'planning' in health care that had set in fourteen years before. However, the elements proposed by the Dekker-committee would very much demand balancing. How much 'market' would be possible in a system in which, it was readily acknowledged, solidarity was such a foundational tenet? How did substitution of care relate to the broadly respected right to health care enshrined since the 1960s? And what would the 'retreat' of a 'paternalistic' government look like in view of the state's by now far-reaching responsibilities in guaranteeing access to affordable health care? The fact that the report left much room for interpretation with regard to the answers to these questions would turn health care reform into a political debacle in the two decades to come.

\section{Rethinking the System, One Report at a Time}

The 1987 Dekker-report led to what was arguably the biggest ordeal in health care policymaking since the government had begun to see this as a state task. As we have seen in previous parts, in the course of the twentieth century many attempts at (re)structuring health care, insurance arrangements, or the provisions through which access was granted to citizens had failed. Abraham Kuyper's 1904 attempt to create a mandatory health insurance scheme had led to nearly 40 years of political discussion and prevarication on the subject. Van Rhijn's post-war report on creating social (health) security had failed within a year of its appearance. In the mid1960s political heavyweight Veldkamp had to severely prune proposals for what he initially envisaged as a broad national insurance - and that in the context of the booming economy of that decade. And when health care for the first time became a real political headache because of the cost explosion of the early 1970s, State Secretary Hendriks soon came to realize just how unmanageable the top-down organization of such a complex, historically grown sector of society was. But the mostly failed attempts to implement the reforms proposed by Wisse Dekker's committee in the period between 1987 and 1994 were accompanied by an unprecedented loss of support for systemic changes, which for a time made the very notion of political, top-down reform truly toxic.

${ }^{17}$ Dekker, Bereidheid, 8. 
The trials and tribulations of health care reform that the Dekker-report in 1987 set in motion can be readily summarized by glancing at the titles of the subsequent reports aimed at implementing Dekker's ideas. In order of appearance, the Lubbers-cabinet responded in 1988 with a report welcoming the proposed system overhaul, confidently called Change Assured (Verandering verzekerd). In 1990, this assuredness was toned down with the appearance of a report titled Working on Care Innovation (Werken aan zorgvernieuwing). And just two years later, when grand system reform as a strategy began to backfire, government officials and the then responsible State Secretary Hans Simons were no longer optimistic about anything more radical than Careful Progress (Weloverwogen verder). These consecutive titles immediately make clear that Dekker's new governmentality was not easily implemented. In part, this had to do with the different political-ideological stances which could be (and were) taken on the road towards reform. However, from a longue durée perspective, the most important reason for the overall failure of reforming the health care system in such a way as to meet Dekker's ideas of a regulated health care market was the fact that a top-down, blueprint approach did not agree with how Dutch health care had grown organically in the past.

After State Secretary Hans Simons left the political stage in 1994, disillusioned by the failed attempts to turn the 1987 report into a reality, large-scale reform of the health care system became political anathema until 2001. This 'cooling down period' for blueprint changes was at the same time an incubation period, however, in which measures were taken which very much prepared the Dutch health care system for market-oriented reform. Implementing Dekker's proposals in their entirety would not happen until 2006, but gradual policy changes and a new stance by the parties in the field did in fact during the 1990s make the system more market-oriented. In this way, the 'governmentality' of the regulated health care market, though conceived as a political solution to the problem of growing costs, came to be embraced and even gradually introduced by parties who were traditionally very keen on their autonomy. And in 2006, both the parties in the field and the government would together create a system marked by extensive solidarity and apparent respect for 'private initiative', now in the form of private market parties. Let us first turn to the highly publicized political rhetoric concerning system reform, before we see what happened on the ground in the years following the Dekker-report.

\section{Change Assured?}

Because the Dekker-report was written by a group of outsiders to the governmental bureaucracy, it was first necessary for the government to present its own view and to decide whether it would adopt the reforms suggested in Willingness to Change. This view was presented in 1988, under the aforementioned title Change Assured. In this report - as was to be 
expected - the ruling Christian-Democratic (CDA) and Liberal parties reacted favorably to Dekker's proposals, although the liberals laid the emphasis on the introduction of more market elements. This is in part why it took a year for Change Assured to materialize. Because the pillars on which the plan was built allowed an emphasis on this or that element - more social security through a broader basic insurance or, conversely, more freedom of the market - prime minister Lubbers of the Christian-Democrats had to work hard to create unity within the ranks of his cabinet. ${ }^{18}$ But this had results. Although the government report appeared a year after Willingness to Change, it followed many of its recommendations to the letter. ${ }^{19}$ "The Dutch cabinet has decided to implement, broadly speaking, the proposals made in the report of the committee Dekker, both those concerning the revision of the Dutch insurance scheme and those governing rules and regulations in health care [...] Ultimately this will lead to more market elements and professional autonomy in health care, alongside a diminishing role for the government." 20

To make the move towards universal insurance, in the following years care traditionally provided for through the Sickness Fund Act as well as private insurance policies would gradually be transferred to the AWBZ, turning the latter into the 'carrier' of the reform of the insurance system. ${ }^{21}$ To foster market competition, private and public insurers would have to converge in the following years, ultimately leading to the dissolution of the distinction between the two. Parallel to that development, mechanisms for making negotiations between insurers, clients and health care providers possible would be implemented. In effect, this would create three types of market relations: one between insurers and clients, one between clients and health care providers, and one between providers and insurers. ${ }^{22}$ Crucially, Change Assured followed Dekker's recommendations concerning the amount of care covered by mandatory and voluntary insurance policies. This was to be set at $85 \%$ respectively $15 \%$, alleviating the pressure on the general budget while introducing an element of cost awareness on the part of patients. ${ }^{23}$ Insurers had to accept anyone wishing to conclude a contract with them, and could not charge different premiums for identical insurance packages. ${ }^{24}$ Such measures would ensure equity and solidarity in the system. But the possibility for competition between insurers was based on the premise that different insurers could charge different base premiums for the mandatory

\footnotetext{
${ }^{18}$ Vonk, Recht of schade, 296.

${ }^{19}$ See G.H. Okma, 'Verandering verzekerd: stand van zaken van het plan Dekker', Ned Tijdschr Geneeskd. 13345 (1989) 2242-8.

${ }^{20}$ Letter presenting the report Change Assured, 7-3-1988 (Kamerstukken II, 1987-1988, 19945, nos. 27-28)

p. 2.

${ }^{21}$ Schut, Competition in Dutch Health Care, 76.

22 Report Verandering Verzekerd (Amstelveen 1989), 8-10.

${ }^{23}$ Verandering verzekerd, 11.

${ }^{24}$ Ibid., 16-18.
} 
package, thereby giving clients actual alternatives to choose from. However, this could only happen if insurers would be allowed to negotiate with care providers on the cost and efficiency of health care delivery. ${ }^{25}$

With Change Assured, the government embraced the regulated market in health care. In 1992 the system would have to be fully operational, and until that time intermediate steps would have to be taken on the path towards reform. ${ }^{26}$ Both this timetable and the government's firm commitment to pushing through the radical reforms proposed by Dekker met with mixed support on the publication of Change Assured. ${ }^{27}$ But the positive receptions of the proposed plans would not last. While the Dekker-plan was initially received well by political parties because of its proposal to finally solve long-festering problems of the health care system, the practical attempts to implement market elements while further enshrining solidarity soon began to chafe with these same parties. Shortly after the appearance of Change Assured, a majority of the Christian Democrats started to lean more towards the basic insurance scheme than towards the market elements, while they simultaneously stressed the responsibility of citizens to take care of themselves. ${ }^{28}$ Interestingly, on the side of 'field parties' especially the for-profit private insurers were very critical. These insurers - who in recent decades had been increasingly pushed towards providing ever more 'social' health insurance - saw in the Dekker-plan the final convergence of their market operations with what was in essence a mandatory insurance scheme in which the government would have a large say. ${ }^{29}$ The fact that private insurers with a for-profit history were now the most vocal opponents of plans to introduce the 'market' into health care, already pointed to the deep paradoxes inherent in the proposed system. But these paradoxes would shortly become even more evident, when Liberal State Secretary Dick Dees was replaced by Hans Simons, a Social-Democrat who continued on the path indicated by the Dekker-report.

\section{An End to Assurances: From Dekker to Simons}

In 1988 elections were held in which the Social Democrats performed better than the Liberals. Prime Minister Ruud Lubbers stayed on to spearhead his third cabinet, now consisting of Christian-Democrats and Social Democrats. Replacing Liberal State Secretary Dick Dees was

\footnotetext{
${ }^{25}$ Ibid. $22-23$.

${ }^{26}$ Ibid., 52-59.

27 See, e.g., Vonk, Recht of schade, 288-291; Kamerstukken II 1993-1994, 23 666, no. 2 (Willems-committee, Onderzoek besluitvorming volksgezondheid) 42; Companje, Convergerende belangen, 267-269.

${ }^{28}$ Vonk, Recht of schade, 291; Onderzoek besluitvorming volksgezondheid, 29.

${ }^{29}$ Vonk, Recht of schade, 289.
} 
Hans Simons, a Social Democrat intent on pushing through the 1987 reforms. This change in political signature would impact the way the plans for reform were now picked up. Shortly after taking up his position, Simons already began to 'mix and match' various elements of the Dekkerplan. In the 1990 report Working on Care Innovation, the new State Secretary gave a more social twist to the universal health insurance scheme. Where Dekker had suggested a $85-15 \%$ division for mandatorily respectively voluntarily insured care in the new arrangement, Simons shifted this balance to a $95-5 \%$ division, while he simultaneously reduced the income-dependent portion of the mandatory insurance premium. ${ }^{30}$ This move created plenty of space for detractors to charge that the state secretary was now propagating a universal health insurance scheme with little regard for citizens' personal responsibility, under the cover of Dekker's market plans.

Nevertheless, as one commentator noted, "With the details of the [1990] Simons-plan becoming clear, there seems to be no doubt that the statesman has been infected by the Dekker-virus." ${ }^{31}$ Simons remained on course for implementing Dekker, which meant instituting market elements and merging public and private insurance - though he moved the timeframe for implementation to 1995 . $^{32}$ The most striking example of these two policy lines coming together was a 1991 televised debate between Hans Simons and Alexander Rinnooy Kan, head of the Dutch federation of employers VNO. While Rinnooy Kan argued for strong governmental control over the health insurance scheme, Social Democrat Simons actually defended continuing on the market path. ${ }^{33}$

This debate, however, was the beginning of the end for Simons' ambitions of rapidly introducing 'Dekker' with the now expanded coverage. Ultimately, implementing both the social aspects of a broad people's insurance, as well as market elements premised on the notions of a smaller state and private initiative, proved impossible in such a short time period. Moreover, the haste with which the system reform was pushed through led to a rapid souring of potential support from both political parties and those in the field. By 1994, when both debate and reform had reached an undeniable impasse, a governmental committee investigated the reasons for the failure of the 'system reform', and provided a general explanation in the introduction:

Reports and memos with well-sounding names were published; laws were prepared and submitted to Parliament. Many changes were put in motion through government action. Yet these moves towards changing the system have as of yet not managed to win public and therefore political support. ${ }^{34}$

\footnotetext{
30 Kamerstukken II, 1989-1990, 21 545, no. 2 (Werken aan zorgvernieuwing) 36; Willems-committee, Onderzoek besluitvorming volksgezondheid, 16.

31 'Het plan Simons', NRC Handelsblad March 7, 1990.

32 Helderman et al, 'Market-Oriented Health Care Reforms', 198.

33 Willems-committee, Onderzoek besluitvorming volksgezondheid, 46.

${ }^{34}$ Onderzoek besluitvorming volksgezondheid, 3.
} 
This 1994 report, produced by the committee on 'Decision-Making in Health Care', provided a clarifying overview of the rapid dwindling of support for the reform plans by relevant actors in the field. ${ }^{35}$ As noted, there had already been critical voices when the Dekker-plan was first published. But with the shift towards universal health care coverage proposed by Simons, these criticisms were turned around. For instance, where the Liberals and Christian Democrats had mostly welcomed the proposals by Dekker in 1987 while the Social Democrats had voted against them in Parliament, by 1990 these stances had been reversed. According to the Christian Democrats and Liberals, the amount of care covered by the mandatory insurance package had become so large in the Simons-plan that instilling any real sense of responsibility and costawareness into patients now was an illusion. Moreover, the new division with regard to the care that was to be included in the mandatory package became a focal point to such an extent that the market elements - which were, as shown above, essential to the Liberals - were pushed to the background in the discussion. ${ }^{36}$ On the other hand, the Social Democrats were now in favor of what they saw as the essence of Dekker: universal health insurance. The gradual loss of support from the Christian and Liberal parties that Simons experienced as a result of this shift were a devastating blow to the reforms and served to poison the general debate on health care reform. For instance, in 1992 the more politically pragmatic party D66 revoked support for the plans because of the by then highly confusing plethora of arguments and presumptions concerning the effects that the new system could or would have on citizens' responsibility and income. $^{37}$

This change of political positions was matched by the very mixed response of the insurers. Both the private insurance companies, as well as the sickness funds had had mixed feelings about 'Dekker' from the beginning. The sickness funds, which still fulfilled their public role of allocating funds without needing to make a profit, had been doubtful about the orientation towards the market of the Dekker report. ${ }^{38}$ As it became clear that Simons would use the 1987 report as a springboard to institute a new insurance scheme, however, they initially turned around because of the positive effects such a system would have on the equitable distribution of (costs in) health care. The private insurers, however, took the exact opposite route. Initially praising Dekker's emphasis on the market mechanism - which they had been operating under for decades - as the plans progressed and the focus shifted towards the

\footnotetext{
35 Ibid., 23-34, 42-43.

${ }^{36}$ Ibid., 29-30.

${ }^{37}$ Ibid., 30-31.

${ }^{38}$ By way of illustration, in 1986 the secretariat of the VNZ had presented the report The Sickness Fund Independent (Het ziekenfonds op eigen benen), which argued in favor of a market-orientation. However, this report soon created a schism amongst the ranks of the sickness funds, many of whom experienced it as a form of selling out the ideal of solidarity (Companje, Convergerende belangen, 263).
} 
insurance part of the proposals, their enthusiasm quickly dwindled. ${ }^{39}$ Add to this the critique on the part of patients' and consumers' organizations with regard to the weak role of patients as critical health care 'consumers' ${ }^{\prime 0}$, the withdrawal of support from the organized general practitioners ${ }^{41}$, and the fact that the forcefulness with which the State Secretary acted was by many perceived as too much and too fast. These factors had created a minefield that effectively prevented the successful introduction of 'Dekker'.

\section{System Reform Grinding to a Halt}

Regardless of the complexity of Dekker's proposed new system, the speed with which it was supposed to be implemented had the effect that both users and providers of care were, by 1991, put off of the idea of shaking up the system in the short term. Where the public perception of the plans was concerned, in October 1991 rumblings about the problems of turning health care into a 'market' turned into an eruption in the aforementioned televised debate between State Secretary Simons and the head of the Dutch federation of employers Alexander Rinnooy Kan. That ideas about the possible effects of the proposed changes were based more on presuppositions than on reality was evidenced by the fact that the " [...] statesman lost...the debate on points and 'performance', even though the available departmental data in large part discredited the facts brought forward by the employers' organization." 42 By this time, however, the print media had also begun to pay serious attention to the 'Simons-plan', with national newspapers and magazines publishing scathing columns and referring to the State Secretary's ideas as 'Simons' Satan's Plan'. ${ }^{43}$ Finally, on top of the chaos that shifting ideological positions and complex arguments surrounding income effects had created there was a very real financial mishap. In 1991, the State Secretary had calculated that private insurance premiums could be reduced by some $15,5 \%$ on the basis of the transfer of various forms of care to the AWBZ. ${ }^{44}$ However, for such a reduction to be actually realized Simons had to rely on the insurers, with whom relations had become increasingly strained in

\footnotetext{
${ }^{39}$ Companje, Convergerende belangen, 286-287; Willems-committee, Onderzoek besluitvorming volksgezondheid, 25.

${ }^{40}$ Ibid., 25.

${ }^{41}$ Simons aggravated the GPs by opting for a functional description of the GP within the context of the new AWBZ-carrier. This would allow other practitioners to encroach upon their terrain. See G.H. Okma, Studies on Dutch Health Politics, Policies and Law (diss. Utrecht University 1997), 131.

42 Willems-committee, Onderzoek besluitvorming volksgezondheid, 46.

${ }^{43}$ Okma, Dutch Health Politics, Policies and Law, 130.

44 W.P.M. Dols and A.H.M. Kerkhoff, 'De Algemene Wet Bijzondere Ziektekosten. Debatten en ontwikkelingen vanaf 1987', in: Companje, Tussen volksverzekering en vrije markt, 795-880, 801.
} 
previous years. Unfortunately, this group feared an increase in medical consumption because of the growth of the insurance package and as a result refused to lower their premiums. With this refusal the cost of the system reform turned out to be several billions of guilders higher than anticipated, an outcome distinctly unfavorable from the perspective of public support. ${ }^{45}$

By the summer of 1992, Simons came to realize that the eagerness with which he had tried to tackle the system change had backfired. In the aptly-named memorandum Careful Progress, the State Secretary took stock of the changes and had to concede that the cabinet had " [...] thoroughly reassessed the goals and methods of the revision of the health care sector." 46 One of the conclusions was that the main thrust of the earlier report was still valid, but that "the mistake of implementing a 'grand design'" was now to be avoided. ${ }^{47}$ By this time, however, real momentum for pushing through the reforms had been lost. The changes to what were already deeply complex proposals in 1987, as well as the unexpected financial consequences of the system reform had riled the public and the field of health care to such an extent that the damage could not be undone. By 1993, the same Christian Democrats who in 1987 had welcomed the Dekker-report, retracted their support for Simons' system change in the Senate. A year later, the committee that had investigated the failure of health care reform would argue that one of the most important causes had been the fluidity with which parties and interest groups could shift from support to opposition and vice versa. This goes a long way towards explaining why the acceptance of the Dekker-plan in 1987 could evaporate so quickly, and it led to the damning condemnation that "Obscure language, false metaphors and concealed interests prevent citizens from understanding the essence of the debate." ${ }^{48}$ In the elections of the following year, the State Secretary did not return.

\section{Laying Out the Market Tracks}

With the implementation of Dekker's proposals grinding to a halt in 1994, 'grand design' system reform in health care and the institution of an extensive mandatory health insurance scheme became political no-go areas for the remainder of the decade. The fact that open debate on the subject had turned toxic, however, can easily obscure the way in which Simons was actually rather successful in clearing the ground for the market reforms proposed by Dekker seven years

\footnotetext{
45 Dols and Kerkhoff, 'De Algemene Wet Bijzondere Ziektekosten vanaf 1987', 801; T.E.D. van der Grinten and J. Kasdorp, 25 jaar sturing in de gezondheidszorg: van verstatelijking naar ondernemerschap (Den Haag: Sociaal en Cultureel Planbureau 1999), 29; Companje, 'Verzekering van zorg 1943-2007', 590.

${ }^{46}$ Report Modernisering zorgsector. Weloverwogen verder (Den Haag: Sdu Uitgeverij 1992) 4.

${ }^{47}$ Kamerstukken II, 1991-1992, 22393 no. 20 (letter presenting the report Careful Progress) 1.

48 Onderzoek besluitvorming volksgezondheid, 60.
} 
earlier. Where the rhetoric of publicized reports and televised debates stalled in 1994, the reality of new opportunities for the parties in the field to start operating in a more competitive fashion was changed in subtle, but fundamental ways. In 1992, a set of important measures passed parliament after concessions made by Simons to the CDA. ${ }^{49}$ As part of the 'Act on the System Change Health Care Insurance Phase Two', several mechanisms were instituted which broke open the rigid system of contracting and allocating care within which sickness funds and private insurers until that time had operated - and which had been such an eyesore for the Dekkercommittee in its quest to make health care susceptible to elements of competition.

First, the 'Act on Limiting the Duty to Contract' created the possibility for sickness funds to terminate contracts with care providers more easily and to enter voluntarily into negotiations with other providers. ${ }^{50}$ Up until then, this had been nearly impossible, which seriously curtailed the freedom of sickness funds to contract in a way which would force care providers to increase efficiency. At the same time, the system of set tariffs was abolished in favor of maximum tariffs, so that negotiation on lower tariffs between insurers and care providers became a possibility. ${ }^{51}$ Added to this new element was the scrapping of the regional 'areas of operation' for sickness funds. In just a short period, Simons granted all sickness funds the right to begin operating on a national scale, allowing nation-wide competition where, before, regional monopolies had been the norm. ${ }^{52}$ From the patient or demand perspective, this move towards more competition was facilitated by an act which gave patients the freedom to enter into a contract with a health insurer of their choice, where before they had been obliged to enroll in the sickness fund located in their region. ${ }^{53}$ Finally, in 1993 the system of retrospective reimbursement of sickness fund expenditures - very problematic from the perspective of cost control - was partially replaced by a system in which budgets would be set beforehand, forcing funds to bear some financial risk for expenses incurred by their clients and therefore instilling a sense of costawareness. ${ }^{54}$ Still, the introduction of these measures should not create the impression that the market dynamic was given free rein in the middle of the 1990s. Most measures were introduced in such a way that the possibility for competition and negotiation was created but not yet made mandatory. But scholar of public administration Jan-Kees Helderman has argued that through these actions, State Secretary Simons instigated a new 'policy stream' for health care, steering

\footnotetext{
49 Dols and Kerkhoff, 'De Algemene Wet Bijzondere Ziektekosten vanaf 1987', 798-799.

${ }^{50} \mathrm{~W}$. van de Ven, Het beste zorgstelsel? Afscheidscollege 2 oktober 2015 (Rotterdam: Erasmus University Rotterdam 2015) 16; Staatsblad 1991, 584.

51 Plomp, Winst in de zorg, 118-119.

52 Vonk, Recht of schade, 311.

${ }^{53}$ Dols and Kerkhoff, 'De Algemene Wet Bijzondere Ziektekosten. Debatten en ontwikkelingen vanaf 1987 ', 800.

${ }^{54}$ Helderman et al, 'Market-Oriented Health Care Reforms', 199.
} 
the development of the field in a distinct direction. ${ }^{55}$ And as we shall see, many parties in health care indeed started acting in a more market-oriented manner in the years under Simons' successor. This despite the fact that system reform in the vein of Dekker ostensibly went 'underground' until the early 2000s.

\section{From Grand Designs to No Regrets}

In an ironic turn of events, by the end of his tenure Social Democrat Hans Simons had actually been more successful in preparing health care for an orientation towards the market than in instituting the basic health insurance his party had distilled from the Dekker-report. Still, after the State Secretary suffered the sensitive blow of failing to implement his far-reaching agenda and consequently left national politics in 1994, both the fields of health care and that of politics were highly divided over the necessity and desirability of the system change. In many respects, a fresh start was called for. Such a fresh start came in the form of two important developments resulting from the 1994 elections. First, the election result was historic because for the first time since 1918, no confessional (Christian) party partook in government. Instead, the new cabinet was made up of Liberals and Social Democrats - working together for the first time in 40 years as well as the Social-Liberal D66 party. As a result, the political left, right and center were now forced to reach a consensus over the way out of the health care impasse. This after years in which Simons had clearly suffered from the fact that Dekker had been prepared under a Confessional-Liberal constellation, but had to be implemented with backing from his SocialDemocratic Party. And indeed, the policy measures set in motion during the tenure of the two 'Purple' cabinets that would reign until 2002 would be a mixed-bag in terms of state involvement and/or market mechanism. ${ }^{56}$

The second important change concerned the person tasked with introducing these policy measures. New Minister of Health Els Borst-Eilers from the D66 party was a medical doctor, who for the most part of her long career had mostly been involved in managerial and professorial duties. Despite hardly ever having practiced medicine, Borst-Eilers deftly made use of her 'persona' as a member of the medical caste in order to restore the disrupted relations

55 J.-K. Helderman, Bringing the Market Back In? Institutional Complementarity and Hierarchy in Dutch Housing and Healthcare (diss. Erasmus University Rotterdam 2007) 216-217.

${ }^{56}$ The term 'Purple' referred to the mixed party colors of the Social-Democrats (red) and the Liberals (blue). For discussions, see https://www.parlement.com/id/vh8Inhronvvu/kabinet kok i 19941998 , accessed on 20-08-2019, and K. Peters, Een doodgewoon kabinet. Acht jaar Paars 1994-2002 (Amsterdam: Boom 2015). 
between central government and the health care field. ${ }^{57}$ It was telling that the editor-in-chief of the medical journal Medisch Contact lauded the arrival of this new Minister of Health shortly after her installment, whereas just two years earlier he had called for the resignation of State Secretary Simons. ${ }^{58}$ But Borst-Eilers also maintained her good reputation because she shied away from grand reform, opting instead for small measures, which would ultimately prove mostly ineffective in solving the issues Dekker had been called in to address. Borst-Eilers' reluctance to pursue system reform was in line with the soothing words of the 1994 coalition agreement, which expressly refrained from referring to Dekker or to grand designs for health care in general. Moreover, any and all policy in health care must be such that all parties in the cabinet would be able to live with it: "Policy will be geared less towards attaining final future goals, but rather towards implementing attainable measures of a no-regret nature. This means that they should not pose an obstacle to the end goals of the separate factions." ${ }^{59}$ In the years that followed such a course of 'no regrets' would be steered through the implementation of small, incremental changes that were mostly aimed at cost containment and at improving the overall efficiency of health care financing and delivery. By the late 1990s, however, such incremental measures had done little to alleviate the problems already identified in 1987, leading to calls, in 2001, for reviving the 'Dekker' proposals.

Nevertheless, Borst-Eilers actively took steps to reverse parts of the failed system reform of 1994. Shortly after coming into power, the Minister of 'small steps' decided to reverse important measures Simons had taken in transferring various types of care to the AWBZ in an effort to turn this insurance scheme into the 'carrier' of basic insurance. This roll-back was intended as the most obvious cure for the hangover of the failed system change, and it meant that the AWBZ went back to its former protean shape - covering not just forms of care which would be uninsurable on a free market, but various other things alongside of this. To give further body to this 'new old' arrangement, in 1995 Borst-Eilers officially divided health care into three compartments. The first compartment contained classic AWBZ-care; the second those types of cure traditionally covered by the Sickness Fund Act; and the remainder was to be covered by private insurance. In part, this arrangement meant little more than a move back to the pre-1992 era - moreover, it was strongly reminiscent of the triptych thought up earlier by

\footnotetext{
${ }^{57}$ N. Beyens, Forthcoming biography on Els Borst, chapter 6. See also N. Beyens and T. Bolt, "A Medical Doctor in Politics'. Els Borst-Eilers and the Rise of Evidence-Based Healthcare', Low Countries Historical Review 1321 (2017) 16-37, 21, 31-33.

${ }^{58}$ C. Spreeuwenberg, 'Hans: treedt af!', MC 4727 (1992) 835; C. Spreeuwenberg, 'Een dokter voor de volksgezondheid', MC 4936 (1994) 1107.

59 Kamerstukken II, 1993-1994, 23 715, no. 11, 36-38, quote on p. 36. At most, insurers and care providers had to take upon themselves more responsibility, and patients had to become more aware of the costs of health care. See also Handelingen II, 1994-1995, no. 86, 5812.
} 
Gerard Veldkamp and Joop van der Reijden. The Minister emphasized that in the first compartment, the market mechanism would not be allowed to operate. ${ }^{60}$

Moreover, in an important respect Borst-Eilers held on to the most effective legacy of the 'planning' paradigm of the 1970s: the general budgeting of health care costs was still a state task. This strong instrument for keeping rising health care costs under control was still necessary, and it did not go together well with a market paradigm in which insurers and care providers would have to negotiate over prices to bring down general expenditures. Nevertheless, it was precisely that policy which by the late 1990s would lead to 'Dekker' being revived again, as by that time tight budgeting arrangements began to lead to serious problems of scarcity, as well as to a broad public call for reform of the health care system. We will return to this when discussing the problem of the waiting lists. However, although she rolled back AWBZ-reforms and held on to statist budgeting while rejecting talk of 'grand reform', a familiar dynamic - much health care governance over the past century had revolved around a discrepancy between the rhetoric espoused by policy-makers and the reality of how the system was evolving - was at play during Borst-Eilers' tenure. Despite the fact that 'Dekker' had gone underground, the new Minister did little to prevent the parties in the field from organizing themselves in a more competition-oriented fashion after the measures instituted by Hans Simons in 1992. This had the result that hospitals and insurers would keep following the track towards regulated competition, while on the national political level any reference to large-scale system reform could be avoided. In effect, these parties were adopting the 'governmentality' outlined out in 1987, while the national government turned a blind eye to these developments.

\section{A 'Silent Revolution'}

While Borst-Eilers refrained from discussing grand system reform in the vein of Dekker, important shifts were in fact taking place in the system during her tenure. We have already seen how Hans Simons, despite the failure to implement the mandatory insurance scheme, had in 1994 managed to implement several changes proposed by Dekker in order to institute more market-oriented elements. As noted, these measures did not immediately substantially affect health care. A 1995 report by the Sickness Fund Council, for instance, found that the goals of the 1992 market measures with regard to free contracting and tariff negotiations had not been met, in part because of the instability and uncertainty brought on by the constant shifts on the level

${ }^{60}$ De Haan en Duyvendak, In het hart van de verzorgingsstaat, 279; Dols and Kerkhoff, 'De Algemene Wet Bijzondere Ziektekosten vanaf 1987', 807. 
of politics about the shape that system reform would take. ${ }^{61}$ (The report did acknowledge, however, that its conclusions were premature, given how recent these important changes to the system had been.) Still, there is much to be said for the claim that in this period various actors in the system gradually adopted elements of Dekker's new 'governmentality'. First, the 1990s decision to again expose sickness funds to financial risk had given them a form of financial responsibility not seen in fifty years - we will recall from part 2 that the Sickness Funds Decree had curbed the autonomy of the funds to quite an extent, and much to their dismay. Now, the actual percentage of financial risk borne by the funds grew steadily: from $3 \%$ in 1995 to $50 \%$ in $2003{ }^{62}$ This was complemented by the abolishment of the contracting obligation between sickness funds and doctors, which gave back to the sickness funds the negotiating power they had lost in 1941, when the obligation to conclude contracts with every doctor in their region of operation was codified. ${ }^{63}$ On top of this, the decision to abolish the regional areas of operation of the sickness funds was relevant, as it created the possibility for the funds to start operating on the national level where before they had been bound to their regional areas of operation.

None of these developments were halted by the Minister of Health, which created room for the market part of 'Dekker' to progress in fairly unobstructed fashion. In a 1997 dissertation by health economist Kieke Okma, the continuities and discontinuities in policy between the third Lubbers cabinet and the Purple cabinet that came to power in 1994 were clearly outlined. ${ }^{64}$ Although Borst-Eilers rolled back changes with regard to the AWBZ-package, she did not reverse the measures taken by Simons to facilitate convergence between public sickness funds and private insurers - a precondition in Dekker's proposals for a system based on competition. This convergence meant "[...] a. creating a similar insurance package for both persons insured under a sickness fund arrangement and persons insured privately, for types of care which are mandatorily insured; b. the gradual convergence of the methods of levying premiums." ${ }^{65}$ Most crucially, in 1991 State Secretary Simons had opened up the possibility for commercial insurers to start exploiting the sickness fund scheme - a mirror development to the way in which sickness funds from the 1950s onwards had started offering private insurance through their 'superstructures'. In effect, this measure opened the door for mergers and acquisitions between

\footnotetext{
61 Ziekenfondsraad, Evaluatie Overeenkomstenstelsel Ziekenfondswet en AWBZ (Amstelveen: Ziekenfondsraad 1995) 29-32. The report did acknowledge, however, that its conclusions were premature, given how recent these important changes to the system had been (p. 4).

62 F.T. Schut, De zorg is toch geen markt? Laveren tussen marktfalen en overheidsfalen (Rotterdam: inaugural lecture Erasmus Universiteit Rotterdam 2003) 22. By 2006, this percentage would (still only) be 53\% (Van de Ven, Het beste zorgstelsel?, 16). This measure was accompanied by the move from retrospective reimbursement to prospective budgeting for the sickness funds.

${ }^{63}$ See Bertens and Huisman, Recht of macht.

${ }^{64}$ Okma, Studies on Dutch Health Politics, 141-142.

${ }^{65}$ Kamerstukken II, 1993-1994, 23 715, no. 11, 37.
} 
sickness funds and commercial insurers, which would have great effects on the growing closer of the sickness fund and 'private' insurance compartments. ${ }^{66}$

All of these developments introduced something of a 'silent revolution' in the sickness fund landscape. ${ }^{67}$ The measures introduced in the early 1990s had brought private and public insurers closer to such an extent that in 1995 the formal associations of both parties merged into one group: the Association of Dutch Health Insurers. ${ }^{68}$ This 'convergence of interests' was far more than a symbolic gesture. Outweighed by the sickness funds after this merger, the commercial insurers hoped to retain a measure of equality and independence in the field of health insurance. ${ }^{69}$ But in effect, the move to integrate interest groups represented the swan song of the commercial insurers, who over the past decades had moved ever more towards the social provision of health insurance. Moreover, because private insurers left this market, their market share declined from a third to about a quarter in the period between 1985 and $1995 .^{70}$

The decision of many private insurers to leave the market was accompanied by another development, highly relevant from the perspective of competition - but not quite the type the Dekker-committee would have hoped for. In the absence of active governmental policy to implement the twin goals of Dekker (mandatory insurance and the market), in the 1990s sickness funds and private insurers rapidly dwindled in number but grew in size, through mergers and acquisitions. In effect, this would leave less room for real competition by the time that the Dekker-plans were implemented in 2006. Table 4.1 illustrates the dwindling number of sickness funds and private insurers in the absence of coherent governmental policy - indicating the growth of their power positions in this period given a stable population of insureds:

\section{Table 4.1 Number of sickness funds and private insurers, 1986-1996}

\begin{tabular}{|l|l|l|}
\hline & $\mathbf{1 9 8 6}$ & $\mathbf{1 9 9 6}$ \\
\hline Sickness funds & 48 & 29 \\
\hline Private insurers & 75 & 44 \\
\hline Total & 123 & 73 \\
\hline
\end{tabular}

Source: E. Brouwer and P. van den Broek, 'Het perspectief van de zorgverzekeraars', in: E. Elsinga and Y. van Kemenade (eds.), Van revolutie naar evolutie. Tien jaar stelselwijziging in de Nederlandse gezondheidszorg (Lochem: De Tijdstroom 1997), 104-124, 119.

\footnotetext{
${ }^{66}$ Vonk, Recht of schade, 311-312.

${ }^{67}$ For the term and its discussion, see Van de Ven, Het beste zorgstelsel?, 16-17.

${ }^{68}$ Companje, Convergerende belangen, 298, 310-313.

69 Vonk, Recht of schade, 318-321.

${ }^{70}$ Ibid., 263-264.
} 
This concentration of power also took place where health care providers (mostly hospitals) were concerned, as we will see later on. Moreover, where hospital, home care and the operations of insurance companies were concerned, a mentality change seemed to be taking place: a new orientation on patients' needs, cost control and competition had begun to mark the internalization of a decade of market rhetoric. This change was felt perhaps most strongly in the way hospitals had started to shift their orientation from a supply-based to a demand-based 'health care economy'. Despite the fact that real changes in financing were still held back because of tight government budgeting, a new cultural-institutional stance seemed to be making its entrance. "Although we can say that the 'perestrojka' effect and the impetus for rapid change have faded long ago, the Dekker-plan set in motion a process of change, especially where the reigning mentality in health care is concerned [...] core concepts are [now] patientcenteredness, business-mindedness and gaining a good market position. ${ }^{171}$ While Borst-Eilers stayed away from the basic insurance proposed by Dekker, the market-oriented changes put forward in 1987 were now very much becoming a reality. These changes fit in very well with the general policies of the Purple cabinets, which focused on deregulation and the stimulation of market competition as new tools for 'governance'. ${ }^{72}$ But while the rhetoric of system reform in health care had failed on the level of national politics, the reality of a gradually increasing market-orientation was in fact taking place, pushed forward by the parties in the field. It would take a crisis in health care brought on by tight budgeting, however, which would once again make system reform a political top priority. We will turn to this now.

\title{
Limits to the Incremental Approach
}

\begin{abstract}
In legal terms, the right to health care is a command directed at the government. Morally speaking, it is a claim on the part of citizens. As such, the right to health care entails an obligation for the government towards its citizens [to ensure practical access to health care]. The government can delegate the practicalities of fulfilling this obligation, but ultimately it retains the responsibility for such fulfilment and the task of seeing to it that certain preconditions are met. ${ }^{73}$
\end{abstract}

\footnotetext{
${ }^{71}$ M.J.M. Le Grand-van den Bogaard, D.K. Munsterman and R.L.W.M. Spaay, 'Het perspectief van de ziekenhuizen', in: Elsinga and Van Kemenade (eds.), Van revolutie naar evolutie, 52-77, quote on p. 52.

${ }^{72}$ As illustrated, for instance, by the interdepartmental project Market, Deregulation and Quality of Legislation. Kamerstukken II, 1994-1995, 24 036, nos. 1 and 7.

${ }^{73}$ H.J.J. Leenen, Recht op zorg voor de gezondheid. Preadvies voor de Vereniging voor Gezondheidsrecht (Utrecht 1997), p. 7.
} 
With these words, Professor of Social backgrounds to health and health care Henk Leenen opened his 1997 address to the Dutch association of health care law. Three decades after he had defined the right to health care as a far-reaching claim with regard to governmental action - as discussed in chapter 4 - the picture Leenen sketched in his address about the state of Dutch health care was bleak. The exhortation aimed at the government was clear: whether through private initiative or statist action, the state quite simply had far-reaching obligations to provide health care to its citizens. However, when it came to evaluating the way in which the system of health care as it had grown in previous years actually managed to meet these demands, Leenen's assessment was damning:

Despite verbal rituals to that effect, real coherence between a thought-out health care policy, the structuring of the system and its financing, distributive justice and the imperatives of the right to health care, has never really been achieved. Such comprehensive policy has been blocked time and again by the primacy of economic arguments, various interests, a battle of disciplines, political ideologies and fragmentation at the level of the government. ${ }^{74}$

When Leenen presented his address - halfway into the eight-year rule of the 'Purple' cabinets it was fast becoming clear that minister Borst-Eilers' policy of 'no regrets' was in fact leading to regrettable situations in health care. More than anything, one particular problem had begun to loom ever larger on the agendas of policy makers. This problem was that of the waiting lists, which in the preceding period had been growing in hospitals and care institutions. Before BorstEilers even entered office, the 1994 coalition agreement had set volume growth in health care at $1.3 \%$, with the qualification that this percentage could be adjusted upward should it prove too chary. ${ }^{75}$ But given the near $2.0 \%$ growth in previous years, it was clear that this policy goal of tight budgeting was highly ambitious, and that the room for unexpected developments was extremely limited. ${ }^{76}$ Table 4.2 illustrates the problem succinctly:

Table 4.2 Estimated and actual volume growth in health care, 1990-2002

\begin{tabular}{|l|l|l|l|}
\hline & $\begin{array}{l}\text { Lubbers-III 1990- } \\
\mathbf{1 9 9 4}\end{array}$ & Purple-I 1994-1998 & Purple II 1998-2002 \\
\hline $\begin{array}{l}\text { Volume growth } \\
\text { according to coalition } \\
\text { agreement }\end{array}$ & $1,0 \%$ & $1,3 \%$ & $2,3 \%$ \\
\hline $\begin{array}{l}\text { Actual volume } \\
\text { growth }\end{array}$ & $1,9 \%$ & $2,0 \%$ & $4,7 \%$ \\
\hline
\end{tabular}

\footnotetext{
${ }^{74}$ Leenen, Recht op zorg voor de gezondheid, 5.

75 Kamerstukken II, 1993-1994, 23 715, no. 11 (reprint) (Coalition Agreement 15-8-1994) 15.

${ }^{76}$ Kerkhoff and Dols, 'De Algemene Wet Bijzondere Ziektekosten vanaf 1987', 805-806; De Haan en Duyvendak, In het hart van de verzorgingsstaat, 278.
} 
Source: Schut, Zorg is toch geen markt, 11.

In response to this mismatch between political expectations and on the ground realities, during the tenure of the Purple-cabinets the parties in the field started to react by effectively rationing health care through waiting lists. A case study of these waiting lists illustrates how, by the late 1990s, the lack of structure and the necessity to contain costs in Dutch health care, combined with the level of access and solidarity now expected of it, created a policy problem which once again forced politicians to 'rediscover' system reform.

\section{Case Study: The Growing Pain of Waiting Lists}

Waiting lists did not crop up all of a sudden in the second half of the 1990s. Already in 1983, when the Act on Tariffs in Health Care for the first time made active budgeting of health care expenditures possible, the dangers which pre-set budgets could pose to the accessibility of care were pointed out. With the shift from open-ended retrospective reimbursement to budgeting, questions were raised about what it would mean for both clients and providers of health care if budgets were exceeded. ${ }^{77}$ However, initially, these dangers only rarely materialized in practice, for instance in two court cases in the early 1990s, in which patients took their sickness fund and the state to court for failing to provide adequate and timely care. ${ }^{78}$ Though important from a legal point of view, these cases did not yet draw broad attention to the problem of delayed care delivery. ${ }^{79}$ However, measures taken in the early years of the 1990 s would only serve to exacerbate the problem. From the outset of the first Purple cabinet, the policy of incremental (and ineffective) measures and tight budgets led to an increase in the number and average length of waiting lists in health care. Limiting budgets through imposing a low ceiling for growth rapidly led to unanticipated and sometimes perverse effects. Already in 1993, medical specialists

\footnotetext{
${ }^{77}$ A.P.J. van der Eyden, 'Budgettering gezondheidsrechtelijk bezien', Tijdschrift voor Gezondheidsrecht 83 (1984) 105-116, specifically p. 111-114.

${ }^{78}$ Arrondissementsrechtbank 's-Hertogenbosch 24-11-1989, TVGR 1990/20; Gerechtshof 'sHertogenbosch 2-6-1990, TvGR 1990/81; Rechtbank 's-Gravenhage 11-3-1992, TvGR 1993/32.

${ }^{79}$ Already in the legal annotation to the 1989 case, the question was posed how heavy a storm this ruling would raise because of its implications for health insurers and providers alike. Still, it took a while before more in-depth discussion followed. For this see: E.W.M. Meulemans, 'Gezichtspunt. De zorgplicht van de staat', Tijdschrift voor Gezondheidsrecht 195 (1995) 265; J.G. Sijmons, 'De civielrechtelijke hulpverleningsplicht van arts en ziekenhuis', Tijdschrift voor Gezondheidsrecht 196 (1995) 332-345; G.R.J. de Groot, 'Wachtlijsten in de gezondheidszorg', Tijdschrift voor Gezondheidsrecht 202 (1996) 58-70; J. Legemaate, De (dubbel)rol van de arts, in: H.D.C. Roscam Abbing, J. Legemaate, G.R.J. de Groot, Zorg, schaarste en recht. Preadvies Vereniging voor Gezondheidsrecht 2002 (Utrecht 2002), 36-63, 49-50; G.R.J. de Groot, Verantwoordelijkheid en aansprakelijkheid voor tekorten in de zorg, in: Roscam Abbing et al, Zorg, schaarste en recht, 64-121, 74-75.
} 
had exceeded their allocated budget by 700 million guilders. When volume growth was then set at the record low of $1.3 \%$ in 1994, some specialists opted for cutting their intake of patients altogether, knowing that treatments that exceeded the budget would not be reimbursed by either government or sickness funds. ${ }^{80}$

From about 1994 onwards, attention began to be paid in national politics to the growth of the waiting lists and to the question of how to combat them. In rapid order, various reports pushed the problem into the spotlight, creating serious political nervousness. ${ }^{81}$ By 1996 , delays in treatments had taken on such a shape that Minister Borst-Eilers was forced to act. In a response to the growing problem, in December 1996 she presented parliament with the report Waiting Times in Curative Care. In a survey conducted among 114 hospitals, three quarters of these institutions had stated that they faced problematic waiting lists in areas such as ophthalmology, cardiology and internal medicine. ${ }^{82}$ However, given a lack of adequate information about patient care, the extent of the waiting lists remained somewhat 'invisible'. ${ }^{83}$ Despite this, the urgency of the problem was such that Borst began her campaign to reduce the waiting lists by disregarding budgetary limits. Hospitals and specialists could appeal to a newly created Waiting List Fund for extra funds, on the condition that they would improve registration. ${ }^{84}$ A more structural approach towards solving the issue consisted of no less than seventeen measures, to be taken in the short term; the focus lay on adequate and uniform data collection with regard to waiting lists, better cooperation between various providers in the health care 'chain', more and better information for patients, and the institution of a so-called 'waiting list brigade'. ${ }^{85}$ In 1998, the cabinet approved of a 'one-time' financial bonus of 75 million guilders to deal with the problem. ${ }^{86}$

Relevant about the 1996 report Waiting Times was that the lack of concrete and correct data on waiting lists severely hampered the way government could deal with the problem. The paragraph that discusses possible causes makes clear that there was little consensus at the ministry on what specifically was causing the backlog in the provision of hospital and care

\footnotetext{
${ }^{80}$ L. de Vos, Kwaliteit, disciplinering en sturing. Een historisch sociologisch onderzoek naar de vormgeving van kwaliteit van zorg in ziekenhuizen (diss. Erasmus University Rotterdam 2014) 83.

${ }^{81}$ Most relevantly, the reports by the Nationale Raad voor de Volksgezondheid en College voor ziekenhuisvoorzieningen, Wachtlijsten (Zoetermeer: Nationale Raad voor de Volksgezondheid 1994) Wachtlijsten II (Zoetermeer: Nationale Raad voor de Volksgezondheid 1995) and De wachtende werknemer (Zoetermeer: Nationale Raad voor de Volksgezondheid 1995). See also E. van Gameren, Regionale verschillen in de wachtlijsten verpleging en verzorging. Een empirisch onderzoek naar verklarende factoren (Den Haag: np 2005) 17.

82 Kamerstukken II, 1996-1997, 25 170, no. 1, 5-6.

83 De Vos, Kwaliteit, disciplinering en sturing, 83.

${ }^{84}$ Ibid., 13.

${ }^{85}$ Ibid., 14-17.

${ }^{86}$ Kamerstukken II, 1997-1998, 25 170, no. 6, 9.
} 
facilities. The report did not go much further than to point vaguely in the direction of changes in care provisions themselves, at a lack of efficiency and coordination within and between health care providers, and at the rise of the autonomous patient who was more critical about the kind of care he or she wanted to receive. ${ }^{87}$ But by 1998 such hesitations had mostly gone. In a status report on the waiting lists, minister Borst-Eilers now clearly identified five causes. Alongside the lack of adequate information, two causes were specifically linked to the government policy aimed at cutting costs and reorganizing the system of health care: tight budgeting and the resulting 'strategic behavior' ${ }^{88}$ This last cause entailed behavior such as that mentioned above, with medical specialists simply refusing to treat more patients for lack of a sufficient budget. By now, such behavior came to be attributed to a lack of market mechanisms in the general system. Even though care providers had a professional duty to help those in need, tight budgeting had forced them to either increase efficiency, exceed their budget (with the risk of being punished afterwards), or cut down on 'production'. Moreover, given the lack of bargaining power sickness funds had in their dealings with care providers and the obstructive power the latter could exert by threatening to halt patient care, the system increasingly approached an impasse in the absence of more budget and incentives for 'the field' to optimize their operations. ${ }^{89}$

In 1998, the ministry therefore formulated the situation as follows: "Alongside financial constraints, [the problem of waiting lists] is quite possibly primarily a question relating to the organization of care, necessitating the replacement of perverse incentives with positive ones." ${ }^{90}$ Still, the replacement of 'incentives' with large-scale system reform was not yet considered an attractive option by the Purple cabinet (which got a second mandate in the 1998 elections). Centralized budgeting, deregulation and cooperation were still a priority in the coalition agreement: "There is a growing willingness within the sector to work so efficiently that adequate care is provided and no undue waiting lists are created for patients - all of this preferably within a multiannual financial framework [...] It is important that peace and quiet is created within the health care field $[. . .]^{\prime \prime}{ }^{91}$ However, by this time the sluggish interplay between government, sickness funds and health care providers increasingly came to be synonymous with inaction in the eyes of the public. For instance, an article published in the magazine Vrij Nederland in May 2000 called attention to the ultimate horror scenario: patient deaths caused by people having to

\footnotetext{
${ }^{87}$ Ibid., 5.

${ }^{88}$ Kamerstukken II, 1997-1998, 25 170, no. 6, 1-2. The other causes had to do with unexpected developments in medical technology and possibilities and the subsequent creation of a new group of patients eligible for care.

${ }^{89}$ For a discussion of this interplay, see: L.J. Stokx and D. Post, "Volksgezondheid toekomst verkenning' 1997. VII. Zorgbehoefte en zorggebruik', Nederlands Tijdschrift voor Geneeskunde 14223 (1998) 1338-

1342.

90 Kamerstukken II, 1997-1998, 25 170, no. 6, 2.

${ }^{91}$ Kamerstukken II, 1997-1998, 26 024, no. 10, 43. For the general plans, see p. 40-46.
} 
wait too long for an operation. ${ }^{92}$ And in a 2002 analysis of health care coverage over the years 2000 and 2001 by three major newspapers, it turned out that over a third of all articles had to do with the problem of the waiting lists. Increasingly, such articles had moved from discussing the problem of budgeting to the inefficiency of the health care sector itself - opening the door for public discussions about the regulated market as a superior alternative to a (governmental) bureaucratic system. ${ }^{93}$

The background of the growing discontent was that in 1998 the economic situation had significantly improved compared to earlier years. ${ }^{94}$ In late 1999, growing publicity and discontent over scarcity in a time of abundance led to a climax in the form of two court cases which pushed the government to move the health care system more in the direction of the market. The first of these cases concerned a claim brought to court in Utrecht. ${ }^{95}$ Four patients with an indication for receiving home care under the AWBZ had been placed on a waiting list because of a lack of budget. This formed the basis for suing the so-called 'care office' for failing to meet its obligation to provide the care claimants had a right to. ${ }^{96}$ What followed was a clash over the distribution of responsibilities under the highly complex arrangement for mandatorily insured long-term care. First off, the decision to place patients on a waiting list despite a valid medical indication was quite clearly at odds with the provisions of the AWBZ. According to the judge, the AWBZ held that insureds had a right to care which had to be practically attainable within a "reasonable term" ${ }^{97}$ Placing indicated patients on a waiting list was at odds with such an interpretation of the law. The main question, however, was who was to be held responsible if the promised care was not delivered?

For the claimants to take on the care office - an administrative subsidiary of sickness funds or health insurers - was a logical move, as this office had the task to make sure enough care provisions were available. However, the AWBZ was a wholly public provision which depended on premiums collected at the level of government and then distributed through a public entity (the COTG) amongst health insurers. This allowed the care office in question to argue that not the office, but the state was to be held responsible for the lack of care. The fundamental issue thereby became the tension between a mandatory insurance arrangement guaranteeing virtually unlimited care and the government's policy to keep health care

\footnotetext{
92 Handelingen II, 1999-2000, 4798.

93 J. Timmermans, C. van Campen and J. Hessing, 'Zorg', in: Sociaal en Cultureel Planbureau, Sociaal en Cultureel Rapport 2002. De kwaliteit van de quartaire sector (Den Haag: Sociaal en Cultureel Planbureau 2002) 273-337, 275-277.

${ }^{94}$ See, e.g., Companje, 'Verzekering van zorg 1943-2007', 591.

95 Rb. Utrecht (pres.), 29-10-1999, TVGR 2000/28.

96 'Care offices' were and are subsidiaries of health insurers, tasked with contracting and providing AWBZprovisions.

${ }^{97}$ Rb. Utrecht (pres.), 29-10-1999, TVGR 2000/28, par. 4.4-4.6.
} 
expenditures in check. ${ }^{98}$ This issue also formed the key element of an appeals case heard in December 1999 by the Court of Appeal in The Hague, where claimants with similar grievances sued the state. ${ }^{99}$

At first sight, in both cases the decision seemed to rule in favor of the state, with the insurer/care office being held primarily responsible for contracting enough provisions to fulfill their legal obligations under the AWBZ. The health care system as a whole was to be interpreted in such a way that health insurers were responsible for making sure enough care was available, and could therefore be called to account by patients waiting for care. ${ }^{100}$ However, from the perspective of the general accessibility of health care, two considerations were highly relevant. Firstly, the judge in Utrecht explicitly ruled that the state could not appeal to the argument of financial insolvability, as the AWBZ would not allow patients to become the victim of budgetary considerations. ${ }^{101}$ In the second place, the court of appeals in The Hague clearly stated that the indication for care at home did not permit those responsible to put patients on a waiting list. ${ }^{102}$ All in all, the judgments very much mirrored the remarks made by Leenen in his 1997 address (quoted above). It did not much matter how government made sure citizens got access to health care, as long as such access was practically attainable.

To outsiders, these cases might have looked like the settlement of a dry debate concerning arcane health care legislation. But they proved to be catalysts in changing the approach of government took towards both health insurers and patients in the system. On a practical level, two consequences directly ensued from the rulings. In a report delivered to parliament just a month and a half after the appeals ruling in The Hague, the State Secretary of Health discussed the direct steps to be taken. First, arrangements were to be made to increase production in home care, meeting the judges' demand for reducing the waiting lists. ${ }^{103} \mathrm{~A}$ less direct second effect was that, in furthering the causes of increasing capacity and transparency in the fight against waiting lists, the parties in the field got together to discuss the creation of norms and protocols with regard to acceptable waiting times. This would result in the so-called Treeknorms of April 2000 - rules still in force today that set limits to waiting times in health care. ${ }^{104}$ Over the years, these norms would come to be accepted by insurers and health care providers as well as by the government as guidelines for the timely provision of care. ${ }^{105}$

\footnotetext{
${ }^{98} \operatorname{TVGR} 2000 / 28$, par. 4.2.

99 Hof 's-Gravenhage, 23-12-1999, TVGR 2000/27.

100 Ibid., par. 5.3; TVGR 2000/28, par. 4.7.

101 Ibid.

102 TVGR 2000/27, par. 5.1.

103 Kamerstukken II, 1999-2000, 26 801, no. 35, 5-6

104 Companje, 'Verzekering van zorg 1943-2007', 593.

105 Kamerstukken II, 2002-2003, 25 170, no. 31. Although they are guidelines, judges in fact refer to them in cases concerning waiting lists. See, e.g.: Nederlandse Zorgautoriteit, Letter to Minister van
} 


\section{System Reform Back on the Agenda}

For historian of the sickness funds Karel-Peter Companje, "[...] the battle against the waiting lists was the most visible example of the move from supply to demand in the provision of health care. ${ }^{\prime 106}$ And indeed, the way in which waiting lists illustrated the limits of the budgeting scheme in providing timely access to health care was an enormous impulse for the government to once again think about problems of allocation, control, and market 'incentives' in improving the efficiency of the health care system. However, while the waiting lists offered the most visible problem concerning the governmentality of the system as a whole, by the late 1990s other, less publicized developments were under way. These also emphasized the need for coherent, systemic reform in health care.

In 1997, a report by the Scientific Council for Government Policy (WRR) was published, which took a wide scope in assessing the challenges for Dutch health care in the (near) future. ${ }^{107}$ Not since 1987 had there been a report which was so agenda-setting in its discussion of the deep problems facing health care. Moreover, this agenda was tied to a concrete policy proposal very reminiscent of the Dekker-proposals. According to the 1997 report, the core problem at the heart of symptoms such as waiting lists was that the Dutch health care system had not kept pace with more structural challenges facing health care. After years of incoherent measures, the problems brought on by budgeting while also allowing the parties in the field to continue on the market path came to a head. "The problem is mainly that solidarity [...] is coming under increasing pressure. In large part this is the result of the ageing of the population. Moreover, the government, in introducing a certain amount of market elements in health care and an implicit policy towards convergence, has set insufficiently clear preconditions for maintaining solidarity in the system. ${ }^{108}$ The report acknowledged the opportunities the regulated market in health care could offer for increasing both efficiency and the freedom of choice of the consumer. But the inevitable corollary to this would have to be a mandatory insurance scheme with some room for additional private insurance, to induce both competition and cost-awareness. ${ }^{109}$

Volksgezondheid, Welzijn en Sport Concerning Treeknormen GGZ, d.d. 22-12-2016, p. 2. Accessed via https://www.rijksoverheid.nl/documenten/brieven/2017/01/18/treeknormen-ggz on 17-09-2019.

${ }^{106}$ Companje, 'Verzekering van zorg 1943-2007', 593.

107 Wetenschappelijke Raad voor het Regeringsbeleid, Volksgezondheidszorg (Den Haag: Wetenschappelijke Raad voor het Regeringsbeleid 1997). For a discussion of the report, see Sijmons, Aanbodregulering, 95-99.

108 WRR, Volksgezondheidszorg (Den Haag: Wetenschappelijke Raad voor het Regeringsbeleid 1997) 87.

109 Ibid., 100-103, 110-112. 
It was clear that the specter of Dekker-type reform had returned in policy circles, and several (careful) forays into discussing the old dual plans of a broad basic insurance and a regulated health care market appeared rapidly after the 1997 report. In December 1998 the Council for Health and Health Care (Raad voor de Volksgezondheid \& Zorg, RVZ) presented a report that addressed the governance of a health care system which by now hovered somewhat uncomfortably between state and market. This report did not come out of the blue: Els BorstEilers had explicitly asked the Council to produce a "[...] strategic reconnaissance of the tensions in policy resulting from, on the one hand, supply regulation as marked by clearly defined and verifiable claims to care and by clear budgets for care institutions, and on the other, market elements in the sense of functional decentralization. ${ }^{110}$ The conclusions drawn from this 'tension' by the Council were that more stimulation was needed for insurers and care providers to realize their role as market actors, while simultaneously the health care 'consumer' needed to be provided with real freedom of choice and consumer power on the health care market. ${ }^{111}$ To the necessity of maintaining solidarity through a mandatory insurance scheme was therefore added a meaningful role for the patient as an active and critical health care consumer. In 1999 such thinking also began to find support in the Ministry - this time with regard to the area of AWBZ-care, which Borst-Eilers in 1994 had exempted from market operations. In the memo Setting Sights on Care, state secretary Margo Vliegenthart identified several structural problems in the AWBZ-scheme for the provision of long-term care. Many of these concerned a lack of orientation towards the patient or client of the system, and the task that the government set for itself in a proposed modernization program was primarily to change its supply-driven orientation to one driven by demand. ${ }^{112}$

Finally, in December 2000, two reports were presented which definitively put system reform on the agenda again and this time also nudged government into action. On the one hand, the report Recasting Health Care by the aforementioned RVZ was not much of a surprise, given the report this Council had already produced two years before. To give clients consumer power, serious options for different insurance policies would have to be realized. Health care providers would have to start "feeling the hot breath of consumers in their neck", and insurers would have to be provided with incentives for protecting their clients' interests. ${ }^{113}$ Far more

\footnotetext{
${ }^{110}$ Raad voor de Volksgezondheid \& Zorg, Tussen markt en overheid (Zoetermeer: Raad voor de Volksgezondheid \& Zorg 1998) 10.

${ }^{111}$ Ibid., 32-34, 38-39.

112 Ministry of Health, Welfare and Sports, Zicht op zorg. Plan van aanpak Modernisering AWBZ (Den Haag: 1999) 12-13, 16-19. As to the question of governance in the provision of long-term care, a description only possible in the Netherlands was put forward: "Steering in such a complex environment is not unlike cycling against the wind on the back seat of a tandem bicycle." (p. 14).

${ }^{113}$ Raad voor Volksgezondheid \& Zorg, De rollen verdeeld. Burger, ondernemer en overheid in de gezondheidszorg (Zoetermeer: Raad voor de Volksgezondheid \& Zorg 2000) 6.
} 
interesting from the perspective of the actors in the field, however, was that by now the Social and Economic Council weighed in on the issue. In the report Towards a Healthy Insurance System, this council, which we have encountered before as an advisory body representing both employers and employees, argued for the dual elements of system reform proposed by Dekker: a mandatory insurance system, but also a more demand-driven health care that featured market elements. In this way, social aspects would be served - the report laid a strong emphasis on the solidarity a mandatory insurance scheme would have to show - but the Council also stressed that the entrepreneurial freedom of insurers should not be curbed by government. ${ }^{114}$

\section{Adopting the New Governmentality}

These reports point to the fact that by the late 1990s a striking difference could be observed between the political rhetoric concerning how the health care field and access to it should be organized, and the reality which by had now come to be. Let us take a short look at the changes in governmentality that took place on the ground in a period in which, on the policy level, grand system reform was still avoided because of the debacle of trying to implement 'Dekker' in the 1988-1994 period. As we have seen, the two main tracks of the Dekker-report that would lead to policy action had been the proposal to institute a broad mandatory insurance scheme and an orientation towards the market - the new 'governmentality' envisioned by Dekker, in which a 'paternalistic' state would take more of a backseat with respect to the workings of health care. Though the first proposal had been (indirectly) put forward and rejected many times in the history of Dutch health care, the 'market blueprint' was reminiscent of the old Liberal governmentality of 1848-1912. However, by this time both the historical circumstances and the prevailing mentality concerning access to health care and the role of the state in providing it had changed drastically. Recently, two Dutch scholars who study 'neoliberalism' within the Dutch context have characterized general policy in the 1990s thus - interestingly, with a reference to the post-war era - "Just as in the ' 50 s, the Dutch policy paradigm of the ' 90 s can best be described as a heterogeneous affair instead of an ideological monolith. In other words: it is a complex and contradictory synthesis of neoliberal, corporatist and Social-Democratic elements. ${ }^{115}$ Even though these authors discuss political policy - and not the conduct of the 'field parties' in, for instance, health care - it is striking to what extent politics and field parties in Dutch health care by this time displayed such a strange mix of ideological standpoints, calling

\footnotetext{
114 Sociaal-Economische Raad, Naar een gezond stelsel van ziektekostenverzekeringen (Den Haag: SociaalEconomische Raad 2000) 6-12. See for an English abstract: SER, Towards a sound system of medical insurance (Den Haag: Sociaal-Economische Raad 2001), https://www.ser.nl/en/Publications.

115 Oudenampsen and Mellink, 'Voorbij de controverse', 249.
} 
for autonomy for the parties in the field while also broadly agreeing that rolling back governmental backing of the right to health care was not desirable. Let us see why this was the case.

First, although the plan to institute universal health insurance after 1994 had gone underground on the level of politics, we have seen above how private insurers and sickness funds increasingly started 'converging' - something made possible by measures introduced by Hans Simons in 1992 and 1993. In part, this happened in anticipation of the introduction of market mechanisms, as this would inevitably entail the dissolution of the distinction between the two groups, which created the need to level the playing field beforehand. However, the conduct of especially the private insurers continued the development we have seen in previous chapters, with these parties increasingly adopting the social signature of the sickness funds. And indeed, during the 1990s, many commercial insurers in fact opted out of the health insurance business, leaving the superstructures (connected to the sickness funds) and a few remaining private insurers to continue offering health insurance under social conditions. This meant that, in effect, any future 'market' for health insurance run by private, not public, insurers - in accordance with Dekker's plan - would very much have the social characteristics of the sickness fund scheme in place since the Second World War. And by the time health care reform was implemented in 2006, this is indeed exactly what happened, as we shall see shortly.

There was, moreover, a striking turnabout in the position taken by the Social and Economic Council in its 2000 report, mentioned above. In arguing for both the universal insurance and market elements - in effect the whole 'Dekker-package' - the employers represented in this council now effectively agreed to provide partial health care financing for those previously insured with a private insurer because of their income. A decade before, this had been a point of serious contention, when Simons had attempted to introduce his universal insurance scheme. The employees represented in the Council, on the other hand, agreed that for the system to work in a more effective manner, the market would be an acceptable alternative to the mix-and-match policies pursued for nearly a decade by Social-Democratic and SocialLiberal policymakers. In effect, the representatives of the workers' unions now argued for a liberalization of the administration of health care, whereas employers argued for a vast mandatory insurance scheme backed by the state. Much as in the insurance industry, a convergence of social goals and market-oriented practices was therefore taking place - during a time in which the Purple cabinet and Minister Els Borst-Eilers still shied away from discussions of system reform.

On the whole, the parties in the field and the advisory bodies by the late 1990s therefore subscribed to the new 'governmentality', before this governmentality became politically viable again. After almost a decade of multidirectional policy, it was time for a serious recasting of 
roles in health care. In a new organizing principle for governance, patients, insurers and providers would become dependent on each other (with the patient as central actor), forcing the system as a whole to become less costly through effective market mechanisms, competition and a consumer-driven orientation. As far as government interference in a system which was to become self-regulating was concerned, the maxim was to be a simple "no, unless...". Unless either the solidarity principle or the quality of care came to suffer through an ineffective functioning of the new scheme, the confusing supply-side regulation of the past decade had to make way for the primacy of insurers and care providers in their endeavor to optimize their care 'output' and negotiations on prices. ${ }^{116}$ And in light of the waiting lists that were caused by a 'strong state' in health care, the time had come to revisit 'Dekker'.

\section{From Care Assured to Supplying Demand}

By the early 2000 s, both the highly visible problem of the waiting lists as well as the more structural problems signaled in the various reports mentioned above converged to push the second Purple-cabinet into action. Dealing with the waiting lists, "[...] which had gradually become iconic of health care [...]", was the first point of action in the political plan Care Assured, presented in November 2000. ${ }^{117}$ Care Assured built on the 1998 coalition agreement in putting forth two key policy concerns: fixing the waiting lists and reorganizing health care in such a way as to guarantee convergence between patient demands and efficiency and transparency within the system. ${ }^{118}$ The backdrop to 'assuring care' was the imperative handed down by the 1999 court rulings discussed above: dealing with the waiting lists was a governmental responsibility which could not be shoved aside any longer. The means for achieving the goals set forth in the report were connected in crucial ways. For instance, in 1996 improving registration systems for monitoring care and (the length of) waiting lists had been the top priority. But now the ministry realized that keeping tabs also necessitated instituting universal and unambiguous indications for the types of care patients received, standardization which would prove to be an important tool in granting insurers more knowledge and thereby control over the practice of health care, in the process granting them more power to negotiate with providers. ${ }^{119}$

Where financing was concerned, both the role of insurers and the urgency of restructuring the system once again came to the fore in Care Assured. According to the so-called

\footnotetext{
${ }_{116} \mathrm{RVZ}$, De rollen verdeeld, 96-107.

117 Kamerstukken II, 2000-2001, 25 170, no. 20, 1.

118 Kamerstukken II, 2000-2001, 27 488, no. 1 (Actieplan Zorg Verzekerd) 2-3.

119 Kamerstukken II, 2000-2001, 27 488, no. 1, p. 6-7.
} 
'pay-for-care' principle (in Dutch: 'boter bij de vis') introduced in the report, budget was made available for reimbursing care providers who managed to effectively combat waiting lists. ${ }^{120}$ The distribution of these extra funds was made a responsibility of insurers, who could now either allocate extra funds to care providers or withhold them, depending on whether changes in organization had actually led to improved and more timely patient care. ${ }^{121}$ Such a measure clearly shifted the balance of power towards insurers. That the government was willing to grant more power and responsibility to these parties - and thereby to the market imperative of effective negotiation - was furthermore evidenced by an increase in the financial risk run by sickness funds. ${ }^{122}$ Care Assured designated this development as the "rearranging of responsibilities in the sector". ${ }^{123}$ All of these measures - especially the 'pay-for-care' principle began to bear fruit. Between 2000 and 2003, waiting lists for care would be reduced by 50\%, and by the spring of 2004, Borst-Eilers' successor could report to parliament that only $20 \%$ of the 139.300 people on waiting lists were still awaiting cure on unjustifiable grounds (caused by inadequate allocation or organization of care). ${ }^{124}$ By this time, financial measures had mostly been replaced by ones aimed at increasing efficiency and at creating incentives for care providers to reduce backlogs - that is, measures geared towards a more demand-oriented health care system. ${ }^{125}$

Because of the measures taken, however, the significance of Care Assured extended far beyond 'solving' the waiting lists. In the summer of 2001, the second Purple cabinet presented the report Supplying Demand, a quote from which was given at the beginning of this chapter. With this report the government, after some seven years of avoiding references to the Dekkerdebacle, actively again embraced the notion of the 'regulated health care market'. Supplying Demand identified two main problems that had to be resolved through (once again) large-scale system reform. Firstly, centralized budgeting and supply-side regulation had led to insufficient opportunity and 'incentives' for the parties in the field to act in an effective and qualitatively excellent manner. Secondly, the mix of existing insurance schemes had led to a fragmentation in the provision of care, which had also resulted in limited power on the side of insurers to negotiate and of patients to exert consumer power. ${ }^{126}$ "The cabinet shares the philosophy of the [2000 RVZ and SER reports], that the health care system provides access to necessary care for all

\footnotetext{
120 Companje, 'Verzekering van zorg 1943-2007', 593.

121 'Pay-for-care' applied to both Sickness Fund Act provisions - a responsibility of sickness funds - as well as AWBZ provisions - a responsibility of both sickness funds and private insurers.

122 Kamerstukken II, 2000-2001, 27 488, no. 1, 13-14.

123 Ibid., 13-14.

124 Van Gameren, Regionale verschillen, 9; Kamerstukken II, 2003-2004, 25 170, no. 35, 2.

125 Ibid., 1-2.

${ }^{126}$ Ibid., 3-4.
} 
with risk solidarity between young and old, healthy and ill, and that demand-driven health care needs to be directed by insurers who compete and are exposed to financial risk." ${ }^{127}$

To meet the problems that had arisen after a decade of incremental measures in health care, two things were necessary. First, a market-driven system with insurers as 'care directors' had to be realized. This development was already underway through the practice of 'convergence', next to the incremental granting of more responsibilities to insurers that had taken place over the past decade. Second, an extensive mandatory insurance guaranteeing farreaching solidarity in health care would have to be realized in the coming years. Here, it was very significant that the 2001 report did not go back to either the $85-15 \%$ split in mandatory and voluntary insurance proposed by the Dekker-committee in 1987, or the $95-5 \%$ split proposed by Simons in 1990. Instead, what should be included in the basic package according to Supplying Demand was 'necessary care', " [...] all forms of which will be included in the statutorily insured package - after evaluation by government." All care provisions considered for inclusion in the basic package would have to be evaluated according to the principles of 'evidence-based medicine', while the efficient application of care in actual practice would have to be paramount in determining what was 'necessary'. ${ }^{128}$ It was clear that with these criteria, the government was in effect getting ready to include the vastly expansive (and expensive) provisions covered under both the Sickness Fund Act and the AWBZ in the new mandatory insurance scheme. ${ }^{129}$ But it was also significant to what extent Supplying Demand was almost a verbatim copy of the 1987 report Willingness to Change. By now, however, the government had to catch up on the way in which the parties in the field had been adopting much of the governmentality set out in that report in the meantime.

\section{Catalyzing the Need for Reform}

With an eye to how closely the 2001 report resembled Dekker's plans, several policy scholars have termed it a 'phoenix from the ashes'. ${ }^{130}$ However, by now circumstances had changed vastly compared to the period of Simons' debacle. This made it possible for 'Dekker' to be implemented nearly twenty years after it had been presented. First, the urgency to implement systemic change - which had been felt less and less in the early 1990s - greatly increased in the

\footnotetext{
127 Kamerstukken II, 2000-2001, 27 855, no. 2, 3 (Memo Supplying Demand).

${ }^{128}$ Ibid., 39-41, quote on p. 41.

${ }^{129}$ The AWBZ or 'first compartment' would in due time be integrated with the 'second compartment' of curative care into one single insurance scheme (Kamerstukken II, 2000-2001, 27 855, no. 2, 49-59). As of 2019, this is not yet the case.

130 Helderman et al, 'Market-Oriented Health Care Reforms', 190.
} 
early 2000s. The first reason for this was political. When Supplying Demand was presented to Parliament in July of 2001, it was still very much couched in terms of careful progress: far from providing a blueprint, the memo should instead be read as an "indicative policy agenda". ${ }^{331}$ Further illustrating the caution of the cabinet was the somewhat laid-back assertion that the details of the system reform would be provided in a new coalition agreement, to be presented by the middle of 2002, with a view to implementing the changes by $2005 .{ }^{132}$ The Purple cabinet put great stock in its re-election, after which the system reform could be gradually prepared without fear of an electoral pushback.

However, the coalition did not take into account the unexpected and rapid rise of a political upstart: Pim Fortuyn. Entering politics in January 2002, Fortuyn in just four months' time set in motion a populist bandwagon, winning public attention with his strong opinions on Islam and refugees and his flamboyant persona. ${ }^{133}$ But in his book The Rubble Heaps of Eight Years 'Purple' - both pamphlet and election program - published in March of that year, Fortuyn went further. Focusing on concerns about safety, education, bureaucratization, corporatism and, significantly, health care, Fortuyn launched a full-frontal assault on the policies of the ruling cabinet of the past eight years. Not only was it entirely unclear what the role of the public sector had become during the rule of the Purple cabinets; neither had the problems that had been growing under its watch been solved. ${ }^{134}$ To remedy the culture of 'regent politics', a thorough reorientation towards active democracy and the citizen was necessary.

Fortuyn also filled the thirty-page chapter on health care in the book with such rhetoric. Explicitly going back to Dekker's recommendations and lamenting what had (not) become of them, Fortuyn went further than any commentators before him in presenting the market as the cure-all for the problems ailing the sector. Exploiting his sense of dramatic flair to full effect, he wrote of the nursing home in which his father lived and which could afford only enough staff to bathe the 86-year old just once a week, and of the 'third-rate care' he himself had once received in a hospital for 'first-rate prices'. ${ }^{135}$ The lesson of such experiences for Fortuyn was that the patient should be placed at the center of the system, and that this would have to be achieved by breaking through red tape and giving insurers, care providers and patients true incentives on a

\footnotetext{
${ }^{131}$ Kamerstukken II, 2000-2001, 27 855, no. 2, 62.

132 Ibid., 62, 65. This delay apparently dismayed Borst, who had hoped to push through reforms on the short term but was confronted with the reappearance of ideological arguments concerning personal responsibility and the amount of state intervention in the system (E. Bassant, Ziekenfonds of particulier? Hoe de basisverzekering er toch is gekomen (Maarssen: Elsevier Gezondheidszorg 2007) 56-57).

133 https://www.parlement.com/id/vhdjhx1hxotm/opkomst en ondergang van de Ipf, accessed on 19-092019.

134 W.S.P. Fortuyn, De puinhopen van acht jaar paars (Uithoorn: Karakter Uitgevers 2002), 10-12.

135 Fortuyn, Puinhopen van paars, 40-41, 18-19.
} 
health care market. ${ }^{136}$ Just two months after his pamphlet was published, the 2002 election campaign came to a shocking end with the murder of Fortuyn. Nevertheless, despite his death or perhaps because of it - Fortuyn's aggressive rhetoric was rewarded posthumously when in the following week his Lijst Pim Fortuyn (LPF) was awarded 26 parliamentary seats (out of 150) in the elections. The other winner of the elections were the Christian-Democrats (CDA), with 'Purple' parties PvdA (Labor) and D66 (social liberals) suffering enormous losses. Following on these results, on 22 July 2002 a cabinet featuring ministers from the CDA, the VVD and the LPF was installed. ${ }^{137}$

Eduard Bomhoff from the LPF party was appointed Minister of Health. Bomhoff now chose an unorthodox route to honor the populist rhetoric of his recently deceased leader. Where Fortuyn had proposed to freeze budgets in health care while system reform was under way, Bomhoff went the exact opposite route. Instead of working on system reform in the vein of Supplying Demand as the coalition agreement had promised, the erratic Bomhoff spent his short tenure in translating the 'power to the people' principle into the bluntest policy-instrument available: open-end financing for combating waiting lists and scarcity in health care. True enough, this approach put the patient at the center in a health care system which was plagued by waiting lists, personnel deficit and a bad public image. But it did not take long before such a radical policy began to impact the budget. Where before 2000 , annual growth in health care expenditures had varied between 2 and 3\%, the RVZ in the aptly named 2003 report Exploding Health Expenditures asserted that from 2001 onwards that growth had risen to 7-10\% annually. ${ }^{138}$ It is only fair to say that Bomhoff's role in this growth was limited: especially the 'pay-for-care' principle introduced in 2001 had led to rapidly rising costs. However, armed with the argument that a 'right to health care' was not a real right if it could not be called upon to get timely care, Bomhoff, echoing Fortuyn, again gave momentum to the need for system reform. ${ }^{139}$ But the lack of leadership in the LPF following Fortuyn's death soon brought to the fore the tensions that existed within a party that had been highly dependent on its standard bearer, and after 87 days of infighting the whole cabinet was officially dissolved. In the cabinet that was formed shortly afterwards the LPF was replaced with D66, making for a conservativeliberal coalition and a return to parliamentary normalcy. The new Minister concerned with pushing through Supplying Demand was the Liberal Hans Hoogervorst, an agile and experienced

\footnotetext{
136 Ibid., 45-49.

${ }^{137}$ https://www.parlement.com/id/vh8Inhrpfxup/kabinet balkenende i 2002 2003, accessed on 19-092019.

138 Raad voor de Volksgezondheid en Zorg, Exploderende zorguitgaven. Signalement over uitgavenmanagement (Zoetermeer: Raad voor de Volksgezondheid en Zorg 2003) 11; Kerkhoff \& Dols, 'Algemene Wet Bijzondere Ziektekosten vanaf 1987', 859-860.

${ }^{139}$ Schut, De zorg is toch geen markt, 12-14, 16.
} 
politician who had been State Secretary and Minister at other departments before. ${ }^{140}$ Hoogervorst would need this experience: on entering the 2003 cabinet, it was clear that he would need to cut back 2,3 billion euros in health care expenditures because of the 'pay-forcare' principle and Bomhoff's 'floodgate' financing. ${ }^{141}$ The urgency for system reform had become stronger than ever.

\section{The Final Stretch}

After the LPF's adventures in health care, the plan to implement the principles of the 2001 report Supplying Demand again became a priority. ${ }^{142}$ It is interesting that this plan - which stressed the market but also universal insurance - was taken up in full by a center-right cabinet. By now, the Christian-Democrats, Liberals and Social Liberals were all by and large in favor of the effects on efficiency that regulated competition would have on the system, while safeguards for solidarity through mandatory insurance were kept in place. The parties differed on relatively small details concerning personal responsibility and the supplementing of cost by patients, but when the coalition agreement between these parties saw the light in May of 2003, the implementation of the plan for both market and broad basic insurance was set at 1 January 2006 in a bid to finally temper the still 'explosive' growth of cost in the sector. ${ }^{143}$ By the middle of 2003, the contours of the new insurance scheme were beginning to take form. The 2000 and 2001 reports had differed in their recommendations of either a public or a private scheme - systems in which either the public sickness funds or the private insurers would administrate mandatory insurance policies. Although at the outset of the new cabinet, the government officials at the Ministry of Health still strongly favored a public scheme, by late 2003 the preference had shifted to a private arrangement with a strong role for the government in guaranteeing accessibility and quality.

\footnotetext{
${ }^{140}$ State Secretary of Social Affairs and Minister of Finances, to be exact. See https://www.parlement.com/id/vg09lllc9opo/j $f$ hans hoogervorst, accessed on 19-09-2019.

${ }^{141}$ T. van der Grinten and J.-K. Helderman, 'De gezondheidszorg: de (on)draaglijke traagheid van een stelselwijziging', in: M. Arentsen and W. Trommel, Moderniteit en overheidsbeleid. Hardnekkige beleidsproblemen en hun oorzaken (Bussum: Coutinho 2005) 85-108, 103.

142 For a highly detailed behind-the-scenes account of the introduction of regulated competition and the basic insurance, see Bassant, Ziekenfonds of particulier.

143 Kamerstukken II, 2002-2003, 28 367, no. 19 (Meedoen, meer werk en minder regels. Hoofdlijnenakkoord voor het kabinet CDA, VVD en D66) 10-11.
} 
The CDA, the largest political party at the time, played a crucial role in this regard, with its stressing of the importance of personal responsibility and private initiative.

After Hoogervorst had been satisfied that a private arrangement would not come into conflict with the rules for free market competition within the European Union, in December of 2003 it was decided that the primacy of governing the system would indeed come to lie with private insurers operating under a public law providing safeguards for quality and solidarity. ${ }^{144}$ These safeguards were very significant. Insurers could not deny coverage: the Health Insurance Act would introduce the obligation for citizens to insure themselves, but also for insurers to accept anyone who applied for the basic insurance. What was covered by the basic package, as we have seen, would turn out to be extensive, 'necessary' care. Moreover, behind the scenes the financing of the insurance scheme showed a high degree of equalization and solidarity; a Sickness Insurance Fund would be created which redistributed funds to insurers on the basis of the risk profile of their insured populations. This meant that insurers covering a population with more care needs would get more money. ${ }^{145}$ After some political negotiation, a no-claim feature was introduced, as was a 'care subsidy' which would subsidize lower-income citizens to make insurance premiums affordable. ${ }^{146}$

At first glance, the choice of a private system seemed to be a technical issue, but its effect on political support was significant. A decade before, Simons' basic insurance plan had irked not just his political opponents, but also both the sickness funds and private insurers - the sickness funds had argued that the system would not be social enough, whereas the private insurers instead saw it as the death blow to their historically more market-oriented operations. By this time, however, the operations of public and private insurers had 'converged' to such an extent that the choice of a private system drew mostly positive reactions from both groups; the difference between 'public' and 'private' would in any case have been mostly marginal by this time (a development discussed more extensively below). But also the federation of employers was now largely in favor of the new organization. ${ }^{147}$ This was an about-turn from the position taken in the televised debate with Hans Simons ten years before, when the employers had argued against the introduction of the market for fear of rising costs. More in general, by the time parliamentary debates on the newly proposed Health Insurance Act commenced in the spring of 2004, Hoogervorst and his close aide, Director-General Martin Van Rijn had begun to make headway in winning support among other groups. For instance, in early 2003 Van Rijn had visited the interest groups representing the hospitals and the patient organizations, and in late

\footnotetext{
144 Kamerstukken I, 2004-2005, 29 763, E (Memorie van Antwoord Zorgverzekeringswet) 33-34.

145 Kamerstukken II, 2003-2004, 29 763, no. 3 (Memorie van Toelichting Zorgverzekeringswet) 6, 20, 49-51.

146 Kamerstukken II, 2003-2004, 29 762, no. 3, (Memorie van Toelichting Wet op de Zorgtoeslag) 1.

147 Bassant, Ziekenfonds of particulier, 83-90.
} 
2003 a secret meeting was held where the contours of the new act were presented to important parties in the field. ${ }^{148}$

Such actions point to the subtle strategies employed by this Minister and his aide in walking a fine line between publicity and secrecy, a subtlety the lack of which had arguably been Hans Simons' downfall. ${ }^{149}$ Still, left-of-center parties PvdA, SP (the Socialist Party) and GroenLinks (the Green Left) opposed a private system in which stimulating cost-awareness on the side of patients could end up privileging wealthier citizens. Outside of parliament, employers were critical of the share of the insurance premiums of their employees that they would have to pay. But Hoogervorst managed to keep many parties on board through subtle concessions and an open debate. When the Act was accepted by the Second Chamber of Parliament in late December, it had won support from all but the three left-of-center parties. ${ }^{150}$ By the time the discussion on health care reform reached the Senate floor in early 2005, discussion had shifted more from ideological issues to matters of practical implementation. Still, Hoogervorst later stated that "[...] the Health Insurance Act could no longer be stopped, but it could be derailed." ${ }^{151}$ However, by now the insurers claimed that too many investments had already been made for the system reform to be rolled back. ${ }^{152}$ Health care providers - primarily GPs - offered some organized resistance with help from the Socialist Party, but to little avail. ${ }^{153}$ On June 14, 2005, the Health Insurance Act passed through the Senate. In late 2005, the Implementation Act that laid down the rules for governing the details of the system reform was passed in Parliament, followed by the act on the supervision of the system through the Dutch Health Care Authority in the middle of 2006 .

\section{A Radical New Paradigm?}

Some twenty years after the Dekker-committee first proposed introducing a system of regulated competition guided by private health insurers administering a universal insurance scheme, these proposals were (finally) enacted. But by the time Hans Hoogervorst left politics - justifiably content at having managed what many statesmen and -women had failed to do before him - it

\footnotetext{
148 Ibid., 75, 87-88. Erasmus University Rotterdam 2006) 12-16.

150 Bassant, Ziekenfonds of particulier, 101-104, 108-117.

${ }^{151}$ Ibid., 145.

152 Ibid., 118-122.

153 Ibid., 128-133.
}

${ }^{149}$ For a discussion of the differences, see T. van der Grinten, Zorgen om beleid. Over blijvende afhankelijkheden en veranderende bestuurlijke verhoudingen in de gezondheidszorg (valedictory address 
was clear that there could be no talk of a strong separation of state from market, solidarity from individuality, private from public in the by now vast mandatory provision of health care to an unprecedented part of the population. A newspaper article written two weeks after the introduction of the Health Insurance Act noted that: "Sixteen years after the fall of the [Berlin] Wall, the planning-economy in health care may have disappeared, but there can be no talk of a free market." 154

This is because of the complex entanglement of social goals with the new, privately administered, system. The Dekker-report of 1987 and the implementation of its primary proposals in 2006 have come to be identified with the proposal to introduce a new model for governing health care: that of the 'regulated health care market'. 'Dekker' soon came to stand for the introduction of a new 'governmentality' based on market principles: competition between insurers, negotiations between insurers and health care providers, a more assertive patient/client, and a more limited role for what the Dekker-committee had disapprovingly called a 'planning, paternalistic government'. The question is how fair this simplistic interpretation is to the committee's proposals, given that a radical reform of the insurance system was seen as the core of the report. And in looking not just at the ideology, but also the implementation of 'Dekker', it becomes clear that the 1987 report in effect led to a culmination of long grown historical relations and cultural sentiments. For alongside the introduction of the regulated health care market in 2006, a long sought-after policy goal was finally achieved: a broad national insurance for every Dutch citizen, with no differentiation between insurance holders on the basis of their income. The road to this universal insurance had not been without obstacles or paradoxes, as we have seen. Where the Social-Democrat Simons failed in introducing it, it would be the Liberal Hoogervorst who by 2005 managed to steer a broad, basic insurance with an unprecedented degree of income-levelling solidarity through Parliament. This happened after an intervening decade in which grand system reform was deemed anathema for having become synonymous with governmental overreach. Nevertheless, by 2006, a true revolution had taken place in the way access to care was now guaranteed through the link between government and private insurers.

Still, from the perspective of the analytical concept of 'governmentality' guiding this dissertation, something revolutionary and radical also took place in the mechanisms of governance underlying Dutch health care - by now truly seen as a more or less coherent system. Here, '2006' would turn out to be a beginning rather than an endpoint. For this new

\footnotetext{
154 M. Peeperkorn, 'Geldverslindend zorgstelsel moest op de schop', 14-01-2006, accessed via https://www.volkskrant.nl/nieuws-achtergrond/geldverslindend-zorgstelsel-moest-op-deschop b8d4c28b/, 19-07-2019.
} 
governmentality had to be actively created to quite an extent. It is time to put forward a quote by Michel Foucault on the 'construction' of the market:

There will not be the market game, which must be left free, and then the domain in which the state begins to intervene, since the market, or rather pure competition, which is the essence of the market, can only appear if it is produced, and if it is produced by an active governmentality. ${ }^{155}$

The intention to 'produce' the new governmentality of regulated competition can be clearly distilled from the core documents surrounding its implementation. The memorandum to the Health Insurance Act of 2006 stated that: "The government is of the opinion that the health care system can improve its operations significantly by replacing, where that is possible, the system of centralized coordination with a more decentrally organized system of regulated competition. ${ }^{156}$ And Dekker's broad vision, as we will recall, was to have a " [...] regulating, planning and paternalistic government [retreat]", with as its final goal that " $[\ldots]$ the health care sector itself puts things in order." 157 To this end, various market mechanisms would have to be introduced by the state to allow for more freedom and choice for insurers, patients, and health care providers. The main players in such a new governmentality were to be the private insurers as the 'directors' of the health care system. ${ }^{158}$ These insurers would have the obligation to offer the basic insurance package to Dutch citizens while competing with each other on premiums. Simultaneously, they would have to start playing a large role in maximizing efficiency and reducing the cost of care through negotiations and selective contracting with health care providers. At the same time, the historical development of growing support for the social goal of accessible health care (and the government's role in safeguarding this) was firmly codified. The Health Insurance Act of 2006 and the accompanying Act on Market Regulation in Health Care made clear that "The government retains systemic responsibility ['systeemverantwoordelijkheid'] for the accessibility, affordability, and quality of health care [my italics, RB]." ${ }^{159}$ It was clear that the government still had an important role to play in protecting these three public goals underlying the system as a whole.

In the historiography, 2006 has thus far been taken to be an end point in the development of Dutch health care. ${ }^{160}$ This is understandable - the introduction of the Health Insurance Act and the regulated health care market are unmistakable milestones. However, at

\footnotetext{
155 Foucault, Biopolitics, 121.

156 Kamerstukken II 2003-2004, 29 763, no. 3 (Memorie van Toelichting Zorgverzekeringswet) 2.

157 See the discussion of the Dekker-report further on.

158 Kamerstukken II, 2003-2004, 29 763, no. 3 (Memorie van Toelichting Zorgverzekeringswet) 9.

159 Ibid., 3.

160 See Vonk, Recht of schade; Companje, Two Centuries of Solidarity and Companje, Tussen volksverzekering en vrije markt; Van Klaveren, Onafhankelijkheidssyndroom.
} 
the time of writing, more than thirteen years have passed since the introduction of the 2006 Health Insurance Act and the Act on Market Regulation in Health Care. It therefore seems appropriate to examine the development of the new governmentality, and ask the question whether - as in previous periods - there is a mismatch between the rhetoric of this new governmentality and the reality on the ground. In an important sense, the regulated health care market goes back to the age-old focus on the private and local initiative that dominated the larger part of the period discussed in this dissertation. Giving back 'control' to the parties in the field fits in well with this (political) philosophy, which was dominant for such a long time in thinking about how to govern health care. And yet, the way in which the state has become implicated in guaranteeing far-reaching access to health care in the post-war era has severely limited the extent to which giving back such control was possible. We will see that in both the workings of the regulated health care market and in transitions in long-term care, the return to old forms of governance has combined in interesting ways with the solidarity that had become an essential characteristic of the system over time. Let us first turn to the market - or rather, markets - of curative care, and their development since 2006.

\section{Constructing the Health Care Markets}

Thus far, in referring to the 2006 system, I have spoken of the regulated health care market, which is a concept that requires some further elaboration. When the health care 'market' was conceptualized in 1987 and dragged from the mothballs again in 2001, the foundational notion was that of a triad of parties competing with each other in order to ultimately make health care more cost-effective and qualitatively sound. In the 2001 report Supplying Demand, this triad was visualized (in simplified form) thus: 


\section{Fig 4.3 The three markets comprising the 'regulated health care market'}

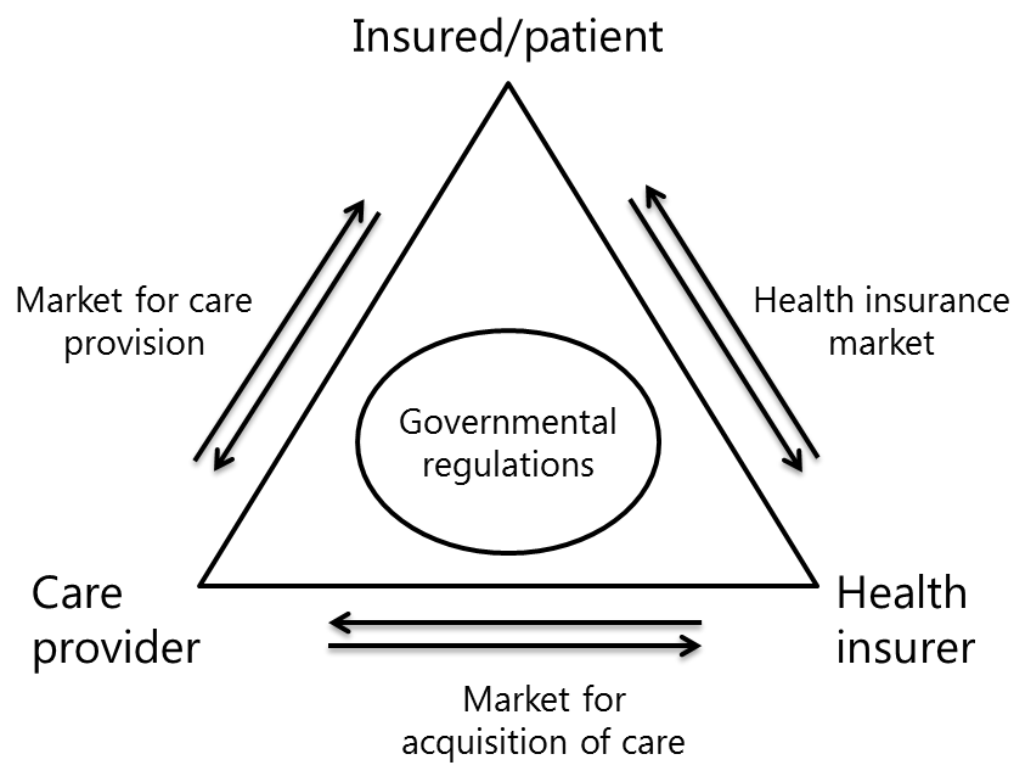

Original figure: Kamerstukken II, 2000-2001, 27855, no. 2 Nota Vraag aan bod, p. 21.

As such, three markets in health care were, in effect, created: one for patients and insurers; one for insurers and care providers; and one for care providers and patients. The constructing of these distinct markets in the overall scheme of health care was intended to effect historicalinstitutional change: as already set out in the Dekker-report, insurers and care providers would have to start engaging in real competition through price negotiation and improved quality, with the end goal of attracting customers in the form of insureds/patients. These would be able to exert their power as consumers with their feet - by choosing their preferred health care provider - and with their wallet, by selecting the cheapest insurance policy. To facilitate all this, while keeping a close watch on the general workings of the system, the government had ostensibly taken a backseat in order to let market operations develop without a framework of 'planning' and state interventions.

However, a closer look at the role the government plays through its regulatory bodies and agreements with 'the field' provides a far more nuanced understanding of public and private power in health care post-2006. After decades in which the state had a visibly strong role in supporting solidarity and access, since 2006 both public opinion and the way parties in the field operate have come to an equilibrium situated somewhere in between 'state' and 'market'. Still the safeguarding of affordable access to a broad package of qualitatively good health care is seen as the desirable end result by all. It seems that when these goals are threatened by 'too much market', the government intervenes in what are sometimes far more consequential ways than the rhetoric of the new governmentality of the regulated market suggests. As a recent 
overview of the results of the 2006 system overhaul puts it: "It is during implementation that reforms acquire a 'true' face." ${ }^{\prime 161}$ Let us first look at the extent to which the conditions for market competition have actually been 'constructed' through governmental action.

\section{Creating Competition on an Uneven Playing Field?}

In the run-up to the implementation of the 2001 report Supplying Demand, much attention was paid to the mandatory standard health insurance with regard to its effects on income and solidarity. More important from the perspective of the state and its intention to create optimal conditions for the functioning of the new regulated market, however, was the institution of the Dutch Healthcare Authority (Nederlandse Zorgautoriteit). This 'independent public body' ('zelfstandig bestuursorgaan') came into being in October 2006 and was tasked with a broad and loose mandate in order to regulate and stimulate competition in the health care markets. Its core goals were to stimulate the market where possible, to regulate tariffs where necessary, to provide reliable information on insurance and health care provider quality to patients (facilitating active choice), and to create coherence in the regulation and supervision of the health care markets. To achieve these goals, the Healthcare Authority was the primary governmental body involved in setting tariffs in care, as well as in supervising both insurers and care providers and in making sure that legislative obligations that came with the Health Insurance Act were met. ${ }^{162}$

From the perspective of competition, the most crucial task of the Healthcare Authority and its general, non-health care specific sister, the Authority for Consumers and Markets (henceforth: $\mathrm{ACM})^{163}$, was the creation of a level playing field for insurers and providers, which would allow competition to flourish with no parties becoming so powerful that they would be able to effectively coerce other parties or in other ways unduly distort the market. To this end, the two market watchdogs were tasked with preventing risky concentrations of power and cartel behavior on the health care markets and were equipped with the authority to prevent mergers, as well as to fine or otherwise sanction parties. ${ }^{164}$ However, right from the institution of the

\footnotetext{
${ }^{161} \mathrm{H}$. Maarse, P. Jeurissen, D. Ruwaard, 'Results of the market-oriented reform in the Netherlands: a review', Health Economics, Policy and Law 11 (2016) 161-178, 163.

162 Kamerstukken II, 2004-2005, 30 186, no. 3 (Memorie van Toelichting Wet marktordening gezondheidszorg), 4-5. See also: E. Steyger, 'Marktwerking in oprichting: de bevoegdheden van Zorgautoriteit en NMa en de werking in de praktijk', Tijdschrift voor Gezondheidsrecht 1 (2006) 2-15, 2-4, 14; Dute and Legemaate, Handboek gezondheidsrecht, 769-773.

163 Nederlandse Mededingingsautoriteit, since 2013 the Autoriteit Consument \& Markt. 164 See M.P.M. Wiggers, De NMa en de NZa in de curatieve zorgsector. Een toetsing aan het Europees mededingingsrecht (Deventer: Kluwer 2013) 26-28.
} 
Healthcare Authority it seemed clear that this duty would be daunting. When the Healthcare Authority was installed, a professor of health care law critically opined: "The match has started, the referee must enter the field. But will he be able to keep up with the game?"165 This question would shortly be answered in the negative. The state's mission to construct health care markets in which competition was possible proved hard, but in large part because it was reluctant to let its competition watchdogs bark, let alone bite, at rapidly growing concentrations of power.

The competition authorities were dealt a bad hand to begin with, given the consolidation of power on the insurance and (primarily) hospital markets that had already taken place in the 1980s and 1990s. Just a year after the publication of the 2001 Supplying Demand report, a committee was installed to investigate power concentrations in the various health care markets to be created. In 2002 it was found that of these three markets only the market of patients and insurers was not marked by significant concentrations of power. Still, even there, only five insurance concerns controlled $62 \%$ of the market shares of sickness funds and private insurance combined. ${ }^{166}$ Not surprisingly, the report was very skeptical of the 'active' role insureds would be able to play when faced with an oligopoly of insurers, which moreover only seemed to be growing stronger. ${ }^{167}$ Where health care providers and institutions were concerned, the situation was even more dire: there could be no mistaking the growth of power concentrations through mergers in especially the hospital market in the preceding decades. Though the biggest wave of mergers had actually taken place in the 1980s in response to budgeting policies, in the 1990s hospitals had continued to consolidate their regional power positions in anticipation of the introduction of 'Dekker'. ${ }^{168}$

Even though in 2002 the impact of such concentrations on regulated competition was considered unclear, it was obvious that the number of parties on these markets had been shrinking drastically, which had significantly reduced choices for patients, insurers and providers. For instance, between 1951 and 2002 the number of small hospitals had decreased from about

\footnotetext{
165 J.C.J. Dute, 'Gezichtspunt. Zorgen om de Zorgautoriteit', Tijdschrift voor Gezondheidsrecht 301 (2006) 1. ${ }^{166}$ Ministry of Health, Welfare and Sport, Geconcentreerd dereguleren? Onderzoeksnotitie naar bestaande concentraties en machtsposities in de zorg (Den Haag: 2002), 5-6, 27.

167 "The position of the patient as a client on the health care market is still weak [...] Through mergers among insurers the number of insurers competing with each other is shrinking", a 2003 report by the RVZ concluded (Raad voor de Volksgezondheid \& Zorg, Van patiënt tot klant (Zoetermeer: Raad voor de Volksgezondheid \& Zorg 2003) 18).

${ }^{168}$ For a history of hospital mergers until 2017, see: A.F. Roos, Mergers and Competition in the Dutch Healthcare Sector (Rotterdam: diss. Erasmus Universiteit Rotterdam 2018) 25-35. Budgeting strategies of the 1980s had led to what in essence amounted to a 'merger bonus' for hospitals, as bigger hospitals were given a relatively larger budget to account for the greater complexity of care they nominally provided. This 'merger bonus' was abandoned by the Ministry of Health only in 2003.
} 
170 to less than $20 .{ }^{169}$ In the years 1990 to 1999 , the total number of hospitals decreased from 125 to $100 .{ }^{170}$ And between 1990 and 2005 the total amount of insurers dropped from 82 to 59. ${ }^{171}$ By the time 'Dekker' was implemented in 2006, the market logic therefore practically screamed for a critical watchdog which would curb (further) mergers and concentrations of power. After all, the new governmentality was predicated on the ability of insurers to compete on premiums, and health care providers to compete on the price (tariffs) of medical interventions. Such opportunities for competition would be severely reduced in markets in which certain parties had so much market share and power that they did not have to respond to the price-setting or business operations of (much) smaller competitors.

Twelve years down the line, it appeared that curbing such power was not a success story for either the Healthcare Authority or the more general ACM. Where health insurers were concerned, the concentration of power was (and is) most glaring. The total number of insurers dropped from 59 in 2005 to just 26 in 2014, and even further down to 23 in 2018 (with most of them subsidiaries of only 10 large concerns). ${ }^{172}$ Moreover, the way the market pie came to be divided in this period clearly points to an entrenched oligopoly. ${ }^{173}$ In 2002, five concerns controlled $62 \%$ of the insurance market. By 2018 , four concerns controlled $86,5 \%$, and the division of the market looked like this:

\footnotetext{
169 Bureau voor Economische Argumentatie KPMG, Marktconcentraties in de ziekenhuissector (Zoetermeer 2003) 20-22, 47-48; RVZ, Van patiënt tot klant, 28-29.

170 Ministry of Health, Geconcentreerd dereguleren, 46.

171 Maarse et al, 'Results of reform', 166.

172 Ibid., 166; NZa, Monitor Zorgverzekeringen 2018, 6.

${ }^{173}$ As of 2018 , the four biggest concerns have a combined market share of $86,5 \%$. However, this is down from 88,5\% in 2016. (NZa, Monitor Zorgverzekeringen 2018, 6).
} 


\section{Fig. 4.4 Market shares on the health insurance market, 2018}

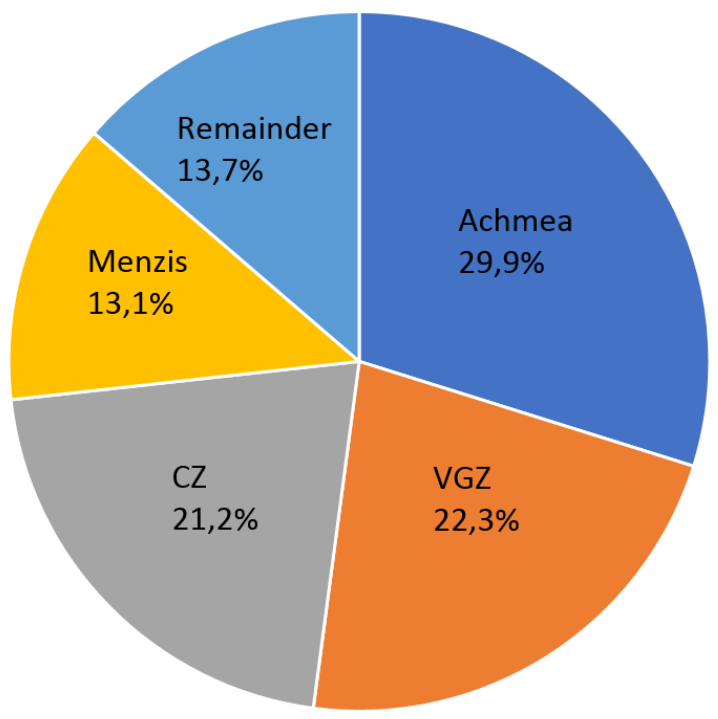

Original figure in: NZa, Monitor Zorgverzekeringen 2018 (Utrecht: NZa 2019) 6.

But also where hospitals are concerned is it clear that the competition authorities have refused to take action or have at any rate been ineffective in curbing further concentration and the consolidation of regional power positions. As noted above, in 1999 there were 100 hospital organizations in The Netherlands. By early 2018, the total number of hospital organizations had declined further, to just 79. ${ }^{174}$ Between 2004 and 2017, only one merger was blocked by the ACM, while 28 were allowed to proceed without a hitch. ${ }^{175}$ Moreover, since the introduction of a 'health care-specific merger test' in 2014, the Healthcare Authority only once forced two merging hospitals to provide more information and to monitor regularly the effects of the merger because of its potentially detrimental effects on competition. On a grand total of 549 positive decisions on mergers between 2014 and 2018, this seems rather underwhelming. ${ }^{176}$

\footnotetext{
${ }^{174}$ It must be noted that these organizations comprise a grand total of 120 hospital locations and 134 outpatient clinics. Data via https://www.volksgezondheidenzorg.info/onderwerp/ziekenhuiszorg/cijferscontext/aanbod\#!node-aantal-instellingen-voor-medisch-specialistische-zorg, accessed on 02-10-2019. In 2016 there was also a grand total of 229 'independent treatment clinics' (zelfstandige behandelcentra). However, these clinics should not be accorded too much weight, as in 2012 they only accounted for 2,5\% of the market share while since then their number has decreased. Roos, Mergers and Competition, 36-37; Nederlandse Zorgautoriteit, Marktscan medisch-specialistische zorg 2016 (Utrecht: NZa 2017) 5. 175 Roos, Mergers and Competition, 35.

${ }^{176}$ M. Varkevisser and E. Schut, 'Fusietoetsing in de zorg: een terug- en vooruitblik', Tijdschrift voor Toezicht (2019) 5-12, 6-7. This grand total also includes mergers between mental health institutions, groups of medical specialists, and other parties.
} 


\section{Competition Watchdogs: Fast Asleep or on a Tight Leash?}

Unsurprisingly, this state of affairs drew critique from commentators who reasoned that in order for competition to work, power concentrations must be minimalized. A 2018 critical assessment of all these mergers wondered whether more aggressive regulation by the competition authorities would therefore not simply be 'too little, too late' to bring about serious competition on the hospital market - it seemed the competition authorities had been fast asleep since their creation. ${ }^{177}$ The economic evidence available suggested that power consolidation in the hospital field often leads to higher prices, whereas effects on improving the quality of care seem meagre. ${ }^{178}$ The concentration of insurers, on the other hand, led to fears from the side of both hospitals and patients that such power could be abused in negotiations with health care providers or through cartel agreements concerning the setting of insurance premiums. ${ }^{179}$ All in all, the apparently lax performance by the Healthcare Authority and the ACM was thoroughly at odds with the goals of stimulating competition on costs (insurers and providers) and quality (providers). ${ }^{180}$ However, from a broader perspective it is rather questionionable whether 'more market' is really what the government has since 2006 been pursuing.

The governing Act of the Healthcare Authority contains a small yet crucial provision: article 7 stipulates that the "Minister can give the Authority general instructions" ${ }^{181}$ In theory, the Authority chooses its own policy instruments in achieving goals formulated broadly by the Minister. In practice, however, the Healthcare Authority has since its creation in 2006 been closely tied to government, illustrating the complex relationship between the state and one of its 'independent public bodies'. In 2014 a critical report noted that despite this 'independent' status, the Healthcare Authority " [...] must be firm and strong-willed to resist unjustified interventions [by the Ministry]". These interventions had indeed taken place in the years before

177 A.F. Roos, E. Schut and M. Varkevisser, 'Een halve eeuw ziekenhuisfusies in Nederland', ESB 1034766 (2018) 440-443, 443. ("[...] de vraag [...] dringt zich op, of een streng fusietoezicht nog veel zoden aan de dijk zal zetten, of dat het kalf in veel regio's inmiddels al verdronken is.")

178 Roos, Mergers and Competition, 42-44.

179 Maarse et al, 'Results of reform', 172-173.

180 See e.g.: E.M.H. Loozen, Mededingingstoezicht in de zorg. Het moet en kan beter (Rotterdam: Instituut Beleid \& Management Gezondheidszorg 2013), specifically the articles 'NMa en NZa: houd je bij je leest! Een analyse van de mededingingsbevoegdheden van beide toezichthouders aan de hand van het Samenwerkingsprotocol NMa-NZa 2010' (p. 87-114) and 'Fusie zorgverzekeraars Achmea en De Friesland: hoezo functioneel concentratietoezicht?' (p. 131-151); Wiggers, NMa en de NZa, specifically p. 367-370; E. Loozen, M. Varkevisser and E. Schut, 'Goede zorginkoop vereist effectief toezicht op marktmacht', ESB 101 4737 (2016) 426-429.

${ }^{181}$ Article 7 Wet marktordening gezondheidszorg. 
$2014{ }^{182}$ But it is very much the question whether after 2014 the government has let the Healthcare Authority 'off the leash' to prevent further concentrations of power and stimulate the true development of competition in Dutch health care.

This can best be seen in the complex interplay between the state and both of its competition authorities. The Healthcare Authority has a large role to play in regulating tariffs in health care. But given its lack of effectiveness in critically evaluating mergers in the health care field, in 2018 legal commentators asked whether the Act on Market Regulation "[...] is not primarily an Act on Health Care Budgeting." ${ }^{183}$ Instead, the onus has increasingly been put on the ACM, as the 'general' competition authority, to foster competition on the health care markets. ${ }^{184}$ However, the $\mathrm{ACM}$, too, has steered an ambiguous course in regulating markets in health care, which would seem to be related to (the government's focus on) the public goals underlying the system. In theory, the Competition Authority is critical of (cartel) agreements between market parties which potentially limit competition - a position that has, on occasion, led to punitive action. ${ }^{185}$ However, the strong public goals underlying the system have pushed the ACM to mostly facilitate the growth of cooperation between insurers and between health care providers in recent years, if such cooperation seems to benefit patients. The competition authority has sought to pre-empt having to act on cartel agreements, by publishing guidelines for, among other things, insurers collectively buying medicines ${ }^{186}$, providers cooperating on complex cancer care ${ }^{187}$, or insurers and providers 'relocating' care to bring it closer to the patient. ${ }^{188}$ Such a strategy is understandable from the perspective of achieving better and

182 H. Borstlap, P.F.M. van der Meer Mohr, L.J.E. Smits, Het rapport van de Onderzoekscommissie intern functioneren NZa, accessed via https://puc.overheid.nl/nza/doc/PUC 3199 22/1/ on 2-10-2019, pp. 107121, quote on p. 121.

183 Dute and Legemaate, Handboek gezondheidsrecht, 744.

${ }^{184}$ A legislative proposal is currently in the works to transfer the Healthcare Authority's powers to assess mergers and power concentrations to the ACM. Kamerstukken II, 2015-2016, 34 445, no. 3.

185 The most notorious example of which was the 2011 decision to fine the Dutch Association of General Practitioners 7,7 million euros for cartel behaviour. This example was notorious, because in the 2015 court case initiated by the GPs, this Competition Authority's decision was overturned and the fine deemed unjust. J.G. Sijmons, 'Sturen in de zorg met de zorgverzekering. De perikelen rond de wijziging van art. 13 Zorgverzekeringswet', Aansprakelijkheid Verzekering en Schade 14 (2015), 88-93.

186 Autoriteit Consument \& Markt, 'Leidraad gezamenlijke inkoop geneesmiddelen voor de medischspecialistische zorg', June 2016, via: https://www.acm.nl/sites/default/files/old publication/publicaties/15959 leidraad-gezamenlijke-inkoopgeneesmiddelen-voor-medisch-specialistische-zorg-2016-06-22.pdf, accessed on 03-10-2019.

${ }_{187}$ Autoriteit Consument \& Markt, letter d.d. 15-07-2016 concerning 'Informele zienswijze samenwerking complexe oncologie UMCU, St. Antonius Ziekenhuis en Meander Medisch Centrum, via: https://www.acm.nl/sites/default/files/old_publication/publicaties/16189 informele-zienswijzesamenwerking-ziekenhuizen-complexe-kankerzorg.pdf,.

${ }^{188}$ Autoriteit Consument \& Markt, 'Concept ACM-beleidsregel over het verplaatsen van zorg in het kader van de Juiste Zorg Op de Juiste Plek', d.d. 19-07-2019, via: 
cheaper health care. At the same time, after a decade of the regulated market, the question is whether the goal of stimulating real competition is gradually being traded in for an emphasis on cooperation in health care, as long as such cooperation does not exceed certain boundaries. ${ }^{189}$

Most insightful with regard to the relationship between the state and the 'constructors' of the health care market was a recent development. It was only in July 2018 - 'too little, too late'? - that the ACM acted on the various signals and the evidence that hospital mergers might not contribute to achieving the ultimate end goal of improving patient care and curbing costs. It did so in response to a request from the Minister of Health to investigate the possibility of more stringent supervision on mergers. Now, the role and the intentions of the government as the guardian of the health care system came more prominently to the fore. In a letter to the Minister, the ACM outlined three options for preventing further consolidation or concentration of power in the health care field: to prohibit mergers when one of the parties involved already has a considerable market position; to force health care providers with a considerable power position to delegate certain care tasks; or to prohibit flat-out mergers which would lead to institutions exceeding a certain size. ${ }^{190}$ In response, Minister of Health Hugo de Jonge (of the Christian-Democrats) replied that of the three options, only the first one would be worth exploring. In short, only mergers where one party already has a strong power position should be assessed critically and possibly forbidden.

But despite the Minister's view that the ACM could (but not: should) prohibit such mergers, the reasoning vis-á-vis the other types of power concentrations was very revealing. Although undesirable concentrations of power stood in the way of true market competition, forcing parties in the field to slim down through the delegation or the disposal of care tasks was not the way to go: "[...] as this would have consequences for the opportunities for providers and insurers to enter into good agreements on good care for patients [...]". And concerning the ACM's proposal to automatically forbid mergers which would lead to institutions of a certain scale, "I am of the opinion that setting a limit to the size of health care institutions would unduly emphasize scale at the expense of the public goals of affordability, quality and accessibility of

https://www.acm.nl/sites/default/files/documents/2019-07/consultatiedocument-acm-beleidsregeltoezicht-op-verplaatsing-zorg-jzojp.pdf, accessed on 03-10-2019.

${ }^{189} \mathrm{~W}$. van der Schors, R. Kemp and M. Varkevisser, 'Toepassing kartelverbod in de zorg laat veel ruimte voor samenwerking', ESB (to be published), via: https://esb.nu/esb/20057102/toepassing-kartelverbod-inde-zorg-laat-veel-ruimte-voor-samenwerking?utm source=nieuwsbrief\&utm campaign=esbwekelijks\&utm medium $=$ email\&utm content $=20200109$, accessed on 17-01-2020. See also: B. Kiers, 'Leon van Halder wil 'markt-samenwerking', Zorgvisie 48 12-13 (Dec 2018) 24-27; S. Broersma, 'Marktwerking maakt plaats voor samenwerking', Skipr 12 9-10 (Sept 2019) 3; B. Kiers, 'RVS-voorzitter Jet Bussemaker: 'Aansturing van de zorg moet anders", Zorgvisie 49 (Sept 2019).

190 Autoriteit Consument \& Markt, ACM/UIT/496816 (Letter to Minister of Health, d.d. 19-07-2018). 
care [...] I will therefore not look into this suggestion any further." ${ }^{191}$ It seems that in such a view the rhetoric of fostering competition is made subservient to the reality of the government's acquiescence in the growth in size of health care providers, as long as this does not endanger the main public goals underlying the system.

The 2006 Act on Market Regulation in Health Care created the legislative and institutional tools for governing/creating the health care markets. But as two health economists recently stated: "The problem lies not with the legal instruments themselves, but in their application." ${ }^{192}$ Serving the public goals of accessibility, affordability and quality was not the 'problem'. Rather, the fact that since 2006 the government has been reluctant to enforce the spirit of the law in order stimulate serious competition was at odds with the rhetoric of the 'regulated market' which was (and is) nominally the governmentality under which the Dutch health care system operates. This reluctance left little room for the 'independent' competition authorities to 'construct' the health care markets by breaking up existing power concentrations in the health care field. Instead, the state seems firmly in control - also through the exertion of influence on its competition 'watchdogs'. What of the new governmentality in the health insurance field? In 2006, the imperative to 'direct' health care was laid on private insurers, who would be the 'spiders in the web' of health care. ${ }^{193}$ Has the state in fact allowed them to fulfill this role, delegating tasks to 'the field' in the manner envisioned by the Dekker-committee in $1987 ?$

\section{A New Role for Insurers and Patients}

As was briefly discussed earlier in this part, by the time Supplying Demand was taken up again, the decision had not yet been made whether the insurers that would be mandated to provide the standard insurance would be public or private entities. By late 2003, the choice had, however, been made in favor of private insurers. But to many of those involved, this was a relatively arbitrary matter. As Minister of Economic Affairs Laurens Jan Brinkhorst of the D66 party put it: "I don't care if the cat is black or white, as long as it catches mice." 194 This might have been an off-the-cuff remark, and in the accompanying memorandum to the Health Insurance Act, the choice was also hardly elaborated upon. The government later even termed it

\footnotetext{
${ }^{191}$ Minister of Health, Welfare and Sport, Letter to the Chair of the Second Chamber of Parliament, 'Ontwikkelingen fusietoezicht in de zorg', d.d. 22-10-2018, p. 4.

192 Varkevisser and Schut, 'Fusietoetsing', 11.

${ }^{193}$ For a discussion of the (original) role reserved for health insurers in the 2006 system, see G.R.J. de Groot, 'De zorgverzekeraar: spin in het web?', Tijdschrift voor Gezondheidsrecht 291 (2005) 40-60. ${ }^{194}$ Cited in Bassant, Ziekenfonds of particulier, 88.
} 
a 'coin toss'. After all, how big would the difference be between a public insurance scheme privately administered, or a private scheme with public safeguards? ${ }^{195}$ But the decision to let private insurers be the carriers of health insurance was not inconsequential. Even if many of the insurers that operated after 2006 were former (social) sickness funds or had merged with those funds in the run-up to the system reform, the profit motive that had historically characterized the commercial insurers could in theory now be embraced by all insurers offering the standard package; insurers would get real bargaining power vis-a-vis health care providers; and the choice for a private system in general signified that the government would have less say over the operations of health care - which was highly relevant for the system's new 'governmentality'. 196

But the choice of a private system also led to critique and to fears of 'too much market' in the provision of a social insurance scheme for health care. Fears were uttered that certain developments potentially at odds with the core goals of accessibility and affordability could once again creep into the system - such as risk selection, a practice that was gradually phased out in the commercial insurance industry from the late 1960s onwards, as we have seen in previous parts. Allowing and codifying a commercial motive on the part of insurers could push them to once again look for ways to prevent already ill (and therefore costly) patients from applying for health insurance. ${ }^{197}$ Moreover, we have already seen (fig. 4.2) how the market for insurance was (and is) marked by a great degree of market concentration. Market shares in 2018 were divided between four large concerns and a number of smaller insurers, with the former parties accounting for $86,5 \%$ of the entire health insurance market. This raised the concern that if they so desired, these insurers could act in concerted fashion - even without explicit cartel agreements - in pushing up insurance premiums. After all, in the new system the government had less say over premiums than when it still set them within the sickness fund scheme. ${ }^{198}$ Clearly, such practices would be at odds with the public goals underlying the new governmentality - foremost, access and affordability of care. However, it seems that since the institution, in 2006, of the health insurance market as one of the three pillars of the new governmentality, insurers have opted to neither fulfil their role as critical 'market directors' through tough negotiations and competition, nor attempted to tighten the screws on

195 G.R.J. de Groot, 'De schuivende panelen van de zorgverzekering', in: J.G. Sijmons, T.A.M. van den Ende and G.R.J. de Groot, Stelsel onder stress. Preadvies 2011 Vereniging voor Gezondheidsrecht (Den Haag: Sdu Uitgevers 2011) 139-231, 148-149.

196 Kamerstukken II, 2004-2005, 29 763, no. 7, p. 26-27.

197 See, e.g.: Maarse et al, 'Market-oriented reform', 165; S. Phlippen, 'Interview met Wynand van de Ven', ESB 1004718 (2015) 568-570, 570; Nederlandse Zorgautoriteit, Rapport Risicoselectie en risicosolidariteit zorgverzekeringsmarkt (Utrecht: NZa 2016), specifically p. 41-51.

198 Maarse et al, 'Market-oriented reform', 172-173. Nonetheless, the government still sets guidelines for the target yearly premiums ideally paid by insureds ('nominale rekenpremie'). 
clients/patients through the increasing of prices. This is due to a combination of the social goals codified in the health care system and the historical signature (as sickness funds) of many insurers, but also to the unwillingness of the government to loosen the reins of statist control with regard to health care. Let us now turn to how the crucial role of the insurers in the governmentality of regulated competition has developed.

\section{Market Roles, Social Goals}

It was noted already that the Health Insurance Act created the legal obligation for insurers to accept anyone applying for the basic insurance package. This obligation mirrors the obligation for citizens to insure themselves, and it put a legal prohibition on risk selection. Premium differentiation for identical insurance policies for the standard package was prohibited under the Health Insurance Act. Moreover, echoing the court cases from the last chapter where insurers and/or the state were forced to realize actual access to care, health insurers retained the legal obligation to provide good and timely care ('zorgplicht'). ${ }^{199}$ For instance, they are still tied to the 'Treeknormen' set in 2000 as a response to the problems of the waiting lists. When waiting times are exceeded, insurers have an obligation to intercede on behalf of the patient and to find another health care provider in short order. ${ }^{200}$

As such, legislation already laid a heavy burden on insurers to act in such ways that access and affordability of health care were served. But in an arena teeming with truly competition-oriented operators, one would nevertheless have expected insurers to find loopholes allowing cut-throat business tactics - potentially at the expense of patients. However, as far as business operations are concerned, the way most insurers have chosen to act since 2006 goes against such a supposition. Firstly, despite the fully legal possibility of turning a profit, insurers have in fact mostly been stocking up reserves since 2006. This is in part because of European guidelines on solvency. ${ }^{201}$ Nevertheless, excess parts of these reserves were in recent years used to subsidize insurance premiums (reducing them for insureds). ${ }^{202}$ Moreover, out of the 23 insurers active in 2018, only 3 nominally pursued a profit. These insurers are nevertheless members of the association of insurers (Zorgverzekeraars Nederland) and are signatories to its

\footnotetext{
${ }^{199}$ Art. 11 par. 1 Health Insurance Act.

200 https://www.consumentenbond.nl/zorgverzekering/wachtlijstbemiddeling, accessed on 03-10-2019.

${ }^{201}$ See, e.g.: De Nederlandsche Bank, Visie op de toekomst van de Nederlandse zorgverzekeraars. Verzekerd van goede zorg (Amsterdam: De Nederlandsche Bank 2017) 28-32.

202 NZa, Monitor Zorgverzekeringen 2018, 11-12.
} 
promise to invest profits solely in health care. ${ }^{203}$ Apart from this, despite their role as health care 'directors', insurers suffer from a serious public relations problem and risk losing face - and market shares - rapidly if they act in a manner which rubs their insureds the wrong way. In spite of the large market shares of the 'big four' and the central role of insurers in the health care system, the question is whether these parties can actually exert all that much power.

This question came prominently to the fore in 2014/2015, when general practitioners called for a radical change of the practice of GP care contracting by health insurers. Discontented about the role it had been given as a 'market party' in 2006, the national organization of GPs (Landelijke Huisartsen Vereniging) started a public relations campaign intended to show how insurers were cornering them into signing contracts they had no control over. Despite the nominal 'directing' role of insurers, the GPs won much public support, and ultimately the government had to step in to facilitate negotiations between the two groups. Ultimately, the GPs seemed to have come out of these negotiations stronger, with increased room for forms of co-operation that were seen as cartel behavior by some commentators. ${ }^{204}$ But even outside of PR considerations, it is doubtful whether insurers ever truly desired to be tough negotiators on the health care market. In over a decade after the introduction of the triad of health care markets, the crucial market for 'health care purchasing' and negotiations between insurers and care providers has not really materialized. A recent dissertation by health economist Suzanne Ruwaard investigating this crucial market found that this is partly because insurers act as facilitators of a solidarity-based health care system rather than as true directors who negotiate tight contracts and compete on the basis of premium prices and the quality of health care. ${ }^{205}$

From a governmentality perspective, however, most significant of all is the fact that centralized budgeting has remained very much a core component of the system - though it has been transformed to make it less visible. In analyzing power relations in the new governmentality by way of an examination of who holds the purse strings, it becomes clear that the actual boundaries for this system seemingly 'directed' by insurers is set by the state. We will recall that budgeting first became a real policy instrument in 1983, when the Act on Tariffs was employed to this end. Then, in 1987 'Dekker' advised to put an end to the governmentality of

\footnotetext{
203 M. van der Geest, "Het zijn allemaal zakkenvullers' - zes onderbuikgevoelens over zorgverzekeraars, en wat daarvan klopt', De Volkskrant 09-11-2018, via: https://www.volkskrant.nl/economie/het-zijn-allemaalzakkenvullers-zes-onderbuikgevoelens-over-zorgverzekeraars-en-wat-daarvanklopt b1f8a2e1/?referer=https\%3A\%2F\%2Fwww.google.com\%2F, accessed on 03-10-2019.

${ }^{204}$ See F.T. Schut and M. Varkevisser, 'Hebben zorgverzekeraars te veel macht?', Ned Tijdschr Geneeskd. 160 (2016) D1133.

205 S. Ruwaard, Purchasing healthcare: Beyond getting the financial incentives right (Tilburg: diss. Tilburg University 2018) 159. This is all the more important, since the market for purchasing health care was supposed to be the centerpiece of the regulated market in bringing down costs and raising quality. Maarse et al, 'Market-oriented reforms', 166.
} 
planning in health care - and though government would still have to safeguard the accessibility of care, it might have been assumed that insurers would get more say over budgets in their new 'directing' role. But in 2006, when the regulated market was introduced, insurers were given very little room to assume an active role in steering the system in a certain (financial) direction. For a few years after 2006, budgeting indeed seemed to have disappeared, leading to experiments in liberalizing tariffs in health care. ${ }^{206}$ However, in 2011 the Act on Market Regulation was modified to introduce the so-called 'Macro Control Instrument' ('Macrobeheersingsinstrument'). This governmental instrument was as ominous as its name suggests: with it, government effectively created a sword of Damocles hanging over the health care sector. Stating that "[...] the government does not want to embark on an adventure in health care expenditures $[. . .]^{\prime 207}$, the Healthcare Authority in 2011 was invested with the authority to recoup budgetary excesses caused by health care providers who exceed their budget.

In effect, this was an instrument with which the government could retrospectively punish providers for exceeding their budgets. However, the MCI was designed as an emergency measure. In order to preclude its use, the government reintroduced budgeting arrangements, but not through a heavy-handed capping of health care volumes and tariffs - as had been the case in the era of 'planning'. Instead, since 2011 agreements in the form of covenants have been made with insurers and health care providers. These covenants are far 'softer' arrangements than the budgeting strictures of the 1980s and 1990s, in the sense that the government sets a general Budgetary Framework for health care, and insurers and care providers have to negotiate on how these budgetary goals are to be met. And not without success: three covenants signed between 2011 and 2015 brought down the growth of hospital expenditures from 2.5\% to 1\%. ${ }^{208}$ But all of this creates the illusion of market negotiations, while the public goal of keeping health care affordable is still firmly guarded by the government. This, in turn, has led to a subtle but significant shifting of responsibilities. "Budgeting by the Healthcare Authority has in effect been replaced by budgeting through the insurers. " ${ }^{209}$ The rhetoric of the 'regulated market' is that the

\footnotetext{
${ }^{206}$ With the most glaring failure here being the liberalization of dentistry tariffs in 2012-2013. Already after the first year of what was to be a three-year experiment with free negotiations between insurers and dentists over tariffs, Minister Schippers had to roll back this operation due to the rapid increase in prices. P. van den Dool, 'Einde aan vrije tandartstarieven - tandartsen naar de rechter', NRC Handelsblad 05-072012.

207 Kamerstukken II, 2009-2010, 32 393, no. 3 (Wijziging van de Wet marktordening gezondheidszorg), p. 10.

208 Maarse et al, 'Market-oriented reforms', 171; see also J.J. Rijken, 'Leve het ziekenfonds! Vier argumenten voor een publiekrechtelijke volksverzekering tegen ziektekosten', Tijdschrift voor Gezondheidsrecht 412 (2017) 135-142, 139; J.G. Sijmons, 'Inleiding', in: E. Steyger et al, Op weg naar 10 jaar nieuw zorgstelsel. Terug- en vooruitblik. Preadvies 2015 Vereniging voor Gezondheidsrecht (Den Haag: Sdu Uitgevers 2015) 13-30, 23.

${ }^{209}$ Rijken, 'Leve het ziekenfonds', 139.
} 
insurers have been placed in the driver's seat of the health care system. However, since the Macro Control Instrument is a stick firmly in the hand of the Ministry it is clear that insurers and therefore the care providers they contract with - ultimately have to fear the wrath of central government if budgets are exceeded. At the time of writing (December 2019) the covenants are leading to tight budgets, stops to patient intakes because of 'care ceilings' and broad discontent in the health care field over the work pressure resulting from tight budgets. ${ }^{210}$ However, such discontent ultimately should not be directed at the insurers, but to the state (still) setting the limits of health care expenditures.

Finally, a 2016 analysis of the results of the 2006 reform draws attention to another interesting element: " [agreements aimed at curbing expenditures] signify the use of classic 'corporatist-like' instruments [...] They demonstrate that competition is not only regulated by a formal institutional framework, but also by complementary rules of the game. These rules lack legal status but include a moral commitment on the part of the signatories." ${ }^{211}$ Concerning this 'moral commitment' of the players in the market game: in 2016 a legislative proposal to ban the profit motive for private insurers was put forth. The Parliamentarians responsible represented the Socialist Party, but also the Christian-Democrats and Social-Democrats. Though broadly leftof-center, the proposal nevertheless attests to the interesting position taken by the ChristianDemocrats, who again wanted to emphasize the primarily social role that insurers are to play in the system of regulated competition. Should this legislation pass Parliament sometime in the future, any profits insurers make can only be used to strengthen financial reserves or improve the quality and accessibility of care - the latter through the reduction of insurance premiums. ${ }^{212}$ If that happens, the Christian Democrats, who played such a crucial role in pushing the Dekkerplan of the late 1980s, will be partly responsible for further curbing its market aspects.

All of these qualifications of the workings of the current system do not imply that 'managing' health care through a mix of governmental and market elements has not proven successful. Governmental figures covering the period 2006-2018 show a successful curbing of health care expenditures, as can be seen in figure 4.3:

\footnotetext{
${ }^{210}$ https://www.nrc.nl/nieuws/2019/08/23/zorg-in-last-door-omzetplafonds-a3970897; https://www.nrc.nl/nieuws/2019/11/20/de-wereld-op-zn-kop-patienten-maken-zich-zorgen-om-onsa3981028.

${ }^{211}$ Maarse et al, 'Market-oriented reforms', 172.

212 Kamerstukken I, 2016-2017, 34522 A. For discussions: https://www.eerstekamer.nl/wetsvoorstel/34522 initiatiefvoorstel leijten; https://www.medischcontact.nl/nieuws/laatste-nieuws/artikel/cda-pvda-en-sp-verder-met-verbodwinstuitkering-verzekeraars.htm
} 
Fig. 4.5 Projected (Dotted Line) and Actual (Continuous Line) Health Care Expenditures under Mandatory Public Insurance (Zvw and Wlz) (x billion, net costs), 2006-2018

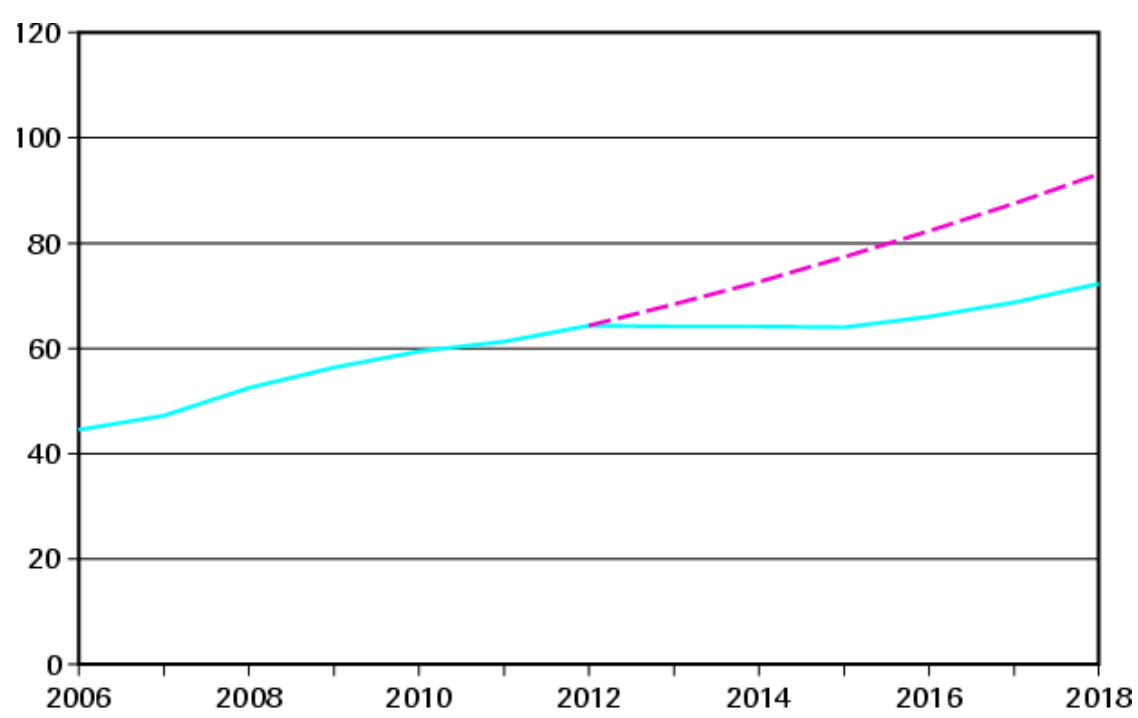

Source: Ministry of Health, Welfare and Sport, accessed via http://www.rijksbegroting.nl/2018/voorbereiding/begroting,kst236981 33.html on 28-09-2019

Yet, in the explanations given for this successful curbing of expenditures, market operations seem to play only a limited role. Equally important were the covenants that were negotiated with actors in the curative care field, as well as the policy collectively followed by insurers to only reimburse preferential medicines (always the cheapest of a class of equally efficacious drugs). ${ }^{213}$ The governmentality of the regulated market is therefore marked by much rhetoric concerning the 'directing' role of the insurers, while the reality of the system and its affordability still seems to hinge very much on state interventions.

\section{Quality and Choice in a Regulatory Regime}

There is one final development in the governmentality of the 'regulated health care market' which points to the state refusing to delegate important responsibilities to the parties in the field. This development pertains to the third public goal underlying the system: the safeguarding of the quality of health care by the state. When the system of regulated competition was introduced in 2006, one actor was given a crucial role in motivating both insurers and health care providers to reduce the price and improve the quality of their services: the patient. We will

\footnotetext{
213 http://www.rijksbegroting.nl/2018/voorbereiding/begroting,kst236981 33.html. For a similar interpretation, see Maarse et al, 'Market-oriented reforms', 172.
} 
recall that driving the system reforms of 2003 was a move from supply-oriented to demandoriented health care. In this way, the critiques of the 1970s and 1980s that sought to give patients more autonomy and freedom of choice in health care were taken seriously and combined with the necessity to bring down costs through competition. At the same time, this consumer choice would theoretically serve to push health care providers to continuously improve the quality of their services. An important theoretical basis for patient-centered competition was the notion of value-based health care, which created a link between improved quality of health care and reduced costs: concentration of care (volume) would lead to more expertise and therefore better results (such as lower hospital mortality rates or fewer unnecessary diagnostic procedures). ${ }^{214}$

In a model based on quality, a 'virtuous cycle' of ever-increasing specialization will lead to better patient care and, therefore, theoretically, to a better market position for excellent care providers as patients get to know about differences in quality and act on them. ${ }^{215}$ The relevance to the governmentality created in 2006 is of course that the patient becomes an active consumer, who - with his feet and wallet - can actively choose the best care provider, for the lowest (insurance) price. However, regardless of fundamental problems concerning 'free choice' in health care - already in 1963, economist Kenneth Arrow pointed to problems such as the unpredictable nature of when a patient will need it and the complexity of measuring its quality $^{216}$ - even here, the government has since the introduction of the market increasingly come to regulate what quality means and how it should be safeguarded. Where the state has a significant role in guaranteeing the quality of care - the third public goal underlying the health care system - the question is to what extent this is a market responsibility. In this regard, recent developments in patient's rights legislation are interesting, as well as developments concerning the State Inspectorate instituted by Thorbecke a century and a half ago.

Contrary to the guiding philosophy of 'deregulating health care' prevalent in the Dekkerreport and the positive stance of the Purple cabinets of the 1990s with regard to cutting back bureaucracy, that decade saw a large expansion of legislation tightening control over the overall quality of medical institutions, as well as individual practitioners in health care. Examples are the 1994 Act on the Medical Care Agreement which enshrined patients' rights; the 1994 Act on

\footnotetext{
${ }^{214}$ M.E. Porter and E.O. Teisberg, Redefining Health Care. Creating Value-Based Competition on Results (Cambridge, MA: Harvard Business School Press 2006). For a discussion, see J.G. Sijmons, 'De cure: transitie en onbalans', in: Sijmons, et al, Stelsel onder stress, 13-87, 47-55; G.R.J. de Groot, 'De schuivende panelen van de zorgverzekering', in: Sijmons et al, Stelsel onder stress, 139-231, 217-218.

${ }^{215}$ For 'virtuous cycle', see De Groot, 'Schuivende panelen', 218.

${ }^{216}$ K.J. Arrow, 'Uncertainty and the Welfare Economics of Medical Care', The American Economic Review 53 5 (1963) 941-973.
} 
Professions in Individual Health Care; and the 1997 Act on Quality in Health Care Institutions. ${ }^{217}$ In 2012, a legal commentator referred to this storm of patient- and quality-oriented legislation and noted that as a result, the Inspectorate had gone from being a 'silent force' to a 'public watchdog'. ${ }^{218}$ Since then, the role of the Inspectorate only seems to have grown rather than diminished. In 2016, the Act on Quality was merged with the 1995 Act on Complaints in Health Care, creating an Act on Quality, Complaints and Conflicts in Health Care. ${ }^{219}$ This act has created far-reaching obligations for institutions and care providers to register incidents and calamities, while it at the same time broadened the possibilities for patients to file complaints or to start a litigation at the 'healthcare courts' that every health care provider is obliged by law to register with. $^{220}$

Moreover, the rhetoric of 'self-regulation' on the health care market is belied by the paradoxical fact that in recent years the government has been pushing field parties to selfregulate. In the area of governance of health care institutions, but also where improving safety and quality standards in hospitals and the safe use of medical technology are concerned, covenants and 'care codes' have been formulated. ${ }^{221}$ And the Inspectorate sees to it that these covenants and codes are adhered to. The 'autonomy' of the parties in the field is therefore rather questionable, with governmental bodies looming in the background: "The underlying pressure is that if the field does not set its own norms and fixes problems, the government will intervene." 222 Moreover, the powers of the Inspectorate to enforce legislation on quality of care and patient safety are being strengthened further at the time of writing. ${ }^{223}$ One may conclude developments since 2006 as follows: "Although the everyday practice of health care has been put at a distance from the government, there is much (conditioned) self-regulation by way of guidelines and protocols, and while the field clamors for a more independent role, the

\footnotetext{
${ }^{217}$ Wet op de geneeskundige behandelingsovereenkomst; Wet op de beroepen in de individuele gezondheidszorg; Kwaliteitswet zorginstellingen 1997.

218 J.H. Hubben, 'De IGZ: van stille kracht naar publieke waakhond', Tijdschrift voor Gezondheidsrecht 362 (2012) 96-108.

${ }^{219}$ Wet kwaliteit, klachten en geschillen zorg.

220 See, e.g.: W.R. Kastelein, 'De Wkkgz is er: een nieuwe klachten- en claimregeling in de zorg!', Tijdschrift voor Gezondheidsrecht 402 (2016) 62-71; P.S. Kahn, 'Het toezicht, de meldingsplicht en de rechtsbescherming van de zorgverlener', Tijdschrift voor Gezondheidsrecht 402 (2016) 72-83. These new 'courts' ('geschilleninstanties') are an addition to the age-old medical-disciplinary courts ('tuchtcolleges') which guard the overall quality of health care offered by individual practitioners, and also to civil courts, which can award damages in cases of medical malpractice. See also A. Wilken, 'De geschilleninstanties in de zorg; een groot en bont gezelschap', Tijdschrift voor Gezondheidsrecht 417 (2017) 477-478.

${ }^{221}$ See, e.g.: https://www.igj.nl/zorgsectoren/medische-technologie/toezicht-op-veilig-gebruik/convenant, accessed on 01-10-2019.

222 Sijmons, 'Inleiding', 19.

${ }^{223}$ Kamerstukken II 2017-2018, 34 874, no. 2; https://www.nysingh.nl/actueel/igj-kan-binnenkort-demedewerkingsplicht-afdwingen/, accessed on 02-10-2019.
} 
government is looked to when it comes to effective control over the quality and safety of health care." $^{224}$

All of this does not preclude actions on the part of patients and patient organizations to push for better quality in care - the State Inspectorate nominally merely prevents quality of care from dipping below a certain level. And indeed, various parties work towards creating quality indicators such as rankings, and there are both government and patient-sponsored websites that aim to facilitate consumer choice (www.kiesbeter.nl; www.zorgkaartnederland.nl). It remains the question to what extent patients are truly interested in selecting care providers by criteria of quality - research seems to point towards limited interest on the part of patients to actively choose providers, outside of pragmatic reasons of distance or referral by their GP. ${ }^{225}$ Regardless, in recent years the responsibility of public bodies to guard the overall quality of care seems to have become greater, rather than having been delegated to market parties. Moreover, given the measure of equality enshrined in the system since 2006, it remains the question whether the state would allow the growth of real quality differences nationwide as a result of increasing market competition.

\section{The New Governmentality, 2006-2019}

The 1987 proposals put forth by the Dekker-committee revolved around the creation of an unprecedented level of health security through an extensive mandatory standard insurance. At the same time, the health care system as a whole was seen as having become too statecoordinated, a state of affairs that called for a new governmentality in order to organize the parties involved and to curb costs - by the mid-1980s an important task for the state. Much in line with the political-ideological thinking which had (for the most part) dominated debates about the state's relation to the health care field since Thorbecke, autonomy would have to be given back to 'field parties' through the creation of a regulated market in health care. In 2006, these proposals were put into law. With the Health Insurance Act, the mandatory insurance scheme executed by private insurers came into force. And the Act on Market Regulation in Health Care gave the government (through its Healthcare Authority) the power to construct or develop the three distinct health care 'markets' which should serve to curb costs while increasing quality and the market power of health care 'consumers'. But thirteen years down the line, it seems that the new governmentality has hardly come to fruition, in large part because

\footnotetext{
224 Hubben, 'Stille kracht', 99.

${ }^{225}$ A. Victoor and J. Rademakers, 'Waarom kiezen patiënten niet voor het 'beste' ziekenhuis?', Ned Tijdschr Geneeskd. 159 (2015) A8164; C. Lako and H. Dortant, 'Why don't the Dutch use quality information in their hospital choice? Results from a survey among 479 patients from a Dutch hospital', Health 61 (2014) 1-5.
} 
little actual 'de-statification' has taken place. Instead, the new governmentality seems marked by the historically recurring mismatch between the rhetoric concerning the dominant governmentality in Dutch health care, and the actual reality of the state having an important say in how the field is organized and financed.

Firstly, as far as 'constructing' markets is concerned, the state has kept its competition authorities on a tight leash, which has led to ever-growing concentrations of power in the insurance and hospital markets. The argument is that as long as accessibility and affordability of health care are not threatened, actively creating competition between smaller parties is not a priority. The paradox might in future be that through its policy of allowing power concentrations to grow, the state is in fact bringing about less consumer choice, as well as potential increases of prices by powerful market actors. But so far strong action in order to develop competition is not being pursued by the state and its Healthcare and Competition Authorities. Secondly, where the performance of health insurers as the new 'directors' of the system is concerned - having theoretically taken over this role from the state in 2006 - it seems that this 'directing' role is one not gladly taken up by the insurers. Although just four of them account for a vast majority of the health insurance market, these power positions have neither led to harsh insurance practices with regard to clients, nor to tough negotiation on prices with health care providers. All of this has to do with the social underpinnings of the health insurance system, but also with the important role the state still plays in setting the budget for health care and the general 'rules of the market game'. This has hardly tempted insurers to act like powerful 'directors' of the health care system - driving the crucial market of health care acquisition - but rather as facilitators of what is basically a state-backed social insurance scheme. Finally, the government plays an important and seemingly growing role in the safeguarding of quality of care. The imperative on the market of patients and health care providers is that of ever-increasing quality in order to lure health care 'consumers'. However, through its active pushing of 'self-regulation', the government's Health Inspectorate seems to have grown beyond the role of mere 'watchdog' charged with the task to guarantee a certain quality level of health care.

All in all, it seems that since its inception, the focus has shifted ever more towards the 'regulated' part of the 'regulated market' in health care. Stimulating the public goals of accessibility, affordability and quality that underlie the health care system has, up till now, only been pursued through a very light market-oriented policy - and not at all through the creation of real competition in health care, or the serious delegation of crucial tasks such as budgetsetting. Oddly, a reversal of roles has seemingly taken place in an area of health care traditionally shielded from private or market operations: long-term care. Moreover, part of that care has been decentralized, much in line with an old governmentality in which municipal governments had an important role to play in facilitating access to health care. We turn now to these transitions. 


\section{Long-Term Care: Back to Thorbecke?}

The final important development in Dutch health care discussed in this dissertation serves as a fitting conclusion to what started out with the legislation set in motion by Johan Rudolf Thorbecke more than a century and a half ago. Thorbecke, as we saw in chapter 1 , saw in local (and mostly private) initiatives the best perspective and opportunities for 'organic growth' of the 'vital power' of the Dutch nation. Citizens should be empowered in order to realize their true potential, and the state had only a (limited) role in removing obstacles from the road to such self-realization. For health care, this was partly realized through the Poor Law and the 1865 legislation that created the State Inspectorate. Though the Poor Law of 1854 was enacted not by Thorbecke, but by a conservative-Catholic cabinet which gave the responsibility for poor care primarily to the church, the principle of subsidiarity was in line with what Thorbecke had envisioned. As we have seen in part 2, it would take until 1912 before a revision of the Poor Law created far more leeway for municipal governments to support the poor and facilitate selfrealization by subsidizing and creating (ever greater) access to health care. To this decentralized responsibility for health care came and end, first, in 1941, when many of the tasks taken up by municipalities in subsidizing hospital care were subsumed under the Sickness Funds Decree. And in 1965 and 1968, central government centralized the provision of health care even further with the General Act on Financial Assistance and the AWBZ.

In the years between 2007 and 2015, something of a reversal of these developments took place, in which rhetoric and argumentation very reminiscent of that used by Thorbecke and his contemporaries resurfaced. This time, a century and a half after the first small steps were taken towards a bigger role for (municipal) government in creating a safety net for destitute citizens, the context was quite the opposite. Given the perceived necessity to cut back the budget for long-term care, many tasks with respect to providing care and welfare services were 'given back' to municipalities, under the banner of a return to 'self-care' and a more independent citizenry - and the argument that municipalities constitute government on the level closest to citizens. Though it would be highly anachronistic to say that reforms in health care since 2007 have aimed to bring the role of the state in health care back to Thorbeckian proportions, important institutional and cultural changes to the 1968 Act on Exceptional Medical Expenses and the provision of care on the municipal level nevertheless recall the spirit of the old Poor Law and its attendant focus on self-care, local solidarity and private initiative. 


\section{A New Role for Municipalities?}

The move towards a 'new culture' of strengthening the autonomy of patients and bringing care closer to citizens ran parallel to the institution of the regulated market in curative care.

Somewhat in the shadow of the Health Insurance Act, the Balkenende-cabinet in 2003 came up with a legislative proposal which would strengthen the responsibilities of municipalities to provide care, mostly in the form of social support. This proposal suggested an important overhaul concerning long-term care: to improve clarity as to what care citizens were entitled to, while it potentially also created budgetary space, services for those dependent on long-term care such as domestic help, housing and transport would be made a responsibility for municipalities. This also meant redrafting some legislation, such as the Act on Provisions for the Handicapped. This meant in practice that some 1,3 billion euros of AWBZ funds would now become the responsibility of municipalities. The Act on Societal Support (Wet maatschappelijke ondersteuning) passed in late 2006, and came into force on 1 January 2007.226

This move could be seen as an important development, not just in the provision of longterm care and social support, but in the identity of the Dutch welfare state. As one commentator put it: "The Act on Societal Support is an important beacon in what I call a broad social innovation [...] innovation through privatizing, strengthening of citizenship and decentralization seems to be foundational to this act $[. . .]^{\prime \prime 227}$ At the same time, the act met with criticism for the vague way in which entitlement to municipal care was worded. Crucial was the "[...] fostering of the participation in society and the independent functioning of the target group." 228 Such participation would be facilitated by municipalities providing house cleaning, medical aids such as wheelchairs, and home adaptations in order to keep people from having to move into a care home. The decentralization of such care was presented as an improvement on the one-size-fitsall approach under the old AWBZ. However, decentralization also meant relying on the subjective judgment of municipal civil servants as to what care was needed for different patients, and codifying this subjectivity in national legislation. This was an interesting development from

\footnotetext{
226 J.K. Helderman et al, Dike-Reeve of the health care polder (Zorginstituut Nederland 2014), 42-43; K.P. Companje, 'Financing high medical risks in the Netherlands: healthcare, social insurance and political compromises', in: K.P. Companje (ed.), Financing high medical risks. Discussions, developments, problems and solutions on the coverage of the risk of long-term care in Norway, Germany and the Netherlands since 1945 in European perspective (Amsterdam: Amsterdam University Press 2014) 101-175, 164-166.

${ }^{227} \mathrm{H}$. van Ewijk, 'De Wmo als instrument in de transformatie van de welvaartsstaat en als impuls voor vernieuwing van het sociaal werk', Sociale Interventie 3 (2006) 5-16, 9.

${ }_{228}$ M.F. Vermaat, 'Wet maatschappelijke ondersteuning: alles mag, niets moet?', Tijdschrift voor Gezondheidsrecht 301 (2006) 16-28, 19.
} 
the perspective of the longer development of the Dutch welfare state and the historical governmentalities prevalent in health care. Where the 1941 Sickness Funds Decree and the 1968 AWBZ had codified nationally-set standards for what types of care citizens had access to, the Act on Societal Support again delegated such standard-setting to the level of local government - in essence a return to the Poor Law of 1912, even if the basic level of care was by now vastly different. "Practically speaking, 467 municipalities will decide for themselves what 'participation' by and for citizens entails." ${ }^{229}$ The spirit of Thorbecke seemed to have returned, albeit under vastly different circumstances.

The 2007 Act on Social Support therefore reintroduced local government as an important player in supporting citizens in matters of care and social support. Moreover, it would be further expanded in the 2015 Act on Social Support. The proposal for the 2015 act was presented alongside the proposal for the Long-Term Care Act (discussed below), and further involved municipalities in supporting citizens with disabilities or chronic mental or psychosocial problems. ${ }^{230}$ The arguments given were that fostering independence and living at home needed to be further strengthened, but also that the greater role for municipalities would contribute to an 'inclusive society'. Moreover, bringing local government 'back to the people' again - with a mandate to strengthen social networks - would hopefully lead to " [...] new mixed forms of solidarity, in which government and society complement and strengthen each other." Lastly, financial considerations played a role. ${ }^{231}$ All in all, "[the State] Government expects that this will benefit people needing these provisions, because municipalities, as 'first governments', stand closest to the people and are capable of taking into account differences between people and their varied needs for support." ${ }^{232}$ Under the new Act, municipalities have the obligation to enter into conversation with patients seeking assistance, and to provide a 'tailored solution' to meet their needs. Providing a personalized care budget is also still an option. ${ }^{233}$ In 2015 decentralizing and 'self-care' therefore became firmly entrenched in the overall provision of health care, a development mirrored in the Act on Long-Term Care, to which we now turn.

\footnotetext{
${ }^{229}$ Vermaat, 'Alles mag, niets moet', 22.

${ }^{230}$ As part of a broader package of reforms involving also the Youth Act (Jeugdwet) and Act on Social Participation (Participatiewet), laws which would also involve municipal government to an important extent.

${ }^{231}$ Kamerstukken II, 2013-2014, 33 841, no. 3 (Memorie van toelichting Wet maatschappelijke ondersteuning 2015) 1-3. Quote on p. 3.

232 Ibid., p. 6.

233 Dute and Legemaate, Handboek gezondheidsrecht, 741-742.
} 


\section{Reforming Long Term Care}

On 25 April 2013, State Secretary for Health Care Martin van Rijn sent a letter to the chair of the Second Chamber of Parliament in which the future of the AWBZ was discussed. ${ }^{234}$ The letter began with a positive assessment of the way in which the Dutch health care system had, for a long time, provided extensive care to the most vulnerable patients in the system: those groups of patients needing long-term or permanent care because of physical or mental disabilities. But now, change was called for in this sector. Two reasons were given for this: on the one hand, the AWBZ had increasingly come to function as a repository for all sorts of care. We recall the commentator reacting to the AWBZ when it was first proposed in the 1960s: given the broad category of mental and physical problems potentially falling under care for 'high medical risks', the new law on long-term care would come to have a 'spiraling effect'. By 2013, this effect was indeed unmistakable: when the AWBZ was first proposed, it was intended to meet the needs of some $0,6 \%$ of the population. By 2013 , the AWBZ had come to grant support to nearly $5 \%$ of the population. And contrary to expectations that the ageing of the population would be the biggest factor in expanding AWBZ provisions, it was in fact active policy choices which had continuously expanded access to provisions falling under the act. ${ }^{235}$ As a result, Van Rijn's letter noted that choices in cutting back the AWBZ would have to be made in order to keep the solidarity in the system intact for future generations. Certain provisions could be cut with the argument that not everything had to be paid for by the collective, but could also be argued to fall under citizens' personal responsibility.

More interesting from a cultural perspective was the second reason for revising longterm care. "We are lucky to grow older, partly as a result of health care. At the same time, this results in new demands on our quality of life. People want to live at home for as long as possible and without being lonely. Often, support from their own social network or (municipal) home care provider will be needed." ${ }^{236}$ The State Secretary here seemed to note a mentality shift although arguably one also desired by the government in order to bring down expenditures. Finally, Van Rijn's letter offered an interesting perspective on the part of the government (consisting of Liberals and Social-Democrats) on long-term care. "We must not return to a time when participation was dependent on charity. At the same time, we do not want a society in which the fending off of loneliness is dependent on care that is paid for." ${ }^{237}$ What the letter

\footnotetext{
234 Kamerstukken II, 2012-2013, 30 597, no. 296 (Letter 'Toekomst AWBZ').

235 Kamerstukken II, 2013-2014, 33 891, no. 3 (Memorie van toelichting Wet langdurige zorg) 5.

${ }^{236}$ Kamerstukken II, 2012-2013, 30 597, no. 296 (Letter 'Future AWBZ'), 1.

${ }^{237}$ Ibid., 1-2.
} 
broadly called for was a return to private social networks alongside more self-care, with the government providing a safety net in case such measures no longer sufficed.

By the time the legislative proposal for the new Act on Long-Term Care (Wet Langdurige Zorg) was put forward in 2013, the two arguments given in the letter on the future of the AWBZ had been turned into three arguments for reforming this act: improving the quality of care and support, keeping the long-term scheme financially sustainable in the future, and strengthening social solidarity ("taking care of each other more"). ${ }^{238}$ Significantly, where the quality of care was concerned, the accompanying Memorandum again stated that demands of patients had changed: "Clients want to have autonomy over [their care, RB], act freely, make choices and obtain tailored care ['maatwerk']". 239 The dominant medical focus of the AWBZ no longer offered enough flexibility for chronically ill or old patients who nevertheless wished for more autonomy in giving shape to their lives and health care. The similarity between patients 'directing' their lives and the insurers 'directing' the regulated market was perhaps hard to miss. In order to achieve all of this, turning the AWBZ into the Act on Long-Term Care meant 'slimming down' to a core-AWBZ - which would still cover stays in institutions, personal care and nursing tailored to the disability or impairment in question, and medical aids. Significantly, in order to facilitate 'autonomy', the personalized care budget that allowed patients to contract their own long-term care provider was kept in place in the new act. Certain care provisions would be transferred to the Health Insurance Act (broadly: curative care and district nursing). ${ }^{240}$ Finally, care provisions crucial to enabling citizens to 'participate' once again would be delegated to municipalities. ${ }^{241}$ In late September 2014, the Act on Long-Term Care passed in Parliament, and in January 2015 replaced the AWBZ.

Given the arguments that focused on increased independence and autonomy for the vulnerable categories of patients needing long-term care, as well as the clear budget-cutting incentive behind the reform, fears were uttered over the reform's potential effect on solidarity. ${ }^{242}$ Still, it is the question whether the transformations embodied in the Act on Long-Term Care were all that drastic. Because of the underlying goal of cutting down expenditures in this care sector, access to the provisions falling under the act has been made more difficult. At the same

\footnotetext{
${ }^{238}$ Kamerstukken II, 2013-2014, 33 891, no. 3 (Memorie van toelichting Wet langdurige zorg) 4.

239 Ibid., 4.

${ }^{240}$ For long-term provisions falling under the Health Insurance Act in October 2019, see https://www.zorginstituutnederland.nl/Verzekerde+zorg/w/wijkverpleging-zvw, accessed on 10-10-2019. For the care provisions falling under the Act on Long-Term Care, see Dute and Legemaate, Handboek Gezondheidsrecht, 736-740.

241 J.A.E. van der Jagt-Jobsen, J.J. Rijken and M.A.M. Verduijn, 'Van AWBZ naar Wlz: een trendbreuk met het verleden?', Tijdschrift voor Gezondheidsrecht 387 (2014) 540-552, 541-542.

242 M.J. van der Aa et al, 'Hervorming van de langdurige zorg. Blijft de solidariteit behouden?', Ned Tijdschr Geneeskd. 158 (2014) A8253.
} 
time, the precise provisions that insureds have a right to - with still $100 \%$ of the population being mandatorily insured - have been codified more strongly in the new Act. ${ }^{243}$ Moreover, a more strict separation has been made between truly long-term care, curative care, and social care designed to facilitate 'participation', theoretically making for a clearer understanding of what these types of care entail - and who in the system is responsible for delivering them. The difference in cost resulting from the reform of long-term care was also limited. Under the new system, some $80 \%$ of costs covered under the AWBZ still fell under the Act on Long-Term Care and the Health Insurance Act; the remainder was delegated to the municipalities on the basis of the Social Support Act. ${ }^{244}$ This leads us to the question of what the reform of long-term care has meant for the 'governmentality' of that part of the health care system?

\section{Long Term Reform in Culture?}

All in all, the effects of this 'decentralization' on overall health care should not be overstated. In 2018 the distribution of costs within the health care system came down to the following:

\section{Fig. 4.6 Distribution of Health Care Expenditures by Compartment in 2018}

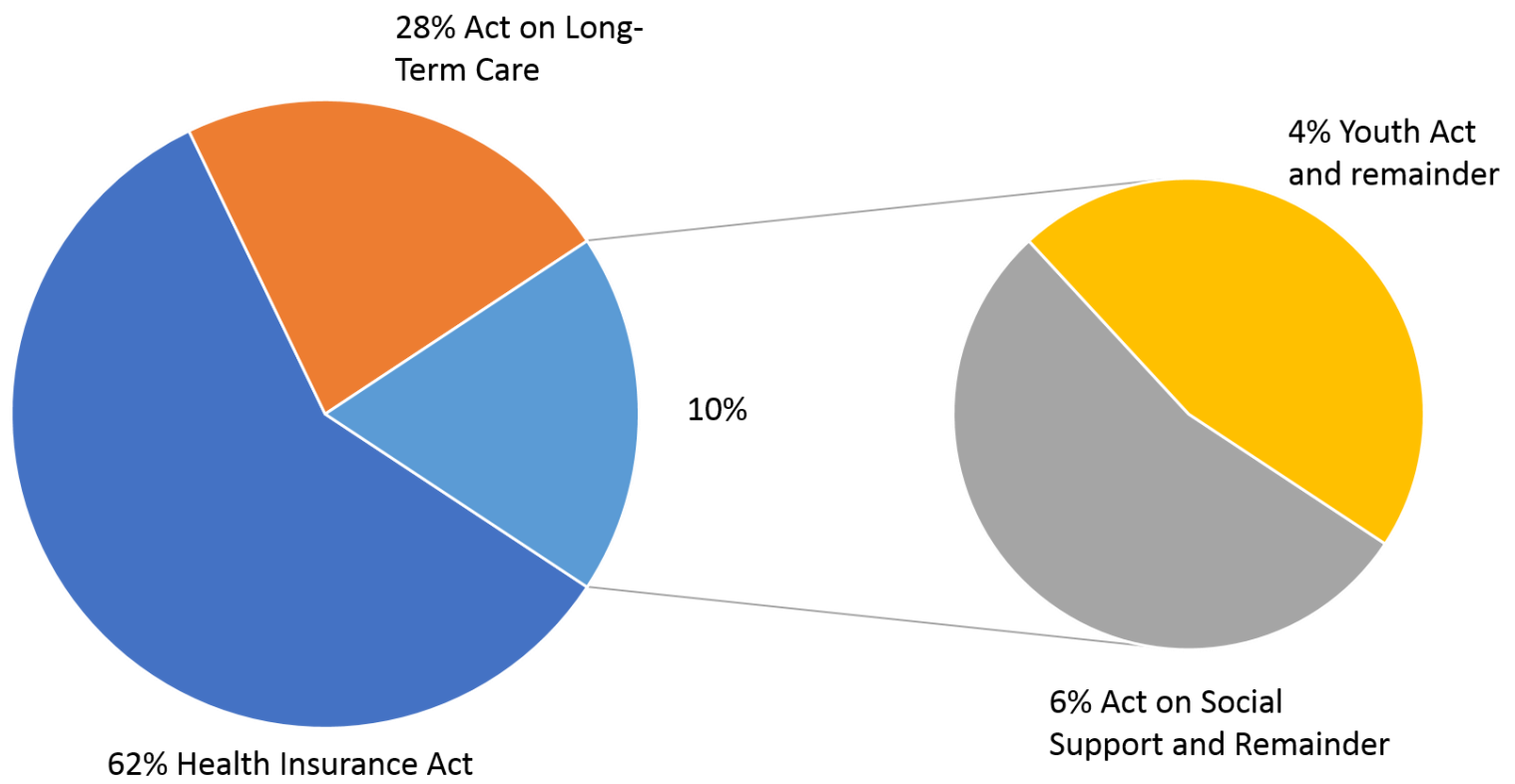

${ }^{243}$ Van der Jagt-Jobsen, Rijken and Verduijn, 'Van AWBZ naar Wlz', 549-552.

244 Van der Aa et al, 'Hervorming van de langdurige zorg'. 
Original figure: Ministry of Health, Welfare and Sport, data collated by National Health Care Institute, accessed via http://www.rijksbegroting.nl/2018/voorbereiding/begroting,kst236981 33.html on 28-09$2019^{245}$

Still, change has undoubtedly set in in this 'sector' of care. Apart from the Act on Social Support, governance arrangements in large part have remained similar to what was the state of affairs under the AWBZ: care offices linked to insurers still take care of 'traditional' AWBZ-care such as long-term stays in institutions - it should be noted that market operations also do not play a role here, although there is a growing focus on the effectiveness of contracted care. ${ }^{246}$ Nevertheless, the central government is clearly opting for a new mentality in long-term care, a mentality that once again emphasizes going back to the local level and to (private) self-care the spirit of Thorbecke in general pervades these transitions, not only where the Act on Social Support is concerned. So far, the transitions in long-term care suggest that the hope that citizens will radically reinvent themselves as active 'participants' in society and as 'directors' of their own care may turn out to be wishful thinking - after all, the AWBZ traditionally provided care to the most vulnerable categories of patients. The first evaluation by the Netherlands Institute for Social Research of the operation to reform long-term care identifies bottlenecks precisely where the abilities of such patients to find their way in the new governmentality for long-term care and social support are concerned. In particular, there are problems concerning the ease with which both patients and medical professionals find their way in the new complexities of the system - so far 'self-care' and strong autonomy for these patients seem indicative more of a shift in governmental thinking than in that of patients. ${ }^{247}$

However, the evaluation also shows that far from being merely budget-cutting - in that regard reform has been a success - the operation has also had the desired results: municipalities have taken up their role of acting as 'friendly local governments', and patients are generally pleased with home nursing and local public support. Moreover, there seems to be support both in the populations of patients and civil servants for the rediscovered emphasis on self-reliance and private initiative. ${ }^{248}$ Still, a recent survey of municipal civil servants engaged in implementing the Act on Social Support also provides other interesting insights. A recurring theme with civil

\footnotetext{
${ }^{245}$ As of 2019, expenditures under the Act on Societal Support and the Youth Act no longer fall under the budget for the Ministry of Health, but have mostly been transferred to the Ministry of the Interior. For the relative distribution of costs between Wlz and Health Insurance Act in the 2019 budget for Health Care, see http://www.rijksbegroting.nl/2019/voorbereiding/begroting,kst248591 29.html, accessed on 28-092019.

${ }^{246}$ See, e.g.: Nederlandse Zorgautoriteit, Doelmatige zorg in de Wlz. Hoe bevorderen zorgkantoren doelmatige zorg? (Utrecht: NZa 2016).

247 Sociaal en Cultureel Planbureau, Veranderde zorg en ondersteuning voor mensen met een beperking. Landelijke evaluatie van de Hervorming Langdurige Zorg (Den Haag: Sociaal en Cultureel Planbureau 2018; paper version) $17-22$.

${ }^{248}$ SCP, Veranderde zorg, 17-19.
} 
servants apparently is that not just the institutional, but the cultural change set in motion by the new governmentality sought after here will take "years, decades, or even generations." 249 This is also clear from the perspective of the right to health care which came to be embedded in the health care system in the 1960s and has only grown stronger since. Since the implementation of the 2015 Act on Social Support, hundreds of cases have been brought to court, mostly by patients who felt that their municipality was not meeting its obligations under the Act to provide necessary and personalized care. In short, where a hundred years ago people would have been happy to receive a modicum of care from a municipality which chose to give its own interpretation to the vague wordings of the Poor Law, judges now by and large limit the arbitrariness and subjective nature of, for instance, the Rotterdam municipality choosing to reimburse fewer hours of house cleaning than the municipality of Leeuwarden. ${ }^{250}$ Where the government's focus on stimulating 'participation' and self-care is concerned, the jury is still out. For civil servants, in 2018 the glass was both half-full and half-empty where the implementation of the reform of long-term care was concerned. ${ }^{251}$ Nevertheless, in a reaction to the evaluation, the Minister of Health has stated that rolling back reforms or changing the way long-term care is organized is not on the table. Instead, the way forward lies in improving the current system by strengthening participation, informal care, and coherence in the provision of care. ${ }^{252}$ The new (and yet 'old') governmentality of 'friendly' local governments and self-care will have to prove its staying power.

\section{Conclusion}

When in 2006 the regulated health care market was introduced, it could be seen as the culmination of a long political process set in motion with the 1987 Dekker-report, and picked up again in 2001 after the political call for systemic reform had reached a high point. Understood from both the perspective of practical governance arrangements as well as the broader mentality underlying these developments, the implementation of 'Dekker's' core proposals in 2006

\footnotetext{
${ }^{249}$ M. den Draak and L. van der Ham, 'Gemeenten over de uitvoering van de Wmo 2015: het glas is halfvol én halfleeg', Tijdschrift voor Gezondheidswetenschappen 96 (2018) 348-353, 351.

${ }^{250}$ For discussions of this jurisprudence, see SCP, Veranderde zorg, 22-23; C.W.C.A. Bruggeman, R. Stijnen and J.C. de Wit, 'Kroniek van het gemeentelijk sociaal domein (deel 2)', Gemeentestem 7453 (2017); W. Koelewijn and B. Wallage, 'Onrechtmatig Wmo-beleid. Wat nu?', NJB 1394 (2016); B. Wallage and W.I. Koelewijn', Resultaatgericht indiceren op grond van de Wmo 2015 niet langer mogelijk? Een botsing tussen maatwerk en rechtszekerheid', Gemeentestem 7486 (March 2019) 179-182.

251 Den Draak and Van der Ham, 'Glas is halfvol'.

252 Letter from Minister of Health, Welfare and Sport to the Chair of the Second Chamber of Parliament, 'Aanbieding en eerste beleidsreactie op de evaluatie van de hervorming van de langdurige zorg' d.d. 27 06-2018, p. 3-4.
} 
ostensibly stood for the replacement of a 'strong state' in health care with market parties (insurers and health care providers) that competed for patients. The new governmentality envisioned in 2001 and implemented in 2006 was intended to reduce the role of the central government and to delegate tasks formerly performed by the state, while it also aimed at achieving the older goal of cost reduction - which had been the primary motivation behind the governmentality of 'planning' dominant between 1974 and 1987. To introduce this new governmentality, three new 'markets' in health care had to be introduced: one of insurers and patients, one of insurers and care providers, and one of patients and care providers. Within and between these separate markets, market characteristics such as negotiation over prices, active consumer choice and the lowering of insurance premiums and the raising of the quality of care to attract patients were deemed essential features to protect and improve three social goals underlying the system: good affordability, accessibility and quality of care. However, thirteen years down the line, it seems that where governing the system is concerned, the weight of history cannot be easily thrown off. As we have seen in this chapter, the active and theoretically necessary development of the separate 'health care markets' has not really been stimulated by a central government reluctant to endanger the public goals of accessibility, affordability and quality of care. And health insurers have not made much of their crucial role of 'directors' of the health care system, and are, instead, still subjected to a general budgetary framework set by the government - a relic from the era of 'planning', but one reintroduced after just five years of 'unbudgeted' health care.

Although the regulated market was by definition never intended to be a free market, the state has kept far tighter hold of the reins in health care than could have been the case if competition was what the state had really pursued since 2006. That this was not so might have been expected, given the fact that in 2006 also the broad mandatory insurance package for the entire Dutch population was introduced. This was an active and unprecedented choice for the ideology of government-backed health security and solidarity. Not surprisingly, the social goals underlying the system have limited the 'governmentality' of market operations in health care, and in important senses the state has become more important than ever in coordinating and regulating parties operating in the field of health care. The question for the (near) future is whether the state's interests and power in pursuing the social goals underlying the health care system will not grow to the point at which the health care 'market' is little but a reality on paper, and the mismatch between the rhetoric and the reality of the system's governmentality can no longer credibly be disguised.

Where long-term care is concerned, we can see a somewhat less ambiguous development. With the decentralization set in motion with the 2015 Act on Long-Term Care and the Act on Social Support, there is something to be said for the argument that we see a return to a more 'Thorbeckian' governmentality. Moving health care provisions that facilitate the social 
'participation' of vulnerable patient groups to municipalities recalls the Liberal rhetoric of the mid- $19^{\text {th }}$ century with respect to self-care and self-reliance, as well as to local solidarity and, ultimately, government as the final links in a chain of care 'subsidiarity'. Still, the context in which this reform took place is virtually incomparable to the role government accorded itself in Thorbecke's time. Nowadays, the responsibilities of the state in regulating and safeguarding the goals of the health care system are vast. And where both the practices of governing and pushing forward the 'regulated health care market' and the operations of municipalities are concerned, thus far the government has vacillated in limiting the access to care of Dutch citizens. Changes in the political climate, new medical technologies, or deteriorating financial circumstances might change that, however. Such developments will be a test for both the resilience of the social goals that historically became ingrained in the Dutch system, as well as to the 'governmentality' that has primarily been dominant since Thorbecke's time, with its emphasis on 'private initiative', autonomous citizens, and local government as the first port of call for public support in matters of health care. 


\section{Conclusion}

\section{Dutch Health Care 1848-2015: Access to Health Care under a Banner of Private Initiative}

To an outside observer confronted with what is called the 'regulated health care market' in The Netherlands, it is tempting to focus on the word 'market' and assume that Dutch health care is organized in a liberal, bottom-up fashion, relatively free from the dictates of heavy-handed state interventions. In the introduction to this dissertation, however, I called into question the status of this market, highlighting the qualifier 'regulated', and thus pointing to the way in which the market mechanism introduced in the system in 2006 seems to be in large part rhetoric obscuring a very different reality of strong and extensive state powers in health care. This paradox ${ }^{1}$ led me to investigate the much-longer history of 'rhetoric' versus 'reality' in the way in which Dutch health care has been governed since the state first came to take an interest in its citizens' health as a partly public affair in the middle of the $19^{\text {th }}$ century. I analyzed such governing with reference to Michel Foucault's notion of 'governmentality'. With that concept, Foucault referred to both formal structures of governance - legislation, institutions - but also to the mentalities underlying the way in which such structures are constructed or allowed to develop. In this dissertation, I took these mentalities as a lens through which to analyze Dutch health care in a longue durée time frame.

My assumption was that such a longue durée perspective can offer us a level of understanding that eludes those who focus on shorter time spans or very specific parts of this history. And indeed, having analyzed a wide variety of sources and historical literature on the evolving role of the state vis-á-vis the health care field, I can in this dissertation present two overarching conclusions. First, the time frame 1848-2015, as seen through the lens of 'governmentality', can be divided into four specific periods in Dutch health care governance, periods which are different and highly distinctive for the way in which government and the mostly private health care field interacted with each other. Second, this longue durée history is characterized by a great and recurring mismatch between a politically and publicly dominant rhetoric of limited state intervention in health care, and a reality in which the state in fact grew continuously stronger over the past century. Both of these conclusions, as well as the four 'governmentalities' that can be distinguished in this history, can be summed up in the following figure:

\footnotetext{
${ }^{1}$ See: Hassenteufel et al, 'Transformation of European Health Care States'; Helderman, Bevan, and France, 'The rise of the regulatory state in health care'; Vonk, Recht of schade.
} 
Fig. I The four governmentalities of Dutch health care and the state

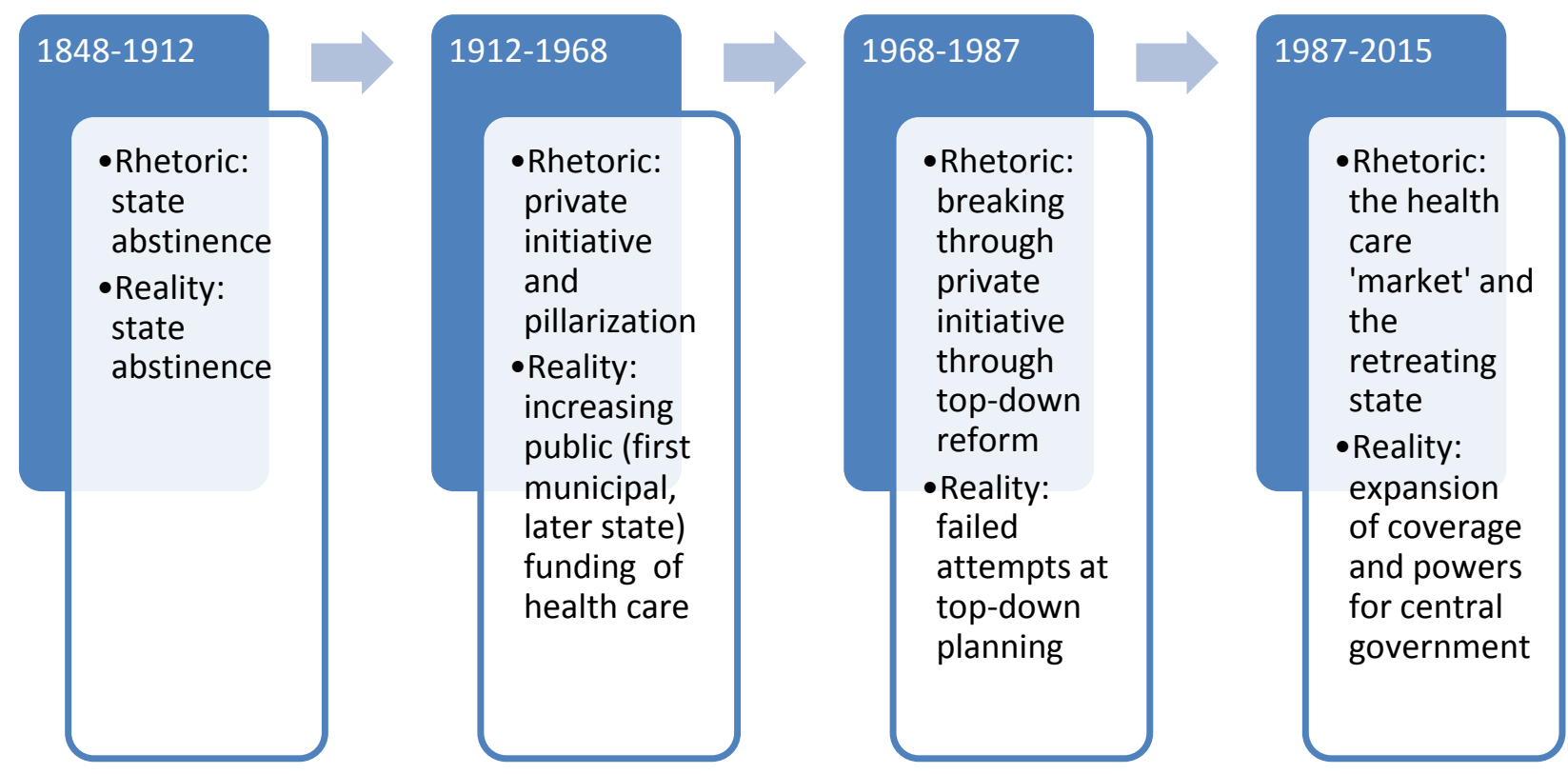

Using the analytical concept of 'governmentality' to analyse the evolving interaction between the Dutch government and the field of health care, this dissertation contributes to rethinking the state, a challenge posed by the historian of the welfare state Peter Baldwin: "States are often thought to differ mainly in having stronger or weaker abilities and desires to intervene.

[However] such a simple two-dimensional view of what states do fails to account for the full range of their activities. [...] States are, in this sense, qualitatively different, not merely stronger or weaker than one another." ${ }^{\prime 2}$ Following this call, I suggest that the Dutch health care system for the most part of the $20^{\text {th }}$ century has been governed through a mix of 'weak state' rhetoric and 'strong state' practice. The Dutch state has grown increasingly important as a force with respect to guaranteeing access to health care, but not in a way which would create the impression of a strong 'interventionist' state. Instead, the government has had to fine-tune its way of influencing health care as a distinct sector of society through accommodating and including parties in the field of health care, time and again exemplifying the Dutch corporatist practice of 'poldering'. ${ }^{3} \mathrm{~A}$ shared sense of collective responsibility for mitigating individual adversity - even across

\footnotetext{
2 P. Baldwin, 'Beyond Weak and Strong: Rethinking the State in Comparative Policy History', The Journal of Policy History 171 (2005) 12-33, 13.

3 Prak en Van Zanden, Het poldermodel; Kennedy, Beknopte geschiedenis, 8-9, 385-387.
} 
factional (religious) lines - especially after the Second World War often trumped notions of the care for health as primarily an individual affair. Though Dutch consensus politics and negotiations with and between parties in the health care field regularly led to lethargy and policy-making at a snail's pace, the interplay of private and public actors also led to unexpected strides in increasingly offering the public access to health care without heavy-handed policy interventions from above.

In this conclusion, I will first analyse the four distinct governmentalities in Dutch health care, as they can be consecutively discerned during the period 1848-2015. I will then discuss the interplay of static elements and the more rapid changes that took place over this long period, changes which serve to explain why the state came to take upon itself ever more tasks in providing health care to its citizens, and why this extension of powers took the particular shape it did. I conclude by linking the tensions between rhetoric and successive realities to future developments in the provision of health care in the Netherlands.

\section{The Liberal Governmentality: 1848-1912}

Chapter 1 discussed the 1848 liberal blueprint for both the fledging Dutch nation and its exhortation of citizens and 'civil society' to take action in developing the fields of medicine and health care, and in organizing social provisions such as those pertaining to health. Outside of fighting epidemic diseases - which posed a problem to the entire population - the state hardly saw the health of individual citizens as its concern. Nevertheless, the first steps taken towards legislation concerning health care and the role of Johan Rudolf Thorbecke were significant. The Poor Law first envisioned by Thorbecke gave to municipalities the task to create some sort of safety net for the destitute, also where access to health care was concerned. More importantly, in 1865, not only did Thorbecke institute a factual monopoly for certain types of medical professionals, but the institution of a State Inspectorate meant that government began to take on the responsibility for safeguarding public health. But all of this should be understood in the light of the new constitution of 1848: in essence Thorbecke's philosophy of state abstinence in favor of citizen initiative and his view of the 'vital force' of the nation as something to be developed from the bottom up. And indeed, in the era of the 'Liberal' governmentality, Thorbecke's 'rhetoric' was in accordance with the reality of limited state intervention. In the period 1848-1912 the state's attempts to influence the general health of citizens had little impact - the State Inspectorate was highly ineffective in the first half century of its existence and poor relief did not really impact the provision of health care until 1912. But especially where private insurance arrangements were concerned, the growing importance of sickness funds by the last third of the $19^{\text {th }}$ century pointed to civil society increasingly taking the initiative to 
combat dangers to health that were increasingly associated with industrialization and the 'Social Question'.

\section{The Ambivalent Governmentality: 1912-1968}

This situation began to change from 1912 onwards, when government began to invest in growing access to health care for average citizens. Although the political-ideological focus on private initiative and the non-interventionist state remained intact after 1912, both private and public actors now increasingly also came to facilitate health care for individual citizens. However, such access did not come about through action on the level of the central state. The period between 1904 and 1939 saw the failure of various proposals to enact mandatory health insurance, pointing to broadly felt political reluctance concerning governmental interventions in health care. In the absence of such legislation but given the advent of new medical-scientific developments and important new locations for health care such as the hospital, the first decades of the $20^{\text {th }}$ century saw the rise of new commercial parties on the insurance market supplementing the (increasingly solidarity-based) sickness funds. But it was not just private parties increasingly opening up access to the new and expensive wonders of medicine. With the subtle revision of the 1912 Poor Law, local government in the form of municipalities increasingly began to offer health care provisions on the one hand, and to subsidize private care institutions such as hospitals on the other. And so it could happen that despite the dominant ConfessionalLiberal political rhetoric of this period, a rhetoric that rejected a strong central state in health care, on the eve of the Second World War municipalities were actually furnishing about a third of all hospital costs, while municipalities, provinces and the central state together provided similar levels of subsidies to 'private initiative' organizations such as the Cross Associations. It is because of this that I have characterized the era discussed in chapter 2 as the era of 'ambivalent' governmentality, in which nominally 'private' initiative increasingly came to be backed by public funds.

Contrary to what might be assumed at first glance, the 1941 Sickness Funds Decree instituted by the Nazi occupier in fact perpetuated this governmentality. The institution of this Decree meant that a significant part of the population now had to be mandatorily insured for a vast range of provisions, including hospital care. Moreover, after decades of political struggle to keep government 'out' of health care, the state was now given an important role in guaranteeing access, setting premiums, as well as determining the extent of the basic package every person insured through a sickness fund could make a claim to. As such, the Decree seemed to radically overhaul both access to health care, as well as the relationship between the state and private actors facilitating access up until that point. And yet, the post-war period for 
the most part continued the pre-war governmentality. Although the legislation instituted by the Nazis formed a break with the mantra of non-intervention by the state, post-war Dutch politics and society largely reverted to a philosophy of a limited role for the state vis-á-vis social provisions such as health care.

This could be seen clearly in two developments. First, the so-called Van Rhijn-report was published in 1945 in the war-battered Netherlands. Despite this report's lofty ideals of social security for every citizen provided by a stronger central state, already in 1946 most of its practical ideas for giving the state more power in social affairs had been broadly rejected in favor of leaving it to the parties in the field to create social arrangements. Moreover, on the level of the organization of health care, the post-war context offered possibilities for coordinated, top-down policy in (re)constructing a health care field which was routinely referred to as a patchwork. But such ideas also came to very little. The 'crowning achievement' in this regard was the 1956 Health Act, which effectively only served to consolidate the role of private initiative in health care, thereby leaving government standing by on the sidelines, which perpetuated the 'ambivalent' governmentality of favoring private initiative supported by substantive public backing.

\section{The State Planning Governmentality: 1968-1987}

Although the 1945 Van Rhijn-report hardly led to practical results, the Social-Democratic well from which it had sprung would prove influential in pushing politicians in the 1950s and 1960s to rapidly expand the welfare state. In chapter 3 I discussed how, after the Roman-Red coalitions of the 1950s, the Social-Democratic rhetoric combined with new discourses about human rights to push the Catholics towards expanding social provisions. This rhetoric also found its way into thinking about health care; in 1964 the Sickness Funds Decree was replaced by the Sickness Fund Act, and for much of the 1960s, health care was allowed to grow unfettered, continuing the primacy of private initiative in health care. The first real caesura in the way the government combined both the newly developed 'right to health care' with a more active style of intervening in the way such health care became available to the citizenry was through the 1968 Act on Exceptional Medical Expenses. With this cornerstone of the welfare state, the government created a firm safety net for those in need of vastly expensive medical care. At the same time, now that the state had implicated itself so fundamentally in guaranteeing access to health care, it had to act on a problem which had been a long time coming: the growth of health care expenditures for which the government by now bore a significant responsibility. 
In chapter 3 we saw how, in the 1970s, the need for the government to curtail rising expenditures led to the first real attempts to gain control over health care through a state-led 'planning' paradigm. Much of this can be attributed to Catholic State Secretary Jo Hendriks, who with his 1974 Structure Report heralded the governmentality of state planning. Hendriks' plans to get the state more prominently involved in health care amounted to a policy triptych which would institute a national insurance scheme as well as laws governing the coordination of health care facilities on the one hand, and health care tariffs on the other. However, already within a decade after these plans were presented, serious resistance grew from multiple sides to the state trying to insert itself so strongly into what had up until then been a field governed by 'private initiative'. It was not just resistance to bureaucracy that grew, but also broader cultural sentiment that a 'cradle to the grave' welfare state would lead to an overly paternalistic government. All of this points to the tenacity of the rhetoric which for so long had dominated political thinking about the role the state should play with regards to health care, a far more limited role than was envisioned by Hendriks in the Structure Report. As a result, by the early 1980s the rhetoric of 'state planning' was traded in for a policy-making in health care which revolved around 'incremental measures' to curb rapidly rising costs.

\section{The Regulated Market Governmentality: 1987-2015}

In 1987, however, the idea that a 'blueprint' still was necessary to create some sort of order in such an uncoordinated health care field led to the presentation of the Dekker-report. After only thirteen years of 'planning' in health care, the emphasis on a greater role for the state in health care was once again traded in for a more private initiative-oriented system, now christened the 'regulated health care market'. In this market, health insurers and health care providers would have to compete for the favor of patients. Nevertheless, by now the large role government had come to play in guaranteeing access to and solidarity in health care could not be dispensed with. And so market competition would mostly have to take place within a mandatory insurance scheme for all of the population, to be instituted by the state. It took more than a decade of political debate and preparations in the health care field - during which time the 'grand reform' envisioned by Dekker proved politically highly volatile - before increasing problems with regard to the accessibility of care forced through this systemic overhaul of health care, and in 2006, the regulated health care market was introduced. The sickness funds were abolished, with many of them turning into private health insurers, who since 2006 have been the nominal 'directors' of health care.

But while the rhetoric of the 'market' created the impression that the government extracted itself from health care, in reality '2006' has led to the situation that the government 
tightly guards the arena of health care, with safeguards for an (extensive) basic package, risk and

income solidarity, and affordable access for all citizens. In the final chapter, an analysis was given of how the historically grown ideal of access to health care, as well as the by now deep entanglement of government and private parties, have since 2006 combined in interesting ways. The state has hardly been very active in creating the market conditions envisioned by the 1987 Dekker-report, and has instead opted to retain a very strong presence in health care in order to protect the three public goals of accessibility, affordability and quality of health care that underlie the system instituted in 2006. Only in long-term care, a reversal of sorts compared to the pre-war governmentality has taken place with the system reform of 2007-2015. In long-term care and social services, there has been a reappraisal of old notions of self-care and the delegation of tasks to local governments to facilitate the maximal 'participation' in society of those citizens needing social support. And yet, the judiciary still fiercely guards the right to health care, and through the curative and long-term care packages the government by and large offers its citizens access to an array of health care services which would have been unimaginable not too long ago.

\section{Setting the Stage for Continuity}

If we oversee this long history, two periods stand out for the way in which the political rhetoric and the realities of the provision and financing of health care on the ground mostly coincided: 1848-1912, when Liberal and later Confessional political parties both espoused and in practice adhered to limited state interventions in health care; and the years 1968-1987, in which the government tried to implement the Social-Democratic vision of expanding access to health care with centralizing legislation - though this effort rapidly failed, as we have seen. Outside of these periods, there is no denying the mismatch between the dominant political-ideological rhetoric concerning how government should relate to health care (namely, not too much), and its increasing entanglement in it. How can we understand this recurring mismatch, and how can we explain both continuity and change in the way the relationship between the Dutch state and the health care field evolved over the past century and a half? First, we must make explicit the one element that remained fairly stable over the course of the more than 150 years analyzed in this dissertation. Starting from that stable element then allows us to grasp how important historical changes were consequently 'filtered' through that element, ultimately resulting in the unique (and often paradoxical) qualities of the Dutch health care landscape.

The clearly discernible stable element defining this history over the past century and a half has been the pervasiveness and consistency of Dutch Liberal and confessional political thinking, which from the beginning of modern politics in The Netherlands has regarded local 
and private initiative as a more promising avenue for achieving political or social goals than interventions on the part of central government. Overseeing the four successive governmentalities in the period between 1848 and 2015, it is clear that the foundational philosophies of Liberalism, sphere sovereignty and subsidiarity that developed in the latter half of the $19^{\text {th }}$ century laid deep and lasting tracks for the way thinking about how the state should relate to health care would develop. Starting with Thorbecke's idea of 'organic growth' in society, these philosophies made sure that national politics and central government were assigned a backseat when it came to directing 'social affairs' such as care for the sick. This ideological blueprint would be reproduced time and again - during the 'pillarization' of Dutch society, which was of such enormous cultural significance in the decades between the 1930s and 1960s, and then again from the 1980s onwards, when Christian-Democrat Ruud Lubbers wished to shrink the role and size of central government in favor of local initiatives and private business. As a political tendency, the rhetoric of governmental restraint remains dominant until the present day. Far from being anomalous, political thinking emphasizing local and private initiative at the expense of central and public powers has been the norm in the century and a half under study, and it has had a vast impact on the way Dutch politics and government has related to health care.

\section{New Realities Filtered through the Old Rhetoric}

But how to explain the mismatch between this stable political ideology of a small state and the reality of government's ever-growing power and influence in health care? To answer this crucial question, we must revisit three of the most important historical changes that took place in the period between 1848 and 2015. Seeing how these changes were 'filtered' through the political rhetoric dominant between 1848 and 2015 allows us to understand how the focus on private organization of health care in The Netherlands in fact went hand-in-hand with the growth of governmental backing of access to such health care - leading to the 'Liberal solidarity' of this dissertation's title.

The first crucial change was brought about by the so-called Social Question of the late $19^{\text {th }}$ century. It was through the plight of the working classes that parties from all sides of the political spectrum first came to support a larger role for the government in providing access to health care than had been possible under the Thorbeckian liberal governmentality. After a few decades of health care policy focused on threats to collective health, the responsibility of the collective for individual health now came to the forefront. But, significantly, it was not the socialists who were the driving force or even the loudest voice in this debate about making health care more accessible for ordinary people. Rather, it was through a mix of progressive 
liberal and confessional politics that the first steps toward social and health security were taken - let us recall the Liberal Pierson-cabinet of the turn of the century, and Protestant leader Abraham Kuyper, who drafted the first legislation which would make health insurance mandatory. As we have seen, between 1904 and 1939 such plans came to little on the national level. However, this should not divert our attention from the arresting fact that in a country in which socialist or social-democratic politics meant very little before the Second World War, highly individualistic notions of care for the self also did not become mainstream. Whether it be spurred on by Liberal philanthropy or by Protestant or Catholic appeals to Christian love of one's fellow man, the seeds of collective responsibility for individual well-being were sown in this period. And this growing social ideal, coupled with the deeply rooted preference for private initiative and the local level, led to the rapid growth of private sickness funds and the increasing role municipalities came to play in providing access for many citizens as time progressed.

Such social thinking, backed by relatively successful bottom-up initiatives in providing health care, was strengthened by that second of most crucial changes: the introduction of the welfare ideology in The Netherlands in the decades after the Second World War. Much has been written about the Sickness Funds Decree and its impact on (finally) giving central government a role in providing health care. However, more interesting from the perspective of 'Liberal solidarity' was how well the Decree in spite of itself fit into a small state governmentality because of its implementation through private sickness funds - and how rapidly new plans for giving the state more centralized powers were discarded after the war. It was clear that Dutch politics and society reverted to old ways of doing things after the immediate impact of revolutionary new ideas thrown up by the war had dissipated. And yet, the post-war spirit of renewal, especially in social terms, survived and resurfaced a decade and a half later. Again, it was not the Social-Democrats who were primarily responsible. The immediate post-war decade necessitated economic revival through austerity policies, and extensive new welfare provisions did not fit that framework. However, when the economy picked up rapidly in the 1960s, it turned out that the Catholics had internalized the post-war notion of social security and health care as a social right to be facilitated by government, and they rapidly put this notion into practice with help from other parties. But again, notions of self-regulating organizations in health care organized according to the dominant cultural paradigm of 'pillarization' - stayed dominant, leading to little governmental control over the unstructured growth of health care provisions.

The third change was brought on by the inevitable consequence of combining the social ideal of access to health care with the by now significant role that the state had taken upon itself in guaranteeing such access for a large majority of the population. This consequence was the need for government to contain the rapidly rising cost of health care, a theme which has arguably been the most dominant and constant one in health care politics since the mid-1970s. By this time, the social ideal had become so ingrained that attempts to curb costs were not 
brought in relation to the limiting of access to provisions. And even when this did happen, in the 1980s, it should rather be understood as triggered by a growing cultural discomfort with a 'cradle to the grave' welfare state that sapped the autonomy of citizens, than as the disintegration of the idea of health care as a collective affair to be backed by the state. We have seen how the initial strategy for curbing costs through a bigger role for the state rapidly failed in the 1970s, only to be replaced (paradoxically) by a blueprint for state-led market regulation in 1987. Clearly, the Dekker-report of that year and the implementation of its proposals that led to the 'health care market' in 2006 signaled a return to long-dominant notions of private initiative and of autonomy for the parties in the field. But contrary to the idea that the 'Neoliberal' age that had its beginning in the 1980s would curb access to social provisions, the ultimate implementation of the ideas formulated in the 1987 report led to unprecedented health insurance coverage in The Netherlands. 'Liberal solidarity' became a fact, but it had been well over a century in the making.

\section{Closing Remarks}

All things considered, the 'filter' of a political philosophy that accentuates small or limited state interventions in the operations of health care has not stood in the way of the gradual expansion of the backing by the state of access to health care. Nor does the recurring mismatch between rhetoric and reality seem to have been a problem for the Dutch electorate, which voted for parties espousing 'private initiative' while it increasingly backed an extensive welfare state. ${ }^{4}$ What does all this mean for the future of health care policy in The Netherlands? The growth of access to health care as a social provision, increasingly backed by the government during the past century and a half, has set both Dutch society and its government on a track from which it seems hard to diverge. Despite recent controversies over the waiting lists that once again cropped up in health care and over backlogs in psychiatric and youth care, as well as criticisms concerning high prices for medicines and the general effectiveness of the health care 'market' in safeguarding accessibility, nothing suggests a turning away from the 'regulated market' course. ${ }^{5}$

\footnotetext{
${ }^{4}$ Noteworthy in this regard is the historically high voter turnout in The Netherlands: on average some $80 \%$ of people turn up to vote for the Tweede Kamer, strengthening the representative nature of elected government. https://www.parlement.com/id/vh8Inhrp8wsz/opkomst bij tweede kamerverkiezingen, accessed on 24-04-2020.

${ }^{5}$ See, for just a few examples: https://www.nrc.nl/nieuws/2019/10/18/ziekenhuispersoneel-staakt-voorhet-eerst-landelijk-a3977196; https://www.nrc.nl/nieuws/2020/01/19/actie-tegen-stille-ramp-in-de-ggza3987416; https://www.volkskrant.nl/nieuws-achtergrond/staatssecretaris-blokhuis-eist-aanpak-wachttijdggz b78c23f2/; https://www.trouw.nl/nieuws/de-jonge-marktwerking-in-de-zorg-is-
} 
For politicians, limiting access to care is a very hard choice and unattractive option. But the necessity of keeping costs within certain limits in order to keep the ship of state financially afloat is at the same time inescapable. In keeping the Dutch health care system accessible and affordable, tough political choices with regard to not just the content of the insured package and its cost, but also the governance of the system as a whole seem inevitable now and in the future. Given the analysis provided by this dissertation, it seems that such choices have the best chance to succeed if they respect the history of the institutions and the mentalities that have played a role in the relations between health care, civil society, and government in the past century and a half. Practically speaking, this will mean taking into account the historically dominant rhetoric of the importance of private initiative, autonomy, and civil society, while at the same time respecting the reality of health care as an entrenched social right and the state as its de facto guardian. With some prescience, in his 1869 valedictory address, Johan Rudolf Thorbecke - instrumental in bringing about the first, Liberal, governmentality for health care foresaw the hard task facing future politicians if the role of the state in social affairs should grow:

Faced with so many social interests [...] and surrounded on so many sides by claims and pleas from those who clamor not for freedom to better themselves, but for support from this or that authority, the State finds that abstinence can be a more complex art than action. Moreover, it would find that if it were to retreat into what it earlier saw as its remit, lacunae would be created in society, which would bring about general standstill or decline. ${ }^{6}$

Standstill or even decline in the provision of health care in The Netherlands seems undesirable, to say the least. But to maintain the system in the long run will necessitate hard choices, choices which need to be based on a deep understanding of the historical development of this enormously complex and equally important sector of society. To such an understanding this analysis of historical and current 'governmentalities' in Dutch health care hopes to contribute.

doorgeslagen ba2476e4/; https://www.nrc.nl/nieuws/2020/01/30/wie-krijgt-medicijn-van-2-miljoena3988831, all accessed on 12-02-2020.

${ }^{6}$ Thorbecke, 'Narede', viii-ix. In original: "Met deze en zoovele andere sociale belangen, regeling van stoffelijken arbeid en goederenverkeer, in aanraking, van alle kanten gedrongen door vragers, niet zoozeer van vrijheid, die den wil om zich zelven te helpen onderstelt, als om bijstand van het gezag, ondervindt de Staat, dat onthouding soms grooter kunst dan handelen is. Ook zou hij, op eenmaal zich binnen zijne grenzen terugtrekkende, leemten in de zamenleving doen ontstaan, die een algemeenen stilstand of achteruitgang zouden veroorzaken." 


\section{Bibliography}

\section{Archival materials}

- National Archives, inventory 2.04.47.02, no. 2, Betreffende de instelling van een (nietofficiële) Commissie bezuiniging kosten ziekenhuiswezen

- National Archives, inventory 2.04.47.02, no. 12, Commissie Bezuiniging Kosten Ziekenhuiswezen

- National Archives, inventory 2.04.55, no. 326; Verslag van de Commissie voor de Ziekenverzorging

- National Archives, inventory 2.04.55, no. 611, Centrale Commissie voor de Statistiek, 'Bericht op schrijven van 8 juli 1919, no. 5506, Afd. A. betreffende Statistiek van het Armwezen', s-Gravenhage 5 mei 1923

- National Archives, inventory 2.04.55, no. 611, Centrale Commissie voor de Statistiek, 'Nota van mr. Coffrie betreffende het verzamelen en verstrekken van gegevens inzake het verleenen van kostelooze genees-, heel- en verloskundige hulp buiten ziekenhuizen', 1935

- National Archives, inventory 2.15.37 (Afdeling Volksgezondheid), no. 872, Letter from Van den Berg to the Secretary-General of the Ministry of Social Affairs, d.d. 01-04-1941

- National Archives, inventory 2.15.38, no. 18, Verhandeling van de hoofdinspecteur dr J.Th. Terburgh inzake de geschiedenis van het Staatstoezicht op de Volksgezondheid (1928)

- National Archives, inventory 2.15.38, no. 219, betreffende de Instelling van Gezondheidsdiensten. Directeur van de Gemeentelijke Geneeskundige Dienst Leiden, Dec 1926, 'Schets van een districts-gezondheidsdienst Leiden-Gouda met raming der jaarlijkse bedrijfskosten'

- National Archives, inventory 2.15.38, no. 219, Stukken betreffende de organisatie van de gezondheidsdiensten in Nederland (onder andere kosten, gebiedsvaststelling, vestiging in kleinere plaatsen, regelingen)

- National Archives, inventory 2.15.38, no. 252. W.J.A.J. Duynstee and W.R. Casparie, Rapport over een Voor-ontwerp Ziekenhuiswet, d.d. 20-5-1949

- National Archives, inventory 2.15.38, no. 252, N. Arkema, Letter to the Chair of the Central Committee for Health, d.d. 17-08-1949

- National Archives, inventory 2.15.38, no. 252, Vereniging van Katholieke Ziekenhuizen, 'Voorontwerp-Ziekenhuiswet', d.d. 21-12-1951

- National Archives, inventory 2.15.38, no. 255, Letter from Chief Inspector Cornelis Banning to Regional Health Inspector for Groningen Piet Muntendam d.d. 2-11-1943 
- National Archives, inventory 2.21.218, no. 171, Ziekenfondsraad, Cijfers Secretariaat Ziekenfondsraad

- National Archives, inventory 2.27.15, no. 1, Centrale Commissie voor de Volksgezondheid

- National Archives, inventory 2.27.15, no. 8, Centrale Commissie voor de Volksgezondheid

- National Archives, inventory 2.27.15, no. 55, Ontwerp-Memorie van Toelichting Regeling van het Ziekenhuiswezen (Ziekenhuiswet 1948)

- National Archives, inventory 2.27.15, no. 55, Letter from H.W. Julius to the Central Committee for Health, d.d. 8-9-1949

- National Archives, inventory 2.27.15, no. 55, J.J. Brutel de la Rivière (chair of the Central Committee for Health), Advice Concerning the Draft Hospital Act, d.d. 1-11-1949

- National Archives, inventory 2.27.15, no. 55, Ontwerp van wet tot regeling van het Ziekenhuiswezen, August 1951

- National Archives, inventory 2.27.15, no. 55, 'Brief van C. Banning aan Brutel de la Rivière, d.d. 27-11-1951'

- National Archives, inventory 2.27.20, no. 3, Verslagen van het 52e congres van het Nederlandsch Congres voor Openbare Gezondheidsregeling op 4 en 5 juli 1952 te Breda en van het 53e congres op 8 en 9 oktober 1954 te Arnhem, concepten 1952-1954

\section{Parliamentary documents}

- Bijlagen Handelingen II, 1938/39, 271, no. 2-3

- Bijlagen Handelingen II, 1945/46, 123, no. 2

- Bijlagen Handelingen II, 1952/53, 2981, no. 3

- Bijlagen Handelingen II 1953/54, 2981, no. 4

- Bijlagen Handelingen II 1954/55, 2981, no. 5

- Kamerstukken I, 1955/56, 2981, no. 49

- Kamerstukken II, 1961/1962, 6808 no. 3

- Kamerstukken II, 1962/63, 6796, no. 5

- Kamerstukken II, 1965/66, 8462, no. 1

- Kamerstukken II, 1967/1968, 9717, no. 3

- Handelingen II, 1972/1973, no. 41

- Kamerstukken II, 1973/1974, 13 012, no. 1

- Kamerstukken II, 1973/1974, 13 012, no. 2

- Handelingen II, 1982/1983, 22-11-1982

- Kamerstukken II, 1983/1984, no. 18 279, no. 2

- Kamerstukken II, 1985/86, 19 387, no. 3

- Kamerstukken II, 1987-1988, 19 945, no. 27 
- Kamerstukken II, 1987-1988, 19 945, no. 28

- Kamerstukken II, 1989-1990, 21 545, no. 2

- Kamerstukken II, 1991-1992, 22393 no. 20

- Kamerstukken II 1993-1994, 23 666, no. 2

- Kamerstukken II, 1993-1994, 23 715, no. 11

- Handelingen II, 1994-1995, no. 86, 5812

- Kamerstukken II, 1994-1995, 24 036, no. 1

- Kamerstukken II, 1994-1995, 24 036, no. 7

- Kamerstukken II, 1996-1997, 25 170, no. 1

- Kamerstukken II, 1997-1998, 25 170, no. 6

- Kamerstukken II, 1997-1998, 26 024, no. 10

- Handelingen II, 1999-2000, 4798

- Kamerstukken II, 1999-2000, 26 801, no. 35

- Kamerstukken II, 2000-2001, 27 488, no. 1

- Kamerstukken I, 2000-2001, 27 855, no. 2

- Kamerstukken II, 2000-2001, 25 170, no. 20

- Kamerstukken II, 2002-2003, 25 170, no. 31

- Kamerstukken II, 2002-2003, 28 367, no. 19

- Kamerstukken II, 2003-2004, 25 170, no. 35

- Kamerstukken II, 2003-2004, 29 762, no. 3

- Kamerstukken II, 2003-2004, 29 763, no. 3

- Kamerstukken II, 2004-2005, 29763, no. 7

- Kamerstukken I, 2004-2005, 29 763, E

- Kamerstukken II, 2004-2005, 30 186, no. 3

- Kamerstukken II, 2009-2010, 32 393, no. 3

- Kamerstukken II, 2012-2013, 30 597, no. 296

- Kamerstukken II, 2013-2014, 33 841, no. 3

- Kamerstukken II, 2013-2014, 33 891, no. 3

- Kamerstukken II, 2015-2016, 34 445, no. 3

- Kamerstukken II, 2015/2016 34 522, no. 2

- Kamerstukken I, 2016-2017, 34522 A

- Kamerstukken II, 2017-2018, 34 874, no. 2 


\section{Governmental publications}

- --- Ontwerp Ziekenfondswet, waaromtrent door de Minister van Sociale Zaken en Volksgezondheid advies is gevraagd aan de Sociaal-Economische Raad ('s-Gravenhage: Staatsdrukkerij- en Uitgeverijbedrijf 1951)

- --- Verandering Verzekerd (Amstelveen 1989)

- Adviescommissie inzake het industriebeleid, Een nieuw industrieel elan (Den Haag: Staatsuitgeverij 1981)

- Agt, A.A.M. van e.a., Bestek '81. Hoofdlijnen van het financiële en sociaal-economische beleid voor de middellange termijn (Den Haag: Staatsuitgeverij 1978)

- $\quad$ Autoriteit Consument \& Markt, ACM/UIT/496816 (Letter to Minister of Health, d.d. 1907-2018).

- Berchick, E.R., Hood, E. and Barnett, J.C., Health Insurance Coverage in the United States: 2017. Current Population Reports (U.S. Government Printing Office: Washington, DC 2018)

- Centraal Bureau voor de Statistiek, Armenzorgstatistiek over het jaar 1938 ('s Gravenhage: N.V. Drukkerij Albani: 1940)

- Centraal Bureau voor de Statistiek, De verzekering tegen de kosten van Ziekenhuisverpleging in Nederland op 1 Januari 1940 (Den Haag: Albani 1940)

- Centraal Bureau voor de Statistiek, Overzicht van de Kruisvereenigingen in Nederland (Den Haag: Rijksuitgeverij 1942)

- Centraal Bureau voor de Statistiek, Armenzorgstatistiek over 1940 ('s Gravenhage: Drukkerij Albani C.V. 1942)

- Centraal Bureau voor de Statistiek, Kosten en financiering van de gezondheidszorg in Nederland in 1953 (Zeist: Uitgeversmaatschappij W. de Haan N.V. 1957)

- Centraal Bureau voor de Statistiek, Statistiek van de plaatselijke kruisverenigingen 1957 (Zeist: Uitgeversmaatschappij W. de Haan N.V. 1960)

- Centraal Bureau voor de Statistiek, Statistiek van de algemene bijstand 1965 en 1966 ('sGravenhage: Staatsuitgeverij 1969)

- Centraal Bureau voor de Statistiek, Kosten en financiering van de gezondheidszorg in Nederland 1968 ('s-Gravenhage: Staatsuitgeverij 1972)

- Centraal Bureau voor de Statistiek, Kosten en financiering van de gezondheidszorg 19721992. Costs and financing of health care 1972-1992 ('s-Gravenhage: Sdu 1994)

- Commissie Structuur en Financiering Gezondheidszorg (chair: W.P. Dekker), Bereidheid tot verandering ('s-Gravenhage: Distributiecentrum Overheidspublikaties 1987)

- Geneeskundig Staatstoezicht, Verslag aan den Koning van de bevindingen en handelingen van het Geneeskundig Staatstoezigt in het jaar 1866 (Den Haag: Van Weelden en Mingelen 1866) 
- Geneeskundig Staatstoezicht, Verslag aan den Koning van de bevindingen en handelingen van het Geneeskundig Staatstoezigt in het jaar 1896 (Den Haag 1896)

- Geneeskundige Inspectie van de Volksgezondheid, De gemeentelijke gezondheidszorg en zijn organisatie (n.p.: 1965)

- Minister van Volksgezondheid, Welzijn en Sport, Letter to the Chair of the Second Chamber of Parliament, 'Aanbieding en eerste beleidsreactie op de evaluatie van de hervorming van de langdurige zorg' d.d. 27-06-2018

- Minister van Volksgezondheid, Welzijn en Sport, Letter to the Chair of the Second Chamber of Parliament, 'Ontwikkelingen fusietoezicht in de zorg', d.d. 22-10-2018

- Ministerie van Sociale Zaken en Volksgezondheid, 'Persbericht No. 1811. Ontwerp Ziekenfondswet ingediend' ('s Gravenhage 21-08-1962)

- Ministerie van Volksgezondheid, Welzijn en Sport, Zicht op zorg. Plan van aanpak Modernisering AWBZ (Den Haag: Ministerie van Volksgezondheid, Welzijn en Sport 1999)

- Ministerie van Volksgezondheid, Welzijn en Sport, Geconcentreerd dereguleren? Onderzoeksnotitie naar bestaande concentraties en machtsposities in de zorg (Den Haag: Ministerie van Volksgezondheid, Welzijn en Sport 2002)

- Ministerie van Volksgezondheid, Welzijn en Sport, Het Nederlandse Zorgstelsel (Den Haag: Ministerie van Volksgezondheid, Welzijn en Sport 2016), via https://www.rijksoverheid.nl/documenten/brochures/2016/02/09/het-nederlandsezorgstelsel; https://international.commonwealthfund.org/countries/netherlands/

- Ministerie van Welzijn, Volksgezondheid en Cultuur, Modernisering zorgsector. Weloverwogen verder (Den Haag: Sdu Uitgeverij 1992)

- Nationale Raad voor de Volksgezondheid, Wachtlijsten (Zoetermeer: Nationale Raad voor de Volksgezondheid 1994)

- Nationale Raad voor de Volksgezondheid, Wachtlijsten I/ (Zoetermeer: Nationale Raad voor de Volksgezondheid 1995)

- Nationale Raad voor de Volksgezondheid, De wachtende werknemer (Zoetermeer: Nationale Raad voor de Volksgezondheid 1995)

- Nederlandse Zorgautoriteit, Rapport Risicoselectie en risicosolidariteit zorgverzekeringsmarkt (Utrecht: NZa 2016)

- Nederlandse Zorgautoriteit, Doelmatige zorg in de Wlz. Hoe bevorderen zorgkantoren doelmatige zorg? (Utrecht: NZa 2016)

- Nederlandse Zorgautoriteit, Marktscan medisch-specialistische zorg 2016 (Utrecht: NZa 2017)

- Nederlandse Zorgautoriteit, Monitor Zorgverzekeringen 2018 (Nederlandse Zorgautoriteit: Utrecht 2018), via https://puc.overheid.nl/nza/doc/PUC 254666 22/1/

- Raad voor de Volksgezondheid \& Zorg, Tussen markt en overheid (Zoetermeer: Raad voor de Volksgezondheid \& Zorg 1998) 
- Raad voor Volksgezondheid \& Zorg, De rollen verdeeld. Burger, ondernemer en overheid in de gezondheidszorg (Zoetermeer: Raad voor de Volksgezondheid \& Zorg 2000)

- Raad voor de Volksgezondheid en Zorg, Exploderende zorguitgaven. Signalement over uitgavenmanagement (Zoetermeer: Raad voor de Volksgezondheid en Zorg 2003)

- Raad voor de Volksgezondheid \& Zorg, Van patiënt tot klant (Zoetermeer: Raad voor de Volksgezondheid \& Zorg 2003)

- Sociaal en Cultureel Planbureau, Veranderde zorg en ondersteuning voor mensen met een beperking. Landelijke evaluatie van de Hervorming Langdurige Zorg (Den Haag: Sociaal en Cultureel Planbureau 2018)

- Sociaal-Economische Raad, Naar een gezond stelsel van ziektekostenverzekeringen (Den Haag: Sociaal-Economische Raad 2000)

- Van Rhijn-Committee, Sociale Zekerheid. Rapport van de Commissie, ingesteld bij Beschikking van den Minister van Sociale Zaken van 26 maart 1943, met de opdracht algemeene richtlijnen vast te stellen voor de toekomstige ontwikkeling der sociale verzekering in Nederland. Deel I. Overzicht van de bestaande stelsels in Nederland en een aantal andere landen, benevens van de in sommige dezer landen uitgewerkte plannen tot herziening en uitbreiding der bestaande voorzieningen ('s-Gravenhage: Algemeene Landsdrukkerij 1945-1946)

- Van Rhijn-committee, Sociale zekerheid. Deel III. De Organisatie van Geneeskundige Voorzieningen en de Rehabilitatie van Gebrekkigen (Den Haag: Algemeene Landsdrukkerij 1946)

- Wetenschappelijke Raad voor het Regeringsbeleid, Herwaardering van Welzijnsbeleid (Den Haag: Staatsuitgeverij 1982)

- Wetenschappelijke Raad voor het Regeringsbeleid, Volksgezondheidszorg (Den Haag: Wetenschappelijke Raad voor het Regeringsbeleid 1997)

\section{Weblinks}

- https://www.parlement.com/id/vh8Inhrp1wzu/periode 18481872 het tijdperk van

- https://www.parlement.com/id/vh8Inhrp1wzr/periode 18881918 antithese

- https://www.parlement.com/id/vhzpckjlgvz9/de vergissing van troelstra 1918

- https://www.parlement.com/id/vh8Inhrp1wzs/periode 19181939 interbellum

- https://www.parlement.com/id/vh8Inhrpfxu8/sociaal democratische arbeiderspartij

- https://www.parlement.com/id/vg09|l5ssays/a a aat van rhijn

- https://www.parlement.com/id/vjw7eih0q7q3/troonrede 1945 volledige tekst

- $\quad$ https://www.parlement.com/id/vh8Inhronvwk/kabinet beel i 19461948 
- https://www.parlement.com/id/vh8Inhronvwq/tweede kamerverkiezingen 1956

- https://www.parlement.com/id/vh8Inhrp8ws1/kabinet de geer ii 19391940

- https://www.parlement.com/id/vgok2t90lozj/w willem banning

- https://www.parlement.com/id/vh8lnhronvwe/kabinet de quay 19591963

- https://www.parlement.com/id/vh8Inhronvwd/kabinet marijnen 19631965

- https://www.parlement.com/id/vh8Inhronvwa/kabinet biesheuvel i en ii 19711973

- https://www.parlement.com/id/vh8Inhronvwv/tweede kamerverkiezingen 1977

- https://www.parlement.com/id/vh8Inhronvw8/kabinet van agt i 19771981

- https://www.parlement.com/id/vh8Inhronvw7/kabinet van agt ii 19811982

- https://www.parlement.com/id/vh8Inhronvw3/kabinet lubbers iii 19891994

- https://www.parlement.com/id/vh8Inhronvvu/kabinet kok i 19941998

- https://www.parlement.com/id/vhdjhx1hxotm/opkomst en ondergang van de lpf

- https://www.parlement.com/id/vh8Inhrpfxup/kabinet balkenende i 20022003

- https://www.parlement.com/id/vg09lllc9opo/j f hans hoogervorst

- https://www.parlement.com/id/vh8Inhrp8wsz/opkomst bij tweede kamerverkiezingen

- http://pubnpp.eldoc.ub.rug.nl/FILES/root/verkiezingsprogramma/TK/arp1948/arp1948.p df

- http://dnpprepo.ub.rug.nl/244/1/Verkiezingsprogram\%20PvdA\%201956.pdf

- http://dnpprepo.ub.rug.nl/239/

- https://www.wbs.nl/publicaties/honderd-jaar-joop-den-uyl-1919-1987

- https://www.parlement.com/id/vh8Inhrp8wtg/liberale staatspartij de vrijheidsbond

- https://vvd-digitaal.dnpp.nl/perioden/1948-1963/verkiezingen-en-regering

- https://international.commonwealthfund.org/countries/netherlands/

- http://avalon.law.yale.edu/wwii/atlantic.asp

- https://www.nrc.nl/nieuws/2019/10/28/kabinet-trekt-voorstel-voor-winstuitkering-inziekenhuiszorg-in-a3978265

- https://www.cbs.nl/nl-nl/nieuws/2014/50/premie-basisverzekering-bleef-lange-tijdgelijk-vermogens-van-zorgverzekeraars-stegen

- https://read.oecd-ilibrary.org/social-issues-migration-health/health-at-a-glance2017/health-expenditure-as-a-share-of-gdp-2016-or-nearest-year health glance-2017graph112-en\#page1

- https://data.oecd.org/healthstat/life-expectancy-at-birth.htm

- https://www.commonwealthfund.org/blog/2018/first-look-health-insurance-coverage2018-finds-aca-gains-beginning-reverse

- https://www.nytimes.com/2019/01/23/upshot/rate-of-americans-without-healthinsurance-rising.html

- http://www.vatican.va/content/leo-xiii/en/encyclicals/documents/hf Ixiii enc 15051891 rerum-novarum.html 
- http://www.vatican.va/content/pius-xi/en/encyclicals/documents/hf pxi enc 19310515 quadragesimo-anno.html

- http://statline.cbs.nl/Statweb/publication/?DM=SLNL\&PA=37556\&D1=a\&D2=1,21,41\&V $\underline{W}=\mathrm{T}$

- https://archive.org/details/in.ernet.dli.2015.275849/page/n4

- https://www.socialezekerheidsstelsel.nl/id/vhnnmt7jpb01/stichting van de arbeid

- https://www.rijksoverheid.nl/documenten/brieven/2017/01/18/treeknormen-ggz

- https://www.volkskrant.nl/nieuws-achtergrond/geldverslindend-zorgstelsel-moest-opde-schop b8d4c28b/

- https://www.volksgezondheidenzorg.info/onderwerp/ziekenhuiszorg/cijferscontext/aanbod\#!node-aantal-instellingen-voor-medisch-specialistische-zorg

- https://puc.overheid.nl/nza/doc/PUC 3199 22/1/

- https://www.acm.nl/sites/default/files/old publication/publicaties/15959 leidraadgezamenlijke-inkoop-geneesmiddelen-voor-medisch-specialistische-zorg-2016-0622.pdf

- https://www.acm.nl/sites/default/files/old publication/publicaties/16189 informelezienswijze-samenwerking-ziekenhuizen-complexe-kankerzorg.pdf

- https://www.acm.nl/sites/default/files/documents/2019-07/consultatiedocument-acmbeleidsregel-toezicht-op-verplaatsing-zorg-jzojp.pdf

- https://www.consumentenbond.nl/zorgverzekering/wachtlijstbemiddeling

- https://www.volkskrant.nl/economie/het-zijn-allemaal-zakkenvullers-zesonderbuikgevoelens-over-zorgverzekeraars-en-wat-daarvanklopt b1f8a2e1/?referer=https\%3A\%2F\%2Fwww.google.com\%2F

- https://www.nrc.nl/nieuws/2019/08/23/zorg-in-last-door-omzetplafonds-a3970897

- https://www.nrc.nl/nieuws/2019/11/20/de-wereld-op-zn-kop-patienten-maken-zichzorgen-om-ons-a3981028

- https://www.eerstekamer.nl/wetsvoorstel/34522 initiatiefvoorstel leijten

- https://www.medischcontact.nl/nieuws/laatste-nieuws/artikel/cda-pvda-en-sp-verdermet-verbod-winstuitkering-verzekeraars.htm

- http://www.rijksbegroting.nl/2018/voorbereiding/begroting,kst236981 33.html

- https://www.igj.nl/zorgsectoren/medische-technologie/toezicht-op-veiliggebruik/convenant

- https://www.zorginstituutnederland.nl/Verzekerde+zorg/w/wijkverpleging-zvw 


\section{Literature}

- $\quad$--- 'Het plan Simons', NRC Handelsblad March 7, 1990

- Aa, M.J. van der et al, 'Hervorming van de langdurige zorg. Blijft de solidariteit behouden?', Ned Tijdschr Geneeskd. 158 (2014) A8253

- Abma, H.G., 'De Volksgezondheidsnota 1966', De Banier. Partijblad van de Staatkundig Gereformeerde Partij (6-10-1966) 2-3

- Achterhuis, H., De markt van welzijn en geluk. Een kritiek van de andragogie (Baarn: Basisboeken Ambo 1979/80)

- Aerts, R., 'Een staat in verbouwing. Van Republiek naar constitutioneel koninkrijk, 17801848', in: Aerts, R. et al, Land van kleine gebaren. Een politieke geschiedenis van Nederland 1780-2012 (8th revised edition: Amsterdam: Boom 2016) 13-108

- Aerts, R., Thorbecke wil het. Biografie van een staatsman (Amsterdam: Prometheus 2018)

- Arrow, K.J., 'Uncertainty and the Welfare Economics of Medical Care', The American Economic Review 535 (1963) 941-973

- Bakker, C.T., Geld voor GGZ: de financiering van de geestelijke gezondheidszorg en de invloed van geld op de zorgpraktijk (1884-1984) (Amsterdam: Amsterdam University Press 2009)

- Baldwin, P., 'Beyond Weak and Strong: Rethinking the State in Comparative Policy History', The Journal of Policy History 171 (2005) 12-33

- Banning, W., 'Een nieuwe bladzijde', Socialisme en Democratie 3 (1946)

- Baruch, J.Z., 'Dr. B.H. Sajet, sociaal-geneeskundige van formaat', NTVG 130 (1986) 2273-5

- Bassant, E., Ziekenfonds of particulier? Hoe de basisverzekering er toch is gekomen (Maarssen: Elsevier Gezondheidszorg 2007)

- Beaufort, F. de and Schie, P. van, Sociaal-liberalisme (Amsterdam: Boom 2014)

- Berg, C. van den and Revers, H.J.D., De financieele verhouding tusschen het rijk en de gemeenten (Alphen aan den Rijn: N. Samsom N.V. 1936)

- Bertens, R., Gezondheid tussen staat en markt. De opkomst van het marktdenken in het Nederlandse zorgstelsel, 1974-1987 (MA thesis: Universiteit van Amsterdam 2015)

- Bertens, R.M., Care, Cost and Questions of Control. Dutch Health Care Reform 1987-2006 (MA thesis: Utrecht University 2016)

- Bertens, R.M. and Huisman, F.G., 'Vrije artsenkeuze: recht of macht?', Ned Tijdschr Geneeskd 2016160

- Bertens, R. and Vonk, R., E Pluribus unum. Forging a public-private health insurance system in the Netherlands (forthcoming article)

- Beveridge, W.H., (chairman), Social Insurance and Allied Services (London: 1942)

- Beyens, N., Immer bereid en nooit verlegen. Hector Treub. Vrouwenarts in een mannenmaatschappij (Amsterdam: Boom 2013) 
- Beyens, N., Forthcoming biography on Els Borst

- Beyens, N. and Bolt, T., "A Medical Doctor in Politics'. Els Borst-Eilers and the Rise of Evidence-Based Healthcare', Low Countries Historical Review 1321 (2017) 16-37

- Blanksma, C., 'Critiek op "sociale zekerheid" (Rapport van Rhijn, Deel III)', Medisch Contact 21 (3-01-1947) 4-9

- Blok, G., 'Soelaas voor geest en samenleving: de GGZ als werkveld', in: Hillen, H., Houwaart, E. and Huisman, F., (eds.), Leerboek medische geschiedenis (Houten: Bohn Stafleu van Loghum 2018) 207-219

- Blom, J.C.H., 'Jaren van tucht en ascese. Enige beschouwingen over de stemming in herrijzend Nederland (1945-1950)', BMGN - Low Countries Historical Review 962 (1981) 300-333

- Booij, H.L., Wet Voorzieningen Gezondheidszorg (doctoral thesis Rijksuniversiteit Utrecht 1988)

- Bottenburg, M. van, Vries, G. de and Mooij, A., Zorg tussen staat en markt. De maatschappelijke betekenis van de Ziekenfondsraad 1949-1999 (Zutphen: Walburg Pers 1999)

- Brenkman, C.J., 'Districts-Gezondheidsdiensten. Een nieuw stadium', Tijdschrift voor Sociale Geneeskunde 12 (1928) 145-148

- Brouwer, A., 'Het gemeenteartsen-probleem en de gemeentelijke gezondheidsdiensten (I), Tijdschrift voor Sociale Geneeskunde 4019 (1962) 537-546

- Brouwer, E. and Broek, P. van den, 'Het perspectief van de zorgverzekeraars', in: Elsinga, E. and Kemenade, Y. van, (eds.), Van revolutie naar evolutie. Tien jaar stelselwijziging in de Nederlandse gezondheidszorg (Lochem: De Tijdstroom 1997), 104-124

- Bruggeman, C.W.C.A., Stijnen, R. and Wit, J.C. de, 'Kroniek van het gemeentelijk sociaal domein (deel 2)', Gemeentestem 7453 (2017)

- Bruggen, A.C. van, 'Arts en samenleving. De Ziektewet-Talma', Ned. Tijdschr. v. Geneesk. 64 (1920) 2582-2593

- Bruinsma, G.W., Nieuw Geneeskundig Wetboek. Overzicht en aanwijzing van wetten, besluiten, reglementen enz. Die van belang zijn voor Geneeskundigen, Apothekers enz. (Haarlem: De Erven F. Bohn 1898)

- Bureau voor Economische Argumentatie KPMG, Marktconcentraties in de ziekenhuissector (Zoetermeer: 2003)

- Bynum, W.F., Science and the Practice of Medicine in the Nineteenth Century (Cambridge: Cambridge University Press 1994)

- Bynum, W.F., 'The rise of science in medicine, 1850-1913', in: Bynum, W.F. et al, The Western Medical Tradition. 1800 To 2000 (Cambridge: Cambridge University Press 2006) 111-245

- Cannegieter, D., Honderdvijftig jaar Gezondheidswet (Assen: Van Gorcum 1954) 
- Centrum voor Staatkundige Vorming, Grondslagen voor een Wettelijke Regeling van de Gezondheidszorg ('s-Gravenhage 1950)

- Companje, K.P., Over artsen en verzekeraars. Een historische studie naar de factoren, die de relatie ziekenfondsen-artsen vanaf 1827 op landelijk en regionaal niveau hebben beïnvloed (Twello: Van Tricht 1997)

- Companje, K.P., Convergerende belangen. Belangenbehartiging van de zorgverzekeraars in historisch perspectief 1900-2001 (Zeist: Zorgverzekeraars Nederland 2002)

- Companje, K.P., 'Ziekteverzekering volgens Bismarckrecept?', in: Companje, K.P., (ed.), Tussen volksverzekering en vrije markt. Verzekering van zorg op het snijvlak van sociale verzekering en gezondheidszorg 1880-2006 (Amsterdam: Aksant 2008) 47-95

- Companje, K.P. and Vonk, R.A.A., 'Ziektekostenverzekeringen en wettelijk geregelde arbeidsverhoudingen tot 1941', in: Companje, K.P., (ed.), Tussen volksverzekering en vrije markt. Verzekering van zorg op het snijvlak van sociale verzekering en gezondheidszorg 1880-2006 (Amsterdam: Aksant 2008) 173-224

- Companje, K.P., 'Ziekenzorg en ziekengeld gescheiden verzekeringen, 1908-1940', in: Companje, K.P., (ed.), Tussen volksverzekering en vrije markt. Verzekering van zorg op het snijvlak van sociale verzekering en gezondheidszorg 1880-2006 (Amsterdam: Aksant 2008) 225-350

- Companje, K.P., 'Verzekering van zorg 1943-2007: gezondheidszorg of sociale zekerheid?', in: Companje, K.P., (ed.), Tussen volksverzekering en vrije markt. Verzekering van zorg op het snijvlak van sociale verzekering en gezondheidszorg 1880-2006 (Amsterdam: Aksant 2008), 559-628, in:

- Companje, K.P. and Rigter, D., "Ontwerp der wet regelende de ziekenverzorging', of de spanning tussen overheidsfinanciën en volksgezondheid, 1918-1941', in: Companje, K.P., (ed.), Tussen volksverzekering en vrije markt. Verzekering van zorg op het snijvlak van sociale verzekering en gezondheidszorg 1880-2006 (Amsterdam: Aksant 2008) 399-476

- Companje, K.P., 'Het Ziekenfondsenbesluit en de gevolgen voor de verzekering van zorg, 1940-1986', in: Companje, K.P., (ed.), Tussen volksverzekering en vrije markt. Verzekering van zorg op het snijvlak van sociale verzekering en gezondheidszorg 1880-2006 (Amsterdam: Aksant 2008) 477-558

- Companje, K.P., 'Het Ziekenfondsenbesluit en de verstrekking van zorg', in: Companje, K.P., (ed.), Tussen volksverzekering en vrije markt. Verzekering van zorg op het snijvlak van sociale verzekering en gezondheidszorg 1880-2006 (Amsterdam: Aksant 2008) 629-708

- Companje, K.P., Hendriks, R.H.M. and Veraghtert, K.F.E., Two Centuries of Solidarity: German, Belgian and Dutch social health insurance 1770-2008 (Amsterdam: Aksant 2009)

- Companje, K.P., 'Financing high medical risks in the Netherlands: healthcare, social insurance and political compromises', in: Companje, K.P., (ed.), Financing high medical risks. Discussions, developments, problems and solutions on the coverage of the risk of 
long-term care in Norway, Germany and the Netherlands since 1945 in European perspective (Amsterdam: Amsterdam University Press 2014)

- Companje, K.P. et al, Vijftig jaar kostenbeheersing in de zorg. Deel I: 1966-1995 (Den Haag: Sdu 2018)

- Couperus, S., De machinerie van de stad. Stadsbestuur als idee en praktijk, Nederland en Amsterdam 1900-1940 (Amsterdam: Amsterdam University Press 2009)

- Deknatel, J.W., Inleiding tot de studie van den werkkring der geneeskundigen bij de verplichte verzekering tegen ongevallen, overgedrukt uit het Nederlandsch Tijdschrift voor Geneeskunde 1900, Deel I (Amsterdam: 1900)

- Dols, W.P.M. and Kerkhoff, A.H.M., 'De Algemene Wet Bijzondere Ziektekosten. Debatten en ontwikkelingen vanaf 1987', in: Companje, K.P., (ed.), Tussen volksverzekering en vrije markt. Verzekering van zorg op het snijvlak van sociale verzekering en gezondheidszorg 1880-2006 (Amsterdam: Aksant 2008) 795-880

- Dool, P. van den, 'Einde aan vrije tandartstarieven - tandartsen naar de rechter', NRC Handelsblad 05-07-2012

- Doorn, J.A.A. van, 'De verzorgingsmaatschappij in de praktijk', in: Doorn, J.A.A. van and Schuyt, C.J.M. (eds.), De stagnerende verzorgingsstaat (Amsterdam: Boom Meppel 1978) 17-46

- Draak, M. den and Ham, L. van der, 'Gemeenten over de uitvoering van de Wmo 2015: het glas is halfvol én halfleeg', Tijdschrift voor Gezondheidswetenschappen 96 (2018) 348353

- Drentje, J., Thorbecke. Een filosoof in de politiek (Amsterdam: Boom 2004)

- Dute, J.C.J., 'Gezichtspunt. Zorgen om de Zorgautoriteit', Tïdschrift voor Gezondheidsrecht 301 (2006) 1

- Dute, J.C.J. and Legemaate, J. (eds.), Handboek gezondheidsrecht (Den Haag: Boom Juridisch; 7th edition 2017)

- Dworkin, R., Law's Empire (Oxford: Hart Publishing, reprint 1998)

- Economisch-Sociologisch Instituut, 'Enige notities over de financiële positie van het Centraal Ziekenfonds', in: Uden, C.W.A. van, Gezondheidszorg in eigen hand. Vijfentwintig jaar geschiedenis van het Centraal Ziekenfonds in het bisdom Den Bosch (Tilburg: Centraal Ziekenfonds voor het Bisdom 's-Hertogenbosch 1955) 155-179

- Editorial, Nederlands Tijdschrift voor Geneeskunde, 11 (1857) 1-2

- Editorial, 'Berichten Binnenland', Nederlands Tijdschrift voor Geneeskunde 8 Tweede Reeks, Eerste Afdeling (1865) 383

- Egeraat, L. van, 'Nederland krijge sociale zekerheid', in: De Nieuwe Eeuw 28: 1410 (1947) 124

- Ewijk, H. van, 'De Wmo als instrument in de transformatie van de welvaartsstaat en als impuls voor vernieuwing van het sociaal werk', Sociale Interventie 3 (2006) 5-16 
- $\quad$ Eyden, A.P.J. van der, 'Budgettering gezondheidsrechtelijk bezien', Tijdschrift voor Gezondheidsrecht 83 (1984) 105-116

- Festen, H., Geschiedenis van de Koninklijke Nederlandsche Maatschappij tot bevordering der Geneeskunst. 125 jaar geneeskunst en maatschappij (Utrecht: KNMG 1974)

- Festen, H., 'De geschiedenis van het ontstaan van het Centraal Orgaan Ziekenhuistarieven', in: Wolff, L.J. de (ed.), De Prijs voor Gezondheid. Het Centraal Orgaan Ziekenhuistarieven (Baarn: Ambo 1984) 13-45

- Festen, H., Spanningen in de gezondheidszorg. 25 jaar Centrale Raad voor de Volksgezondheid (Zoetermeer: Nationale Raad voor de Volksgezondheid 1985)

- Flew, T., 'Michel Foucault's The Birth of Biopolitics and contemporary neo-liberalism debates', Thesis Eleven 1081 (2012) 44-65

- Fortuyn, W.S.P., De puinhopen van acht jaar paars (Uithoorn: Karakter Uitgevers 2002)

- Foucault, M., 'Governmentality', in: G. Burchell, C. Gordon and P. Miller (eds.), The Foucault Effect. Studies in Governmentality (Chicago: The University of Chicago Press 1991) 87-104

- Foucault, M., The Birth of Biopolitics. Lectures at the Collège de France 1978-1979 (New York: Picador 2008; transl. G. Burchell)

- Foucault, M., Security, Territory, Population. Lectures at the Collège de France, 1977-1978 (Basingstoke: Palgrave Macmillan 2009; transl. G. Burchell)

- Freidson, E., Professionalism. The Third Logic (Cambridge: Polity Press 2001)

- Gamble, A., 'Ideologies of governance', in: Payne, A. and Phillips, N., (eds.), Handbook of the International Political Economy of Governance (Cheltenham: Edward Elgar 2014) 1331

- Gameren, E. van, Regionale verschillen in de wachtlijsten verpleging en verzorging. Een empirisch onderzoek naar verklarende factoren (Den Haag: Sociaal en Cultureel Planbureau 2005)

- Genabeek, J. van, Met vereende kracht risico's verzacht. De plaats van onderlinge hulp binnen de negentiende-eeuwse particuliere regelingen van sociale zekerheid (Amsterdam: diss. Vrije Universiteit Amsterdam 1999)

- Generaal, C. and Mensink, N., De Ziekenfondsen, de Wet Voorzieningen Gezondheidszorg en de Wet Tarieven Gezondheidszorg (doctoral thesis Rijksuniversiteit Utrecht: 1983)

- Goeman Borgesius, H., De nieuwe Armenwet. Met beknopt overzicht van stelsel en inhoud der wet, den tekst en aanteekeningen bij de artikelen (Sneek: J.F. van Druten 1912)

- Goudsmit, C.J., 'Volksgezondheid en Recht', in: Goudsmit, C.J., Volksgezondheid en recht (Ymuiden: Vermande Zonen N.V. 1966; reprint from Tijdschrift voor Sociale Geneeskunde 1954) 7-26

- Goudsmit, C.J., 'De nieuwe Gezondheidswet', in: Goudsmit, C.J., Volksgezondheid en Recht (Ymuiden: Vermande Zonen N.V. 1966) 28-32 
- Gratama, S., Geneeskundige Wetten. Met Aantekeningen, Bevattende de Jurisprudentie tot den Laatsten Tijd, benevens Koninklijke Besluiten, Ministerieele Beschikkingen, Beslissingen van Geneeskundige Raden en Aanschrijvingen van Inspecteurs en Adjunct-Inspecteurs voor het Geneeskundig Staatstoezicht (Schoonhoven: S. \& W.N. van Nooten 1881)

- Grinten van der, T.E.D. and Kasdorp, J., 25 jaar sturing in de gezondheidszorg: van verstatelijking naar ondernemerschap (Den Haag: Sociaal en Cultureel Planbureau 1999)

- Grinten, T. van der and Helderman, J.K., 'De gezondheidszorg: de (on)draaglijke traagheid van een stelselwijziging', in: Arentsen, M. and Trommel, W., Moderniteit en overheidsbeleid. Hardnekkige beleidsproblemen en hun oorzaken (Bussum: Coutinho 2005) 85-108

- Grinten, T. van der, Zorgen om beleid. Over blijvende afhankelijkheden en veranderende bestuurlijke verhoudingen in de gezondheidszorg (valedictory address Erasmus University Rotterdam 2006)

- Groot, G.R.J. de, 'Wachtlijsten in de gezondheidszorg', Tijdschrift voor Gezondheidsrecht 202 (1996) 58-70

- Groot, G.R.J. de, Tarieven in de gezondheidszorg (Utrecht: diss. Universiteit Utrecht 1998)

- Groot, G.R.J. de, Verantwoordelijkheid en aansprakelijkheid voor tekorten in de zorg, in: Roscam Abbing, H.D.C., Legemaate, J., Groot, G.R.J. de, Zorg, schaarste en recht. Preadvies Vereniging voor Gezondheidsrecht 2002 (Utrecht: Vereniging voor Gezondheidsrecht 2002) 64-121

- Groot, G.R.J. de, 'De zorgverzekeraar: spin in het web?', Tijdschrift voor Gezondheidsrecht 291 (2005) 40-60

- Groot, G.R.J. de, 'De schuivende panelen van de zorgverzekering', in: Sijmons, J.G., Ende, T.A.M. van den and Groot, G.R.J. de, Stelsel onder stress. Preadvies 2011 Vereniging voor Gezondheidsrecht (Den Haag: Sdu Uitgevers 2011) 139-231

- Guldi, J. and Armitage, D., The History Manifesto (Cambridge: Cambridge University Press 2014)

- Haan, I. de and Duyvendak, J.W., In het hart van de verzorgingsstaat. Het ministerie van Maatschappelijk Werk en zijn opvolgers (CRM, WVC, VWS), 1952-2002 (Zutphen: Walburg Pers 2002)

- Hardy, A. and Tansey, E.M., 'Medical enterprise and global response, 1945-2000', in: Bynum, W.F. et al, The Western Medical Tradition. 1800 To 2000 (Cambridge: Cambridge University Press 2006), 405-533

- Hassenteufel, P. et al, 'Programmatic Actors and the Transformation of European Health Care States', Journal of Health Politics, Policy and Law 354 (2010) 517-538

- Heffen, O. van and Kerkhoff, T., 'Gezondheidszorg: van blauwdrukdenken naar incrementeel sleutelen', in: Trommel, W. and Veen, R. van der, (eds.), De herverdeelde 
samenleving. De ontwikkeling en herziening van de Nederlandse verzorgingsstaat (Amsterdam: Amsterdam University Press 1999) 185-215

- Heide, H. ter, 'Ervaringen met het COZ als ordeningsmodel', in: L.J. de Wolff (ed.), De Prïs voor Gezondheid. Het Centraal Orgaan Ziekenhuistarieven (Baarn: Ambo 1984) 47-64

- Heijermans, L., 'Open brief Aan Zijne Excellentie den Minister van Arbeid, Handel en Nijverheid', Tijdschrift voor Sociale Geneeskunde 6, vol. 12 (1928) 179-185

- Heijermans, J., Gemeentelijke gezondheidszorg in Nederland (Amsterdam: Ontwikkeling 1929)

- Helderman, J.-K., Bringing the Market Back In? Institutional Complementarity and Hierarchy in Dutch Housing and Healthcare (Rotterdam: diss. Erasmus University Rotterdam 2007)

- Helderman, J.K. et al, 'Market-Oriented Health Care Reforms and Policy Learning in The Netherlands', Journal of Health Politics, Policy and Law, 30 1-2 (2005) 189-209

- Helderman, J.K., Bevan, G. and France, G., 'The rise of the regulatory state in health care: a comparative analysis of The Netherlands, England and Italy', Health Economics, Policy and Law 7 (2012) 103-124

- Helderman, J.K. et al, Dike-Reeve of the health care polder (Zorginstituut Nederland 2014)

- Hellema, D., Nederland en de jaren zeventig (Amsterdam: Boom 2012)

- Hoeven, H.C. van der, Ziekenfondsen en de Duitse bezetting (Den Haag: Koninklijke Vermande B.V. 1989)

- Hoeven, H.C. and E.W. van der, Om welzijn of winst. 100 jaar ziekenfondsen en sociale zekerheid (Deventer: Kluwer 1993)

- Hoffman, B. Health Care for Some. Rights and Rationing in the United States since 1930 (Chicago: University of Chicago Press 2012)

- Hoogenboom, M., Standenstrijd en zekerheid. Een geschiedenis van oude orde en sociale zorg in Nederland (Amsterdam: Boom 2004)

- Horstman, K., 'Om het beheer van de arbeidsongeschiktheid. Het politieke debat over de Ongevallenwet en het wel en wee van een medische markt', Tïdschrift voor Sociale Geschiedenis 254 (1999) 383-406

- Houwaart, E.S., De hygiënisten. Artsen, staat en volksgezondheid in Nederland 1840-1890 (diss. Rijksuniversiteit Maastricht: Maastricht 1991)

- Houwaart, E., 'De ontwikkeling van het ziekenhuis in de moderne tijd', in: Bakker, M.S.C. et al, Techniek als cultuurverschijnsel. Casusboek (Heerlen, Open Universiteit 1996) 238355

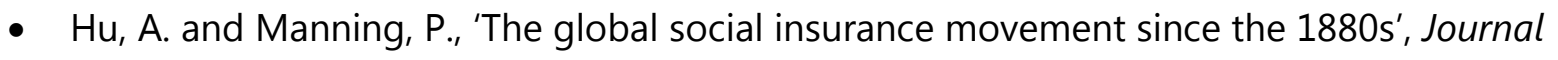
of Global History 5 (2010) 125-148

- Hubben, J.H., 'De IGZ: van stille kracht naar publieke waakhond', Tijdschrift voor Gezondheidsrecht 362 (2012) 96-108 
- Huisman, F.G., Stadsbelang en standsbesef. Gezondheidszorg en medisch beroep in Groningen 1500-1730 (Rotterdam: Erasmus Publishing 1992)

- Huisman, F.G., 'Ziek en gezond in het huis van Thorbecke', (forthcoming article)

- Jacobs, N., Ethics by committee. Governing human experimentation in the Netherlands, 1945-2000 (diss. Universiteit Maastricht 2018)

- Jagt-Jobsen, J.A.E. van der, Rijken, J.J. and Verduijn, M.A.M., 'Van AWBZ naar WIz: een trendbreuk met het verleden?', Tijdschrift voor Gezondheidsrecht 387 (2014) 540-552

- Jonkers, H., Het Koninklijk Besluit Bezettingsmaatregelen van den 17 Sept. 1944 (Goes: Fa. Gebrs. Stepman 1945)

- Juch, A., De medisch specialisten in de Nederlandse gezondheidszorg. Hun manifestatie en consolidatie, 1890-1941 (diss. Erasmus University Rotterdam: Rotterdam 1997)

- Juda, M., Dooremaal, J.C. van and Menno Huizinga, J., 'Rapport over den toestand der ziekenfondsen in Nederland', NTVG 26 II (1890) 134-147

- Juffermans, P., Staat en gezondheidszorg in Nederland (Nijmegen: SUN 1984)

- Julius, H.W., 'Het Recht op gezondheid', Tijdschrift voor Sociale Geneeskunde 32; 17 (1954) 340-350

- Jurrema, J.W., 'De Armenwet 1912-1922. Werking der Wet op de Burgerlijke Armenzorg. Wenschen en wegen ter verbetering', in: Geschriften van de Nederlandsche Vereeniging voor Armenzorg en Weldadigheid te Amsterdam XXXII (1922) 5-48

- Kahn, P.S., 'Het toezicht, de meldingsplicht en de rechtsbescherming van de zorgverlener', Tijdschrift voor Gezondheidsrecht 402 (2016) 72-83

- Kappelhof, T., 'Omdat het historisch gegroeid is'. De Londense Commissie-Van Rhijn en de ontwikkeling van de sociale verzekeringen in Nederland (1937-1952)', Tijdschrift voor Sociale en Economische Geschiedenis 12 (2004) 71-91

- Kasdorp, J.P. and Schrijvers, G., 'Deregulering, een recept voor de gezondheidszorg?', Conference Deregulering in de gezondheidszorg (Utrecht: Rijksuniversiteit Utrecht 1984) 7-36

- Kastelein, W.R., 'De Wkkgz is er: een nieuwe klachten- en claimregeling in de zorg!', Tijdschrift voor Gezondheidsrecht 402 (2016) 62-71

- Kennedy, J., Nieuw Babylon in aanbouw. Nederland in de jaren zestig (3rd revised edition; Amsterdam: Boom 2017)

- Kennedy, J.C., Een beknopte geschiedenis van Nederland. (Amsterdam: Prometheus 2017)

- Kerkhoff, A.H.M., Honderd jaar gemeentelijke geneeskundige en gezondheidsdiensten (Bussum: Dick Coutinho 1994)

- Kerkhoff, A.H.M., Raadsbesluiten als remedie. Openbare gezondheidszorg in Zwolle en de regio IJssel-Vecht 1900-1995 (Rotterdam: Erasmus Publishing 2001)

- Kerkhoff, A.H.M. and Dols, W.P.M., 'De Algemene Wet Bijzondere Ziektekosten. Debatten en ontwikkelingen tot 1987', in: Companje, K.P., (ed.), Tussen volksverzekering en vrije 
markt. Verzekering van zorg op het snijvlak van sociale verzekering en gezondheidszorg 1880-2006 (Amsterdam: Aksant 2008) 709-794

- Kersbergen, L.C., 'Openingsrede', in: Handelingen van het Nederlandsch Congres voor Openbare Gezondheidsregeling 1943-1946 (16 April 1946) 12-16

- Kersbergen, K. van, Social Capitalism. A study of Christian democracy and the welfare state (Abingdon: Routledge 1995; reprint 2007)

- Kersbergen, K. van, 'Religion and the Welfare State in the Netherlands', in: Kersbergen, K. van and Manow, P. (eds.), Religion, Class Coalitions, and Welfare States (Cambridge: Cambridge University Press 2009) 119-145

- Keulen, S., Monumenten van beleid. De wisselwerking tussen Nederlands rijksoverheidsbeleid, sociale wetenschappen en politieke cultuur, 1945-2002 (Hilversum: Verloren 2014)

- Klaveren, K.J. van, Het onafhankelijkheidssyndroom. Een cultuurgeschiedenis van het naoorlogse Nederlandse zorgstelsel (Amsterdam: Wereldbibliotheek 2016)

- Kleijn, A., 'Organisatie van de gezondheidszorg in de locale sfeer', in: Nederlands Congres voor Openbare Gezondheidsregeling. Klein congres 1955. Gehouden op 7 juni te Utrecht (Den Haag: Lankhout-Immig N.V. 1955) 6-15

- Klijn, A., Verlangen naar verbetering. 375 jaar academische geneeskunde in Utrecht (Amsterdam: Boom 2010)

- Koelewijn, W. and Wallage, B., 'Onrechtmatig Wmo-beleid. Wat nu?', NJB 1394 (2016)

- Kolk-Kousemaker, M. van der, Het beleid van Het Witte Kruis, Het Groene Kruis en Het Wit-Gele Kruis over de periode 1875-1945 (diss. Universiteit Utrecht: 2005).

- Kuyper, A., Het sociale vraagstuk en de christelijke religie. Rede bij de opening van het sociaal congres op 9 november 1891 (Amsterdam: J.A. Wormser 1891)

- Lako, C. and Dortant, H., 'Why don't the Dutch use quality information in their hospital choice? Results from a survey among 479 patients from a Dutch hospital', Health 61 (2014) 1-5

- Larsson, B., Letell, M. and Thörn, H., 'Transformations of the Swedish Welfare State: Social Engineering, Governance and Governmentality. An Introduction', in: Larsson, B., Letell, M. and Thörn, H., Transformations of the Swedish Welfare State. From Social Engineering to Governance? (Houndmills: Palgrave MacMillan 2012) 3-22

- Lawrence, C., 'Continuity in crisis: medicine, 1914-1945', in: Bynum, W.F. et al, The Western Medical Tradition. 1800 To 2000 (Cambridge: Cambridge University Press 2006), 247-403

- Le Fanu, J., The Rise and Fall of Modern Medicine (New York: Basic Books: revised edition 2012)

- Le Grand-van den Bogaard, M.J.M., Munsterman, D.K., and Spaay, R.L.W.M., 'Het perspectief van de ziekenhuizen', in: Elsinga, E. and Kemenade, Y. van, (eds.), Van 
revolutie naar evolutie. Tien jaar stelselwijziging in de Nederlandse gezondheidszorg (Lochem: De Tijdstroom 1997) 52-77

- Leenen, H.J.J., Sociale grondrechten en gezondheidszorg (diss.: Rijksuniversiteit Utrecht 1966)

- Leenen, H.J.J., 'Gezondheidsrecht. Een poging tot plaatsbepaling', Tijdschrift voor Sociale Geneeskunde 46 (1968) 778-785

- Leenen, H.J.J., Recht op zorg voor de gezondheid. Preadvies voor de Vereniging voor Gezondheidsrecht (Utrecht: Vereniging voor Gezondheidsrecht 1997)

- Legemaate, J., De (dubbel)rol van de arts, in: Roscam Abbing, H.D.C., Legemaate, J., Groot, G.R.J. de, Zorg, schaarste en recht. Preadvies Vereniging voor Gezondheidsrecht 2002 (Utrecht: Vereniging voor Gezondheidsrecht 2002), 36-63

- Levi-Faur, D., 'From "Big Government" To "Big Governance"?', in: Levi-Faur, D., (ed.), The Oxford Handbook of Governance (Oxford: Oxford University Press 2012) 3-18

- Liagre Böhl, H. de, 'Consensus en polarisatie. De kwaliteit van de democratie 1945-2000', in: Aerts, R. et al, Land van kleine gebaren. Een politieke geschiedenis van Nederland 17802012 (8th revised edition: Amsterdam: Boom 2016) 283-349

- Lieburg, M.J. van, 'De tweede geneeskundige stand (1818-1865). Een bijdrage tot de geschiedenis van het medisch beroep in Nederland', in: Tijdschrift voor geschiedenis 96 (1983) 433-453

- Lieburg, M. van, 'The Civil Medical Services in The Netherlands during World War II', in: Hers, J.F.Ph. and Terpstra, J.L., (eds.), Stress. Medical and Legal Analysis of Late Effects of World War II Suffering in The Netherlands (Leiden 1988) 15-29

- Loghem, J.J. van, 'De nieuwe Gezondheidswet', Ned. T. Geneesk. 10014 (28-01-1956) 238-239

- Loozen, E.M.H. Mededingingstoezicht in de zorg. Het moet en kan beter (Rotterdam: Instituut Beleid \& Management Gezondheidszorg 2013)

- Loozen, E., Varkevisser, M. and Schut, E., 'Goede zorginkoop vereist effectief toezicht op marktmacht', ESB 1014737 (2016) 426-429

- Luyten, D., 'Social Security and the End of the Second World War in France, the Netherlands and Belgium. Social Peace, Organizational Power and the State', in: Hoffman, S.L. et al, Seeking Peace in the Wake of War. Europe, 1943-1947 (Amsterdam: Amsterdam University Press 2015) 247-275

- Maarse, H., Jeurissen, P., Ruwaard, D., 'Results of the market-oriented reform in the Netherlands: a review', Health Economics, Policy and Law 11 (2016) 161-178

- Mahoney, J., 'Path Dependence in Historical Sociology', Theory and Society 294 (2000) 507-548

- Maioni, A., Health Care in Canada (Oxford: Oxford University Press 2014) 
- Marshall, T.H., 'Citizenship and Social Class', in: T.H. Marshall, Citizenship and Social Class and other essays (Cambridge: Cambridge University Press 1950) 1-85

- Meijer, W., Welzijnsbeleid. Een keuze voor verandering van de maatschappij (Alphen aan den Rijn: Samsom 1978)

- Melief, P.B.A., De strijd om de armenzorg in Nederland 1795-1854 (diss. Nijmegen University: Groningen: J.B. Wolters 1955)

- Mellink, B., 'Tweedracht maakt macht. De PvdA, de doorbraak en de ontluikende polarisatiestrategie (1946-1966)', Low Countries Historical Review 1262 (2011) 30-53

- Meulemans, E.W.M., 'Gezichtspunt. De zorgplicht van de staat', Tijdschrift voor Gezondheidsrecht 195 (1995) 265

- Michielsen, A.B., 'Sociale Zekerheid. Het Rapport-van Rhijn', in: Katholiek Cultureel Tijdschrift 1 vol. 2 (1945-46) 382-387

- Mijle, C.H.A. van der, Onze Geneeskundige Wetgeving. Historisch overzicht der inzonderheid sinds 1813 uitgevaardigde Voorschriften op Geneeskundig gebied, met bijzondere beschouwing der thans van kracht zijnde Bepalingen. Handboek voor geneeskundigen, apothekers, ambtenaren en gemeentebesturen (Ooltgensplaat: M. Breur 1896)

- Mooy, A.M., De krankzinnigenwet van 1884 (diss. Utrecht University: Utrecht 1964)

- Mukherjee, S., The Emperor of All Maladies. A Biography of Cancer (New York: Scribner 2010)

- Muntendam, P., 'Samenvatting en slotwoord', in: Nederlands Congres voor Openbare Gezondheidsregeling, Doelmatigheid van de organisatie van de zorg voor de volksgezondheid. Congres 1967 (Amsterdam: reprint of Tijdschrift voor Sociale Geneeskunde 45; 2 (1968)

- Muntendam, P., 'De betekenis van patiëntenverenigingen voor de gezondheidszorg in Nederland', Ned. T. Geneesk. 12322 (1979) 933-936

- Nederlandsche Bank, De, Visie op de toekomst van de Nederlandse zorgverzekeraars. Verzekerd van goede zorg (Amsterdam: De Nederlandsche Bank 2017)

- Noordam, F., 'De personele werkingssfeer van de Nederlandse sociale verzekering (19012001)', in: Berghman, J. et al (eds.), Honderd Jaar Sociale Zekerheid in Nederland (Delft: Eburon 2003) 19-35

- Okma, G.H., 'Verandering verzekerd: stand van zaken van het plan Dekker', Ned Tijdschr Geneeskd. 13345 (1989) 2242-8

- Okma, G.H., Studies on Dutch Health Politics, Policies and Law (diss. Utrecht University 1997)

- Oosterhuis, H. and Gijswijt-Hofstra, M., Verward van geest en ander ongerief. Psychiatrie en geestelijke gezondheidszorg in Nederland (1870-2005) (Houten: Bohn Stafleu van Loghum 2008) 
- Oosterhuis, H. and Huisman, F., 'The Politics of Health and Citizenship: Historical and Contemporary Perspective', in: Huisman, F. and Oosterhuis, H. (eds.), Health and Citizenship: Political Cultures of Health in Modern Europe (Abingdon: Routledge 2015) 140

- Orlow, D., Common Destiny. A Comparative History of the Dutch, French, and German Social Democratic Parties, 1945-1969 (New York: Berghahn Books 2000)

- Oudenampsen, M. and Mellink, B., 'Voorbij de controverse: het Nederlandse neoliberalisme als onderwerp van onderzoek', Beleid en Maatschappij 462 (2019) 235254

- Perri 6, 'Governance: if governance is everything, maybe it's nothing', in: A. Massey and K. Johnston, The International Handbook of Public Administration and Governance (Cheltenham: Edward Elgar 2015) 56-80

- Peters, K., Een doodgewoon kabinet. Acht jaar Paars 1994-2002 (Amsterdam: Boom 2015)

- Philips, J.F.R., Gezondheidszorg in Limburg. Groei en acceptatie van de gezondheidsvoorzieningen 1850-1940 (Assen: Van Gorcum 1980)

- Phillips, N. and Payne, A., 'Introduction: the international political economy of governance', in: Phillips, N. and Payne, A., (eds.), Handbook of the International Political Economy of Governance (Cheltenham: Edward Elgar 2014) 1-9

- Phlippen, S., 'Interview met Wynand van de Ven', ESB 1004718 (2015) 568-570

- Plomp, E., Winst in de zorg. Juridische aspecten van winstuitkering door zorginstellingen (diss. Universiteit van Amsterdam 2011)

- Ponsioen, J. and Veldkamp, G.M.J., De menselijke samenleving. Volume II. Vraagstukken der hedendaagse samenleving (Bussum: Paul Brand N.V. 1956)

- Porter, M.E. and Teisberg, E.O., Redefining Health Care. Creating Value-Based Competition on Results (Cambridge, MA: Harvard Business School Press 2006)

- Porter, R., Blood and Guts. A Short History of Medicine (London: Allen Lane 2002)

- Post, H., 'Soevereniteit in eigen kring plooit pluriforme samenleving', Tijdschrift voor Religie, Recht en Beleid 23 (2011) 52-71

- Prak, M. and Zanden, J.L. van, Nederland en het poldermodel. Sociaal-economische geschiedenis van Nederland, 1000-2000 (Amsterdam: Bert Bakker 2013)

- Querido, A., Een eeuw Staatstoezicht op de Volksgezondheid, (Den Haag: Staatsuitgeverij 1965)

- Randeraad, N., 'Gemeenten tussen wet en werkelijkheid', in: Sas, N.C.F. van and Velde, H. te, (eds.), De eeuw van de Grondwet. Grondwet en politiek in Nederland, 1798-1917 (Deventer: Kluwer 1998) 246-265

- Rang, J.F., Zorgen over de Volksgezondheidsnota 1966 (reprint from: Anti-Revolutionaire Staatkunde 36 4, april 1966) 
- Rang, J.F., 'Patiëntenrecht', in: Vereniging voor Gezondheidsrecht, Oratiebundel gezondheidsrecht. Verzamelde redes 1971-2011 (Den Haag: Sdu Uitgevers 2012) 43-72

- Reijden, J.P. van der, Onze kostelijke gezondheid (Amsterdam: Balans 1987)

- Renwick, C., Bread for All. The Origins of the Welfare State (London: Allen Lane 2017)

- Rhodes, R.A.W., 'Waves of Governance', in: Levi-Faur, D., (ed.), The Oxford Handbook of Governance (Oxford: Oxford University Press 2012), 33-48

- $\quad$ Rigter, R.B.M., Met raad en daad. De geschiedenis van de Gezondheidsraad 1902-1985 (Rotterdam: diss. Rotterdam University 1992)

- Rigter, D., 'Het effect van de invoering van de Ongevallenwet 1901 op de gezondheidszorg', in: K.P. Companje (ed.) Tussen volksverzekering en vrije markt. Verzekering van zorg op het snijvlak van sociale verzekering en gezondheidszorg 18802006 (Amsterdam: Aksant 2008) 97-172

- Rijken, J.J., 'Leve het ziekenfonds! Vier argumenten voor een publiekrechtelijke volksverzekering tegen ziektekosten', Tijdschrift voor Gezondheidsrecht 412 (2017) 135142

- Roos, A.F., Mergers and Competition in the Dutch Healthcare Sector (Rotterdam: diss. Erasmus Universiteit Rotterdam 2018)

- Roos, A.F., Schut, E. and Varkevisser, M., 'Een halve eeuw ziekenhuisfusies in Nederland', ESB 1034766 (2018) 440-443

- Rooy, P. de, Republiek van rivaliteiten ( $5^{\text {th }}$ revised edition: Amsterdam: Wereldbibliotheek 2014)

- Rooy, P. de, A Tiny Spot on the Earth. The Political Culture of the Netherlands in the Nineteenth and Twentieth Century (Amsterdam: Amsterdam University Press 2015)

- Rooy, P. de, 'Een zoekende tijd. De ongemakkelijke democratie 1913-1949', in: Aerts, R. et al, Land van kleine gebaren. Een politieke geschiedenis van Nederland 1780-2012 (8th revised edition: Amsterdam: Boom 2016), 195-282

- Roscam Abbing, H. and Rutten, F.F.H., Verleden en toekomst van het ziektekostenverzekeringsstelsel in Nederland (Deventer: Kluwer 1985)

- Rosenstein, S., 'De vooruitgang der geneeskunde in de laatste vijftig jaren', Nederlandsch Tijdschrift voor Geneeskunde 353 (1899) vol. II, 114-122

- Ruwaard, S., Purchasing healthcare: Beyond getting the financial incentives right (Tilburg: diss. Tilburg University 2018)

- Scholtens, A.L., 'Sociale Zekerheid', in: Weekblad voor Gemeentebelangen 24: 19 (1945) 193-197

- Scholtens, A.L., 'Sociale Zekerheid II', in: Weekblad voor Gemeentebelangen 24: 27 (1945) 309-313

- Schors, W. van der, Kemp, R., and Varkevisser, M., 'Toepassing kartelverbod in de zorg laat veel ruimte voor samenwerking', ESB (to be published) 
- Schouwenburg, M.G.L. van, Unificatie der sociale verzekering (Leiden: diss. Universiteit Leiden 1946)

- Schouwenburg, M.G.L. van, 'Hervorming der sociale verzekering', Sociaal Maandblad 2: 12 (1947) 270-282

- Schut, F.T., Competition in the Dutch Health Care Sector (Rotterdam: diss. Erasmus Universiteit Rotterdam 1995)

- Schut, F.T., De zorg is toch geen markt? Laveren tussen marktfalen en overheidsfalen (Rotterdam: inaugural lecture Erasmus Universiteit Rotterdam 2003)

- Schut, F.T. and Varkevisser, M., 'Hebben zorgverzekeraars te veel macht?', Ned Tijdschr Geneeskd. 160 (2016) D1133

- Sijmons, J.G., 'De civielrechtelijke hulpverleningsplicht van arts en ziekenhuis', Tijdschrift voor Gezondheidsrecht 196 (1995) 332-345

- Sijmons, J.G., Aanbodregulering en de Wet toelating zorginstellingen (Groningen: diss. Groningen University 2006)

- Sijmons, J.G., 'De cure: transitie en onbalans', in: Sijmons, J.G., Ende, T.A.M. van den and Groot, G.R.J. de, Stelsel onder stress. Preadvies 2011 Vereniging voor Gezondheidsrecht (Den Haag: Sdu Uitgevers 2011) 13-87

- Sijmons, J.G., 'Sturen in de zorg met de zorgverzekering. De perikelen rond de wijziging van art. 13 Zorgverzekeringswet', Aansprakelijkheid Verzekering en Schade 14 (2015), 8893

- Sijmons, J.G., 'Inleiding', in: E. Steyger et al, Op weg naar 10 jaar nieuw zorgstelsel. Terugen vooruitblik. Preadvies 2015 Vereniging voor Gezondheidsrecht (Den Haag: Sdu Uitgevers 2015) 13-30

- Sijses, G.P., Algemene Wet Bïzondere Ziektekosten (Deventer: Kluwer 1968)

- Smissaert, J., Overzicht van het Nederlandsch Armwezen (Haarlem: H.D. Tjeenk Willink \& Zoon; 2nd edition 1910)

- Smit, W.B., Het vraagstuk der ziekenhuisverpleging voor de gemeenten (diss. Rijksuniversiteit Utrecht: H.D. Tjeenk Willink \& Zoon: Haarlem 1939)

- Snoeck Henkemans, J.R., Christendom en Maatschappij. De Sociale Beteekenis der Nieuwe Armenwet (Utrecht: G.J.A. Ruys 1912)

- Spreeuwenberg, C., 'Hans: treedt af!', Medisch Contact 4727 (1992) 835

- Spreeuwenberg, C., 'Een dokter voor de volksgezondheid', Medisch Contact 4936 (1994) 1107

- Spruyt, G.H., 'Politicians and Epidemics in the Bible Belt', Utrecht Law Review 12 (2016) 114-126

- Steyger, E., 'Marktwerking in oprichting: de bevoegdheden van Zorgautoriteit en NMa en de werking in de praktijk', Tijdschrift voor Gezondheidsrecht 1 (2006) 2-15 
- Stichting Nationaal Ziekenhuisinstituut, Ontwikkeling van de ziekenhuiskosten 1953-1968 ('s-Gravenhage 1969)

- Stoeder, W. et al, De Ziekenfondsen in Nederland. Rapport Uitgebracht door eene Commissie van Onderzoek (Amsterdam: S.L. van Looy \& H. Gerlings 1895)

- Stokx, L.J. and Post, D., 'Volksgezondheid toekomst verkenning' 1997. VII. Zorgbehoefte en zorggebruik', Nederlands Tijdschrift voor Geneeskunde 14223 (1998) 1338-1342

- Swaan, A. de, Zorg en de staat. Welzijn, onderwijs en gezondheidszorg in Europa en de Verenigde Staten in de nieuwe tijd (Amsterdam: Bert Bakker 2004)

- Thoenes, P., De crisis als uitdaging: opstellen over heden en toekomst van de verzorgingsstaat (Amsterdam: Kobra 1984)

- Thorbecke, J.R., 'Narede', in: J.R. Thorbecke, Parlementaire redevoeringen, vol. 6, 18651866 (Deventer: A. ter Gunne 1870) v-xx

- Thorbecke, J.R., 'Over het hedendaagsche staatsburgerschap', in: Thorbecke, J.R., Historische schetsen (Den Haag: Martinus Nijhoff; 2nd edition 1872) 84-96

- Timmermans, J., Campen, C. van and Hessing, J., 'Zorg', in: Sociaal en Cultureel Planbureau, Sociaal en Cultureel Rapport 2002. De kwaliteit van de quartaire sector (Den Haag: Sociaal en Cultureel Planbureau 2002) 273-337

- Tuohy, C.H., Remaking Policy. Scale, Pace and Political Strategy in Health Care Reform (Toronto: Toronto University Press 2018)

- Valk, L. van der, Van pauperzorg tot bestaanszekerheid. Een onderzoek naar de ontwikkeling van de armenzorg in Nederland tegen de achtergrond van de overgang naar de Algemene Bijstandswet, 1912-1965 (Delft: Eburon 1986)

- Valk, L.A. van der, 'Gilden, gildenbussen en vrijwillige contracten: de ontwikkeling van de verzekeringsmarkt 1780-1850', Tijdschrift voor sociale geschiedenis 272 (2001) 175-200

- Valk, L. van der, 'De ziekenfondskwestie rond 1840: een Amsterdams of een nationaal probleem?', Gewina 26 (2003) 22-39

- Varkevisser, M. and Schut, E., 'Fusietoetsing in de zorg: een terug- en vooruitblik', Tijdschrift voor Toezicht (2019) 5-12

- Veder-Smit, E., Nota Patiëntenbeleid 1981 (Den Haag: Staatsuitgeverij 1981)

- Velde, H. te, 'Van grondwet tot grondwet. Oefenen met parlement, partij en schaalvergroting 1848-1917', in: Aerts, R. et al, Land van kleine gebaren. Een politieke geschiedenis van Nederland 1780-2012 (8th revised edition: Amsterdam: Boom 2016) 109-194

- Velden, H.F. van der, Financiële toegankelijkheid tot gezondheidszorg in Nederland, 18501941 (Rotterdam: diss. Rotterdam: Erasmus University Rotterdam 1993)

- Velden, H. van der, 'The Dutch Health Services before Compulsory Health Insurance 1900-1941', Social History of Medicine 1996, 49-68 
- Velden, H. van der, 'Groot of klein: de opbouw van het Nederlandse ziekenhuiswezen, 1890-1950', Tijdschrift voor Sociale Geschiedenis 25 (1999) 407-424

- Veldkamp, G.M.J., Individualistische karaktertrekken in de Nederlandse sociale arbeidsverzekering: een critisch onderzoek naar de grondslagen der sociale arbeidsverzekering (Tilburg: diss. Universiteit Tilburg 1949)

- Veldkamp, G.M.J., 'Openingsrede', De welvaartsstaat. Verslag van het congres gehouden op 22 en 23 april 1963 ter gelegenheid van het XIIle Lustrum van de Katholieke Studentenvereniging Sanctus Virgilius (n.p. 1963)

- Ven, F.J.H.M. van der, 'Sociale grondrechten', Maandschrift Economie 18; 3 (1953) 89-104

- Ven, W. van de, Het beste zorgstelsel? Afscheidscollege 2 oktober 2015 (Rotterdam: Erasmus University Rotterdam 2015)

- Venugopal, R., 'Neoliberalism as concept', Economy and Society 442 (2015) 165-187

- Vermaat, M.F., 'Wet maatschappelijke ondersteuning: alles mag, niets moet?', Tijdschrift voor Gezondheidsrecht 301 (2006) 16-28

- Victoor, A. and Rademakers, J., 'Waarom kiezen patiënten niet voor het 'beste' ziekenhuis?', Ned Tijdschr Geneeskd. 159 (2015) A8164

- Vledder, I. et al, 'Particuliere laboratoria in Nederland. Deel 1: opkomst en bloei, 18651914', in: NEHA-Jaarboek voor economische, bedrijfs- en techniekgeschiedenis 62 (1999) 249-290

- Vonk, R.A.A., 'In It for the Money? Insurers, Sickness Funds and the Dominance of NotFor-Profit Health Insurance in The Netherlands', in: B. Harris (ed.), Welfare and Old Age in Europe and North America: The Development of Social Insurance (London: Pickering \& Chatto 2012) 167-187

- Vonk, R., 'Een taak voor de staat? De Duitse bezetting en de invoering van de verplichte ziekenfondsverzekering in Nederland, 1939-1949', BMGN - Low Countries Historical Review 1273 (2012) 3-28

- Vonk, R., Recht of schade? Een geschiedenis van particuliere ziektekostenverzekeraars en hun positie in het Nederlandse zorgverzekeringbestel, 1900-2006 (Amsterdam: diss. University of Amsterdam 2013)

- Vonk, R.A.A. and Schut, F.T., 'Can universal access be achieved in a voluntary private health insurance market? Dutch private insurers caught between competing logics', Health Economics, Policy and Law 14 (2019) 315-336

- Vos, J., 'De Algemene Bijstandswet: van armenzorg naar een recht op werk en inkomen', in: Berghman, J. et al (eds.), Honderd Jaar Sociale Zekerheid in Nederland (Delft: Eburon 2003) 249-264

- Vos, L. de, Kwaliteit, disciplinering en sturing. Een historisch sociologisch onderzoek naar de vormgeving van kwaliteit van zorg in ziekenhuizen (Rotterdam: diss. Erasmus University Rotterdam 2014) 
- Vreeze, J.Th.M. de, Voor en na de Gezondheidswet 1956. Eadem sed aliter (Nijmegen: inaugural lecture Catholic University Nijmegen 1968)

- Vuijsje, H., Nieuwe Vrijgestelden. De opkomst van het spijkerpakkenproletariaat (Baarn: Anthos 1977)

- Wallage, B. and Koelewijn, W.I., 'Resultaatgericht indiceren op grond van de Wmo 2015 niet langer mogelijk? Een botsing tussen maatwerk en rechtszekerheid', Gemeentestem 7486 (March 2019) 179-182

- Webster, C., The National Health Service. A Political History (Oxford: Oxford University Press 1998)

- Weisz, G., Divide and Conquer. A Comparative History of Medical Specialization (Oxford: Oxford University Press 2006)

- Widdershoven, B.E.M., Het dilemma van solidariteit. De Nederlandse onderlinge ziekenfondsen, 1890-1941 (diss. Tilburg University: Amsterdam: Aksant 2005)

- Wiggers, M.P.M., De NMa en de NZa in de curatieve zorgsector. Een toetsing aan het Europees mededingingsrecht (Deventer: Kluwer 2013)

- Wilken, A., 'De geschilleninstanties in de zorg; een groot en bont gezelschap', Tijdschrift voor Gezondheidsrecht 417 (2017) 477-478

- Wolf, H.R., 'Een wissel op de toekomst. Mislukte ziekenhuiswetgeving, 1935-1951', in: W.P. Blockmans and L.A. van der Valk (eds.), Van particuliere naar openbare zorg, en terug? Sociale politiek in Nederland sinds 1880 (Amsterdam: NEHA 1992) 195-208

- Wolffram, D.J., Vrij van wat neerdrukt en beklemt. Staat, gemeenschap, sociale politiek, 1870-1918 (Amsterdam: Wereldbibliotheek 2003)

- Zanden, J.L. van, The Economic History of the Netherlands, 1914-1995: A Small Open Economy in the 'Long' Twentieth Century (London: Routledge 1998)

- Zanden, J.L. van and Riel, A. van, Nederland 1780-1914. Staat, instituties en economische ontwikkeling (Amsterdam: Balans 2000)

- Ziekenfondsraad, Kort overzicht van de ontwikkeling van de Nederlandse ziekenfondsverzekering (Amsterdam: Ziekenfondsraad 1960)

- Ziekenfondsraad, Studiecommissie Ziekenfondsverzekering, Werkgroep Onderzoek Kostenstijging, Resultaten van een onderzoek naar de oorzaken van de kostenstijging bij de verplichte ziekenfondsverzekering in de periode 1948-1960 (Amsterdam 1964)

- Ziekenfondsraad, Evaluatie Overeenkomstenstelsel Ziekenfondswet en AWBZ (Amstelveen: Ziekenfondsraad 1995)

- Zwaard, W. van der, Van rechtsgrond tot grondrecht. Sociale wetgeving en het dilemma van particulariteit (1840-1960) (Den Haag/Utrecht: MA thesis Raad voor Maatschappelijke Ontwikkeling 2013) 


\section{Nederlandse samenvatting}

De gezondheidszorg is een enorm complex krachtenveld, dat toegankelijk voor burgers moet zijn maar tegelijkertijd door talloze partijen met soms tegenstrijdige belangen draaiende wordt gehouden. Die complexiteit weerspiegelt zich ook in het hedendaagse Nederlandse stelsel van 'gereguleerde marktwerking', dat zowel sterk verankerde solidariteit als marktmechanismen kent. De relatie van de overheid tot die zorg is zo mogelijk nog moeilijker te duiden. Dit roept de vraag op hoe die verhoudingen zich historisch hebben ontwikkeld, en hoe wij de relatie tussen 'staat' en 'gezondheidszorg' kunnen begrijpen - zowel historisch als vandaag de dag.

In dit proefschrift wordt de verhouding tussen de overheid en de gezondheidszorg tussen 1848 en 2015 onderzocht, met bijzondere aandacht voor de groeiende toegang tot zorg als een kwestie waar de overheid zich in de loop der tijd mee is gaan bemoeien.

De historische analyse vindt primair plaats aan de hand van het concept 'governmentality'. Hiermee wordt niet alleen gedoeld op instrumenten voor 'governance' zoals die door de tijd zijn ontwikkeld voor de zorg - wetgeving als het Ziekenfondsenbesluit uit 1941 of de Zorgverzekeringswet 2006, of budgettering in de zorg - maar juist ook de breder heersende politiek-ideologische en culturele mentaliteiten omtrent de rol die de overheid zou moeten innemen ten opzichte van de gezondheidszorg.

Dit leidt tot het onderscheiden van vier specifieke 'governmentalities' in de geschiedenis van de Nederlandse gezondheidszorg: Liberaal; particulier initiatief met publieke steun; planning; gereguleerde marktwerking. In de vier delen van deze dissertatie wordt de historische ontwikkeling van deze opeenvolgende 'governmentalities' empirisch onderzocht en geanalyseerd.

De hoofdconclusie is daarbij dat deze opeenvolgende periodes vrij consistent een verschil laten zien tussen een politieke en culturele retoriek die de nadruk legde op een 'kleine overheid', particulier initiatief en marktwerking, en een realiteit van almaar groeiende toegang tot zorg, gegarandeerd door een overheid die zich nominaal op afstand hield. 


\section{Dankwoord}

Mijn dank gaat allereerst uit naar de instituten die dit onderzoek financieel mogelijk hebben gemaakt: het Julius Centrum voor Gezondheidswetenschappen en Eerstelijns Geneeskunde van het Universitair Medisch Centrum Utrecht; de Faculteit Rechtsgeleerdheid van de Universiteit Utrecht; en het Descartes Centre voor Wetenschapsgeschiedenis en Wetenschapsfilosofie van de Universiteit Utrecht. Daarbij gaat mijn dank in het bijzonder uit naar de personen die de steun namens die instituten hebben verleend: Hans van Delden, Ton Hol, en Bert Theunissen.

Mijn promotoren hebben dit werk echter inhoudelijk mogelijk gemaakt. Frank, mijn dank aan jou is moeilijk in woorden te vatten. Niet alleen heb je mij destijds actief geworven als promovendus nadat wij hadden kennisgemaakt in het kader van een onderzoeksassistentschap en de master HPS, en heb je me gedurende mijn promotieperiode uitstekend begeleid door mij continu prikkelend en socratisch te ondervragen over een onderwerp waar jij als vroegmodernist van origine niet direct in thuis was. Dat kan zeker niet altijd makkelijk zijn geweest gegeven mijn koppigheid, mijn soms sceptische opvattingen over ons vakgebied - en het feit dat ik opeens zo'n 100 jaar terug de tijd in ging met mijn onderzoek. Maar daarnaast heb jij je keer op keer een uiterst hartelijke en meelevende begeleider betoond, die ook echt betrokken was bij mijn persoonlijk wel en wee (en dat van je andere promovendi). In zoverre past de Duitse term Doktorvater jou beter dan 'promotor'. Het doet me nog steeds deugd dat we er destijds in zijn geslaagd jou bij het UMC tot promotor van het jaar te laten bombarderen. Dat verdiende je toen, en dat verdien je nog steeds.

Jaap, het was altijd een genoegen jou weer te zien bij onze besprekingen. Je brede belezenheid en intimiderende intelligentie staan als een paal boven water, en na elke bespreking waren het vaak inzichten die jij haast terloops van de hand had gedaan die mij in de weken en maanden daarna aan het denken zetten. Omgekeerd vond jij het volgens mij verfrissend om met Frank en mij (en later met Robert erbij) te sparren over een proefschrift dat buiten jouw directe academische bezigheden en drukke advocatenpraktijk viel. Uiteindelijk heb ik je niet gevolgd in die praktijk, maar vond ik het desondanks een voorrecht om, met mr. Garvelink, bij mijn eerste (!) kort geding tegenover jou te staan in Zwolle. Laten we de advocatuurlijke en academische banden warm houden.

Robert, het is moeilijk te ontkennen dat wij uit iets ander hout gesneden zijn. Dat kwam de afgelopen jaren vaak tot uiting in stevige discussies, waar we na wat meta-analyse toch weer zeer vriendschappelijk uitkwamen. Jouw droge gevoel voor humor was daarbij essentieel. Anderzijds wordt het sterkste ijzer in het heetste vuur gesmeed, en was de input die uit deze discussies en jouw commentaar volgde echt van onschatbare waarde voor mijn onderzoek. Ik was dan ook verheugd dat jij halverwege de rit als co-promotor betrokken raakte bij mijn 
proefschrift. Daarnaast hebben we ons uitstekend vermaakt als een dynamisch duo in Sevilla, en zijn we er (na enige deliberaties) in geslaagd afgelopen jaar een prachtig artikel in Social Science $\&$ Medicine gepubliceerd te krijgen. Dat smaakt naar meer.

Dan mijn leescommissie. My thanks go out to professors Bont, De Haan, Gelderblom, Hendriks, Marchildon and Trappenburg, for critically reading my dissertation and acting as opponents at my defense.

En de 'informele' leescommissie van Timo, Noortje, Bram en Bas: hartelijk dank voor jullie inspanningen om mij bij de proefpromotie voor te bereiden op de echte verdediging.

Dan mijn collega's van Medical Humanities. Veel dank voor de borrels, de barbecues, en het met elkaar overleggen over studenten en lastige vraagstukken op het snijvlak van recht en ethiek. In het bijzonder dank ik daarbij Menno. Toen ik net begon bij het Julius vond je me volgens mij maar een kereltje met een grote mond. Ik weet niet in hoeverre ik daarin helemaal veranderd ben, maar ik ben toch erg blij dat wij nu een fraaie subsectie gezondheidsrecht vormen (mede dankzij Hans!). Aan de studentevaluaties te zien vullen wij elkaar uitstekend aan, en ik ervaar dat ook altijd zo dankzij jouw warme collegialiteit. Ook dank ik van de $\mathrm{MH}^{\prime}$ ers nog in het bijzonder Karin Jongsma: laten wij in het vervolg het jurist-ethicus overleg erin houden, en de wereld deelgenoot maken van onze conclusies in NRC, MC of waar dan ook. Dan staan we ooit ook wel een keer in Nature Medicine!

Mijn dank gaat ook uit naar mijn nieuwe werkgever, Van Benthem \& Keulen Advocaten en Notariaat te Utrecht, voor de steun in de aanloop naar mijn verdediging en de inspanningen van Johan Koggink en Carida Kleijn ten behoeve van media-zichtbaarheid.

Wouter Koelewijn van VBK verdient meer in het algemeen mijn dank, wegens zijn al lang geleden uitgesproken wens mij als advocaat onder zijn hoede te nemen en de zeer prettige samenwerking nu dat daadwerkelijk het geval is. Wouter, dank voor de vrijheid om naast de advocatuur 'met één been' in de academie te blijven staan. En: nu kunnen we elkaar bij het opnemen van de telefoon wederzijds op niveau aanspreken als 'mr. dr.' En Bastiaan, Bas, Sebastiaan en Freek: promoveren kan (eindelijk) afgestreept worden van mijn lijst met kwartaaltargets!

Naast advocatuurlijke leermeesters verdienen hier ook nog twee van mijn academische leermeesters een expliciet woord van dank: Floris Cohen en Joost Vijselaar. Floris zette mij lang geleden tijdens een uitstekend (ik zou haast zeggen: revolutionair) onderzoeksseminar op het spoor van de wetenschapsgeschiedenis, een spoor dat indirect naar Frank en dit proefschrift leidde. Joost wil ik danken voor het mij bijbrengen van de alledaagse kneepjes van de empirische geschiedschrijving gedurende een lang onderzoeksassistentschap (dat overigens in het geheel niet over een alledaags onderwerp ging). 
Dan mijn paranimfen.

Tim, wat hebben we de afgelopen jaren gelachen (en, toegegeven, ook wel eens een traantje weggepinkt). Vanaf onze eerste dag waren we inderdaad onafscheidelijk - en daarnaast ook moeilijk van elkaar te onderscheiden voor onze collega's. Daarom ook dank hier aan al die moedige zielen van kamers 5.143, 5.14 en daaromheen - Tessa, Denise, Josan, Laura, Lisanne, Valentijn, Katrien, Amy, Renée - die zich konden verheugen in het dagelijks aanschouwen van onze onnavolgbare duo-act. Tim, onze chemie makte vier lange jaren een stuk minder lang hoewel ik oprecht niet weet of we onze dissertaties nu minder snel of juist (veel) sneller hadden geschreven als we elkaar niet hadden ontmoet. En het zal je misschien teleurstellen dat ik dit dankwoord niet schrijf terwijl ik een Versace-pyjama draag, maar ik weet niet of ik zonder jou ooit blue suede shoes had aangeschaft. Twijfelachtig? Wellicht. Goed idee? Zonder twijfel. Het is een eer en genoegen je als paranimf te hebben, amice.

Robbert, maestro: het is ook een grote steun dat mijn meer ingetogen evenknie als paranimf aan mijn zijde staat. Dank daarvoor. Van ons plan een cabaret-act te beginnen is tot op heden weinig terechtgekomen, maar ik denk dat we er best goed in zouden zijn (ik meen mij iets met een lied over communistische staatshoofden te herinneren). Hoe dan ook ben ik buitengewoon blij dat jij je destijds herinnerde dat ik een banjo had en me er vervolgens toe verleidde me te verdiepen in Scruggs-style fingerpicking, bluegrass, en meer van zulk moois uit de Appalachen. High Horse was altijd een fijne afleiding gedurende het promotietraject, ook in mindere tijden. Onze bespiegelingen over politiek, filosofie en het functioneren (of niet) van de academie tijdens het eten maakten daar voor mij een essentieel onderdeel van uit. Daarbij kan ook Jantien natuurlijk niet onvermeld blijven. Let's put the band back together.

Dan mijn lieve familie. Red en Laura: nou nou, wat zijn we toch weer geleerd allemaal. Laten we ook gewoon bier blijven drinken en over rare boeken blijven praten.

Mam en pap: ik hoef hier niet lang uit te weiden. De liefde en trots die ik altijd van jullie heb ontvangen en ervaren is geheel wederzijds. Het kritisch bespreken, lezen en redigeren van het proefschrift was daarnaast een enorme hulp bij het voltooien van dit werk.

And last but most certainly not least, my sweet Katuš. Your support has been invaluable and has, moreover, made the past two and a half years pretty fantastic. Such support ranged from the romantic (just being there) to the more prosaic - "it's not your life's work, just get the thing done already". Practically speaking, your academic and editorial acumen has made the conclusion to this dissertation infinitely stronger. It is much appreciated. On the personal front: first we take Berlin, then New York, and now our windy city by the sea (let's hope the dikes hold). I look forward to exploring Rotterdam and our new life there together with you.

Fin! 


\section{Curriculum vitae}

Roland Bertens was born on 4 October 1989 in Zeist. After high school, he enrolled in the bachelor programme of History and (one year later) Law at Utrecht University. During this period, he was active as a teaching assistant at the History Department, teaching courses on the historical method and the history of racism.

After this, he obtained a master's degree in Health Law at the University of Amsterdam, and a research master's degree in History and Philosophy of Science at Utrecht University. During this period, he worked as research assistant on a ZonMw-subsidized project into the history of sexual delinquency and surgical castration in The Netherlands. Parallel to this, he worked as an intern in the section Legal Services at PwC.

Between December 2015 and December 2019, he worked as a PhD candidate at the University Medical Center Utrecht, also teaching courses in health law and medical humanities.

As of February 2020, he has been working as a healthcare lawyer at the offices of Van Benthem $\&$ Keulen in Utrecht. Alongside this, he still works one day a week as an assistant professor in Health Law at the University Medical Center Utrecht. 
